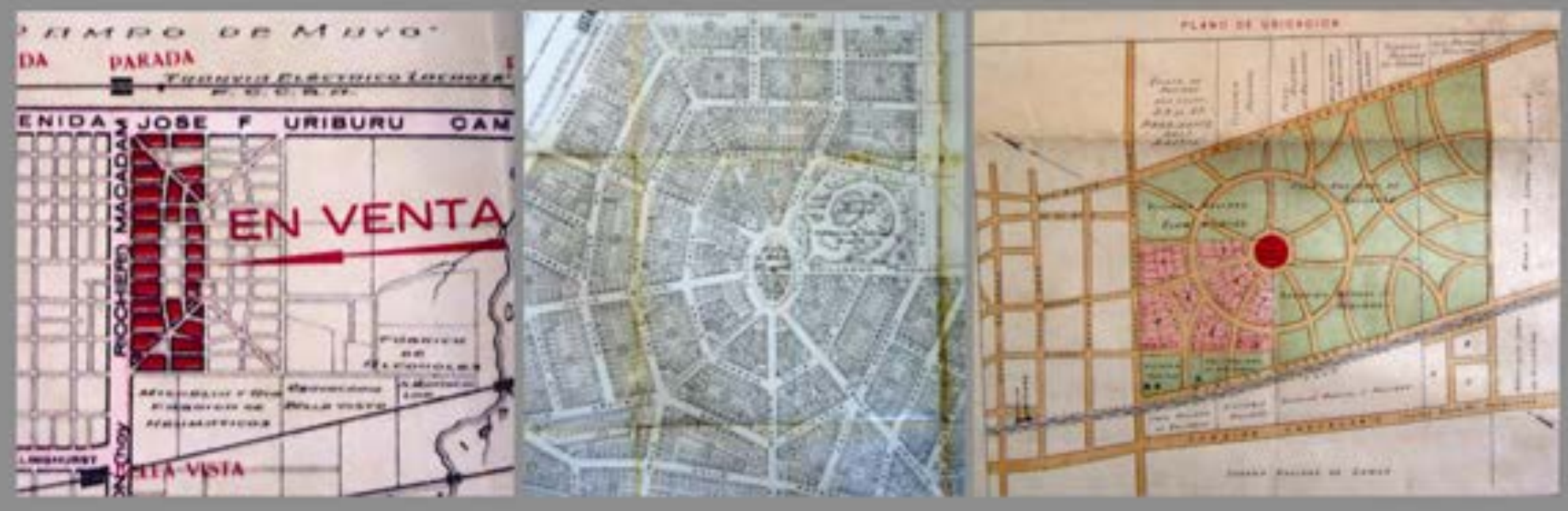

\title{
LAS FORMAS DE LA EXPANSIÓN. 1910-1950
}

Barrios Parque y loteos de fin de semana en la construcción del espacio metropolitano de Buenos Aires

Ana Gómez Pintus

Director

Fernando Aliata

Co-directora

Alicia Novick

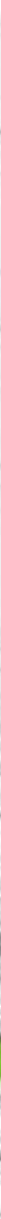




\section{INDICE}

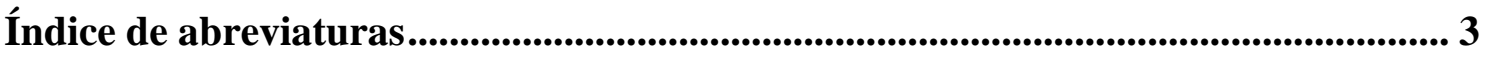

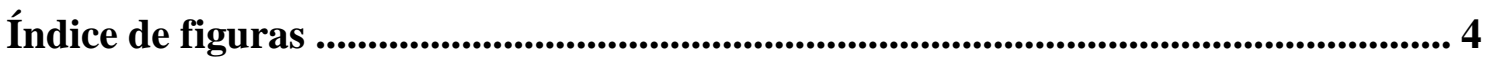

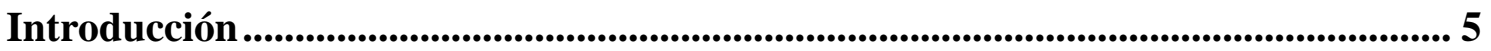

CAPÍTULO 1. Temas y Problemas .................................................................... 11

1.1. Metrópolis y expansión: materiales y metodología ........................................... 11

1.2. Miradas sobre el crecimiento metropolitano .................................................. 24

1.3. Configuraciones territoriales: palabras, nociones y problemas...................... 46

CAPÍTULO 2. Los barrios parque y de fin de semana en el mapa de la expansión 53

2.1. El proceso de la expansión ..............................................................................5 56

2.2. Una vista panorámica sobre los barrios parque .......................................... 66

2.3. El ciclo 1910-1935 ....................................................................................... 73

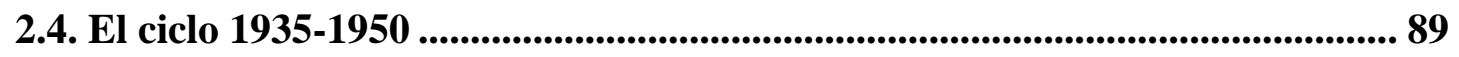

CAPÍTULO 3. Aproximaciones morfológicas ................................................................ 113

3.1. Núcleos a la manera pintoresca............................................................ 116

3.2. Núcleos en grilla..................................................................................... 130

CAPÍTULO 4. Actores, normas e instituciones en la producción del GBA.......... 137

4.1. El modus operandi de la expansión: loteos y subdivisiones........................... 141

4.2. El corpus legislativo, los funcionarios y los organismos públicos ................ 160

CAPÍTULO 5. La arquitectura y las imágenes suburbanas ................................. 187

5.1. El ideal de la casa propia y el week-end .................................................................. 189

5.2. Las residencias, las arquitecturas y sus modelos............................................ 200 
CAPÍTULO 6. Excursiones suburbanas: algunos estudios de casos

6.1. El suburbio exclusivo: el Barrio Parque Aguirre 245

6.2. El suburbio moderno: el Barrio Parque Peluffo 259

6.3. El primer Barrio Parque del Oeste: Castelar 275

Reflexiones finales 295

Apéndice de loteos 310

Bibliografía. 347

Agradecimientos 370 
Índice de abreviaturas

AHCD Actas Honorable Concejo Deliberante

AMBA Área Metropolitana de Buenos Aires

C.J. Ciudad Jardín

CACyA Revista del Centro de Arquitectos Constructores y Afines

CAGBA Comisión Asesora del Gran Buenos Aires

C.F. Capital Federal

CNCB Comisión Nacional de Casas Baratas

FFCC Ferrocarriles

GBA Gran Buenos Aires

IGN Instituto Geográfico Nacional

MOP Ministerio de Obras Públicas. Provincia de Buenos Aires.

PE Poder Ejecutivo

SCA Sociedad Central de Arquitectos

UPC Universidad Politécnica de Cataluña 


\section{Índice de figuras}

Mapa 1. Localización de los barrios parque y núcleos de fin de semana en el AMBA y distancias a la Capital ......................................................66

Mapa 2. Localización de emprendimientos de barrio parque o fin de semana. Área GBA. Período 1910-1935. .73

Mapa 3. Estaciones ferroviarias y densidades de población por sectores para el año 1914. 75

Mapa 4. Eje Norte. Localización de emprendimientos de barrios parque y de fin de semana y "áreas edificadas". 1935

Mapa 5. Eje Oeste. Localización de emprendimientos de barrios parque y de fin de semana y "áreas edificadas". 1935 .79

Mapa 6. Eje Sur. Localización de emprendimientos de barrios parque y de fin de semana y "áreas edificadas". 1935 .81

Mapa 7. Localización de emprendimientos de barrio parque o fin de semana. Área GBA. Período 1935-1950.

Mapa 8. Estaciones ferroviarias y densidades de población por sectores para el año 1948

Mapa 9. Eje Norte. Localización de emprendimientos de barrios parque y de fin de semana y "áreas edificadas". 1948 .93

Mapa 10. Eje Oeste. Localización de emprendimientos de barrios parque y de fin de semana y "áreas edificadas". 1948 .95

Mapa 11. Eje Sur. Localización de emprendimientos de barrios parque y de fin de semana y “áreas edificadas”. 1948.

Mapa 12. Tipos de urbanizaciones y su distribución territorial.

Cuadro 1. Datos completos del corpus de barrios parque seleccionado.

Cuadro 2. Valores de los precios por parcela (por mes) y distancia a la Capital, para los barrios parque y urbanizaciones de week-end. Período 1920-1935

Cuadro 3. Valores de los precios por parcela (por mes) y distancia a la Capital, para los barrios parque y urbanizaciones de week-end. Período 1935-1950. 


\section{Introducción}

En las últimas dos décadas, la Región Metropolitana de Buenos Aires ha experimentado un nuevo proceso de expansión. Solamente entre 1996 y 2000 se concretaron 160 emprendimientos de urbanizaciones cerradas destinadas a usos residenciales de los sectores medios y altos, ocupando un área de 30.000 ha, vale decir, una vez y media la superficie de la Capital Federal. La caída en la inversión pública, que contribuyó al deterioro de las áreas centrales, y la construcción de nuevas vías rápidas de acceso a los grandes centros urbanos propiciaron la formación de urbanizaciones privadas que se localizaron cercanas a un cruce de vías rápidas de circulación o a los accesos de las autopistas, determinando el asentamiento de importantes sectores de la población en áreas periurbanas de la ciudad. "La tranquilidad del campo", "el contacto con la naturaleza" y la posibilidad de "disfrutar de la familia" y de los "deportes al aire libre", junto a los crecientes problemas de inseguridad asociados a las grandes ciudades fueron algunas de las fórmulas esgrimidas tanto en las ofertas de los agentes inmobiliarios como en las demandas de los habitantes a la hora de explicar el traslado de la residencia por fuera del área urbana. Este fenómeno, de larga data en otros países de América Latina no fue privativo de Buenos Aires pues, en menor escala, se fue experimentando en Rosario, Córdoba, Mendoza y La Plata.

Una amplia gama de estudios recientes examinan la multiplicidad de factores que están por detrás de los procesos de suburbanización iniciados a fines de la década del ochenta. ${ }^{1}$ Sin embargo, si bien se trata de un fenómeno de nueva generación, desde

\footnotetext{
${ }^{1}$ Para un análisis particular del fenómeno de suburbanización y construcción de urbanizaciones cerradas en el Área Metropolitana de Buenos Aires ver, Maristela Svampa, Los que ganaron. La vida en countries y barrios cerrados. Editorial Biblos, Buenos Aires, 2001; Daniela Szajnberg, "La producción del espacio residencial en la Región Metropolitana de Buenos Aires. El caso de los barrios privados en Pilar y Berazategui”, en Actas del Seminario de Investigación Urbana. El nuevo milenio y lo urbano, Instituto de Investigaciones Gino Germani, FCS, UBA; Instituto de Geografía, Facultad de Filosofía y LetrasUniversidad de Buenos Aires; Centreo de Estudios Urbanos-Universidad de Buenos Aires; Universidad Nacional de Quilmes; Instituto del Conurbano, Universidad Nacional de General Sarmiento. 2001; Sonia Vidal-Koppmann, “Las urbanizaciones privadas: ¿una innovación para la transformación del territorio?”, en Scripta Nova. Revista electrónica de geografía y ciencias sociales. Vol. IV, no. 69 (Ejemplar dedicado
} 
una perspectiva histórica la formación de núcleos extraurbanos de usos exclusivamente residenciales, que favorecieran las prácticas recreativo-deportivas y la unión familiar en un entorno "natural" no son del todo novedosos en la expansión territorial del Gran Buenos Aires (GBA). Aunque es conocido el perfil predominantemente popular que caracterizó al crecimiento metropolitano, no es menos cierto que, en su mayor parte, muchas de las lógicas de ocupación territorial, de las imágenes y de los valores que guían actualmente el proceso de suburbanización de los sectores medios y medios-altos, ya se habían hecho presentes en otros escenarios y signaron los procesos de expansión residencial que experimentó el Gran Buenos Aires. ${ }^{2}$

En el marco del renovado interés que suscitan los recientes procesos de suburbanización, este trabajo se propone identificar el rol que tuvieron los núcleos y emprendimientos suburbanos, asociados inicialmente a formas de habitar modernizadoras, que vincularon residencia no permanente, actividades recreativas y deportivas en un entorno "natural", con el objetivo de iluminar algunas de las lógicas que se dirimen en la formación del territorio metropolitano y de sus arquitecturas.

La investigación se centra en el análisis de los denominados barrios parque y loteos de fin de semana que tuvieron un rol destacado en el proceso de suburbanización. En cierto modo la idea de "barrio parque" es tributaria de las propuestas gestadas en el campo del urbanismo, pues se constituye genéricamente en la articulación del modelo de Ciudad Jardín de Ebenezer Howard y de los ordenamientos residenciales suburbanos vinculados al parque informal inglés. Aunque, como es sabido, esos referentes fueron objeto de infinitas reformulaciones, dando lugar a "barrios parque", "barrios jardín", "suburbios jardín",....

Desde esa perspectiva, los emprendimientos residenciales barrios parque y loteos de fin de semana se consideran según las denominaciones efectuadas en los avisos publicitarios: "Lomas de Haedo, 197 lotes para week-end" o "famoso barrio

a: Innovación, desarrollo y medio local. Dimensiones sociales y espaciales de la innovación: II Coloquio Internacional de Geocrítica) Universidad de Barcelona, Barcelona, 2000

2 Anahí Ballent presentó algunas reflexiones acerca de los sucesivos procesos de expansión protagonizados por los sectores medios-altos. Ver, Anahí Ballent, “Country Life: los nuevos paraísos, su historia y sus profetas”, en Block n², 1998. 
parque arbolado Los Nogales" "3 que remiten a una constelación de significados que van más allá de las caracterizaciones eruditas. En efecto, localmente se ha utilizado la calificación de "barrio parque" como recurso para legitimar, al mismo tiempo, un nuevo emprendimiento, un tipo de vivienda y una forma de vida que intenta diferenciarse del loteo tradicional en cuadrícula y de un estilo de vida urbano, aunque en lo morfológico-constitutivo, como abordaremos más adelante, también se puede presentar como una cuadrícula con diagonales y plazas o como un trazado destinado a vivienda permanente. Dentro de este grupo, se pueden encontrar barrios muy diferentes, en relación a sus características, su implantación, a las tendencias de localización en relación a los ejes de crecimiento y a las pre-existencias -dentro de la estructura histórica territorial ${ }^{4}$ - que daban cuenta de diferentes grados de consolidación presentes en las áreas de inserción.

Según planteamos, el estudio de estas propuestas - que dieron lugar a una serie de loteos particulares y de urbanizaciones fragmentarias en su conjunto- permite iluminar algunas de las modalidades según las cuales se fue configurando la expansión metropolitana durante la primera mitad del siglo XX. Más allá de sus diferencias y del rol limitado que en términos materiales tuvieron los barrios parque en la expansión metropolitana, su relevancia radicó en su capacidad para consolidar los ejes de crecimiento, y configurar en su irradiación formas particulares de la expansión.

3 Promoción de Lomas de Haedo, 1945, en Carpeta de Remates-Partido de Morón, Departamento de Investigación Histórica Cartográfica, Dirección de Geodesia, MOP, Pcia. de Buenos Aires; Promoción del Barrio Parque Los Nogales, 1949, en Carpeta de Remates-Partido de Moreno, Departamento de Investigación Histórica Cartográfica, Dirección de Geodesia, MOP, Pcia. de Buenos Aires.

${ }^{4}$ Horacio Caride refiere que el actual Área Metropolitana de Buenos Aires (AMBA) posee una estructura histórica territorial que adquiere buena parte de su forma definitiva antes de la federalización de la ciudad de Buenos Aires, en 1880. Y que dentro de este proceso fueron fundamentales caminos, capillas, puertos, guardias y fortines que, con distintos grados de relación, estuvieron vinculados con los primeros asentamientos urbanos del área. Ver, Horacio Caride, Un poco antes del horizonte. Estructura administrativa de la Campaña de Buenos Aires en el siglo XVIII, en Cuadernos de Crítica, IAA, $\mathrm{n}^{\mathrm{o}} 52$. 1994. 
Un nutrido corpus bibliográfico examina las lógicas que estuvieron presentes en los procesos de suburbanización del Área Metropolitana de Buenos Aires (AMBA). ${ }^{5}$ Desde la esfera del urbanismo, varias investigaciones de los años setenta intentaban encontrar la estructura interna de la ciudad latinoamericana (Schteingart y Torres, Yujnosky) o desentrañar los modelos de ocupación territoriales (Vapñarsky, Sargent). ${ }^{6}$ En la década del ochenta, los estudios se centraron en los modos de producción y transformación del suelo en general (Clichevsky) o en particular en estudios de caso. ${ }^{7} \mathrm{Y}$ si bien la historia del área metropolitana esta aun por escribirse, hubo algunos avances generales (Gutman y Hardoy), trabajos específicos sobre desarrollo territorial en la larga duración (Caride) $\mathrm{y}$, desde la perspectiva de los estudios culturales, estudios que trabajaron la relación entre las políticas públicas, los programas de infraestructura y de vivienda que signaron cambios en los modos de vida y en la configuraron el espacio metropolitano (Ballent y Gorelik). ${ }^{8}$ De algún modo, esta bibliografía que da cuenta de diferentes aristas y

5 Algunas reseñas acerca de las investigaciones que tienen por objeto al AMBA son: Lorena Vecslir, "La Región Metropolitana de Buenos Aires como área de investigación”, Informe Universidad Nacional de General Sarmiento, 2009; Alicia Novick, "City Planning in the history of the city", en Bruce Stiftel, Vanessa Watson and Henri Acselrad (dirs), Dialogues in Urban and Regional Plannig Vol. 2, Routledge, 2007. pp. 268-295; Hilda Herzer, La investigación urbana en la Universidad de Buenos Aires, Documento de trabajo, Programa Especial de Investigaciones Ciudad. Universidad de Buenos Aires, 1996; Nora Clichevsky y Mabel Manzanal, El Estado de la investigación urbana en la Argentina: sus perspectivas. Centro de Estudios Urbanos y Regionales. Buenos Aires, 1987.

${ }^{6}$ Oscar Yujnosky, La estructura interna de la ciudad. El caso latinoamericano. SIAP, Buenos Aires, 1971; Marta Schteingart y Horacio Torres. "Procesos Sociales y estructuración metropolitana en América Latina. Estudio de casos", en Desarrollo Económico, Revista de Ciencias Sociales, N ${ }^{a}$ 48, vol. 12, eneromarzo de 1972. Instituto de Desarrollo Económico y Social, Buenos Aires, pp. 725- 760; Horacio Torres, “El mapa social de Buenos Aires en 1943, 1947 y 1960. Buenos Aires y los modelos urbanos.”, en Desarrollo Económico. Revista de Ciencias Sociales, Vol. 18, No 70, 1978. pp. 163-204; César Vapñarsky, La aglomeración Gran Buenos Aires. Expansión espacial y crecimiento demográfico entre 1869 y 1991, Eudeba, Buenos Aires, 2000; Charles Sargent, The Spatial Evolution of Greater Buenos Aires, 1870-1930, Publicado por Center for Latin American Studies, Arizona State University, 1974

${ }^{7}$ Nora Clichevsky, El mercado de tierras en el área de la expansión de Buenos Aires y su incidencia sobre los sectores populares, período 1943-1973. Centro de Estudios Urbanos y Regionales, Instituto Torcuato Di Tella, Buenos Aires, 1975.

${ }^{8}$ Margarita Gutman y Jorge Enrique Hardoy, Buenos Aires 1536-2006. Historia urbana del Área Metropolitana. Ediciones Infinito, Buenos Aires, 2007. (reformulación del texto editado por Mapfre en 
posturas ante la problemática de la expansión metropolitana fue tomada en cuenta, si bien, a diferencia de esos enfoques, esta tesis esta centrada en las configuraciones territoriales y en las formas urbanas y arquitectónicas que fueron configurando esa expansión en las primeras décadas del siglo XX y cuyas huellas están aún presentes.

En síntesis, el estudio se propone examinar el rol que les cabe a esas urbanizaciones en el proceso de metropolización de la ciudad de Buenos Aires. Si bien no dan cuenta de la totalidad del fenómeno, permiten vislumbrar algunos de los actores y factores que están por detrás de la expansión. Desde el interés por examinar los cambios materiales, el análisis pone el foco en tres dimensiones de análisis. En primer lugar, se analizan las características y los modos de localización de estos barrios parque y loteos de fin de semana a los efectos de dar cuenta de las "formas" -en un sentido amplio, como configuración espacial y como condensadora de una serie de procesos e ideas que están por detrás- que organizan esa expansión. En segundo lugar, se identifica el perfil de

1992); Horacio Caride, Un poco antes del horizonte. Estructura administrativa de la Campaña de Buenos Aires en el siglo XVIII, op.cit; Anahí Ballent y Adrián Gorelik, "País urbano y país rural: la modernización del país y su crisis”, en Alejandro Cattaruzza (dir.), Crisis Económica, avance del estado e incertidumbre politica (1930-1943), Nueva historia Argentina, tomo VII, Sudamericana, Buenos Aires, 2001

${ }^{9}$ La discusión sobre la noción de forma es extensa; pueden verse: Wladislaw Tatarkiewicz, Historia de seis ideas. Arte, belleza, forma, creatividad, mímesis, experiencia estética. Madrid, Tecnos, 1992; Theodor W.Adorno, Teoría Estética. Madrid, Orbis-Hyspamérica, 1984.

Por otra parte, en el debate sobre la relación entre la forma (como morfología, como materialización de una idea o como forma de organización del espacio) y los contenidos que alberga (en cuanto a ideas y a formas de organización social), es necesario problematizar las miradas más formalistas, de origen marxista, en las que prevalece una lectura de las formas urbanas como traducciones del orden social. En los últimos años, en cambio, se ha privilegiado la idea de que las formas no son unívocas, no existen relaciones evidentes o trasparentes entre las formas y un esquema simplificado a partir del cual entender la sociedad. Para evitar estas simplificaciones hay que entender que las formas no son impuestas de una vez y para siempre, de la misma manera que la sociedad está en constante transformación y reorganización. En ese sentido, un análisis complejo debería insertar las formas en el juego de los actores, entendiendo que ni lo social ni lo formal se subordinan mecánicamente uno a otro. Ver, Marcel Roncayolo, Lectures des villes. Formes et Temps.Editions Parentheses, Marseille, 2002. 
algunos de los actores y empresas privadas, así como también de las normas y las instituciones públicas que estuvieron por detrás de su formación y regulación. En tercer lugar, se estudian las arquitecturas y las representaciones urbanas que acompañaron este proceso. Finalmente, en situaciones específicas, se apuntó a revisitar las huellas de esas propuestas que persistieron en el tiempo. 


\section{CAPÍtulo 1. Temas y Problemas}

"Es indudable que nuestra época ha introducido cambios fundamentales en la manera de vivir (...) Por esos cambios, el descanso de fin de semana fuera de la ciudad ya no es un lujo, ni un "snobismo", para las personas, hombres, mujeres o niños que trabajan o estudian en las grandes ciudades, encerradas en las cuatro paredes de las habitaciones, o circulan por calles estrechas, aturdidos por los ruidos del tráfico $\mathrm{y}$ asfixiados por los desprendimientos de anhídrido carbónico" (Arq. James Nobody, "Casas para fin de semana", en $C A C y A$ n49, Junio 1931.p.34. )

\subsection{Metrópolis y expansión: materiales y metodología}

A partir de 1910 se asistió en el área metropolitana al crecimiento de un tipo particular de suburbio moderno, articulado en torno a la residencia de verano o de fin de semana en combinación con la oferta deportiva o paisajística de un área, destinado a la habitación de sectores medios y medios-altos. ${ }^{10}$ En la base de la expansión de los

10 En este punto es necesario proponer, al menos ampliamente, una definición para el concepto de sectores medios. En principio, este se define más fácilmente por aquellos grupos sociales a los que excluye -sectores trabajadores manuales, obreros, operarios y en el otro extremo los sectores ricos de la elite tradicional- antes que por los que incluye. Desde el punto de vista de las condiciones “objetivas" de vida, notamos grandes diferencias entre los sectores que hoy denominamos medios; tanto en lo que refiere a niveles de ingresos como al prestigio social del que gozan. En esta oportunidad, hemos optado por utilizar la fórmula sectores medios para los grupos profesionales, comerciantes, oficinistas o empleados públicos de ingresos medios; mientras que aplicaremos la fórmula sectores medios-altos, para aquellos grupos que, aunque provenientes en muchos casos de las mismas actividades señaladas para los sectores medios, perciben ingresos superiores. Comparables, en cuanto al capital económico que poseen, a muchas familias de elite, aunque no en los rasgos de distinción o el status social que detentan, estos sectores fueron denominados comúnmente nuevos ricos, advenedizos o parvenue.

Para un análisis clásico de la clase media en Argentina ver Gino Germani, "La clase media en la ciudad de Buenos Aires: Estudio preliminar”, en Boletín del Instituto de Sociología, n¹, Facultad de Filosofía y Letras UNBA, 1942. Una visión contrapuesta, sobre todo en cuanto al rol que jugaron las clases medias en el proceso de modernización en Argentina, fue recientemente expuesta en el trabajo de 
suburbios residenciales modernos, se encontraban procesos de modernización técnicos, culturales y sociales. La ampliación de las redes ferroviarias y camineras, la difusión de las tendencias higienistas, la incorporación de pautas de sociabilidad vinculadas al sport y al uso del tiempo libre, la transformación de los modos y los modelos de habitar así como los procesos de ascenso económico, potenciados a su vez por los procesos de metropolización que sufrió la ciudad de Buenos Aires a comienzos de siglo, llevaron a que algunos sectores sociales intentaran compensar las características de la vida urbana con el refugio en sitios aislados. ${ }^{11}$

Este proceso se enmarca dentro de lo que varios autores coinciden en señalar como el ciclo expansivo de Buenos Aires, que habría tenido lugar entre 1887 y $1970^{12}$ y dentro del cual se reconocen, dos subperíodos, que dieron lugar a dos lógicas de crecimiento muy diferentes. La primera expansión, formada entre 1887 y 1938, es tributaria del gran crecimiento poblacional marcado por la fuerte presencia de inmigración europea, cuando se fue generando una corona de barrios periféricos dentro del área de la Capital, ligada a procesos de ascenso social de los sectores populares (artesanos y obreros inmigrantes, pequeños comerciantes inmigrantes o criollos,

Ezequiel Adamovsky, Historia de la clase media argentina. Apogeo y decadencia de una ilusión, 19192003, Editorial Planeta, Buenos Aires, 2009.

${ }^{11}$ Cuando hablamos de metrópolis, remitimos al concepto expuesto por Georg Simmel, en donde se reconocen transformaciones cualitativas que se asocian a la ampliación de la urbe, entre ellas, un cambio en los hábitos y las actitudes de los urbanitas que comienzan a experimentar un creciente sentimiento de anomia y desarraigo generado por la intensificación de los estímulos actuantes sobre la "vida nerviosa" y el avance de los procesos de homogeneización social y cultural. Georg Simmel, "Las grandes urbes y la vida del espíritu”, en El individuo y la libertad. Ensayos de crítica de la cultura, Península, Barcelona, 1986.

Para el caso de Buenos Aires, el pasaje de la gran ciudad a la metrópolis fue señalado por Adrián Gorelik -en clave simmeliana- al reconocer procesos materiales, culturales y políticos que comenzaron a gestarse a partir de la expansión territorial de 1887 y que introdujeron, no sólo un cambio de escala, sino también la masividad de los nuevos sectores populares a la ciudad y a la ciudadanía. Adrián Gorelik, La grilla y el parque. Espacio público y cultura en Buenos Aires, Universidad Nacional de Quilmes, Buenos Aires, 1998.

12 Adrián Gorelik, “Peripheries: Decentering Urban Theory”, en International Conference, UC Berkeley, 5-7 February 2009; Horacio Torres, El Mapa Social de Buenos Aires. 1940-1990, serie Difusión n 3, Facultad de Arquitectura y Urbanismo, UBA, 1993. 
profesionales y burócratas criollos) que a través de loteos económicos lograron acceder a la vivienda propia, a la vez que se esbozaban los primeros pasos de la expansión por fuera de la Capital. ${ }^{13}$ La segunda periferia se organizó por fuera de los límites de la ciudad, justo en el momento en que éstos se materializaban a partir de la construcción de la avenida de circunvalación General Paz (1936-1941). Conjuntamente con la consolidación de la Capital se hacía evidente un proceso de expansión que la sobrepasaba ampliamente y se extendía sobre los espacios intersticiales de los tres brazos principales de la urbanización (Norte, Oeste y Sur), estructurados desde fines del siglo XIX por el ferrocarril. Pero las transformaciones del Gran Buenos Aires ${ }^{14}$ muestran procesos de suburbanización muy variables en cuanto a los sectores que los protagonizaron y a su dimensión espacial y temporal.

En la primera década del siglo $\mathrm{XX}$, los trazados ferroviarios, en conjunción con las ligeras elevaciones conocidas como "lomas", estuvieron por detrás del crecimiento de los pueblos más “aireados” del Sur: Adrogué, Lomas, Temperley o Banfield, elegidos como destino residencial por gran parte de la comunidad británica. ${ }^{15}$ Simultáneamente, en las barrancas del Norte se consolidaban algunos pueblos de veraneo como San Fernando y San Isidro, que acogían a las clases acomodadas porteñas, especialmente, luego de que, años antes, la epidemia de fiebre amarilla fortaleciera la costumbre de pasar las temporadas cálidas en sitios abiertos y elevados. Entretanto, la

${ }^{13}$ Uno de los textos que mejor abordó este proceso es el ya clásico estudio de James Scobie, Buenos Aires: del centro a los barrios, 1870-1910. Ediciones Solar, Buenos Aires, 1977.

14 El decreto provincial 70/48 del 8 de enero de 1948 establecía la condición oficial del "Gran Buenos Aires" incluyendo a la Capital federal y a los diecisiete partidos que habían formado parte del relevamiento censal de 1947. Sin embargo, otro decreto $n^{\circ} 23.438$ del 6 de octubre de 1949 otorgó estatus jurídico a este territorio restringido, pero excluyó a la Capital Federal. Datos citados por Horacio Caride, La construcción de una idea: El Conurbano Bonaerense, 1925-1947, Instituto de Arte Americano e Investigaciones Estéticas "Mario J. Buschiazzo” FADU, UBA, Colección Crítica n ${ }^{\circ}$ 76, Buenos Aires, 1977.

${ }^{15}$ Varios textos ponderan el rol que desde la segunda mitad del siglo XIX tuvo la comunidad británica en la introducción de la sensibilidad pintoresca y en los cambios en las formas de habitar urbana y rural. Ver, Graciela Silvestri, "La vida en clave verde. Cambios en las formas de habitar urbana y rural a mediados del siglo XIX”, en Registros, n 5, Abril 2008, pp. 16-29 y Jorge Buján, La colectividad británica en Quilmes, Buenos Aires, Tesis de Maestría, U.B.A. 2006 
suburbanización protagonizada por los sectores populares se instalaba en la zona Sur donde se registraba un constante crecimiento de la demanda laboral en sectores predominantemente industriales como Avellaneda y Lanús.

Si observamos los resultados de ese desarrollo en un momento en que el área metropolitana ofrecía un grado de consolidación relevante, como es el año 1938, notamos que su configuración general presentaba una superposición de usos que combinaba actividades agrícolas, industriales y residenciales, éstas últimas en su mayor parte de carácter eminentemente popular. ${ }^{16}$ En cuanto al tejido resultante, la trama urbana se extendía principalmente sobre los tres brazos de la expansión que organizaba el trazado ferroviario, con núcleos más densos en torno a las estaciones, y que se iban diluyendo a medida que se alejaban de ellas, dejando espacios vacíos en las áreas intermedias y, sobre todo, dejando grandes áreas vacantes entre las líneas de urbanización mas consolidadas que señalaba el paso de la vía férrea.

Pero es justamente durante la década del treinta cuando las lógicas de ocupación del suelo dictadas por el ferrocarril empiezan a quebrarse por la ampliación de la red caminera y por el proceso de expansión masivo que se experimenta en el GBA. Hacia fines de esta década se inició lo que Horacio Torres caracterizó como el segundo proceso de suburbanización, que tuvo como protagonistas a los estratos de menores ingresos y se diferenció del período anterior en tres cuestiones fundamentales que son: a) el carácter masivo, b) el alejamiento creciente de las áreas de residencia de los sectores populares y c) la presencia creciente del colectivo. ${ }^{17}$

Sin embargo, acompañando una ampliación general en la oferta de lotes y urbanizaciones en áreas periféricas, se percibe hacia los años treinta, un crecimiento

\footnotetext{
${ }^{16}$ Se toma como fecha 1938 por ser el año de realización del Censo Provincial y por lo tanto se cuentan con informes y datos estadísticos precisos. Ver, César Vapñarsky, La aglomeración Gran Buenos Aires. Expansión espacial y crecimiento demográfico entre 1869 y 1991, op.cit.

17 Las zonas de suburbanización "buenas", definidas como aquellas con índices socio-habitacionales superiores a la media, mantuvieron -durante todo el período- una distancia al centro promedio de $9 \mathrm{~km}$, mientras que las zonas "malas" irían tomando localizaciones más alejadas, de manera tal que en 1960 se encontraban a una distancia promedio de $18 \mathrm{~km}$. Horacio Torres, El Mapa Social de Buenos Aires. op.cit y H. Torres, "Evolución de los procesos de estructuración espacial urbana. El caso de Buenos Aires" en Desarrollo Económico, Vol. 15, No. 58 (Jul. - Sep., 1975), pp. 281-306.
} 
particular de aquellas subdivisiones que apelan a consolidarse como barrios parque o sitios para la residencia de week-end, asociados, a inicios del periodo a los núcleos de habitación de los sectores acomodados.

Queremos plantear, entonces, que es posible reconocer un proceso de larga duración, que se habría iniciado hacia 1910 -Cesar Vapñarsky señala a la década que va de 1904 a 1914 como el período en el que se registran la mayor cantidad de loteos en el GBA- y concluiría alrededor de 1950 y en el que se asiste a la formación y consolidación de núcleos suburbanos surgidos de operaciones inmobiliarias que se plantean como predominantemente residenciales de fin de semana, y que contribuyen a imprimir una matriz diferente de aquella de carácter masivo que definió Horacio Torres.

Estos procesos se asentaron inicialmente sobre la tradición de las clases altas, fortalecida a fines del siglo XIX por las residencias secundarias -recreativas- de pasar la temporada cálida en sitios abiertos y elevados. Hacia inicios del siglo XX el crecimiento de estas localidades y la formación de nuevos núcleos habitados por familias de sectores altos contribuyeron a instalar y difundir tempranamente en nuestro país prácticas modernas asociadas al veraneo, el turismo, los deportes o el habitar suburbano. Si bien, estos núcleos en las primeras décadas del siglo XX son parte de un fenómeno de dimensiones reducidas, estructurado alrededor de algunas estaciones ferroviarias con poca relevancia, por el prestigio que adquieren estos sitios poseen un peso innegable que contribuye a la formación de un imaginario urbano que incidió no sólo en los protagonistas del fenómeno sino en sectores más amplios. ${ }^{18}$ Este fenómeno comenzaría a ampliarse a lo largo de los años veinte y treinta, junto con la ampliación en la oferta de los loteos en zonas suburbanas de reciente accesibilidad, siguiendo una lógica de ocupación territorial nueva, hegemonizada por el tendido de la red vial. Desde

${ }^{18}$ Es necesario reflexionar sobre las divergencias entre las transformaciones materiales que sufre un objeto, espacio o paisaje y las imágenes que sobre él se construyen. El abordaje de conceptos como representaciones o imaginarios nos remite a los aportes propuestos por el análisis cultural que han señalado el carácter cultural de los elementos materiales tal como se presentan en los discursos literarios y sociales. Raymomd Williams plantea que la percepción y valoración que tenemos de la ciudad desde las crónicas literarias, no sólo nos permite conocer el objeto estudiado, sino que también revela el punto de vista del observador que opera cargándolo de significados sociales y culturales de acuerdo al contexto vigente. Ver, Raymond Williams, El campo y la ciudad, Paidós, Buenos Aires, 2001. 
el punto de vista socio-cultural, la ampliación de los procesos de suburbanización especulativa destinados a usos residenciales de fin de semana hacia sectores medios, debe ser entendida a la luz de la creciente movilidad social que experimentaba la sociedad argentina y que daba lugar a procesos de "democratización del bienestar". ${ }^{19}$ En la práctica, esto significó la extensión de imágenes y prácticas culturales asociadas inicialmente a los sectores altos y medios-altos hacia capas más amplias de la sociedad. ${ }^{20}$ En esa orientación, es posible plantear que los nuevos emprendimientos se asentaron sobre un imaginario que comenzó a tomar forma a comienzos del siglo XX alrededor de los núcleos suburbanos residenciales y que plantearon la extensión del "estilo de vida suburbano",21, asociado al "espíritu del suburbio jardín"22 y al disfrute del week-end hacia las capas medias de la sociedad. Gran parte de los emprendimientos inmobiliarios suburbanos iniciados en este período pretendieron alzarse como continuadores de una tradición del habitar residencial suburbano legitimado en el período previo por sectores acomodados de la población.

19 Desde los años treinta se impulsaron políticas estatales de fomento al turismo, ciertas leyes sociales como el sábado inglés (1932), y la primera de vacaciones pagas (empleados de comercio, 1934). Estos beneficios, además, se intensificarían a partir del periodo peronista.

El concepto de "democratización del bienestar" es desarrollado por Elisa Pastoriza y Juan Carlos Torre. Ver, Elisa Pastoriza y Juan Carlos Torre, “La democratización del bienestar”, en (dir.) Juan Carlos Torre, Los años peronistas. (1943-1955), Colección Nueva Historia Argentina, Editorial Sudamericana, 2002.

${ }^{20}$ Un debate sobre las formas de intercambio cultural y simbólico que se producen entre diferentes grupos sociales puede verse en, Claude Grignon y Jean-Claude Passeron, Lo culto y lo popular. Miserabilismo y populismo en sociología y literatura. Ediciones Nuevas Visón, Buenos Aires, 1991; o en la introducción a Carlo Guinzburg, El queso y los gusanos, Muchnik Editores, Barcelona, 1981.

21 Adherimos aquí a la caracterización que hace Lewis Mumford, que asocia la vida suburbana con la imagen de un mundo inocente en el que sólo tenían lugar las actividades placenteras: los juegos de golf, el club, y los niños corriendo libremente en el jardín. Ver, Lewis Mumford, La ciudad en la historia, Ediciones Infinito, Buenos Aires, 1979.p. 656.

22 Jeoffrey Whitehand, "England's interwar suburban landscape: myth and reality", en Journal of Historical Geography, vol 25, issue 4, octubre 1999. pp. 483-501. 


\section{1.a Interrogantes}

Ahora bien, en relación a la manera en que se materializaron estos cambios creemos que es necesario abordar el proceso general de la expansión desde la perspectiva de la historia urbana y territorial. A través de esta mirada buscamos reconocer las transformaciones y procesos de crecimiento de núcleos antiguos y formación de nuevos. En particular, se trata de comprender las dimensiones del fenómeno, de identificar las relaciones que se establecen entre las urbanizaciones y los ejes de crecimiento, en relación a su localización y a los momentos de su crecimiento. ${ }^{23}$ Observaremos que el cambio en las lógicas de ocupación del territorio, ligadas principalmente al pasaje de un sistema de ocupación estructurado por el ferrocarril a otro hegemonizado por la ampliación del sistema vial no solo redunda en una distribución diferente de las nuevas urbanizaciones en el esquema territorial, sino que remite a una progresiva incorporación de nuevas imágenes y formas de habitar. Por último, analizaremos los procesos expansivos a partir de su materialización, en tanto permiten iluminar cómo se pusieron en juego, concientemente o no, los modelos de crecimiento urbano en pugna.

¿Qué procesos estuvieron por detrás de las transformaciones materiales del territorio? Este constituirá nuestro segundo campo de preocupaciones. A pesar de una visión extendida que ha tendido a minimizar el rol del Estado en los procesos de estructuración y crecimiento urbano, creemos que es necesario considerar las relaciones entre el sector público y los sectores privados; reconociendo el elenco de actores, normativas e instituciones involucrados en las operaciones de loteo y venta. ${ }^{24}$

\footnotetext{
23 El tipo de análisis morfológico es deudor de los estudios realizados por el Laboratorio de Urbanismo de la Universidad Politécnica de Cataluña para el área de Barcelona. Ver, Manuel de Solà-Morales, Las formas de crecimiento urbano, Ediciones UPC, Barcelona, 1997; y Joan Busquets, La urbanización marginal, Ediciones UPC, Barcelona, 1999.

${ }^{24}$ Es una idea constantemente reiterada, -particularmente desde los ámbitos no académicos- aquella que desestima la implicancia de las políticas públicas y las acciones legislativas del Estado en materia de ordenamiento territorial. A pesar de esto, debe quedar claro que ya sea por acción o por omisión, el Estado es un agente fundamental en la conformación del territorio.
} 
Siguiendo esta línea, nuestro trabajo coincide con las propuestas desarrolladas por la historia y la ciencia política, que consideran el carácter complejo del Estado y la diversidad de cuestiones-actores que entran en juego a la hora de formular e implementar políticas públicas. ${ }^{25}$ Desde ahí se dirime la necesidad de un análisis que ponga de relieve el papel de los funcionarios y las estructuras organizativas en los permanentes reacomodamientos que se producen hacia el interior del Estado y de la interlocución de los actores y agencias estatales con otros actores y esferas no estatales. Por esta razón, conocer la dinámica del sector inmobiliario, la emergencia de las diferentes figuras - públicas y privadas- involucradas en los procesos de formación del suelo, sus formas de organización empresarial y sus lógicas de inversión, posibilita vislumbrar la complejidad del escenario. En ese marco, cabe identificar las alternativas de los trámites para la aprobación de los loteos, las agencias involucradas a nivel Provincial y Municipal, los cuadros legislativos y regulatorios vigentes con el objetivo de conocer el marco de posibilidades dentro del cual se inserta la expansión y la incidencia de las urbanizaciones en el esquema territorial.

Por otra parte, y teniendo en cuenta que la versión local del barrio parque no sólo se construyó en relación a un trazado de calles irregulares y a la baja densidad, sino también en estrecha vinculación a una imagen arquitectónica particular, es que la arquitectura $^{26}$ que acompañó y materializó estos procesos de modernización urbana

25 Theda Skocpol, "Bringing the State Back In: Strategies of Analysis in Current Research”, en P.Evans, D. Rueschemeyer y Th. Skocpol (editors) Bringing the State Back In, Cambridge University Press, Cambridge, U.K. 1985 pp.3-44; Katryn Sikkink, "Las capacidades y la autonomía del Estado en Brasil y la Argentina: un enfoque neo-institucionalista.", en Desarrollo Económico, Buenos Aires. 1993 Pp. $32-$ 128; Oscar Oszlak, La formación del Estado argentino: orden, progreso y organización nacional. Editorial Planeta, Buenos Aires. 1982; Ernesto Bohoslavsky y Germán Soprano, Una evaluación y propuestas para el estudio del Estado en Argentina, en Bohoslavsky, Ernesto y Soprano, Germán (editores) Un Estado con rostro humano. Funcionarios e instituciones estatales en Argentina (desde 1880 a la actualidad). UNGS y Prometeo, Buenos Aires, 2010. Pp. 9-55.

26 Utilizamos la palabra "arquitectura" con minúscula para referirnos al conjunto de la producción edilicia en general y, también a la "Arquitectura" con mayúscula. Entendida esta última como una manera particular de organizar la producción orientada a dar cobijo que se construye procurando comunicar de modo consciente un sentido. Constituye un sistema de pericias técnicas, conceptos y definiciones teóricas, estrategias de ideación, reglas compositivas y jerarquías organizativas. En cuanto a 
constituirá nuestro tercer eje de análisis. En efecto, se observa la incorporación de elementos modernizadores en relación a la vivienda y a los trazados urbanos. Como se ha verificado en procesos de suburbanización similares producidos en otros países, y como se observa de manera muy evidente en el caso de Buenos Aires, gran parte de las imágenes que acompañaron estos procesos no corresponden a la estética modernista sino a la pintoresquista. ${ }^{27}$ Dentro de este marco, nos preguntamos por los actores intervinientes en la construcción de los suburbios y por los vínculos que se establecieron entre ellos y la construcción de una arquitectura doméstica. Si bien se reconoce que a lo largo del siglo XX los programas residenciales comenzaron a ocupar un lugar cada vez más importante en la práctica profesional de los arquitectos, es sabida la escasa participación que estos han tenido, al menos de manera directa, en la construcción de las viviendas de los sectores medios. ${ }^{28}$

Llegados a este punto, es pertinente plantear la discusión expuesta por Carlo Guinzburg, en donde se pregunta por la relación que existe entre la cultura de las clases populares y la de las clases dominantes. Pregunta que puede extenderse al ámbito de la arquitectura doméstica de las clases populares y las clases dominantes. ¿Hasta qué punto es la primera subalterna a la segunda? O, por el contrario, ¿en qué medida expresa la primera contenidos, cuando menos, parcialmente alternativos? ¿Es posible

las relaciones que la Arquitectura establece con el resto de la edilicia, serán tema de análisis particular de este trabajo.

27 Para comprender esta escisión entre modernización y estética modernista, podemos apelar a la diferenciación clásica entre modernización y modernismos, tal como ha sido analizada por Marshal Berman, quien reflexionó sobre las relaciones complejas registradas entre modernización (concepto referido a los procesos estructurales, que en el caso de la vivienda pueden verse en la compactación, distribución y especialización de los espacios, además de la incorporación progresiva de elementos de confort) y modernismos (respuestas culturales y estéticas a los procesos de modernización, que en el caso que nos ocupa implican la adopción de estéticas despojadas, tendientes a la geometrización y a la abstracción formal). Ver, Marshal Berman, Todo lo sólido se desvanece en el aire. La experiencia de la modernidad, Siglo XXI, Madrid, 1988.

28 Horacio Caride analizó el papel desarrollado por las revistas populares en la definición de las tipologías y estilos adoptados por las clases medias en la construcción de la vivienda propia. Ver, Horacio Caride, "La casa propia: el caso del chalet. Notas en las revistas populares de Buenos Aires durante la década infame.", en $D A N A, n^{\circ} 31 / 32$, 1992. pp. 57-64 
hablar de circularidad entre ambos niveles de la cultura? ${ }^{29}$ Desde esta perspectiva, cobran importancia, por un lado, los procesos de difusión que se registraron de manera creciente con el avance del siglo XX; de manera que proponemos analizar revistas, manuales de construcción, tratados y suplementos periódicos, para conocer cuáles eran las tipologías y las imágenes arquitectónicas impulsadas desde una elite profesional en relación a los programas residenciales suburbanos, tanto en el ambiente local como internacional. Contrastar este panorama con las obras construidas en los suburbios, nos permitirá conocer el contexto y los debates dentro de los cuales se integran, a la vez que reconocer los modos de apropiación, las particularidades o no, que se desarrollaron en torno al nuevo programa en el contexto local.

\section{1.b Metodología}

En tanto los temas que investigamos tienen un alcance muy amplio, este trabajo no se propone agotarlos, pero sí contribuir con una puesta a punto de materiales y con una primera serie de hipótesis de trabajo. Uno de los principales problemas metodológicos a los que se enfrenta se desprende directamente de la delimitación del objeto de estudio dentro de la esfera de las prácticas privadas, lo cual supone analizar un universo de acciones dispersas que cobran sentido por el peso que adquieren en el escenario de la expansión, pero son difíciles de aprehender en los archivos. En correlato, se plantea también la consistencia de las fuentes que se derivan de la lógica fragmentaria que caracteriza los procesos de suburbanización. En este sentido el trabajo propone una metodología que considere el tipo de fuentes disponibles.

En general, consideramos tres ejes principales de investigación: las transformaciones materiales del GBA, los barrios parque en relación a sus configuraciones y a los actores, normas e instituciones que intervienen y en relación a la arquitectura, las tipologías y las imágenes suburbanas. Finalmente, a modo de epílogo, se buscó poner en relación los diferentes aspectos abordados, a través del estudio en profundidad de algunos casos.

${ }^{29}$ Carlo Guinzburg, El queso y los gusanos, op.cit. 
En este marco, el núcleo central del análisis está formado principalmente por los datos relevados en el Departamento de Investigación Histórica Cartográfica de la Dirección de Geodesia del MOP, de donde obtuvimos la información sobre los loteos. Construimos un corpus con ochenta y dos casos, de los que seleccionamos aquellos loteos y urbanizaciones que son mencionados como barrios parque o como urbanizaciones de fin de semana. Esta selección apunta a rescatar una caracterización de los años que analizamos, si bien muchos de los trazados no reflejan formalmente las características asociadas al barrio jardín -que supondría lotes amplios, baja densidad y un entorno natural favorable. ${ }^{30}$ No obstante, según nuestra hipótesis, por detrás de esos casos denominados barrios parque es posible dar cuenta del peso cultural y del prestigio que, a partir de los años treinta, adquieren este tipo de urbanizaciones. En efecto, la difusión de nuevos proyectos y, sobre todo, el uso indiscriminado del término forma parte de una estrategia inmobiliaria, que independientemente de las características reales del emprendimiento, remite a una aspiración compartida.

${ }^{30}$ En el campo del urbanismo el concepto de "barrio parque" debe entenderse a partir de la articulación de dos líneas urbanísticas, por un lado dentro de las formas, o marco de ideas, provenientes de lo que la cultura urbanística conoce como "ciudad jardín" derivadas de las propuestas urbanísticas de Ebenezer Howard, y las primeras materializaciones de Raymond Unwin y Barry Parker. Y Por otro lado, dentro de la tradición urbanística del parque informal inglés y los ordenamientos residenciales suburbanos planteados como alternativas al crecimiento urbano, compacto y continuo, que autores como John Wood el joven o Jhon Nash comenzaron a plantear desde fines del siglo XVIII en Inglaterra.

La primera de estas dos corrientes planteaba en la Ciudad Jardín, no sólo la formación de un nuevo entorno urbano sino también de una nueva sociedad. La Ciudad Jardín debía ser autónoma e incorporar distintos tipos y condiciones de personas, incluyendo áreas para la industria, el comercio, la residencia, así como un gran parque rodeándola en forma de cinturón verde. Finalmente, la propiedad de la tierra, así como su desarrollo y control se haría de forma comunitaria. La segunda corriente, en cambio, debe entenderse fundamentalmente como parte de un movimiento que buscaba modificar o mejorar las formas de crecimiento urbano, pero que de ninguna manera se planteaban como alternativa a la ciudad.

Por último, si bien esta que presentamos es una definición amplia que trata de reflejar los múltiples orígenes que se condensan en la idea de "barrio parque", en el Capítulo 2, veremos cuales son los elementos a los que más comúnmente se asoció la idea local del barrio parque dentro del contexto de la expansión. Ver, Ebenezer Howard; Garden Cities of To-Morrow, Faber\&Faber, London, 1902; Raymond Unwin y Barry Parker, Town Planning in Practice: an introduction to the art of designing cities and suburbs. T. Fisher, London, 1909. 
La información básica correspondiente a cada uno de los casos fue ordenada a través de la confección de fichas (ver apéndice), en donde constan los principales datos obtenidos: 1. Localidad a la que pertenece el emprendimiento, 2. nombre de la urbanización, 3. Distancia a la Capital, 4. Dimensiones de la urbanización, 5. Inmobiliaria, 6. Tipo de trazado, 7. Dimensiones de los lotes, 8. Valores de los terrenos, 9. Vinculación con la red vial y 10. Discursos de promoción. Sobre esa base se avanzó en tres procedimientos simultáneos. Por un lado, se construyó una tipología que permite una caracterización de casos. Por otro lado, esas fichas plantean interrogantes que pueden iluminarse con otras fuentes $y$ fue posible profundizar en torno de la identificación de los propietarios de esas tierras, de las inmobiliarias que intervinieron en los loteos con los archivos privados de rematadores y de compañías inmobiliarias. Asimismo, el mapeo de los casos permite detectar regularidades en relación a los ejes metropolitanos de expansión.

En relación al análisis de las acciones del Estado, sus instituciones, sus normativas, nos concentraremos en las memorias de Departamento Topográfico de la Provincia de Buenos Aires, en la formulación de la Ley provincial de formación de pueblos y ejidos $n^{\circ}$ 3. 487(1913), en sus sucesivas reglamentaciones, y en las memorias de la Comisión Asesora del Gran Buenos Aires.

En cuanto a las dimensiones de esa arquitectura suburbana se construyó un corpus de obras que se publicaban en afiches y folletos inmobiliarios. Complementariamente, se examinó el rol que les cupo a los tratados, manuales de construcción, revistas especializadas y revistas destinadas al público en general (ver apéndice) que publicaban ejemplos con imágenes y referencias sobre los modelos residenciales destinados a barrios suburbanos, viviendas de fin de semana y zonas turísticas. En esa clave se estudiaron los discursos de propaganda, promoción y venta de estos emprendimientos.

Finalmente, en los estudios de caso en profundidad, se recurre a un procedimiento diferente de las secciones precedentes. Se trata de reconstruir la trama espacial y arquitectónica, por lo cual a los materiales de archivo se suman los relevamientos in situ. A propósito de esta última parte, es posible referirse a la figura del "historiador como tejedor", tal como la propone Carl Schorske, tomando los aportes de las 
diferentes áreas disciplinares pero combinándolas en un único tejido. ${ }^{31}$ En otras palabras, si bien en los ejes de análisis anteriores se abordan temáticas específicas relativas a la expansión, en esta instancia se busca conocer cómo se construyeron algunos de estos barrios, qué queda hoy de los trazados y las propuestas iniciales. Desde esta perspectiva, es posible apelar a una propuesta de Bernando Secchi en la que intenta superar los debates que plantean explicaciones históricas a través de cortes o continuidades. Recomienda, antes que entender o describir la formación del área metropolitana priorizando una u otra variable, pensar que algunos de los hilos que nos mantienen ligados al pasado de vez en cuando se rompen, mientras otros permanecen bien visibles y fuertes. De esta manera, la "narración" remite a los estudios de caso en profundidad que dan cuenta de detalles y matices imposibles de aprehender de otro modo. Así, se trata de verificar en algunos casos significativos el devenir de la expansión.

En síntesis, el trabajo aborda el proceso de formación y difusión de sectores de suburbanización destinados predominantemente a usos residenciales de veraneo o fin de semana. Para ello, el trabajo se funda en tres núcleos principales, el estudio de la dimensión material de la expansión, el de las normas y las instituciones que contribuyeron a su formación y regulación, y el de la arquitectura y las representaciones urbanas que acompañaron este proceso.

${ }^{31}$ Carl Schorske, La Viena de fin de siglo. Politica y Cultura. Editores Siglo XXI, Buenos Aires, 2011. (1ra edición 1961) 


\subsection{Miradas sobre el crecimiento metropolitano}

La pregunta más amplia que atraviesa este trabajo se interpela por los procesos de suburbanización que, a lo largo de la primera mitad del siglo XX, tuvieron lugar en el área del GBA asociados a los procesos de difusión de la Ciudad Jardín y los barrios parque. Como ya señalamos, los últimos procesos expansivos y la producción historiográfica que les siguió han servido -a nuestro criterio- para reintroducir en la agenda la pregunta por los procesos de suburbanización previos, a la vez que han dejado en evidencia la escasez de estudios y abordajes que existen en el medio local en relación a este tema.

En este marco, la construcción de nuestro objeto propone el recorte de una de las dimensiones que forman parte del proceso histórico de expansión del GBA y que tiene que ver con la formación de núcleos y emprendimientos suburbanos asociados mayoritariamente a usos residenciales no permanentes. El trabajo propone abordar algunos aspectos del proceso material de formación del territorio, en relación a los procesos sociales, culturales y económicos que lo afectan, teniendo en cuenta que forma parte de un área de estudios aún no abordada y que nos permite poner en dimensión histórica muchos de los fenómenos actuales de suburbanización de las elites.

La construcción de una mirada integral sobre estos temas exige conocer conceptos y debates que han sido elaborados tanto por la historiografía del campo internacional como por la producción local. El presente capítulo aborda una serie de textos heterogéneos que son parte de la construcción del objeto de análisis que se despliega a lo largo de la tesis. De acuerdo a lo dicho, los diferentes aportes que se entrelazan para poder pensar la formación del Gran Buenos Aires como área de expansión residencial, responden a varios niveles de abordaje que presentaremos a partir de tres núcleos problemáticos.

En principio, se retoma un grupo de trabajos reunidos en su afán de explicar los procesos de suburbanización. Desde la Historia Urbana, la Geografía Urbana o la Historia Económica se tendió a analizar la expansión en lo relativo a los diferentes factores que incidieron en su formación. Los primeros estudios de la década del sesenta tendieron a presentar el carácter general de la expansión, mientras que en una etapa posterior, nuevos trabajos buscaron una mayor especificidad al analizar y ponderar 
variables sociales, culturales y económicas que pudieron contribuir a definir la expansión.

En este sentido, hemos incluido también dentro de esta sección aquellos trabajos que reflexionan sobre los procesos de expansión, enfatizando en el estudio y la actuación de los agentes, tanto del sector público como del privado. Veremos que en torno a esta preocupación se nuclean trabajos de carácter más teórico, provenientes del área de las ciencias sociales, junto a otros que analizan procesos particulares.

Asimismo, dentro de este mismo núcleo se incorporaron los trabajos que se cuestionan por el desarrollo actual del área. Si bien no es posible entenderlos como antecedentes en el sentido más tradicional del término, sería posible pensar que funcionan como disparadores de preguntas-problemas que atraviesan a nuestro objeto en una perspectiva de la larga duración.

En segundo lugar se abordan los procesos de suburbanización en relación a las transformaciones residenciales que los acompañan, asumiendo principalmente el estudio de las dimensiones culturales que éstos implican. El énfasis suele estar puesto en las transformaciones del habitar, las pautas de consumo o las nuevas formas de sociabilidad asociadas a los procesos de modernización y suburbanización. De ellos no ocuparemos en el segundo núcleo de análisis.

Finalmente, para el estudio que proponemos, es necesario dar cuenta de aquellas contribuciones que se centraron en la materialidad de la expansión urbana y que operan en un nivel intermedio entre las dos líneas que señalamos. Se trata de los aportes que, con lejanas huellas en los trabajos pioneros de los italianos, intentan dar cuenta de las transformaciones materiales del territorio considerando su "morfología" urbana y territorial.

\section{2.a La conformación del área metropolitana}

La expansión suburbana desde la teoría de la modernización

Los primeros trabajos que abordaron los procesos de suburbanización como núcleo de estudios independientes, surgieron en el continente latinoamericano hacia los años sesenta y setenta; cuando la Historia Urbana se estaba configurando como campo de estudios. En este contexto, surgieron las primeras investigaciones que abordaron los 
procesos de suburbanización como problemática de la ciudad latinoamericana. Aquí el enfoque casi excluyente fue el de los procesos de urbanización, objeto de estudio de los "Simposios sobre la Urbanización de América Latina desde sus orígenes hasta nuestros días", que comenzaron a sesionar bianualmente en los Congresos Internacionales de Americanistas desde 1966.

En este período de enorme productividad surgieron trabajos que compartieron la voluntad de formar parte de una "teoría de la ciudad latinoamericana"; reconociendo las particularidades locales estos abordajes se oponían a la tesis que planteaba una relación paralela entre el proceso de urbanización latinoamericano y el de los países capitalistas dominantes, como resultado del proceso de industrialización y concentración de las fuerzas productivas en las áreas urbanas. ${ }^{32}$ El trabajo de Richard Morse "Urbanization in Latin America" (1969), o el ya clásico estudio de José Luis Romero, Latinoamérica: las ciudades y las ideas (1976), revalorizaron a la ciudad como objeto de la cultura, mientras que otros estudios como los de Manuel Castells, Imperialismo y Urbanización en América Latina (1973), priorizaron el análisis de la urbanización dependiente. ${ }^{33}$ Desde estas miradas, la periferia urbana ha sido analizada en relación al proceso de modernización urbano más amplio y su formación entendida, mayoritariamente, como producto de la propagación en las ciudades del éxodo rural generado por la decadencia de las economías locales luego de la crisis de 1930, y en segundo lugar, como consecuencia del proceso de industrialización y dinamismo económico de la ciudad. ${ }^{34}$ El trabajo de José Luis Romero incorporó a los tópicos ya señalados, el nuevo concepto de "ciudad masificada" para caracterizar el fenómeno de transformación verificable en las ciudades latinoamericanas a partir de la crisis de 1930. A través de esta imagen estableció una relación entre el proceso expansivo de las ciudades y la formación de una sociedad nueva -“sociedad de masas”- producto de la fusión entre una sociedad

\footnotetext{
32 Ver, J.Dorselaer y A. Gregory, La urbanización en América Latina, FERES-CRSR, Friburgo-Bogotá, 1962.

33 Adrián Gorelik, "Historiografía Urbana", en Jorge Liernur y Fernando Aliata (dirs.), Diccionario de Arquitectura en la Argentina, Clarín, Buenos Aires, 2004.

34 Richard M. Morse, "Urbanization in Latin America”, en Latin American Review, otoño 1969; José Luis Romero, Latinoamérica: las ciudades y las ideas, Siglo XXI, Buenos Aires, 1976; Manuel Castells, Imperialismo y Urbanización en América Latina, Gustavo Gili, Barcelona, 1973.
} 
constituida y la llegada de "mucha gente de impreciso origen" que procuraba instalarse en la ciudad. ${ }^{35}$

Continuando la línea de la Historia Urbana, en el ambiente local, se destacan las investigaciones de Horacio Torres, Cesar Vapñarsky y Elena Chiozza, que han analizado los procesos históricos de suburbanización a escala más general. El trabajo más importante de Horacio Torres, El mapa social de Buenos Aires. 1940-1990 (1978), proveniente del área de la geografía urbana, resulta fundamental para nuestro estudio y más de treinta años después de su publicación sigue constituyendo el corpus básico para todos aquellos que pretendan abordar alguno de los aspectos que nutren la formación del Gran Buenos Aires. Su importancia radica en la creación de "mapas sociales" para analizar el proceso de metropolización de Buenos Aires. A través del cruce de variables sociales, físico-ambientales y económicas logró mostrar de una manera simple el complejo fenómeno de la expansión. En particular, su trabajo se concentró en el proceso de suburbanización masiva reconocido en el período que se extiende desde la década de 1940 y hasta 1960 y al cual caracterizó como un movimiento "popular" hacia la periferia protagonizado, fundamentalmente, por trabajadores urbanos y por migrantes del interior del país, beneficiados por la expansión de las líneas de colectivos que contribuyeron a mejorar la accesibilidad en zonas periféricas donde los costos de la tierra eran relativamente accesibles. ${ }^{36}$

Otro aporte incalculable para analizar las líneas más generales del proceso de construcción material del GBA fue realizado por César Vapñarsky en dos trabajos: El crecimiento urbano en la Argentina (1989), junto a N.Gorojovsky y La aglomeración Gran Buenos Aires (2000). En este último particularmente se confeccionó y analizó una cantidad de mapas que ponen de manifiesto la amplia red de núcleos poblacionales y localidades que conforman el área metropolitana y permiten seguir su desarrollo en los diversos ejes de crecimiento que, desde 1869 hasta 1991, dieron lugar a formación del

35 En el segundo apartado veremos como el trabajo de J. C. Torre y E. Pastoriza contrapone a esta hipótesis la idea de una sociedad constituida que sólo fue modificada superficialmente por la llegada de las masas migrantes.

36 Horacio Torres, "Evolución de los procesos de estructuración espacial urbana. El caso de Buenos Aires" op.cit y Horacio Torres, El Mapa Social de Buenos Aires. 1940-1990, op.cit. 
área metropolitana de Buenos Aires. ${ }^{37}$ Desde otras aristas, el artículo de Elena Chiozza "La integración del Gran Buenos Aires" (1983) propuso un panorama general en el que combina la dimensión material y cultural para entregarnos una imagen en donde se ponen de manifiesto las diversas facetas que se combinan en el proceso de formación del Gran Buenos Aires. ${ }^{38}$

Actores

Estas discusiones pudieron ser ampliadas durante los años ochenta cuando un grupo de trabajos provenientes de los campos de la Sociología y la Economía Urbana trataron de examinar las características de los procesos de expansión, analizando los diferentes actores involucrados y los mecanismos de producción de la tierra. En principio, cabe mencionar el trabajo de Christian Topalov, sobre el mercado de la vivienda en Francia (1987); y en el contexto latinoamericano, a la investigación de Marta Schteingart, Los productores del espacio habitable: Estado, Empresa y sociedad en Ciudad de México (1989), que comparte junto al trabajo de Samuel Jaramillo, "Producción de vivienda y Capitalismo dependiente: el caso de Bogotá" (1981), el interés por reconocer el rol de los productores de vivienda en el proceso de expansión. ${ }^{39} \mathrm{Y}$, por otra parte los trabajos

37 César Vapñarsky, La aglomeración Gran Buenos Aires. Expansión espacial y crecimiento demográfico entre 1869 y 1991, Eudeba, Buenos Aires, 2000.

Por supuesto, otra serie de estudios diversos acompañan y complementan a los mencionados; entre ellos podemos nombrar a: Charles Sargent, The Spatial Evolution of Greater Buenos Aires, 1870-1930, op.cit; James Scobie, Buenos Aires del centro a los barrios, Ediciones Solar, Buenos Aires, 1977; Guy Bourdé, Buenos Aires: Urbanización e inmigración, Huemul, Buenos Aires, 1977; Ana María Faccioso, “Crecimiento industrial, expansión metropolitana y calidad de vida: El asentamiento obrero en la región metropolitana de Buenos Aires desde principios de siglo.”, en Desarrollo Económico, vol 20, n 80, pp. 549-568; Adriana Marshal, "Inmigración, demanda de fuerza de trabajo y estructura ocupacional en el área metropolitana argentina”, en Desarrollo Económico, vol 17, n 65, p-p. 201-214; Patricio Randle, "Algunos aspectos de la geografía urbana de Buenos Aires.", en Anales de la Sociedad Argentina de Estudios Geográficos, Serie Especial n 11.

${ }^{38}$ Elena Chiozza, "La integración del Gran Buenos Aires”, en José Luis Romero y Luis Alberto Romero (dirs.) Buenos Aires, historia de cuatro siglos. Editorial Abril, 1983.

39 Christian Topalov, Le Logement en France. Histoire d'une marchandise impossible. Presses de la Fondation Nationale des ciences Politiques, París, 1987; Martha Schteingart, Los productores del espacio 
de Nora Clichevsky sobre el mercado de tierras (1975; 2000), o los de Martín Smolka, acerca de la formación de los precios de tierra $(1981 ; 1987) .{ }^{40}$ Dentro del mismo campo afín a la economía, pero desde una nueva perspectiva que se enmarca en la corriente de la Business History, hay que destacar los más recientes aportes de Norma Lanciotti, concentrados en el análisis del mercado inmobiliario y los actores que contribuyeron a su formación. ${ }^{41}$

Problematizando las perspectivas que hicieron hincapié en las prácticas privadas de producción del suelo, señalando en muchos casos la actitud "permisiva" y la "falta de controles" que el Estado impuso a lo largo del proceso expansivo, es necesario introducir la mirada más compleja que algunos trabajos han venido imponiendo desde los años ochenta. Si bien ninguno de los autores que mencionaremos a continuación se ha concentrado particularmente en la cuestión urbana, sus aportes en relación al estudio del Estado serán retomados en el Capítulo 4 en relación a sus mecanismos de acción y su dinámica institucional. En relación a nuestro objeto, analizar al Estado en sus diferentes escalas y niveles de acción puede ser un camino para determinar las implicancias que las políticas públicas y las acciones legislativas pudieran tener en materia de ordenamiento territorial. En el debate internacional, uno de los trabajos pioneros en este tipo de abordaje ha sido el de Theda Skocpol, "Bringing the State Back In: Strategies of Analysis in Current Research" (1985). Aunque también puede mencionarse el trabajo de Pierre Rosanvallon, La crisis del Estado providencia

habitable: Estado, Empresa y sociedad en Ciudad de México, Ed. El colegio de México, México DF, 1989; Samuel Jaramillo, "Producción de vivienda y Capitalismo dependiente: el caso de Bogotá”, en Cede- Uniandes, Bogotá, 1981.

${ }^{40}$ Nora Clichevsky, El mercado de tierras en el área de la expansión de Buenos Aires y su incidencia sobre los sectores populares, período 1943-1973. op.cit; Nora Clichevsky, Tierra Vacante en Ciudades Latinoamericanas, Nora CLichevsky Editora, Toronto, 2002; Martín Smolka, "Precio de la tierra y valorización inmobiliaria urbana: esbozo para una conceptualización del problema”, en Revista Interamericana de Planificación. Vol,15. $\mathrm{N}^{\circ} 60$, diciembre, 1981; O capital incorporador e seus movimentos de valorizacão, en Cadernos IPPUR/UFRJ, n¹, jan-abril. Rio de Janeiro, 1987.

41 Norma Lanciotti, "Mercado inmobiliario en Rosario: inversores, empresas y empresarios en la expansión urbana entresiglos, 1880-1914.", en Séptimas Jornadas "Investigaciones en la Facultad" de Ciencias Económicas y Estadística, Universidad Nacional de Rosario, octubre 2002; y De rentistas a empresarios. Inversión inmobiliaria y urbanización en la pampa argentina. Rosario, 1880-1910. Edición de la Universidad Nacional del Litoral, Rosario, 2009. 
(1995). ${ }^{42}$ Mientras que, la comprensión de la organización y dinámica institucional del Estado y sus agencias en la Argentina se ha visto beneficiada por los trabajos concretados desde la década de 1970 por Oscar Oszlack. ${ }^{43}$ Y más recientemente, por un conjunto de trabajos que desarrollaron análisis en torno a la formación y desarrollo de cuerpos de expertos en las agencias estatales ${ }^{44}$

\section{Nuevos enfoques}

En el último decenio, y en vistas de las últimas transformaciones sufridas en el conurbano bonaerense, reconocemos un nuevo impulso en los estudios sobre la periferia urbana que pueden resumirse en los trabajos surgidos desde el Instituto del Conurbano perteneciente a la Universidad Nacional de General Sarmiento; o los artículos reunidos en el número 194 de la Revista de Arquitectura, donde autores como

42 Theda Skocpol, "Bringing the State Back In: Strategies of Analysis in Current Research" op.cit.; Rosanvallon, Pierre, La crisis del estado providencia, Civitas, Madrid, 1995; Katryn Sikkink, "Las capacidades y la autonomía del Estado en Brasil y la Argentina: un enfoque neo-institucionalista.", en Desarrollo Económico, Buenos Aires, 1993. Pp. 32-128.

${ }^{43}$ Oscar Oszlak, La formación del Estado argentino: orden, progreso y organización nacional. Editorial Planeta, Buenos Aires. 1982

44 José Sánchez Román, El Estado como recaudador: de la Dirección Nacional del Impuesto a los Réditos a la Dirección General Impositiva (1932-1955), en Bohoslavsky, Ernesto y Soprano, Germán (editores) Un Estado con rostro humano. op.cit; Ricardo González Leandri, Breve historia del Departamento Nacional de Higiene. Estado, gobernabilidad y autonomía médica en la segunda mitad del siglo XIX, en Bohoslavsky, Ernesto y Soprano, Germán (comp.), Un Estado con rostro humano. op.cit; Fernando Aliata, "Departamento Topográfico", en Jorge Liernur y Fernando Aliata (dirs.) Diccionario de Arquitectura en la Argentina, Clarín, Buenos Aires, 2004; Anahí Ballent, "Ingeniería y Estado: la red nacional de caminos y las obras públicas en la Argentina, 1930-1943.", en Hist. ciênc.saùdeManguinhos; 15 (3): 827-847. jul-set. 2008; Noelia Fernández, “Temas y problemas: obras públicas y política en el gobierno de Fresco, 1936-1940”, en Iras Jornadas de Investigadores en formación, IDES, Noviembre, 2011; Hernán González Bollo, La estadística pública y la expansión del estado argentino: una historia social y política de una burocracia especializada, 1869-1947. Tesis del Programa de Posgrado en Historia, Universidad Torcuato Di Tella, 2007; Valeria Gruschetsky, Saberes sin fronteras. La vialidad norteamericana como modelo de la Dirección Nacional de Vialidad, 1920-1940., en Mariano Plotkin y Eduardo Zimmerman (comps.) Saberes de Estado en la Argentina, siglos XIX y XX. Editorial Edhasa, Buenos Aires, 2012 Pp 185-212. 
Adrián Gorelik, Alicia Novick, Horacio Caride o Roberto Fernandez, entre otros, debaten sobre pasado y presente del Gran Buenos Aires. ${ }^{45}$ Entre estos vale la pena destacar una de las hipótesis que expone Horacio Caride, contraria a la idea de la expansión creciendo en forma de "mancha de aceite" 46 , en cambio, propone que la estructura espacial de lo que, posteriormente se llamaría el GBA, se fue consolidando a partir de las preexistencias: caminos, capillas, puertos, guardias y fortines que, con distintos grados de relación, estuvieron vinculados con los primeros asentamientos urbanos del área, los cuales serían fundamentales para guiar su desarrollo posterior. ${ }^{47} \mathrm{Si}$ bien este último trabajo se concentra en la formación de los primeros asentamientos del siglo XVIII, se reconoce como de fundamental importancia en tanto puede pensarse como puntapié inicial a la hora de analizar la inserción de los barrios parque y su vinculación con la estructura territorial existente.

Cabe señalar, por último, que dentro del área de los estudios sobre el Gran Buenos Aires, juegan un rol importante las academias y juntas de historiadores locales. Interesados siempre en difundir y preservar el carácter vernáculo, estas juntas publican boletines, diarios y revistas que reúnen artículos e imágenes producidos por historiadores, docentes, periodistas y aficionados del ámbito regional. ${ }^{48}$

No obstante reconocemos en estos trabajos las líneas fundacionales para el estudio de la expansión metropolitana, se trata de obras globales que incitan a profundizar el análisis desde nuevas perspectivas. En efecto, el denominador común de

45 José Borello, (coord.), Aproximaciones al mundo productivo de la Región Metropolitana de Buenos Aires, Universidad Nacional de General Sarmiento, Los Polvorines, 2007; Horacio Caride, La idea de conurbano. 1925-1947, Instituto del Conurbano, Universidad Nacional de General Sarmiento, San Miguel, 1999; Adrián Gorelik, "Buenos Aires en la encrucijada: modernización y política urbana", en Revista de Arquitectura, $\mathrm{n}^{\circ}$ 194, septiembre de 1999, pp. 20-29; Horacio Caride y Alcia Novick, "El Gran Buenos Aires. Apuntes de una historia imposible.”, en Revista de Arquitectura, $n^{\circ} 194$, septiembre de 1999. pp. 30-35.

${ }^{46}$ Esta definición fue dada por la CONADE 1969.

47 Horacio Caride, Un poco antes del horizonte. Estructura administrativa de la Campaña de Buenos Aires en el siglo XVIII, op.cit.

${ }^{48}$ Se pueden mencionar como aglutinantes de estas actividades el Instituto Histórico de Morón; la Junta de Estudios Históricos del Partido de Pilar; el Instituto Histórico Municipal de Lomas de Zamora y el Instituto Histórico Municipal de San Isidro. 
estos trabajos, exceptuando las historias locales, ha sido el análisis de los grandes procesos de suburbanización, generalizables a casi todas las grandes ciudades del continente latinoamericano en relación a procesos migratorios internos o cambios en la estructura económica, mientras que, se ha otorgado escasa relevancia al estudio de la materialidad de dichos procesos.

\section{Expansión y globalización}

Más recientemente, y como contrapartida al panorama de estudios más generales que venimos de presentar, los procesos de expansión contemporáneos son objeto de un sinnúmero de estudios. Creemos en la necesidad de su introducción en este capítulo en tanto problematizan temas actuales capaces de establecer un diálogo con problemáticas similares planteadas desde una perspectiva histórica en relación a nuestro objeto.

Siguiendo la clasificación propuesta por Lorena Vecslir, se reconocen tres "temas-problemas" definidos de manera "ampliada", a fin de dar lugar a la incorporación de estudios de diversa índole pero que presentan en común algunos rasgos distintivos. ${ }^{49}$ Así, asumiendo los riesgos que supone un intento de clasificación de estas características, se exponen a continuación los resúmenes ejecutivos de los trabajos más destacados o que resultan más representativos de las siguientes líneas temáticas:

-Procesos de construcción de la ciudad

Esta primera línea incluye aquellos trabajos enmarcados en la discusión sobre las transformaciones territoriales recientes en el contexto de la "ciudad capitalista" y los procesos de globalización. Aborda la relación entre territorio y dinámicas económicas contemporáneas.

Se destacan los trabajos producidos por el Instituto de Geografía de la UBA, dirigido por Pablo Ciccolella, en donde se lleva adelante una línea de investigación centrada en los efectos que resultan de las grandes inversiones, generalmente

\footnotetext{
${ }^{49}$ Lorena Vecslir, “La Región Metropolitana de Buenos Aires como área de investigación”, op.cit.
} 
extranjeras, en las nuevas formas y contenidos del crecimiento metropolitano. ${ }^{50}$ Los que surgen en relación al proyecto de investigación dirigido por David Kullock, "La construcción del caso Buenos Aires a partir de la obra de Horacio Torres: Paradigmas Teóricos y Mapas Sociales" con sede en el Centro de Investigación Hábitat y Municipio. Facultad de Arquitectura, Diseño y Urbanismo. Universidad de Buenos Aires. $^{51} \mathrm{Y}$ aquellos que han profundizado la investigación sobre los procesos de suburbanización residenciales: Daniela Szajnberg, "Tendencias en la organización del espacio residencial en la RMBA en los noventa. Torres amuralladas y urbanizaciones cerradas: la recentralización del centro de la metrópolis y la suburbanización de las elites" (2000); "Urbanizaciones cerradas en la región metropolitana de Buenos Aires ¿Se ha de replantear la estructura de centralidades suburbanas? El caso de los partidos de Pilar y Tigre”. (2000); Sonia Vidal-Koppmann, "Las urbanizaciones privadas: ¿una innovación para la transformación del territorio?” (2000); y Julieta Frediani, Lógicas y tendencias de la expansión residencial en áreas periurbanas. En Partido de La Plata, Buenos Aires, Argentina, entre 1990 y 2010 (2010). ${ }^{52}$

${ }^{50}$ Pablo Ciccolella, “Grandes inversiones y dinámicas metropolitanas: Buenos Aires ¿Ciudad global o ciudad dual del siglo XXI?", en Mundo Urbano. Buenos Aires: Secretaría de Comunicación y Tecnologías de la Información de la Universidad Nacional de Quilmes, 2000; “Distribución global y territorio. Modernización y concentración comercial en Argentina en los años '90", en Economía, Sociedad y Territorio. Vol. II, no. 7. Toluca: El Colegio Mexiquense, 2000.pp. 459-496; Lorena Vecslir y Pablo Ciccolella, "Nuevos territorios del ocio y el comercio en la región metropolitana de Buenos Aires (1990-2008)", en Proyección. Vol. 2, n 7. Mendoza: CIFOT. 2009; Pablo Cicolella y Lorena Vecslir, “Dinámicas, Morfologías y singularidades en la restructuración metropolitana de Buenos Aires", en Riurb 08-2012, Buenos Aires: Procesos metropolitanos, Barcelona-Buenos Aires, 2012.

${ }^{51}$ Artemio, P., Abba, Nuevas tendencias socioterritoriales en el Área Metropolitana de Buenos Aires, en David Kullock y Alicia Novick (coords.), Debates sobre ciudad y territorio. Ediciones Fadu, Nobuko, Buenos Aires, 2010; Federico Collado, El caso Nordelta. Reflexiones sobre el futuro del suburbio de los ricos, en David Kullock y Alicia Novick (coords.), Debates sobre ciudad y territorio. Ediciones Fadu, Nobuko, Buenos Aires, 2010.

52 Daniela Szajnberg, “Tendencias en la organización del espacio residencial en la RMBA en los noventa. Torres amuralladas y urbanizaciones cerradas: la recentralización del centro de la metrópolis y la suburbanización de las elites", en La Metrópolis Postsocial. Buenos Aires entre la economía global y la sociedad polarizada. Pablo Ciccolella e Iliana Mignaqui (comps.). Eudeba, Buenos Aires, 2000; "Urbanizaciones cerradas en la región metropolitana de Buenos Aires ¿Se ha de replantear la estructura 
- Hábitat, reforma urbana, derecho urbanístico

Esta línea remite a un área de investigación focalizada en los problemas de pobreza y marginalidad, funcionamiento del mercado de tierras y sus efectos sobre la configuración del espacio urbano.

Los principales referentes de este campo lo constituyen los últimos trabajos de Nora Clichevsky, "Algunas reflexiones sobre informalidad y regularización del suelo urbano" (2009); “Acceso a la tierra urbana y políticas de suelo en el Buenos Aires Metropolitano" (2012), o nuevas investigaciones que se insertan en esta línea como las de Luis Baer, "Sobre el funcionamiento del mercado inmobiliario porteño y las mayores restricciones para acceder a la vivienda luego de la crisis 2001-2002” (2009), "Mercados del suelo y producción de vivienda en Buenos Aires y su área metropolitana." (2012). ${ }^{53}$

Mientras que dentro de la temática que indaga entorno a los procesos de exclusión, segregación y fragmentación que las nuevas modalidades de hábitat (formal

de centralidades suburbanas? El caso de los partidos de Pilar y Tigre", en Área. Agenda de Reflexión en Arquitectura, Diseño y Urbanismo. Facultad de Arquitectura, Diseño y Urbanismo, Universidad de Buenos Aires, 2000, pp. 21-38; Sonia Vidal-Koppmann, "Las urbanizaciones privadas: ¿una innovación para la transformación del territorio?", en Scripta Nova. Revista electrónica de geografía y ciencias sociales. Vol. IV, no. 69 (Ejemplar dedicado a: Innovación, desarrollo y medio local. Dimensiones sociales y espaciales de la innovación: II Coloquio Internacional de Geocrítica) Universidad de Barcelona, Barcelona, 2000; Julieta Frediani, Lógicas y tendencias de la expansión residencial en áreas periurbanas. El partido de La Plata, Buenos Aires, Argentina, entre 1990 y 2010. Tesis Doctoral en Geografía, Universidad Nacional de La Plata, FaHCE, 2010.

${ }^{53}$ Nora Clichevsky, “Algunas reflexiones sobre informalidad y regularización del suelo urbano”, en Bitácora Urbano Territorial, vol. 14, enero-junio 2009, Universidad Nacional de Colombia, Bogotá, 2009. pp. 63-89; “Acceso a la tierra urbana y políticas del suelo en el Buenos Aires Metropolitano”, en Riurb 08, Buenos Aires: procesos metropolitanos, Barcelona-Buenos Aires, 2012; Luis Baer, "Sobre el funcionamiento del mercado inmobiliario porteño y las mayores restricciones para acceder a la vivienda luego de la crisis 2001-2002", en Serie Urbana, año 9, $\mathrm{n}^{\circ}$ 18, Instituto de Investigaciones en Humanidades, UBA, Colegio Nacional Buenos Aires, 2009; "Mercados del suelo y producción de vivienda en Buenos Aires y su área metropolitana", en Riurb 08, Buenos Aires: procesos metropolitanos, Barcelona-Buenos Aires, 2012. 
e informal) generan, se destacan, entre otras, las investigaciones de Maristella Svampa. ${ }^{54}$

- Redes de infraestructura y transporte

En relación a la movilidad y el nuevo espacio metropolitano, destacan en general los aportes del equipo del Programa de Transporte y Territorio del Instituto de Geografía de la Facultad de Filosofía y Letras (UBA), coordinado por Andrea Gutiérrez. Y los trabajos generados en Facultad de Arquitectura y Urbanismo de La Plata, dentro del ámbito del Instituto de Investigaciones y política del ambiente construido (IIPAC). ${ }^{55}$

Una segunda cuestión dentro de las "redes de infraestructura" como tema prioritario, es la relación entre asentamiento y servicios infraestructurales. Producto de un trabajo de investigación realizado entre 1997 y 2001, Pedro Pírez, Elías Rosenfeld, Jorge Karol y Gustavo San Juan (2003) integran dos perspectivas sobre los problemas urbano regionales que se han desarrollado de manera relativamente autónoma en el estudio de las infraestructuras y servicios: el de las redes como componentes estructurales y materiales y el de los servicios como actividades sociales. Así, en los diferentes capítulos del libro El sistema urbano-regional de redes de servicios $e$ infraestructura (2003) desarrollan los elementos teóricos de sistémica y redémica para los servicios y sus relaciones, abordan el estudio de los servicios a partir del concepto del sistema político institucional, exponen diferentes modelos de gestión en las metrópolis de Buenos Aires y La Plata, y debaten los problemas teóricos y de gestión involucrados en la privatización de servicios y en la interacción de los distintos actores sociales $^{.56}$

${ }^{54}$ Maristella Svampa, Los que ganaron. La vida en los countries y barrios privados. Op.cit; La brecha urbana. Countries y Barrios privados en Argentina. Editorial Biblos, Buenos Aires, 2004.

55 Andrea Gutierrez, "Gestión Metropolitana del transporte colectivo en Buenos Aires", en Riurb 08, Buenos Aires: Procesos Metropolitanos, Barcelona-Buenos Aires, 2012; Olga Ravella y Nora Giacobbe, "Hábitat y movilidad en la restructuración urbano territorial del siglo XXI. El caso del Gran La Plata", en Avances en energías renovables y Medio Ambiente. vol 8, $\mathrm{n}^{\circ}$ 1, 2004, u Olga Ravella, H. Olivera y Laura Aon, "El transporte Urbano como Estructurador del Futuro Desarrollo", IDEHAB, FAU, UNLP, diciembre, 2007

${ }^{56}$ Pedro Pírez, Elías Rosenfeld, Jorge Karol y Gustavo San Juan, El sistema urbano-regional de redes de servicios e infraestructura, Editorial Universitaria de La Plata (EDULP), 2003. 


\section{2.b Habitación suburbana y prácticas culturales}

Abordaremos ahora una serie de estudios que se relacionan con la problemática de la expansión desde la perspectiva de los estudios culturales. La diversidad de fuentes y de discursos que desde esta corriente se han incorporado a los estudios históricos permitirá analizar las transformaciones sociales y culturales que se organizan en torno a la expansión. $^{57}$

Dentro del marco general que nos proponemos analizar, organizaremos la presentación de los trabajos surgidos en este ambiente a través de dos grupos. En el primer grupo, enseñaremos, algunas reflexiones teóricas generales sobre los valores culturales asociados a la expansión suburbana. En un segundo apartado, veremos que varios trabajos han analizado recortes particulares, como las imágenes urbanas, las tipologías arquitectónicas, los procesos de difusión cultural o las prácticas sociales que acompañaron los procesos de modernización y expansión urbana.

A partir de los años ochenta nuevas temáticas se organizaron en torno al estudio de la ciudad y se ocuparon de problemas como su forma, su paisaje, su expansión, su construcción, la conformación del espacio público, los modos de habitar, las políticas estatales en torno a la vivienda o la construcción de imaginarios y sus representaciones. Como parte de este contexto, nos interesan particularmente algunos autores que analizan cuestiones singulares, como la arquitectura, las imágenes y las prácticas culturales que surgen en tono al habitar, acompañando los procesos de modernización que se hacen presentes a través de la modernización territorial, la expansión suburbana, o el auge del turismo.

57 En su artículo, "Notas sobre Historia Cultural Urbana. Una perspectiva latinoamericana", Arturo Almandoz señala como desde los años '80 en Latinoamérica, la historia cultural de las ciudades se ha caracterizado en gran parte por la diversidad de fuentes y los discursos utilizados para recrear, generalmente, en una aproximación microhistórica las manifestaciones culturales de los diferentes actores citadinos, así como sus formas de representación. Arturo Almandoz, "Notas sobre Historia Cultural Urbana. Una perspectiva latinoamericana”, en revista electrónica Perspectivas Urbanas, 2002. http://upcommons.upc.edu/revistes/html/2099/20/art01-3.htm 
Reflexiones generales

Para poder pensar la formación del Gran Buenos Aires como área de expansión residencial, ofreceremos en principio una breve síntesis sobre dos trabajos clásicos que han abordado algunos conceptos generales en relación al estudio de la expansión residencial suburbana y los modos de vida asociados a ella. En este sentido las investigaciones de Lewis Mumford, Richard Sennet y Robert Fishman, a pesar de que se fundan sobre procesos de suburbanización de carácter residencial permanente, han sido inspiradores de algunos temas que abordaremos en nuestro análisis.

Una de las miradas más agudas a propósito de la expansión suburbana de las clases medias y a la formación de suburbios residenciales en el medio anglo-americano fue introducida por Lewis Mumford como parte de su tarea como activista y actualizador de la ciudad jardín como alternativa a la concentración metropolitana. Sus trabajos en el campo de la historia de la cultura urbana y, especialmente, La ciudad en la historia (1961) presentaron un análisis de las ideologías y los deseos que impulsaron la "huida de la ciudad". Desde esta óptica, la retirada hacia el suburbio funcionó, para las llamadas clases acomodadas, como un refugio de privacidad y calma ante las ciudades congestionadas, al cual se asocia un "modo de vida suburbano" que el autor caracterizó como menos reglamentado y menos formal en el sentido de los centros urbanos orientados a la producción, y detrás del cual se esconde el deseo de generar una comunidad segregada, no solo en el espacio sino en su intención de conformar una especie de ghetto dedicado a la elite. En este sentido, los suburbios reflejaron desde su propio inicio un deseo de separación impulsado por ciertos sectores que se consideraban diferentes del resto de la sociedad.

Muchos años después, Richard Sennet (1975) se refirió al "mito de la comunidad purificada" para caracterizar a los nuevos sectores residenciales suburbanos de lo que él llamaba la "clase media opulenta". También hizo hincapié en la necesidad -a la cual responderían estos espacios- de esta nueva clase de construir un "nosotros" acabado y definitivo como contrapartida a los grandes cambios y desplazamientos que se producen en la sociedad. La inestabilidad e inseguridad resultante estaría en la matriz 
de toda imagen de comunidad a fin de proporcionar cierto orden al caos imperante. ${ }^{58}$

Como continuador de alguno de los conceptos ya planteados, el libro de Robert Fishman, Burgeois Utopias (1987), se alzó como uno de los textos ineludibles para quienes desearan abordar el tema de los suburbios residenciales. Dentro de su análisis, nos interesa especialmente el enfoque puesto en reconocer los valores y las ideas subyacentes en la formación de los suburbios anglo-americanos. En este espacio, Fishman reconoció la representación del triunfo de los valores de la clase media. El ideal de la vida familiar y del hogar propio, como santuario privado alejado de la alienación que genera el mundo urbano-laboral, fueron traducidos en una imagen formal de baja densidad y casas individuales con jardín a los lados ${ }^{.59}$

En esta sintonía, la comprensión de los suburbios residenciales como símbolos del habitar de las clases medias es un concepto que retomaremos, en cuanto invita a cuestionarse sobre la situación local. Precisamente, nos permitirá pensar en las imágenes que funcionaron como meta para amplios sectores de la población y que operaron detrás de la masificación de los loteos.

Imágenes arquitectónicas y prácticas culturales en torno al habitar suburbano

Los trabajos que se presentan a continuación, nucleados en torno a las experiencias que tuvieron lugar en Inglaterra, han analizado los suburbios residenciales y las variables que operaron en el proceso de ampliación social y demográfica de dichas áreas, desde el cambio de siglo hasta la década del veinte. En líneas generales puede afirmarse que los primeros trabajos, realizados en la década del treinta partieron de un interés particular por los arquitectos. Desde este enfoque las zonas residenciales suburbanas fueron entendidas en relación directa a las prácticas profesionales. A partir de los años setenta esta hipótesis se ha ido modificando con sucesivos trabajos que comenzaron a investigar la producción material de los suburbios de clase media, no sólo como producto de los arquitectos, sino de un complejo entramado de actores que incluyó también dueños de la tierra, inversores, constructores y comitentes.

\footnotetext{
58 Richard Sennet, Vida urbana e identidad personal. Los usos del desorden. Editorial Península, Barcelona, 1975.

${ }^{59}$ Robert Fishman, Burgeois Utopias: the rise and fall o suburbia, Basic Books, 1987. p11
} 
Si bien, estas investigaciones han sido realizadas sobre áreas suburbanas de vivienda permanente, su análisis resulta pertinente dentro de nuestra investigación ya que, como mencionamos en la introducción, funcionaron como modelos ideales -difundidos en catálogos y revistas- para la formación de núcleos de fin de semana, además de que atravesaron procesos de difusión y ampliación similares a los que analizaremos en el contexto local.

Cabe señalar que dentro del ambiente inglés, se mantuvo siempre una línea historiográfica simpatizante con las tendencias arquitectónicas y urbanas que de alguna manera resumían el carácter de lo inglés. Interesada siempre en difundir y preservar la arquitectura nacional, esta vertiente puede resumirse en primer lugar, en la actuación de la Society of Architectural Historians of Great Britain, cuyos más reconocidos protagonistas, Christopher Hussey y Mark Girouard, han sido también colaboradores de la revista Country Life y han revisado sus archivos para rescatar parte de la tradición británica y a sus grandes arquitectos. ${ }^{60}$ En segundo lugar, a partir de la línea historiográfica demarcada por la revista Architectural Review, durante el período de dirección de Nikolaus Pevsner (1947-1970) junto a la colaboración de Thomas Gordon Cullen (1947-1959). Particularmente entre fines de los años cuarenta y a lo largo de toda la década del cincuenta la revista mantuvo vigente la línea del pintoresquismo, entendido, no como estilo sino como respuesta arquitectónica adecuada a las condiciones locales, asignando un rol primordial al concepto de genius loci dentro de la arquitectura británica.

En este contexto, la carrera de Nikolaus Pevsner merece sin duda una mención especial. Fue el mayor difusor de la tradición pintoresquista británica, considerado además como uno de los fundadores de la historiografía de la Arquitectura Moderna. En su libro Pioneros del Diseño Moderno (1936), rescató la tradición arquitectónica de la isla como base para una nueva arquitectura, señalando una continuidad entre las teorías medievalistas de Ruskin o Morris, el movimiento Arts and Crafts y los inicios

\footnotetext{
${ }^{60}$ Ver por ejemplo, Christopher Hussey, The life of Sir Edwin Lutyens, Country Life, 1953; Christopher Hussey, English Country Houses, Country Life, 1955; Mark Girouard, The Victorian Country House, Clarendon Press, 1971.
} 
del Movimiento Moderno. ${ }^{61}$ El autor remarcó la avanzada de los profesionales ingleses durante el siglo XIX con respecto a los colegas del continente y señaló a la arquitectura como condensadora de las mejoras en torno al hábitat y la vivienda. La visión expuesta por Pevsner tendió a unificar mejoramiento de las condiciones de habitabilidad, arquitectura pintoresca y conformación del hábitat suburbano. Esta perspectiva ha tenido -y tiene todavía- una influencia muy importante en el imaginario suburbano que entiende como parte de un mismo conjunto a los suburbios residenciales de clase media, los suburbios jardín y la arquitectura pintoresquista, otorgándole a esta última un rol fundamental en la conformación de ese espacio.

En el año 1982 se editó en Italia un volumen sobre la arquitectura doméstica en Gran Bretaña, dentro de este texto resulta particularmente interesante el artículo de Guido Zucconi "De la fase heroica a la estandarización”, en él analizó la etapa de desarrollo y definición de las tipologías de arquitectura doméstica en Inglaterra, entre 1860-1905 y el proceso de difusión que le siguió, entre 1905-1920. Frente a las historias tradicionales que tendieron a valorizar a los grandes arquitectos de fines del siglo XIX, el autor señaló la importancia del período de difusión como de avance hacia la estandarización y puesta en práctica de los modelos previamente experimentados. En su hipótesis, este pasaje permitió la apropiación por parte de profesionales que trabajaban para las clases medias en ascenso de una serie de elementos e imágenes arquitectónicas anteriormente vinculadas a un grupo de arquitectos de elite que de esta manera pasarían a formar parte de las residencias de los sectores medios que conformarían mayoritariamente los suburbios ingleses en el siglo XX. ${ }^{62}$

Continuando esta idea, en la década del noventa, Peter Hall (1996) encontró que después de la Primera Guerra Mundial grandes cambios en la estructura económica del país dieron lugar a la formación de una nueva clase media cuyos ingresos les permitían acceder a la compra de una vivienda adosada en los nuevos suburbios desarrollados por

\footnotetext{
61 José María Montaner señala al texto de Pevsner, Pioneros del Diseño Moderno, como básico en el estudio de la historia de la Arquitectura Moderna, remarcando que fue además el primer texto en utilizar el término "Movimiento Moderno" que tanto se popularizaría después. José María Montaner, Arquitectura y Crítica, Gustavo Gilli, Barcelona, 1999.

62 Guido Zucconi, De la fase heroica a la estandarización, en Calabi, Donatela (comp) Architettura domestica in Gran Bretagna. 1890-1939, Electa Editrice, Milan, 1982.
} 
promotores y sociedades constructoras, quienes recrearon las imágenes del suburbio romántico a un costo moderado, destinado a un público de clase media en constante expansión. $^{63}$

Por último, los estudios más recientes de Jeoffrey W. Whitehand $(1999 ; 2001)$ han señalado en el proceso de suburbanización inglesa de la década del veinte, la expansión del "espíritu del suburbio jardín"-garden suburb ethos- que, junto con otras prácticas de difusión como las exposiciones anuales de vivienda (Ideal Home Exhibition) o la difusión de manuales de arquitectura y construcción, ofrecieron imágenes del habitar suburbano y objetos arquitectónicos legitimados culturalmente que fueron reproducidos a un costo módico por una clientela de sectores medios en expansión. ${ }^{64}$

Desde preocupaciones similares, investigadores del ámbito local desarrollaron una serie de reflexiones que ponen de relieve los procesos de difusión y democratización, tanto de las imágenes y las prácticas relacionadas al habitar como de las tipologías arquitectónicas.

Dentro de una línea interpretativa, varios trabajos de Jorge Francisco Liernur (1984; 1999) han abordado el análisis de la construcción de la modernidad en nuestro país en su relación con la arquitectura y la ciudad. Dentro de este marco, el autor profundizó el estudio referido a la modernización de los "modos de habitar" en relación a las tipologías de vivienda. ${ }^{65}$ Sus estudios sobre compactación de la vivienda dejaron ver, entre otras cosas, el alcance en la difusión de las tradiciones anglosajonas que

${ }^{63}$ Peter Hall; Ciudades del mañana. Historia del urbanismo en el siglo XX, Ediciones del Serbal, Barcelona, 1996.

${ }^{64}$ J. Whitehand y C. Carr; Twentieth-Century Suburbs: A Morphological Aproach, Routledge, Londres, 2001; J. Whitehand, "England's interwar suburban landscape: myth and reality", en Jorunal of Historical Geography, vol 25, issue 4, octubre 1999. pp. 483-501.

${ }^{65}$ El concepto de "modos de habitar" surge fundamentalmente de los trabajos en torno a los estudios de la vida privada. Ver, Michelle Perrot, "Modos de habitar. La evolución de lo cotidiano en la vivienda moderna", en $A \& V$ monografias, $\mathrm{n}^{\circ} 14$, El espacio privado. Madrid, 1988 y Georges Teyssot, "Lo social contra lo doméstico. La cultura de la casa en los últimos dos siglos.”, en $A \& V$ monografías, n ${ }^{\circ} 14$, op.cit. 
allanaron la incorporación de tipologías compactas y que permitieron comprender a los ámbitos de dimensiones pequeñas dentro de la noción de modernización. ${ }^{66}$

Por su parte, los trabajos de Anahí Ballent, "La "casa para todos": grandeza y miseria de la vivienda masiva" (1999) y Las huellas de la política (2005), se concentraron en la relación entre la vivienda, los modos de habitar y las acciones implementadas desde el Estado en torno al tema. En el artículo que aborda el desarrollo de la vivienda masiva en nuestro país, la autora sugiere que la introducción de las tipologías de "vivienda moderna" al habitar masivo comprendió dos fases: en la primera (1930-1945) los modelos e imágenes fueron difundidos entre los sectores medios y altos, para, en el siguiente período (1945-1955), extenderse a la vivienda de otros sectores sociales a través de la acción del Estado. De esta manera, la redistribución operada por el peronismo permitía -a fines de los años cuarenta- a los sectores medios compartir imágenes y espacios que anteriormente les estaban vedados. Algunos años más tarde, en el segundo texto, se centró en la compleja relación entre arquitectura y política en los años del peronismo. Allí ha demostrado cómo algunas imágenes de la arquitectura californiana que se incorporaron a nuestro país hacia la década del treinta, de la mano de operaciones residenciales de carácter exclusivo, pasaron luego -en el momento en que su uso declinaba entre sus cultores iniciales- a incorporarse al habitar de los sectores medios a través de un proceso de difusión masivo y de redistribución operado por el peronismo, que apelaba a imágenes asociadas con el habitar de los sectores medios y altos y que todavía conservaban su prestigio entre un público amplio. ${ }^{67}$

Por último, en un análisis de las transformaciones socio-culturales que atravesó la Argentina en la década del cuarenta, Juan Carlos Torre y Elisa Pastoriza (2002)

66 Jorge F. Liernur, "Buenos Aires: la estrategia de la casa autoconstruida", en AA. VV. Sectores populares y vida urbana, CLACSO, Buenos Aires, 1984; Jorge F. Liernur, “Casas y Jardines. La construcción del dispositivo doméstico moderno (1870-1930)", en Historia de la Vida Privada en la Argentina, Fernando Devoto (dir.), Taurus, Buenos Aires, 1999, pp. 103-104.

67 Anahí Ballent, “Country Life: los nuevos paraísos, su historia y sus profetas”, en Revista Block n², UTDT, Buenos Aires, 1998; A. Ballent, "La "casa para todos": grandeza y miseria de la vivienda masiva”, en Fernando Devoto y Marta Madero (dirs.), Historia de la vida privada en Argentina, Taurus, Buenos Aires, 1999; A. Ballent, Las huellas de la política. Vivienda, ciudad, peronismo en Buenos Aires, 1943-1955, Prometeo y UNQUI, Buenos Aires, 2005. 
proponen una visión que complejiza la idea tradicional que supone un país transformado desde sus cimientos, en sus esquemas de ideas y modelos de comportamiento por la irrupción de las masas peronistas. ${ }^{68}$ En cambio, plantean que durante este período tuvo lugar un proceso de asimilación de dichas masas (provenientes en su mayoría del interior del país) a una sociedad receptora que para la década del treinta se encontraba sustancialmente consolidada, y cuyos valores y estilos de vida, popularizados por las radios, los periódicos y las revistas, estaban además revestidos de un prestigio consolidado. De esta manera, y en particular en relación a las prácticas culturales, los autores señalan que vastos sectores populares siguieron las pautas ya desarrolladas por los sectores medios. Y que, incluso una vez instalado el peronismo, no se asistió a un cambio en los modelos culturales, sino que la gran transformación consistió en crear oportunidades que pusieran al alcance de nuevas mayorías los ideales y las costumbres que los sectores medios ya habían probado y en los que la ciudad se reconocía ufana. ${ }^{69}$

De los últimos trabajos expuestos surgen las claves principales para comprender en su dimensión social y cultural el fenómeno que analizamos (la ampliación de los procesos de suburbanización especulativa que priorizan los usos residenciales no permanentes en el área metropolitana), en cuanto podemos pensar que este se inscribe en un contexto más amplio en el cual fue común la extensión de imágenes y prácticas culturales asociadas inicialmente a los sectores medios y medios-altos hacia capas más amplias de la sociedad.

\section{2.c La construcción del territorio}

Los ejes que planteamos hasta el momento ponen de manifiesto dos escalas de análisis contrapuestas. Por un lado, los primeros estudios han abordado las grandes transformaciones estructurales que condicionaron el proceso de la expansión; en el otro

\footnotetext{
${ }^{68}$ Recordemos por ejemplo el trabajo ya citado de José Luis Romero, Latinoamérica: Las ciudades y las ideas, que si bien no se concentra en el caso argentino en particular, habla de la formación de una nueva sociedad a partir de la llegada de las masas populares a las ciudades.

69 Juan Carlos Torre y Elisa Pastoriza, "La democratización del bienestar”, op.cit. p. 266.
} 
extremo, el enfoque fue puesto en fenómenos más particulares, que tienen que ver con las transformaciones de la residencia y la vida privada en el marco de un proceso de modernización habitacional y territorial. Ambos ejes deben ser entendidos como manifestaciones extremas que iluminan ciertos aspectos del proceso de urbanización del Gran Buenos Aires, del cual todavía quedan muchas preguntas por hacer. Analizar este proceso, aunque sólo sea en relación a la formación de loteos y núcleos de fin de semana, nos lleva a preguntarnos por la forma que adquirió la expansión. ¿Cómo se materializan los procesos de transformación territorial? ¿Quiénes y cómo se determinan los loteos, la parcelación, los ejes principales de la expansión?

Cómo se ordenan las "cosas” en el territorio o cuáles son los criterios que guían la expansión son preguntas que provienen del área de los estudios morfo-tipológicos y que decidimos retomar porque nos permitirán mostrar de qué manera se materializa la expansión.

En esta área reconocemos dos núcleos fundamentales, en principio, el conjunto de estudios realizados en el Laboratorio de Urbanismo de la Universidad Politécnica de Cataluña (UPC), Barcelona, que se inscriben en la tradición de análisis difundida por Aldo Rossi.70 El grupo de profesionales dirigido por Manuel de Solà- Morales, Antonio Font o Joan Busquets ha acuñado una serie de métodos y conceptos particulares para comprender los procesos de materialización de la ciudad y las distintas fases de construcción de las formas residenciales. ${ }^{71}$ Un ejemplo concreto lo constituye el libro La urbanización marginal de Joan Busquets (1999), en donde el autor retoma una serie de variables que aplica al análisis de la formación de áreas residenciales en la urbanización de Barcelona -el origen parcelario, la condición topográfica, la formación tipológica, las características arquitectónicas, las invariantes morfológicas, el terreno y la localización urbana- con la intención de desvelar patrones urbanísticos y poder establecer situaciones típicas por sectores. ${ }^{72}$

\footnotetext{
70 Aldo Rossi, La arquitectura de la ciudad, Ediciones Gustavo Gili, Barcelona, 1976.

71 Manuel de Solà-Morales, Las formas de crecimiento urbano, Ediciones UPC, Barcelona, 1997.

72 Joan Busquets, La urbanización marginal, Ediciones UPC, Barcelona, 1999.
} 
Otra línea de investigación importante proviene del área de geografía y estudios urbanos británicos que combinaron los estudios históricos con conceptos fundamentales desarrollados para el análisis morfológico de las ciudades y sus áreas de expansión. ${ }^{73}$

El panorama historiográfico analizado, tanto en el ámbito nacional como internacional, ha demostrado la amplitud de los abordajes en relación a los diferentes aspectos que se conjugan en torno al tema de la expansión. En efecto, sobre este tema han operado los instrumentos y los intereses tradicionales de la historia de la arquitectura, centrados en la producción arquitectónica -sobre todo en cuanto a sus aspectos formales, tipológicos y estilísticos-, de la historia cultural y también los enfoques de la historia urbana, que han examinado los procesos de expansión de la ciudad y la conformación de áreas suburbanas residenciales. Dentro del contexto latinoamericano, este campo de estudios ha privilegiado el estudio de los procesos de gran escala, particularmente los procesos de expansión masiva.

De lo expuesto hasta aquí podemos señalar que es necesario profundizar, desde la perspectiva histórica, la dimensión material de la expansión, teniendo en cuenta que, a diferencia de lo que ha ocurrido con la Capital Federal, en torno a la cual desde la década del ochenta se han sucedido una serie de estudios que trazaron su historia material, esta sigue siendo una perspectiva escasamente desarrollada en los estudios sobre la formación del GBA. ${ }^{74}$ Creemos, a su vez, que el estudio de esta dimensión

73 J. Whitehand y C. Carr, Twentieth-Century Suburbs: A Morphological Aproach, op.cit; J. Whitehand, "British Urban Morphology: the Conzenian tradition”, en Urban Morphology, 2001, pp. 103-109; J. Whitehand, "Fringe Belts: A neglected aspect of Urban Geography", en Transactions of the Institute of British Geographers, $\mathrm{n}^{\mathrm{o}} 41$ (junio 1967), pp. 223-233. version on line: http://www.jstor.org/stable/621338

${ }^{74}$ Para profundizar sobre el proceso de formación de la ciudad de Buenos Aires ver, Fernando Aliata, $L a$ ciudad regular. Arquitectura, programas e instituciones en el Buenos Aires posrevolucionario, 18211835, Prometeo y Universidad Nacional de Quilmes, Buenos Aires, 2005; Anahí Ballent, Las huellas de la política. Vivienda, ciudad, peronismo en Buenos Aires, 1943-1955, Prometeo y Universidad Nacional de Quilmes, Buenos Aires, 2005; Adrián Gorelik; La grilla y el parque. Espacio público y cultura en Buenos Aires. 1887-1936, op.cit.; Alicia Novick; Planes realizados y proyectos inconclusos en la construcción de la ciudad moderna. Buenos Aires, 1900-1940, Tesis doctoral, Buenos Aires, 2006; Graciela Silvestri; El color del río. Historia Cultural del Paisaje del Riachuelo, Prometeo y Universidad Nacional de Quilmes, Buenos Aires, 2003; Graciela Favelukes, El plano de la ciudad. Expansión y 
puede funcionar como articulador entre las explicaciones más generales y las prácticas más particulares que algunos autores han señalado como estrechamente vinculadas a cierto tipo de expansión, para dar como resultado un panorama complejo del GBA.

\subsection{Configuraciones territoriales: palabras, nociones y problemas}

Por otra parte, antes de avanzar con el desarrollo de la tesis también parece inevitable incluir una reflexión sobre las diversas voces que nombran el territorio -expansión, periferia, suburbio- y su dificultad para comprender la dimensión compleja del espacio. Para ello, en las páginas que siguen prestaremos atención a las voces que intentan definirlo y caracterizarlo, entendiendo la conflictividad que surge al trabajar sobre un objeto en constante transformación y que reúne en un mismo espacio tantas situaciones diferentes. En otras palabras, es necesario discutir el sentido mismo de las voces que lo nombran, teniendo en cuenta que ninguna de ellas es autoevidente, monolítica, ni refiere a un objeto simple y unidimensional.

En este sentido, entender al Área Metropolitana de Buenos Aires como territorio condensador de tiempos, habitantes y proyectos superpuestos dificulta, como veremos a lo largo de la tesis, la definición de este espacio dentro de las categorías más tradicionales de urbano y rural.

El término "suburbio", lo utilizaremos para referirnos a los núcleos o barrios que analizamos, retomando una categoría que se impuso entre inicios y mediados del siglo XX, de marcado sesgo anglo-americano y que, etimológicamente, define áreas de urbanización homogénea, diferenciadas, pero cercanas a la ciudad y conectadas funcionalmente a ella. ${ }^{75}$ Como explican Daniel Hiernaux y Alicia Lindón, en el

control urbano en la modernización temprana de Buenos Aires (1750-1870). Tesis doctoral, Facultad de Filosofía y Letras, Universidad de Buenos Aires, 2004; James Scobie, Buenos Aires: del centro a los barrios, op.cit.

75 En Inglaterra la palabra "suburb" toma su siginificado actual, asociado a barrios residenciales de clase media en la afueras de la ciudad recién hacia 1840, cuando este tipo de desarrollo ya contaba con casi medio siglo de historia. En su acepción anterior, la palabra tenía una connotación negativa vinculada a 
contexto latinoamericano, el suburbio ha hecho referencia a zonas de expansión como promesa de una vida mejor. ${ }^{76}$ En el escenario local, esta categoría resulta especialmente útil para referirse a los primeros momentos de la expansión, en la cual algunos pueblos suburbanos y barrios -núcleos residenciales, de veraneo- se recortaban dentro del territorio predominantemente rural. Dentro de este escenario, suburbio denomina algunas áreas particulares que presentan cierta homogeneidad hacia el interior y que se incorporan dentro de otro espacio mayor, el territorio del GBA, del cual no da cuenta el primer término. La pregunta es qué sucede cuándo, el creciente número de loteos y núcleos de residencias, modifican la relación entre espacio rural y áreas urbanas. A medida que los núcleos suburbanos primigenios van creciendo, agregando pequeñas propiedades alrededor del núcleo que alguna vez les dio origen, van perdiendo su carácter compacto, homogéneo hacia el interior y capaz de ser diferenciado de un espacio "otro" que está por fuera, supuestamente rural o semi-rural y también homogéneo.

En diferentes grados, junto con el avance de la expansión, los usos y los tipos de urbanización: urbana, suburbana, industrial, rural comienzan a mezclarse complejizando la aprehensión del espacio. Apelamos, entonces, al concepto de periferia. Esta voz lleva consigo la herencia geométrica que nombra: espacio exterior, zona que rodea a otra área central, pero que, en un sentido estricto, no describe las características intrínsecas del lugar. La periferia es el espacio "otro", el afuera, que no es en sí mismo ni denso ni extendido, ni urbano ni rural y, probablemente, a causa de esa cualidad lábil, de definir de manera tan amplia, que permite incluir tantas subdefiniciones y subáreas en su interior, es la que mejor se aplica a un territorio que contiene todo: lo urbano, lo rural y todas las opciones intermedias. Sin embargo, la extensión de su uso hacia los años sesenta, como parte de las teorías sociales de la dependencia, construyó una relación dicotómica, donde centro y periferia fueron entendidos, más que como referencias espaciales, como dos componentes del orden social sustentados en una evidente desigualdad, tanto económica como social, política y

áreas residenciales de los sectores bajos, densamente pobladas que se amontonaban en los bordes de la ciudad. Oxford English Dictionary, "suburb".

${ }^{76}$ Daniel Hiernaux y Alicia Lindón, "La periferia: voz y sentido de los estudios urbanos", en Papeles de Población nº42, Universidad Autónoma del Estado de México. Toluca, México, 2004. 
territorial. ${ }^{77}$ En este camino, se redujo la noción de periferia y la diversidad de usos y espacios que pudiera albergar.

En las últimas décadas, con la intención de analizar los espacios de la expansión y las nuevas formas de ordenamiento territorial, se han propuesto nuevas categorías para comprender a las ciudades y sus áreas metropolitanas. ${ }^{78}$ Algunas de estas categorías, tratando de dar cuenta de los diferentes matices en la relación urbano-rural, proponen que el territorio se ordenaría en anillos concéntricos desde lo urbano a lo rural: el espacio urbano propiamente dicho; el espacio periurbano o áreas discontinuas; el espacio semi-urbano en el que se alternan los usos; el espacio semi-rural urbanizado; el espacio rural dominado por la actividad agraria pero con influencias urbanas y el espacio puramente rural. ${ }^{79}$

Desde la perspectiva del territorio metropolitano y en particular las áreas que analizamos en donde se localizan los barrios parque y núcleos de fin de semana, podemos aplicar tres de estas categorías, el periurbano, el semi-urbano y el semi-rural. Justamente, estos espacios intermedios son los que en los últimos años han adquirido mayor atención y desde los estudios provenientes de la geografía se han caracterizado

${ }^{77}$ Entre los estudios que abonaron a las teorías sociales de la dependencia cabe citar fundamentalmente a los trabajos de Manuel Castells.

78 El estudio de Franceso Indovina sobre la "ciudad difusa", incluso pone en discusión a esta última categoría de área metropolitana, proponiendo en cambio la hipótesis de la urbanización difusa, que surge en relación al estudio del territorio Veneto, pero que sería aplicable a los ordenamientos territoriales que se verifican actualmente es casi toda Europa. El autor define a la ciudad difusa como un fenómeno territorial caracterizado por una masa consistente (de ciudad) no sólo de población, sino también, de servicios y actividades productivas; una dispersión de tal masa en un territorio vasto que no presenta, en conjunto, fenómenos de alta densidad; y que, por último, presenta una alta conexión entre los distintos puntos del territorio. Es decir, que a diferencia del área metropolitana, en donde existe un territorio jerarquizado, con un centro y una serie de ciudades satélites o áreas menores ligadas a él a través de conexiones verticales (del centro a las periferias, pero no conectando a las periferias entre sí); en la ciudad difusa las jerarquías son de menor intensidad y las conexiones fluidas en todas las direcciones (conexiones horizontales). Franceso Indovina, "Algunes consideracions sobre la ciutat difusa", en Documents d'Anàlisi Geogràfica, no 33. Universidad Autónoma de Barcelona- Universidad de Girona, 1998. pp. 21-32

${ }^{79}$ M.D. García Ramón, Geografia Rural, Síntesis, Madrid, 1995. 
de dos maneras, desde la fragmentación o la hibridación. ${ }^{80}$ En el primer sentido, una manifestación espacial fragmentaria es la que se produce a través de la conformación de áreas parciales independientes, originadas a partir de fuertes divisiones funcionales que darían lugar a pensar el territorio como archipiélago. Bernardo Secchi propone que la "ciudad contemporánea" es eminentemente fragmentaria; a diferencia de la "ciudad moderna" (europea) cuya principal figura ha sido la de la continuidad. ${ }^{81}$ Lo que en cualquier escala se representa en la ciudad y la cultura contemporánea es el fragmento. La ciudad contemporánea es una ciudad fractal: el espacio físico, social, económico, institucional, político y cultural, caracterizado por un mismo grado de fragmentación, es producto de racionalidades múltiples y legítimas -en sí mismas-, pero con frecuencia simplemente adosadas unas a otras. ${ }^{82}$

En cuanto a las áreas residenciales, esta caracterización supondría entender los núcleos que analizamos como elementos de cierta homogeneidad, con fronteras permeables pero bien definidas que posibiliten el reconocimiento de una zona interior y otra exterior. ${ }^{83}$

Al respecto de la segunda definición, Bruno Latour señaló que un objeto híbrido surge de la confluencia de una acción o proceso que tiene lugar en el presente y se encuentra con las formas de acción y organización sobrevivientes de una operación anterior que han pasado a formar parte de la "naturaleza" local. Por su parte, García Canclini, uno de los principales teóricos de la hibridación (aunque sus estudios han hecho especial hincapié en procesos sociales, y no territoriales) la define como "el

${ }^{80}$ C. Barros, "De lo rural a lo rururbano: transformaciones territoriales y construcción de lugares al sudoeste del Área Metropolitana de Buenos Aires”, en Scripta Nova. Revista Electrónica de Geografía y Ciencias Sociales. Universidad de Barcelona, 45 (51) Agosto 1999; Francesco Indovina, “Algunes consideracions sobre la ciutat difusa", op.cit.

${ }^{81}$ En la hipótesis de Secchi, la ciudad contemporánea es aquella que comienza a vislumbrarse entre los años sesenta y ochenta del siglo XX y cuyas líneas no están aún totalmente definidas. En cambio la ciudad moderna que la precede, es el resultado de una construcción lenta y prolongada entre el Renacimiento y el siglo XIX. Bernardo Secchi, Ciudad moderna, ciudad contemporánea y sus futuros, en Lo Urbano en 20 autores contemporáneos. Ediciones UPC, Barcelona, 2004.

${ }^{82}$ Bernardo Secchi, Ciudad moderna, ciudad contemporánea y sus futuros, op,cit.

83 Michael Janoschka, "El nuevo modelo de la ciudad latinoamericana: fragmentación y privatización", en EURE v.28 n. 85. Santiago dic. 2002. 
conjunto de procesos en que estructuras que existían en forma separada, se combinan para generar nuevas estructuras, objetos y prácticas en las que se mezclan los antecedentes". 84

A la luz de esta tesis, también sería posible pensar en una tercera opción, que sería la Ciudad Genérica (1994) que define Rem Koolhaas. En la cual se asiste a una convergencia, y paulatina homogeneización urbana que sólo es posible luego de haberse perdido las identidades particulares. ${ }^{85}$ En el Gran Buenos Aires reconocemos que entre mediados y fines del siglo XIX el espacio rural que rodeaba a la ciudad habría comenzado a ser afectado por la aparición de usos diferentes del agrícola, sin embargo, la escala de estas transformaciones no habrían alcanzado para modificar el orden predominante. Es decir, que durante un largo período todavía fue posible seguir considerando ese territorio como dominantemente rural. Recién hacia la década del veinte, la aparición de loteos económicos y posteriormente de emprendimientos asociados a la construcción de segunda residencia, habrían dado lugar a una sumatoria de usos, fabriles y de explotaciones agropecuarias entre los que se disponían usos residenciales populares y conjuntos de segundas residencias, modificando el carácter original de la zona. Conduciéndola lentamente hacia una pérdida de identidad. Salvo en sectores particulares, (el eje sur predominantemente industrial, o el eje norte residencial) la introducción de nuevos usos no alcanzó a desplazar a las actividades originales que caracterizaban el lugar, dando paso a la formación de nuevas áreas en donde alternaban usos rurales con usos urbanos del suelo, formas de sociabilidad rural y urbanas. Cada vez fue más frecuente, como examinó Clichevsky, la competencia de usos generada por el propio sistema de mercado. Este determinó que en la periferia de las áreas metropolitanas, se encontraran desplazándose mutuamente o coexistiendo el uso residencial de los sectores de bajos ingresos y el uso residencial temporario de las clases medias y altas, las áreas de recreación de esas mismas clases, las actividades

\footnotetext{
${ }^{84}$ Bruno Latour, Nunca fuimos modernos. Ensayo de Antropología simétrica, Siglo XXI, Buenos Aires, 2007; Nestor García Canclini, “Hibridación”, en Carlos Altamirano (ed), Términos críticos de sociología de la cultura, Paidós, Buenos Aires, 2002. p 124.

85 Rem Koolhaas, La ciudad genérica, en Lo Urbano en 20 autores...op.cit.
} 
industriales y la actividad agropecuaria. ${ }^{86}$ Para algunos habitantes el espacio "rururbano" siguió siendo el lugar de su actividad agropecuaria alterado por la incorporación de nuevos residentes, para otros se convirtió en el espacio de habitación posible (loteos económicos), o la materialización de lo rural como objeto de consumo (barrios parque). Unos y otros construyeron lugares con formas nuevas, intercalándose, superponiéndose, integrándose o entrando en conflicto a partir de las diferentes formas de habitar. En esa orientación y con respecto del territorio, no será difícil observar que cada capa de la urbanización lleva los residuos de las anteriores en los términos de la fabulosa metáfora del palimpsesto de André Corboz. ${ }^{87}$

A modo de corolario, en medio de un escenario en constante transformación, solo es posible resaltar la variabilidad de situaciones que se intercalan en el territorio, mientras que algunos barrios constituirían verdaderos espacios de significación aportando a la construcción de un espacio fragmentado en donde verdaderamente existiría un adentro y un afuera, en muchos casos las fronteras serían más difusas y maleables. Abordaremos estas diferencias en los capítulos que siguen.

${ }^{86}$ Nora Clichevsky, El mercado de tierras en el área de expansión de Buenos Aires y su incidencia sobre los sectores populares. Periodo 1943-1973. CEUR, UTDT, 1975. P 29

87 André Corboz, "El territorio como palimpsesto", en Lo Urbano en 20 autores contemporáneos, Ediciones UPC, Barcelona, 2004. 


\title{
CAPÍTULO 2. Los barrios parque y de fin de semana en el mapa de la expansión
}

\author{
"el desarrollo de las áreas suburbanas de las grandes \\ ciudades está últimamente ligado a los servicios que \\ prestan los medios de transporte. Y para comprobarlo \\ basta echar una ojeada al mapa del Gran Buenos \\ Aires para darse cuenta de que allí, donde ha habido \\ medios de movilidad eficaces y regulares, el \\ crecimiento de los centros ha sido rápido $\mathrm{y}$ \\ satisfactorio y que en las zonas que están atravesadas \\ por un transporte deficitario, se ha producido un \\ desorden que ha llegado a determinar un retroceso en \\ los precios de la tierra (...)" \\ (El servicio ferroviario suburbano, en Revista Casas \\ y Jardines, Enero, 1937) \\ "tres cosas necesita nuestra República, caminos, \\ caminos y caminos" \\ (Revista Automovilismo no 79, mayo de 1925.p. s/n.)
}

En el año 1900 la ciudad de Buenos Aires alcanzaba el millón de habitantes, en su periferia se distinguían algunas industrias rodeadas de núcleos urbanos obreros y algunas poblaciones que habían surgido alrededor de antiguas estancias o pueblos coloniales. Para mediados de los años treinta, la ciudad y el cinturón formado por Vicente López, San Martín, Morón, La Matanza, Avellaneda y Lanús, ya superaban ampliamente los cuatro millones de habitantes. Buenos Aires ingresaba al siglo XX como una de las ciudades más grandes del mundo y la más importante de Latinoamérica. Ciudades como México, Río de Janeiro y San Pablo alcanzaron el millón de habitantes sólo para 1930. La Habana, Lima, Santiago, Bogotá, Caracas y Montevideo llegaron a esa cifra después de 1950. Para esta fecha, las primeras ciudades en experimentar procesos de expansión y metropolización ya presentaban fenómenos de conurbación. Desde el mismo momento en que se inicia la tendencia a la concentración creciente de la población en áreas urbanas, privilegiándose el 
crecimiento de una ciudad, generalmente la Capital, en relación al desarrollo más lento de las ciudades de provincia, se organizan los primeros esquemas para su crecimiento. ${ }^{88}$

En el Gran Buenos Aires, una porción importante de este crecimiento se dio principalmente sobre la base de loteos particulares, muchos de los cuales tomaron inicialmente la forma de barrios parque o de fin de semana, y se integraron -más o menos- a las áreas urbanizadas según las acciones del Estado, y en menor medida de los promotores o agentes que impulsaran el loteo y de la acción de los propios habitantes.

Durante este período, si bien la expansión reproduce una matriz de crecimiento en base a tres ejes definidos precedentemente, podemos decir - aunque de manera algo esquemática- que se termina de definir el carácter de esos ejes, en donde se asiste, inicialmente, a la ocupación residencial de baja densidad protagonizada por los sectores medios y medios-altos en la zona Norte; y al crecimiento del sector Oeste después, reuniendo este último la mayor cantidad de nuevas urbanizaciones. ${ }^{89}$

Desde la bibliografía, a pesar del nutrido grupo de autores que se ha dedicado a analizar la expansión dentro del área de la Capital $^{90}$; por fuera de este sector, sólo se han avanzado algunas hipótesis enfatizando diversas cuestiones: la expansión del transporte y las renovadas modalidades de especulación de la tierra, como la implementación de los pagos en cuotas para la compra de terrenos periféricos (Charles Sargent); el crecimiento demográfico que habría comenzado a registrarse en áreas cercanas a Buenos Aires a comienzos de los años cuarenta con la llegada de migrantes

88 Horacio Torres y Marta Schteingart, "Procesos sociales y estructuración metropolitana en América Latina”, en Richard Morse (comp.), La investigación urbana latinoamericana: tendencias y planteos. Ediciones Siap, 1971.

89 En coincidencia con esta visión, los autores del Estudio del Plan de Buenos Aires, 1948-1949. Publicado en 1956 bajo el título "Evolución del Gran Buenos Aires en el tiempo y en el espacio" habían encontrado en una clasificación funcional para los suburbios, una tendencia al "habitar" en el norte (Belgrano, Nuñez, San Isidro), al "recrearse” al oeste (Flores, Ramos Mejía, Morón) y al "trabajar" en el sur (Barracas, Avellaneda, Quilmes) que se originaba desde fines del siglo XIX. Estudio del Plan de Buenos Aires. 1956. pp. 69-70

90 Estos autores son: Fernando Aliata, Anahí Ballent, Adrián Gorelik, Alicia Novick, Graciela Silvestri, Graciela Favelukes y James Scobie, entre otros. Sus trabajos han sido revisados más ampliamente en el apartado "Miradas sobre el crecimiento metropolitano" 
del interior del país y que abonó a un proceso de suburbanización masivo con características marcadamente populares que se organizó sobre la base de los loteos económicos en cuotas y las mejoras en el transporte público (Horacio Torres); o la amplia red de núcleos poblacionales surgidos a escala territorial con anterioridad al proceso expansivo y que, eventualmente, sirvieron de base para la posterior ocupación residencial del GBA (César Vapñarsky). ${ }^{91}$

Más allá de estas caracterizaciones, es posible reconocer procesos particulares que contribuyeron a la generación del GBA. Sobre el corpus seleccionado, el objetivo es el de presentar una caracterización de los núcleos de fin de semana en el ámbito de la expansión metropolitana. La voluntad que guía este capítulo es la de reconocer las transformaciones y procesos de crecimiento de núcleos antiguos y formación de nuevos. Sobre esta base podremos formular algunas hipótesis acerca de los procesos de expansión que, como vimos, han sido muy estudiados para la ciudad de Buenos Aires y abordados de manera genérica para el área metropolitana.

Ampliamente nos preguntamos si se trata de loteos populares, como señaló mayoritariamente la bibliografía; o si es posible pensar que, en paralelo a esta tendencia, se promovían modelos alternativos en relación al habitar suburbano.

En cuanto a la configuración del Gran Buenos Aires, nos interesa saber ¿Cómo se incorporaron los nuevos loteos en el territorio?, ¿dónde se localizaron y cómo se fueron modificando estas lógicas a lo largo del período que analizamos? Por otra parte, ¿en relación a qué variables o elementos urbanos preexistentes se localizaron y cómo dialogaron con ellos? A grandes rasgos, estos son los temas que nos proponemos abordar, ¿cómo contribuyeron los barrios de fin de semana a definir la nueva periferia?

Para responder a estas preguntas, presentaremos una pintura amplia que contribuya a dar cuenta de la diversidad de situaciones que conviven en este territorio, incluso cuando nos ceñimos al corpus reducido de los barrios parque y de fin de semana. Trataremos de dar cuenta de las principales características del proceso expansivo, respondiendo a quiénes fueron sus protagonistas, cuáles fueron los usos

91 Charles Sargent, The Spatial Evolution of Greater Buenos Aires, 1870-1930, op.cit; Horacio Torres, “Evolución de los procesos de estructuración espacial urbana. El caso de Buenos Aires” op.cit y Horacio Torres, El Mapa Social de Buenos Aires. 1940-1990, op.cit; César Vapñarsky, La aglomeración Gran Buenos Aires. Expansión espacial y crecimiento demográfico entre 1869 y 1991, op.cit. 
predominantes que allí se localizaron, qué diferencias había entre los sectores de la expansión. Abordaremos luego el análisis de las áreas de la expansión en coincidencia con los dos períodos que definimos, tratando de reconocer las transformaciones territoriales que acarrea en cada momento y en relación a cada uno de los ejes principales de crecimiento la incorporación de los núcleos suburbanos. En segundo lugar, buscamos construir una tipología de las urbanizaciones. En la base de la clasificación de una cantidad de casos variados se pretende lograr una síntesis capaz de dar cuenta de forma sencilla de los principales modos de apropiación del suburbio que podemos reconocer en relación con los procesos de formación de núcleos de fin de semana.

\subsection{El proceso de la expansión}

Si nos centramos en la primera década del siglo $\mathrm{XX}$, vemos que se inició un período de rápido crecimiento poblacional en los partidos aledaños a la Capital Federal. Acompañando la extensión de las redes ferroviarias proliferaban los loteos y la formación de pueblos, aunque gran parte del crecimiento verificado se debió a una densificación de los núcleos que existían con anterioridad, generando la incorporación de nuevos territorios al mercado inmobiliario. La paulatina emergencia de loteos yuxtapuestos a aglomeraciones surgidas hacia fines del siglo XIX fue intensa y sostenida en tierras de partidos actualmente lindantes con la Capital Federal que ya empezaban a adquirir las características que se consolidarían a lo largo del siglo XX.

Con la llegada del ferrocarril los tradicionales pueblos de veraneo de la elite con sus quintas del siglo XIX - Adrogué, Lomas y Temperley al Sur; San Fernando, San Isidro y Tigre al Norte y, más tímidamente, Morón o Hurlingham hacia el Oestecomenzaron a rodearse de chalets $^{92}$, a la vez que se incorporaban clubes e instalaciones

\footnotetext{
92 La denominación "chalet" se utilizó entre el público masivo en Argentina para designar a toda construcción individual pintoresca, de cubierta inclinada, en general de planta compacta, que puede desarrollarse en uno o varios niveles. Fue originalmente considerado un tipo de residencia suburbana, o casa de veraneo, aunque en la Argentina, a partir de fines de los años treinta, su uso se extendió en muchos casos a las ciudades. El término de origen francés da cuenta de la importancia de las referencias
} 
deportivas que ponían de manifiesto el proceso de modernización social y cultural que estaba teniendo lugar. Si bien en este momento la formación de núcleos de veraneo y de fin de semana era prerrogativa exclusiva de las clases altas se percibía que lentamente comenzaban a perder su carácter aristocrático. ${ }^{93}$

El rápido desarrollo del mercado inmobiliario, impulsado por lo que se vivía como un proceso de expansión inagotable de la ciudad y de los medios técnicos que la propiciaban, hacía posible, además de la revalorización de antiguos pueblos, del completamiento de manzanas y vacíos intersticiales en áreas ya pobladas, pensar en la creación de núcleos suburbanos para el establecimiento de quintas o residencias de fin de semana en algunos sentidos de la expansión. Así, para 1910, se contaban hacia el Norte -sobre la línea de ferrocarril a Tigre- nuevas poblaciones intermedias como Victoria y Martínez. Hacia el Sur, sobre la línea que unía Constitución y La Plata, surgía el pueblo de Bernal en relación al conglomerado más grande que constituía Quilmes. Al mismo tiempo, se observaba un crecimiento importante del pueblo de Villa Elisa, fundado a fines del siglo XIX y surgían las pequeñas estaciones de Gonnet y City Bell, más cercanas a La Plata. En un desprendimiento de este mismo ramal, que conectaba a la Capital con la zona Sur, se observaba la pequeña estación de Ranelagh. Hacia el Oeste se distinguían como poblaciones de cierta dimensión- comparables con San Isidro o San Fernando- los núcleos de Hurlingham, Bella Vista, Ramos Mejía, Haedo, Morón e Ituzaingó.

A la vez que los procesos de suburbanización de los sectores medios-altos y altos, convertían a los pueblos de veraneo -especialmente sobre la franja costera al

de ese origen para las arquitecturas pintorescas en el medio local. Ver, Anahí Ballent, "chalé (chalet)", en Jorge Liernur y Fernando Aliata (dirs.) Diccionario de Arquitectura en la Argentina, Clarín, 2004.

93 En efecto, a partir de la década de 1910, los espacios anteriormente reservados a la considerada "alta sociedad" asistieron a una "invasión democrática", mediante la cual aquellas prácticas y sitios antiguamente asociados a la elite pasaron a estar al alcance de franjas más vastas de la sociedad de una manera en que no lo habían estado antes. Leandro Losada y Anahí Ballent señalaron como a partir de este momento, centros vacacionales, como Mar del Plata o Tigre, anteriormente reservados a la elite, perdían el carácter aristocrático con que habían sido concebidos, para convertirse en destino de las clases medias altas, representantes de la nueva "aristocracia del trabajo". Leandro Losada, La alta sociedad en la Buenos Aires de la Belle Epoque, Anahí Ballent, "Country Life: los nuevos paraísos, su historia y sus profetas" op.cit. 
Norte de la Capital- en sitios de uso cada vez más frecuente, podían registrarse nuevos emprendimientos que se sumaban a esta tendencia de crecimiento. ${ }^{94}$ En líneas generales, se puede decir que la expansión hacia la zona Norte de la Capital siguió un modelo de crecimiento de baja densidad, predominantemente residencial -de carácter no permanente en las primeras décadas del siglo y que lentamente se convertiría en sitio de primera residencia-, que se ubicó sobre tierras altas, con notoria presencia de áreas verdes, dada originalmente por la cercanía a la costa del río y por haber sido asiento de estancias forestadas desde épocas tempranas. El asentamiento de la población afectó sólo levemente las características naturales de la zona, que en líneas generales pudo conservar la profusa forestación en plazas, espacios públicos y veredas. Tendencia que se vio favorecida por la ubicación de clubes deportivos que mantuvieron grandes áreas verdes fuera del mercado de tierras. Hacia la zona Oeste y Sur de la Capital, salvo casos muy puntuales, el crecimiento tomó la matriz urbana más tradicional, que repetía el modelo porteño típico de manzanas con lotes angostos y profundos y viviendas entre medianeras con terreno al fondo.

Las condiciones naturales en el Sur no eran tan diferentes de las mencionadas para la zona Norte; salvo por la zona del Riachuelo y las tierras inundables de su cuenca cuyos retratos prevalecieron en la formación del imaginario urbano, sobre todo, porque sus costas atrajeron desde muy temprano el asentamiento de actividades productivas. ${ }^{95}$ Desde mediados del siglo XIX se habían emplazado allí las primeras industrias nacionales, saladeros y posteriormente frigoríficos, y entre 1880 y 1920 se instalaron en la zona otras veinte industrias de importancia. ${ }^{96}$ Los núcleos que precedieron la consolidación del área industrial: Temperley, Adrogué o Banfield, lograron mantener su carácter original como áreas residenciales de densidad reducida.

94 Para mayor detalle sobre los procesos de suburbanización ver Horacio Torres, El mapa social de Buenos Aires, op.cit.; Charles Sargent, The Spatial Evolution of Greater Buenos Aires, op.cit.; Horacio Bozzano, "Buenos Aires desde sus orígenes. Transformaciones territoriales y mutaciones productivas", op.cit.; César Vapñarsky, La aglomeración Gran Buenos Aires, op.cit.

95 Para profundizar sobre las condiciones naturales de la cuenca Riachuelo-Matanzas. Ver, Graciela Silvestri, El color del río. Historia Cultural del Paisaje del Riachuelo, op.cit.

96 Podemos señalar la fábrica textil Alpargatas (1885), los establecimientos alimentarios Bagley (1892), Molinos (1900), Canale (1910) y Terrabusi (1919); y las metalúrgicas Tamet (1902) y Gurmendi en 1919. Datos citados por Horacio Bozzano en "Buenos Aires desde sus orígenes...”, op.cit. 
Pero el resto del área se vio transformada hacia 1890 por una serie de loteos en Barracas al Sur - hoy Lanús y Avellaneda- que acompañaban el constante crecimiento de la demanda laboral en zonas que se delineaban como predominantemente industriales tal como daban cuenta los nombres de algunas de las nuevas urbanizaciones: Villa Industriales o Villa Obrera.

Hacia el Oeste, el crecimiento fue similar al que acabamos de describir en cuanto a la composición social predominantemente popular. Signado por la lejanía al centro metropolitano y la escasa penetración de los medios de transporte, el paisaje urbano se caracterizaba por las bajas densidades producidas por un tejido urbano discontinuo, marcado por la existencia frecuente de terrenos baldíos y espacios abiertos "informales" en contraposición a la inexistencia de espacios abiertos públicos, incorporados al trazado original.

Con el avance del siglo XX las características diferenciadoras de la expansión no harían más que profundizarse. Sobre todo si tenemos en cuenta el área de tierras periféricas más cercanas a la Capital que se consolidan en estos años y por lo tanto comienzan a adquirir identidades locales más definidas.

Una pintura amplia sobre los procesos de suburbanización que comenzaba a atravesar el área metropolitana dejaría ver su carácter predominantemente popular. En tanto el área central de Buenos Aires se fortalecía y los suburbios residenciales que analizamos se organizaron a modo de fragmentos que no lograron imponer el tono predominante del área, aunque sí puede decirse que favorecieron, en términos culturales, a difundir un fenómeno que posteriormente se haría más amplio. ${ }^{97}$

97 A diferencia de lo ocurrido en otras ciudades, Buenos Aires atravesó, en paralelo al proceso de suburbanización, un fenómeno de modernización urbana de su área central, -verificable en el ensanche de avenidas, apertura de la avenida norte-sur (actual 9 de Julio), construcción del obelisco- que significó una revalorización, tanto en términos materiales como simbólicos, que mantuvo intacto su carácter privilegiado y exclusivo. Ver, Anahí Ballent, Las huellas de la política, op.cit. p. 33. 

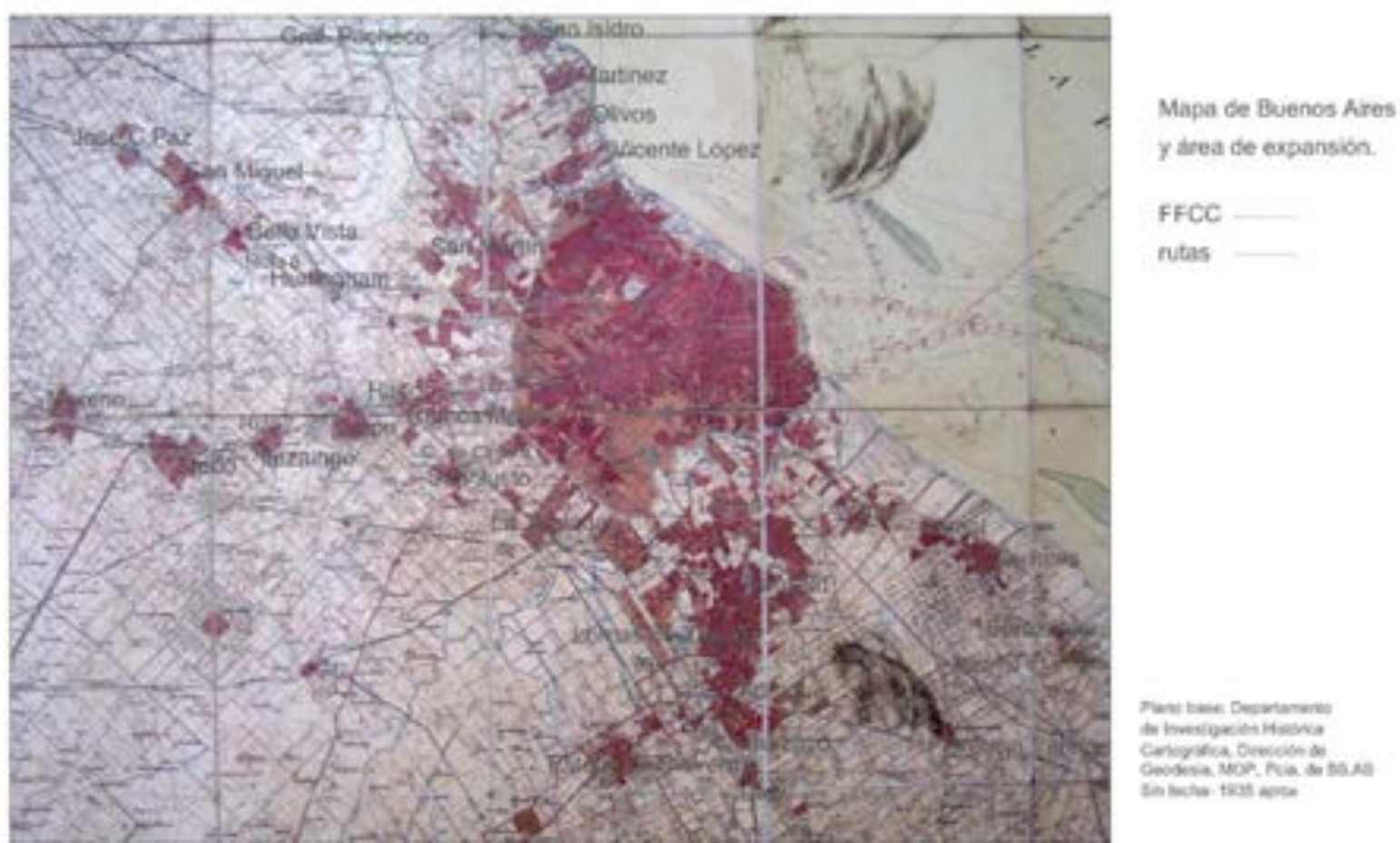

Siguiendo las tendencias que marcaba la Capital, los contrastes socio-espaciales que se registraban estuvieron definidos mayoritariamente por la división Norte-Sur. Conforme las categorías introducidas por Horacio Torres, la expansión se caracterizó, ampliamente, por la condensación de "zonas malas", definidas como aquellas con índices socio habitacionales inferiores a la media, en la extensión Sur y Sur-Oeste, y “zonas buenas" en la expansión Norte y Nor-Oeste. ${ }^{98}$

Sin embargo, de acuerdo a este mismo autor, podemos decir que este escenario comenzaría a modificarse hacia la década del cuarenta, cuando el proceso de suburbanización residencial se amplió considerablemente, diferenciándose del período anterior por una serie de factores. El primero, sería la masividad del fenómeno, originada principalmente por la llegada de migrantes del interior del país. Los 8.000 provincianos que recibía Buenos Aires y su periferia hasta 1936, pasaron a un promedio de 70.000, entre 1937 y 1943, y ascendieron a 117.000, entre 1944 y 1947. En total, sumaron un millón de nuevos residentes que se localizaron principalmente en la periferia de la Capital. Podemos observar que en el período 1935-1945 la tasa de crecimiento anual del Gran Buenos Aires fue de 4,3\%, superando ampliamente la

${ }^{98}$ H.Torres, El mapa social de Buenos Aires. Op.cit 
misma medición para el área de la Capital $(2,7 \%)$ y para el total del país $(1,7 \%)$. Esta tendencia se profundizaría en el período siguiente 1945-1960, con un crecimiento de $6,0 \%$ para el GBA, contra un $0 \%$ para la Capital y un valor estable para el resto del país. ${ }^{99}$ En segundo término, se modificaría el mapa definido por la dimensión social de la segregación, que comenzó a desdibujarse en relación a las coordenadas Norte-Sur a la vez que registraba diferencias más marcadas en los ejes radiales (centro-periferia). Las zonas de suburbanización "buenas" mantuvieron -durante todo el período- una distancia al centro promedio de $9 \mathrm{~km}$, mientras que las zonas "malas" irían tomando localizaciones cada vez más alejadas, de manera tal que en 1960 se encontraban a una distancia promedio de $18 \mathrm{~km} .{ }^{100} \mathrm{Al}$ mismo tiempo, se verificó durante el período una transformación en los medios de transporte. Particularmente, la expansión de la red vial y de las líneas de colectivos contribuyó a mejorar la accesibilidad de zonas periféricas intersticiales entre las estaciones de los grandes ejes ferroviarios, posibilitando la incorporación de nuevas tierras al mercado inmobiliario. ${ }^{101}$

El nuevo impulso inmobiliario que se inició en la década del treinta, equivalente al que tuvo lugar durante la primera década del siglo $\mathrm{XX}$, redefiniría la matriz territorial. Dentro del mapa metropolitano, los diferentes sectores de la expansión ya comenzaban a organizarse de acuerdo a una lógica de estratificación territorial doble: por una parte, es posible reconocer en los tres brazos principales de la urbanización (Norte, Oeste y Sur), una gradación en la capacidad económica de Norte a Sur (siendo el eje Norte sobre la costa del Río de la Plata el área predilecta para la residencia de

99 Datos citados por Juan Carlos Torre y Elisa Pastoriza, "La democratización del bienestar”, op.cit. p. 262

100 H. Torres, El Mapa Social de Buenos Aires. op.cit y H. Torres, "Evolución de los procesos de estructuración espacial urbana. El caso de Buenos Aires", op.cit.

101 La brusca expansión de la frontera agropecuaria a fines del siglo XIX por el avance sobre los territorios indios hace suponer la disminución relativa de la presión de la zona agrícola sobre la zona urbana y por ende una necesaria variación de la distancia entre los valores de la renta agraria y urbana. Precisar este punto es de primordial importancia por cuanto define a los sectores sociales que pueden ser afectados: la característica del proceso de expansión registrado en Buenos Aires es -aunque relativamente- su fácil accesibilidad a amplios sectores populares. Jorge F.Liernur, "Buenos Aires: la estrategia de la casa autoconstruida", en A.A.V.V, Sectores populares y vida urbana, Ediciones Clacso, 1984. 
sectores sociales medio-altos, y el eje Sur el área más especializadamente industrial); por otra parte, es posible comprobar que en cada una de las líneas de la expansión existe un núcleo principal, en torno de cada uno de los cuales se desarrollan anillos subperiféricos que van disminuyendo la capacidad socio-económica a medida que se alejan de cada subcentro.

Si contrastamos este diagrama con la situación real de la expansión para 1930, observamos que hacia el Norte -sobre la línea de ferrocarril a Tigre- las poblaciones intermedias Olivos, Martínez y San Isidro, constituían un continuo urbano con características socio-habitacionales medias y medias-altas entre la franja delimitada por la extensión de la actual Avenida del Libertador y la línea del ferrocarril a Tigre. Hacia el Sur, sobre la línea que unía Constitución y La Plata, las poblaciones más importantes absorbían a otras más nuevas para formar un único conglomerado, tales fueron los casos de Quilmes-Bernal, en el extremo Sur del primer anillo de suburbanización y Berazategui-Ezpeleta, un poco más al Sur sobre ese mismo ramal. Hacia el Oeste se distinguían como poblaciones consolidadas, los núcleos de Hurlingham, Ramos Mejía, Haedo, Morón y Castelar, aunque no constituían todavía una línea de urbanización continua sobre las arterias principales que las vinculaban con la Capital. ${ }^{102}$ En medio de este panorama, aún permanecían como tierras de cultivo, pequeñas granjas o áreas destinadas al uso industrial, las tierras más alejadas de los núcleos poblados.

Pero la urbanización seguiría expandiéndose a partir de la apertura de nuevas fronteras. ${ }^{103}$ Una vez que el anillo de tierras periféricas más cercanas a la Capital mostraba señales de completamiento -principalmente en torno a las vías radiales de acceso a la Capital, lo cual ocurrió entre las décadas de 1930-1950-, nuevos territorios comenzaron a incorporarse a la urbanización. La puesta en marcha de nuevos loteos significó, para la década del treinta, el ingreso al mercado inmobiliario de una nueva

102 Sobre el primer período de suburbanización de la zona Oeste, anterior a la expansión de los años treinta se puede ver el trabajo de Garciela Saez, "El tiempo de las quintas", en Revista de Historia Bonaerense, año IV, nº 17, junio de 1998. pp. 7-12.

${ }^{103}$ La sanción de la Ley Nacional de Vialidad que dio origen a la Dirección Nacional de Vialidad (DNV) en 1932 fue decisiva para la extensión y modernización de la red vial, a la vez que puede entenderse como expresión de la actitud modernizadora que emprendía el Estado nacional. Ver, Anahí Ballent y Adrián Gorelik, "País urbano y país rural: la modernización del país y su crisis", op.cit 
franja periférica formando un cinturón alrededor de la Capital alejado entre 20 y 40 $\mathrm{km}^{104}$

Es conocido el movimiento de expansión popular que en el período que analizamos se asienta sobre las zonas periféricas más cercanas a la Capital. Donde, los sectores populares pueden acceder -movidos por el deseo de escapar a las condiciones de hacinamiento que se viven en la ciudad y por deseo de cumplir el "ideal de la casa propia"-, no sin sacrificios, a comprar un lote en cuotas en las afueras, esperando, al cabo de algunos años poder construir una pequeña vivienda. ${ }^{105}$ Pero, poco se sabe del proceso de ocupación que se registraba en este momento en las tierras de reciente incorporación.

Teniendo en cuenta que estas nuevas áreas se ubican por fuera de las zonas de la expansión residencial, incluso las más alejadas. Cabe preguntarse, ¿qué rol adquirieron estas áreas en el nuevo impulso expansivo, en relación a qué usos se incorporaron?

Los estudios demográficos sugieren que para el período que analizamos, el primer cordón del Conurbano incorporó un millón de habitantes, pasando de un millón en 1930 a 2 millones en 1950, en cambio, el anillo exterior mantuvo hasta 1950 una población estable, menor al medio millón de habitantes, y recién a partir de ese momento su tasa de crecimiento habría comenzado un alza vertiginosa. ${ }^{106}$

Pero, como ya dijimos, la prosperidad de la expansión industrial que generó el auge de loteos y urbanizaciones económicas en las áreas cercanas, también dio lugar a otro tipo de loteo, el de quintas de fin de semana que prometían un descanso reparador

${ }^{104}$ Los dos sectores de la urbanización a los cuales hago referencia, uno a continuación de la Capital y el otro alejado $20 \mathrm{~km}$ o más de ella, fueron definidos con posterioridad al período que aquí analizamos como 1er y 2do cordón del Conurbano Bonaerense, siendo el Camino de Cintura el que señala el límite entre estas dos áreas.

105 Algunos de los trabajos que pueden verse en relación a este tema son: J.F.Liernur, "Buenos Aires: la estrategia de la casa autoconstruida”, op.cit; Diego Armus (comp.), Mundo Urbano y Cultura Popular, Buenos Aires, Sudamericana, 1990; R. Gonzalez Leandri, "La nueva identidad de los sectores populares", en A. Cataruzza (dir.), Crisis Económica, avance del estado e incertidumbre política (19301943), Nueva Historia Argentina, t VII, Buenos Aires, Sudamericana, 2001.

106 Informe sobre la problemática estructural del Conurbano. Dirección provincial del Conurbano Bonaerense, Ministerios de Gobierno de la Provincia, Dirección de Impresiones del Estado y Boletín Oficial, 1992. 
al alcance de una nueva clase media. ${ }^{107} \mathrm{~A}$ lo largo de las rutas nacionales, a escasa distancia de las estaciones ferroviarias o adentrándose un poco por los caminos de tierra de las zonas intermedias ya era posible acceder de esa "paz campestre" que se ofrecía en las promociones de los loteos.

Sin embargo, si contrastamos los valores de crecimiento poblacional del Gran Buenos Aires (que ya presentamos) con la localización de los nuevos loteos, se pone en evidencia que el boom inmobiliario y la creciente cantidad de loteos que reconocimos, no estuvieron acompañados -como cabría suponer- por un traslado significativo de población hacia ese sector. Presumiblemente, existiría una brecha entre el momento en que los lotes se incorporan al mercado y el momento en que comienzan a formar parte de la urbanización. Esto es indicativo de una práctica extendida donde la oferta de tierras se adelanta a las demandas reales de la expansión, es decir, que se produce una oferta exagerada que no alcanza a ser ocupada, generando un crecimiento discontinuo, en el que predominan enormes sectores baldíos y más importante, condiciones aptas para la especulación. ${ }^{108}$ En las nuevas áreas de la urbanización algunas familias de los recientemente engrosados sectores medios comprarían un "terrenito" barato pensando en levantar de a poco la casa de fin de semana, otros comprarían pensando en hacer una pequeña inversión en cuotas y esperarían a que la expansión siga su curso y eleve el valor de las tierras para una futura reventa. ${ }^{109}$

${ }^{107}$ Para un estudio clásico sobre clases sociales en Argentina, ver: Gino Germani, "La clase media en la ciudad de Buenos Aires: Estudio preliminar", op.cit. Versión on-line: http://www.jstor.org/stable/3466371. y Estructura social de la Argentina: análisis estadístico. Raigal, Buenos Aires, 1955.

108 En el Capítulo 4 se hace referencia al crecimiento discontinuo como una de las características principales de la expansión, consecuencia de los mecanismos a través de los cuales se llevó a cabo. Ver, Capítulo 4, Actores, normas e instituciones en la formación del GBA. Parte 4.1. Loteos y subdivisiones: el modus operandi de la expansión.

${ }^{109}$ Este tipo de práctica especulativa se ve especialmente favorecida cuando el impuesto inmobiliario se mantiene subvaluado con respecto al valor de mercado del suelo y no existen otros mecanismos que penalicen la tenencia de lotes en desuso. En el Capítulo 4, se presenta un análisis sobre el funcionamiento del mercado de tierras en la expansión y un estudio en relación al marco legal actuante y su vinculación con las formas de materialización de la expansión. 
De esta manera, la incorporación de nuevos territorios urbanizables a un proceso de expansión que todavía no había completado la fase de urbanización anterior, vino a abonar lo que ya se presentaba como un proceso de expansión difuso. Y contribuyó a retrasar el completamiento del anillo periférico más cercano a la Capital, dando lugar a una urbanización por islas, anulando el sueño de muchos de lograr una trama urbanizada continua hasta la Capital, lo cual, se esperaba, pudiera garantizar la unificación y la extensión de las redes de servicio e infraestructura, como había sucedido en la expansión de la ciudad-capital. ${ }^{110}$

Pero en este nuevo proceso de suburbanización, a raíz del sentido que registraba la modernización de la ciudad, ya no podría tener lugar una nueva integración, o al menos no plenamente. Es que la modernización urbana de este período, -verificable en la transformación del área central: ensanche de avenidas, apertura de la avenida nortesur, construcción del obelisco- significó la inversión del sentido inclusivo que históricamente había tenido la expansión urbana en todo su ciclo moderno, planteando un novedoso repliegue de la ciudad capital sobre sí misma que desconoció el proceso de formación de los radios metropolitanos. ${ }^{111}$ Contrario a las ideas de inclusión y homogeneización, se arraigaba la imagen de un escenario heterogéneo. En la periferia más cercana, como ya apuntó Torres, se instalaban las zonas residenciales "buenas", un poco más afuera (a un promedio de $18 \mathrm{~km}$ ) se encontraban las zonas "malas"; pero la expansión continuaba mucho más, alejándose hasta $40 \mathrm{~km}$ por fuera de la ciudad capital. En este segundo cordón, entre 1910 y 1950, cuando las cartas aún no estaban jugadas, la residencia estable todavía era una opción poco probable y se ofrecieron, en su mayor parte, alternativas urbanas que buscaron consolidar fragmentos cualificados dentro de la lógica del week-end adoptando ciertos patrones de habitación suburbana de los sectores medios-altos inspirados en la difusión del barrio jardín.

\footnotetext{
110 Adrián Gorelik señaló que la existencia de un tablero público extendido no sólo a la ciudad existente, sino previendo el crecimiento futuro, fue una de las bases materiales urbanas que generó en Buenos Aires la posibilidad de una integración social y cultural, evitando la formación de una periferia como un patchwork de alto contraste entre "barrios altos" y arrabales miserables. Sin embargo, esta definición sólo puede aplicarse a la expansión ocurrida dentro del área de la Capital. Ver, Adrián Gorelik, La grilla y el parque, op.cit.

111 Adrián Gorelik y Anahí Ballent, "País urbano o país rural”, op.cit.
} 


\subsection{Una vista panorámica sobre los barrios parque}

Acostumbrados a las figuras contemporáneas que nombran al primer y segundo cordón del conurbano, olvidamos los sectores diferenciales que lo conforman y sobre todo el proceso de acciones múltiples que condujeron a dicho resultado.

Como ya se adelantó, trabajaremos algunos aspectos de este crecimiento a partir de un corpus de 82 casos, cuyas características principales pueden encontrarse en el Cuadro 1, y cuya distribución en el territorio se traduce en el Mapa 1. A partir de este último se puede ver, en primer lugar, que los núcleos de los nuevos loteos dibujan lo que, de manera general, se puede describir como un anillo alrededor de la Capital con un límite que adquiere mayor definición en la zona interior, dada por una sucesión de emprendimientos sobre la línea que se consolidaría como el Camino de Cintura (1941) y un límite externo más difuso, que sólo se consolida en la porción Norte-Noroeste, uniendo las poblaciones de San Fernando, General Pacheco, San Miguel, Bella Vista y Moreno, a través de lo que sería el Segundo Camino de Cintura y que se desvanece sobre la porción Sur.
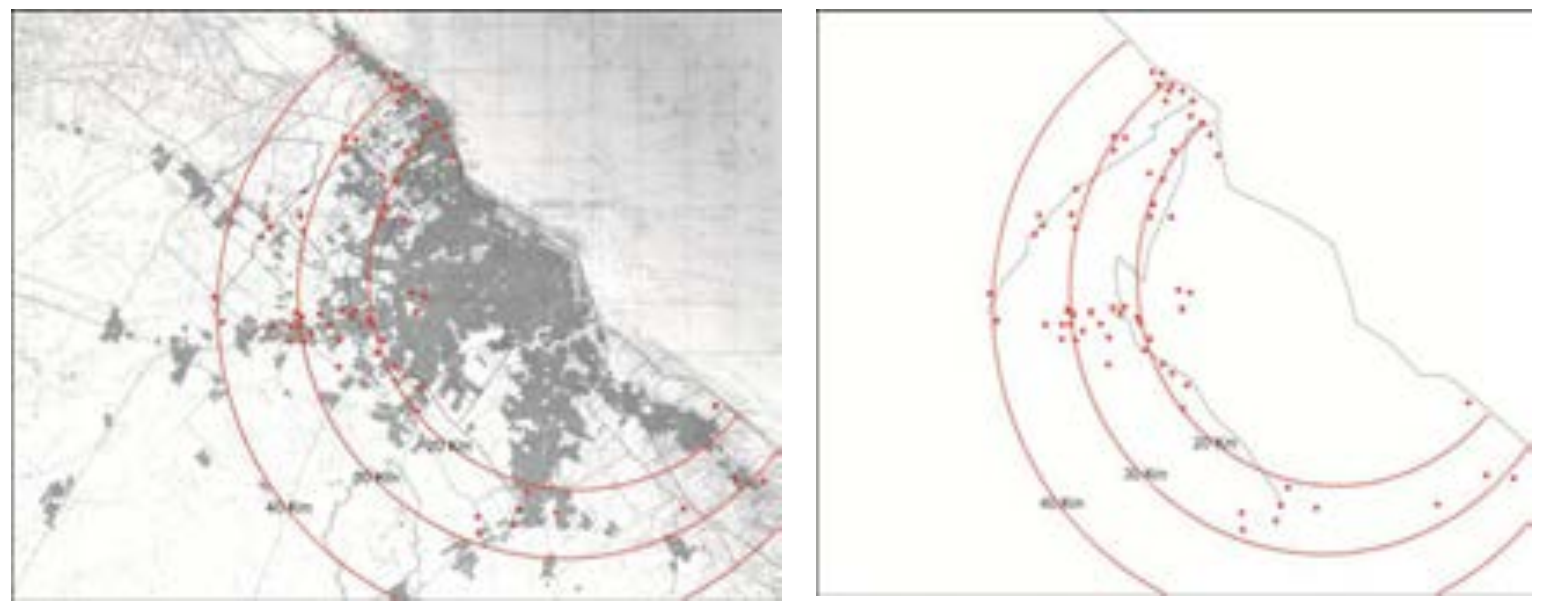

Mapa 1. localización de los barrios parque y núcleos de fin de semana en el AMBA y distancias a la Capital

Elaboración propia sobre el plano base de Randle que señala áreas urbanizadas para 1948

Como ya adelantamos, hacia el interior del anillo, los nuevos loteos favorecen a delimitar áreas diferenciales, siguiendo un patrón de asentamiento que define una porción de territorio de las zonas Norte y Noroeste y alejadas de la Capital a una distancia de entre 20 y $40 \mathrm{~km}$ que se incorporan al mercado inmobiliario; siguiendo 
lógicas de ocupación generadas por el ferrocarril y posteriormente, por la ampliación y extensión de las carreteas.

Desde otra perspectiva, si ponemos la lupa sobre el conjunto de los barrios parque que analizamos, también es posible dar cuenta de algunas características morfológicas que los definen. Más allá de lo que anuncian los discursos publicitarios que suelen exaltar el contacto con la naturaleza- o de lo que consideraría la urbanística moderna -el barrio parque como modelo con trazado de calles irregulares, baja densidad y predominio de áreas verdes-, en los hechos, y dentro del contexto de la expansión del GBA, los barrios parque aparecen, predominantemente, asociados a las dimensiones de los lotes más que al tipo de trazado que los contiene. Lamentablemente, no contamos con información detallada que nos permita conocer la dimensión de los lotes en la totalidad del universo analizado. Aunque, más allá de estas deficiencias, el acceso completo a la información de 74 casos nos permite formular una idea bastante precisa. Pudimos ver que en 48 de ellos se ofrecían quintas ${ }^{112}$ o como se promocionaban asiduamente, dobles lotes, que implicarían medidas superiores a los $600 \mathrm{~m} 2$. Además, en algunos casos singulares, se pusieron a la venta fracciones de entre 1.000 y $1.500 \mathrm{~m} 2$, susceptibles de ser subdivididas de acuerdo al crecimiento y densificación que fuese adquiriendo la zona. Sólo en 13 casos encontramos tamaños de lotes pequeños (entre $300-500 \mathrm{~m} 2$ ), con medidas que generalmente toman la proporción de $10 \mathrm{mt}$ de frente y largos variables.

De acuerdo a este análisis, el apelativo de barrio parque se asociaría, fundamentalmente, a la baja densidad más que a otras cuestiones como el trazado. Esta imagen, a su vez se fortalece, cuando observamos que del total de los barrios parque, el $50 \%$ presentan trazados urbanos irregulares, del tipo pintoresco y el 50\% restante presentan diferentes variaciones de trazados en grilla. ${ }^{113}$

\footnotetext{
112 Quintas: la legislación denomina así a los bloques que se trazan a continuación de las manzanas en el tejido urbano de un pueblo; estas quintas pueden ser subdivididas en fracciones de quintas que en ningún caso serán menores a la suma de dos lotes. Ley n 3487 , De creación de nuevos centros de población y ampliación de ejidos. 19 de junio 1913; Decreto reglamentario del 26 de octubre e 1927, artículo 9.

113 En otras ciudades como Mar del Plata, para este mismo período Perla Bruno analiza que la imagen compartida y generalizada de "Mar del Plata ciudad jardín” se basa fundamentalmente en la profusión de parques públicos y jardines privados, en el tratamiento pintoresco de los detalles, la abundancia de aire y sol, sin considerar aspectos económicos, ni límites de densidad ni superficie, ni definición de las partes.
} 
Incluso una vez que se establece la primer Ordenanza de Barrio Parque en 1943, su vinculación con la idea de ciudad jardín, es fundamentalmente estética, definida por una edificación retirada de la línea con jardines al frente. Ver, Perla Bruno, "Mar del Plata en los años 1930. El Plan ¿ausente?", en Carlos Mazza (editor), La Ciudad de Papel. Análisis histórico de Normativas y Planes Urbanos para la ciudad de Mar del Plata, 1885-1975. Facultad de Arquitectura, Urbanismo y Diseño. Universidad Nacional de Mar del Plata, 1997. 
Cuadro 1. Datos completos del corpus de barrios parque seleccionado. Fuente: Elaboración propia.

\begin{tabular}{|c|c|c|c|c|c|c|c|c|c|c|}
\hline & Partido & Núcleo & $\begin{array}{l}\text { Cantid } \\
\text { ad de } \\
\text { parcel } \\
\text { as }\end{array}$ & $\begin{array}{l}\text { Superf } \\
\text { icie de } \\
\text { la } \\
\text { parcel } \\
\text { a (en } \\
\text { m2) }\end{array}$ & $\begin{array}{l}\text { Dime } \\
\text { nsión } \\
\text { del } \\
\text { núcleo } \\
\text { (en } \\
\text { ha) } \\
\end{array}$ & $\begin{array}{l}\text { valor } \\
\text { económi } \\
\text { co de la } \\
\text { parcela } \\
\text { (en \$) x } \\
\text { mes }\end{array}$ & $\begin{array}{l}\text { Año de } \\
\text { realizaci } \\
\text { ón del } \\
1 \text { er loteo }\end{array}$ & $\begin{array}{l}\text { Tipologí } \\
\text { a }\end{array}$ & $\begin{array}{l}\text { cantid } \\
\text { ad de } \\
\text { cuotas }\end{array}$ & $\begin{array}{l}\text { distan } \\
\text { cia a } \\
\text { la } \\
\text { Capita } \\
1\end{array}$ \\
\hline 1 & Alte. Brown & $\begin{array}{l}\text { B. P. Manuel } \\
\text { Obligado }\end{array}$ & 2.000 & 400 & 80 & $\$ 5$ & 1929 & C.N.P. & 100 & 22 \\
\hline 2 & Alte. Brown & B.P. Burzaco & 100 & 300 & 3 & $\$ 10$ & $\mathrm{~s} / \mathrm{d}$ & L.S. & 120 & 25 \\
\hline 3 & Alte. Brown & $\begin{array}{l}\text { La Carmen } \\
\text { Bonorino }\end{array}$ & 65 & 900 & 5,85 & $\$ 10$ & 1947 & P.P & & 26 \\
\hline 4 & Boulogne & Gral. Urquiza & 416 & 500 & 20,8 & $\$ 8$ & 1946 & L.S. & 120 & 28 \\
\hline 5 & G.Sarmiento & B.P.Mattaldi & 700 & 400 & 28 & $\$ 10$ & 1926 & L.S. & 0 & 20 \\
\hline 6 & G.Sarmiento & $\begin{array}{ll}\text { B.P. } & \text { Santa } \\
\text { Mónica } & \end{array}$ & 113 & 1.000 & 11,3 & $\$ 15$ & 1946 & P.P & 120 & 21 \\
\hline 7 & G.Sarmiento & $\begin{array}{l}\text { B.P.San } \\
\text { Andrés }\end{array}$ & 200 & 500 & 10 & $\$ 7$ & 1931 & N.E & 100 & 15 \\
\hline 8 & G.Sarmiento & $\begin{array}{l}\text { B.P.La } \\
\text { Primavera } \\
\end{array}$ & 200 & 800 & 16 & & 1946 & L.S. & & 34 \\
\hline 9 & G.Sarmiento & B.P. La Huella & 109 & 800 & 8,72 & $\$ 15$ & 1947 & L.S. & & 30 \\
\hline 10 & G.Sarmiento & $\begin{array}{ll}\text { Quintas } & \text { San } \\
\text { Miguel } & \\
\end{array}$ & 133 & 900 & 11,97 & $\$ 10$ & 1940 & L.S. & & 32 \\
\hline 11 & G.Sarmiento & B.P. Bellaflor & 80 & 700 & 5,6 & & 1944 & P.P & & 30 \\
\hline 12 & $\begin{array}{l}\text { Gral.San } \\
\text { Martín }\end{array}$ & Villa Zagala & 200 & 400 & 8 & $\$ 4$ & 1936 & P.P & & 12 \\
\hline 13 & La Matanza & Puente Ezcurra & 700 & 400 & 28 & $\$ 7$ & 1948 & & 100 & 18 \\
\hline 14 & La Matanza & Golden Park & & 800 & 0 & $\$ 35$ & 1949 & L.S. & 0 & 25 \\
\hline 15 & La Matanza & $\begin{array}{l}\text { B.P. Gral. San } \\
\text { Martín }\end{array}$ & 134 & 900 & 12,06 & $\$ 10$ & 1945 & L.S. & & 23 \\
\hline 16 & La Matanza & B.P. Peluffo & 400 & 1.000 & 40 & $\$ 50$ & 1945 & L.S. & 0 & 23 \\
\hline 17 & La Matanza & Parque Ibañez & 400 & 1.800 & 72 & & 1947 & L.S. & 20 & 20 \\
\hline 18 & La Matanza & $\begin{array}{ll}\text { B.P. } & \text { Santa } \\
\text { Clara } & \\
\end{array}$ & 100 & 1.500 & 15 & $\$ 20$ & 1945 & L.S. & 120 & 18 \\
\hline 19 & La Matanza & El Pino & 0 & 0 & 0 & $\$ 30$ & 1950 & & & 24 \\
\hline 20 & La Matanza & Santa Amelia & 270 & 350 & 9,45 & $\$ 30$ & 1945 & & & 22 \\
\hline 21 & La Matanza & La Ganga & 31 & 400 & 1,24 & $\$ 0$ & 1947 & P.P & & 25 \\
\hline 22 & La Matanza & Camping Club & 150 & 900 & 13,5 & & & P.P & 0 & \\
\hline 23 & $\begin{array}{ll}\text { Lomas } & \mathrm{de} \\
\text { Zamora } & \end{array}$ & B.P. Lavallol & 600 & 400 & 24 & $\$ 10$ & 1933 & N.E & 0 & 31 \\
\hline 24 & $\begin{array}{ll}\text { Lomas } & \mathrm{de} \\
\text { Zamora } & \end{array}$ & Las Torres & 270 & 900 & 24,3 & $\$ 30$ & 1949 & & 0 & 30 \\
\hline 25 & $\begin{array}{l}\text { Lomas de } \\
\text { Zamora }\end{array}$ & $\begin{array}{l}\text { Lomas de } \\
\text { Beheran }\end{array}$ & & 1.200 & & $\$ 60$ & 1948 & L.S. & 0 & 30 \\
\hline 26 & $\begin{array}{c}\text { Lomas de } \\
\text { Zamora }\end{array}$ & $\begin{array}{l}\text { San Juan de } \\
\text { Biocca }\end{array}$ & 438 & 800 & 35,04 & $\$ 6$ & 1948 & P.P & & \\
\hline 27 & Merlo & $\begin{array}{l}\text { Gran.B.P.San } \\
\text { Martín }\end{array}$ & 5.000 & 400 & 200 & $\$ 15$ & 1949 & C.N.P. & 0 & 35 \\
\hline 28 & Merlo & El Pericón & 300 & 300 & 9 & $\$ 15$ & 1950 & L.S. & 130 & 33 \\
\hline
\end{tabular}




\begin{tabular}{|c|c|c|c|c|c|c|c|c|c|c|}
\hline 29 & Merlo & La Esmeralda & 300 & 800 & 24 & $\$ 70$ & 1949 & P.P & 126 & 34 \\
\hline 30 & Merlo & $\begin{array}{l}\text { Est. Agustín } \\
\text { Ferrari }\end{array}$ & 2.000 & 800 & 160 & $\$ 20$ & 1950 & N.E & 120 & 37 \\
\hline 31 & Merlo & Paso del Rey & 800 & 600 & 48 & $\$ 20$ & 1947 & C.N.P. & 120 & 33 \\
\hline 32 & Merlo & $\begin{array}{ll}\text { B.P. } & \text { Gral. } \\
\text { Alvear } & \\
\end{array}$ & 130 & 1.000 & 13 & $\$ 20$ & 1946 & L.S. & & 28 \\
\hline 33 & Merlo & B.P. Los Indios & 100 & 800 & 8 & & 1946 & L.S. & & 30 \\
\hline 34 & Merlo & $\begin{array}{ll}\text { B. } & \text { Golf } \\
\text { Ituzaingo } & \\
\end{array}$ & 300 & 400 & 12 & $\$ 10$ & 1932 & C.N.P. & 120 & 27 \\
\hline 35 & Merlo & $\begin{array}{ll}\text { B.P. } & \text { San } \\
\text { Antonio } & \\
\end{array}$ & 140 & 800 & 11,2 & $\$ 16$ & 1945 & P.P & 120 & 32 \\
\hline 36 & Merlo & La Teja & 450 & 1.200 & 54 & $\$ 15$ & 1947 & L.S. & 120 & 35 \\
\hline 37 & Merlo & $\begin{array}{l}\text { Pradera } \quad \mathrm{de} \\
\text { Merlo }\end{array}$ & 500 & 900 & 45 & $\$ 250$ & 1950 & $\mathrm{~S} / \mathrm{D}$ & 0 & \\
\hline 38 & Merlo & $\begin{array}{l}\text { San Antonio de } \\
\text { Padua }\end{array}$ & 0 & 0 & 0 & $\$ 24$ & & P.P & & 28 \\
\hline 39 & Merlo & $\begin{array}{ll}\text { B.P. } & \text { San } \\
\text { Martin } & \\
\end{array}$ & 1.000 & 400 & 40 & $\$ 8$ & & & & \\
\hline 40 & Moreno & El Ensueño & 240 & 1.800 & 43,2 & $\$ 25$ & 1947 & L.S. & 120 & 45 \\
\hline 41 & Moreno & Rancho Grande & 300 & 1.000 & 30 & $\$ 25$ & 1947 & L.S. & 0 & 34 \\
\hline 42 & Moreno & Santa Teresa & 300 & 800 & 24 & $\$ 80$ & 1948 & L.S. & 0 & 35 \\
\hline 43 & Moreno & Parque Trujui & 26 & 2.000 & 5,2 & $\$ 100$ & 1949 & L.S. & 120 & 34 \\
\hline 44 & Moreno & Juan Pastorini & 23 & 800 & 1,84 & $\$ 90$ & 1950 & P.P & & 35 \\
\hline 45 & Moreno & Las Catonas & & & 20 & $\$ 30$ & & L.S. & 120 & 23 \\
\hline 46 & Moreno & Los Nogales & 120 & 800 & 9,6 & $\$ 30$ & 1949 & P.P & 120 & 34 \\
\hline 47 & Morón & Alto Verde & 128 & 500 & 6,4 & $\$ 3$ & 1945 & L.S. & 0 & 31 \\
\hline 48 & Morón & $\begin{array}{l}\text { Francisco } \\
\text { Verde }\end{array}$ & 300 & 500 & 15 & $\$ 10$ & 1945 & L.S. & 0 & 30 \\
\hline 49 & Morón & Parque Leloir & 500 & 2.250 & 112,5 & $\$ 100$ & 1947 & L.S. & 0 & 30 \\
\hline 50 & Morón & $\begin{array}{l}\text { Ituzaingo } \\
\text { Residencial }\end{array}$ & 9 & 500 & 0,45 & $\$ 40$ & 1947 & P.P & 120 & 30 \\
\hline 51 & Morón & B.P. Castelar & 620 & 400 & 24,8 & $\$ 20$ & 1929 & C.N.P. & 100 & 25 \\
\hline 52 & Morón & Parque Quirno & 230 & 1.000 & 23 & $\$ 10$ & 1947 & L.S. & 120 & 30 \\
\hline 53 & Morón & $\begin{array}{l}\text { B.P.San } \\
\text { Francisco }\end{array}$ & 260 & 800 & 20,8 & $\$ 30$ & 1947 & L.S. & 100 & 29 \\
\hline 54 & Morón & $\begin{array}{l}\text { B.P.Lomas de } \\
\text { Castelar }\end{array}$ & 150 & 1.000 & 15 & & 1943 & L.S & & 25 \\
\hline 55 & Morón & $\begin{array}{l}\text { Parque } \\
\text { Guiraldes }\end{array}$ & 133 & 1.200 & 15,96 & $\$ 40$ & 1946 & L.S. & & 30 \\
\hline 56 & Morón & B.P. Maupas & 200 & 800 & 16 & $\$ 12$ & 1948 & L.S. & & 31 \\
\hline 57 & Morón & Parque Morón & 1.000 & 400 & 40 & $\$ 6$ & 1932 & L.S. & 120 & 27 \\
\hline 58 & Morón & $\begin{array}{ll}\text { Nuevo } & \text { B.P. } \\
\text { G.Alvear } & \\
\end{array}$ & 120 & 800 & 9,6 & $\$ 20$ & & P.P & 120 & 25 \\
\hline 59 & Morón & $\begin{array}{l}\text { Morón Week- } \\
\text { end }\end{array}$ & 196 & 500 & 9,8 & $\$ 10$ & 1945 & L.S. & & 22 \\
\hline 60 & Morón & $\begin{array}{l}\text { Lomas } \quad \text { de } \\
\text { Haedo }\end{array}$ & 197 & 800 & 15,76 & $\$ 5$ & 1945 & L.S. & & 20 \\
\hline 61 & Morón & Villa Ariza & 0 & 0 & 50 & $\$ 0$ & 1939 & & & 22 \\
\hline 62 & Morón & Los Angeles & 195 & 400 & 7,8 & $\$ 2$ & 1945 & L.S. & & 24 \\
\hline 63 & Quilmes & B.P.Jacarandá & 1.400 & 300 & 42 & $\$ 20$ & 1949 & L.S. & 120 & 19 \\
\hline 64 & Quilmes & $\begin{array}{ll}\text { San } & \text { Juan } \\
\text { Pereyra } & \\
\end{array}$ & 30 & 3.000 & 9 & $150(45)$ & 1946 & L.S. & 36 & 20 \\
\hline 65 & Quilmes & Balneario Quil & 200 & 500 & 10 & $\$ 80$ & 1947 & L.S. & & 18 \\
\hline
\end{tabular}




\begin{tabular}{|l|l|l|l|l|l|l|l|l|l|l|}
\hline 66 & $\begin{array}{l}\text { San } \\
\text { Fernando }\end{array}$ & La Floresta & 90 & 400 & 3,6 & $\$ 15$ & 1950 & S/D & 130 & 26 \\
\hline 67 & San Isidro & B.P.Elortondo & 51 & 400 & 2,04 & $160(64)$ & 1931 & P.P & 48 & 21 \\
\hline 68 & San Isidro & B.P. Nelson & 51 & 400 & 2,04 & s/d & 1934 & P.P & 0 & 21 \\
\hline 69 & San Isidro & B.P. Atalaya & 10 & 800 & 0,8 & $250(50)$ & 1949 & P.P & 24 & 22 \\
\hline 70 & San Isidro & B.P.Aguirre & 300 & 600 & 18 & $250(50)$ & 1920 & N.E & 24 & 22 \\
\hline 71 & San Isidro & B.P. Balcarce & 107 & 600 & 6,42 & $170(34)$ & 1935 & P.P & 60 & 21 \\
\hline 72 & San Isidro & $\begin{array}{l}\text { B.P. } \\
\text { Longchamps }\end{array}$ & 158 & 500 & 7,9 & $180(72)$ & 1945 & P.P & 48 & 22 \\
\hline 73 & San Isidro & $\begin{array}{l}\text { B.P. Santa } \\
\text { Rosa }\end{array}$ & 63 & 1.000 & 6,3 & $\$ 100$ & 1945 & P.P & 48 & 24 \\
\hline 74 & San Isidro & $\begin{array}{l}\text { B.P. Federico } \\
\text { Alvear }\end{array}$ & 156 & 1.500 & 23,4 & $\$ 250$ & & L.S. & 0 & 27 \\
\hline 75 & San Isidro & B.P ViVot & s/d & s/d & 6 & $125(25)$ & 1935 & P.P & 24 & 21 \\
\hline 76 & San Isidro & B.P. Alvear & 0 & 350 & 5 & $\$ 300$ & 1940 & P.P. & & 24 \\
\hline 77 & San Martín & Villa Bosch & 500 & 600 & 30 & $\$ 6$ & 1934 & N.E & & 17 \\
\hline 78 & San Martín & $\begin{array}{l}\text { C.J. Lomas de } \\
\text { Palomar }\end{array}$ & & 700 & 35 & $\$ 0$ & 1946 & C.N.P. & & 24 \\
\hline 79 & San Martín & $\begin{array}{l}\text { Parque } \\
\text { Villegas }\end{array}$ & 523 & 400 & 20,92 & $\$ 4$ & 1942 & P.P & 120 & 21 \\
\hline 80 & Tigre & $\begin{array}{l}\text { Parque } \\
\text { Sancalal }\end{array}$ & 200 & 1.300 & 26 & $\$ 40$ & 1948 & L.S. & 0 & 28 \\
\hline 81 & Tigre & $\begin{array}{l}\text { B.P. } \\
\text { Guadalupe }\end{array}$ & 400 & & & $\$ 40$ & 1948 & L.S. & 120 & 29 \\
\hline
\end{tabular}





\subsection{El ciclo 1910-1935}

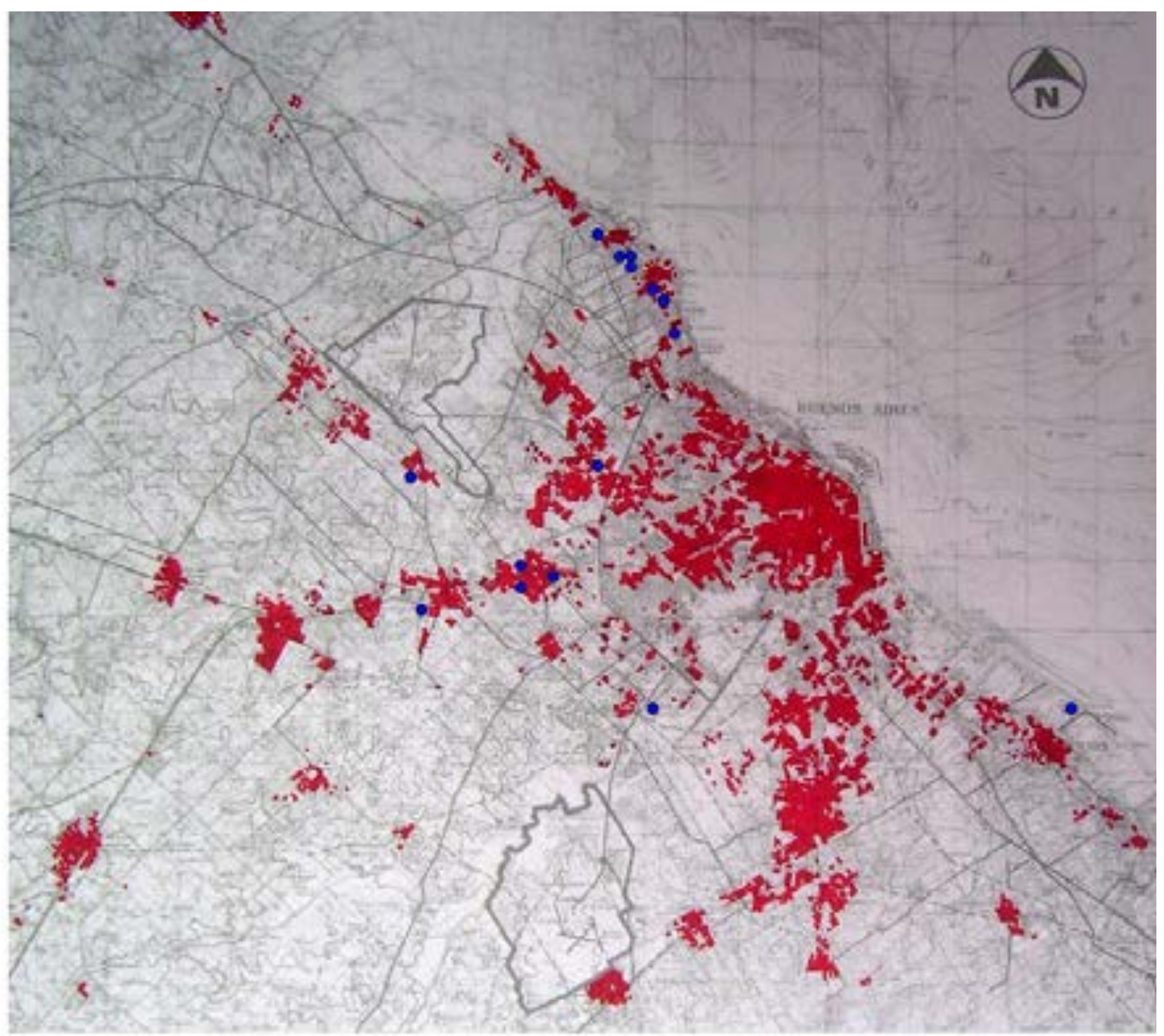

Mapa 2. Localización de emprendimientos de barrio parque o fin de semana. Área GBA. Período 19101935

Confeccionado sobre el plano base de Randle, que muestra el crecimiento de las áreas urbanas para 1910.

Un panorama...

En relación a la expansión, este primer momento puede caracterizarse como de suburbanización incipiente, reúne aproximadamente el 20\% del total del corpus que analizamos para todo el período; concentrados, fundamentalmente, en el sector Norte de la expansión y alrededor de algunos pueblos tradicionales del Oeste, destinados a los llamados sectores acomodados de la sociedad.

Es sabido que se trata de un período signado por la existencia del ferrocarril. Con su llegada, los tradicionales pueblos de veraneo de la elite iniciaban un proceso de transformación. Se subdividían las chacras y antiguas quintas que incorporaban sus 
tierras al mercado inmobiliario; y aquellas que permanecían se rodeaban de chalets y de instalaciones deportivas que propiciaban una interacción activa, más que contemplativa hacia la naturaleza. Un simple análisis sobre el mapa de la expansión nos muestra la concentración residencial entorno a la estaciones del FFCC, que hasta aproximadamente la década de 1930 dejaría ver -exceptuando la zona sur- que cada estación y el conjunto de manzanas relativamente consolidadas que la rodean forman núcleos en sí mismos, envueltos por una porción de campo que lo separa del núcleo siguiente. Asimismo, la lectura de los avisos publicitarios que acompañan los loteos que analizamos puede ser un indicio de la primacía de la red ferroviaria en los primeros años de la expansión: se observa que en la referencias geográficas se consigna, además de la distancia a la Capital, la distancia que separa a la estación de los terrenos en venta; situación que se revertirá en el segundo período que analizamos cuando empiezan a tomar importancia las redes viales y rutas pavimentadas.

En este momento, entonces, el análisis de los emprendimientos muestra que en los primeros años de la expansión predominan aquellos loteos relacionados al ferrocarril que consolidan núcleos previos -muchos de ellos surgidos en el siglo XIX como Morón o Adrogué- y las operaciones entorno a nuevas estaciones que van surgiendo en las zonas donde se presiente una mayor densificación y existen intereses concretos, generalmente inmobiliarios, que buscan favorecer la subdivisión del suelo y la creación de nuevos loteos. ${ }^{114}$ En cualquiera de los dos casos, (ya sea que los loteos se adjuntaran a un pueblo original o se constituyeran junto a nuevas estaciones) este tipo de núcleos solía encontrarse a una distancia aproximada de entre 2 y $4 \mathrm{~km}$ del núcleo siguiente, que es la distancia promedio que separaba las estaciones en las zonas más urbanizadas.

\footnotetext{
114 Si recordamos lo que señaló Charles Sargent, la década de 1890 representa el auge de la especulación “institucional" consistente en la venta por parte de los terratenientes de grandes extensiones a los empresarios de la especulación urbana, muchas veces antes de que se hiciera efectiva la inversión pública y privada en transporte y equipamiento. Recién luego de la recuperación de 1904 y una vez que se contaba con cierta infraestructura mínima, a la vez que se expandía la costumbre de pasar el verano en alguna quinta en las afueras de la ciudad, las tierras de las antiguas estancias -a veces en manos de inversores y otras por parte de las mismas familias- comenzaron a lotearse para dar lugar a la formación de pueblos, concentrados especialmente en aquellas tierras más cercanas a la estación.
} 


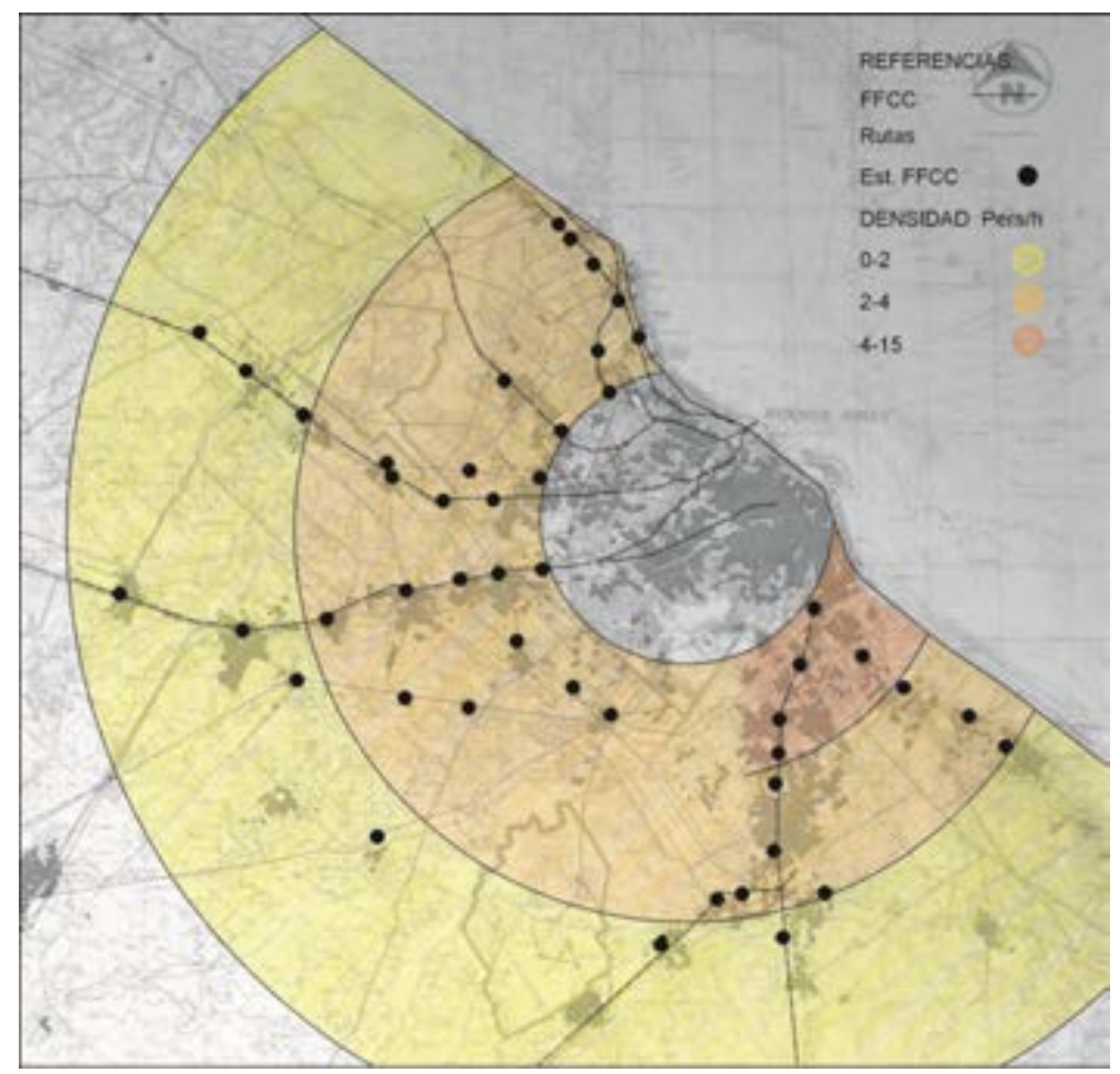

Mapa 3. Estaciones ferroviarias y densidades de población por sectores para el año 1914.

Elaboración propia sobre el plano base Áreas Urbanizadas, Randle 1914, densidades de población según el Atlas Ambiental Buenos Aires (AABA)

Es importante señalar, como anticipamos, que incluso en las áreas más consolidadas, en los primeros años de la suburbanización, cada pueblo forma un núcleo en sí mismo cuyas dimensiones aparecen determinadas por la distancia que una persona puede caminar de ida y vuelta a la estación. Un emprendimiento característico de este primer período de suburbanización, el Barrio Parque Aguirre (San Isidro, 1913) muestra una planta urbana de 20 ha, diseñada de forma tal que, incluso los terrenos más alejados no superen las diez cuadras hasta la estación. En este punto nos atenemos a lo que señaló Lewis Mumford a propósito de los suburbios dependientes del ferrocarril: eran discontinuos y lograron mantener una escala adecuada, no por la intervención de legislación alguna, sino por el límite natural dictado por el traslado a pie. ${ }^{115}$

115 Lewis Mumford, La ciudad en la Historia, Ediciones Infinito, 1979 (primera edición 1961), pp. 667669 


\section{Geografías}

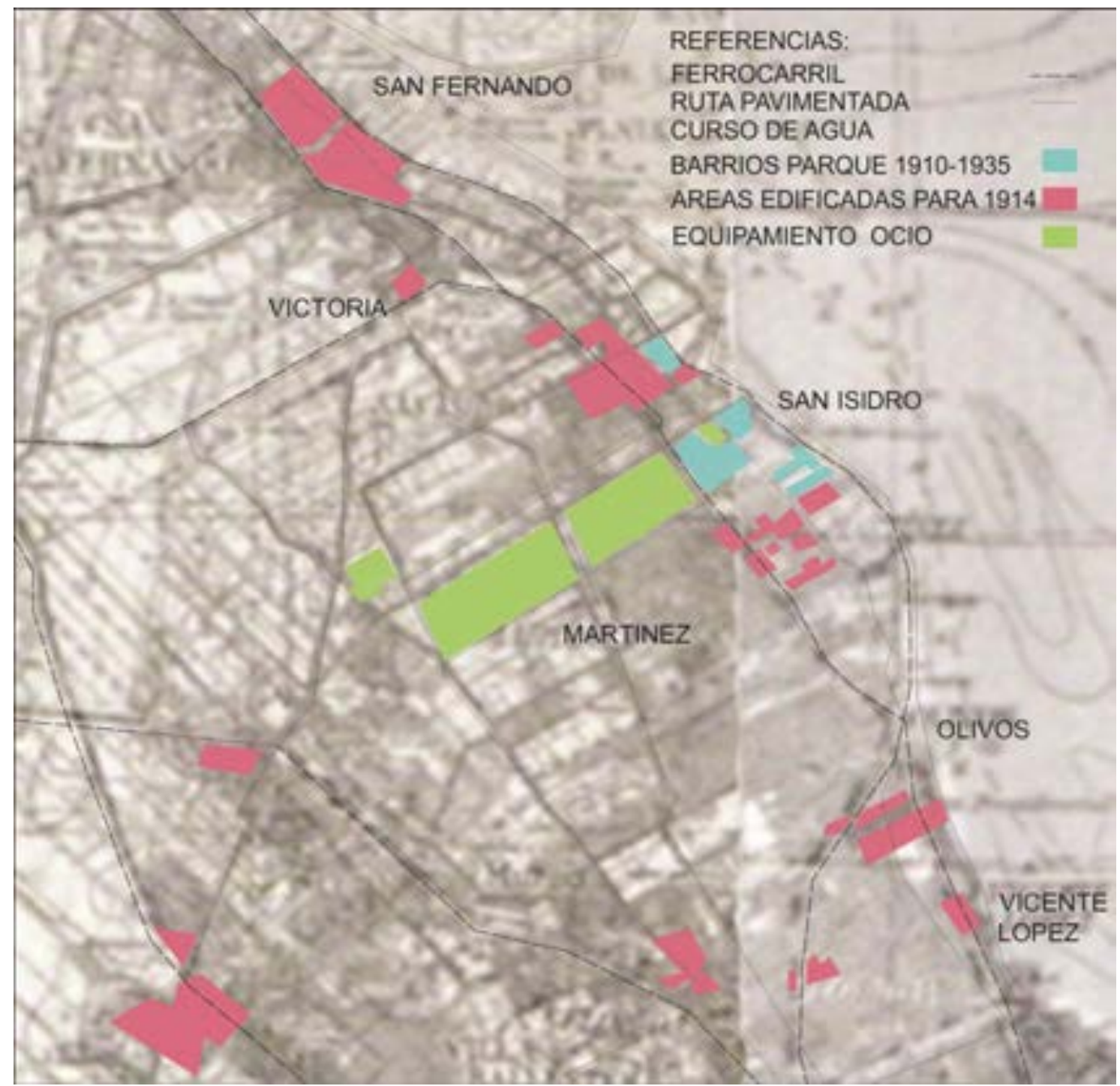

Mapa 4. Eje Norte. Localización de emprendimientos de barrios parque y de fin de semana y "áreas edificadas". 1935.

Elaboración propia sobre la Carta Topográfica IGN. Escala 1:100.000 


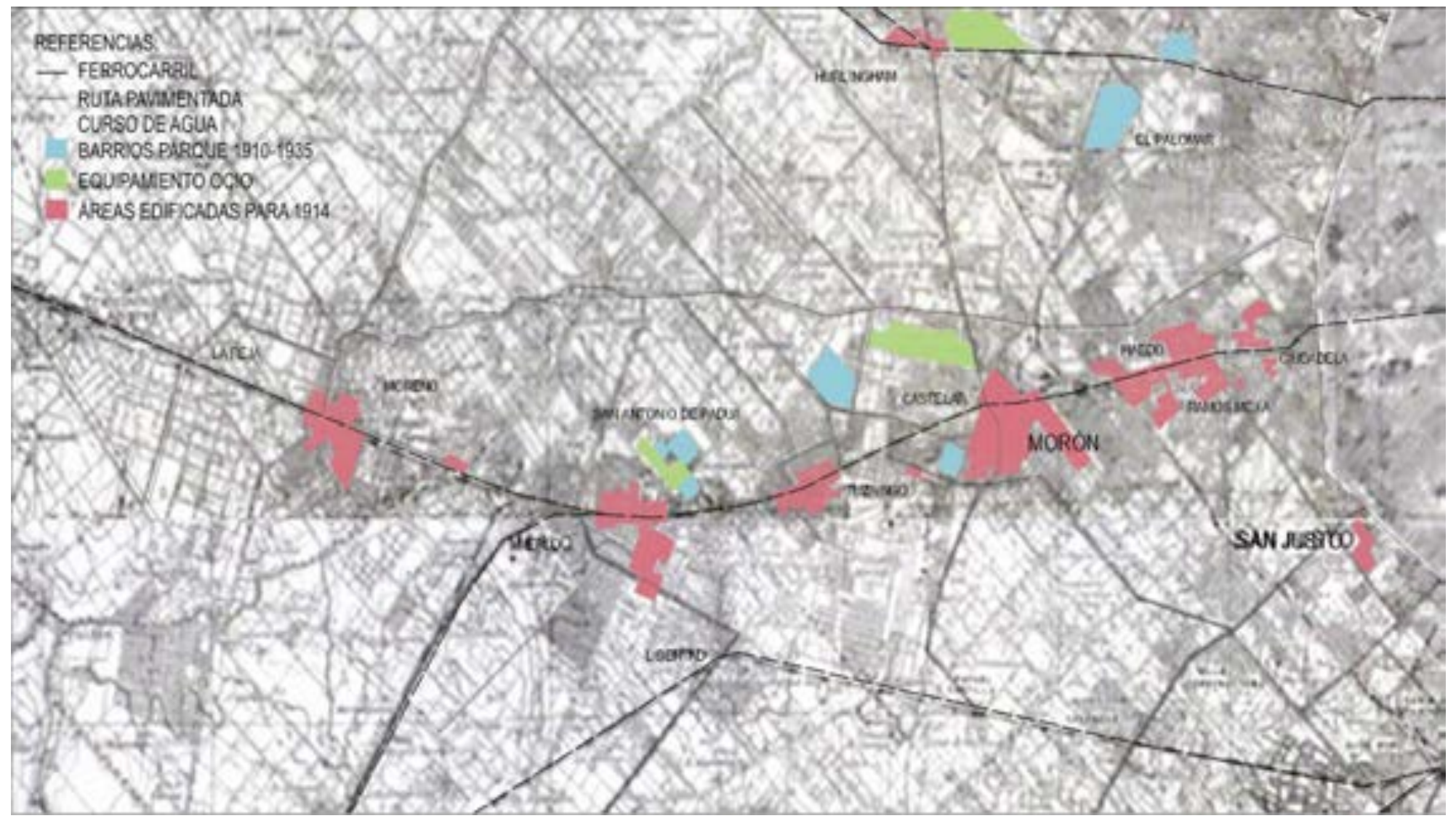

Mapa 5. Eje Oeste. Localización de emprendimientos de barrios parque y de fin de semana y "áreas edificadas". 1935. Elaboración propia sobre la Carta Topográfica IGN. Escala 1:100.000 


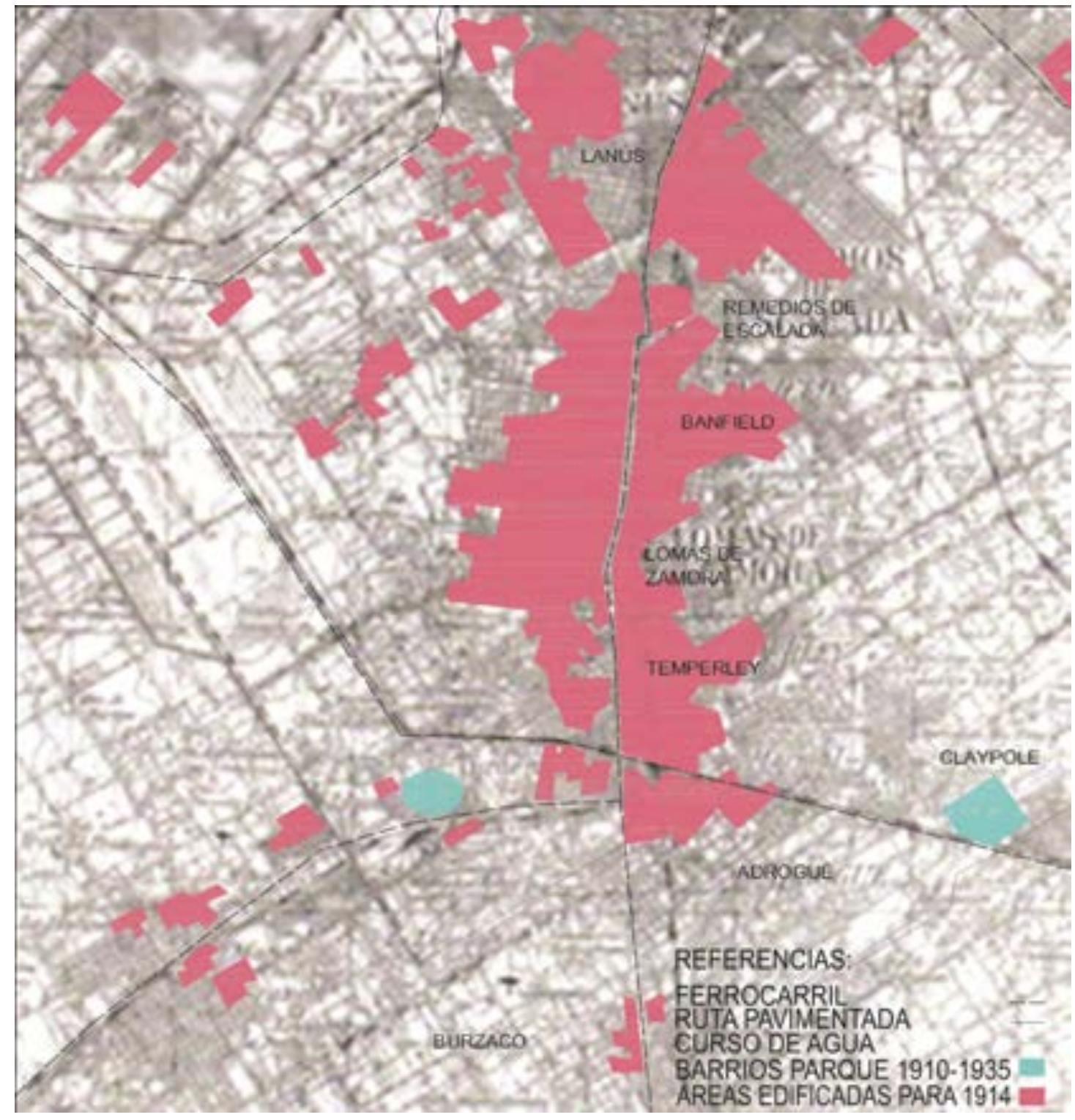

Mapa 6. Eje Sur. Localización de emprendimientos de barrios parque y de fin de semana y "áreas edificadas". 1935. Elaboración propia sobre la Carta Topográfica IGN. Escala 1:100.000 
Los Mapas 4, 5 y $6^{116}$, nos permiten analizar el crecimiento y la inserción de los barrios parque para cada uno de los ejes de la expansión. En ellos se muestran las "áreas edificadas" (definidas por Cesar Vapñarsky como áreas de dos o más edificios por manzana) y los barrios parque en relación a la red de transporte, estaciones ferroviarias y equipamientos deportivo-recreativos que se han considerado de importancia.

En el eje Norte (Mapa 4) se puede ver, para la segunda década del siglo XX, que la población se concentra, fundamentalmente, en torno a las estaciones ferroviarias. Mientras que los nuevos núcleos de barrios parque se incorporan al territorio sobre las tierras vacantes a lo largo de los ejes ferroviarios que aglomeran los pueblos de más antigua fundación, el Ferrocarril Mitre, que une las estaciones Retiro-Tigre y la continuación de la Avenida del Libertador.

Para este mismo período en el eje Oeste (Mapa 5), los núcleos residenciales alrededor de las estaciones definen un área de ocupación más dispersa y, a su vez, núcleos de menor tamaño, quedando gran cantidad de tierras vacantes sobre la traza del FFCC entre un núcleo y otro. En cuanto a los barrios parque, se localizaron, preferentemente, cerca de los núcleos poblados sobre la línea del FCO y la Ruta $n^{\circ} 7$ (continuación de la Avenida Rivadavia).

En cambio, en el sector Sur (Mapa 6), las densidades de población son más altas y prácticamente no se reconocen áreas vacantes sobre la línea que traza el FFCC. En contraposición a los dos casos desarrollados, se observa la localización de los primeros barrios parque alejados de la línea principal que aglutina la expansión del eje Sur, el Ferrocarril General Roca (F.C.G.R). Dicha situación, podría obedecer, como ya

\footnotetext{
116 Construcción de la cartografía: En relación a los mapas referidos, para su construcción, se han tomado como base las Cartas Topográficas del Instituto Geográfico Nacional (IGN), allí se han localizado, para cada sección, los emprendimientos que componen nuestro corpus y que corresponden a las incorporaciones de las décadas del veinte y hasta mediados del treinta. También se han superpuesto las “áreas edificadas” para 1914, estudiadas por César Vapñarsky y definidas como áreas con dos o más edificios por manzana.

El segundo período que comprende nuestra investigación está representado en el Mapa 2 de cada sector, en ellos se localizan la totalidad de urbanizaciones que componen nuestro corpus, si bien se mantiene la diferenciación entre aquellas que corresponden al primer y segundo período, junto a las "áreas edificadas" definidas por Vapñarsky para 1948, en donde se incluyen las ya detectadas para el período anterior.
} 
adelantamos, a la ocupación más densa que ya se verificaba sobre este eje para la segunda década del siglo XX y que no dio lugar a la formación de nuevos asentamientos, sino sólo en áreas alejadas de la urbanización.

En efecto, en este primer período, las zonas que concentran mayor cantidad de emprendimientos son el eje del Ferrocarril Oeste (50\% de los barrios parque 19101935) y en segundo lugar el eje hacia el Norte de la Capital, (35\% de los barrios parque 1910-1935). El sector Sur, como ya se mencionó anteriormente, fue el de más temprano crecimiento e, inversamente, el que reconoce la menor incidencia de urbanizaciones de barrios parque (15\% de los barrios parque 1910-1935). ${ }^{117}$

En otro orden de cosas, una aproximación que analice las variaciones de los valores del suelo en relación a los ejes de la expansión, mostraría, en principio, que el rango en los valores de las cuotas mensuales es muy amplio, con ofertas que van desde $\$ 10$ mensuales (Barrio Mattaldi, 1926, General Sarmiento), hasta \$160 la mensualidad (Barrio Elortondo, 1931, San Isidro). Esta división tan marcada, se refleja en el territorio, siguiendo una tendencia en donde, para igual distancia a la Capital, los partidos de la zona Norte concentran los barrios parque que alcanzan los valores del suelo más altos, contra los partidos del Oeste, en donde se localizan aquellos barrios que asumen valores del suelo más bajos; al igual que los dos barrios parque alojados para este período en la zona Sur.

Este panorama, obedecería a factores históricos que anteceden la incorporación de las nuevas urbanizaciones: la existencia de sectores ya consolidados como áreas recreativas, sumado a la tradición de las antiguas quintas de la elite porteña en zonas tradicionales como San Isidro, determinaron la mayor concentración de núcleos nuevos en este sector y los valores superiores que alcanzaron, gracias a la formación de un área residencial más homogénea y consolidada, en comparación con el crecimiento mucho más lento registrado en el sector Oeste. En este sentido, la localización espacial era un componente importante que determinaba las posibilidades de éxito y el carácter que tomarían los emprendimientos, de acuerdo a las posibilidades de acceso, la cercanía a

117 Zona Sur (282.137 habitantes), Zona Norte (140.281 habitantes) y Zona Oeste (63.863 habitantes). Datos citados por Cesar Vapñarsky, correspondientes al censo de 1914. Ver, Cesar Vapñarsky, La Aglomeración Gran Buenos Aires, op.cit. p 79. 
zonas productivas o clubes deportivos y a otros núcleos de veraneo ya legitimados. También determinaba diferencias entre los sectores sociales que podían acceder o no al emprendimiento de acuerdo a las variaciones del costo de la tierra y a procesos de suburbanización de más larga data que marcaban un contraste socio-espacial entre las direcciones que tomaba la expansión.

Finalmente, lo que podemos ver en el proceso expansivo del GBA es que recién hacia la década del treinta comienzan a distinguirse indicios de una nueva transformación. En los sectores más consolidados de la expansión, se verifica una mayor actividad inmobiliaria, en general, y una mayor cantidad de loteos periféricos de pequeñas dimensiones que se anexan a los trazados originales de los pueblos, generando las primeras señales en la trasformación del carácter suburbano. En la misma dirección, la mayor cantidad de loteos periféricos en un área estaría dando cuenta de un nivel de consolidación creciente en las zonas "centrales" del núcleo de referencia que haría posible la incorporación de nuevos terrenos al mercado. De hecho, los primeros loteos de este tipo se registraron en zonas intermedias a núcleos del eje Norte -"15 lotes de la antigua quinta Lezica" o "18 lotes lindando con el B.P.Aguirre". ${ }^{118}$ Donde, como ya mencionamos, el hecho de formar parte de un cordón de suburbanización que presentaba señales de transformación y la existencia de una población cercana de mayor importancia y tamaño, generó un efecto de renovación en las zonas intermedias y de atracción hacia nuevas inversiones y emprendimientos.

Hacia la década del treinta los efectos de la expansión urbana se empezaron a sentir sobre las zonas rurales, que comenzaron a desaparecer a causa de loteos y urbanizaciones. Sin embargo, salvo en sectores muy particulares de la expansión, durante este período se conservó el esquema materializado a fines del siglo XIX, de la ciudad Capital con su constelación de suburbios vinculados por los ferrocarriles.

En cuanto a la manera en que estos fragmentos de suburbio residencial se materializaron, se reconoce que durante este primer período siguieron dos tipos fundamentales.

\footnotetext{
${ }^{118}$ Carpeta de Remates -San Isidro, en Departamento de Investigación Histórica Cartográfica, Dirección de Geodesia, MOP, Provincia de Buenos Aires.
} 
Consolidación de un núcleo previo

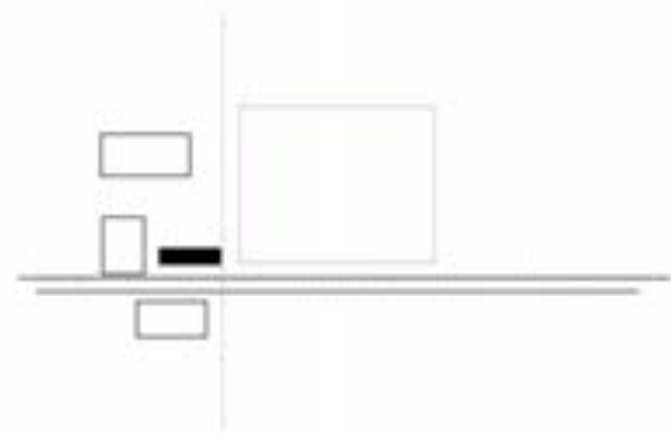

Croquis esquemático: se grafica en rosa la formación de un núcleo nuevo de población de importantes dimensiones entorno a una estación ferroviaria y a unos loteos previos (en negro) de menores dimensiones

Entre los tipos más habituales de fraccionamientos que se dieron en los primeros años de la expansión se encontraban aquellos dependientes del FFCC. Algunos nuevos loteos se organizaban en torno a núcleos ferroviarios que los antecedían. La expansión de las redes ferroviarias en el área que rodea la Capital se remonta a fines del siglo XIX, en ese momento muchas de las estaciones servían a estancias productivas en torno a la ciudad y posteriormente a quintas de veraneo de la elite porteña. Acompañando el crecimiento de la Capital, muchas de las antiguas estancias suburbanas fueron compradas por inversores y especuladores, y las quintas de recreo de menores dimensiones, loteadas por los propios dueños, que veían la oportunidad económica de convertir esas tierras rurales en tierra urbana. ${ }^{119}$

Estos loteos, una vez que ya había tenido lugar la especulación "institucional” a la que se refirió Sargent y que se contaba con cierta infraestructura mínima, se destinaban a particulares y se producían en el momento en que comenzaba a ampliarse la expansión, produciendo uno de los primeros indicios que marcaba un quiebre entre el veraneo de la elite y la posibilidad de acceso a las clases medias y medias-altas. De esta forma, se incorporaban nuevas parcelaciones y emprendimientos de dimensiones intermedias, que variaban entre las 10 y las 30 ha afectadas y se subdividían en parcelas

119 Muchísimos de los loteos que se promocionan hacen referencia a que son fraccionamientos de antiguas quintas o sucesiones de estancias de importantes familias. Entre ellos podemos mencionar, al Barrio Parque Aguirre (San Isisdro, 1913); el Barrio Parque Balcarce (San Isidro, 1935), el Barrio Parque residencial, la Cabaña “La Carmen” (Almirante Brown, 1947) y el Barrio Parque antigua Quinta Galli (Morón, 1930). 
que superaban el lote urbano típico (entre 400-800m2), de acuerdo a la idea local del barrio parque, buscando conservar algo del carácter distinguido de aquellas quintas que le habían dado origen. Los trazados de estas urbanizaciones presentaron calidades de diseño muy variables: desde las grillas que buscaban acomodarse en relación a alguna vía existente, pasando por algunos casos - Barrio Parque Castelar- en los que se buscaba dar respuesta a dos situaciones: generar una identidad propia hacia el interior del núcleo, aunque sin perder conexión con el trazado existente. Por último, en oportunidades excepcionales, -Barrio Parque Manuel Obligado en Claypole- la autonomía del nuevo trazado frente a la trama existente era tan fuerte que se insertaba a modo de sello pasando por alto particularidades y marcas locales. ${ }^{120}$

En relación a la morfología territorial, la inserción de estos loteos daba lugar a una urbanización discontinua resultado de sucesivas operaciones inconexas de medianas dimensiones. Pudiendo muchas veces leerse, en la morfología resultante, la huella de la antigua parcelación de las quintas que los habían antecedido.

Por otro lado, desde una lectura culturalista, en este tipo de poblaciones se logró generar un alto grado de autoidentificación, atribuible, posiblemente a su origen de pueblo independiente, en donde, desde épocas tempranas, se desarrollaban actividades de fomento y se verificó una amplia participación de la población en instituciones públicas, generalmente ligadas a las necesidades locales, (escuela, iglesia, departamento policial).

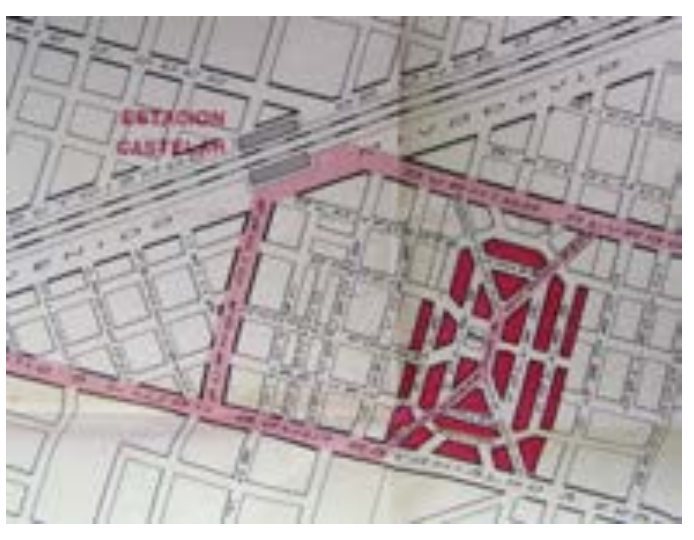

a. Barrio Parque Castelar. Circa 1930 Fuente: Carpeta de Remates- Partido de Morón, Departamento de Investigación Histórica Cartográfica, Dirección de Geodesia, MOP, Pcia Bs As.

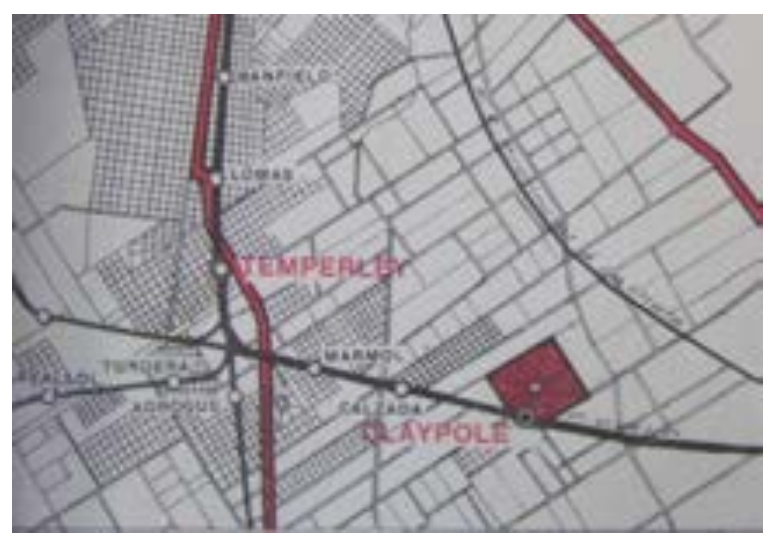

b. Barrio Parque Manuel Obligado sobre la estación Claypole. Circa 1929 Fuente: Carpeta de RematesPartido de Alte. Brown, Departamento de Investigación Histórica Cartográfica, Dirección de Geodesia, MOP, Pcia Bs As.

${ }^{120}$ Ver, Apéndice de loteos. 


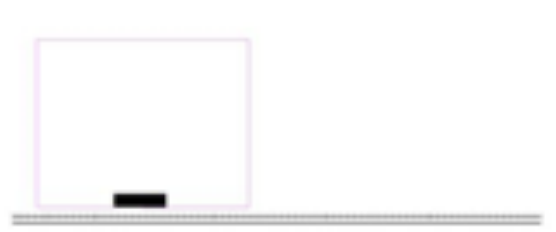

Croquis esquemático: se grafica en rosa la formación de un núcleo de población de importantes dimensiones entorno a la estación ferroviaria.

El creciente proceso de suburbanización al que se asistió en las primeras décadas del siglo XX dio lugar a la formación de estaciones intermedias en las líneas del ferrocarril cuyas áreas aledañas se encontraban más pobladas. Así se generaron nuevos núcleos ante la aparición de las nuevas paradas del FFCC.

Diferentes fórmulas daban lugar a este tipo de operaciones, la más común era a través de un pedido del dueño de las tierras a establecer una nueva estación para lo cual se ofrecía a ceder parte de los terrenos para área pública, asegurándose la prosperidad del negocio inmobiliario y el incremento en el valor de la tierra; otras veces los dueños de las tierras eran los mismos accionistas de las empresas ferroviarias. Por último, también se verificaron casos más puntuales, como el de San Antonio de Padua, donde la compañía inmobiliaria Vinelli financió las obras de la nueva estación y obtuvo la comisión para el remate de las tierras lindantes. ${ }^{121}$

Una de las características primordiales que se asocian a este tipo de emprendimiento es que tendieron a generar núcleos compactos y auto-contenidos como resultado del tipo de intervención generada por un único agente y en una sola etapa. $\mathrm{Si}$ bien comprendieron, mayoritariamente, áreas de dimensiones importantes -que superaban las 15 ha-, por cuanto debían constituir un núcleo suburbano completamente nuevo, mantuvieron una extensión relativamente reducida dependiente de las distancias recorribles a pie entre la estación y los lotes más alejados. En cuanto al tipo de

${ }^{121}$ En el Capítulo 4, se abordarán los agentes que intervinieron en el mercado de tierras suburbano. Allí se analizarán particularmente los mecanismos a partir de los cuales las compañías inmobiliarias participaban del negocio de la expansión. 
parcelamiento que se produjo, las medidas de todos los lotes suelen ser bastante homogéneas, variando entre los 400-600 m2. En ningún caso adoptan grandes dimensiones, puesto que se busca que toda la parcelación goce de una posición relativamente central con respecto al foco más importante que es la estación. Morfológicamente, adoptaron mayoritariamente trazados informales, lo cual suponemos que fue una opción bastante simple de generar cuando se contaba con un terreno completamente "vacío" y "virgen" sobre el cual intervenir.

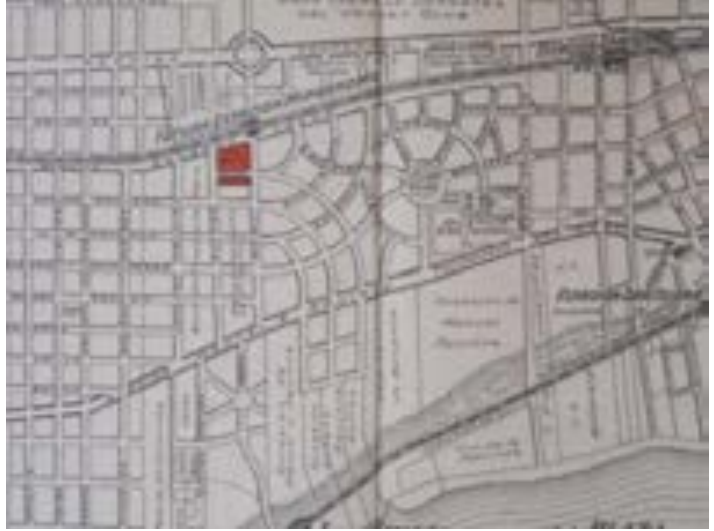

a. Barrio Parque Aguirre junto a la futura Estación Hipódromo (actualmente Acassuso) circa 1920.

Fuente: Carpeta Barrio Parque Aguirre. Museo y Archivo Histórico San Isidro

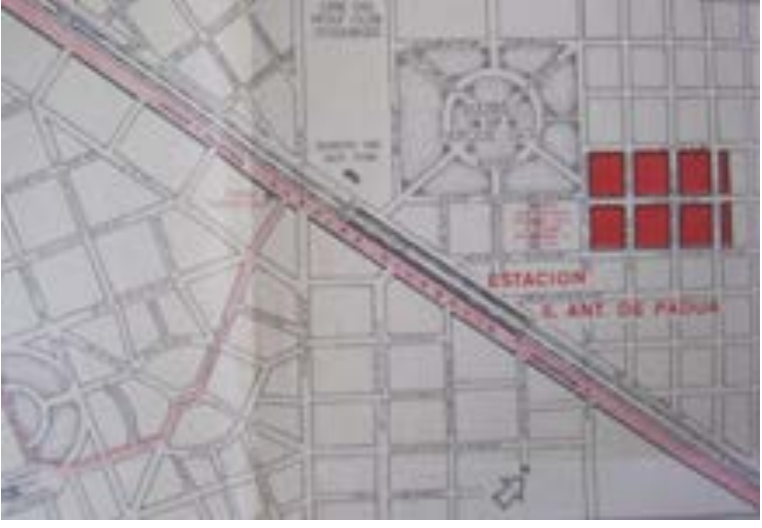

b. Pueblo San Antonio de Padua, por encima de la diagonal que marca el trazado del FFCC el barrio pionero Barrio Parque Golf. 1932 Fuente: Carpeta de Remates- Partido de Merlo, Departamento de Investigación Histórica Cartográfica, Dirección de Geodesia, MOP, Pcia Bs As.

Por otra parte, salvo contadas excepciones, como el Barrio Parque Aguirre, que por su ubicación geográfica se valorizó rápidamente; se puede sostener que la gran oferta de tierras y la posibilidad casi ilimitada de crecimiento, que al menos en un primer momento se asoció a estos núcleos, afectó negativamente su valorización.

Por último, una reflexión que puede servir para las dos tipologías que hasta ahora mencionamos - consolidación de núcleos previos y nuevas estaciones- es que este tipo de loteos, en los cuales grandes áreas se incorporaban al mercado mediante una única operación inmobiliaria, fueron especialmente significativos en los primeros momentos de producción de tierra urbana, cuando el proceso de suburbanización era todavía incipiente. 


\subsection{El ciclo 1935-1950}

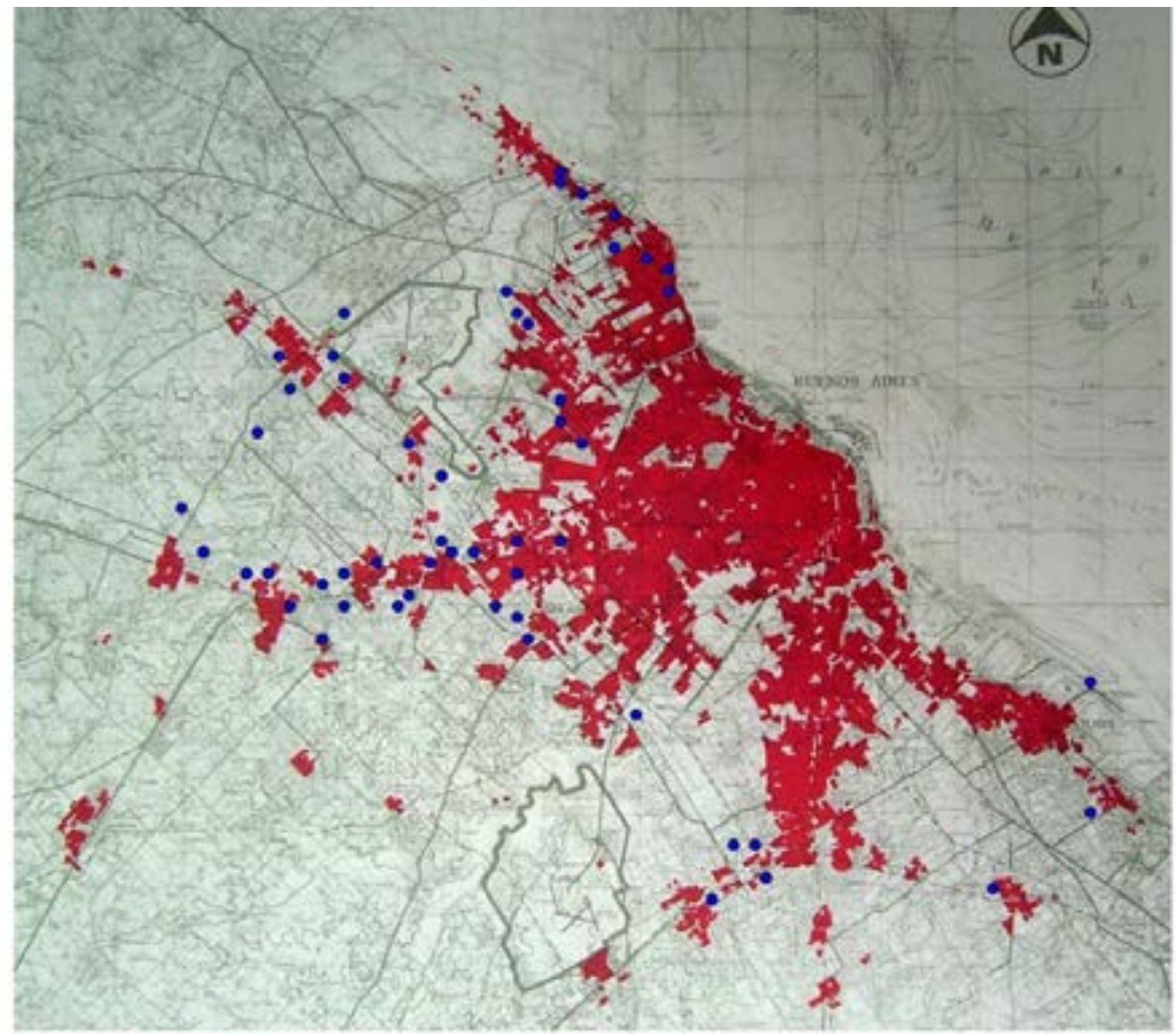

Mapa 7. Localización de emprendimientos de barrios parque y de fin de semana. Área GBA. Período 1935-1950

Confeccionado sobre el plano base de Randle, que muestra el crecimiento de las áreas urbanas para 1948.

\section{Un Panorama...}

En el segundo período de suburbanización creció enormemente la cantidad de emprendimientos que se incorporaron al mercado inmobiliario. En estos quince años se concentra el $80 \%$ del total de los núcleos de barrios parque y de fin de semana que analizamos en el Gran Buenos Aires. Especialmente, los loteos aumentaron hacia fines del período cuando se hizo factible obtener tasas de beneficio más altas que en otros sectores de la economía como consecuencia de la mayor demanda de lotes urbanos y 
del proceso inflacionario que se desencadenó hacia mediados de la década del cuarenta y generó un flujo de capitales hacia el mercado de tierras. ${ }^{122}$

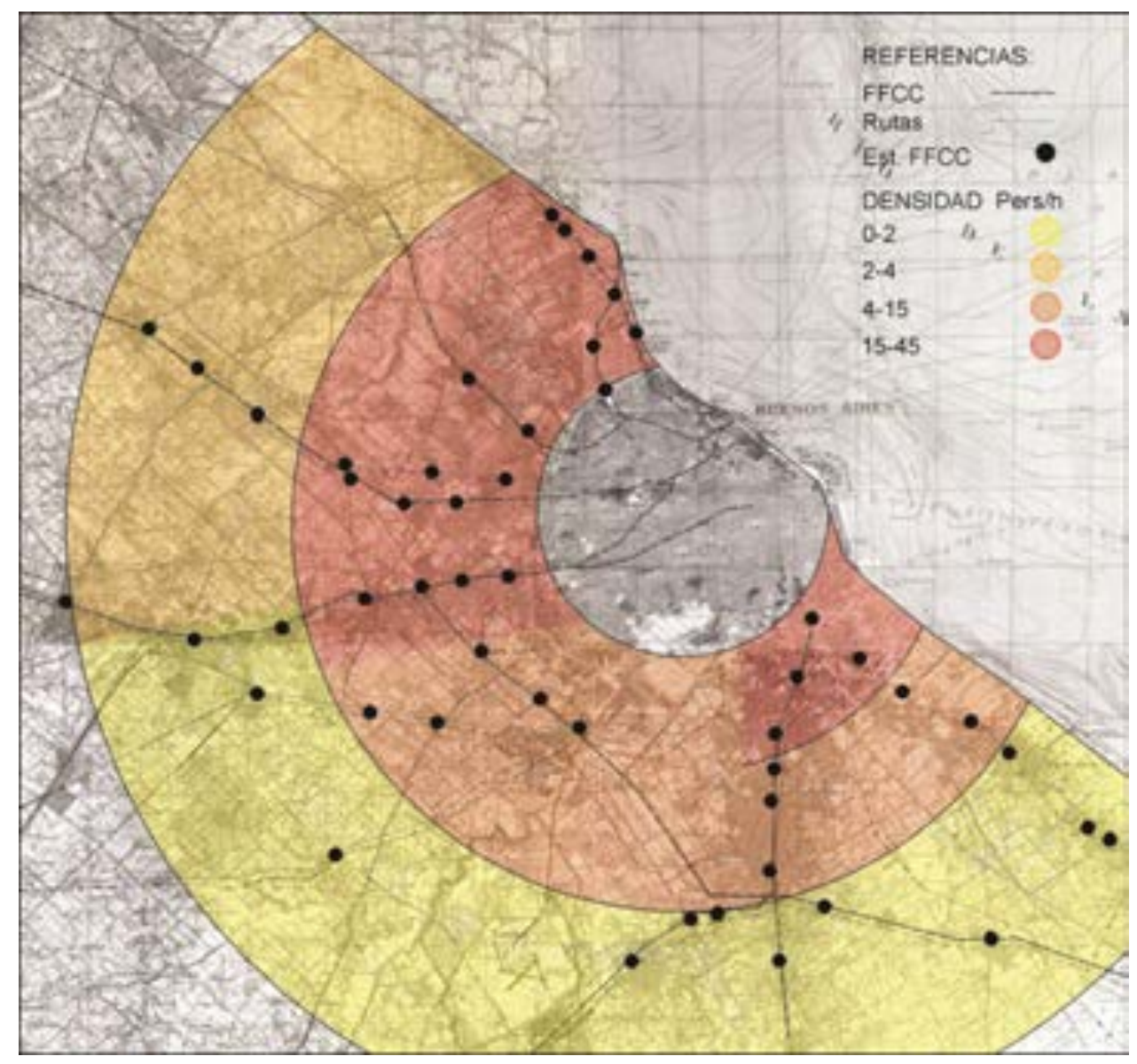

Mapa 8. Estaciones ferroviarias y densidades de población por sectores para el año 1948. Elaboración propia sobre el plano base Topográfico del IGM 1950, densidades de población según el Atlas Ambiental Buenos Aires (AABA)

Siguiendo la tendencia que ya se perfilaba en el período anterior, la distribución geográfica de los emprendimientos distó de ser homogénea. El Mapa 7 deja ver que los partidos de Morón, Moreno, Merlo y San Isidro cobijaron la mayor cantidad de emprendimientos, entre estos cuatro partidos sumaron más del $50 \%$ de los emprendimientos correspondientes al total del área (17 partidos). Dentro de estos partidos se generaron patrones de asentamiento disperso como producto de la configuración más homogénea de vías de acceso que permitía el automotor en contraste

122 Nora Clichevsky, El mercado de tierras en el área de expansión. Op.cit. p. 15. 
con el trazado ferroviario. ${ }^{123}$ A pesar de que las principales carreteras siguieron recorridos similares a los que ya tenía el ferrocarril, -la continuación de la Avenida Rivadavia, actual ruta $\mathrm{n}^{\mathrm{0}} 7$, coincidente con el FCO o la Avenida pavimentada de Pilar a Capital, José F. Uriburu (actual ruta 8), paralela a la traza del ferrocarril a Estación Federico Lacroze- algunas vías de importancia secundaria aparecían de manera transversal a las vías de tránsito principales. Como la campaña de Ford remarcaba astutamente en una publicidad, el automóvil particular posibilitaba un movimiento más libre que, junto a la ampliación de la red de carreteras, daba lugar a la conformación de una trama más homogénea que la que se desprendía del FFCC. ${ }^{124}$ En particular, algunas de estas nuevas avenidas, como la Avenida Gaona (vía que atraviesa parte de la zona Oeste, desde Ciudadela hasta Moreno, con recorrido perpendicular a la Avda. Gral Paz), o el Camino de Cintura (vía que corre paralela a la Avda. Gral Paz atravesando varios partidos del GBA, a una distancia de entre $10 \mathrm{~km}$ y $15 \mathrm{~km}$ por fuera de la primera) tendieron a concentrar en sus márgenes gran cantidad de operaciones. ${ }^{125}$

En relación directa con la ampliación de los suburbios y con las nuevas vías que penetraban en el territorio se comprueba que el tipo de loteos predominantes en este período fueron aquellos loteos "periféricos" y de dimensiones menores que se anexaron a aglomeraciones de cierta importancia y, por otra parte, loteos "sueltos" de grandes

${ }^{123}$ La década del treinta marca el paso del ferrocarril al automóvil. En este momento el Estado desplegó un plan de construcción de caminos - especialmente durante la presidencia de Agustín P.Justo (19321938)- que contribuiría a modificar el territorio pampeano.

124 "Hay muchos lugares hermosos, próximos a la ciudad, que usted y su familia no conocen. Compre un Ford y adquiera cabal conocimiento de todos los barrios de la ciudad y de sus pintorescos alrededores. Guíe usted mismo. Vaya por la calle o camino que le parezca más interesante. (...)”

(Publicidad de Ford, en Femenil 14/09/1925.p. s/n.)

125 Algunas investigaciones de geógrafos y arquitectos han mostrado que las formas fundamentales del plano y que tienen mayor significado funcional son las calles, y especialmente aquellos ejes básicos que unen polaridades destacadas en el tejido urbano. Tienden a actuar como marcos morfológicos que condicionan la génesis y el crecimiento de las formas subsiguientes. Estos autores se refirieron a "trayectos matrices", "trayectos de implantación de edificación", o "trayectos de unión entre trayectos de implantación”. Ver, Canniggia y Maffei; Tipología de la edificación. Estructura del espacio antrópico. Madrid, Celeste Ediciones, 1995. (1ra edición 1979). 
dimensiones ubicados sobre las nuevas rutas intersticiales, y que, como veremos, jugaron un rol fundamental al guiar nuevos sectores para la expansión

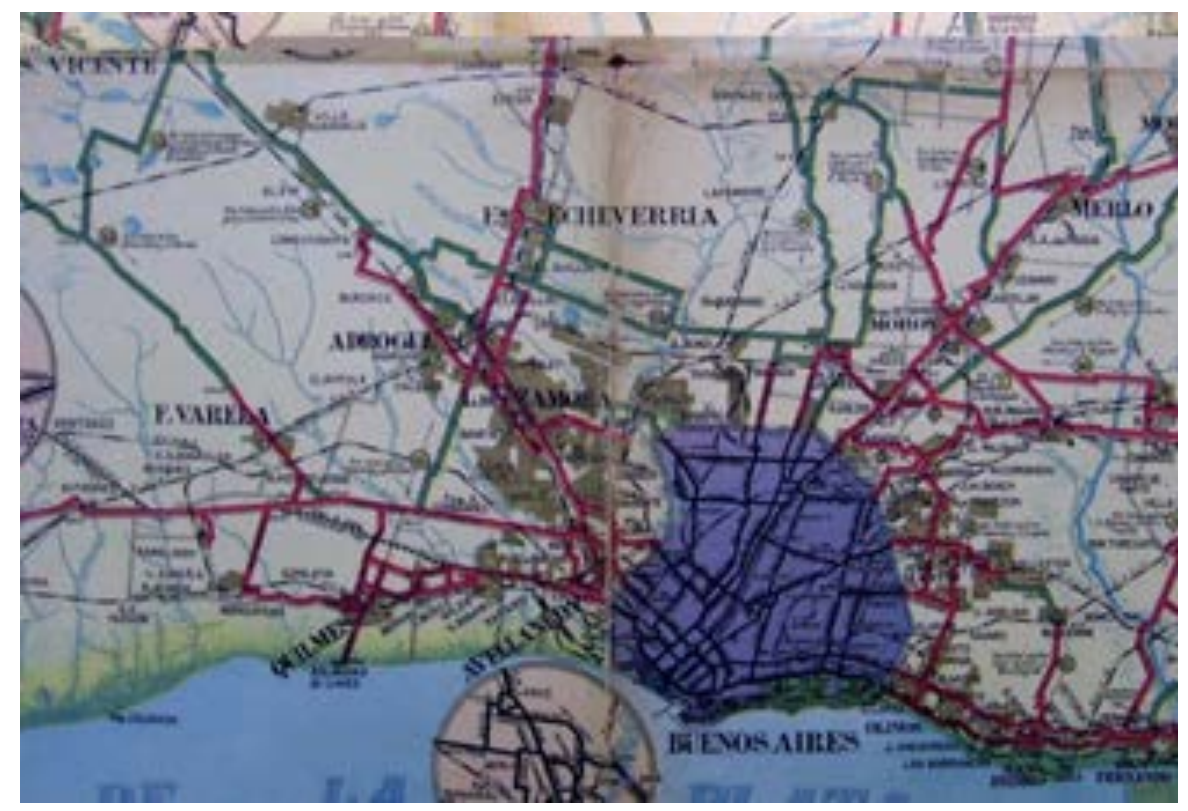

Plano de los caminos principales $\quad \mathrm{y}$ ferrocarriles de los alrededores de la Pcia de Buenos Aires. Ejecutado para el diario La Prensa. Cartógrafo, Oscar Novella. 1935

Rojo: rutas pavimentada Verde: caminos de tierra

Negro punteado:

Los primeros, -loteos periféricos- surgieron en gran medida como resultado de un proceso de densificación en áreas pre-existentes y de especulación terminal, donde la aparición de algunos loteos pequeños ilumina un proceso de subdivisión que alcanzó la escala de los particulares, que loteaban sus propias viviendas ante el negocio ventajoso que prometía la expansión.

Los segundos, -loteos sueltos- se reconocerían si pusiéramos la lupa en alguna de las vías mencionadas, que concentraron la mayor cantidad de loteos. Allí, podríamos ver que estos emprendimientos tendieron a agruparse de manera consecutiva, o enfrentados. En general, aprovechando una calle principal -muchas veces la única pavimentada de la zona o aquella que cobra importancia porque une polaridades destacadas dentro del tejido urbano- o el éxito que pudiera generar un loteo vecino anterior, en el que ya se observaban algunas construcciones o mejor aún la existencia de un club que se convertía en la principal referencia para los emprendimientos vecinos. 


\section{Geografías}

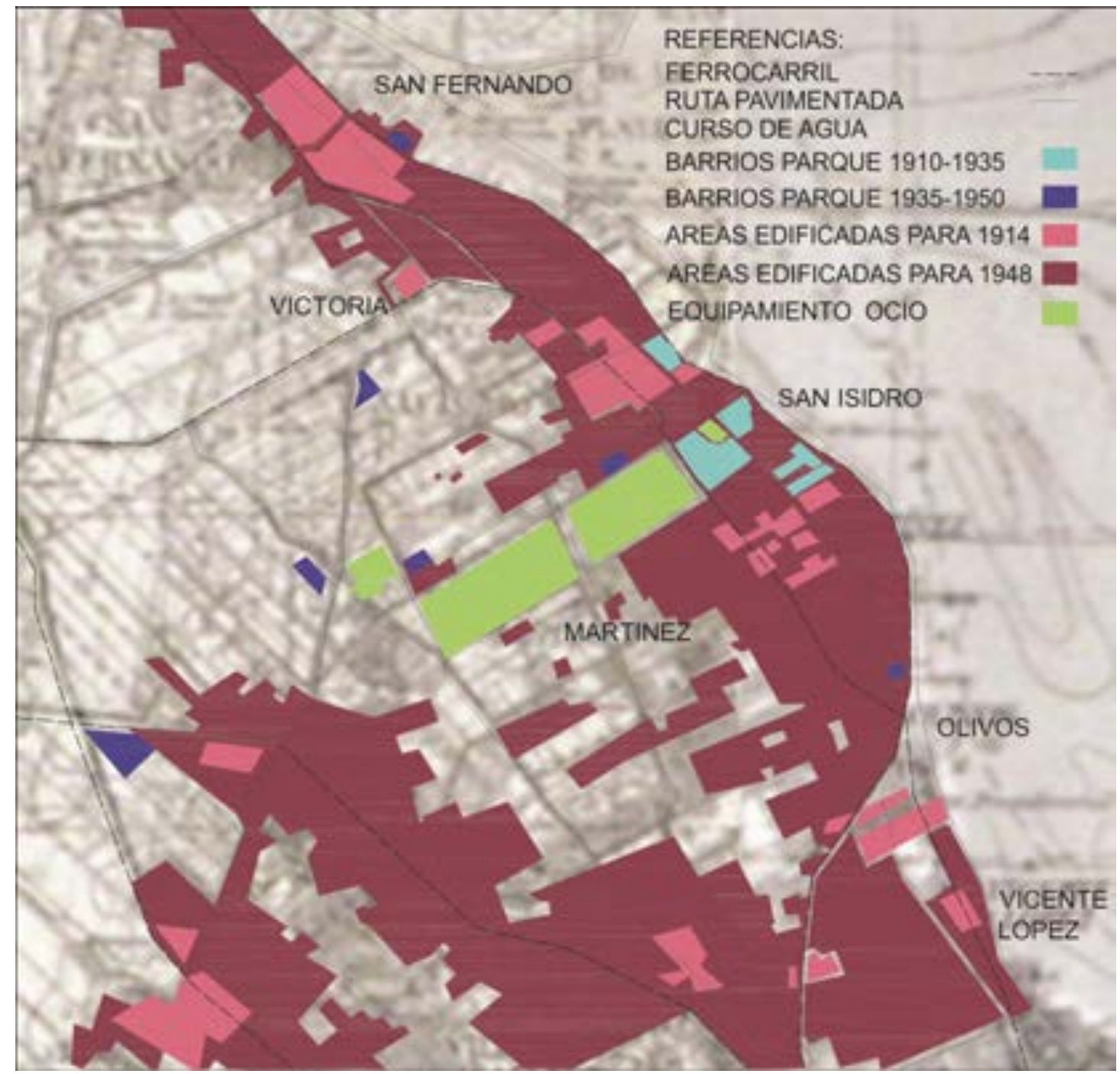

Mapa 9. Eje Norte. Localización de emprendimientos de barrios parque y de fin de semana y "áreas edificadas". 1948.

Elaboración propia sobre la Carta Topográfica IGN. Escala 1:100.000 


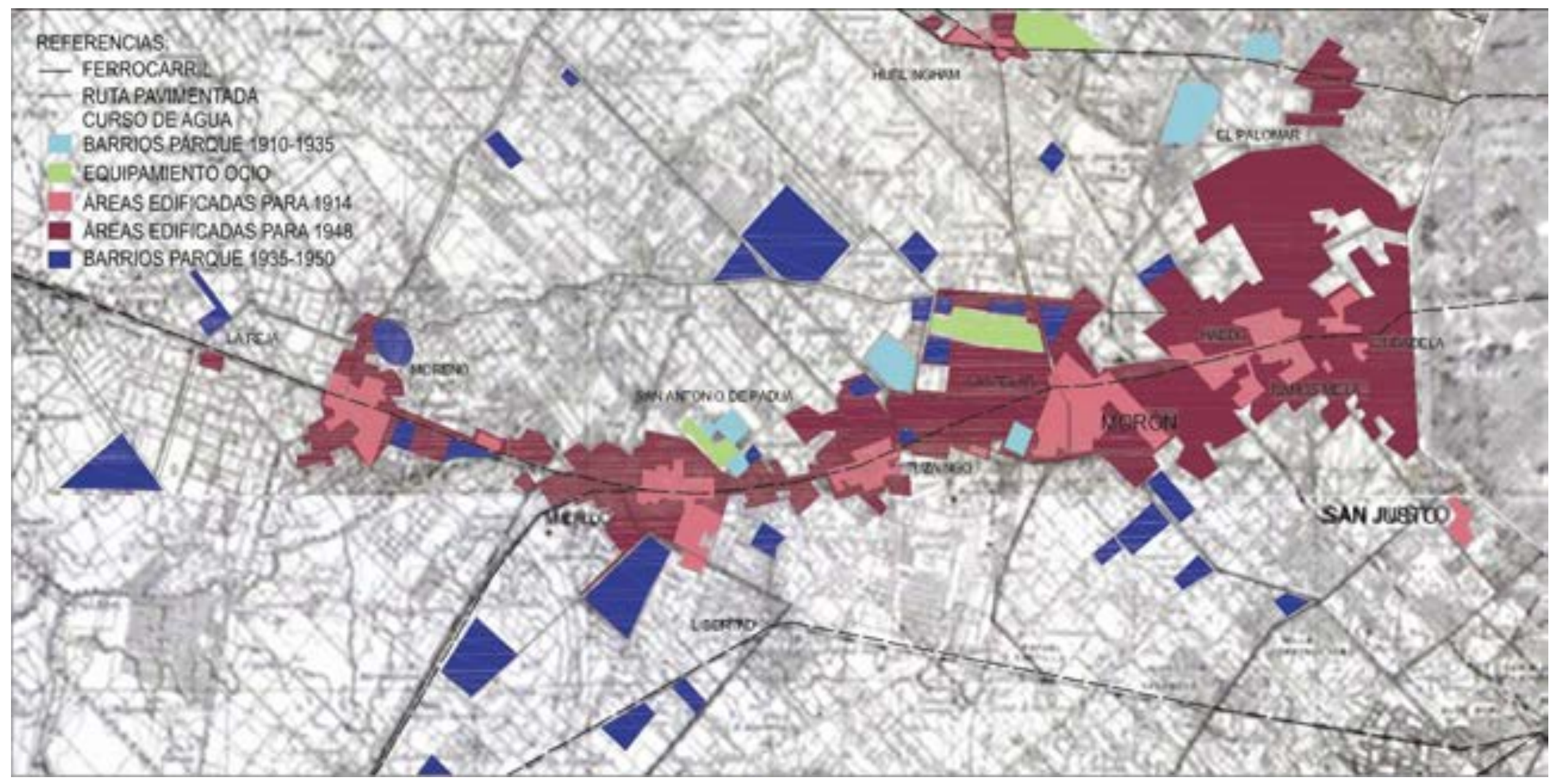

Mapa 10. Eje Oeste. Localización de emprendimientos de barrios parque y de fin de semana y "áreas edificadas". 1948. Elaboración propia sobre la Carta Topográfica IGN. Escala 1:100.000 


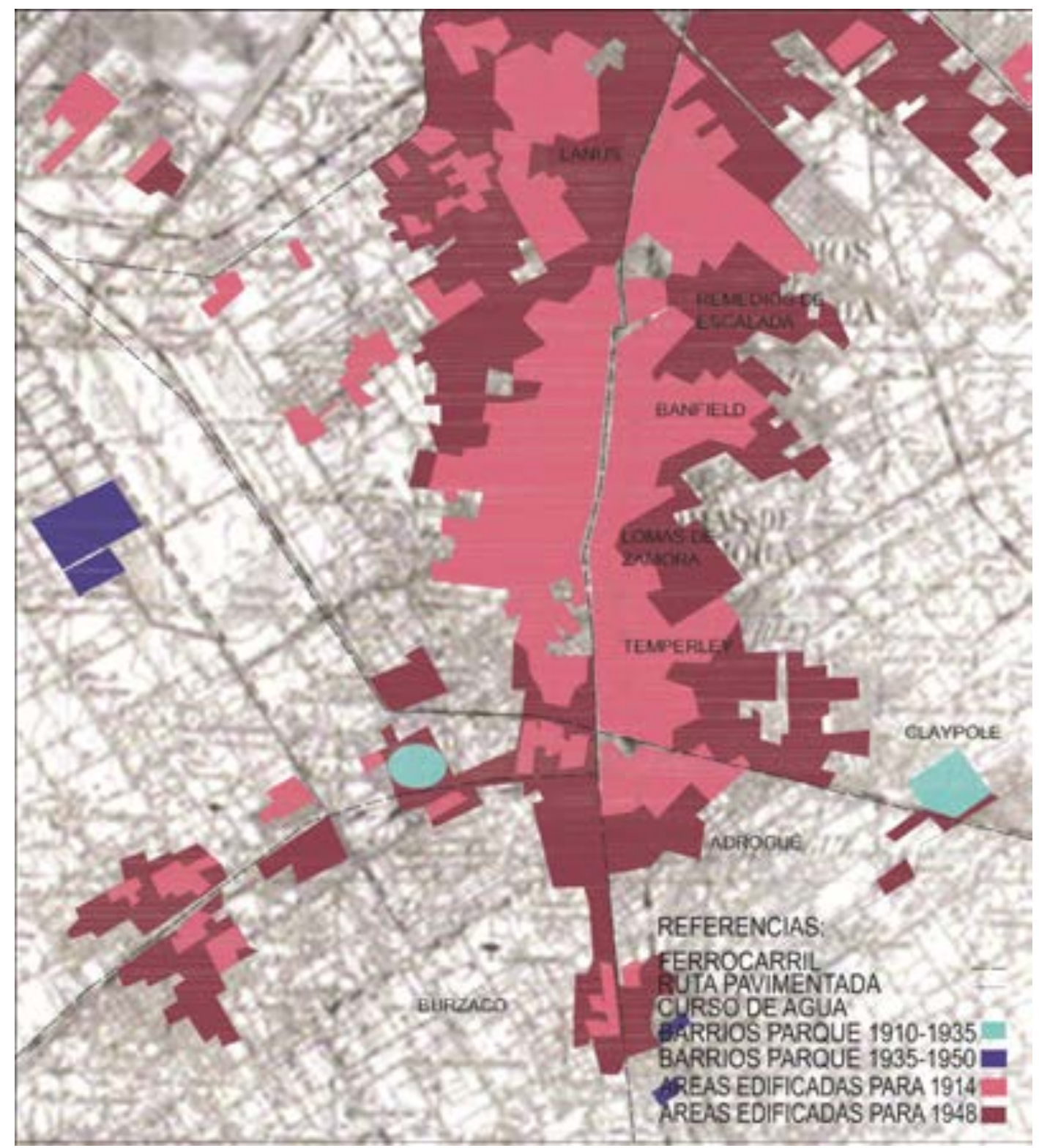

Mapa 11. Eje Sur. Localización de emprendimientos de barrios parque y de fin de semana y “áreas edificadas". 1948.

Elaboración propia sobre la Carta Topográfica IGN. Escala 1:100.000 
En relación a los ejes de la expansión, la incidencia de los primeros -loteos periféricosfue más notoria en la zona Norte, y de los segundos -loteos sueltos- en la zona Oeste; mientras que en el sector Sur, aunque se reconoce la existencia de ambos tipos -como puede constatarse en el Mapa 11- su incidencia en relación al total de "áreas edificadas" es exigua.

Como muestra el Mapa 9, de los barrios parque incorporados durante el segundo período en la zona Norte, una parte de ellos contribuyó a densificar las áreas residenciales sobre el eje de crecimiento tradicional -aquel que se había consolidado durante el primer período-. Mientras que la mitad restante, puede decirse que se incorporó en busca de nuevas áreas de crecimiento que, para 1947, sólo parcialmente quedaron anexados a la expansión.

A su vez, dentro del sector Oeste, particularmente, en las áreas urbanas que incorporaron mayor número de urbanizaciones de barrios parque, como pueden ser Castelar e Ituzaingo, se reconoce en la construcción del Mapa 10 una cantidad considerable de loteos pequeños y medianos -que en un primer momento contribuyeron a consolidar núcleos pre-existentes y que más tarde se anexaron generando nuevas áreas expansión-. Ambos tipos favorecieron la consolidación de áreas urbanas en las que predominó un crecimiento de baja densidad, caracterizado por tipologías residenciales compactas de perímetro libre e imágenes pintoresquistas que -como se abordará en el Capítulo 5- mayoritariamente se asociaban a estos núcleos. Siguiendo otras lógicas, dentro de este mismo eje, los loteos de mayores dimensiones -casi exclusivamente aquellos que denominamos como "sueltos"- se introducían en áreas alejadas, predominantemente rurales, sobre las cuales el nuevo emprendimiento generaba un pequeño "campo de acción" que atraía nuevos loteos.

Un caso significativo de este tipo de agrupamiento se registró sobre el Camino de Cintura, cerca de la estación Morón, donde se agruparon una serie de emprendimientos, iniciados con el loteo del Barrio Parque Peluffo (1945) y al que le siguieron el Barrio Parque San Eduardo (19?), el Barrio Parque Gral. San Martín (1945), El Barrio Parque La Ganga (1947), una nueva fracción del Barrio Parque Peluffo (1949) y los Barrios Parque Golden Park (1949) y Los Pinos (1950). ${ }^{126}$ De una

\footnotetext{
${ }^{126}$ En el Capítulo 6 puede encontrarse un análisis detallado sobre el núcleo que se conforma en torno al Barrio Parque Peluffo.
} 
situación similar, da cuenta también, el núcleo que se formó en Don Torcuato. Luego de que hacia fines de la década del treinta se construyera el Hindú Club se lotearon los barrios Parque Sancalal (1948) frente al Hindú Club, y lindando con este, el Barrio Parque Guadalupe (1948) y la nueva fracción del Barrio Parque Guadalupe (1950-sin fecha pero se promociona mencionando el loteo anterior).

Mediante este tipo de agrupamiento se generaba paulatinamente la urbanización de un área. En donde, no todos los loteos se reconocían necesariamente como barrios parque, algunos eran simples parcelamientos que seguían la tendencia predominante en el área, que de esta manera empezaba a adquirir un carácter diferencial, suburbano, que se distinguía en medio del paisaje predominantemente rural y se perfilaba como un enclave modernizador de referencia.

En otro orden de cosas, los loteos que se ofrecían formando parte, o como ampliación de lo que los contemporáneos llamaban un núcleo "progresista"127 tenían mayores posibilidades de venta y de alcanzar valores más altos en relación al promedio de ese partido.

En cuanto a este último punto -los valores del suelo que asumieron los ejes de la urbanización-, se repiten las marcadas diferencias que ya observamos para el período anterior. Tres partidos: Morón, Moreno, Merlo, dentro del eje de crecimiento hacia el Oeste, asumieron valores del suelo promedio en un rango bajo y medio-entre los \$5-25 y entre \$25-100 mensuales- y un único partido mostró valores promedio más altos -San Isidro, dentro del eje de crecimiento hacia el Norte-, mayores a los $\$ 100$ la mensualidad.

Los valores del suelo generales para el sector Norte se ubicaron alrededor de un $75 \%$ por encima de localidades situadas a igual distancia de la Capital en la

127 Así se nombraban en las publicidades algunas de las áreas de mayor crecimiento, por ejemplo: "rodeados de espléndidos chalets y casas quinta en un paraje alto y sano de los alrededores de la Capital, ideal para vivir o para quinta de recreo. Próximo al progresista pueblo de Hurlingham.” propaganda de un loteo en el año 1929; en Carpeta de Remates Partido de Gral Sarmiento, Departamento de Investigación Histórica Cartográfica, Dirección de Geodesia, MOP, Provincia de Buenos Aires. O "una zona progresista entre Castelar e Ituzaingo" propaganda de un loteo en el año 1946, en Carpeta de Remates Partido de Morón, Departamento de Investigación Histórica Cartográfica, Dirección de Geodesia, MOP, Provincia de Buenos Aires. 
suburbanización Oeste, y más de un 100\% por encima de los loteos en el Sud-Oeste. Como ya señalamos, la mayor parte de las urbanizaciones de la zona Norte, se localizaron en intersticios vacantes de zonas predominantemente urbanizadas; lo cual, daría como resultado que el total de estos loteos presentaran valores superiores a los otros ejes, con cuotas que exceden los $\$ 100$ mensuales. Algunos ejemplos concretos nos lo proporcionan el Barrio Parque Vivot con cuotas de \$125 para el año 1935, o el Barrio Parque Balcarce, con lotes algo más grandes y cuotas de $\$ 170$ para el mismo año. Como puede observarse en el Cuadro 3, en ninguno de estos loteos se ofrecieron plazos de venta tan extendidos como aquellos que se ofrecían en los loteos populares. Este tema ya fue señalado por Charles Sargent, quien reconoció la reducción en el número de cuotas y en los plazos de pago como una de las estrategias más aplicadas a la hora de generar áreas residenciales segregadas, en las que se pretendía excluir a los sectores de menores recursos. ${ }^{128}$ Tengamos en cuenta, por ejemplo que para este período, los datos obtenidos del Departamento Nacional de Trabajo muestran una estimación del costo de vida de una familia en \$160 mensuales, el sueldo promedio de un obrero alcanzaba los $\$ 150$ mensuales y el de un oficial, por ejemplo ferroviario, los $\$ 450$ mensuales. $^{129}$ Lo cual nos sirve para estimar los grupos sociales que podían acceder a cada sector.

Concluyendo, más allá del reconocimiento de estos emprendimientos como barrios parque o barrios de week-end, una revisión detallada expone una gran diversidad en

\footnotetext{
${ }^{128}$ Charles Sargent, op.cit. p 78.
}

Por otra parte hay que indicar que, si bien las cuotas eran altas, se amortizaban en menos de la mitad del tiempo (48 cuotas) que lo que promocionaban la mayoría de los loteos (120 cuotas). De lo cual se deduce que aunque el valor de cada cuota triplicara o cuadruplicara a la de otros loteos, esta diferencia no se traducía en la misma proporción a los valores netos de los lotes. Un lote de $500 \mathrm{~m} 2$ en el B.P Federico Alvear en 1945 valía aproximadamente \$10.000, y por ejemplo en el Barrio Golf de Ituzaingo, en Merlo, valía \$6.000. La diferencia es que por el tipo de venta que se proponía para cada caso, el primero implicaba un gasto de $\$ 200$ mensuales contra $\$ 50$ del segundo. Fuente: Carpeta de Remates- partido de Merlo, y Carpeta de Remates-partido de San Isidro, en Departamento de Investigación Histórica Cartográfica, Dirección de Geodesia, MOP, Provincia de Buenos Aires.

129 Estos datos pertenecen al Boletín Mensual del Departamento Nacional de Trabajo, Noviembre 1932; Boletín Informativo del Departamento Nacional de Trabajo, Enero, Febrero, Marzo de 1936. 
cuanto a los usos, dimensiones y calidades urbanas que los constituyen. Cuanto más nos acercamos a mediados de siglo, la paulatina superposición de tramas y núcleos que analizamos entran en conflicto. La imagen que se observa en el mapa del Gran Buenos Aires es predominantemente fragmentaria; sobre todo, si nos acercamos a alguno de los nodos que concentran mayor número de emprendimientos y en donde se conforma, al menos en el plano, una urbanización continua a partir de la sumatoria de acciones individuales, aunque, contrariamente a la experiencia de la expansión dentro de la Capital donde la sumatoria de las partes quedó homogeneizada bajo la lógica más potente que imponía la cuadrícula, en este caso la falta de cualquier tipo de trazado regulatorio da cuenta del carácter por partes de la expansión.

Las "periferias" de los pueblos.

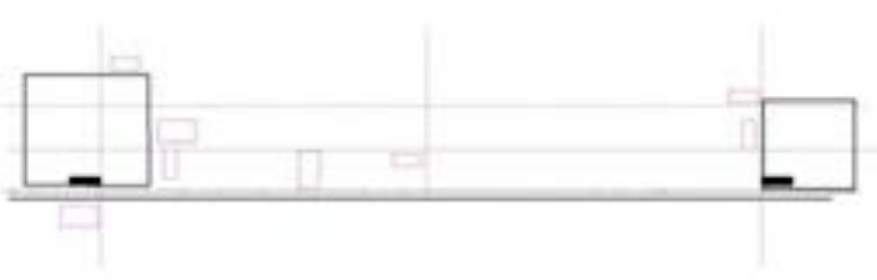

Croquis esquemático: en rosa se grafica la forma en que los nuevos loteos se incorporan a las áreas previas señaladas en negro.

Se observa en la parte inferior la traza del la vía pavimentada junto al FFCC y lo cortan de manera transversal rutas secundarias.

El mayor desarrollo de la urbanización al que se asiste a partir de la década del treinta se realiza frecuentemente en relación a la existencia de núcleos previos. Uno de los tipos de loteos más comunes, es el que denominaremos "loteos periféricos". Se diferencian de las tipologías predominantes en el primer período de la urbanización porque constituyen emprendimientos de menores dimensiones yuxtapuestos a aglomeraciones surgidas con anterioridad. Son pequeñas fracciones de terreno que en ningún caso superan las 10ha, y cuyo promedio general se ubica entre las 4ha y 5 ha. En muchas oportunidades surgen del fraccionamiento de quintas cuyos propietarios deciden lotear ante los valores económicos crecientes que toman los terrenos una vez que las aglomeraciones a las que se anexan registran cierto grado de consolidación, generando nuevas demandas. En relación a este tema, los valores económicos que adoptan son superiores a la media del grupo total de barrios parque y superiores a los que en este mismo período se observaban en los loteos "sueltos" que abordaremos 
seguidamente. Lo fundamental de este tipo de loteos, en especial analizados en relación a cualquiera de los dos casos anteriores, es que a medida que la retícula inicial se extiende, el valor del suelo del núcleo primigenio aumenta. Lo dicho arroja como resultado plusvalías crecientes en las partes ya asentadas, pero también, asegura valores de base mínimos para los nuevos "loteos periféricos". Además, el carácter limitado de tierra que se ofrece a la venta afecta, mejorándolos, los valores del suelo. ${ }^{130}$

En cuanto a la morfología, la dimensión reducida de este tipo de parcelamiento prácticamente anula la posibilidad de que presenten trazados pintoresquistas complejos, pero sí morfologías alternativas con trazados informales. Además, por las condiciones que mencionamos, no generan núcleos en sí mismos y se ven más beneficiados cuando el tipo de trazado viario puede articularse con la red vial existente. El tamaño de las parcelas que los componen suelen ser mayores que el trazado urbano tradicional $(400 \mathrm{~m} 2)$, sin tampoco superar los tamaños del doble lote $(800 \mathrm{~m} 2)$, lo cual hace suponer que no se proponen para futuras subdivisiones. Con respecto a este tema, algunos estudios europeos sobre morfología urbana han tomado el tamaño de las parcelas como una variable definitoria a la hora de clasificar los sectores sociales a los que se destinaba una urbanización, considerándose que por encima de $\operatorname{los} 400 \mathrm{~m} 2$ se trata de parcelamientos para las clases de altas rentas. ${ }^{131}$ En Argentina, la mayor cantidad de tierra disponible y la consecuente disminución de los precios hace más difícil aplicar una clasificación tan estricta cuando analizamos, por ejemplo, el caso de muchos de los grandes loteos que en este mismo momento se producían en áreas apenas más alejadas donde se realizaba el pasaje de tierra rural a tierra urbana.

La gran importancia que adquiere este tipo de loteos en el escenario de la expansión, está dada por la gran cantidad de emprendimientos realizados, representando una proporción importante de las operaciones registradas. Aunque, por las dimensiones siempre pequeñas de los loteos, no fueron igual de significativos en relación a la cantidad de tierras que incorporaron al mercado.

\footnotetext{
${ }^{130}$ Horacio Capel, La morfología de las ciudades. Op.cit. p. 200.

131 Ibid. p. 475.
} 


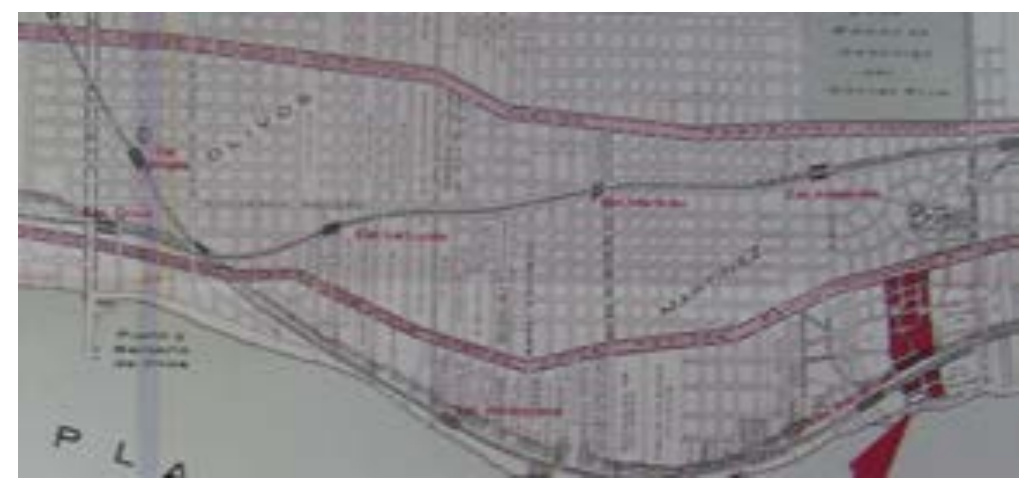

Loteos de barrios parque que se anexan en los alrededores de áreas consolidadas previamente. Fuente: Carpeta de RematesPartido de San Isidro, Departamento de Investigación Histórica Cartográfica, Dirección de Geodesia, MOP, Pcia Bs As

En otras palabras, se puede decir que este tipo de loteo contribuyó a consolidar áreas vacantes entre sectores de la urbanización que se encontraban en crecimiento, adoptando, en cuanto a morfología y tejido urbano, tendencias que ya estaban presentes en esos sectores de la urbanización. Es decir, que la gran cantidad de urbanizaciones de barrios parque que se corresponden con esta clasificación (véase el Cuadro 1), daría cuenta (como se ve en la zona norte y en menor cantidad en la Oeste) de que en las áreas de suburbanización más alejadas en donde se incorporan (entre 20 y 40km por fuera de la Capital), el espíritu del "suburbio jardín" - garden suburb ethos ${ }^{132}$ estaba en alguna medida presente; de modo tal que estos pequeños loteos fueron receptores de una tendencia que ya existía, y la que a su vez contribuyeron a difundir.

\section{Loteos "sueltos"}

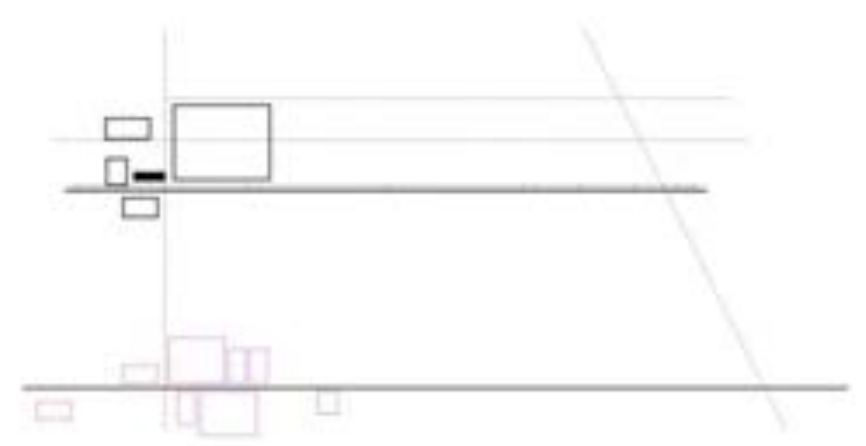

Croquis esquemático: se observa en la parte superior un núcleo de población tradicional aledaño a la estación ferroviaria, por donde atraviesa, además, una ruta transversal secundaria.

En la parte inferior, en rosa, se grafica la forma en que los nuevos loteos conforman un núcleo nuevo en torno al cruce de dos carreteras.

En los últimos años de expansión que analizamos, el quiebre en las lógicas de asentamiento suburbano estuvo marcado por el uso creciente del automóvil y los

\footnotetext{
132 J. Whitehand, "England's interwar suburban landscape: myth and reality", en Journal of Historical Geography, vol 25, issue 4, octubre 1999. pp. 483-501.
} 
nuevos trazados de carreteras. ${ }^{133}$ Así, en estos años surgió un nuevo tipo de loteo que denominamos "libres" o "sueltos". Ubicados en relación a las nuevas vías de comunicación de reciente apertura o pavimentación, ocupando los espacios intersticiales entre los ejes de crecimiento marcados por el trazado ferroviario.

En la mayoría de los casos estos loteos presentaron grandes fracciones de terreno en áreas alejadas de núcleos de población y consecuentemente de las obras de infraestructura. Pueden compararse a los tipos que encontramos más frecuentemente en el primer período de la expansión, (aquellos que consolidan un núcleo previo o que se generan en torno a nuevas estaciones, en su intencionalidad de conformar una entidad en sí mismos) lo cual implicaba la incorporación de áreas de mayores dimensiones en el mercado (entre 10 y 30 ha). Pero sólo hasta aquí llegan las semejanzas; en cuanto al trazado tomaron alternativamente ordenamientos en grilla o de trazado informal y el parcelamiento de las manzanas fue de lo más variable, con dimensiones entre los $400 \mathrm{y}$ $1.200 \mathrm{~m} 2$, dependiendo fundamentalmente del uso y del sector de la demanda a la que se pensara destinar el emprendimiento. Así, se constata que en los loteos sueltos prevaleció, por un lado, la venta de grandes lotes, con más de $700 \mathrm{~m} 2$ en zonas alejadas, y en algunos casos se lotearon barrios con terrenos de tipo urbano de entre $300-400 \mathrm{~m} 2$, cuando la tendencia previa de la zona se orientaba hacia el asentamiento de sectores populares. $^{134}$

Otro contraste fundamental con los primeros loteos realizados hasta mediados de los años treinta, cuya referencia era generalmente la estación de ferrocarril, es, tal como mencionamos, la referencia a una ruta o vía de acceso principal. En el mapa

133 Aunque el crecimiento explosivo en la venta de automóviles se reconoce a partir de la década del veinte, no sería hasta la década del treinta, que gracias a los planes de construcción de caminos y carreteras se modificarían las formas de acceso en el GBA. Para analizar más en detalle el crecimiento del parque automotor y de los trazados de carreteras puede verse, Melina Piglia, “Automóviles, Turismo y Carreteras como problemas públicos: los clubes de automovilistas y la configuración de las políticas turísticas y viales en la Argentina (1918-1943)”. Tesis de Doctorado inédita, UBA, 2009; Fernando Rocchi, "La americanización del consumo: las batallas por el mercado argentino, 1920-1945”, en María I. Barbero y Andrés Regalsky (editores), Americanización. Estados Unidos y América Latina en el Siglo XX. Transferencias económicas, tecnológicas y culturales, Buenos Aires, Eduntref, 2003.

134 En el Capítulo 4 analizaremos las estrategias de venta que impulsaban las inmobiliarias junto a los inversores de acuerdo al tipo de público al que se esperaba llegar. 
territorial, este pasaje de la lógica del ferrocarril a la del automóvil arroja como resultado una distribución lineal de los núcleos en torno a una carretera, en vez de a un núcleo central (estación). Y en una escala más amplia, en torno a una trama difusa de carreteras, en contraste con la fuerte presencia de núcleos centralizados a lo largo de la línea del ferrocarril.

En relación a los sectores geográficos de la expansión, los nuevos loteos se ubicaron preferentemente en los partidos del Oeste que experimentaron un crecimiento más tardío y por lo tanto presentaban mayor disponibilidad de áreas vacantes. Son contados los casos en que estas urbanizaciones pueden considerarse como base de un nuevo pueblo. El poblamiento lento y disperso, el uso residencial no permanente de la mayoría de los ocupantes dio como resultado núcleos exentos de instituciones barriales capaces de nuclear a una población anónima, sin siquiera algunos comercios básicos que generaran cierta centralidad o un foco simbólico de reunión de la población. Además, salvo pocas excepciones carecieron de espacio público -veredas y mucho menos plazas- dado que el propio carácter de la parcelación suponía los espacios libres, recreativos, como función privada dentro de cada parcela. Por otra parte, el trazado viario interno solía ser deficiente, en tanto sólo se consolidaban las calles que permitían llegar desde las parcelas ocupadas hasta una vía central que uniera al conjunto parcelario con la red urbana.

En cuanto a la nueva configuración que adquiría el GBA, estos barrios deben ser tenidos en cuenta porque representan casi la mitad de las urbanizaciones de fin de semana en el área. Con una superficie promedio de 800 ha ocupadas, y que por su localización, originalmente alejada de los núcleos de población funcionaron como polos de atracción para el crecimiento futuro.
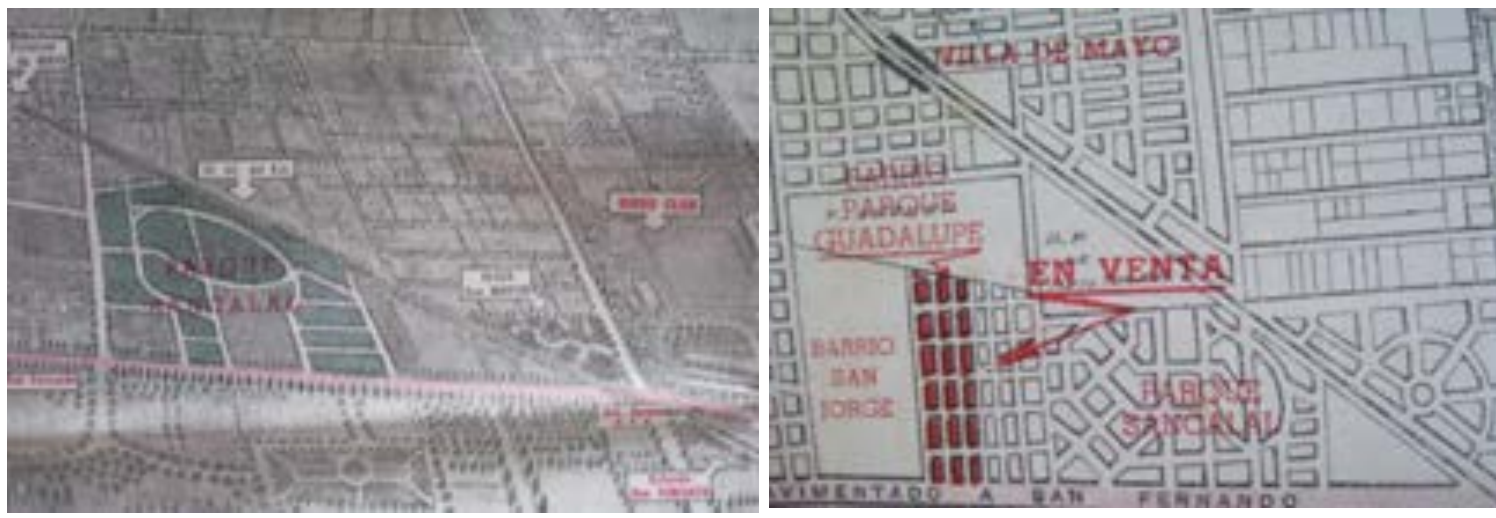

a y b. Núcleo de barrios parque entorno a la Est. Don Torcuato y al Hindú Club. circa 1948 Fuente: Carpeta de remates-partido Tigre. Departamento de Investigación Histórica Cartográfica, Dirección de Geodesia, MOP, Pcia Bs As 



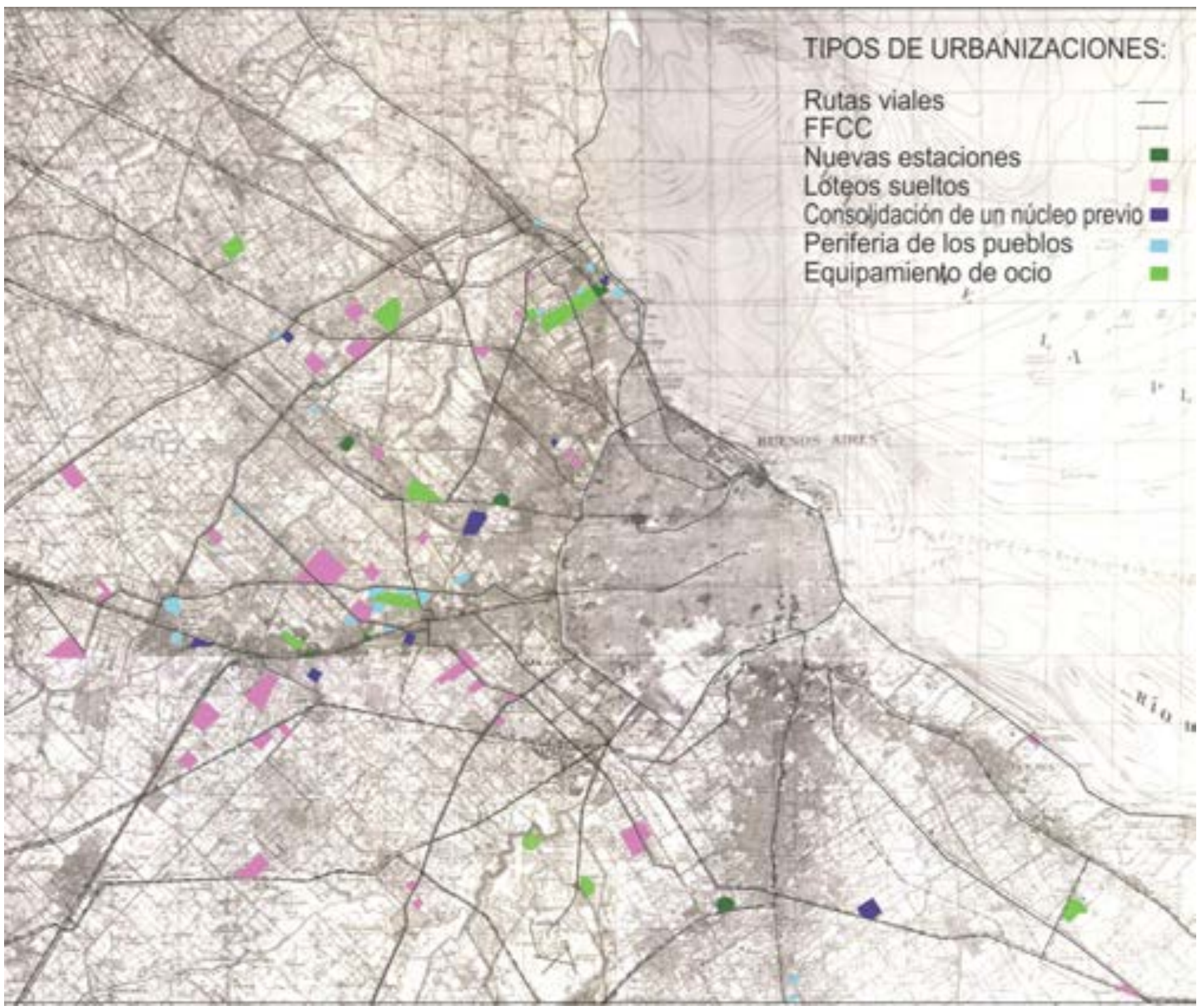

Mapa 12. Tipos de urbanizaciones y su distribución territorial.

Elaboración propia sobre la Carta Topográfica IGN. Escala 1:100.000 
En síntesis, los nuevos loteos perpetuaban un esquema de crecimiento radial en base a los ejes ferroviarios delineados en el siglo XIX y cuya primacía comenzaría a quebrarse a lo largo del período. (Mapa 12)

Durante los primeros años se asistió a un proceso de expansión que mantuvo el esquema de urbanización lineal en torno a las vías del ferrocarril y que afectó mayoritariamente a los ejes Norte y Oeste. Este último fue adquiriendo mayor protagonismo hasta convertirse en el área de mayor crecimiento hacia las décadas del treinta y del cuarenta.

Si tomamos en cuenta todo el período, una porción de los nuevos loteos contribuyó - en los primeros años- a consolidar los pueblos de campaña del siglo XIX, y a su expansión, en las décadas posteriores. Más importante fue el aporte que un número significativo de nuevos barrios hizo hacia formas de urbanización dispersa, generadas por la localización de grandes emprendimientos siguiendo las líneas que dictaban las rutas viales, abriendo nuevas fronteras para la urbanización. 
Cuadro 2. Valores de los precios por parcela (por mes) y distancia a la Capital, para los barrios parque y urbanizaciones de week-end. Período 1920-1935. Fuente: Elaboración propia.

\begin{tabular}{|c|c|c|c|c|c|c|}
\hline número & Partido & Núcleo & $\begin{array}{l}\text { valor económico } \\
\text { de la parcela (en } \\
\text { \$) x mes }\end{array}$ & $\begin{array}{l}\text { Año de } \\
\text { realización } \\
\text { del 1er loteo }\end{array}$ & $\begin{array}{l}\text { cantidad } \\
\text { de } \\
\text { cuotas }\end{array}$ & $\begin{array}{l}\text { distancia a } \\
\text { la Capital } \\
(\mathrm{KM})\end{array}$ \\
\hline 1 & Alte. Brown & $\begin{array}{l}\text { B. P. Manuel } \\
\text { Obligado }\end{array}$ & $\$ 5$ & 1929 & 100 & 22 \\
\hline 2 & G.Sarmiento & B.P.Mattaldi & $\$ 10$ & 1926 & 0 & 20 \\
\hline 3 & G.Sarmiento & B.P.San Andrés & $\$ 7$ & 1931 & 100 & 15 \\
\hline 4 & $\begin{array}{l}\text { Gral.San } \\
\text { Martín }\end{array}$ & Villa Zagala & $\$ 4$ & 1936 & 100 & 12 \\
\hline 5 & $\begin{array}{l}\text { Lomas de } \\
\text { Zamora }\end{array}$ & B.P. Lavallol & $\$ 10$ & 1933 & 0 & 31 \\
\hline 6 & Merlo & B. Golf Ituzaingo & $\$ 10$ & 1932 & 120 & 32 \\
\hline 7 & Morón & B.P. Castelar & $\$ 20$ & 1929 & 100 & 25 \\
\hline 8 & San Isidro & B.P.Elortondo & $\$ 160$ & 1931 & 48 & 21 \\
\hline 9 & San Isidro & B.P. Nelson & $\mathrm{s} / \mathrm{d}$ & 1934 & 0 & 21 \\
\hline 10 & San Isidro & B.P.Aguirre & $\$ 250$ & 1920 & 24 & 22 \\
\hline 11 & San Isidro & B.P. Balcarce & $\$ 170$ & 1935 & 60 & 21 \\
\hline 12 & San Isidro & B.P. Vivot & $\$ 125$ & 1935 & 24 & 21 \\
\hline 13 & San Martín & Villa Bosch & $\$ 6$ & 1934 & & 17 \\
\hline
\end{tabular}


Cuadro 3. Valores de los precios por parcela (por mes) y distancia a Capital, para los barrios parque y urbanizaciones de week-end. Período 1935-1950. Fuente: Elaboración propia.

\begin{tabular}{|c|c|c|c|c|c|c|}
\hline & Partido & Núcleo & $\begin{array}{l}\text { Superficie de } \\
\text { la parcela } \\
(\mathrm{en} \mathrm{m} 2)\end{array}$ & $\begin{array}{l}\text { valor económico } \\
\text { de la parcela (en } \\
\text { \$) x mes }\end{array}$ & $\begin{array}{c}\text { Año de } \\
\text { realización } \\
\text { del 1er loteo }\end{array}$ & $\begin{array}{l}\text { distancia a } \\
\text { la Capital }\end{array}$ \\
\hline 1 & Alte. Brown & B.P. Burzaco & 300 & $\$ 10$ & 1942 & 25 \\
\hline 2 & Alte. Brown & $\begin{array}{l}\text { La Carmen } \\
\text { Bonorino }\end{array}$ & 900 & $\$ 10$ & 1947 & 26 \\
\hline 3 & Boulogne & Gral. Urquiza & 500 & $\$ 8$ & 1946 & 28 \\
\hline 4 & G.Sarmiento & $\begin{array}{l}\text { B.P. Santa } \\
\text { Mónica }\end{array}$ & 1.000 & $\$ 15$ & 1946 & 21 \\
\hline 5 & G.Sarmiento & B.P.La Primavera & 800 & & 1946 & 29 \\
\hline 6 & G.Sarmiento & B.P. La Huella & 800 & $\$ 15$ & 1947 & 30 \\
\hline 7 & G.Sarmiento & $\begin{array}{ll}\text { Quintas } & \text { San } \\
\text { Miguel } & \end{array}$ & 900 & $\$ 10$ & 1940 & 32 \\
\hline 8 & G.Sarmiento & B.P. Bellaflor & 700 & & 1944 & 30 \\
\hline 9 & $\begin{array}{l}\text { Gral.San } \\
\text { Martín }\end{array}$ & Villa Zagala & 400 & $\$ 4$ & 1936 & 12 \\
\hline 10 & La Matanza & Puente Ezcurra & 400 & $\$ 7$ & 1948 & 18 \\
\hline 11 & La Matanza & Golden Park & 800 & & 1949 & 25 \\
\hline 12 & La Matanza & $\begin{array}{l}\text { B.P. Gral. San } \\
\text { Martín }\end{array}$ & 900 & $\$ 10$ & 1945 & 23 \\
\hline 13 & La Matanza & B.P. Peluffo & 1.000 & $\$ 50$ & 1945 & 23 \\
\hline 14 & La Matanza & Parque Ibañez & 1.800 & & 1947 & \\
\hline 15 & La Matanza & B.P. Santa Clara & 1.500 & $\$ 20$ & 1945 & 18 \\
\hline 16 & La Matanza & El Pino & 0 & $\$ 30$ & 1950 & 24 \\
\hline 17 & La Matanza & Santa Amelia & 350 & $\$ 30$ & 1945 & 22 \\
\hline 18 & La Matanza & La Ganga & 400 & $\$ 0$ & 1947 & 25 \\
\hline 19 & $\begin{array}{l}\text { Lomas de } \\
\text { Zamora }\end{array}$ & Las Torres & 900 & $\$ 30$ & 1949 & 30 \\
\hline 20 & $\begin{array}{l}\text { Lomas de } \\
\text { Zamora }\end{array}$ & $\begin{array}{l}\text { Lomas de } \\
\text { Beheran }\end{array}$ & 1.200 & $\$ 60$ & 1948 & 30 \\
\hline 21 & Merlo & $\begin{array}{l}\text { Gran.B.P.San } \\
\text { Martín }\end{array}$ & 400 & $\$ 8$ & 1950 & 35 \\
\hline 22 & Merlo & El Pericón & 300 & $\$ 15$ & 1950 & 33 \\
\hline 23 & Merlo & La Esmeralda & 800 & $\$ 70$ & 1949 & 34 \\
\hline 24 & Merlo & $\begin{array}{l}\text { Est. Agustín } \\
\text { Ferrari }\end{array}$ & 600 & $\$ 20$ & & 35 \\
\hline
\end{tabular}




\begin{tabular}{|c|c|c|c|c|c|c|}
\hline 25 & Merlo & Paso del Rey & 600 & $\$ 20$ & 1947 & 33 \\
\hline 26 & Merlo & B.P. Gral. Alvear & 1.000 & $\$ 20$ & 1946 & 28 \\
\hline 27 & Merlo & B.P. Los Indios & 800 & & 1946 & 30 \\
\hline 28 & Merlo & B.P. San Antonio & 800 & $\$ 16$ & 1945 & 32 \\
\hline 29 & Merlo & La Teja & 1.200 & $\$ 15$ & 1947 & \\
\hline 30 & Merlo & Pradera de Merlo & 900 & $\$ 250$ & 1950 & \\
\hline 31 & Merlo & $\begin{array}{l}\text { San Antonio de } \\
\text { Padua }\end{array}$ & 0 & $\$ 24$ & & 30 \\
\hline 32 & Merlo & B.P. San Martin & 400 & $\$ 8$ & & \\
\hline 33 & Moreno & El Ensueño & 1.800 & $\$ 25$ & 1947 & 35 \\
\hline 34 & Moreno & Rancho Grande & 1.000 & $\$ 25$ & 1947 & 34 \\
\hline 35 & Moreno & Santa Teresa & 800 & $\$ 80$ & 1948 & 35 \\
\hline 36 & Moreno & Parque Trujui & 2.000 & $\$ 100$ & 1949 & 34 \\
\hline 37 & Moreno & Juan Pastorini & 800 & $\$ 90$ & 1950 & 35 \\
\hline 38 & Moreno & Las Catonas & & $\$ 30$ & & 36 \\
\hline 39 & Moreno & Los Nogales & 800 & $\$ 30$ & 1949 & 34 \\
\hline 40 & Morón & Alto Verde & 500 & $\$ 3$ & 1945 & 31 \\
\hline 41 & Morón & Francisco Verde & 500 & $\$ 10$ & 1945 & 30 \\
\hline 42 & Morón & Parque Leloir & 2.250 & $\$ 100$ & 1947 & 30 \\
\hline 43 & Morón & $\begin{array}{l}\text { Ituzaingo } \\
\text { Residencial }\end{array}$ & 500 & $\$ 40$ & 1947 & 30 \\
\hline 44 & Morón & Parque Quirno & 1.000 & $\$ 10$ & 1947 & 30 \\
\hline 45 & Morón & $\begin{array}{l}\text { B.P.San } \\
\text { Francisco }\end{array}$ & 800 & $\$ 30$ & 1947 & 29 \\
\hline 46 & Morón & $\begin{array}{l}\text { B.P.Lomas de } \\
\text { Castelar }\end{array}$ & 1.000 & & 1943 & 25 \\
\hline 47 & Morón & Parque Guiraldes & 1.200 & $\$ 40$ & 1946 & 30 \\
\hline 48 & Morón & B.P. Maupas & 800 & $\$ 12$ & 1948 & 31 \\
\hline 49 & Morón & Parque Morón & 400 & $\$ 6$ & 1946 & 27 \\
\hline 50 & Morón & $\begin{array}{ll}\text { Nuevo } & \text { B.P. } \\
\text { G.Alvear } & \end{array}$ & 800 & $\$ 20$ & & \\
\hline 51 & Morón & Morón Week-end & 500 & $\$ 10$ & 1945 & 22 \\
\hline 52 & Morón & Lomas de Haedo & 800 & $\$ 5$ & 1945 & 20 \\
\hline 53 & Morón & Villa Ariza & 0 & $\$ 0$ & 1939 & 22 \\
\hline 54 & Morón & Los Angeles & 400 & $\$ 2$ & 1945 & 24 \\
\hline 55 & Quilmes & B.P.Jacarandá & 300 & $\$ 20$ & 1949 & 19 \\
\hline 56 & Quilmes & San Juan Pereyra & 3.000 & $\$ 150$ & 1946 & 20 \\
\hline 57 & Quilmes & $\begin{array}{l}\text { Balneario } \\
\text { Quilmes }\end{array}$ & 500 & $\$ 80$ & 1947 & 18 \\
\hline
\end{tabular}




\begin{tabular}{|c|c|c|c|c|c|c|}
\hline 58 & San Fernando & La Floresta & 400 & $\$ 15$ & 1950 & 26 \\
\hline 59 & San Isidro & B.P. Atalaya & 400 & $\$ 250$ & 1949 & 22 \\
\hline 60 & San Isidro & B.P. Longchamps & 500 & $\$ 180$ & 1945 & 22 \\
\hline 61 & San Isidro & B.P. Santa Rosa & 1.000 & $\$ 100$ & 1945 & 24 \\
\hline 62 & San Isidro & B.P. Alvear & 350 & $\$ 300$ & 1940 & 24 \\
\hline 63 & San Martín & $\begin{array}{l}\text { C.J. Lomas de } \\
\text { Palomar }\end{array}$ & 700 & $\$ 0$ & 1946 & 24 \\
\hline 64 & San Martín & Parque Villegas & 400 & $\$ 4$ & 1942 & 21 \\
\hline 65 & Tigre & Parque Sancalal & 1.300 & $\$ 40$ & 1948 & 28 \\
\hline 66 & Tigre & B.P. Guadalupe & & $\$ 40$ & 1948 & 29 \\
\hline
\end{tabular}




\section{CAPÍTULO 3. Aproximaciones morfológicas}

"Un barrio de lujo que va a formarse en el pueblo más pintoresco y aristocrático de las barrancas del norte. (...)El trazado del nuevo barrio con sus calles curvas que convergen sobre dos avenidas circulares concéntricas, sobre un rond-point en que se formará una plaza, va a permitir dar a la edificación las más hermosas perspectivas, desapareciendo el monótono abigarramiento que se produce en el vulgar amanzanamiento colonial." (Propaganda de un loteo en San Isidro, 1913) ${ }^{135}$

Como sugiere Robert Fishman, el proceso de materialización y diseño involucrado en la formación de áreas suburbanas, debe ser entendido, no sólo como un elemento cosmético sino -como se menciona en el acápite- como condicionante del carácter y desarrollo futuro que las urbanizaciones podían alcanzar. Así, establecer el tipo de amanzanamiento o las dimensiones del loteo, implicaba tomar decisiones sobre la relación que el conjunto establecía con las parcelaciones y pueblos de aparición anterior -si seguía o no las pautas de diseño operantes-, sobre la densidad futura y los posibles usos del suelo - que más allá de las disposiciones legales, quedaba implícita en la dimensión de los lotes.

En el contexto global, desde fines del siglo XVIII, en Inglaterra, y mediados del siglo XIX, en Estados Unidos, el habitar suburbano -inicialmente de carácter no permanente- entendido como una opción consciente de los grupos de elite por escapar del ambiente insalubre y bullicioso de la ciudad se asoció, mayoritariamente, a modelos urbanos de ordenamiento informales -a la manera del jardín informal o pintoresco inglés- con trazados de calles curvas, árboles y arbustos creciendo sin una lógica aparente en el terreno y residencias unifamiliares aisladas en medio de las áreas verdes. ${ }^{136}$ Veremos que en nuestro país, el acercamiento a este tipo de trazados no

\footnotetext{
135 Propaganda de loteo, 1913. Inmobiliaria Adolfo Bulrich \& Cia. Carpeta Barrio Aguirre, Archivo Histórico San Isidro.

136 Cuando hablemos de suburbio, estamos haciendo referencia a un ámbito de uso residencial extraurbano que se diferencia, en cuanto a usos, densidad de población, características formales y de
} 
aparece, inicialmente, en relación a la expansión suburbana; sino que, los primeros proyectos se estructuraron dentro de los ámbitos de discusión afines a la cuestión urbana -personajes vinculados a la política, arquitectos, ingenieros y paisajistas- en relación al área de la Capital. Fue con posterioridad que gran parte de los emprendimientos inmobiliarios destinados a conformar núcleos vacacionales o de vivienda no permanente -aunque no todos- trataron de condensar la imagen del barrio jardín de matriz anglosajona que seguía la pauta introducida al país por los integrantes de la comunidad británica en sitios como Quilmes, Belgrano o Lomas de Zamora. En efecto, los trabajos de Graciela Silvestri y Jorge Buján ponderaron el rol que desde la segunda mitad del siglo XIX tuvo la comunidad británica en la introducción de la sensibilidad pintoresca y en los cambios en las formas de habitar urbana y rural. ${ }^{137}$

Sería recién hacia fines de los años veinte, una vez que estos modelos ya habían transitado un largo proceso de difusión, que se volvieron especialmente atractivos para dar forma al proceso de expansión de la ciudad, por los modos de vida que tradicionalmente se asociaban a él, a pesar de que, como ya se desarrolló en el capítulo anterior, en el ambiente local muchos de los llamados barrios parque se formalizaron, fundamentalmente, a partir de promover loteos de baja densidad más que a organizaciones morfológicas o trazados informales. De hecho, se verifica que sólo el $50 \%$ de los barrios parque se materializaron a través de trazados pintorescos con calles curvas. Veremos, entonces, que los ideales de la vivienda unifamiliar en medio de un área ajardinada como figura condensadora de una vida tranquila y de la felicidad familiar, también se aplicaron en núcleos con trazados que repetían el modelo de cuadrícula de la ciudad tradicional. ${ }^{138}$

diseño, tanto de la ciudad como del campo. Esta acepción se remonta a la tradición del suburbio angloamericano como espacio elegido para la habitación, inicialmente de sectores altos de la sociedad y que a partir del siglo XX se pone al alcance de sectores más amplios.

Cuando sea necesario hacer referencia a las áreas extraurbanas que concentran una alta superposición de usos: industriales, comerciales, y residenciales de carácter popular hablaremos simplemente de la expansión.

137 Graciela Silvestri, "La vida en clave verde. Cambios en las formas de habitar urbana y rural a mediados del siglo XIX”, op.cit y Jorge Buján, La colectividad británica en Quilmes, op.cit.

${ }^{138}$ En otras ciudades latinoamericanas, como Sao Paulo se reconocen casos paradigmáticos como Jardín América, el barrio jardín diseñado en 1913 por los arquitectos ingleses Raymond Unwin y Barry Parker. 
A partir de este horizonte, un análisis sobre las diversas formas y figuras con que se consolidaron los loteos nos permitirá iluminar cómo, a través de su materialización, se ponían en juego, concientemente o no, modelos diversos en relación a la ciudad y a su expansión. $^{139}$

Concretamente, proponemos realizar un recorrido histórico que nos permita, a través de una visión global, conocer en relación a qué sectores sociales y a qué ideas de ciudad se moldearon este tipo de urbanizaciones. En cuanto a este tema, es clave analizar tanto el panorama nacional como internacional, para dar cuenta de la circulación de modelos y su inserción en diferentes contextos. ${ }^{140}$ Por último, este

Por otra parte, también se reconocen como barrios jardín algunas urbanizaciones surgidas de emprendimientos inmobiliarios que tratan de reproducir las condiciones de baja densidad y urbanización ajardinada en la línea del urbanismo de la C.J., aunque se materializan a través de la extensión de la grilla tradicional. Ver, Silvia Santos Wolf, Jardín América: el primer barrio jardín y su arquitectura. Editora da Universidade de Sao Paulo, San Pablo, 2001; Izaskun, Landa. "Modelos urbanos y transferencias en Caracas: el caso del primer suburbio jardín de Manuel Mujica", en Proceedings, 11th Conference of the Internacional Planning History Society. Barcelona, 2004.

${ }^{139}$ Utilizamos la noción de forma en un sentido amplio, como morfología, como materialización de una idea, pero también como formas de organización del espacio. Como mencionamos en el Capítulo 1, la discusión sobre este tema es extensa; pueden verse: Wladislaw Tatarkiewicz, Historia de seis ideas. Arte, belleza, forma, creatividad, mímesis, experiencia estética. Op.cit; Theodor W. Adorno, Teoría Estética, op.cit.

Por un lado, la noción de forma como materialización de una idea es deudora de la filosofía clásica, donde forma es esencia conceptual que constituye e informa la materia. Como señala Graciela Silvestri, en esta versión la forma no se construye; pero aún así, las evocaciones filosóficas de la palabra han sido aplicadas en el campo de las artes asociadas a la idea. En arquitectura, todavía hoy, idea y forma del objeto van de la mano en el proceso proyectual. Ver, Graciela Silvestri, El color del río, op.cit. p 36. Por otro lado, y como adelantamos en la introducción, en cuanto a la noción de forma como morfología u organización del espacio, cabe recordar que la vinculaciones entre forma e idea, o entre forma y organización social que contiene no son unívocas y se determinan mutuamente.

140 Pierre Bourdieu acuñó el concepto de "traducción" en relación al análisis de la circulación internacional de ideas. Allí problematizó las alternativas del "contexto de recepción”. De acuerdo a este autor los textos, ideas y modelos viajan sin su contexto y son reinterpretados en función de los temas y las problemáticas en juego en el ambiente en donde se introducen. Ver, Pierre Bordieu, "Les conditions sociales de la circulation internationale des idées “, Conférence prononcée le 30 octobre 1989 pour l'inauguration du Frankreich-Zentrum de l'université de Fribourg. Publicado en 1990 en les Cahiers d'histoire des littératures romanes (14e année, 1-2, p.1-10). . 
panorama más teórico se articula de forma empírica con el análisis de los casos que registramos en el área de estudio. La intención es superar las indagaciones teóricas y analizar la forma en que se materializaron y las ideas a las que se asociaron en un contexto de recepción particular. ${ }^{141}$

\subsection{Núcleos a la manera pintoresca}

3.1.a La inserción del barrio parque en el trazado urbano

Las primeras propuestas de parcelación con tramas urbanas informales tendieron a plantearse como alternativas residenciales al crecimiento urbano compacto y continuo. Desde fines del siglo XVIII, en Inglaterra primero y en Estados Unidos después, comenzaron a desarrollarse modelos como el Royal Crescent de Bath (John Wood el joven, 1767-1774)), el Regent's Park de Londres (Jhon Nash, 1823), o Riverside en Illinois (Frederick Olmsted, 1869) que combinaban la construcción de viviendas junto al desarrollo de áreas ajardinadas, generando un escenario de prestigio para la vivienda de sectores acomodados. Estas tres creaciones plasmaron conscientemente lo que hasta ese momento eran soluciones surgidas de manera espontánea. Dichos profesionales sabían que era necesario ofrecer a los pobladores un reaseguro de que las cualidades urbanas, estéticas y la distinción social que se asociaba a un emprendimiento no corrían peligro de perderse con el avance de la ciudad. Encontraron la solución a través de un proceso cuidadoso de diseño que incluyó la construcción de calles curvas, parques públicos y frondosa vegetación. De esta forma lograron elevar el valor de los terrenos y

\footnotetext{
${ }^{141}$ En este sentido el debate -adelantado en la introducción- sobre la forma urbana y las ideas o formas de vida que contiene se ve beneficiado por la lectura histórica que permite comprender en el esquema más amplio un recorrido cargado de ecos, de marchas y contra-marchas, de reinterpretaciones, que nos previenen de las lecturas más mecanicistas que tienden a ver una subordinación de lo social a lo formal o vise-versa. Ver, La morphologie entre la matiére et le social, en Marcel Roncayolo, Lectures de villes. Formes et Temps. op.cit. pp.161-179.
} 
aislar los lotes a la venta en medio de un área verde y ajardinada que funcionaba como una muralla defensiva ante el "ataque" de usos, y sobre todo de gentes, indeseables. ${ }^{142}$

A lo largo del siglo XIX aparecieron muchas propuestas similares que se adaptaron a diferentes públicos. En Buenos Aires, se enmarcó dentro de esta tradición la construcción del barrio parque Gran Bourg -Palermo Chico- diseñado por el paisajista Carlos Thays, que por esos mismos años trabajaba en un diseño pintoresco para el Balneario Carrasco en Uruguay. ${ }^{143}$ Realizado en 1912, el trazado del barrio porteño se caracterizó por el diseño pintoresquista que, en ruptura con la rigurosidad geométrica imperante en la cuadrícula tradicional, planteó la alternativa de calles curvas y, complementariamente, la ocupación parcial del suelo y el retiro de línea municipal, a fin de generar un tejido urbano libre y con predominio del verde en aceras y jardines. Si bien, el trazado no incorporaba un área de parque propia, se proyectó como continuación del Parque Tres de Febrero, en el momento en que los parques urbanos, en el contexto de la densificación de la ciudad, generaban una ruptura en la masa más o menos indiferenciada originada por la extensión de la cuadrícula española, introduciendo alteraciones que funcionaron como polos de crecimiento diferenciado dentro de la ciudad. ${ }^{144}$

142 Robert Fishman desarrolla algunos de los recursos de diseño incorporados como elementos esenciales en la definición de los suburbios anglo-americanos. Ver, Burgeois Utopias. Op.cit. p. 121.

143 Alberto De Paula, "Thays, Carlos", en Jorge Liernur y Fernando Aliata (dirs.) Diccionario de Arquitectura en la Argentina. Editorial Clarín, Buenos Aires, 2004.

144 Adrián Gorelik señaló que la reforma urbana en las primeras décadas del siglo XX incorporaba algunos temas puestos en el tapete por las nuevas perspectivas urbanísticas que contemporáneamente se difundían en Europa y de rápida recepción en el período. Los planteos de Camilo Sitte, los Planos de Viena (1905), de Berlín (1910), la Town Planning Conference (1909) y los distintos planes de extensión conocidos a través de la bibliografía influyeron en el medio local planteando la necesidad de generar en la ciudad perspectivas pintorescas y espacios recoletos, un aumento de las áreas verdes y la necesidad de conjuntos monumentales, que desde la sensibilidad que impuso el pintoresquismo de raíz sitteana significaría el reemplazo de las largas perspectivas monumentales por plazas llenas de vida, diseñadas para los peatones. Ver, A. Gorelik, La Grilla y el Parque, op.cit. 
3.1.b Núcleos a la manera pintoresca como áreas de crecimiento planificado

En una etapa un poco posterior, este tipo de trazados pudieron pensarse como alternativas a la expansión urbana desordenada, o a los más tradicionales planes de ensanche. ${ }^{145} \mathrm{~A}$ escala mundial, las tramas ortogonales sufrieron un fuerte retroceso en la segunda década del siglo XX. En Brasil, la tradición de extender el área urbana por medio de barrios jardines se inició con la presencia temprana de los arquitectos Unwin y Parker en el barrio Jardín América (1919) en San Pablo, inaugurando una práctica que se extendería a experiencias posteriores, como el barrio vecino Jardín Europa (1921) o la ciudad de Goiâna (1933), capital del Estado de Goiás, entre otras. ${ }^{146}$ Mientras que, en Uruguay, el arquitecto Mauricio Cravotto estableció, desde 1929, un plan de crecimiento de Montevideo hacia el Este al que llamó de "aldeas felices" siguiendo el espíritu de la "ciudad jardín", vía la "traducción” del urbanista norteamericano Lewis Mumford. ${ }^{147}$ Efectivamente, la difusión de las ideas de la "ciudad jardín" hizo que se propagaran al mismo tiempo los diseños de calles curvilíneas frecuentemente asociados a ella, y no sólo para las urbanizaciones destinadas a las clases acomodadas, sino también para aquellas destinadas a la vivienda popular.

En este clima, se enmarcaron en el Concejo Deliberante porteño los primeros debates encolumnados detrás de la figura del barrio parque y que seguirían actuando en

145 Entre los planes de ensanche más difundidos por la urbanística de fines del siglo XIX se puede mencionar al que se conoce como "Ensanche Cerdá", cuyo primer anteproyecto corresponde al Plano de los alrededores de Barcelona levantado por orden del gobierno para la formación del proyecto de Ensanche de Barcelona (1855) realizado por el ingeniero Idelfonso Cerdá . Para la misma Buenos Aires, se publicó en 1904 el plano de extensión realizado por el Departamento de Obras Públicas de la Municipalidad, allí el trazado de la cuadrícula se extendía a los nuevos territorios anexados a la ciudad en 1878.

Ver, Idelfonso Cerdá, Teoría general de la urbanización y aplicación de sus principios al Ensanche de Barcelona, Madrid, 1867. Reedición, Madrid, Instituto de Estudios Fiscales, 1967 y A.A.V.V., "Buenos Aires”, en jorge Liernur y Fernando Aliata (dirs.), Diccionario de Arquitectura en la Argentina, Clarín, 2004.

146 Ver, Perla Bruno, "Reflexiones para una historia conjunta: derivaciones americanas de la ciudad jardín en la extensión y planificación moderna de ciudades de Argentina y Brsil. 1930-1945.” op.cit 147 Ver, Mauricio Cravotto y Antonio Cravotto, Mauricio Cravotto, 1893-1962. Editorial Dos Puntos, 1995. 
el debate público y sobre todo a través de las asociaciones profesionales durante toda la década del diez.

En los primeros años del siglo XX el crecimiento de la ciudad se estructuraba a partir de los típicos recursos barrocos: boulevards y avenidas con perspectivas monumentales que quebraban la grilla más densa del centro consolidado. Sin embargo, lentamente y a través de proyectos puntuales empezarían a colarse ciertas ideas que desde la recepción del movimiento de la City Beautiful o el pintoresquismo centroeuropeo debatían variantes a la expansión cuadriculada y la superioridad de la calle recta. Dentro de este marco, se debatió en 1908 la construcción del Parque Centenario para el cual el concejal Guerrico propuso que "La municipalidad debe adquirir el terreno (las tierras del señor Parmenio Piñero, actual Parque Centenario) con el objeto de levantar allí un parque y un barrio municipal modelo. (...) se podría hacer un barrio abierto, entre jardines, un barrio notable que sería una excepción en esta ciudad construida en damero". 148

Lo que se traduce en esta propuesta es una nueva perspectiva para la expansión, que ya no es la extensión de la ciudad central en la prolongación de las avenidas hacia la periferia, sino la posibilidad de incorporar nuevos elementos del urbanismo que den lugar en la periferia a una ciudad diferente de la tradicional.

En el contexto de la urbanística internacional, el fecundo debate en torno al crecimiento y ordenamiento urbano debía resolver una difícil ecuación entre lo bello y lo útil, materializado a través de una división que planteaba la superioridad estética de la urbanística pintoresca con sus calles curvas y perspectivas cortadas frente a la eficiencia de la avenida recta. A pesar de esta supuesta contradicción, Ana María Rigotti planteó que, desde perspectivas diferentes, las principales corrientes del urbanismo de principios de siglo proponían un compromiso. Por una parte, Camilo Sitte -principal exponente dentro del pensamiento alemán de la corriente de la urbanística pintoresca- consciente de los procesos de modernización, nos invitaba a negociar sólo una parte de la ciudad para lo bello y los arquitectos, dejando el resto a las demandas del tráfico y las necesidades de la vida diaria. Una estrategia similar -construir un centro cívico bajo el dominio de la belleza y los arquitectos, en paralelo a la ciudad de los negocios y sus leyes- estaba presente en el movimiento americano de la City

148 Concejal Guerrico, AHCD, 29 de septiembre de 1908, pp. 361-366. 
Beautiful (1893-1907). Aunque en este caso, la distinción entre espacios de belleza y de utilidad, no se planteaba en términos de resignación, sino de una discriminación eficientista justificada en términos económicos, aumentando los valores de la propiedad inmobiliaria. ${ }^{149}$

En el caso de Buenos Aires, ambas expresiones estuvieron presentes en el debate por la compra de los terrenos del Parque Centenario, donde la opción de construir un barrio parque se planteó como introductor del quiebre de la trama, y de variación en la cuadrícula, invirtiendo la ecuación centro-europea. Como planteó Gorelik, si el pintoresquismo centroeuropeo partía de la reivindicación de la trama curva como elemento histórico y cultural, y por lo tanto buscaba conservar el centro histórico como núcleo de belleza, en la ciudad de Buenos Aires, la lógica pintoresquista debió inventarse, introduciendo en la expansión una malla de avenidas curvas que se opuso al damero existente, con una carga fuertemente esteticista. ${ }^{150}$

El afán de algunos sectores por la creación de "barrios parque" residía en su capacidad de renovar y de imprimir una vocación estética al contexto de la expansión, a lo cual se sumaba la opción de generar renta inmobiliaria. No obstante, esta última cuestión se mantenía en segundo plano y prevalecía la componente nostálgica de raíz sitteana que repetía la primacía por la belleza que impulsaba estos trazados. Existía en la sociedad cierto consenso sobre la dicotomía entre lo bello y lo útil, que se traducía al plano de la expansión mediante la dicotomía entre el trazado con calles curvas y/o en grilla y que se hacía extensivo a la aspiración estética o económica asociada, respectivamente, a cada una de estas formas. La Ley Provincial de Creación de Nuevos Pueblos del año 1913 no dejaba lugar a dudas sobre esta conexión: "los casos de trazados radiales y curvilíneos, como el de las ciudades y jardines en los que predominan el concepto estético en lugar del económico..."151 y en la misma línea, en

149 Ana María Rigotti, "La eterna lucha entre lo bello y lo útil: la difícil conciliación de técnica y estética en el urbanismo científico de principios de siglo", en Revista del Centro de Estudios de Arquitectura Contemporánea, Block nº 1, Buenos Aires, 1997. pp71-82.

150 Adrián Gorelik, La Grilla y el parque, p.192.

${ }^{151}$ Ley no 3487 de Creación de nuevos centros de población y ampliación de ejidos. En el Capítulo 4 se analizará más en detalle la legislación referente a la expansión metropolitana de la Provincia de Buenos Aires. 
el debate del proyecto de ordenanza de formación de "barrios parque" se reconocía que "Si este proyecto se hubiese convertido en realidad hace diez años, Buenos Aires sería una de las capitales más hermosas e higiénicas y no ofrecerían sus alrededores ese aspecto antiestético de la edificación económica, con calles angostas, sin pavimento, sin nada que las hermosee y en donde solo se ha preocupado sacar a la tierra el mayor rendimiento posible". ${ }^{152}$

Paradójicamente, al mismo tiempo que desde el sentido común y desde algunos grupos técnicos se afianzaban los pares de opuestos belleza-trazado pintoresco contra cuadrícula-rendimiento económico, la propuesta en discusión se justificaba en base a argumentos de orden económico, que de ninguna manera se entendían como aspectos contradictorios dentro del proyecto, sino como condición intrínseca que permitiera encontrar la financiación para el desarrollo de la expansión. Así lo exponía el autor del proyecto: "Una vez sancionado este proyecto - de formación de barrios parque- y convertido en ordenanza ella misma suministrará con creces los fondos necesarios (para la formación del parque y urbanización de las manzanas de barrio parque que lo rodeen), dado que es de suponer el mejoramiento que obtendrían los terrenos destinados a la venta -el 20\% del área a desarrollar- producirá en la generalidad de los casos, un valor igual o mayor al costo total del barrio parque formado."153

Se filtraban en la discusión cuestiones que remitían al debate de la segunda mitad del siglo XIX en Norteamérica, y que sin duda encontraban un origen anterior en urbanizaciones como Regent's Park en la ciudad de Londres. Como señaló Francesco Dal Co, después de los años cincuenta (1850) el problema de los parques urbanos se había convertido en Norteamérica en tema central del debate sobre el papel que el gasto público debía asumir en la creación de servicios sociales, debate que encontraba formas de resolución cuando el desarrollo del propio parque se financiaba con el aumento del valor de las áreas residenciales circundantes. ${ }^{154}$

\footnotetext{
152 AHCD, Ordenanza Formación de Barrios Parque, 1911, pp556

${ }^{153}$ Ibíd., pp556

${ }^{154}$ Francesco Dal Co, De los parques a la región. Ideología progresista y reforma de la ciudad americana, en A.A.V.V, La Ciudad Americana. De la guerra civil al New Deal, Gustavo Gili, Barcelona, 1975. p. 170.
} 
Así, en el ambiente local, la formación de parques y barrios parque que los rodeaban podían ser pensados, fundamentalmente durante la década del diez, y en menor medida, del veinte, como opción urbanística justificada en base a argumentos de orden económico-funcionales, sin dejar de lado su función social. De acuerdo a lo que proponía la ordenanza, los barrios parque dejaban de ser una intervención excepcional en la ciudad, por la doble oportunidad que representaban: de producir negocios inmobiliarios rentables, que le permitieran a la municipalidad financiar los servicios y la infraestructura que debía acompañar la expansión, a la vez que motores para la transformación urbana, en tanto, al igual que al propio parque, se les adjudicaba cierta capacidad reverberante, para influenciar y determinar el progreso en sus áreas circundantes.

Por último, en el caso del Proyecto Orgánico para la Urbanización del Municipio de la Comisión de Estética Edilicia, 1923-1925, dentro del programa propuesto, se marcó una diferenciación entre la zona urbana, organizada a partir de trazados reguladores de grandes avenidas, mientras que, para las zonas expansión, se previó una distribución más pintoresca ligada a lo natural y al fomento de las actividades recreativas y deportivas con la construcción de parques destinados a ejercicios físicos en torno a los barrios obreros.

"En estos barrios, los terrenos o quintas arboladas que el trazado rectilíneo de la calle destruiría, deberán ser motivo de bifurcaciones o de líneas curvas encargadas de aumentar el sentido pintoresco.

Con igual criterio las pequeñas lomas, lejos de ser allanadas con trabajosos desmontes, darán ocasión a que las nuevas calles o avenidas pierdan su apática horizontalidad, tanto más, que nuestra ciudad, por su naturaleza, carece por lo general de éstos desniveles tan favorables para animar las perspectivas de esas calles." 155

155 Buenos Aires. Proyecto Orgánico para la urbanización del municipio. El plano regulador y de reforma de la Capital Federal, Bs.As., talleres Peuser, 1925. 
En esta nueva etapa la incorporación de barrios parque, va dejando de lado la lógica de la singularidad y es planteado como un instrumento del urbanismo que puede ponerse al servicio del desarrollo de la ciudad.

En estas dos versiones, el barrio parque como forma urbana para la localización de residencias exclusivas, o como alternativa a los planes de ensanche ortogonales, las urbanizaciones en la línea de la Ciudad Jardín fueron en un primer momento introducidas en nuestro país por grupos de expertos: dentro de la práctica privada, en coincidencia con los sectores sociales más exclusivos de la sociedad, y desde los proyectos impulsados por el Estado, en relación a sectores más amplios.

\section{1.c Núcleos de organización informal como vehículo de la expansión especulativa}

Hacia fines de la década del diez e inicios de los años veinte, la difusión de este tipo de tramas dio lugar a su incorporación por parte de un grupo de profesionales más amplio técnicos, agrimensores, ingenieros- que los que hasta aquí se han mencionado.

A propósito de la difusión de la que empezaban a gozar este tipo de trazados, hay que señalar que en la Biblioteca de la Sociedad Central de Arquitectos (SCA) permanecen una serie de manuales y tratados europeos del siglo XIX, en los que abundan las páginas con láminas y planos con propuestas para el diseño de trazados urbanos informales en una amplia variedad de escalas y presupuestos. ${ }^{156}$ Ya hacia fines de la década del treinta, revistas de edición local dedicadas no sólo a profesionales, sino también a técnicos y constructores, entre las que podemos nombrar, El Arquitecto constructor o la Revista del Centro de Arquitectos Constructores y Afines (CACyA) comenzaban a difundir en sus páginas modelos para loteos suburbanos o pequeñas urbanizaciones de week-end. ${ }^{157}$

\footnotetext{
${ }^{156}$ Dos textos fundamentales permanecen en la SCA, Payne, A.H, The Builders Practical Director. Plans, sections and elevations with detailed estimates, quantities \& prices, Liepzig and Dresden, London, 1859. y Wesser, Rudolf, Beiterage zur Bauwissenschaft, Verlag von Ernst Wasmuth, Berlin, 1903.

157 Plano de Urbanización General Pacheco, por el Ingeniero Monti, en El Arquitecto Constructor, Marzo 1948; Barrio Parque "El Querubin” en Los Talas, Berisso, en El Arquitecto Constructor, diciembre, 1949.
} 
De tal manera que, en coincidencia con el proceso de expansión del GBA, gran parte de las áreas que experimentaron el tránsito de tierras rurales a tierras urbanas lo hicieron a través de la incorporación de diferentes tipos de trazados informales como vehículo de la expansión especulativa. A diferencia de la grilla, en la difusión de estos modelos de diseño estaba implícito el concepto de "unión entre el campo y la ciudad" que le daba sustento a la propia idea de suburbio, en tanto constituía una zona diferente de la línea de edificación continua que caracterizaba a la ciudad y de los campos abiertos de las áreas rurales. Así, lo entendían también los promotores locales que anunciaban para un loteo: "Mire el verde horizonte que de allí se divisa sin obstáculos en todas las direcciones y usted verá como es posible estar a la vez en la pampa y en Buenos Aires." 158

En contraposición a la homogenización que producía la cuadrícula, los desarrollos de tramas informales daban lugar a la singularidad, en un doble sentido, del conjunto urbano en relación al área que lo rodeaba -como lo deja ver el acápite que da inicio a este capítulo- y, en menor escala, de cada manzana y parcela dentro del conjunto. Al respecto, el propio Olmsted decía:

"No hay, intencionalmente, ningún lugar mejor que otro en esos bloques (manzanas). El oficinista o el mecánico y su joven familia, deseando vivir modestamente en una casa por sus propios medios, sin sirvientes, es provisto de modo idéntico que el saludable mercader, quien, con una gran familia y numerosos sirvientes, desea disponer obras de arte, formar una gran biblioteca, y disfrutar de la compañía de muchos huéspedes."159

En el mapa del Gran Buenos Aires, podemos comprobar que la incorporación de trazados informales, se reconocían como especie de hitos, dentro del panorama difuso de la expansión. A la manera de los rígidos patterns morfológicos que, según describió Benedetto Gravagnuolo, se insertaban en la París medieval rompiendo su lógica abigarrada, en la escena local cualquier figura que rompiera la traza cuadricular con su

158 Moreno, Parque Residencial El Ensueño 1947, en Carpeta de Remates-partido de Moreno, en Departamento de Investigación Histórica Cartográfica, Dirección de Geodesia, MOP, ${ }^{159}$ Citado por Adrián Gorelik, La grilla y el parque. Op.cit. p 40. 
correspondiente manzana compacta lograría consolidar cierto carácter distintivo, que muchos de estos emprendimientos mantienen hasta la actualidad. ${ }^{160}$

\section{1.d Barrios parque y expansión}

Sin duda es dentro de ésta última vertiente que debemos comprender los núcleos de barrio parque que se incorporan a las áreas de expansión, aunque ahora veremos que incluso dentro de este marco acotado los resultados varían con diseños, tamaños y calidades de las más dispares. Siguiendo una clasificación morfológica presentaremos tres grupos.

- Los emprendimientos de mayores dimensiones, entre 30 y 50 ha, asumieron más comúnmente trazados radio céntricos, organizados en forma de anillos sucesivos desde una plaza central, como puede ser el caso de Barrio Parque Aguirre, Lavallol, o el Barrio Parque Manuel Obligado. La morfología final tomaba la figura de un círculo inscripto en un cuadrado, de manera que el conjunto pudiera insertarse en una trama de calles rectas en donde la vía de acceso principal -ruta o ferrocarril- quedaba recostada en uno de los laterales. De esta manera, se rompía la supuesta simetría del trazado, en la que se prefiguraba un crecimiento parejo en todas las direcciones con respecto al punto central -plaza-, por la incorporación del conjunto al plano más amplio de la suburbanización. Analizados como morfologías abstractas, este grupo de diseños exalta mejor que cualquier otro los valores del barrio jardín como espacio de distinción, generando un trazado vial que, a pesar de mantener ciertas vinculaciones, se distingue de la expansión indiferenciada. En los hechos, estos trazados no implicaron necesariamente parcelas de grandes dimensiones, ni aseguraron -como suponían los teóricos ingleses- la formación de áreas exclusivas. El espacio verde público se redujo en todos los casos a la plaza central de dimensiones ínfimas en relación a la totalidad de la planta urbana. Pero, por sobre todo, a diferencia de los modelos ingleses que mencionamos, luego de que se materializara el trazado viario y se concretaran los loteos, la urbanización de estas áreas quedaba a cargo de la acción de los particulares.

160 Benedetto Gravagnuolo, Historia del Urbanismo en Europa. 1750-1960. Ediciones Akal, Madrid, 1998. 
De la actitud de los propios habitantes dependió la adopción de las imágenes nuevas y modernas asociadas al habitar suburbano, y en consecuencia, la configuración final del espacio urbano. ${ }^{161}$ Algunos de estos barrios se transformaron en relación con el contexto y los sectores sociales que los ocuparon y les otorgaron nuevo sentido, muchas veces llegando a revertir los objetivos iniciales, supuestamente implícitos en la propia morfología.
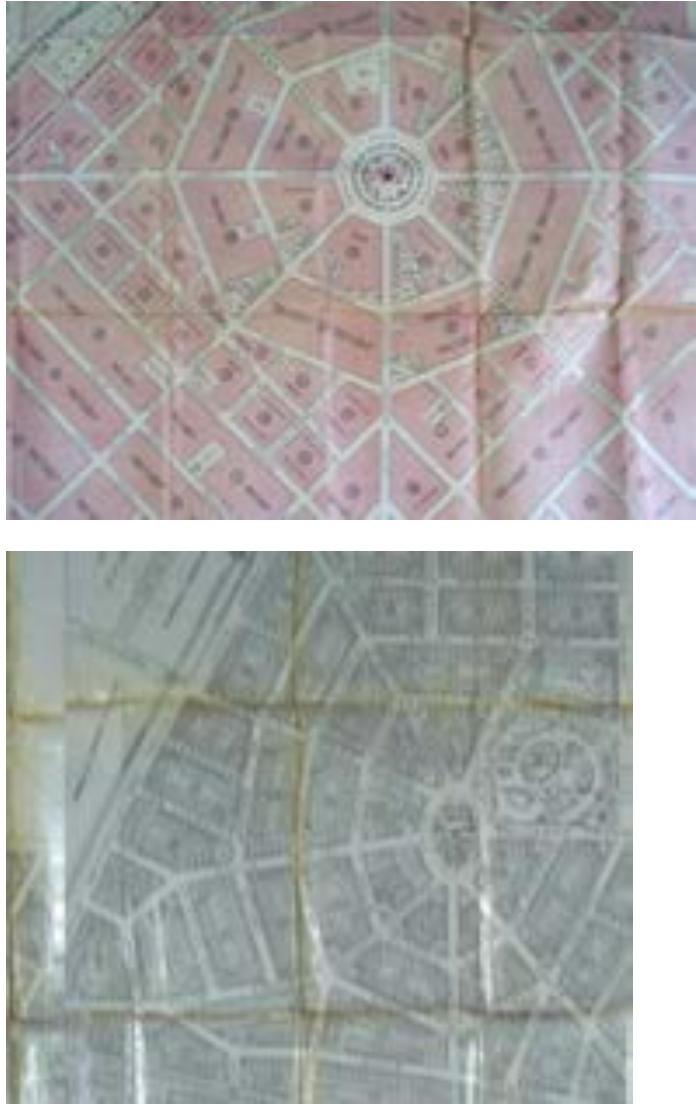

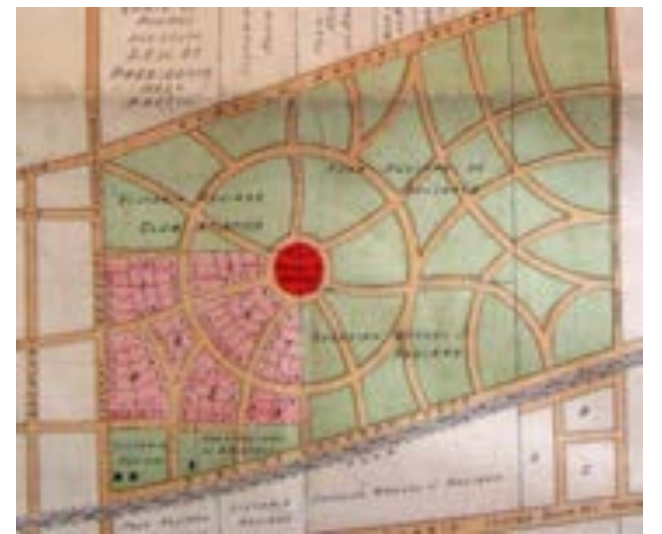

a- B.P Manuel Obligado. Fuente: Carpeta de Remates-Partido de Alte. Brown, Departamento de Investigación Histórica Cartográfica, Dirección de Geodesia, MOP, Pcia Bs As.

b- B.P Manuel Aguirre. Fuente: Carpeta Barrio Parque Aguirre, Archivo y Museo Histórico de San Isidro.

c- Lavallol. Fuente: Carpeta de RematesPartido de Lomas de Zamora, Departamento de Investigación Histórica Cartográfica, Dirección de Geodesia, MOP, Pcia Bs As.

${ }^{161}$ En un trabajo anterior he demostrado cómo algunos núcleos particulares, fundamentalmente aquellos en donde se concentraban grupos de la elite, buscaron reproducir el escenario y los modos de vida provenientes de los principales polos de referencia de la época (inicialmente Francia e Inglaterra y ya hacia la década del treinta, Estados Unidos) que conocían directamente en el exterior o por medio de publicaciones internacionales. En estos sitios, se lograba traducir de manera más fiel el espíritu del barrio parque proveniente de los modelos ingleses que mencionamos. Ver, Ana Gómez Pintus, "Las dimensiones del pintoresquismo. Suburbios residenciales, arquitectura y prácticas profesionales. Buenos Aires, 1910- 1940.” Tesis de Maestría, UTDT. Abril, 2010. 
-Una versión diferente sobre la base del crecimiento concéntrico plantearon algunos loteos que se presentaron como si fueran barrios cercenados a la mitad, es decir, que en vez de tomar el crecimiento concéntrico del círculo, tomaban la figura de un semicírculo. En la práctica esto daba lugar a dos posibilidades, en la primera, la vía de acceso principal constituía el lado recto del semicírculo, de manera que, a diferencia del caso anterior, una parte mucho más significativa de los lotes en venta estaba en contacto con la vía principal (que en la mayoría de los casos era la única pavimentada), tales podrían ser los casos de Villa Bosch, el Barrio Parque La Primavera, Barrio Parque Balneario Quilmes o el Barrio Parque Longchamps. La otra posibilidad, era que el tipo de "semi-barrio" se planteara como la primera fase de la urbanización a la cual se anexionaría la otra mitad cuando se hubieran vendido la mayoría de los lotes del primer emprendimiento. Esta situación se constató por ejemplo en el Parque Mattaldi en Bella Vista o en una urbanización del año 1947 en Hurlingham. En estas urbanizaciones, el tamaño de los lotes se ubica un poco por encima del loteo urbano promedio, oscilando entre $\operatorname{los} 500-700 \mathrm{~m} 2$, aunque manteniendo medidas relativamente homogéneas en toda la planta urbana, como resultado de un proceso de diseño integral. ${ }^{162}$ Por último, en estas urbanizaciones, si bien se mantenía cierto ideal de distinción, que mencionamos para el caso anterior, primaba una actitud más pragmática, en donde se priorizó, por ejemplo, la mayor rentabilidad que generaba la ubicación de los lotes sobre vías de tránsito principales.

${ }^{162}$ Ver Apéndice de loteos y Cuadro 1 

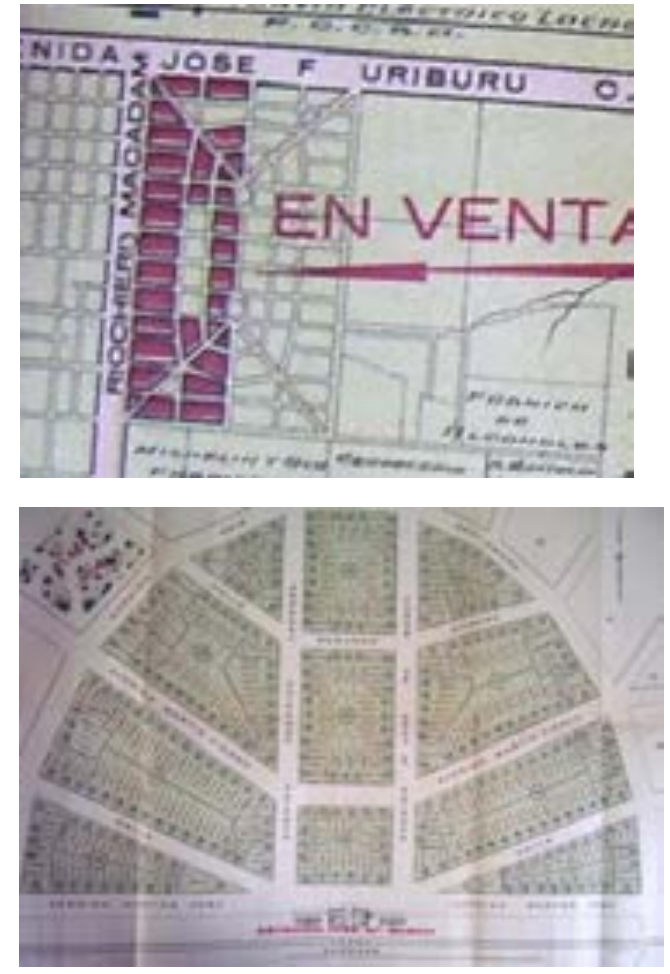

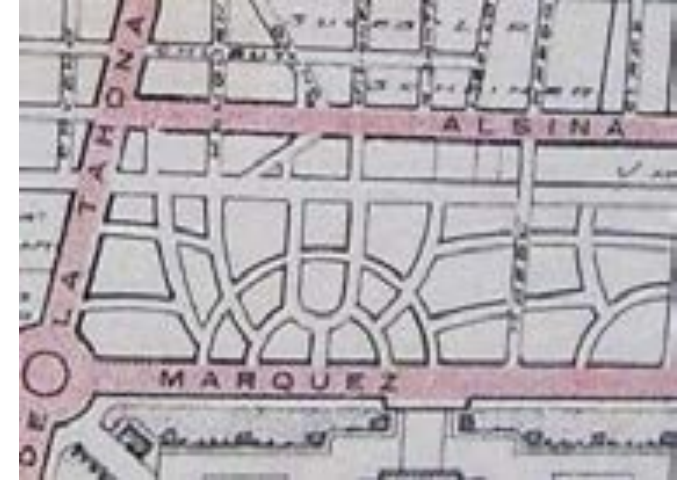

a- B.P Mattaldi. Fuente: Carpeta de RematesPartido de Gral. Sarmiento, Departamento de Investigación Histórica Cartográfica, Dirección de Geodesia, MOP, Pcia Bs As.

b. B.P. Longchamps. Fuente: Carpeta de Remates-Partido de S.I., Departamento de Investigación Histórica Cartográfica, Dirección de Geodesia, MOP, Pcia Bs As.

c. Villa Bosch. Fuente: Carpeta de RematesPartido de S. Martín, Departamento de Investigación Histórica Cartográfica, Dirección de Geodesia, MOP, Pcia Bs As.

- Por último, otros conjuntos de tramas informales daban lugar a organizaciones más libres, en donde con el trazado mínimo de vías de circulación quedaban delimitadas grandes manzanas. Estos conjuntos rara vez funcionaban como una trama abierta de calles, a la manera de la ciudad en cuadrícula tradicional, sino que las calles que daban acceso a los lotes sólo comunicaban con la vía principal. Este tipo de configuración tomaba ventajas de una doble condición, por un lado adscribía a las posibilidades estéticas del tipo de trazado informal, a la vez que aprovechaba las ventajas que en términos de inversión le permitía construir manzanas de grandes dimensiones a las que se podía acceder con un tendido de calles menor - con la consecuente disminución de los costos de infraestructura-.

Por los motivos mencionados, salvo pocas excepciones, carecieron de espacio público -veredas y mucho menos plazas- capaces de nuclear a su población. Es decir, que por la propia morfología, estos trazados tendieron a conformarse de manera cada vez más autónoma, desvinculados de las áreas de expansión de los alrededores. En una 
línea de sucesión muy lejana y en el contexto de "democratización del bienestar"163 que atravesaba el país, estos modelos buscaron representar el ideal suburbano a partir de la popularización y estandarización de algunos instrumentos de diseño retomados para responder a las necesidades de sectores más amplios de la población. En Buenos Aires, por la simplicidad del trazado, porque se podía adaptar fácilmente a urbanizaciones de pequeñas dimensiones y por las ventajas económicas que implicaba, fueron muchos los loteos que, apelando a diferentes alternativas fórmales, se armaron sobre esta base.
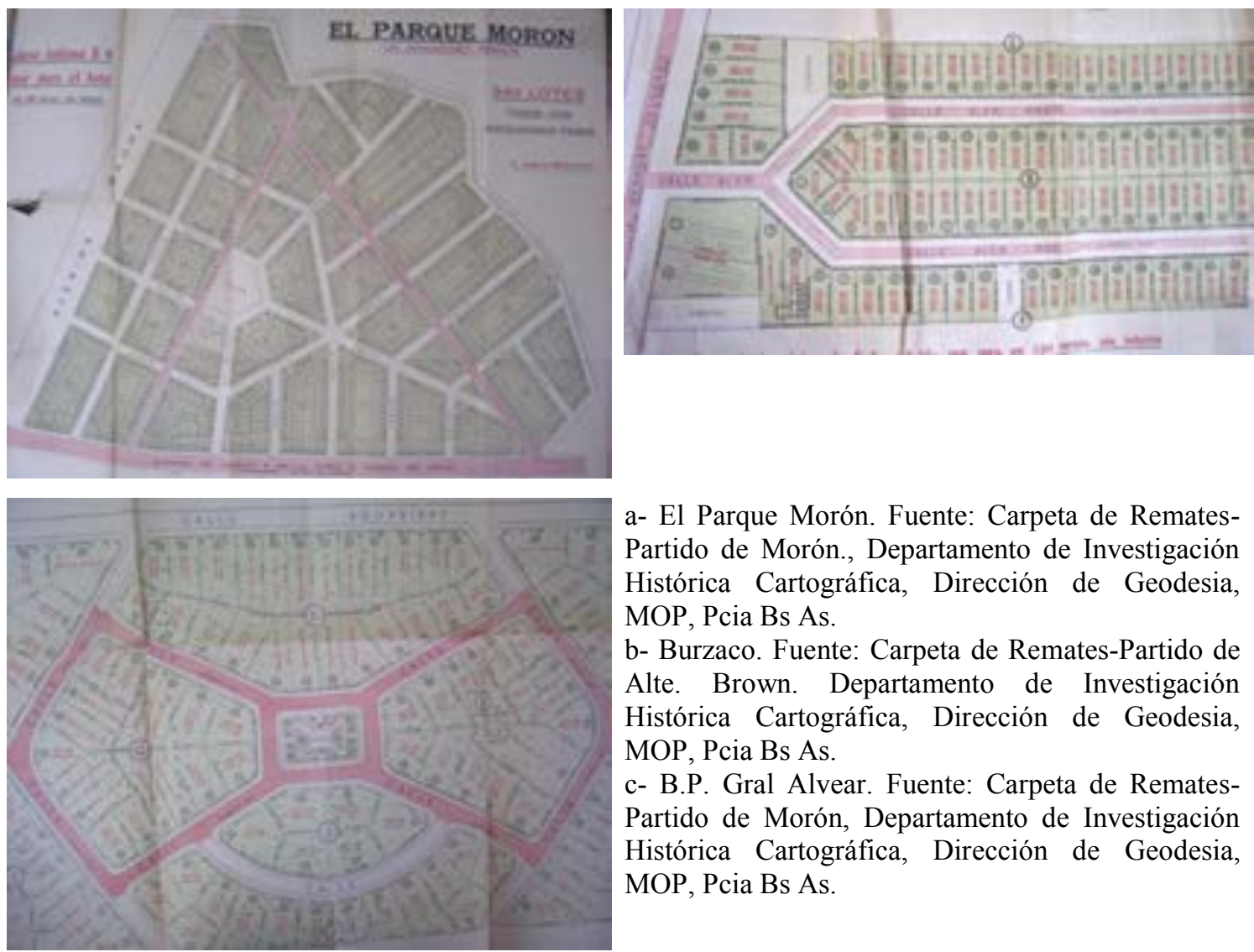

a- El Parque Morón. Fuente: Carpeta de RematesPartido de Morón., Departamento de Investigación Histórica Cartográfica, Dirección de Geodesia, MOP, Pcia Bs As.

b- Burzaco. Fuente: Carpeta de Remates-Partido de Alte. Brown. Departamento de Investigación Histórica Cartográfica, Dirección de Geodesia, MOP, Pcia Bs As.

c- B.P. Gral Alvear. Fuente: Carpeta de RematesPartido de Morón, Departamento de Investigación Histórica Cartográfica, Dirección de Geodesia, MOP, Pcia Bs As.

${ }^{163}$ Ver, Juan Carlos Torre y Elisa Pastoriza; “La democratización del bienestar”, op.cit. 


\subsection{Núcleos en grilla}

Muchos de los valores y críticas que se organizan en torno a la figura de la grilla son por demás conocidas; entre las primeras aparecen la racionalidad, su capacidad de ordenar el espacio: entre las segundas, desde la crítica culturalista se enfatizó su carácter monótono. En Argentina, Sarmiento asoció la figura de la grilla con la barbarie, como condensadora de los valores negativos de la tradición española y la naturaleza anómica de la pampa. ${ }^{164}$ Mientras que, desde una perspectiva internacional, en las lecturas de sesgo socio-económico y político se identificó a la grilla con lo más moderno, como recurso morfológico al servicio de la explotación capitalista del territorio. ${ }^{165}$ Por último, algunas miradas contemporáneas, entre las que se destaca la de Richard Sennet, han entendido la homogeneidad de la cuadrícula como una forma moderna de represión consistente en negar el valor de lo diferente, o reconocieron, como Rem Koolhas, en su aparente neutralidad, en su indiferencia hacia la topografía y las preexistencias, una demostración de la superioridad de la construcción mental por sobre la realidad, del hombre por sobre la naturaleza. ${ }^{166}$ Esta pluralidad de discursos que se organizan en torno a ella son consecuencia de un proceso de ideas que se articularon a través del tiempo y en relación a los diversos contextos o escenarios de los observadores.

Matizando estas hipótesis, por entenderlas como demasiado esquemáticas, algunos textos señalan que no siempre aquellos proyectos - seguidores o detractores de la grilla- se alinearon ordenadamente a las suscripciones ideológicas que supuestamente

164 Sarmiento, D.F. “Arquitectura doméstica” (15-10-1879), en Obras Completas. Citado por Adrián Gorelik, La grilla y el parque. Espacio público y cultura en Buenos Aires. 1887-1936. op.cit.

165 David Schuyler, The New Urban Landscape. The redefinition of City Form in Nineteenth Century America. Johns Hopkins University Press, Baltimore, 1986; Peter Marcuse, "The grid as City Plan: New York City and laissez faire planning in the nineteenth century", en Planning Perspectives $\mathrm{n}^{\mathrm{o}} 2$, Nueva York, 1987; Lewis Mumford, La Ciudad en la Historia, Ediciones Infinito, Buenos Aires, 1979; Carlo Aymonino, Orígenes y desarrollo de la ciudad moderna. Barcelona, G.Gili, 1972.

166 Richard Sennet, "Las ciudades norteamericanas: planta ortogonal y ética protestante”, en Revista Internacional de Ciencias Sociales, Barcelona. $\mathrm{n}^{\circ}$ 125, septiembre 1990. pp. 281-299; Rem Koolhaas, Deliruis New York. A Retroactive Manifesto for Mahattan, The Monacelli Press, New York, 1994. 
se les adjudican. ${ }^{167}$ Pensemos por ejemplo que los argumentos de Le Corbusier a favor de la grilla moderna - generar espacios de luz y aire, a través de los cuales la naturaleza pueda ingresar a la ciudad -fueron los mismos que en el siglo XIX habían llevado a tantos profesionales a introducir el diseño paisajístico y curvilíneo al trazado de la ciudad. En esta misma línea de análisis, que propondría visiones más particularizadas en las que se subraye la importancia del contexto de inserción, Adrián Gorelik reconoció las cuestiones problemáticas y contradictorias que surgen al analizar su implantación en Buenos Aires, "contaminada por diferentes y contradictorias tradiciones". ${ }^{168}$ Gorelik propuso que, aunque en su matriz abstracta y homogénea la grilla puede entenderse como vehículo de la especulación capitalista, su aplicación -a inicios del siglo XX- en la expansión de la ciudad de Buenos Aires, dentro de los actuales límites de la Avenida Gral. Paz, funcionó como elemento homogeneizador de los vastos descampados que rodeaban la ciudad hasta el flamante límite. La definición pública temprana de un vastísimo territorio urbanizable en torno a la ciudad tradicional evitó el crecimiento como producto del mero designio de la especulación inmobiliaria o la modernización técnica. De acuerdo a este autor, esta intervención debe leerse como una manifestación de la voluntad del Estado para que la incorporación al mercado de una enorme cantidad de tierras se hiciera de acuerdo con una delineación pública idealmente equitativa en todas las direcciones de crecimiento potencial de la ciudad. Sirve como ilustración el contraste que fue común en la época en otras ciudades latinoamericanas: en ellas, ante un Estado prescindente o socio directo de los inversores inmobiliarios, los loteos nuevos carecieron de toda reglamentación, de todo contacto entre sí y de toda pertenencia a una imagen global de la futura ciudad que estaban constituyendo. Casos como el de Jardín América en San Pablo muestran la implantación de proyectos de alta calidad urbana destinados a las elites paulistas, los

167 Gabrielle Esperdy, "Defying the Grid: A Retroactive Manifesto for the Culture of Decongestion". Perspecta 1999. 30. Pp.10-33; Spiro Kostof, The City Shaped. Urban Patterns and Meanings Through History, London: Thames \& Hudson, 1991; Leslie Martin, “The grid as generator”, en Urban Spaces and Structures. Martin, Leslie y March, Lionel (ed.) Londres, Cambridge University Press, 1972; Nelson Garret, "Grid and Anti-Grid. A landscape dialectic of socioenvironmental ideals" 2009. http://people.matinic.us/garrett/papers/grid-antigrid.pdf (consulta: 2 de octubre 2011)

168 Adrián Gorelik, La Grilla y el Parque. Op.cit. p 27. 
cuales, sumados a las características geográficas de la ciudad favorecieron la definición de la segregación de las clases sociales en el espacio de la metrópoli. ${ }^{169}$

\section{2.a Grilla y expansión}

La pregunta que surge para Buenos Aires en relación a este tipo de trazado es de qué manera y bajo qué sentido se realiza su incorporación más allá de los límites de la ciudad Capital.

En principio, hay que destacar que además de los significados que podemos atribuirle, su utilización en nuestro país se vinculó a una tradición que Fernando Aliata denomina de urbanismo elemental, iniciada a comienzos del siglo XIX, momento en que se instalaron las prácticas regularizadoras de los ingenieros topógrafos llegados durante el gobierno de Rivadavia. ${ }^{170}$

En cuanto a las características del propio plano: se define por su trama de calles que se cruzan en ángulo recto y conforman un sistema de distribución viario regular y manzanas que pueden ser cuadradas o rectangulares y que permiten obtener un máximo número de parcelas de tamaño uniforme. Además, una de las principales ventajas que presentaba la parcelación en grilla en contraposición a los trazados autocontenidos que analizamos en el apartado anterior, era la posibilidad de crecimiento a través de la agregación de parcelas laterales. Este tipo sigue el más tradicional esquema urbano, por sí mismo, no favorece la formación de centros ni usos jerárquicos; aunque, en la realidad, esto ocurre solo al principio, antes de que la retícula abstracta se materialice en el espacio real. A partir del momento en que se sitúa algo en dicho espacio, todo el resto se reconfigura. Al decidirse un centro, o la ubicación de un equipamiento todo lo demás adquiere respecto a ello un valor determinado, dando lugar a espacios

\footnotetext{
${ }^{169}$ Silvia Santos Wolf, Jardim América ...op.cit.

${ }^{170}$ Para un grupo amplio de profesionales, agrimensores e ingenieros, más que un concepto de ciudad, existía un método para relevarla y diseñarla, para delimitar sus espacios; para establecer relaciones de correspondencia y similitud, y para controlar la serie de variaciones formales con una simple estructura geométrica. Dentro de esta lógica se inscribe la idea de urbanismo elemental. Ver, Fernando Aliata, $L a$ ciudad regular. Op.cit. p. 83.
} 
diferenciados según las relaciones de proximidad, conexión y accesibilidad. Incluso, observamos en relación a los núcleos de trazado radiocéntrico, donde la centralidad aparece marcada desde el inicio por el propio plano, cómo ésta entra en conflicto cuando se relaciona con equipamientos exteriores al trazado original, modificando totalmente la supuesta jerarquía implícita en el trazado.

En el contexto de la expansión del Gran Buenos Aires, su uso dio lugar a dos tipos de amanzanamiento:

-En las ocasiones en que la cuadrícula toma un formato rectangular y alargado se reduce al mínimo el sistema de accesos, generando como configuración final asentamientos compactos y uniformes.

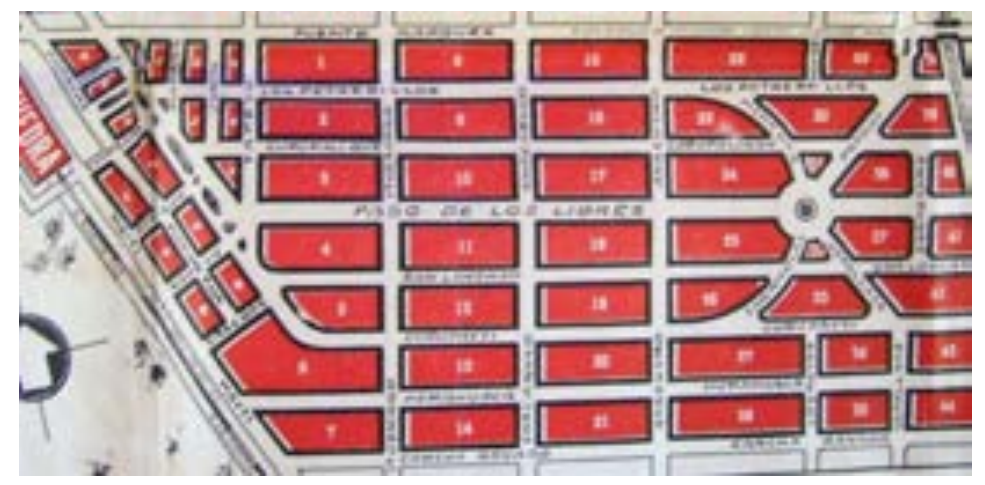

a- Barrio Parque Ibañez. Fuente: Carpeta de RematesPartido de Merlo. Departamento de Investigación Histórica Cartográfica, Dirección de Geodesia, MOP, Pcia Bs As.

- cuando siguen el esquema tradicional del damero porteño es cuando se generan lotes desproporcionados, donde la profundidad de la parcela llega hasta a quintuplicar su ancho. En este sentido, puede decirse que el damero porteño echa por tierra la idea de la racionalidad geométrica al servicio exclusivo de la explotación de la renta del suelo. Si se la compara con las enormes manzanas del plano berlinés de Hobrecht, que favorecían la concentración de grandes operadores, o con la manzana rectangular popularizada en el plano de Nueva York, que anula todo elemento residual en la renta del suelo, queda demostrada su condición de irracionalidad. 

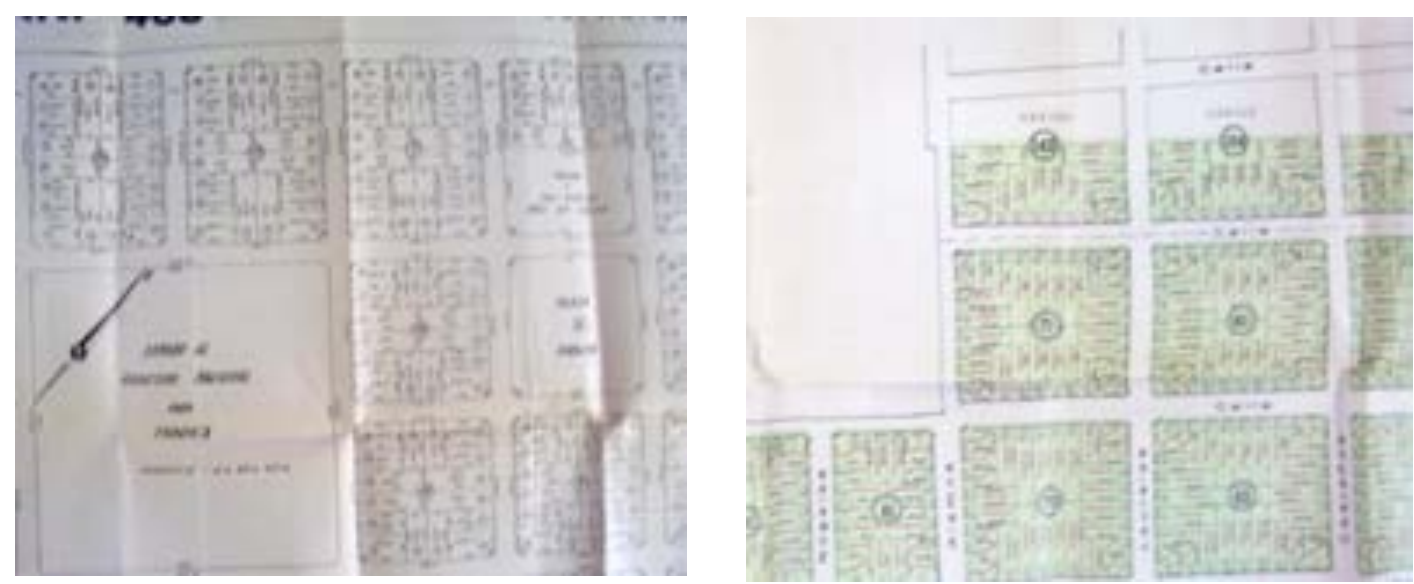

a- B.P. San Juan de Biocca. Fuente: Carpeta de Remates-Partido de La Matanza. Departamento de Investigación Histórica Cartográfica, Dirección de Geodesia, MOP, Pcia Bs As.

b- B.P. Jacarandá. Fuente: Carpeta de Remates-Partido de Quilmes. Departamento de Investigación Histórica Cartográfica, Dirección de Geodesia, MOP, Pcia Bs As.

Desde el punto de vista económico, el damero implica la generación de enormes áreas vacantes sin posibilidades de usufructo. Mientras que, desde una perspectiva estética, si bien contribuye a mantener la condición de baja densidad (dada generalmente por la profundidad de los lotes), el hecho de que las áreas libres quedaran relegadas a los interiores de la manzana, excluía toda posibilidad de construir, en la sumatoria total de lotes el ideal suburbano de "casitas en medio de un espacio verde".

De acuerdo a lo expresado anteriormente, es posible decir que a partir de la década del diez y, de manera más notoria, a partir de los años treinta la incorporación de urbanizaciones de barrios parque y de fin de semana buscó extender el ideal suburbano a partir de la popularización y estandarización de algunos elementos de diseño retomados para responder a las necesidades de sectores más amplios de la población.

En primer lugar, su introducción en el GBA, a través de loteos especulativos, contribuyó a la especulación desordenada de la gran ciudad.

En segundo lugar, estos modelos gestados en medios técnicos trataron de oponerse a la cuadrícula tradicional, recuperando el pintoresquismo y determinadas configuraciones morfológicas, entendidas como continuadoras de los valores del barrio parque como espacio de distinción. No obstante, sobre estos trazados operaron también ciertas figuras de la tradición reguladora que hallaron un fuerte sustento en el campo de la praxis, acuñada a través de una larga tradición de regularidad legal y topográfica. 
En tercer lugar, se trató de emprendimientos que apuntaron a obtener la rentabilidad que resulta del pasaje del suelo rural al suelo urbano. Es por eso, que su carácter fragmentario es también tributario de quienes, propietarios fundiarios o compañías inmobiliarias, consideraban que en un determinado momento y lugar se conjugaban las circunstancias necesarias para proponer nuevas operaciones. Desde esta perspectiva, cobra un nuevo interés saber quiénes y dentro de qué marcos regulatorios se construyeron esos barrios. 


\title{
CAPÍTULO 4. Actores, normas e instituciones en la producción del GBA
}

\author{
“(...) en las ciudades, la sociedad (sus individuos y \\ grupos) desarrolla una obra cuyo sentido, si bien se \\ basa en las constricciones estructurales, no parece \\ estar predeterminado, parece más bien depender de \\ cómo juegan sus papeles los actores" \\ (Pedro Pírez, Actores sociales y gestión de la ciudad, \\ en Ciudades 28, octubre-diciembre 1995, RNIU, \\ México)
}

Contar el proceso de expansión del GBA en relación a la incorporación de barrios parque y a las urbanizaciones de fin de semana implica considerar, además de las dimensiones materiales y los proyectos que configuran los barrios; las problemáticas de los loteos que subyacían en relación a la acción del Estado -instituciones, organismos públicos, normativas- y los demás agentes involucrados en la formación del territorio.

Esta perspectiva nos permite superar los aspectos morfológicos y arquitectónicos que intervinieron en la proyección de los barrios para abordar también el tema de su ejecución. ¿Cómo dar cuenta de los procesos (y por ende, los actores) que estuvieron por detrás de las transformaciones urbanas que han sido abordadas en los capítulos previos?

Siguiendo la clasificación propuesta por Pedro Pírez se reconocen tres grupos de actores fundamentales participando en la producción de la ciudad:

Aquellos que realizan procesos orientados predominantemente por una lógica de obtención de ganancia. Son "unidades económicas" (empresarios individuales, empresas, conglomerados de empresas) que realizan actividades dentro del mercado.

Actores que participan en la producción de la ciudad orientados predominantemente en función de una lógica política. (...) se hacen cargo de cuestiones que no son resueltas por los comportamientos orientados por la búsqueda de ganancia, pero son necesarios para garantizar la satisfacción de necesidades y/o el funcionamiento de la ciudad.

Actores que se determinan en razón de la lógica de la necesidad. Se desarrollan fuera (total o parcialmente) del mercado y de las políticas públicas. Son por ejemplo, organizaciones comunitarias de base solidaria que realizan acciones tendientes a la 
satisfacción inmediata de una necesidad, realizadas por quienes la sufren directamente (procesos de autoproducción de la ciudad). ${ }^{171}$

En esta ocasión, creemos que es necesario incorporar un análisis de los procesos de construcción de los suburbios haciendo foco en la vinculación entre políticas públicas y sectores privados. Sin desconocer la participación que también han tenido en la formación de los suburbios los procesos de autoconstrucción de la ciudad, el abordaje de los dos primeros núcleos contribuye a formular interrogantes acerca de los procesos de toma de decisiones y en relación a los procesos de producción del suelo.

En relación a este tema, son muchos los autores que hicieron hincapié en el carácter privado de la expansión.

Por las características que este proceso adquirió en el área metropolitana de Buenos Aires, donde la tierra suburbana pertenecía en su mayor parte a sectores privados, se fortaleció la hipótesis de que la ciudad ha sido construida básicamente utilizando los mecanismos del mercado, resultado de las relaciones de competencia entre actores individuales (dueños de la tierra, promotores y agentes inmobiliarios) que buscaron, primordialmente, la obtención de beneficios económicos. En esta línea, el trabajo de Nora Clichevsky sobre el mercado de tierras en la expansión de Buenos Aires, asigna un rol menor al Estado en la producción de suelo, haciendo énfasis en tres agentes del sector privado: 1. los propietarios de la tierra rural, 2. los inversionistas individuales y 3 . las empresas urbanizadoras y/o comercializadoras. ${ }^{172}$

Por su parte, Horacio Torres si bien no se concentra en este aspecto de la expansión, reconoce desde el Estado una política de laissez faire en relación al control de los usos del suelo y pone el acento en el papel que jugaron las inversiones especulativas en general, y las empresas de transporte -más en particular las líneas de colectivos- que estructuraron las áreas de crecimiento. ${ }^{173}$ Mientras tanto, el trabajo más contemporáneo de Norma Lanciotti pone en evidencia la importancia del empresariado inmobiliario en la formación del mercado de tierras de las ciudades argentinas.

\footnotetext{
${ }^{171}$ Pedro Pírez, Actores sociales y gestión de la ciudad, en Ciudades 28, octubre-diciembre 1995, RNIU, México

172 Nora Clichevsky, El mercado de Tierras en el área de expansión de Buenos Aires... op.cit.

${ }^{173}$ Horacio Torres, El mapa social de Buenos Aires, op.cit
} 
Por último, desde el panorama internacional, puede señalarse el estudio ya clásico de Christian Topalov, Le logement en France (1987). Aquí se reconocen, en el contexto de la expansión suburbana de París (1880-1914), tres tipos de agentes participando en los procesos de producción del suelo. 1. los propietarios de la tierra, que buscan agregar valor a partir de las subdivisiones, 2. la sociedad que conforman los propietarios patrimoniales de la tierras -o sus herederos- junto a otro agente que contribuye a producir el loteo, ya sea, a través del financiamiento de infraestructura o, del apoyo técnico a la división y comercialización de los lotes y 3 . los especuladores que compran tierras con el fin expreso de subdividirlas y generar ganancia en la reventa. Para el caso de París, si bien se reconoce un Estado fuerte actuando en las áreas consolidadas (les Grands Traveaux de Haussman entre 1850-1860 implicaron liberación de suelo en áreas centrales y la creación de un sistema de créditos para la construcción), su participación en las nuevas áreas de expansión fue poco significativa. ${ }^{174}$

Sin subestimar esta realidad, es necesario introducir un análisis más detallado del Estado, advirtiendo que interviene en los procesos de producción de tierra urbana en dos ámbitos bien específicos: por un lado, a través de la intervención directa, con la construcción de obra pública, y de manera indirecta, a través del control que ejerce mediante la construcción de un cuerpo legal de reglamentaciones. Retomando una serie de estudios que a partir de la década del ochenta se han propuesto revisar el rol del Estado y su dinámica institucional, se ponen en duda las visiones más extendidas que desestiman la implicancia de las políticas públicas y las acciones legislativas del Estado en materia de ordenamiento territorial. ${ }^{175}$ En cambio, buscamos reconocer la complejidad de cuestiones que entran en juego al momento de elaborar e implementar políticas públicas. $^{176}$

174 Christian Topalov, Le logement en France. Histoire d'une merchandise impossible. Presses de la Fondation des Sciences Politiques, 1987.

175 Nos referimos a los trabajos de Theda Skocpol, Pierre Rosanvallon, Oscar Oszlack y Ernesto Bohoslavsky, que ya han sido citados en la introducción.

176 Desde las ciencias políticas se utilizan conceptos como los de autonomía o capacidad del Estado para analizar las variables que entran en juego entre la elaboración de políticas públicas y su puesta en práctica. Se entiende que un Estado puede ser denominado fuerte o autónomo en la medida en que puede formular y perseguir metas que no constituyan meramente el reflejo de las exigencias o intereses de los grupos o clases sociales dominantes. La capacidad del Estado, por otra parte, hace referencia a su 
En una escala macro, buscamos reconocer las acciones del Estado, de los sectores técnicos y de los agentes privados, a través de una pregunta genérica: ¿cómo se coordinan y entran en acción estos sectores en el contexto de la expansión urbana? Partimos de la premisa según la cual la construcción del territorio no solo es producto de una serie de ideas, acciones y proyectos coordinados que se suceden a lo largo del tiempo, sino también de las acciones truncas, de los roces, las representaciones, los intereses enfrentados en la toma de decisiones y los desfases que se plantean entre el campo de las ideas y su puesta en práctica. ${ }^{177}$

Estos son los temas que trataremos de desarrollar a lo largo del capítulo a través de dos grandes núcleos: el relacionado a las acciones que tienen lugar dentro de la lógica del mercado y las acciones relativas al Estado en sus diferentes escalas.

facultad para implementar políticas públicas. Ver, Katryn Sikkink, "Las capacidades y la autonomía del Estado en Brasil y la Argentina: un enfoque neo-institucionalista.” Op.cit.

177 Esta perspectiva se vincula con el debate epistemológico generado en torno al predominio de la estructura o del agente como claves analíticas de los procesos sociales, tensión que en el campo metodológico se ha manifestado en la incompatibilidad entre los enfoques macro y microanalítico, respectivamente. Al respecto, la teoría social reciente ha desestimado dicha confrontación a favor de perspectivas no dicotómicas que establezcan la mutua determinación entre estructura y agentes, proponiendo la utilización conjunta de métodos cuantitativos y cualitativos así como la multiplicación de escalas de análisis que representen desde diferentes perspectivas la imagen compleja y dinámica de lo real. Ver, Pierre Bourdieu, Cosas dichas, Gedisa, Barcelona, 1993 y Las estructuras sociales de la economía, Manantial, Buenos Aires, 2001; Pierre Bourdieu y Louis Wacquant, Respuestas: por una antropología reflexiva, Grijalbo, México, 1995. 


\subsection{El modus operandi de la expansión: loteos y subdivisiones}

"Si se toma por ejemplo cualquier partido del Gran Buenos Aires, es fácil comprobar que la labor del Municipio resulta insignificante si se la compara con la obra realizada por los loteadores en su conjunto: kilómetros de caminos y mejorados asfálticos, líneas de colectivos, multitud de barrios de distintas características, en su mayoría de aspecto agradable, hablan con elocuencia del gigantesco esfuerzo de este propulsor del progreso edilicio y social"

(Luis Guaraglia, 1971) ${ }^{178}$

En este apartado buscamos conocer el proceso de producción del suelo urbano, haciendo hincapié en el estudio de la dinámica inmobiliaria y de los actores que conformaban este sector.

Se presta especial atención a la participación de estos grupos en un contexto determinado: la formación de barrios parque y loteos de fin de semana durante la primera mitad del siglo XX. Se hacen algunas referencias a la historia económica del período, tanto en relación al mercado inmobiliario como a los diferentes agentes que lo constituían, pero no se pretende construir la historia de ninguno de estos grupos en particular. Estas problemáticas, por su propia envergadura y complejidad reclaman que se los aborde mediante estudios específicos. ${ }^{179}$

En las páginas que siguen, procederemos primero a presentar un panorama general que sirva para ilustrar ampliamente el proceso de producción de suelo urbano, para detenernos luego a examinar la acción de rematadores, agentes inmobiliarios,

\footnotetext{
178 Luis Guaraglia, Manual del rematador, Ediciones Machi, Buenos Aires, 1971. p. 290

179 Algunos de estos estudios son Jorge Sábato, La clase dominante en la Argentina moderna. Formación y características. Imago Mundi,Buenos Aires, 1991; Roy Hora, Los terratenientes de la pampa argentina. Una historia social y política, 1860-1945. Siglo XXI Editores, Buenos Aires, 2002; Norma Lanciotti, "Mercado inmobiliario en Rosario: inversores, empresas y empresarios en la expansión urbana entresiglos, 1880-1914.”, en Séptimas Jornadas "Investigaciones en la Facultad" de Ciencias Económicas y Estadística, Universidad Nacional de Rosario, octubre 2002; De rentistas a empresarios, op.cit.
} 
promotores y dueños de la tierra, teniendo en cuenta que las diversas formas de producción del suelo dan nacimiento a diferentes tipos de loteos y en consecuencia a diferentes formas de hacer ciudad. A la heterogeneidad en el grupo de agentes y productores se corresponde la heterogeneidad de productos y de sus destinatarios.

\section{1.a Esquema general}

Ante el crecimiento de la ciudad y la posibilidad que crezca la demanda, comienzan los loteos de las viejas quintas y las tierras rurales se subdividen. Los valores suben acentuadamente, sobre todo si aparece la amenaza de la inflación y cunde la tendencia a invertir en tierras. Entonces el valor se torna especulativo. Se supone que la tendencia prioriza algún sector y entonces la tierra sube, en parte porque hay demanda y en parte porque sobre ese sector se lanza la especulación. Sobre el valor de la tierra suburbana loteada y ofrecida como tierra prometida- se carga el costo del loteo, la promoción de las ventas, la publicidad, y aún la tendencia especulativa de los primeros compradores que quieren repetir el negocio. Los sectores de más bajos ingresos que aspiran a construir la casa propia deben alejarse cada vez más hacia los anillos periféricos o a los sectores intermedios a donde difícilmente llegan el asfalto o los servicios. ${ }^{180}$ Así caracterizó, ampliamente, José Luis Romero a los procesos de expansión iniciados en Latinoamérica a comienzos del siglo XX. Sin embargo, esta descripción esconde un proceso mucho más complejo en el que se reconocen actores y tiempos diversos dentro del panorama latinoamericano.

En una primera aproximación, el denominador común que compartieron las áreas metropolitanas de las ciudades latinoamericanas fue su condición de urbanización salteada. Teniendo en cuenta que la tierra suburbana pertenecía en su mayor parte a sectores privados, podemos entender que las ciudades se hayan construido básicamente a partir del cruce de intereses, entre los agentes actuantes dentro de las lógicas del mercado y -como veremos más en profundidad en el capítulo siguiente- las acciones del Estado tendientes a regularlo. En cuanto a éstas últimas, las regulaciones establecieron -en la mayoría de los países- restricciones relacionadas con la

180 J.L.Romero, La ciudad occidental. Culturas urbanas en Europa y América. Siglo Veintiuno Editores, Buenos Aires, 2009. P. 276 
morfología, mientras que, prácticamente no existieron restricciones para que la tierra rural sea transformada en urbana. En Argentina, cualquier tierra de uso rural cuyo propietario decidiera convertirla en tierra urbana, podía pasar a serlo. ${ }^{181}$

En el escenario que se va conformando conviven enormes cantidades de tierras vacantes $^{182}$-muchas de ellas dotadas de equipamientos y de servicios- entre áreas loteadas y urbanizadas con anterioridad, mientras que una enorme cantidad de población queda relegada a áreas lejanas desprovistas de estos mismos servicios y de equipamientos elementales. ${ }^{183}$ Por otra parte, la intensidad de los vacíos es sumamente heterogénea dentro de los diferentes sectores urbanos dependiendo de las formas de crecimiento particular que han tenido los mismos, los tipos de propietarios, los usos según las demandas, las expectativas no concretadas de localización de actividades productivas y las obras públicas realizadas.

A lo largo del proceso de expansión, estas áreas quedaron reducidas, mayoritariamente, a las zonas periféricas de los ejes de la expansión de las ciudades y en menor magnitud, a las áreas centrales intersticiales. En el caso de Buenos Aires, las escasas restricciones impuestas para la producción de tierra urbana, de la mano con las importantes ganancias que las subdivisiones prometían redundó en una enorme

${ }^{181}$ Nora Clichevsky, Construcción y administración de la ciudad latinoamericana. p. 286.

${ }^{182}$ La definición de tierras vacantes no es exactamente la misma para todos los países de Latinoamérica, dependiendo, fundamentalmente, de los límites que se reconozcan como parte del área urbana o metropolitana. Para el área de Buenos Aires se reconoce como tierra vacante a la tierra privada no utilizada que se encuentra subdividida en parcelas denominadas "urbanas" dentro del perímetro de la aglomeración. Así como a la tierra de propiedad fiscal que ha sido desafectada de sus anteriores usos.

Esta es la definición que ha sido propuesta por Nora Clichevsky, y a partir de la cual se obtuvieron los datos que en este capítulo citamos.

183 En ocasión de las reuniones de Municipios del GBA (La Plata, 8 de octubre de 1948), el concejal Ferrari de Lomas de Zamora expresó: “ (...) desgraciadamente tenemos nosotros centenares y centenares de lotes baldíos, dotados de agua corriente, luz eléctrica, medios de transporte, y como los mismos no se venden, tenemos que mandar a nuestros compañeros obreros a construir viviendas a 10 o $15 \mathrm{~km}$ del centro de sus actividades, porque allí es donde se hacen los remates en abundancia, mientras que dentro de la planta urbana, donde se cuenta con todos los servicios públicos y con los elementos de primera necesidad, hay cantidad de lotes que nadie los puede ocupar porque sus propietarios no los sacan a la venta, con el propósito de especular con ellos”. Citado por Pastor, José y Bonilla, José, Estudio sobre uso de la tierra. P. 177. 
cantidad de áreas subdivididas y no loteadas, (en espera de un crecimiento de la demanda y de los valores) y de muchas otras, loteadas y vendidas sólo parcialmente. El área metropolitana de esta misma ciudad poseía para la década del setenta -momento a partir del cual se cuenta con datos más globales- importantes porcentajes de áreas vacantes. ${ }^{184}$ Según los datos propuestos por Clichevsky, en Sudamérica sólo la superaba Río de Janeiro, donde las áreas vacías comprendían el 44\% de la superficie del Municipio; le seguía Buenos Aires con el $32 \%$, y por debajo quedaban Quito, con el $21,7 \%$ del suelo urbano vacante y Lima donde la tierra vacante se estimaba en el $10 \%{ }^{185}$

A lo largo del proceso expansivo se fueron generando, además de zonas de ocupación salteada, circunstancias para el asentamiento de la población en diversas condiciones de irregularidad. Una figura común, que recorre diversos textos que analizan la urbanización en Latinoamérica es la de "ciudad ilegal" que caracteriza la forma de tenencia del suelo de importantes sectores de la población urbana, y no sólo la de menores recursos ya que, como veremos, los orígenes de la ilegalidad podían proceder de diversos factores.

La irregularidad en la tenencia del suelo podía estar precedida por dos formas de transgresiones: a. respecto a las condiciones de dominio y b. respecto a los modos en que se generaba la urbanización. En relación al primer tema, la falta de títulos de propiedad podía ser consecuencia de la ocupación de las tierras, pero la mayor parte de las veces se realizaba la compra en loteos clandestinos o en zonas rurales incorporadas

184 Existen algunos datos más específicos que los que aquí mencionamos y que pertenecen a investigaciones particulares realizadas sobre diferentes municipios. Se ha optado por no incorporar estos datos ya que cubren cuestiones muy parciales en relación a nuestra investigación. Si se quisiera profundizar sobre el tema se puede ver, Claudia Bevilacqua de Cristino, "Procesos de producción y consumo de tierra urbana en la periferia del área metropolitana de Buenos Aires. El caso del municipio de Almirante Brown. 1948-1972.”, en Serie Estudio. Investigaciones nº 14, Universidad Nacional de La Plata, 1993; Nora Clichevsky, Marie F. Prévot Schapira y Graciela Schneier, Graciela, Loteos populares, sector inmobiliario y gestión local en Buenos Aires. El caso del municipio de Moreno, Cuadernos del CEUR, Buenos Aires, 1990.

${ }^{185}$ Nora Clichevsky, Tierra Vacante en Ciudades Latinoamericanas, Nora CLichevsky Editora, Toronto, 2002. p. 4 
al área urbana de forma ilegal. Sin embargo, la mayor forma de irregularidad se asentó sobre las condiciones dudosas de la urbanización. Se vendían tierras que no poseían las condiciones para ser usadas como residenciales (inundables, sin infraestructura), o que al momento de la venta aún no cumplían con todas las condiciones que exigía la legislación vigente, mientras que otros loteos que denominamos clandestinos se vendían sin ser presentados ante las autoridades. ${ }^{186}$

Todas estas situaciones condujeron a que a lo largo del siglo XX la magnitud de población que ocupaba alguna forma de hábitat informal respecto al total de habitantes de cada ciudad se fuese incrementando. Los primeros datos estadísticos que tenemos pertenecen al final de nuestro período, y aunque no nos permiten trazar un recorrido, sirven para dar cuenta de la forma en que la urbanización venía desarrollándose hasta el momento de su obtención. Me remito, por ejemplo, a los estudios realizados por Horacio Torres junto a Martha Schteingart, donde compararon los procesos sociales y de estructuración metropolitana en America Latina, y en donde se observó que tanto en el caso de Lima como en el de Santiago de Chile la ocupación periférica de los sectores de bajos ingresos se dio principalmente a través de la ocupación ilícita de terrenos, a los cuales, muchas veces acudió el Estado con posterioridad legalizando la propiedad de las zonas previamente ocupadas. ${ }^{187}$ En otros análisis, Nora Clichevsky informa que la proporción de personas que vivía en algún tipo de informalidad en Lima y Caracas, pasó del $15 \%$ y $20 \%$ en 1950 al 35\% y 50\% en 1970, respectivamente. En Bogotá, la producción de "loteos piratas" data de la década del cincuenta y llegó a afectar al 54\% de la tierra urbana en 1970. Para esa misma fecha, en México se llegaba al 40\% y en Buenos Aires sólo al 3\%. ${ }^{188}$

A pesar de que, como ya se indicó, resulta difícil ajustar estos datos a nuestro período de análisis, bien sirven para ilustrar de una tendencia que pone a la Argentina en una situación diferente a la del contexto latinoamericano. El nacimiento de las

\footnotetext{
${ }^{186}$ En la segunda parte de este capítulo veremos como muchos de los loteos se consumaban sólo con la aprobación parcial del municipio y se presentaban ante las autoridades provinciales una vez consumados. 187 Horacio Torres y Martha Schteingart "Procesos sociales y estructuración metropolitana en America Latina”, en Desarrollo Económico, vol . XII nº 48.1973

188 Nora Clichevsky, "Informalidad y segregación urbana en América Latina” 2000. versión on-line: www.eclac.org/publicaciones/xml/8/5638/lcl1430e.pdf
} 
diferencias debe buscarse en las distintas situaciones respecto a las normas de cada país, lo cual ha arrojado implicancias diferentes dentro del mercado de tierras. Mientras que en Perú o Brasil, entre otros, la ilegalidad del suelo fue históricamente muy alta, en Argentina era mínima. Lo que se reconoce es que en los países con mayores exigencias legales, la tierra urbana poseía costos de producción mucho más altos que en aquellos donde significaba solo aprobar un plano de subdivisión. ${ }^{189}$

En las ciudades argentinas, en tanto la ocupación del lote precedía a la instalación de servicios públicos, los loteos que pudieron realizarse en zonas periféricas, algo alejadas de los principales ejes de desarrollo, eran sensiblemente más baratos que aquellos ubicados en los pueblos o cabeceras de partido del Área Metropolitana. Esta forma de producción de suelo urbano dio lugar a loteos accesibles, financiados en cuotas a largo plazo, que permitieron que grupos de bajos ingresos pudieran acceder, a través de la autoconstrucción, al sueño de la casa propia sobre lotes con títulos legítimos. Situación que se diferencia notablemente de otras formas de ocupación de la periferia en otras ciudades latinoamericanas.

Por último, en relación a las figuras que intervinieron en los procesos descriptos, nuestro país también presenta algunas particularidades. A diferencia de países como Brasil, donde la posesión de la tierra cercana a los centros urbanos pertenecía a unos pocos latifundistas, la propiedad de la tierra se encontraba mucho más fragmentada. Los principales productores de lotes urbanos eran, a comienzos de siglo XX, las empresas urbanizadoras, en su mayoría asociadas al ferrocarril, y en menor medida, los propietarios rurales, cuya participación entre fines del siglo XIX y comienzos del XX correspondió a numerosas ventas por sucesiones. ${ }^{190}$ La actuación de estos últimos fue

189 En el punto siguiente veremos cómo rematadores y agentes inmobiliarios hacen referencia a la dificultad de realizar loteos con posterioridad al establecimiento de leyes que establecen requisitos que redundan en el encarecimiento de los costos previos a la realización de los loteos.

${ }^{190}$ Norma Lanciotti presenta un estudio detallado sobre este tema para el área de Rosario. Ver, "Mercado inmobiliario en Rosario: inversores, empresas y empresarios en la expansión urbana entresiglos, 1880 1914.”, en Séptimas Jornadas "Investigaciones en la Facultad" de Ciencias Económicas y Estadística, Universidad Nacional de Rosario, octubre 2002. Recuérdese que también fue Charles Sargent quien en líneas generales ya verificó esta situación, hablando de un período de especulación "institucional" consistente en la venta por parte de los grandes terratenientes a los empresarios de la especulación urbana. 
aumentando con el correr de los años, junto con la incorporación al mercado de empresas inmobiliarias que funcionaban, mayoritariamente, como intermediarias entre dueños de la tierra y compradores, haciéndose cargo del proceso de subdivisión y comercialización. Esta última operación se realizaba generalmente a través de grandes remates que constituyeron de alguna manera un episodio característico de la expansión en nuestro país.

Esta última modalidad de producción del suelo es característica de una etapa de capitalismo competitivo, donde la renta urbana es apropiada por propietarios pequeños o medianos. En efecto, cabe señalar, como característica distintiva de nuestro país, la participación -aunque minoritaria- de sectores de menores ingresos tales como empleados, trabajadores especializados, artesanos y agricultores, cuya participación tendió a conformar una inversión inmobiliaria orientada a asegurar el patrimonio. Especialmente, durante la década del cuarenta se generó un flujo de capitales desde otros sectores de la economía como consecuencia de la alta tasa de ganancia relativa que prometía la inversión en tierras. Los análisis económicos muestran que la existencia de gran cantidad de inversores en el mercado llevaría a su funcionamiento en condiciones de "competencia imperfecta", lo que a su vez redundaría en los valores económicos relativamente bajos que se mantuvieron hasta comienzos de la década del cincuenta. Con posterioridad, el proceso de acumulación y concentración del capital y la importancia asumida por el capital financiero que comenzó a interesarse en la tierra como forma de poseer activos fijos, así como para apropiarse de los grandes beneficios que se podían obtener en el sector redundó, entre otras cuestiones, en el encarecimiento de los loteos. ${ }^{191}$

Teniendo en cuenta que en nuestro país, y durante el período que analizamos, la oferta ha sido mayoritariamente de tierras (bajo la forma de lotes que se ponían a la venta sin mejoras y sin construcciones), el mapa que configuraron los agentes oferentes puede delinearse, de acuerdo a su nivel de participación a lo largo de la primera mitad del siglo XX, como se detallará a continuación.

${ }^{191}$ Nora Clichevsky, Construcción y administración de la ciudad latinoamericana. Op.cit. pp. 289-290. 


\section{1.b Las figuras del loteo}

A partir del universo de casos relevados para los dos periodos expansivos y de reconocer a los actores particulares involucrados en los procesos de producción del suelo (promotores -que podían ser inversionistas individuales o empresas urbanizadoras-; agentes inmobiliarios -participaban del negocio aportando capital de trabajo y sólo en ocasiones excepcionales capital financiero-; propietarios de la tierra), proponemos analizar los modos de gestión, las formas de organización empresarial, los comportamientos que caracterizan y diferencian a cada uno de ellos al momento de invertir o impulsar un negocio inmobiliario. En suma, buscamos conocer sus estrategias de acción, con el objetivo de reconstruir los patrones de inversión espacial y económica de cada sector, a fin de ponerlas en relación con la construcción de la ciudad.

Figura 1. Propietarios

Entre los actores que conformaban el mercado de tierras de la expansión, debemos decir -como se desarrollará más adelante- que los propietarios de tierras intervinieron en el proceso de producción de suelo urbano actuando, fundamentalmente, a través de intermediarios. Es decir, proveyendo las tierras sobre las cuales las inmobiliarias delinearían los trazados y procederían a los loteos. A través de esta especie de sociedad los propietarios podían ofrecer sus tierras al mercado de acuerdo a dos opciones: 1 . realizaban las inversiones para contratar al agrimensor y realizar trámites para aprobación de los loteos o, 2. las inmobiliarias costeaban dichos gastos a cuenta de las futuras ventas. Por su parte, las inmobiliarias, ya sea que pagaran los costos del loteo o no, evitaban desembolsar grandes sumas para la compra de tierras.

A pesar de que esta situación se cumple como regla general, también es cierto que en algunos casos particulares fueron los propios dueños de la tierra (o sus herederos) los que encararon la cadena completa de urbanización. Nora Clichevsky indica que al incorporarse al mercado de tierras urbanas como productores de lotes los dueños diversifican su esfera de acción, apropiándose así de los beneficios que otorga la valorización de la tierra rural alcanzada por la expansión de la ciudad, más los 
beneficios obtenidos por la producción y venta de lotes urbanos. ${ }^{192}$ Es el caso de la familia Aguirre, quien desarrolló el Barrio Parque Aguirre, que en esta oportunidad nos servirá para ilustrar la forma en que los propietarios participaban en forma directa del negocio de la expansión.

Este barrio se asentó sobre las tierras de la sucesión de Don Manuel Aguirre y fueron los propios herederos de la familia quienes decidieron la realización de un loteo aprovechando la localización privilegiada -entre las localidades de Martínez y San Isidro- en la que se ubicaban sus tierras. ${ }^{193}$ La familia se encargó de la contratación de un agrimensor a quien sugirió que proyectara un barrio jardín a la manera de la urbanística pintoresca. Seguidamente, para proceder con el proyecto de subdivisión se presentaron los planos para su aprobación en la Intendencia Municipal de San Isidro, que en el año 1913 sancionó una ordenanza aprobando el loteo. ${ }^{194}$ Los mismos propietarios propusieron el tipo de trazado y sugirieron que junto a la aprobación del loteo se dictara una normativa, en la cual se impulsaba la construcción de tipos compactos en medio de un área verde, prohibiendo expresamente la utilización de materiales considerados precarios, con el fin de mantener el prestigio del área y el tipo de urbanización con predominancia de áreas verdes que ya se verificaba en la zona Norte del GBA.

Al igual que en este caso, verificamos que se presentaron a la Dirección de Geodesia y Catastro de la Provincia de Buenos Aires varios pedidos de particulares solicitando "Diligencias de pedidos de mensuras de pueblos", aunque por los datos que

\footnotetext{
192 Nora Clichevsky, El mercado de tierras...op.cit. p 57.

193 Uno de los herederos de la familia, Carlos Ibarguren (hijo) cuenta que tras el deceso de Manuel J. Aguirre (1912), los entonces herederos de la chacra -los Aguirre, los Balcarce y los Gómez- ante la evidencia de que las poblaciones de Martínez y San Isidro habíanse extendido considerablemente, y la valorización de las tierras era constante, se dispusieron a subdividir buena parte de la propiedad, y formar un amplio Barrio-Parque. Ver, Carlos Ibarguren (hijo); Crónica de la histórica chacra de Aguirre en San Isidro. Museo General Brigadier Juan Martín de Pueyrredón, San Isidro, 1982.

194 Ordenanza Municipal aprobando la formación del Barrio-Parque Manuel A. Aguirre. San Isidro, 25 de enero de 1913, en Carpeta Barrio Parque Aguirre, Archivo y Museo Histórico de San Isidro.
} 
pudimos verificar estos no parecen haber tenido el éxito que siguió a la urbanización del Barrio Parque Aguirre. ${ }^{195}$

Todo parece indicar que no fueron muchos los propietarios de tierras que participaron exitosamente en la formación de grandes emprendimientos. Quienes lo hicieron debían, como primera condición, poseer tierras en áreas privilegiadas de la expansión. En segundo lugar, generalmente, pertenecieron a familias de la elite con importantes contactos o relaciones, cuando no procedieron asociados a compañías inmobiliarias que conocían los modos de operar, los vericuetos legales que exigían las aprobaciones y eran capaces de hacerse cargo de la publicidad y venta de los lotes como punto fundamental en la cadena de comercialización. ${ }^{196}$ Mientras que sí se registra la intervención activa de pequeños propietarios que subdividían de a dos o tres lotes una vez que, en determinadas zonas, la demanda se acrecentaba resultando en la mayor densificación de un área, dada por la incorporación de urbanizaciones en las "periferias de los pueblos".

Figura 2. Promotor

La figura del promotor inmobiliario supone una intervención más activa en el proceso de producción del suelo. A diferencia del agente o compañía inmobiliaria (que veremos en el siguiente apartado), este tipo de empresa ejercía el control de la totalidad del proceso (gestión del capital de inversión, urbanización, comercialización de lotes, producción y comercialización de viviendas).

Aquí presentaremos el caso de la Sociedad Anónima City Bell, la cual nos servirá para ilustrar el rol de la figura del promotor en la Argentina. Al igual que en el apartado anterior, la elección de esta compañía obedece a la posibilidad de acceso a la

195 Dirección de geodesia y Catastro de la Pcia, Diligencia de Mensura del pueblo "San Mauricio", propiedad del Sr. Mauricio Duva, 1910; Dirección de geodesia y Catastro de la Pcia, Diligencia de Mensura del pueblo "Estación Sunbland” de Badano Hnos., 1912; Dirección de geodesia y Catastro de la Pcia, Diligencia de Mensura de los terrenos divididos para "Pueblo en el Km. 14 del F.C.C. Bs. As." De las Sras. María Antonia y María Luisa Pereyra de Herrera Vegas, 1932. Departamento de Investigación Histórica Cartográfica, Dirección de Geodesia, MOP, Provincia de Buenos Aires.

${ }^{196}$ En las páginas que siguen volveremos sobre el tema de la aprobación de los loteos y las vinculaciones entre propietarios de la tierra y agentes municipales. 
información, a la vez que nos permite el análisis de un caso concreto. Las conclusiones que se puedan extraer al respecto son ilustrativas de un proceso extendido pero que presentó matices particulares. Por lo tanto, sólo en líneas generales pueden entenderse como extrapolables a la totalidad de barrios o emprendimientos realizados por otras compañías promotoras.

La compañía que analizamos actuó en la urbanización del pueblo de City Bell. Si bien, por su localización, este caso supera el área del GBA definida para nuestro análisis, la formación de este pueblo debe ser comprendida como parte de la suburbanización del área metropolitana de Buenos Aires, en un momento en que algunos sectores -particularmente en la Zona Norte de la Capital- revelaban un crecimiento importante que hacía posible pensar en la incorporación de nuevos territorios en donde reformular la idea del week-end, para promover el acceso a los sectores medios, en contraposición al crecimiento suburbano de carácter exclusivo que se consolidaba sobre la franja costera en dirección a Tigre.

La compañía actuó delineando el pueblo junto a la recientemente fundada estación de ferrocarril homónima, sobre la línea de tránsito que unía la Capital Provincial con la Capital Nacional. Las tierras sobre las cuales se trazó el pueblo pertenecían a la Estancia Grande de la familia Bell. Al fallecer Jorge Bell, las mismas fueron vendidas por su viuda y sus hijos a una Sociedad Anónima que se conformó - en lo que parecía ser una práctica habitual ${ }^{197}$ - con el fin expreso de comprar las tierras mencionadas para desarrollar un negocio inmobiliario y que tomó el nombre de la familia y lo utilizó luego para la designación del pueblo City Bell. ${ }^{198}$

Como accionistas de la compañía aparecen, en primer lugar -como presidenteel señor José Guerrico, quien más tarde sería intendente de la ciudad de Buenos Aires, y

197 Así surge del análisis que realiza Norma Lanciotti sobre las sociedades comerciales que actuaron en la ciudad de Rosario; y también del trabajo de Schvarzer y Gómez en relación a las Sociedades Anónimas que compraban y vendían tierras vinculadas al ferrocarril. Ver, Lanciotti, Norma, De rentistas a empresarios. Inversión inmobiliaria y urbanización en la pampa argentina. Rosario, 1880-1910. Edición de la Universidad Nacional del Litoral, Rosario, 2009 y Jorge Schavarzer y Teresita Gómez, $L a$ primera gran empresa de los argentinos. El ferrocarril Oeste (1854-1862). Fondo de Cultura Económica, Buenos Aires, 2006.

198 Ver, Guillermo Defranco; City Bell. Crónica de la tierra de uno. Edición del autor. Buenos Aires, 2005 . 
como vice-presidente el Dr. Adolfo Labougle, quien formaría parte del HCD de la Capital. Al respecto, Norma Lanciotti ha señalado que, en general, los accionistas de las empresas que invertían en tierras eran hombres de la elite local que, o bien participaban directamente de las decisiones públicas respecto a la dirección y modalidad de la expansión urbana a través de sus funciones en el Concejo Deliberante, o bien tenían los contactos necesarios para conseguir las aprobaciones, y un acceso a la información que les permitía anteceder la compra de tierras conociendo las futuras áreas de expansión, la inauguración de una estación del ferrocarril, como sucedió en este caso, o la apertura de un camino que aseguraría la valorización de un área.

Para esta operación, una vez adquiridas las tierras de la Estancia Grande, la sociedad contrató a un agrimensor para que confeccionara el plano de mensuras para el trazado del pueblo que ocupaba una superficie aproximada de 65 ha de un total de 300 ha que había adquirido la compañía. En el mes de mayo de 1914, el Poder Ejecutivo de la Provinicia aprobó los planos presentados por la S.A. City Bell para la fundación de un nuevo pueblo en el partido de La Plata, de acuerdo a lo dictaminado por el Asesor de Gobierno en el expediente 174, de ese año.

Inicialmente sólo se llevó a cabo el loteo de tierras y durante toda la década del diez el crecimiento de la población fue prácticamente nulo. Las reglas del mercado inmobiliario a las que respondían estos desarrollos buscaban maximizar las ganancias aunque esto implicara minimizar, hasta donde fuera posible, las tareas de gestión. De esto, también da cuenta el caso del Barrio Golf Ituzaingo (1931), promovido por la S.A. Compañía de Tierras del Oeste, en donde la actuación de esta última se limitó a la compra de tierras, su posterior subdivisión y venta.

Por ello, en el caso de City Bell no queda claro si la construcción de infraestructura y de las primeras viviendas que, eventualmente, se realizaron, eran parte del proyecto inicial de la Sociedad o no. Lo cierto es que ante el panorama de crecimiento lento que acabamos de describir la compañía decidió introducir los primeros avances técnicos y construir las primeras viviendas. La operación realizada fue bastante modesta y las intervenciones fueron las mínimas necesarias para acrecentar el valor de las tierras y asegurar su venta. En el año 1922 se presentaron en la Municipalidad de La Plata los planos de las viviendas a construir a nombre de la S.A. City Bell. Estas viviendas presentaban tipologías compactas y repetían modelos de 
chalets -asociados a las imágenes del ferrocarril o neocoloniales- popularizados en manuales y revistas de construcción. ${ }^{199}$ La venta de unidades se realizaba, al igual que en el caso de los lotes, a través de un adelanto en efectivo y cuotas mensuales; con financiaciones a un promedio de diez años y algunos casos excepcionales en donde se llegaban a ofrecer plazos de hasta treinta años. ${ }^{200}$

Además de la S.A. City Bell, la Compañía Zapiola, Furst y Acosta -a la cual encontramos actuando en diversas áreas de crecimiento metropolitano- llevó a cabo la construcción de viviendas económicas de venta a plazos. De modo que en el caso de City Bell sabemos que, además del promotor principal, otras empresas intervenían en diferentes puntos de la cadena de producción. En esta oportunidad se verifica su intervención en la construcción de viviendas, pero fundamentalmente $-\mathrm{y}$ de igual manera que en el Barrio Golf Ituzaingo que ya mencionamos- se reconoce la acción de agentes inmobiliarios actuando como intermediarios, a cargo de los procesos de comercialización de la tierra, incluyendo sobre todo los rubros relativos a la promoción y publicidad.

Más allá del caso de City Bell, en el cual la S.A. adquiere una presencia notoria, tomando acción no sólo en la subdivisión de las tierras, sino también en la construcción de viviendas. Hay que notar que este tipo de operaciones en las que se vislumbra la fuerte presencia de agentes inversores actuando en sucesivas etapas se asocia más a otro tipo de programas: aquellos destinados a cubrir las necesidades de un grupo específico, como pueden ser los emprendimientos asociados a la construcción de vivienda para empleados de ferrocarriles, citemos los casos del pueblo de Ranelagh (Compañía de Tierras del Sur, 1913), en el actual partido de Berazategui; o el pueblo de Fisherton en las afueras de Rosario (Argentine Land and Investement Co. Boardman y Thompson, 1891), y otros más cercanos a la idea de Company Town, como por ejemplo el Barrio de Remedios de Escalada (1907), en Lanús; o el Conjunto New Liverpool en Bahía

\footnotetext{
199 Las tipologías que se construyeron eran de planta compacta, de uno o dos niveles; éstas últimas, sin llegar a ser lujosas eran residencias importantes caracterizadas con elementos de la arquitectura neocolonial, balcones de hierro en voladizo, decoraciones sobre las aberturas y grandes superficies ciegas en revoque blanco. Sobre la popularidad que adquirieron estas imágenes en la década de 1920, ver el Capítulo 5, en donde se abordará el tema de la arquitectura suburbana.

${ }^{200}$ Folletos promocionales de la S.A. City Bell, 1927. Archivo personal de la familia Buchele.
} 
Blanca. ${ }^{201}$ En estos casos, lo que promovía las inversiones no era simplemente el fin económico, sino que se buscaba fijar el mercado de trabajo, y ofrecer, especialmente, dentro de los cuerpos jerárquicos, la opción de residir en áreas suburbanas en donde se instalaban viviendas aisladas, de tipo compacto que se entendían como tipologías modernas en línea con los desarrollos suburbanos que tenían lugar en Inglaterra o Estados Unidos. ${ }^{202}$

A diferencia de Brasil, donde la compañía City of Sao Paulo Improvements and Freeholhand Company Limited compró tierras en la afueras de San Pablo y contrató a los arquitectos británicos Unwin y Parker para la realización de un gran emprendimiento: el barrio parque Jardín América, en el contexto local, hay que resaltar que la actividad de los promotores se encontró más ligada a los mercados inmobiliarios urbanos, donde los porcentajes de ganancia solían ser menores, al igual que los riesgos. $^{203}$

Figura 3. Loteador + propietario

En los apartados anteriores introdujimos a estas dos figuras, por el tipo de mecanismo de venta predominante en Argentina (los remates de tierras y la venta en mensualidades), fueron las compañías inmobiliarias junto a los propietarios de las tierras quienes ocuparon un rol destacado en la formación de los suburbios, particularmente la figura del loteador, quien se encargaba de la subdivisión y posterior venta de un fraccionamiento, generalmente, a través de la realización del remate.

201 El caso de la urbanización de Ranelagh ha sido analizado en un trabajo previo. Ver, Ana Gómez Pintus, "Las dimensiones del pintoresquismo. Suburbios residenciales, arquitectura y prácticas profesionales" op.cit; Saberio Torchiaro y Jaime Barnett (comp.), Ranelagh., Ciudad Jardín, Editado por la Asociación de Amigos de la Estación de Ranelagh, 1977; María Marta Lupano, "vivienda ferroviaria", en Jorge Liernur y Fernando Aliata (dirs.), Diccionario de Arquitectura en la Argentina. Clarín, Buenos Aires, 2004. Sobre Fisherton ver, Fernando Williams, "Estudio Follet. Documentos de una Colección", en Summa + Historia, Buenos Aires, 2004. pp.90-95.

202 En el Capítulo 5 se realizará un estudio más detallado en relación a las imágenes y tipologías arquitectónicas que se incorporaban en los distintos desarrollos suburbanos.

203 Sobre el barrio Jardín América ver, Silvia Santos Wolf, Jardim América.op.cit. 
Con la sola intención de ilustrar la dinámica a partir de la cual se realizaban estos loteos, trazaremos la trayectoria de una compañía tradicional con gran actividad en la región metropolitana. Este caso puede enmarcarse dentro del grupo que Nora Clichevsky clasifica como empresas urbanizadoras y/o comercializadoras. ${ }^{204}$ A la vez que se corresponde al tipo de figura que Christian Topalov encuentra actuando en la expansión de París entre 1880 y 1914; produciendo lotes con mínima infraestructura, destinados a los grupos medios de la burguesía que compran para construir su vivienda particular, generalmente, utilizada como residencia de veraneo. ${ }^{205}$ Se diferencian del promotor, en tanto este último gestiona el capital para la adquisición de los terrenos, la urbanización y construcción, desempeñando en algunos casos las funciones de producción y comercialización, es decir, el trazado, la apertura de las calles, la construcción de viviendas -si las hubiera- y la venta final. ${ }^{206}$ Más allá de esta amplia caracterización, a través de la presentación de un caso, se busca crear una imagen general que permita explicar algunas cuestiones particulares relacionadas a los loteos.

La trayectoria de la empresa Vinelli puede ser puesta en relación con un grupo de empresas familiares, entre las que podemos citar también a la empresa Astoul Bonorino, iniciadas con muy poco capital y gerenciadas por su propio dueño y algún que otro empleado.

La familia Vinelli era una familia de inmigrantes italianos llegados al país en la década de 1880 y vueltos a Italia antes de iniciarse el nuevo siglo. Uno de sus hijos, nacido en nuestro país, debió retornar en la primera década del siglo XX para cumplir el servicio militar obligatorio y "maravillado por el desarrollo y las posibilidades que otorgaba la Argentina decidió quedarse". ${ }^{207}$ Don Francisco Vinelli montó un pequeño negocio que para la década de 1900 se organizaba en un corralón general. Allí se remataban mercaderías diversas, desde amoblamientos y materiales para la construcción, hasta lotes de animales (pollos, gallinas) que se vendían y se retiraban en el mismo local del centro de la ciudad. Hacia 1906 la firma comenzó a involucrarse en

\footnotetext{
${ }^{204}$ Nora Clichevsky, El mercado de tierras en el área de la expansión de Buenos Aires, op.cit. p. 33.

${ }^{205}$ Christian Topalov, Le logement en France, op.cit. p159.

${ }^{206}$ Norma Lanciotti, De rentistas a empresarios, op.cit. p 154

${ }^{207}$ Folleto publicitario de la empresa. "Vinelli. 1906-2006. 100 años de experiencia y dedicación en el mercado inmobiliario"
} 
los pequeños loteos que tenían lugar en los barrios de la Capital y abrió una oficina en la calle San Martín, enclave principal de los martilleros en Buenos Aires. Hasta la década del treinta la empresa participó de operaciones inmobiliarias pequeñas, actividad que todavía compartía con los remates de otras mercaderías. Sin embargo, el crecimiento del negocio le permitió en el año 1926 trasladarse a una nueva oficina -en el sitio que ocupa actualmente- en Hipólito Yrigoyen 710. La década del treinta, representó un salto para la compañía. El constante crecimiento de la ciudad Capital y su expansión sobre el área metropolitana, junto a la incorporación de su hijo, Rodolfo Vinelli, imprimieron una nueva visión y la compañía inició una actividad febril dentro del rubro de los remates inmobiliarios. Paralelamente, se iniciaba una época de grandes loteos, las empresas urbanizadoras y/o comercializadoras que actuaban desde comienzos de siglo en la ciudad de Buenos Aires, a medida que se extendió el área metropolitana extendieron su esfera de acción hacia los nuevos centros de población a los que acudían con sus remates. La misma trayectoria trazó la compañía Astoul Bonorino, con casa central en Capital Federal, en la Avenida Cangallo y luego sobre Florida, y a la cual el auge de los loteos le permitió un crecimiento que se tradujo en la apertura de una primera sucursal en Ituzaingo, y luego en San Miguel y Mar del Plata. $^{208}$

En cuanto a Vinelli, Temperley permanece en la memoria de la empresa como un sitio de grandes intervenciones por haber sido uno de los primeros grandes loteos realizados en el conurbano con ciento cincuenta y siete lotes vendidos en el año 1925. Otra de las grandes intervenciones que puede citarse a cargo de la compañía es el caso de San Antonio de Padua. Con estos loteos se iniciaba el período de mayor actividad de la compañía, hasta 1935 sólo se reconocen 18 operaciones, contra 185 registradas entre 1935-1950.

Ahora, en cuanto al ordenamiento que tomaron en el territorio, dentro de un total de 203 transacciones, se confirma que la zona Oeste fue la principal receptora, con 187 emprendimientos realizados, 9 en la zona Norte y 22 en el Sur-Oeste. ${ }^{209}$ No hay datos que indiquen la existencia de una política corporativa que explique este patrón espacial, y más bien cabe pensar que la coincidencia del inicio de la expansión masiva

\footnotetext{
208 Entrevista a Horacio Astoul Bonorino. 13-01-2012.

${ }^{209}$ Los datos pertenecen al libro de Actas de la inmobiliaria Vinelli. Archivo de la compañía.
} 
en la zona, junto al momento de máximo crecimiento de la empresa fueron el marco propicio para este comportamiento. Al respecto, se ha señalado que no es posible apreciar que las empresas relacionadas al mercado inmobiliario operaran para un determinado sector de la demanda, los pocos datos con los que se cuenta insinúan que en la época de mayores ventas no se efectuó una selección de la demanda, como sí se verificaría en años posteriores, a partir de mediados de la década del cincuenta. Se desconoce, asimismo, la existencia de actuaciones diferenciales por áreas: las ofertas se realizaban en forma discontinua, siguiendo las pautas dadas por la producción de lotes. ${ }^{210}$ En todo caso, la actuación preferencial de una empresa en un determinado sector respondía a un mecanismo que bien podría denominarse de "selección espontánea". Astoul Bonorino concentró la mayor parte de su actividad en el sector Oeste -en donde se encontraba su residencia familiar-, seguramente, a causa de la red de contactos amplia que le garantizaba la realización de algún proyecto exitoso y que, junto a su condición de vecino, contribuía a generar la clientela que proveía los terrenos para lotear.

En todo caso, lo que sí han indicado las propias compañías rematadoras es el reconocimiento de diferentes sectores de la demanda y el modo de actuar en consecuencia. Un famoso rematador cuenta que existían dos puntos de vista que podían condicionar el anteproyecto de un loteo: el primero de ellos estribaba en dirigir la subdivisión con la finalidad de lograr de ella el mayor número de lotes posible, "respetando, naturalmente, las exigencias que sobre las medidas mínimas de los frentes y superficie establecen las ordenanzas respectivas", el otro, prescindía de este minucioso aprovechamiento de la superficie, para tener en cuenta, principalmente, las preferencias del público interesado con respecto a las medidas de los lotes. El primer punto de vista prevalecía por lo general en los loteos de terrenos ubicados en zonas urbanas y suburbanas, con destino a vivienda permanente, mientras que el segundo se aplicaba casi siempre a loteos de predios en lugares residenciales o de fin de semana, semi-rurales. ${ }^{211}$ De manera que, si bien no existió una especialización de los agentes productores de lotes en relación a los diferentes sectores de la demanda, lentamente se fueron instaurando, dentro de una misma empresa, diferentes tipos de ofertas en tanto

\footnotetext{
${ }^{210}$ Nora Clichevsky, El mercado de tierras en el área de expansión de Buenos Aires. Op.cit. p. 86

211 Luis Guaraglia, Manual del rematador, op.cit. p. 298.
} 
pretendían cubrir las necesidades de diferentes sectores de la demanda. De la sagacidad del loteador para promover el negocio correcto, en el lugar, y para el consumidor correcto dependía en gran parte el éxito que pudiera alcanzar el emprendimiento.

Por su parte, Ricardo Vinelli, nieto del fundador de la Inmobiliaria Vinelli, resume fácilmente la manera en que se iniciaban los loteos "venía el dueño de una quinta, o el que tenía algunas hectáreas a ver qué podíamos hacer. Si las tierras estaban más o menos bien ubicadas le proponíamos la subdivisión en lotes para la venta: un equipo de ingenieros trazaba las calles, se hacía la subdivisión de las manzanas y los lotes y ya estaba. (...) solamente se invertía en la apertura de las calles y después, de a poquito se armaba la sociedad de fomento y se pedía la luz, el agua, las cloacas. Todo se hacía con el esfuerzo de la gente." ${ }^{212}$ Aparte de esto, la firma no intervenía en la construcción de infraestructura, de obras, ni de viviendas para los loteos, asumiendo riesgos comerciales mínimos en las operaciones que conducía. Las grandes inmobiliarias tenían más o menos aceitado el mecanismo para la presentación de planos y concesión de permisos. Era común que la propia inmobiliaria se presentara ante los

\footnotetext{
212 Entrevista a Ricardo Vinelli. 02-11-2010.
}

Esta operación entre el dueño de las tierras y el rematador se realizaba a través de lo que se conocía como un "proyecto de venta", un estudio económico-financiero del negocio que el rematador debía confeccionar y entregar al propietario del loteo. Allí se condensaba el informe de tasación, la forma de venta aconsejable de acuerdo a la situación del mercado, y las condiciones en que el rematador tomaría el negocio. Era también una propuesta que el rematador hacía al propietario, debiendo ser clara en todos sus términos ya que tenía la finalidad de persuadir al propietario del bien sobre la conveniencia de vender en esos términos. Ver, Luis Guaraglia, Manual del Rematador.op.cit. p. 303

En cuanto al rol fundamental que adquirían los primeros vecinos, resulta ilustrativo ver en las actas de los Concejos Deliberantes Municipales los recurrentes pedidos de reconocimiento oficial para las Sociedades de Fomento que se formaban en los barrios recién loteados, al igual que las reiteradas demandas de los vecinos y las asociaciones para que se los autorizara a contratar de manera particular la pavimentación de las calles frente a sus propiedades. Por ejemplo, la Sociedad de Fomento "Barrio Parque San Antonio" solicita reconocimiento oficial el 31 de enero de 1946, quedando aprobado en el Expediente n ${ }^{\text {o } 3729-8-53, ~ M u n i c i p a l i d a d ~ d e ~ M o r o ́ n ; ~ l a ~ C o m i s i o ́ n ~ d e ~ F o m e n t o ~ H u r l i n g h a m ~ s o l i c i t a ~}$ permiso para celebrar contrato directo con empresas particulares para adoquinado de varias calles de la localidad. Expediente $n^{\circ}$ 740, 12-12-1929, Municipalidad de Morón; Juan Mayoraz y propietarios del Barrio Parque Castelar solicitan revisión del Contrato de Pavimentación del Barrio Parque Castelar, a firmarse con la empresa Alejandro A. Barberis para la realización de las obras. Expediente n⿳ 740, 12-121929, Municipalidad de Morón 
organismos correspondientes y tramitara, en representación de los "señores dueños", la aprobación del plano de subdivisión de las tierras, trazado y apertura de calles. ${ }^{213}$ “ (...) todo era sencillo, sin trabas burocráticas, señaló Rodolfo Vinelli. Los planos se aprobaban en quince días. Abríamos las calles, las abovedábamos, colocábamos las alcantarillas y rápidamente hacíamos el remate". ${ }^{214}$

Diferentes fuentes (Vinelli, Luis Guaraglia y Nora Clichevsky) coinciden en señalar que hasta la década del cincuenta el precio de producción de tierra urbana era bajo, fundamentalmente, por la estabilidad del mercado y por las pocas exigencias que ponía el Estado, comparado con lo que sucedería en años posteriores. ${ }^{215}$ Antes de la inflación de 1945, era buen negocio comprar en bloque en uno, para vender en tres, subdividido el terreno en lotes, a pagar en 100 mensualidades sin interés. Con posterioridad a esta fecha, los productores de lotes, dueños de la tierra, inversores y rematadores buscaron obtener mayores ganancias para paliar las posibles fluctuaciones de la moneda. Pero, por sobre todo, a partir de la década del cincuenta, con la legislación sobre la venta de tierras en mensualidades (ley 14.005/50) comenzaron lentamente a establecerse diversas limitaciones que redundaron en un encarecimiento de los costos de producción del suelo urbano. ${ }^{216}$

A pesar de que excede nuestro período de estudio, hay que destacar que, entre otras cuestiones, hasta la década de 1960, a pesar de las acciones continuas que muchas

213 Partido Seis de Septiembre, Ordenanza n 669, 11 de Junio de 1937. "El Concejo Deliberante del partido de Seis de Septiembre ha sancionado la ordenanza $n^{\circ}$ 669, aprobando el plano de subdivisión de tierras, trazado y apertura de calles en la localidad de Ituzaingo, presentado por los Sres. Astoul Bonorino \& Cía, en representación de la sucesión de Antonia Mandia de García.

${ }^{214}$ Rodolfo Vinelli, “Aquellos loteos que hicieron historia”, en La Nación, 7/06/1997. Sección countries, p. 5.

215 En la segunda parte de este capítulo se analizarán las normativas que afectaban a la conversión de tierra rural en tierra urbana y a las subdivisiones de tierra.

${ }^{216}$ En el caso de la Provincia de Buenos Aires, para los lotes vendidos a plazos, la ley 14.564 de 1937, estableció la realización de boletos de compra-venta inscriptos en el "Registro de Promesas de Ventas a Plazos", para lo cual se requería certificado de dominio como si fuera una escrituración. En 1950 se sancionó la ley nacional 15.005, estipulando la inscripción preventiva de las "promesas de venta".

Si bien estos procedimientos otorgaron más garantías al comprador, también le ocasionaron más gastos, exigieron a los rematadores una organización especial, más complicada y onerosa que redundó en un traslado de esos costos al valor de la tierra. 
empresas realizaban en el área metropolitana, no contaban con sucursales en los pueblos o cabeceras de partidos; a excepción de aquellas compañías más pequeñas que sólo actuaban en el GBA o de aquellas otras que habían surgido en la periferia y luego se expandieron a la Capital. Situación que se modificaría a partir de esos años por las altas tasas municipales que se comenzarían a cobrar para los agentes no localizados en ellas. ${ }^{217}$ Por último, en diciembre de 1968 el gobierno de la Provincia de Buenos Aires dictó el decreto $\mathrm{n}^{\mathrm{o}}$ 14.381/68 exigiendo la incorporación de infraestructura de servicios básicos (desagües pluviales, energía eléctrica, pavimentos y red de agua potable) en las subdivisiones a realizarse. Esta última ley marcó el fin de los loteos económicos en la periferia.

\title{
4.2. El corpus legislativo, los funcionarios y los organismos públicos
}

\begin{abstract}
"Que hasta la fecha no existe, Plan Regulador urbano y rural de conjunto que guíe el hipertrófico crecimiento de dicho conglomerado urbano (el Gran Buenos Aires) por lo que las condiciones del uso de la tierra son cada día más caóticas, creando serios problemas sociales, higiénicos, económicos y estéticos.
\end{abstract}

Que la actual legislación y sus disposiciones reglamentarias son inadecuadas, total 0 parcialmente, para evitar la desenfrenada especulación negativa con los valores de la tierra y para promover el encauzamiento de la iniciativa privada en un desarrollo positivo dentro de las normas que conduzcan a la creación de nuevos núcleos urbanos conforme al Plan o al remodelamiento de distritos urbanos actualmente deteriorados."

(Decreto $\mathrm{n}^{\mathrm{o}} 70 / 8$ - Enero 1948, dictado por el Poder Ejecutivo Provincial creando la Comisión Asesora del Gran Buenos Aires)

\footnotetext{
${ }^{217}$ Nora Clichevsky, El mercado de tierras en el área de expansión de Buenos Aires. P. 49, 86.
} 
Contemporáneamente $-\mathrm{y}$, en buena mediada, como consecuencia- a la sumatoria de operaciones particulares que hemos ido describiendo, las áreas de expansión asumían una dimensión cada vez más compleja. De la necesidad de organizar una entidad legal que permitiera coordinar acciones entre los distintos Municipios, surgió el GBA -que quedó oficialmente definido a partir del decreto $n^{\circ} 70$, dictado el 8 de enero de 1948-, entendiendo que, además de conformar entidades en sí mismas, dichas reparticiones integraban un conjunto más amplio en su calidad de áreas periféricas a la Capital. En cierta medida, la formación de una Comisión Asesora del Gran Buenos Aires, mediante ese mismo decreto, puso en evidencia una única cuestión: la creciente -y tardíapreocupación por el crecimiento desordenado que tomaba el conglomerado.

El principal objetivo que se fijó para la Comisión Asesora fue la redacción de un informe que examinara la situación del área en relación al estudio del uso de la tierra y que propusiera medidas permanentes y provisorias, a corto y largo plazo, "a fin de encarar las soluciones más convenientes, teniendo en cuenta los hechos existentes derivados de la ocupación y el uso de la tierra". Para su funcionamiento quedaron designados, el funcionario Carlos Marino, director de Geodesia, en representación del Ministerio de Obras Públicas y los señores, arquitecto José Pastor y el ingeniero civil José Bonilla, en carácter de asesores expertos en planeamiento. A su vez, se preveía la actuación de una junta consultiva integrada por representantes de los distintos Ministerios y de los Comisionados Municipales de las Comunas involucradas en el Gran Buenos Aires, con el fin de suministrar datos e informes que contribuyeran a su mejor desempeño.

De esta comisión surgieron algunas críticas principales en relación al estado del crecimiento del GBA: 1-"la falta de política que ha permitido la formación de estos aglomerados hipertróficos que se dañan a sí mismos y al país entero"; y 2- "el juego de la especulación que con el pretexto de facilitar "tierra barata" para la "familia obrera" ha producido el fenómeno de dispersión edificatoria que se aprecia en todo el GBA." 218

Tomando este hecho como punto de llegada se buscan articular tres planos o niveles de análisis presentes en los procesos de formación del territorio dirigidos desde

\footnotetext{
218 José María Pastor y José Bonilla, Estudio sobre el uso de la tierra, Editado por el Instituto de Planeamiento Regional y Urbano, Buenos Aires, 1958. p.119
} 
las lógicas estatales : 1-el específico, referido a la generación de cierta clase de normativa y su puesta en práctica, 2- el relacionado a las repercusiones socio-culturales de las ideas urbanísticas (qué ideas en relación a la expansión y el territorio subyacen en dichas normativas) y 3- el que estipula correlaciones entre las ideas sobre la expansión y su forma concreta de materializarse. El análisis del entrelazamiento de estos tres niveles nos permitirá indagar las posibles tensiones o quiebres entre las esferas discursiva, propositiva y de la propia gestión.

Para analizar estas problemáticas, las páginas que siguen se centran en las memorias de Departamento Topográfico de la Provincia de Buenos Aires, en la formulación de la Ley de Formación de Pueblos y Ejidos de 1913, en sus sucesivas reglamentaciones y en las memorias de la Comisión Asesora del GBA, focalizando, en primer lugar, en el discurso técnico y en el análisis de la matriz intelectual subyacente en la legislación a los efectos de reconocer las tensiones que pudieran generarse al entrar en contacto con la realidad a partir de la cual se estaba llevando a cabo la expansión. En segundo lugar, analizaremos, antes que los propios contenidos, las propuestas de gestión que se establecieron y las tensiones que se generaron entre los ámbitos provincial y municipal a partir de la coexistencia de políticas no del todo coordinadas.

\section{2.a Normativas, reglamentos y códigos}

Habitualmente, la bibliografía soslaya la normativa y los códigos como objeto de estudio de la historia urbana. Como se vio anteriormente, la argumentación corriente atribuye un valor superlativo a las modalidades de producir y concebir el espacio por parte de los actores particulares, relativizando el impacto de las ópticas gestadas desde los cuerpos técnicos y la administración pública.

Como se demostrará también en este capítulo, en lo referente a la gestión, las formas de "hacer ciudad" instaladas desde la normativa y las prácticas instauradas desde la administración central van "colándose en lo cotidiano" hasta instalarse en un plano amplio de acción. En relación al contenido, creemos que la promulgación de cierta legislación y su normativa pueden ser interpretadas como la formalización, en cada caso y en cada momento histórico del diagnóstico que se forja en relación a los 
problemas urbano-territoriales y de una imagen del territorio que se desea ver realizada. Sobre esta imagen trabajaremos en este apartado. Para ello, creemos que es necesario remontarse al siglo XIX, momento en el que se inicia una tradición reguladora de fuerte arraigo en nuestro país y simultáneamente empiezan a fijarse las primeras normativas que se cargan con esta impronta. En un segundo momento veremos que, más allá de su grado de cumplimiento, una vez que ciertas ideas son trasladadas al papel son tomadas como estándar y reproducidas a través de cuerpos técnicos, incidiendo de hecho en la configuración del territorio.

De aquí que proponemos como hipótesis de trabajo que las tensiones generadas en la configuración del GBA, obedecieron, entre otras cuestiones, algunas de las cuales serán tratadas más adelante, no a la intrascendencia de la normativa, sino por el contrario, a su capacidad de sostenerse a través del tiempo dificultando la adaptación a nuevos modelos de la expansión.

El discurso técnico y el análisis de la matriz intelectual subyacente en la legislación. La herencia del siglo XIX

De manera paralela a la creación de los Departamentos de Ingenieros y Arquitectos, de Ingenieros Hidráulicos y el Departamento Topográfico, en la tercera década del siglo XIX, se empezaban a delinear los trazos que marcarían el desarrollo territorial de Buenos Aires hasta bien entrado el siglo XX. Entre ellos, todavía podían reconocerse los lineamientos del paradigma notarial, basado en la regularidad legal que se había instalado desde el siglo XVIII, cuando las irregularidades morfológicas y dimensionales de Buenos Aires fueron motivo de preocupación y acción de las autoridades. Para este período los instrumentos de gestión usuales, tanto para el reparto de tierras como para los controles posteriores, si bien podían incluir operaciones técnicas de medición y verificación, desembocaban indefectiblemente en la producción de documentos notariales: la figura central de la gestión de gobierno es el escribano, que produce los textos que afirman jurídicamente los títulos y los derechos, en un tipo de práctica que se 
apoyó sobre la geometría elemental de la norma urbanística, especialmente, en la figura del cuadrado y en la que el recurso gráfico estaba ausente. ${ }^{219}$

Aunque con variantes a lo largo del tiempo, nunca se renunció a la idea de orden clásico que se difundió con el proyecto de modernización Rivadaviano y que de manera creciente contribuyó a definir el perfil de un Estado centralizado y de una burocracia técnica cuya actuación se reconoce en el perfil de los pueblos de campaña dentro de la tradición regularizadora que señalamos.

Precisamente, desde fines del período borbónico, pero más notablemente a partir de la experiencia del Gobierno Provincial de Buenos Aires (1821-1825), así como durante la breve presidencia de Bernardino Rivadavia (1826-1827) y a lo largo de todo el siglo XIX, el territorio anexo a la ciudad de Buenos Aires, al igual que la propia ciudad, se vieron transformados por una creciente intervención por parte del poder central. Desde la década de 1820 pudo observarse una acción constante dedicada a ampliar y especializar los mecanismos de gestión de la ciudad: se creó el Departamento de Ingenieros Arquitectos, el Departamento de Ingenieros Hidráulicos, y el Departamento Topográfico, el cual inauguró una larga tradición de pragmatismo científico, cuyas consecuencias fueron fundamentales para el desarrollo posterior de la teoría y la praxis urbana en Argentina. Esta práctica intervensionista, aunque con algunas interrupciones, iría creciendo a lo largo del siglo XIX conjuntamente a la conformación de un Estado Nacional, hasta convertirse en una práctica tradicional que los gobiernos adoptarían como recurso de penetración en la sociedad civil. A pesar de las marchas y contramarchas a las que se asistió en la primera mitad del siglo XIX, el alcance más amplio al que conduciría la creación del Departamento Topográfico y su consolidación, reside en la serie de reglamentaciones y mecanismos que a partir de este hecho comenzarían a desarrollarse y que, aunque con modificaciones, persistirían como base del marco legal sobre el que se ejecutaría gran parte de la expansión moderna.

\footnotetext{
219 Graciela Favelukes, "Medios técnicos y construcción de la ciudad", en Registros $n^{\circ} 5$, Facultad de Arquitectura, Urbanismo y Diseño, Universidad Nacional de Mar del Plata, 2008. pp.87-104; "Figuras y paradigmas. Las formas de Buenos Aires (1740-1870)", en Anales del Instituto de Arte Americano e Investigaciones Estéticas “Mario J. Buschiazzo”, Buenos Aires en Proyectos, Universidad de Buenos Aires, Facultad de Arquitectura y Urbanismo, año 2011. pp 11-26
} 
Una vez instituido, entonces, el Departamento Topográfico, en $1853^{220}$, se le encargó la determinación de los ejidos de los pueblos de campaña. Esta resolución afectó a los poblados existentes y a aquellos que estaban estructurándose contemporáneamente; muchos de los cuales, desde inicios del siglo XX, darían lugar a la expansión quedando delimitados dentro del área que analizamos, definida en 1948 como Área Metropolitana de Buenos Aires. ${ }^{221}$

Para la puesta en práctica de esta resolución, se establecía que en cada pueblo o jurisdicción que estuviera a cargo de un juez de paz, debía funcionar una Comisión de Solares. Más allá de los lineamientos morfológicos que esta comisión debía establecer, aquí nos interesa destacar los procedimientos para su puesta en práctica. En principio, una comisión local procedía a delinear el ejido, de acuerdo a las normas generales dictadas por el Departamento Topográfico; posteriormente, un comisionado se encargaba de realizar los planos del ejido y pueblo con su correspondiente proyecto de traza que, finalmente, serían remitidos al Departamento Topográfico para su examen y elevación al Superior Gobierno para su aprobación. ${ }^{222}$ Esta forma de proceder se mantuvo desde la formación del Departamento hasta 1867. En este momento, una nueva reglamentación dictada por el Departamento Topográfico expresa la conveniencia de establecer un Agrimensor o Ingeniero Municipal, para practicar en debida forma la delineación de sus pueblos, calles, caminos, medición de los terrenos públicos de los ejidos mandados vender, así como también para los reconocimientos, nivelaciones y demás trabajos que requiriesen conocimientos facultativos. ${ }^{223}$ De manera

220 La primera creación del Departamento Topográfico de la Provincia de Buenos Aires data de 1826. Posteriormente, su funcionamiento estuvo interrumpido durante el gobierno de Juan Manuel de Rosas.

${ }^{221}$ Para el período 1856-1876, según las investigaciones de Cásar Vapñarsky estos eran: Barracas al Sud (actualmente Avellaneda); San José de Flores y Belgrano (que en ese momento todavía no formaban parte de la ciudad de Buenos Aires); San Martín; San Justo; Ramos Mejía; La Paz (nombre primitivo de Lomas de Zamora); Quilmes; San Isidro, Las Conchas, San Fernando, Morón; Moreno; Merlo y Gral. Rodríguez.

222 Citado por Francisco Esteban en El Departamento Topográfico de la Provincia de Buenos Aires (actual Dirección de Geodesía). Su creación y desarrollo. Antecedentes y documentos demostrativos de la importancia de sus funciones. Breve reseña para su historia. Buenos Aires, 1962. p.108.

223 Citado por Francisco Esteban en El Departamento Topográfico de la Provincia de Buenos Aires... op.cit. p. 50. 
tal que, quince años después de que el mismo Departamento Topográfico estableciera la actuación de la Comisión de Solares e instaurara el desempeño de un comisionado municipal, se vuelve a expresar la necesidad de establecer un Ingeniero Municipal que desarrolle actividades similares, haciendo evidente que, en la práctica, continuaban presentándose los mismos problemas de falta de ordenamiento y de delineación de los trazados definitivos que se habían registrado en la década de 1850.

Todavía, en el año 1873 encontramos reiteradas quejas, formuladas desde el Departamento Topográfico y desde diversas Municipalidades sobre la incumbencia de cada uno de estos agentes en las delineaciones de lotes y subdivisiones.

"para el desempeño de las delineaciones el procedimiento que se observa actualmente es el siguiente; ante el Departamento Topográfico concurren los interesados pidiendo la delineación que solicitan, el Departamento da la delineación por medio de sus empleados, ya sea aplicando las delineaciones vigentes, ya acordando y trazando sobre sus planos las líneas de delineación. Si esas líneas no son aceptadas por el propietario, acude ante la Municipalidad como por vía de apelación y lo que ésta resuelve es lo que se verifica en definitiva." 224

Esta queja, realizada por el Departamento Topográfico, da cuenta de dos cuestiones: por un lado nos habla de una puja de poderes y de la tensión entre órganos provinciales y municipales. Donde se deja entrever, algo que abordaremos más en detalle para la primera mitad del siglo XX, que es la actuación de las municipalidades "por fuera de la reglamentación", más propensas a hacer excepciones y, finalmente, decidiendo en los hechos muchos de los temas relacionados a la expansión. Como señala Oscar Ozlack, una de las principales trabas a las que se enfrentó el Estado Nacional, y en este caso particular el Estado Provincial, a la hora de organizar una estructura centralizada fue el

También puede verse, Fernando Williams, "La formación de los técnicos y profesionales: agrimensores, geógrafos e ingenieros", en Jornadas Interdisciplinarias: formas y representaciones del territorio y la ciudad. Rosario, Agosto del 2000.

${ }^{224}$ Francisco Esteban, El Departamento Topográfico de la Provincia de Buenos Aires...op.cit. p 167 
enfrentamiento con intereses regionales, con tradiciones de administración localista y formas caudillistas de ejercicio del poder. ${ }^{225}$

Por otro lado, la nota antes citada, se inscribe en el pedido del Departamento de cesar sus funciones en el ámbito de las delineaciones; avalando ese pedido al exponer las consecuencias que surgen de las irregularidades en los procedimientos y que terminan produciendo situaciones de confusión. Veremos más adelante que muchas de las situaciones de superposición se trasladarán hasta el siglo $\mathrm{XX}$, al igual que muchos de los pleitos irresueltos sobre las incumbencias. Estas continuarían, incluso después de que en 1875 el Departamento Topográfico fuera suprimido y reemplazado por la División de Geodesia del Departamento de Ingenieros y luego, Dirección de Geodesia dependiente del Ministerio de Obras Públicas de la Provincia de Buenos Aires. ${ }^{226}$

En paralelo a la formación de los órganos e instituciones encargados de establecer, reglamentar y producir las normas de ordenamiento del territorio bonaerense se empezaba a articular una noción que sintetiza, tal vez mejor que ninguna otra, la naturaleza de la transformación que comenzaba a instalarse. Nos referimos a la noción de "regularidad". Como bien han estudiado Graciela Favelukes y Fernando Aliata, este término, no tuvo un único significado a lo largo de la historia y, en principio, no tuvo un alcance que comprendiera solamente al campo de la arquitectura, la ingeniería o la organización urbana. La regularidad, como oposición al desorden o la improvisación era una expresión de uso común en la jerga política y militar de la época. En el ámbito local, la regularidad se presentaba en los discursos militares, literarios, técnicos o científicos como una especie de resultante formal de la "civilización". Si aquello que luego Sarmiento identificaría como "barbarie" muestra como característica fundamental el desorden y el desenfreno, la regularidad sería su oposición más radical. ${ }^{227}$ Así es que, una vez instituido el Departamento Topográfico, varias de estas nociones trataron de llevarse a la práctica. En la traza de los pueblos de campaña las principales

\footnotetext{
225 Oscar Oszlak, La formación del Estado argentino. Op.cit. p. 28.

226 Fernando Aliata, "Departamento Topográfico", en Jorge Liernur y Fernando Aliata, (dirs.) Diccionario de Arquitectura en la Argentina, Clarín, Buenos Aires, 2004.

227 Graciela Favelukes, "Figuras y paradigmas. Las formas de Buenos Aires (1740-1870)".op.cit; Fernando Aliata, La ciudad regular. Op.cit. p 57
} 
reglamentaciones que debían observarse se resumieron a través de dos conceptos: centralidad y orden. ${ }^{228}$

Ya en el siglo XX, el 19 de junio de 1913 se dictaría la ley provincial no 3487 , de Creación de Nuevos Centros de Población y Ampliación de Ejidos, que logró producir un marco más general para las nuevas delineaciones. Con unas pocas reglamentaciones se establecían los procedimientos a seguir para la presentación y aprobación de los trazados y algunos requisitos en relación a cuestiones morfológicas: se establecían anchos mínimos para calles y avenidas, de $15 \mathrm{mts}$ y $20 \mathrm{mts}$ respectivamente; se establecían los porcentajes de superficie que los propietarios debían ceder para uso público y, en cambio, resultaban ausentes las referencias al posible destino y uso de las tierras.

Dentro de este marco amplio se trazaron los primeros barrios que analizamos, hasta que el 26 de octubre de 1927 la reglamentación de la ley estableció, de modo más detallado, la forma de procedimiento que debían observar los propietarios para la fundación o ampliación de pueblos. Se imponían nuevas cuestiones en relación al trazado, medidas mínimas del loteo, orientación de calles y avenidas. Y seguía sin reglamentarse una división de usos del suelo, sólo se reconocían los diferentes tipos de parcelamiento que ya habían sido definidos en la "Ley que divide los ejidos de los pueblos de Campaña”, de 1870, para la planta urbana (o solares), para quintas y, finalmente, chacras.

${ }^{228}$ Estas nociones se expresan a través de ciertos artículos, a saber:

(art. 5) "que el pueblo debe quedar en el centro del ejido, para lo que se medirá una legua a cada viento haciendo centro en su plaza.

(art 6) Si la localidad del pueblo no diese lugar a dejarlo en el centro del ejido por estar a la orilla de algún río o arroyo de consideración o a la de alguna gran laguna, en este caso el ejido deberá extenderse en un solo sentido, procurando siempre la centralidad posible."

(art. 9) Teniendo ya los planos generales se proyectará sobre ellos la traza que mejor convenga tanto en calles, plazas y caminos, como en la disposición de solares, quintas y chacras.

(art. 11) En todo deberá observarse un orden regular, no pudiendo, en ningún caso disminuir el ancho de las calles establecido.

Citado por Francisco Esteban, El Departamento Topográfico de la Provincia de Buenos Aires (actual dirección de Geodesia) Su creación y desarrollo. Antecedentes y documentos demostrativos de la importancia de sus funciones. Breve reseña para su historia. Buenos Aires, 1962. 
En cada uno de estos casos se establecía que cada manzana debía estar limitada por calles en todos sus costados.

a- Dentro de la planta urbana las manzanas no podían superar los $150 \mathrm{mts}$ de frente (medida que refería a las 150 varas que debía medir la cuadra), y los solares que la conformaban debían poseer al menos 10mts de frente -recién en 1949, cuando se reglamenten legalmente los barrios parque, los lotes que lo compongan deberán presentar frentes mínimos de $20 \mathrm{mts}$.

b- En la zona de quintas, que debe trazarse a continuación de las manzanas:

1-“cada quinta debe estar rodeada de calles en relación con el trazado del pueblo, y su superficie no debe superar las 11 ha."

2- "las quintas tendrán las dimensiones que correspondan para contener varias manzanas del pueblo, de manera que en un futuro se pueda realizar la división en manzanas.” (En relación es este punto, la legislación anterior establecía que las quintas no podían superar las cuatro cuadras cuadradas)

3- "es facultativo dividir las quintas en fracciones de quintas; donde cada fracción debe tener frente a la vía pública."

c- Finalmente para las chacras se establecen iguales condiciones que para las quintas, es decir, que: "deben contener quintas regulares capaces de subdivisión y trazado de calles" y "pueden fraccionarse, teniendo cada fracción frente a la vía pública."

Además del carácter general que tiene la ley y su reglamentación, se observa particularmente que en relación al parcelamiento, se aborda el problema pensando desde la lógica urbana y más específicamente desde la tradición regularizadora, que como ya demostramos, se instala de la mano del paradigma notarial, en el siglo XVIII y se mantiene -con escasos cambios- como base para los trazados a lo largo de todo el siglo XIX. Sin embargo, la figura tradicional de centro y áreas periféricas que esta tradición instala, y que sí podría pensarse para la creación de pueblos en el interior de la provincia, o que sirvió al trazado de muchos de los pueblos de campaña (alrededor de los cuales en el período que abordamos comienza a experimentarse la expansión), es difícilmente aplicable al fenómeno que está teniendo lugar en el área metropolitana, donde -como demostramos al abordar la materialización de la expansión- nos encontramos, por un lado, frente a la lógica del crecimiento concéntrico con su núcleo en la Capital y que expande sus brazos sobre el área metropolitana y por otra lado, superponiéndose a estos brazos, se reconoce un panorama de tramas, en relación a los 
diversos núcleos, que se cruzan y superponen ante la falta de un trazado homogeneizador que, al menos en la gran escala, permita entender las intervenciones como parte de un todo coherente.

Ante este panorama complejo, tanto la legislación original como sus sucesivas regulaciones, ofrecen una imagen simplificadora, que da cuenta de la imposibilidad de pensar la complejidad y múltiples dimensiones de la expansión moderna. ${ }^{229}$

A pesar de que reconocemos algunos de los planteos de Adrián Gorelik, en donde expuso que la opinión negativa sobre la cuadrícula ya era completamente hegemónica hacia fines del siglo XIX, incluso entre los técnicos de los equipos municipales. En nuestro análisis se revela que, si bien dentro de la "biblioteca de saberes" de urbanistas y técnicos, la aplicación de la grilla como único elemento para el trazado de nuevas áreas estaba ampliamente superado, en la realidad, la pervivencia de códigos y reglamentaciones que, como demostramos, se seguían rigiendo por el paradigma de la regularidad legal (dentro del cual no se admitían ni los trazados pintorescos, ni otras estructuras urbanas que no estuvieran basadas en el orden ortogonal), dificultaba la puesta en práctica de nuevas figuras y el quiebre con la tradición regularizadora de antaño. Lo que persiste a través de las reglamentaciones son una serie de supuestos sobre los que no se discute: continuidad, regularidad, homogeneidad, integración.

La aplicación de los códigos, reglamentaciones y su adecuación a las problemáticas preexistentes en la expansión

En este punto, es necesario presentar este desfase de manera concreta, y ver de qué forma se articulan los loteos con la reglamentación existente, para ello conviene retomar los casos que analizamos en los Capítulos 2 y 3 .

El primer núcleo problemático que se establece responde a lo que podríamos llamar "la extemporaneidad": entendemos que las reglamentaciones operantes han sido

\footnotetext{
${ }^{229}$ A propósito de esta imagen simplificadora Fernando Aliata habló de una visión predominante durante el siglo XIX, de aplicar figuras simples para organizar un espacio determinado, donde se busca la continuidad y repetición de elementos a fin de que el orden a establecer sea lo más sencillo posible. Ver, Fernando Aliata, La ciudad regular. Op.cit. p. 58.
} 
pensadas para aplicarse en operaciones de grandes dimensiones. Según indica el decreto reglamentario de la ley $\mathrm{n}^{\mathrm{o}} 3487$, de octubre de 1927, se propone para la organización del trazado la subdivisión en planta urbana, quintas y chacras, pensando en una futura expansión que hablaría de un momento en que se establecen núcleos poblacionales incipientes, un momento fundacional, en el que el terreno está libre y se puede "dibujar" el trazado al igual que si fuera un plano en una hoja blanca.

En relación a esto, dijimos que la mayor parte de los pueblos que estructuran el crecimiento del GBA ya existían -aunque, muchas veces en la forma precaria de una estación y algunas quintas- para la década de 1910- y el crecimiento que comienza a experimentarse lo hace superponiendo pequeños trazados autónomos en las áreas vacantes que dejan las pocas vías existentes, generalmente, en lo que hasta ese momento se consideraba la zona periférica de quintas.

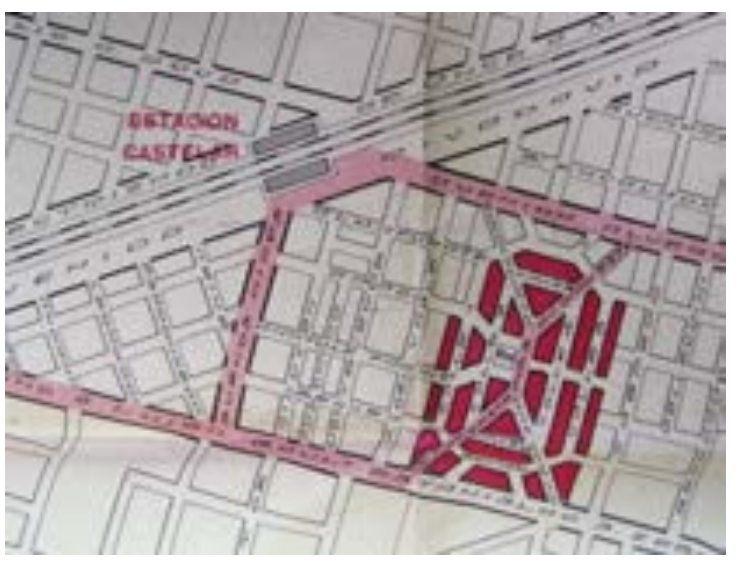

Plano de Ubicación del Barrio Parque Castelar en relación a la Estación Castelar del FCO.

Fuente: Carpeta de Remates- Partido de Morón, en Departamento de Investigación Histórica Cartográfica de la Dirección de Geodesia del Ministerio de Obras Públicas de la Provincia de Buenos Aires.

Si analizamos el caso de Castelar, que será presentado en detalle en el último capítulo de la tesis, el trazado del barrio parque de 1929 se ubica en una zona lateralizada del punto que hasta ese momento constituía el núcleo central del pueblo. Como resultado de esta incorporación, el barrio parque empieza a conformar su propia "área central” y una periferia que, rápidamente, entra en contacto con la zona de la estación del tren, núcleo que históricamente constituye el área central del poblado. En síntesis, lo que este caso nos permite demostrar es la dificultad de pensar este tipo de expansión metropolitana en términos de un área urbana y unas quintas, a la manera de la ciudad colonial. Por el contrario, el tipo de urbanización que aquí analizamos se superpone a otra expansión que ya tuvo lugar, la de los primeros pueblos de campaña y pueblos ferroviarios, presentes seguramente en el pensamiento de aquellos que redactaron la ley, matrizando un tipo de expansión que lleva la marca de los topógrafos y de la lógica 
técnica, en el momento en que se tornaba obsoleta. Se reconoce una inercia con respecto a las medidas y acciones pervivientes del siglo XIX y que en los hechos produce una tensión que es producto de desconocer la realidad sobre la que se está llevando a cabo la expansión. ${ }^{230}$

Esta situación, se puede poner en relación con una serie de proyectos que, entre fines del siglo XIX y comienzos del XX se planteaban para la Capital, en los cuales, si bien se buscaba circunscribir la ciudad construida y jerarquizar el núcleo tradicional, se trazaban una serie de diagonales y nuevas plazas en torno a las cuales podían configurarse nuevos centros de menor jerarquía. De manera que, a diferencia de lo que sucedía con la expansión suburbana, se buscaba ordenar el crecimiento de la ciudad generando asimismo nuevas oportunidades para desarrollos privados- dentro de un esquema definido a priori. ${ }^{231}$

Dentro del panorama del GBA, sólo en los núcleos que se consolidaron junto a las nuevas estaciones se puede pensar en la matriz de crecimiento ordenado que establece la ley de formación de pueblos. Pero ya dijimos que durante el siglo XX los

230 La pervivencia de acciones anteriores en relación a las medidas establecidas para el ordenamiento territorial no son una novedad. Fernanda Barcos remarca ya para el siglo XIX, que a pesar de que desde el discurso el fomento de la población y la actividad agrícola era una preocupación recurrente de las autoridades, esto no se plasmó en un marco legal coherente. Este problema surgió como producto de la supervivencia de normas y costumbres -presentes desde el período colonial- que entraban en contradicción con los intentos de construir una legislación específica, adoptada al nuevo contexto, para las tierras ejidales. Debido a esto, las leyes sobre terrenos de pan llevar reflejaban claramente la tensión entre la ley y las prácticas heredadas. Ver, Fernanda Barcos, "Los ejidos de los pueblos de campaña: ocupación y acceso a la propiedad legal en Monte, 1829-1865.”, en Mundo Agrario, vol 7, n 14, primer semestre de 2007, Centro de Estudios Histórico Rurales, Facultad de Humanidades y Ciencias de la Educación, Universidad Nacional de La Plata.

${ }^{231}$ El Proyecto para Buenos Aires de José Marcelino Lagos (1867), el Proyecto de Avenidas Diagonales del Intendente Crespo (1887), el Plan de Transformaciones de Buenos Aires de Carlos María Morales (1895) y el Plan de Extensión de la Ciudad confeccionado por Bouvard (1909), planteaban la apertura de diagonales desde un centro distribuidor que vinculara los sectores periféricos. Ver, Alicia Novick y Raúl Enrique Piccioni, "Morales, Carlos María”, en Jorge Liernur y Fernando Aliata (dirs.) Diccionario de Arquitectura en Argentina. Clarín, Buenos Aires, 2004 y “Lagos, José Marcelino”, en Jorge Liernur y Fernando Aliata (dirs.) Diccionario de Arquitectura en Argentina. Clarín, Buenos Aires, 2004 
ejemplos de este tipo fueron escasos, y que no lograron constituir áreas significativas dentro de la expansión.

Si bien, entonces, existen algunos núcleos centrales dentro de la expansión generalmente en torno a las estaciones del ferrocarril- y lo que se puede entender como sus áreas periféricas, también es cierto, -como vimos al analizar las tipologías de las urbanizaciones- que la mayor parte de los nuevos emprendimientos comprendieron áreas relativamente pequeñas, que se asentaron en los bordes de los pueblos originales o en zonas intersticiales entre un núcleo y otro.

De esto se desprende lo que denomino un tema de "prioridades". Lo que para la ley $\mathrm{n}^{\mathrm{o}}$ 3487, había constituido su segundo núcleo de preocupación, "la ampliación de ejidos", y donde, por lo tanto, se reconocía un mayor grado de indeterminación legal, por el tipo de expansión fragmentaria que atravesó el GBA, terminó afectando a la mayor parte de los loteos, siendo que gran parte de estos no conformaron nuevos centros de población, sino que quedaron enmarcados como ampliación de ejido o dentro de lo que la legislación determinaba como zona de quintas o chacras. Concretamente, esto implicó, entre otras cosas, la posibilidad de eximirse de ceder tierras para reserva urbana (Art. 13. en las zonas de ampliación, el Poder Ejecutivo podrá eximir al propietario de la obligación de dejar alguna o algunas de las reservas indicadas en el Artículo 14 de esta ley).

Los trámites realizados ante la Dirección de Geodesia del MOP para la aprobación del trazado del Barrio del Golf Ituzaingo (San Antonio de Padua, 1931) nos proveen información detallada para ilustrar esta situación. En el año 1931 el ingeniero Armando Frhener, autorizado por la Compañía de Tierras del Oeste solicita ante el Sr. Director de Geodesia y Catastro la aprobación del plano del "Barrio del Golf":

"Se solicita en esta actuación autorización para ampliar el pueblo de San Antonio de Padua, creando el llamado "Barrio del Golf" en terrenos de la mencionada Compañía, ubicados en el partido de Merlo.

Se trata de regularizar hechos existentes, ya que varios propietarios han comprado lotes, edificado y plantado árboles de buena fe y a fin de no dañar sus intereses y allanar en lo posible las dificultades de la Compañía, por cuya razón pido se contemple lo relacionado con el trazado de las calles que no tienen el ancho reglamentario. Los lotes del nuevo proyecto tienen todos 
frente mínimo de 10mts con excepción de unos pocos que no se pudieron modificar por estar vendidos.

Se agrega copia del proyecto en tela y dos copias (...)

Confío que el Sr. Director quiera considerar la necesidad de regularizar la actual situación en el sentido de allanar en lo posible las dificultades y contribuir a la buena fe de la Compañía de Tierras con una resolución favorable que venga a sanear un estado de cosas que puede ser causa de confusiones y pleitos (...)

Se considera también que no le corresponde a la Compañía de Tierras la cesión de Reservas para uso Público considerando la pequeña cantidad de terreno propiedad de la misma y el hecho de que el pueblo de San Antonio ya posee escuela, iglesia y comisaría en las inmediaciones de los terrenos en cuestión. Además cuando la Municipalidad aprobó los planos presentados por el Sr. Benavides no obligó a Diaz Valdéz (a la sazón propietario de las tierras) a ceder las reservas antes mencionadas." 232

La aprobación definitiva del barrio llegó en 1936, allí se aceptó el plano presentado a pesar del incumplimiento en relación a las medidas de algunos lotes y calles y se exigió escriturar a favor del fisco una parte de las reservas correspondientes. ${ }^{233}$

La resolución final del caso muestra la voluntad de hacer respetar ciertas normas, aunque también permite esgrimir que algunas "licencias o excepciones", como la medida de los lotes o el porcentaje de reservas que se cedían al Municipio, eran admitidas como prácticas cotidianas. En este sentido, si tensionamos al máximo esta posibilidad de exención, podemos imaginar como resultado la materialización de áreas

\footnotetext{
232 Solicitud de aprobación del trazado del "Barrio del Golf”, en Copia de Mensura, Duplicado n54, Merlo, año 1931. Departamento de Investigación Histórica Cartográfica de la Dirección de Geodesia del Ministerio de Obras Públicas de la Provincia de Buenos Aires.

233 Aprobación del Trazado "Barrio del Golf", La Plata, 21 de enero de 1936. en Copia de Mensura, Duplicado n54, Merlo, año 1931. Departamento de Investigación Histórica Cartográfica de la Dirección de Geodesia del Ministerio de Obras Públicas de la Provincia de Buenos Aires.
} 
suburbanas continuas, conformadas a partir de la sumatoria de sucesivos loteos de pequeñas dimensiones, carentes, completamente, de reservas para el uso público.

Este escenario se hace presente en amplios sectores del GBA, como lo demuestran los primeros relevamientos catastrales del área en 1948, o las primeras fotografías aéreas y lo que, como veremos a continuación, denunciaron incansablemente los representantes municipales ante la Comisión Asesora del GBA.

\section{2.b Los barrios parque y el laberinto administrativo. 1913-1948}

Para analizar las tensiones que se generan en los diferentes niveles políticos, y a su vez, entre ellos y los cuerpos técnicos, nos concentraremos en analizar las formas de articulación existentes entre los distintos ámbitos y escalas del poder público: la relación Provincia-Municipio, el funcionamiento al interior de las agencias estatales, poniendo de relieve las fuertes interlocuciones entre actores estatales, societales, del mercado y de la política. Se reconoce, como señala Oszlak, como rasgo característico de los procesos de expansión del Estado, su carácter conflictivo, como consecuencia de la constitución de su aparato en arena de negociación y enfrentamiento. De ahí que sugerimos que existió un quiebre entre las propuestas teóricas y la forma en que se llevó a cabo la expansión que puede reconocerse a través de las dificultades a las que se enfrentó el Estado -a través de sus diferentes reparticiones- a la hora de regular los loteos. $^{234}$

En síntesis, esta sección propone un análisis de la dinámica institucional donde se pongan de relieve el papel de funcionarios y estructuras organizativas como determinantes de los logros resultantes. ${ }^{235}$

\footnotetext{
234 Oscar Ozlack, La formación del Estado Argentino. Op.cit

235 Ernesto Bohoslavsky y Germán Soprano delinean lo que se podría considerar un mapa historiográfico en relación a los estudios del Estado en la Argentina. En este contexto, los estudios sobre la administración pública y la organización de las instituciones del Estado están contenidos dentro de lo que los autores denominan los análisis del "Estado desde adentro". Ver, Ernesto Bohoslavsky y Germán Soprano; Un Estado con rostro humano. Funcionarios e instituciones estatales en Argentina. Op.cit.
} 
El diagnóstico

En la esfera metropolitana, los informes municipales y los debates que tuvieron lugar en las dos Reuniones de Municipios del GBA, celebradas el 8 de octubre de 1948 y el 2 de mayo de 1949, en el marco del plan en el que trabajaba la Comisión Asesora del Gran Buenos Aires, pusieron de manifiesto muchas de las cuestiones a las que de una u otra forma nos hemos referido a lo largo de la tesis. El diagnóstico que se construye en vistas de la futura reforma es más o menos común para los representantes de todos lo Municipios. Pueden resumirse en una diversidad de temas englobados, principalmente, en lo que la comisión entendía como resultado del laissez-faire operante en el área: el crecimiento "caótico y vertiginoso, impulsado por la iniciativa privada", "el avance de las subdivisiones de tierras en zonas rurales", "la forma desordenada, pegando saltos, dejando claros, que tomaba la expansión"236

Como se ve, desde aquellos agentes locales que estaban en contacto más directo con las problemáticas de la expansión se cargan las tintas sobre las resoluciones tomadas en una escala superior: "la legislación, o como ellos dicen "la falta de ella" que estaría por detrás del desarrollo caótico del GBA. Si bien hay algo de verdad en este diagnóstico, y es posible reconocer que muchos de los conflictos que se expresan en la materialización territorial provienen -como señala el decreto $\mathrm{n}^{\circ} 70$ - de la falta de un plan que se adelante a las formas de crecimiento. Sumado a ello, hay que señalar que, muchos de estos problemas obedecen a dificultades en la gestión y la puesta en práctica de la normativa, como resultado de la tensión existente entre las atribuciones que les correspondían a las autoridades provinciales y municipales. $\mathrm{Y}$ al correlato de esta tensión en la materialización del territorio, reconocible en el desfase que se produce entre el "avance modernizador" (como entienden unos) que implicaría el trazado de nuevos barrios y loteos que, sin embargo, permanecen durante años, con un mínimo nivel de ocupación $\mathrm{y}$, más tiempo aún, sin la provisión de servicios de infraestructura. $^{237}$

\footnotetext{
236 José María Pastor y José Bonilla, Estudio sobre el uso de la tierra, op.cit. p.170, 178.

${ }^{237}$ Para conocer más en profundidad la dinámica de los loteos y la incorporación de infraestructuras, ver la primera parte de este mismo capítulo.
} 
La dinámica productora de la expansión lo hace posible cuando permite la superposición en los niveles de intervención. En teoría, es el Poder Ejecutivo de la Provincia - inicialmente, a través de la Secretaría de Gobierno, previo informe de la Oficina Técnica correspondiente, y a partir de 1944 a través de la Dirección de Geodesia del M.O.P- quien tiene jurisdicción sobre la aprobación de los loteos y subdivisiones de tierras de acuerdo a condiciones exigidas en la ley no 3487 de 1913, mientras que a la municipalidad correspondiente se le concede un plazo de 15 días en los que debe verificar el cumplimiento de lo pactado ante las autoridades superiores y expedirse, acordando o no el loteo. En el plano discursivo, las municipalidades aducen la falta de medios legales y de control ante la que se encuentran, y por lo cual no tienen más remedio que aceptar la realización de los loteos aprobados por el P.E; mientras que, de hecho, se reconoce que muchos de los nuevos loteos se aprobaron mediante ordenanzas municipales sin previa consulta a los organismos provinciales.

\section{Acusaciones cruzadas}

A causa de la delimitación confusa que se establece en relación a las funciones que deben asumir las diferentes reparticiones y a la dificultad de cada una de ellas para implementarlas se formulan una cantidad de acusaciones cruzadas sobre las responsabilidades y la capacidad real de cada sector para incidir sobre el fenómeno de la expansión.

En el contexto de las reuniones de la comisión del GBA, y en medio de esta disputa, por una parte, los representantes municipales se reconocen presos de una situación en la que poseen pocas herramientas para actuar. En primer lugar esgrimen que, teniendo en cuenta, los gastos a que se ven abocados rematadores y especuladores cada vez que emprenden una de estas obras, quienes deben controlar y por el tiempo en que se tarda en llevar a cabo esos controles, muchas veces, cuando llegan al sitio se encuentran ante loteos consumados, puestos en marcha con la aprobación de Geodesia o del P.E y ante los cuales no les queda más que aceptar los trazados que ya son una 
realidad. ${ }^{238}$ Esto los expone a su vez ante una nueva problemática, siendo que, como exterioriza el representante de General San Martín,

"son los gobiernos municipales quienes ante la extensión de los fraccionamientos en lotes, deben cumplir con la provisión de luz, limpieza, etc, que generan al erario público problemas de difícil solución, sobre todo si se tiene en cuenta que esta erogación está en desproporción con el número de familias a las que favorece". 239

Ante este debate, muchos Municipios se declaran, directamente, contrarios a la aprobación de nuevos loteos en sus áreas. Al respecto, el intendente de Las Conchas, expresó,

"yo he tomado medidas drásticas; he suspendido los remates por no ajustarse los mismos a lo dispuesto en las ordenanzas municipales y por pasar por sobre las autoridades de la Municipalidad (...) yo, a los rematadores les he tenido que mandar la inspección municipal y pararlos con las bañaderas llenas de gente, con carpas... y con música., 240

Sin embargo, esta constituía una medida extrema que pocas veces pudo hacerse efectiva por la dificultad de su puesta en práctica. ¿Qué capacidad tenían las autoridades municipales para modificar una práctica cada vez más extendida? Como señaló Theda

238 Discurso del Sr. Intendente de Moreno en la Segunda Reunión de Municipios del GBA, citado por José María Pastor y José Bonilla, Estudio sobre el uso de la tierra, op.cit. p.177.

En otros casos, los remates se realizaban incluso antes de ser aprobados. En el pueblo de Almirante Brown se realizó en 1872 el loteo de 250 lotes por orden de Esteban Adrogué, dueño de las tierras. Recién un año más tarde se aprobó el loteo, una vez que una porción de las tierras ya estaban vendidas. Ver, Historia de la Provincia de Buenos Aires y formación de sus pueblos. Archivo Histórico de la Provincia de Buenos Aires. Taller de impresiones oficiales, La Plata, 1941.

239 Informe del Municipio de General San Martín entregado a la Comisión Asesora del GBA, citado por José María Pastor y José Bonilla, Estudio sobre el uso de la tierra, op.cit. pp.171-172.

240 Discurso del Sr. Intendente de Las Conchas en la Segunda Reunión de Municipios del GBA, citado por José María Pastor y José Bonilla, Estudio sobre el uso de la tierra. Op.cit. pp.177-178. 
Skocpol, la respuesta no ha de buscarse sólo desde un análisis del Estado sino en el balance entre los recursos del mismo en comparación con el resto de los actores. ${ }^{241}$ Es decir, que es necesario identificar, por un lado, quiénes encarnan al Estado en un determinado momento o lugar, pero también identificar aquellas instituciones, grupos o personas exteriores a aquel y con las que los agentes estatales generan infinidad de intercambios cotidianos capaces de determinar la concreción de ciertas políticas públicas.

En este caso, los gobiernos municipales se enfrentaban a dos tipos de trabas, por un lado, estaba siempre presente la imposibilidad de controlar la gran cantidad de loteos que tenían lugar en la periferia y por el otro, como ya se mencionó, la suspensión de un remate era una medida que, desde diferentes perspectivas, se oponía a los intereses de grupos contrapuestos: en primer lugar, iba en contra de fuertes intereses privados inmobiliarias, especuladores, dueños de la tierra-, a la vez que podía resultar sumamente antipopular, en cuanto privaba a las clases populares de obtener terrenos baratos. El representante de General Sarmiento, da cuenta de lo extendida que estaba esta vinculación entre nuevos loteos y acceso a la tierra por parte de los sectores populares, cuando en la misma Reunión de Municipios, se sintió obligado a justificar su posición antes de apoyar una medida semejante,

"la prohibición no es una medida antijurídica ni antisocial, desde el momento en que como bien se ha expresado, y es bien del conocimiento público, sobran terrenos en los fraccionamientos ya realizados como para poder absorber las demandas de la población..."242

Por último, y en la misma línea, el Sr. Luis Tenorio, representante de Lomas de Zamora, señala la dificultad de los Concejos Deliberantes locales de dictar ordenanzas

\footnotetext{
241 Th. Skocpol, "Bringing the State Back In: Strategies of Analysis in Current Research”. Op.cit.

242 Discurso del representante de General Sarmiento en la 2da Reunión de Municipios del GBA, citado por José María Pastor y José Bonilla, Estudio sobre el uso de la tierra, op.cit. p.179.
}

El ocupamiento salteado y la permanencia de tierras vacantes, asociado a una baja densidad territorial y dentro de los propios núcleos urbanizados constituye una de las características fundamentales de la configuración de la expansión en Latinoamérica. 
limitando los usos de la tierra, que corren el peligro de ser tachadas de inconstitucionales ante la falta de reglamentación al respecto que existe en la Provincia. $^{243}$ Desde esta perspectiva, tanto los funcionarios, como los gobiernos municipales se presentan como víctimas de una situación consumada, dentro de la cual les quedan pocos medios de acción.

Ahora bien, si indagamos un poco más en profundidad, lo que muestran ciertas fuentes municipales, en contraposición con lo que los mismos agentes declararon, es que muchos de los barrios y loteos que se registran en el GBA fueron aprobados mediante ordenanzas municipales (es por ejemplo el caso del Barrio Parque Manuel Aguirre en San Isidro ${ }^{244}$, o el plano de subdivisión de tierras de la sucesión a nombre de Antonia Mandia de García en Ituzaingo ${ }^{245}$ ), salteando la intervención de la Provincia y del Departamento Topográfico. Dos cuestiones confluyen para dar lugar a esta situación: por un lado, se presume que, agentes, loteadores e incluso dueños de la tierra que llevaban a cabo de forma particular las gestiones para las aprobaciones de los loteos

243 Desde la sanción de la Constitución Nacional de 1853, en donde se establece la necesidad de que las provincias argentinas aseguren el régimen municipal, prevalece la idea del órgano municipal como "una asociación de familias unidas por intereses, bienes y derechos comunes.." unido a la idea de que "la comuna o ciudad, es el orden de las instituciones políticas la primera, como la familia es la primera célula social; su gobierno propio es anterior a todo organismo político", deriva el supuesto de que el órgano municipal define sus competencias y funciones en un orden diferente al del Estado nacional o provincial. Como señala Marcela Ternavasio, estas dirimen sus atribuciones dentro de un ámbito definido como "político", mientras que los municipios mantienen sus acciones dentro de la esfera administrativa. La sanción de la Constitución de la Provincia de Buenos Aires en 1933, no modificó mayormente las atribuciones concedidas a los municipios, cuyas competencias se mantuvieron definidas por la legislación provincial y no por sus propias cartas orgánicas. Ver, Marcela Ternavasio, Municipio y representación local. Santa Fe: 1900-1920; en Julio Pirro y Elisa Pastoriza (editores). Los caminos de la democracia. Alternativas y prácticas políticas, 1900-1943. Pp. 183-200.

244 Ordenanza Municipal aprobando la formación del Barrio-Parque Manuel Aguirre. San Isidro, 25 de enero de 1913. Carpeta Barrio Parque Aguirre, Archivo y Museo Histórico de San Isidro.

245 Partido Seis de Septiembre, Ordenanza no 669, 11 de Junio de 1937. "El Concejo Deliberante del partido de Seis de Septiembre ha sancionado la ordenanza $n^{\circ} 669$, aprobando el plano de subdivisión de tierras, trazado y apertura de calles en la localidad de Ituzaingo, presentado por los Sres Astoul Bonorino \& Cía, en representación de la sucesión de Antonia Mandia de García. Instituto y Archivo Histórico Municipal de Morón. 
preferían moverse en el ámbito local. En esta escala, la trama de relaciones personales y de favores hacía más fácil poner en marcha los mecanismos que resultaran en aprobaciones del ámbito municipal, que pasarían a cumplimentar los trámites de aprobación correspondientes a las autoridades provinciales luego de que los loteos se hubieran realizado, y las urbanizaciones contaran con ciertos niveles de ocupación y desarrollo que, en la práctica, imposibilitaban cualquier acción real sobre el territorio. $^{246}$

Por otra parte, es de suponer que, comparativamente, los niveles de autonomía disminuyeran del ámbito provincial al municipal. Si bien el Estado Provincial aún no tenía un aparato burocrático consolidado -proceso que recién comenzó a delinearse a principios de los años treinta-, por sus mismas dimensiones y por la cantidad de reparticiones que lo conformaban, se hacía más difícil beneficiar a un grupo o interés particular, especialmente cuando hablamos de pequeños propietarios o empresarios locales. En tanto en los ámbitos de acción municipal, que por sus dimensiones reducidas contribuían a producir un nivel superior de informalidad en los procedimientos para la aprobación de los loteos, y por sobre todo, por la amplia red de relaciones y vinculaciones políticas que ostentaban algunas familias de la elite local, se allanaban los caminos y se reducían los tiempos de acción para la aprobación de los loteos. En relación a este tema, frecuentemente se comprueba que en muchos de los cargos públicos, ámbitos de decisión o en los Concejos Deliberantes locales se repiten los apellidos de las familias de la elite local, que son las mismas dueñas de la tierra que se benefician con el negocio de la expansión. ${ }^{247}$ De tal manera que no es difícil

246 Son innumerables las denuncias sobre el reparto de puestos públicos y "favores" que dispensaban los caudillos locales y que convertían a los municipios en ámbitos para prácticas corruptas y fraudulentas. Ver, María Dolores Béjar, El Régimen Fraudulento. La política en la Provincia de Buenos Aires, 1930 1943. Siglo XXI editores, Buenos Aires, 2005.

247 Un caso ilustrativo puede ser el del Barrio Parque Manuel Aguirre en San Isidro. El loteo de las tierras fue aprobado por Ordenanza Municipal en el año 1913. Un año antes, el Presidente de la Nación Roque Saenz Peña le había propuesto a Manuel Aguirre alquilarle su chacra con el fin de pasar los meses de verano cerca de la Capital. Durante ese verano la hija de Manuel Aguirre, María Eugenia Aguirre de Ibarguren solía asistir al té que organizaba semanalmente la primera dama, doña Rosa González.

En 1913, tras la muerte de Manuel Aguirre se loteó parte de la antigua chacra para dar lugar al barrio, según se aprobó por Ordenanza Municipal. Parte restante de las chacras se alquilaba al "Polo Club 
entender que, aunque en el discurso, los agentes municipales culparan a la falta de normativa o a la falta de recursos para explicar una actitud tolerante hacia el indiscriminado pasaje de tierras rurales a urbanas, en la práctica, eran muchos los grupos que se beneficiaban con las crecientes subdivisiones y con el incremento en los valores de la tierra. Asimismo, además de los negocios que las subdivisiones promovían para algunos grupos particulares y -como se mencionó en el apartado anterior-, aunque a largo plazo los fraccionamientos se tradujeran en amplios gastos a cargo de las reparticiones locales, en lo inmediato, muchos de los Municipios alentaban los fraccionamientos y la compra-venta de tierras a las que gravaban con tasas de inspección, impuestos a las transacciones, etc.; lo cual se convertía en una importante fuente de ingresos para el gobierno de turno.

\section{¿Provincia versus Municipio?}

En vistas de lo mencionado, estas dos imágenes que se revelan en apariencia contradictorias -la de los gobiernos municipales como víctimas subordinadas a las decisiones que se toman a nivel provincial y la de políticos y funcionarios locales que

Argentino" por intermedio de Miguel Alfredo Martínez de Hoz, con quien Calos Ibarguren, yerno del ya fallecido Aguirre, compartía su actividad directiva en el Jockey Club de Buenos Aires.

En 1924 se inauguró en la plaza principal del barrio una estatua del General Pueyrredon; al acto asistieron el Presidente de la República, Marcelo T. de Alvear y el Gobernador de Buenos Aires José Luis Cantilo.

En 1937 los herederos de Aguirre tramitaron ante la Dirección de Arquitectura del Ministerio de Obras Públicas la compra de la Quinta de Pueyrredon que formaba parte los bienes heredados y que según aducían los sucesores resultaba muy onerosa de mantener. Pasados unos años sin que el gobierno se pronunciara, Carlos Alberto Pueyrredón Lynch -primo de los Aguirre Lynch- al momento Intendente Municipal de Buenos Aires, sugirió a sus parientes la estratagema de llevar adelante el remate judicial de la finca, suponiendo que esto obligaría a las autoridades a tomar algún tipo de resolución. El hecho conmovió al pueblo de San Isidro y los herederos de Aguirre consiguieron que Rodolfo Gimenez Bustamante, Interventor en la Municipalidad de San Isidro, alentado por el intendente porteño, comprara la chacra a favor de la Comuna de San Isidro.

Ver, Carlos Ibarguren (h); “Crónica de la Histórica Chacra de Aguirre en San Isidro”. Museo Brigadier Juan Martín Pueyrredón, mimeo. San Isidro, 1982. 
se movían con gran autonomía- fueron la expresión de una relación de equilibrio inestable entre el gobierno provincial y las autoridades locales. Desde esta óptica, si consideramos la promulgación de la ley de formación de pueblos por parte de la provincia, y en el otro extremo, los beneficios que con la expansión obtenían los miembros de la elite y de la clase dirigente local es difícil pensar que se trabajara mancomunadamente para la implementación de las políticas reguladoras. ${ }^{248} \mathrm{~A}$ pesar de los sucesivos esfuerzos que se reconocen en la normativa de la ley por mantener bajo el dominio provincial -a través de la intervención del Ministerio de Obras Públicas y de sus oficinas técnicas- los principales asuntos relacionados a la expansión, otorgando a los Municipios competencias menores, de control y supervisión, hay indicios para pensar que estos últimos incidieron en la configuración del territorio más allá de lo que estaban dispuestos a reconocer. ${ }^{249}$ Teniendo en cuenta que, aunque en teoría fuesen ajenos a las grandes decisiones de la expansión, en los hechos, eran los únicos capaces de ejercer el control directo sobre las acciones -loteos, remates- que día a día transformaban el espacio. ${ }^{250}$

Retomando la visión del aparato estatal como arena de negociación y enfrentamiento, el recorrido que narramos puede entenderse como el reflejo de las

248 María Dolores Béjar reconoce que, por ejemplo, durante la experiencia conservadora de Buenos Aires en los años treinta, los enfrentamientos y conflictos entre las diferentes tendencias del partido, fueron una característica del período. De modo tal que, incluso cuando los dirigentes municipales pertenecieran al mismo partido que la dirigencia provincial, en más de una oportunidad se reconocieron fuertes tensiones internas. Ver, María Dolores Bejar, El régimen fraudulento... op.cit.

249 Noelia Fernandez señala que también en otros ámbitos, concretamente en relación a la construcción de obra pública, el Estado Provincial tendió a concentrar en el MOP las tareas relativas a determinar, cómo, dónde y quiénes debían construir en la provincia. Ver, Noelia Gutierrez, "Temas y problemas: obras públicas y política en el gobierno de Fresco, 1936-1940”, en Iras Jornadas de Investigadores en formación, IDES, Noviembre, 2011.

250 La situación que aquí presentamos se contrapone con lo que sucede actualmente, en tanto los gobiernos locales han cobrado relevancia, en virtud de la descentralización administrativa operada sobre la figura de los Municipios (que impactará significativamente en la Provincia de Buenos Aires), y la autonomía de la ciudad de Buenos Aires, producto de reformas y re-acomodamientos institucionales del último decenio del siglo XX. Ver, Daniela Szajnberg, "Guettos de ricos en Buenos Aires”, en Mundo Urbano $\mathrm{n}^{\circ} 13$, Junio 2004, Universidad Nacional de Quilmes. 
constantes pujas que en relación al control sobre el territorio - y todo lo que ello implicaba- tenían el Estado Provincial y los Gobiernos Municipales.

Qué nuevos aportes podemos hacer indagando en las acciones y en las prácticas de aquellos que están, en palabras de Peter Hall, en el "trabajo cotidiano de hacer ciudades", o podríamos decir, tensando esta idea en relación a nuestro objeto, en el trabajo cotidiano de construir la expansión. ${ }^{251}$

En principio hay que resaltar que existe una relación tensa y para nada lineal entre los sectores que deciden los trazos y las políticas de la expansión y los actores particulares, tanto quienes se ven afectados por ellas, como quienes deben llevarlas a cabo. En este cruce, como hemos ido señalando a lo largo de la tesis, el proceso de suburbanización del GBA ha presentado ciertas particularidades.

En relación a los actores privados que intervinieron en este proceso, se produjo un giro desde fines del siglo XIX y comienzos del siglo $\mathrm{XX}$, momento en el que predominaban las empresas urbanizadoras asociadas a los ferrocarriles y los propietarios rurales que intervenían a través de las ventas por sucesiones, hacia una mayor participación de propietarios medianos, junto a compañías inmobiliarias y rematadores, ya entrado el siglo XX. Sin duda, fueron éstos últimos los que imprimieron el rasgo característico de la expansión, lo cual redundó en una participación mayoritaria de inmobiliarias y rematadores, muchas veces en conjunción con los propietarios, en menoscabo de otros actores como los promotores. En el medio local, se reconoce que la acción de particulares y empresas familiares -operando fundamentalmente a través de subdivisiones con mínima infraestructura o de la compraventa de lotes- fue más activa que en otras latitudes.

Por otra parte, en contra de la visión que afirma sobre la falta de legislación y de controles que llevara a cabo el Estado para regular el crecimiento frente a los intereses privados, en la segunda parte de este capítulo hemos registrado un incremento en las funciones del Estado -visible desde el siglo XIX en la redacción de leyes y aplicación de una serie de normativas- tendientes a ordenar el desarrollo territorial. En paralelo, se

${ }^{251}$ Peter Hall, Ciudades del mañana, op.cit. p.12. 
asistió a una ampliación en las capacidades del Estado para llevarlas a cabo que, sin embargo, no parecen haber sido suficientes. Así como tampoco se verificó una adaptación de las mismas al nuevo contexto metropolitano. Pese a estar presentes los instrumentos y ciertos controles, el resultado que se despliega da cuenta de una tensión entre las acciones propuestas y las prácticas heredadas que entorpecían su aplicación, y por otro lado, en la falta de sensibilidad para adecuarse las lógicas de la expansión moderna. 


\title{
CAPÍTULO 5. La arquitectura y las imágenes suburbanas
}

\author{
"Esta encantadora casita destinada para week-end está \\ ubicada en el vecino pueblo de San Isidro. (...) \\ Pequeña y rústica es un refugio hermoso, cómodo y \\ práctico a la vez. En él sus gentiles dueños pasan los \\ fines de semana dedicados al deporte y a la vida al \\ aire libre en alegre compañía de amigos." \\ (Revista Casas y Jardines, Octubre. 1937)
}

En el período que analizamos, la ampliación del número de urbanizaciones de barrios parque no sólo significó la transformación territorial del Gran Buenos Aires, que abordamos en los primeros capítulos, sino también la aparición de nuevos modos de habitar vinculados al suburbio.

En este apartado, buscando una mirada cultural, centraremos nuestra atención en caracterizar otros aspectos asociados a la expansión de los emprendimientos de barrios parque. Asumiendo, por un lado, que la masificación del fenómeno condujo a transformaciones particulares, que superaron los cambios a gran escala del territorio y repercutieron íntimamente en las formas de habitar. Y por otro, y como ya se demostró en el Capítulo 2, que la noción de barrio parque se construyó en la confluencia de una serie de cuestiones, siendo la baja densidad la variable más destacable, pero también la incorporación de tipologías arquitectónicas particulares, es que proponemos analizar las principales respuestas que desde la arquitectura se desarrollaron en torno al nuevo programa y el conjunto de imágenes y representaciones que se concentraron a lo largo del período en torno a la habitación suburbana.

Partimos de la base de que, salvo excepciones particulares, no se registró un proyecto o imagen predeterminada que funcionara como meta, que señalara el "deber ser" del espacio suburbano, ya que dicho espacio constituyó el producto de la actuación de múltiples actores. A diferencia de lo que han demostrado los trabajos que han indagado sobre arquitectura, profesionales y formación de los suburbios en otros países y -como ya se abordó en el Capítulo 4-, el rol de empresas constructoras o grupos especuladores que realizaran intervenciones de escala significativa, capaces de imprimir imágenes representativas, fue escaso. En cambio, se verifica la actuación de profesionales de distintas disciplinas (ingenieros, arquitectos) que operaron dentro de 
un panorama más amplio, hegemonizado por constructores, maestros mayores de obras y los mismos propietarios que se hacían cargo de la construcción de sus viviendas con la ayuda de familiares y, eventualmente, de asistencia técnica para ciertas tareas específicas. ${ }^{252}$

En este escenario, el problema metodológico que planteó este capítulo fue, cómo dar cuenta de la arquitectura suburbana y de sus representaciones, siendo que constituyen un universo amplio y fragmentado dentro del cual resulta difícil reconocer la existencia de obras emblemáticas -sin resultar reductivo-, o la actuación de personalidades significativas que pudieran dar cuenta del panorama más amplio. Decidimos proceder a través de un análisis en dos niveles. Por un lado, el corpus (discursos publicitarios, fotografías y planos de arquitectura) que se difundía dentro de un circuito específico: el de los loteos de barrios parque que se extendían sobre el área metropolitana. Estos se publicitaban en la prensa diaria, y sobre todo, a través de afiches, panfletos y otros elementos de propaganda gráfica en donde se volcaban los datos fundamentales de las subdivisiones. Nos interesan particularmente porque constituyen el dato primario sobre los loteos y la arquitectura que allí se levantaba, a la vez que dan cuenta de la imagen que se buscaba difundir en relación a estos espacios.

Por otra parte, es importante señalar que las obras detectadas en este contexto se integran dentro un imaginario urbano-arquitectónico más amplio que se difundía en revistas y que formaba parte de un debate más extenso en relación a la expansión. Con la intención de conocer este panorama, abordaremos el grupo de imágenes y modelos que a nivel general constituían el horizonte de la arquitectura suburbana.

En cuanto al desarrollo de estas problemáticas, se desplegarán a lo largo de dos secciones. En la primera, proponemos la revisión de los discursos que acompañaban la venta de lotes en las nuevas urbanizaciones, en tanto nos permiten conocer las ideas que se ponían en juego en los suburbios. En la segunda parte, con el fin de conocer sobre la

\footnotetext{
252 En este punto parece importante mencionar un debate que ya se adelantó en la introducción y que plantea la discusión sobre la relación entre la cultura -en este caso, particularmente la arquitectura- de las clases populares (realizada por constructores, maestros mayores de obras) y la de las clases dominantes (realizada por profesionales, arquitectos e ingenieros). ¿Hasta qué punto es la primera subalterna de la segunda? O, por el contrario, ¿en qué medida expresa la primera contenidos, cuando menos, parcialmente alternativos? ¿Se puede hablar de circularidad entre ambos niveles de cultura?
} 
arquitectura que se alzaba en las urbanizaciones de fin de semana, y sobre el circuito a partir del cual los modelos se consolidaban y difundían, abordaremos una revisión de los libros de láminas, tratados, manuales y revistas de circulación más frecuente, para ponerlas en discusión con aquellas obras que surgen directamente en relación a las urbanizaciones que conforman nuestro universo de estudio.

\subsection{El ideal de la casa propia y el week-end}

"La maravilla que es San Antonio de Padua alcanza su expresión máxima en el Barrio Parque La Esmeralda, verdadero modelo de elegante y sugestivo urbanismo. (...) reafirma su política de propender dentro de sus posibilidades la solución de la vivienda propia, haciéndola accesible a la economía más modesta y por eso va a vender en mensualidades."

(Barrio Parque La Esmeralda, 1949) ${ }^{253}$

“A las puertas de la Capital (...) en uno de los sitios de mayor prestigio, por sus excelentes vistas, por la altura y calidad de sus tierras, donde todas sin excepción son espléndidas y magníficas casas quinta que han hecho de esta zona el lugar de preferencia para instalar la residencia de veraneo o de fin de semana"

(Barrio Parque Peluffo, 1947) 254

253 Propaganda de loteo Barrio Parque La Esmeralda en Merlo (1949). Carpeta de remates-partido de Merlo, en Departamento de Investigación Histórica Cartográfica, Dirección de Geodesia, MOP, Provincia de Buenos Aires.

254 Propaganda de loteo Barrio Parque Peluffo en La Matanza (1947). Carpeta de Remates- partido La Matanza, en Departamento de Investigación Histórica Cartográfica, Dirección de Geodesia, MOP, Provincia de Buenos Aires. 
La casa propia y la casa de week-end fueron las fórmulas que condensaron dos conjuntos de representaciones que coexistieron en el período que analizamos, no de manera exclusiva pero sí dominante, bajo la fórmula ambigua del barrio parque para dar forma a un sector importante de la expansión residencial moderna. El grupo mayoritario de las urbanizaciones que relevamos capitalizó los discursos que se relacionaban con alguno de estos universos temáticos, y lo que es más curioso, otros trataron de tomar elementos de cada una de estas tradiciones que, al menos en la teoría, constituían mundos opuestos.

Es que a lo largo del período que analizamos se asistió a una masificación del fenómeno que condujo a un desplazamiento en relación a los significados que originalmente comprendía, tanto desde el punto de vista morfológico como en relación a los valores subyacentes. ${ }^{255}$ Es así, que el término "barrio parque" denominó a barrios residenciales exclusivos, a loteos de baja densidad, a barrios para trabajadores que se insertaban en áreas suburbanas -materializados tanto a través del uso de la cuadrícula como de composiciones con líneas curvas del tipo pintoresco-. Solo dos condiciones debían cumplirse, la baja densidad y la existencia de residencias particulares, para incluir a un nuevo loteo bajo esta denominación.

En este capítulo proponemos la revisión de los discursos que acompañaban la venta de lotes en las nuevas urbanizaciones, teniendo en cuenta que constituyen una pieza clave en tanto dan cuenta del clima de ideas en el cual se incorporan y de las características del mercado al que se dirigen. Es decir, que podemos conocer, sobre los actores y las imágenes que protagonizan la expansión, a través de la oferta que establecen las publicidades y que exponen las constantes que determinados grupos ponían en juego a la hora de invertir en la vivienda. ${ }^{256}$

\footnotetext{
${ }^{255}$ En el Capítulo 3 se presentó un recorrido en relación a las implicancias que produjo la difusión de los modelos de barrio parque. Se enfatizó, fundamentalmente, en las transformaciones materiales a las que se vio expuesto el modelo.

${ }^{256}$ Pierre Bourdieu analiza el mercado de la casa y da cuenta del papel de la publicidad a la hora de definir y redireccionar la demanda de los consumidores. Ver, Pierre Bourdieu, Las estructuras sociales de la economía, Manantial, Buenos Aires, 2001.
} 


\section{1.a La casita de fin de semana}

La opción del habitar en un ambiente tranquilo, cerca de la naturaleza puede rastrearse en Argentina a fines del siglo XIX, con la aparición de las primeras quintas de veraneo, desligadas de los fines productivos a los que se vinculaba la casa de campo o el casco de estancia. En efecto, la exaltación del contacto entre vivienda y naturaleza y el énfasis en los encantos y beneficios de la vida al aire libre se forjaron a la vuelta del siglo $\mathrm{XX}{ }^{257}$ La costumbre de veranear en quintas de los alrededores de la ciudad se vio estimulada por la extensión de las líneas férreas y por la epidemia de fiebre amarilla de 1871, que mostró los beneficios de alejarse de la ciudad y trasladar la vida doméstica a parajes altos considerados más saludables y en contacto con la naturaleza. Los llamados pueblos veraniegos de las afueras de la Capital, registraron a partir de tal momento un nuevo auge, como en los casos de San Fernando, San Isidro, Lomas de Zamora o Adrogué, donde se sumó la instalación de hoteles y clubes a los núcleos de vivienda no permanente.

Los primeros barrios parque se instalaron dentro de esta tradición aristocrática. Entre los más destacados se puede citar el Barrio Parque Aguirre en San Isidro, cuyo loteo inicial data de mediados de la década del diez, pero la costumbre de veranear fuera de la ciudad se amplió notablemente hacia los años treinta, en un momento en que la expansión del automóvil y algunas políticas estatales como la ley del sábado inglés (1932) o la primera de vacaciones pagas (empleados de comercio, 1934) ampliaban las posibilidades del turismo y ponían de moda el week-end entre los sectores medios de la población. $^{258}$

Como señalaron Francisco Liernur o Anahí Ballent, durante este período las revistas femeninas o los suplementos de los diarios constituyeron piezas claves en la

\footnotetext{
${ }^{257}$ Hay que enfatizar que no existió aquí un culto a la naturaleza extendido y sólido como el que se perpetuara en Inglaterra como herencia del romanticismo; de manera que las formas de vida extraurbanas no se plantearon como alternativa a la vida en la ciudad, sino como complemento que comenzó a tomar forma con el auge del turismo, la costumbre del week-end, la casa de fin de semana o de veraneo. Ver, Anahí Ballent, Las huellas de la política. Vivienda, ciudad, peronismo en Buenos Aires, 1943-1955, Universidad Nacional de Quilmes- Prometeo, 2005.

258 Anahí Ballent señala esta transformación en su libro Las huellas de la política. Op.cit. p 26.
} 
formación de un nuevo mercado inmobiliario y en la introducción de las pautas de socialización modernas ligadas al ámbito de la vivienda. En este sentido, los discursos producidos por los emprendedores y agentes inmobiliarios recogen gran parte de los tópicos que en relación al habitar fueron instalados por estos otros medios. De la mano de la masividad que en los años treinta adquirían los medios de comunicación, se extendieron pautas de consumo y modos de vida que calaron especialmente en los nuevos grupos medios y aquellos sectores que no estaban muy seguros del lugar social que ocupaban.

Hacia los años treinta, la impronta de las capas medias era bastante notable, especialmente en Buenos Aires. Estos sectores pasaron de un 38\% de su población en 1914 a un $46 \%$ en $1936 .{ }^{259}$ Esta creciente influencia se hizo especialmente visible en el estilo de vida de la ciudad como conjunto y sobre todo en el horizonte de expectativas, en los gustos y en la conducta que como consumidores empezaban a adquirir. Como mostró L. Losada, en un momento en que las jerarquías se disolvían, vivir en un determinado vecindario o adquirir determinado tipo de bienes se transformaba en una forma de pertenencia o inclusión en cierto grupo social. ${ }^{260} \mathrm{~A}$ juzgar por el léxico y las representaciones mentales que comenzaban a aparecer en las promociones de los loteos, los sectores medios constituían una demanda cada vez más apreciable para las urbanizaciones de fin de semana que se alzaban en la periferia.

Mientras que la residencia temporaria en alguno de los pueblos de veraneo o sitios de fin de semana fue prerrogativa de unos pocos, en las publicidades se podía leer que se ofrecían lotes "en tierras privilegiadas, con la elegancia y aristocracia de los maravillosos grounds de polo, con sus clubs herméticamente cerrados y las suntuosas residencias privadas" 261 o, de manera excepcional, en sitios como San Isidro que, si bien ampliaron su base social nunca estuvieron al alcance de las clases medias

259 Datos citados por Ricardo González Leandri, en "La nueva identidad de los sectores populares", en (dir.) Alejandro Cattaruzza, Crisis Económica, avance del Estado e incertidumbre política (1930-1943). Col. Nueva Historia Argentina, T VII. Editorial Sudamericana, Buenos Aires, 2001.

${ }^{260}$ Leandro Losada, La alta sociedad en la Buenos Aires de la Belle Epoque, op.cit

261 Propaganda de un loteo en Hurlingham (1931), en Carpeta de Remates Partido de Morón, Departamento de Investigación Histórica Cartográfica, Dirección de Geodesia, MOP, Provincia de Buenos Aires. 
trabajadoras como sí lo estuvieron otros sectores de la expansión, y por lo tanto mantuvieron su prestigio a lo largo de todo el período, todavía se podía leer que en la década del cuarenta se ofrecían “(...) suntuosas residencias rodeadas de espléndidos jardines". ${ }^{262}$ Pero, paulatinamente, se aprecia que en los discursos la apelación a las residencias fue dando paso a denominaciones más modestas, para terminar en la "casita de fin de semana" como se publicitaba un loteo en La Pradera de Merlo, en 1950; o "sitio ideal para levantar en sus amplias quintas la coqueta casita de fin de semana y también para la vivienda de todo el año."263 O "residencias coquetas y alegres se cuentan por miles"264

Por un lado se experimentaba un desplazamiento desde los primeros barrios de fin de semana de elite hacia capas más amplias de la sociedad. De tal modo que la residencia de fin de semana daba lugar a la casita, simplificada y compactada, y por lo tanto accesible a los requerimientos de las capas superiores de los nuevos sectores medios y a sectores más amplios que -como abordaremos en el siguiente apartadoestablecían allí su vivienda permanente. La publicidad apelaba a imágenes asociadas con el habitar de los sectores medios y altos, que a partir de la década del veinte, y de manera cada vez más notoria a lo largo de los años treinta se acercaban al universo de los sectores medios, e incluso a los sectores populares cuando las iniciativas provenían del Estado. De hecho, Anahí Ballent señaló que el Ministro Juan Pistarini utilizó en 1945 los adjetivos que reprodujimos más arriba: “(...) casa cómoda, coqueta y alegre” para referirse a un grupo de viviendas producidas por el peronismo, dando cuenta del corrimiento que se producía del universo de imágenes de la elite hacia otros sectores.

Por otra parte, debemos considerar que este cambio de registro que se advertía en relación a la habitación en los suburbios residenciales también se hizo posible

\footnotetext{
262 Propaganda de un loteo en el Barrio Parque Atalaya (1949), en Carpeta de Remates Partido de San Isidro, Departamento de Investigación Histórica Cartográfica, Dirección de Geodesia, MOP, Provincia de Buenos Aires.

263 Propaganda de un loteo en el Barrio Parque Juan Pastorini, La Reja (1950), en Carpeta de Remates Partido de Moreno, Departamento de Investigación Histórica Cartográfica, Dirección de Geodesia, MOP, Provincia de Buenos Aires.

264 Propaganda de un loteo en el Barrio Residencial Ituzaingo (1946), en Carpeta de Remates Partido de Morón, Departamento de Investigación Histórica Cartográfica, Dirección de Geodesia, MOP, Provincia de Buenos Aires.
} 
porque desde la década del diez, como demostró Liernur y como veremos más en detalle en las páginas que siguen, se venía registrando un fenómeno de compactación de la vivienda. En un contexto amplio - no solo afectando a la vivienda de fin de semana o veraneo, sino a la arquitectura residencial en general- hacia la década del veinte los ámbitos de dimensiones pequeñas, anteriormente sólo relacionados con la pobreza, comenzaron a ser sinónimo de practicidad y simplicidad, entendidos como atributos de formas de habitar modernas. ${ }^{265}$

En conjunto, la difusión de las imágenes, la flexibilización de las formas de habitar y los procesos de compactación de la vivienda dieron lugar a que los nuevos suburbios se poblaran de casitas de fin de semana de clase media.

\section{1.b El ideal de la casa propia}

Planteos generales

El segundo grupo de representaciones que surgieron bajo la fórmula del barrio parque se organizó en torno al ideal de la casa propia. El problema de la habitación tomó densidad en Buenos Aires hacia fines del siglo XIX cuando la llegada masiva de inmigrantes europeos puso en evidencia la falta de alojamiento en las ciudades más grandes del litoral. La resolución inmediata para esta situación no incluyó la intervención estatal, sino que fueron los propios recién llegados quienes debieron acomodarse, por lo general en una pieza alquilada de conventillo, o en habitaciones en casas de familias. Estas opciones reunían dos condiciones fundamentales: por un lado constituían una opción posible de acuerdo a los magros ingresos de las familias recién llegadas, y por otro lado, respondían a la idea de transitoriedad, con la cual la mayoría de los inmigrantes prefería asociar su estadía en Argentina.

Este escenario de la vivienda popular, que implicaba desde el punto de vista material condiciones de hacinamiento $\mathrm{y}$ falta de higiene $\mathrm{y}$, desde el punto de vista

Francisco Liernur, “AAdueño. 2 amb. Va.Urq. chiche. 4522.4789. Consideraciones sobre la construcción de la casa como mercancía en la Argentina. 1870-1950”, en Revista SCA, julio, n 217: Modos de habitar, Buenos Aires, 2005, pp. 54-61. 
social, la imposibilidad de ejercer control y autoridad sobre la población comenzó a ser visto desde las clases dirigentes como un caldo de cultivo para la formación de nuevos movimientos políticos (anarquismo y socialismo). Dentro de este marco, tomaron forma aquellas ideas que pretendían incorporar a la vivienda criterios de higiene y salud pública y que fueron pronto superadas para abarcar exigencias morales y de reforma social. Eventualmente, estos discursos comenzaron a articularse con conceptos que otorgaron a la propiedad de la vivienda un sentido político, por cuanto se entendía como clave de la fijación de los individuos al territorio, dentro de una red más amplia de dispositivos de penetración del Estado Nacional en la sociedad civil que incluía la educación, el servicio militar, y diversos registros obligatorios. ${ }^{266}$ Sin embargo, salvo excepciones poco relevantes en el conjunto, las acciones del Estado fueron liberales y dejaron que el tema de la vivienda se rija por criterios de rentabilidad propios de los sectores privados. ${ }^{267}$ De manera tal que, para cuando el ideal de la casa propia fue tomando vigencia hacia la segunda década del siglo $\mathrm{XX}$, los sectores populares se encontraron frente a unas pocas alternativas, signadas las más de las veces por las implicancias del loteo y la especulación inmobiliaria, el gravoso peso de los alquileres en el presupuesto familiar y la ética del esfuerzo personal orientado a la obtención de la casa propia. ${ }^{268}$

En cuanto a la imagen que resumía el ideal de la casa propia, esta debía ser: individual -en tanto no existió hasta 1948 la figura jurídica de la propiedad horizontal

${ }^{266}$ Ver, Francisco Liernur, "Buenos Aires: estrategia de la casa autoconstruida", en AA.VV. Sectores populares y vida urbana, CLACSO, Buenos Aires, 1984.

267 Entre 1880 y 1900 se dictaron alrededor de cuarenta ordenanzas que estipulaban las obligaciones de las casas de vecindad y conventillos, su pintura y blanqueo, su habilitación, así como también procurar la vigilancia de sus residentes.

En 1915 fue creada la Comisión Nacional de Casas Baratas, hasta ese momento solo habían existido algunas intervenciones públicas municipales o provinciales, e igualmente, a partir de este período hay que destacar que la acción de la Comisión no se dirigió a la construcción masiva, sino a difundir y orientar en materia de habitar. Ver, Francisco Liernur, "Comisión Nacional de Casas Baratas", en Jorge Liernur y Fernando Aliata (dirs.), Diccionario de Arquitectura en la Argentina, Clarín, Buenos Aires, 2004.

268 D. Armus y J.E. Hardoy, "Conventillos, ranchos y casa propia en el mundo urbano del novecientos", en Diego Armus (comp.), Mundo Urbano y Cultura popular, Sudamericana, Buenos Aires, 1990. 
que permitió obtener en propiedad unidades funcionales dentro un edificio de departamentos-, y periférica, en coincidencia con la expansión de la Capital. Desde otra perspectiva, a medida que importantes cantidades de trabajadores adquirieron su casa propia fueron cambiando sus pautas de comportamiento. A partir de entonces, un nuevo tipo de privacidad, modelada sobre los estilos de la vida cotidiana da las clases medias, se tornó cada vez más importante, generando un nuevo tipo de sociabilidad orientada hacia el interior y la familia. ${ }^{269}$ Esta situación se reveló así en todos los casos, la vivienda individual, urbana o suburbana -especialmente los tipos compactospromovían la unión familiar y el acercamiento de los sectores populares a las normas burguesas como reacción ante la imagen de hacinamiento y promiscuidad del conventillo o de la pieza compartida.

Para la década del treinta, el consenso sobre la casa propia y su carácter beneficial para el núcleo familiar era amplio. El partido socialista, en palabras de Nicolás Repetto, impulsaba la vivienda propia y compacta. A partir de 1936 la cooperativa "El hogar Obrero" auspiciaría, a través del sistema de créditos, la casa que tuviera como centro un "living" para propender a la reunión de la familia y permitir que "muchos hombres que hasta hace pocos años después de sus comidas abandonaban sistemáticamente la casa permanecieran desde entonces en sus hogares". ${ }^{270}$ Desde otra perspectiva, Alejando Christophersen señalaba, "El problema de la casa propia es una lógica aspiración de todo hombre, aún cuando sus medios sean limitados, deseando vivir en un marco familiar, en su hogar propio". ${ }^{271}$ Un punto culminante en esta discusión sería el Congreso Panamericano de la Vivienda Popular de 1939, en cuyas conclusiones se redactó una recomendación a favor de la vivienda individual que pudiera ser adquirida en propiedad, lo cual permitió ver, entre otras cuestiones, la fuerte

269 Ricardo González Leandri, “La nueva identidad de los sectores populares”, en (dir.) Alejandro Cattaruzza, Crisis Económica, avance del Estado e incertidumbre política (1930-1943). Nueva Historia Argentina, T VII. Editorial Sudamericana, Buenos Aires, 2001.

270 Citado por Jorge Liernur en "Buenos Aires: estrategia de la casa autoconstruida", en AA. VV. Sectores populares y vida urbana, CLACSO, Buenos Aires, 1984.

271 Citado por Horacio Caride, en "La casa propia: el caso del chalet. Notas en las revistas populares de Buenos Aires durante la década infame.”, en DANA. 1992, Num. 31/32. pp. 57-64. 
presencia de profesionales y de figuras públicas vinculadas con sectores católicos militantes y que convergían en torno a esta problemática. ${ }^{272}$

Problemáticas particulares

Ahora bien, si este era el panorama que se reconocía a nivel general, en los sectores suburbanos la vinculación vivienda individual-núcleo familiar se haría más fuerte. Es sabido que la tradición suburbana, en pleno desarrollo a nivel internacional a comienzos del siglo XIX, se relaciona ampliamente con una incipiente preocupación por lo doméstico, asociada a las trasformaciones que sufrió el núcleo familiar que se desplazó del concepto de unidad económica a una unidad basada en la idea del afecto y cuidado de los miembros. ${ }^{273}$ Al mismo tiempo que la familia se redefinía como un grupo electivo que disfrutaba emocionalmente de la unión, los suburbios comenzaron a ser vistos como el sitio ideal para ese desarrollo.

En el contexto de la expansión de Buenos Aires, como ya mencionamos, las nociones de "familia" y "vivienda" adquirieron características particulares. Los primeros desplazamientos hacia la periferia, entre 1900 y 1920, se dieron dentro del área de la Capital. En este momento, la expansión de la ciudad se llevó a cabo a través de una serie de loteos económicos que ayudaron a consolidar una corona de barrios periféricos sobre la base de la vivienda individual. Sin embargo, esta transformación espacial no habría significado, inmediatamente, la constitución de formas de habitar individuales. Según el Censo Escolar de 1943, analizado por Anahí Ballent, durante este período fue común que dos o más familias compartieran una vivienda, repitiendo muchos rasgos de la sociabilidad del conventillo que, además, coexistieron con un nuevo tipo de sociabilidad barrial que tenía lugar fuera de la vivienda y cuyos focos eran la calle, la cuadra, el café, la plaza y el almacén.

En el segundo proceso de expansión que vive Buenos Aires, por fuera de los límites de la Capital, los precios bajos de la tierra determinaron sectores residenciales populares, en donde muchas familias se vieron involucradas en la aventura de adquirir

\footnotetext{
272 Anahí Ballent, Las huellas de la política, p. 60.

${ }^{273}$ Lawrence J. Stone, The family, Sex and Marriage in England, 1500-1800, New York, Harper \& Row, 1977.
} 
el lote para la vivienda propia. A diferencia de la Capital, donde para 1947 se registró que sólo el 17,56\% de las viviendas estaban habitadas por sus propietarios, en el Gran Buenos Aires, para el mismo período los propietarios constituían el 43,3\% de los habitantes de viviendas. ${ }^{274}$

En la formación del Gran Buenos Aires, (exceptuando los barrios más exclusivos) la apelación al hogar -de acuerdo a la matriz anglo-americana- como núcleo de una vida familiar feliz aparece necesariamente cruzada por la componente económica. La instalación de la residencia permanente en áreas extraurbanas estuvo fuertemente determinada por la posibilidad de acceder a la propiedad en los sectores de la expansión en que los valores del suelo eran más baratos, más que a una verdadera elección en pos de lo natural. Aquí, muchas familias podían hacer realidad el "sueño de la casa propia" que se había venido consolidando a lo largo del siglo XX en la prédica de las elites asimilando "casapropismo" con respetabilidad y ascenso social. Para las décadas del treinta y cuarenta, esta visión estaba instalada en la sociedad y se difundía como una cuestión de "sentido común" dentro de los discursos que se dirigían a las clases trabajadoras. La casa propia aparecía como un ámbito donde el trabajador podía convertirse en un ciudadano respetable, al ver reflejado allí el premio al esfuerzo personal y familiar. En este orden de cosas, los operadores inmobiliarios también desarrollaban un rol fundamental, propagando este discurso que, contribuía a sostener su negocio. Al respecto, Luis Guaraglia decía "El hombre que ha comprado un terreno y con mayor razón, en el que ha logrado levantar su casa (...), se ha operado un fenómeno psíquico positivo, empieza a sentirse más seguro de sí mismo, más dueño de su destino". 275

A pesar de que el barrio parque estaba tradicionalmente asociado a la habitación de los sectores medios y medios-altos, al menos dentro de los proyectos generados desde la acción privada; si retomamos el acápite que inicia este capítulo, se vislumbra que se entrecruzan dos universos. Por un lado el Barrio Parque La Esmeralda es modelo de "elegante y sugestivo urbanismo", sin por ello dejar de ser la "solución a la vivienda

\footnotetext{
${ }^{274}$ Horacio Torres, El mapa social de Buenos Aires, op.cit

275 Luis Guaraglia, Manual del Rematador, op.cit. p. 292.
} 
propia, accesible a la economía más modesta". ${ }^{276}$ En esta línea, aunque el mercado de la casa constituye un caso particular, todo parece indicar que se estaban produciendo reacomodamientos similares a los que tenían lugar en otras áreas del consumo, en donde las compañías modificaban sus estrategias de producción, ampliando la oferta hacia bienes que manteniendo una apariencia lujosa eran lo suficientemente económicos para atraer a la creciente clase media. ${ }^{277}$

Sin duda los discursos que se articulan en torno a algunos barrios parque dan cuenta de fenómenos de esta índole. Al parecer, ciertos sectores podían anhelar a acceder a un conjunto de imágenes que, aunque "lavadas", se relacionaban al habitar de las clases medias. En efecto, debemos pensar que la construcción de determinadas tipologías -en este caso todas aquellas englobadas dentro de la figura amplia del chaletdentro de los loteos de barrio parque, implicaban no sólo una decisión racional y eficiente desde el punto de vista económico, sino que también eran un elemento que se exhibía como símbolo del ascenso social y del éxito de una familia.

Recordemos, por otra parte, que a partir de la década de 1910 los espacios, anteriormente reservados a la considerada "alta sociedad", asistieron a la aparición de una "invasión democrática", mediante la cual aquellos sitios asociados a la elite, como Tigre o Mar del Plata, de pronto pasaron a estar al alcance de franjas más vastas de la sociedad de una manera en que no lo habían estado antes. Hacia los años treinta este proceso se intensificaría, y acompañándolo, figuras como el chalet o el barrio parque también comenzaron a democratizarse en versiones que se acomodaban a bolsillos más modestos, como lo prueba este ofrecimiento en un barrio parque de La Matanza hacia fines de los años cuarenta.

\footnotetext{
276 A través de organismos del Estado, por ejemplo, la Comisión Nacional de Casas Baratas - creada a partir de la ley 9.677 de 1915- se construyó en Buenos Aires el Barrio Cafferata en 1923, o el Barrio Rawson en 1928. En ambos casos los trazados eran de tipo pintoresco y las unidades de vivienda eran chalets compactos de dos niveles, adosados en uno de sus lados. En cuanto a los sectores sociales a los que estaban destinadas estas viviendas, si bien, originalmente se habían propuesto como viviendas económicas, por los costos altos que habían alcanzado, terminaron destinándose a los sectores medios. Ver, Francisco Liernur, “Comisión Nacional de Casas Baratas”, en Jorge Liernur y Fernando Aliata (dirs.), Diccionario de Arquitectura en la Argentina, Clarín, Buenos Aires, 2004.

${ }^{277}$ Un análisis más detallado sobre los nuevos consumidores y las estrategias que desde las empresas se implementaron para captarlos aparece en el Capítulo 6.
} 
"ha sido proyectada y realizada en un lugar ideal para la instalación de la casa de fin de semana con sólo una pequeña inversión. Se ha tratado de urbanizar conscientemente para poder ofrecer así a los numerosísimos entusiastas de esta zona una casa bonita, cómoda, barata y de gran porvenir, que podrán adquirir con un pequeño desembolso."278

Así, en algunos casos, lo que para unos era la casita de week-end, para otros constituía el acceso a su primera propiedad en una versión superadora a la del típico loteo popular. Seguramente con iguales carencias -deudoras de la urbanización en los límites de la ciudad- que éstos últimos, pero rodeada de otras "casitas coquetas" y entroncada con una tradición del habitar de alto valor simbólico.

\subsection{Las residencias, las arquitecturas y sus modelos}

Tal como hemos ido señalando, dentro del proceso general de expansión del Gran Buenos Aires se produjeron ciertos núcleos residenciales de características particulares y distintivas. Sabemos que, en la mayoría de los casos, el centro de las operaciones inmobiliarias reposaba en la subdivisión del suelo destinado a usos agrícolas y su venta como lotes suburbanos y que, posteriormente, se iniciaba, de manera particular, la construcción de las primeras viviendas y los esfuerzos por conseguir el mejoramiento de las calles, la llegada de los servicios públicos,....

Podemos hablar, entonces, de dos etapas de crecimiento que ya han sido adelantadas: la primera fase correspondía al momento fundacional en que se realizaba el trazado urbano, que incluía el delineado de las manzanas que iban a ser loteadas y de las áreas públicas, calles y plazas. La segunda fase comenzaba con la incorporación de las primeras viviendas. En algún caso excepcional, como el que presentamos en el

\footnotetext{
${ }^{278}$ Propaganda de un loteo en el Barrio Jardín Puente Ezcurra (1948), en Carpeta de Remates Partido de La Matanza, Departamento de Investigación Histórica Cartográfica, Dirección de Geodesia, MOP, Provincia de Buenos Aires.
} 
Capítulo 4, los mismos agentes que habían intervenido en la subdivisión del suelo, incorporaban la construcción de viviendas, como una forma de impulsar el crecimiento del lugar o como parte de un programa más amplio destinado a cubrir las necesidades de un grupo particular. Pero en su mayoría, el crecimiento y la ocupación de los barrios se realizaba de manera espontánea, sin que se registraran operaciones de diseño urbano de escala notoria por parte de emprendedores o grupos de especuladores. ${ }^{279}$

A partir de este contexto cobran importancia las hipótesis que han sostenido algunos estudios que analizan las experiencias desplegadas en Inglaterra, que han concedido un rol fundamental a los procesos de difusión para la producción material de los suburbios de clase media, señalando que fue la popularización y estandarización de algunos elementos e imágenes retomados por un grupo amplio de profesionales y técnicos, quienes terminaron de conformar la imagen de los suburbios. Y por otro lado, algunos estudios del ambiente local que han trabajado los procesos de difusión que contribuyeron a incorporar a los modos de vida de los sectores medios prácticas anteriormente asociadas a la elite. ${ }^{280}$

Con esta perspectiva en mente, presentaremos, inicialmente, un panorama de las revistas dedicadas a la casa y al jardín, libros de láminas, modelos y catálogos que se difundían en nuestro país y conformaron el universo más amplio que contribuyó a orientar la arquitectura de la periferia.

En cambio, en segundo lugar se analizarán aquellas obras que se recortan directamente en relación a las urbanizaciones que conforman nuestro universo de estudio. Como ya se adelantó al comienzo de este capítulo, era una práctica extendida acompañar la información relativa a los remates con fotografías o dibujos que transportaran mentalmente al interesado hacia ese "espacio soñado". Dado que serán estas imágenes las que constituyan nuestra fuente principal, y teniendo en cuenta que parten de un recorte realizado sobre un universo más amplio -el total de las obras

${ }^{279}$ Ver en el Capítulo 4 un estudio sobre los agentes que intervinieron en el mercado de tierras y cuáles fueron las acciones predominantes asociadas a cada uno de ellos.

${ }^{280}$ Anahí Ballent, "Country Life: los nuevos paraísos, su historia y sus profetas” op.cit; A. Ballent, "La "casa para todos": grandeza y miseria de la vivienda masiva", en Fernando Devoto y Marta Madero (dirs.), Historia de la vida privada en Argentina, Taurus, Buenos Aires, 1999; A. Ballent, Las huellas de la política, op.cit. 
suburbanas- y el cual desconocemos, es que no podemos, ingenuamente, considerarlas representativas del conjunto de obras que se erigían en los suburbios. ${ }^{281}$ En todo caso, debemos suponer que constituyen un registro visual, no de la situación real registrada en los suburbios, sino de sus aspiraciones. Sin desconocer esta situación, proponemos analizar dos aspectos en relación al conjunto de obras que los agentes inmobiliarios incorporaban a las promociones. Por un lado, las analizaremos dentro de su campo específico, es decir, en tanto obras de arquitectura. Y por otra parte, entendidas como imágenes, constituyen una forma de lenguaje, y en consecuencia tienen la capacidad de comunicar. A partir de este supuesto es que podemos proponer que actuaban como señales o guiños que, por su asociación a determinados modos de vida y formas de habitar condensaban las expectativas de un determinado universo de posibles clientes a los que se quería llegar. ${ }^{282}$ En este sentido, como complemento de los discursos que analizamos en este mismo capítulo, las imágenes se presentan en relación a las supuestas expectativas de la sociedad en torno al suburbio como nuevo tipo de paisaje, a la vez que, a partir de difundirlas masivamente, contribuyen a su conformación.

Por último, cabe aclarar que con el fin de presentar un mapa más completo sobre las tendencias de la arquitectura suburbana dentro del ambiente local, los casos se presentarán en relación con el contexto más amplio que proponían las revistas. En síntesis, este análisis nos permitirá conocer a las obras en sí mismas, y a su vez, comprender cómo se insertaban en un contexto arquitectónico más amplio. Es decir, cómo se relacionaban con el contexto internacional y cómo se producían los procesos de difusión y apropiación de tipologías extranjeras. ${ }^{283}$

281 Peter Burke realiza lo que podríamos denominar como una crítica a las fuentes gráficas, problematizando justamente la existencia de "intermediarios" a través de los cuales nos llegan las imágenes y siendo que muchas veces desconocemos los objetivos que guiaron tal recorte. Ver, Peter Burke, Visto y no visto. El uso de la imagen como documento histórico. Editorial Crítica, Barcelona, 2005 .

282 Jorge F. Liernur, “AAdueño. 2 amb. Va.Urq. chiche. 4522.4789. op.cit.

283 Desde un abordaje que privilegie la circulación de imágenes y su apropiación por parte de diferentes sectores sociales hay que tener en cuenta los intercambios desiguales que se producen entre diferentes sociedades, (e incluso grupos sociales). Asumiendo que la dominación social tiene siempre efectos simbólicos sobre los grupos dominantes y dominados que asocia, es necesario describir en cada caso los mecanismos de imposición simbólica o interrogar los eventuales desfases con relación a los mecanismos 


\section{2.a La vivienda suburbana y los modelos internacionales}

Definición de los principales lenguajes y tipologías

Claudia Schmidt señala la importancia que tuvieron los tratados de arquitectura en el ambiente local, sobre todo en las primeras décadas del siglo XX, cuando existía un vacío institucional local - sin escuelas de arquitectura, sin producción bibliográfica específica y con escasos ámbitos de debate sobre la disciplina arquitectónica.

Sin desconocer que el repertorio bibliográfico disponible era más amplio; siguiendo a esta misma autora sabemos que tanto las primeras bibliotecas como los acervos personales contaban con un fondo básico, compuesto por manuales y tratados generales, y material de actualidad seleccionado de acuerdo a los intereses y al tipo de demanda que los profesionales recibieran. Desde esta perspectiva, dos tratados generales - el Traité d'architecture (1898) de Luis Cloquet y Elements et théorie de l'architecture (1909) de Julien Guadet- constituyeron la síntesis final de un conjunto de saberes tradicionales actuando, a la vez, de pivot entre el pasaje de la tradición clásica a la modernidad. ${ }^{284}$ De entre ellos, sólo Luis Cloquet aborda el tema de la composición de la vivienda suburbana como problema específico; a la vez que su importancia radica, esencialmente, en la enorme influencia que ha tenido en nuestro ámbito hasta mediados del siglo $\mathrm{XX}^{285}$ Además de los tratados anteriormente mencionados, también circulaban algunos manuales y libros de láminas más específicos que sirvieron como guía e inspiración para la elección de tipologías suburbanas, así como también para residencias veraniegas. Entre los que se difundían en el medio local, predominaban los

de dominación social; evitando las versiones más mecanicistas que suponen una relación homóloga entre cultura dominante y gusto dominante. Claude Grignon y Jean-Claude Passeron, Lo culto y lo popular. Miserabilismo y populismo en sociología y literatura. Ediciones Nuevas Visón, Buenos Aires, 1991.

${ }^{284}$ Cloquet, Louis; Traité d'architecture, Baudry et cue, s/d, 1898 ; Guadet, Julien, Elements et théorie de l'architecture, Editeur L.C.M., Paris, 1909.

285 Claudia Schmidt, "Mirada y recepción de las principales teorías y libros de imágenes. Algunos conceptos acerca de la tratadistica de arquitectura en Argentina. 1820-1920.”, en Cuadernos de Crítica ${ }^{\circ}$ 58, IAA, 1995. 
de origen francés ${ }^{286}$ (que introducían, tanto tipologías francesas como inglesas, ya que estas últimas se entendían como especialmente adecuadas para el habitar extraurbano), le seguían los ingleses ${ }^{287}$, los italianos ${ }^{288}$, españoles ${ }^{289}$ y alemanes ${ }^{290}$.

De acuerdo, entonces a esta selección, podemos constatar que entre fines del siglo XIX y comienzos del XX, se establecían algunas consideraciones generales en relación a la vivienda suburbana. Estas señalaban la importancia de su carácter aislado, y su disposición sin vecinos próximos ni muros medianeros, en respuesta a la búsqueda de reposo, descanso del espíritu, la vida en libertad, que era, finalmente, la razón de ser de la residencia extraurbana. En una escala más concreta, se remarcaba el valor de las terrazas, las galerías y los bow-windows, que permitieran apreciar la naturaleza desde el confort del hogar. Por último, se sugería la incorporación de cuerpos salientes, ventanas que se adelantaran y que otorgaran al conjunto movimiento y variedad.

286 Colas, Luis, L'Habitation Basque, Moreau, s/d, 1927 ; Lambert, Th, Villas et petites constructions, Ch. Schmidt editeur, Paris, 1900 ; Le Village moderne, d'apres les projets des architectes français et étrangers. Habitations economiques. Constructions rurales, fermes, plans, etc. Ch. Massin editeur, París, 1915 ; Massin, Charles, Villas normandes et anglaises, Ch.Massin editeur, Paris, 1913 ; Schmid, Charles, Villas et Cottages des bords de la mer: façades. intérieurs, plans, s/d, 1910 ; Planat, Pierre, Campagne, villas \& chateaux. Bibliotheque de la construction moderne, habitation particuliers, Dujardin Editeur, Paris, 1907 y L'Architecture du litoral. Côte d'Azur. Librarie de la Construction Moderne, Paris ; Varin, Pierre Amédée, L'Architecture Pittoresque en Suisse ou coix de constrctions rustiques prises dans toutes les parties de la Suisse. Par A. Et E. Varin, A. Morel, París, 1873.

${ }^{287}$ Elder-Duncan, J. H, Country Cottages and Week-end Homes, Cassell and Company Limited, London, 1912; Payne, A. H, The Builders Practical Director. Plans, sections and elevations with detailed estimates, quantities \& prices, Liepzig and Dresden, London, 1859.

${ }^{288}$ Covazzoni, A; Il Villino, Casa Editrice d'Arte Bestetti \& Tumminelli, Milano, 1909; Mella, Edoardo, Elementi di Architettura Lombarda. Torino. Bocca. 1885.

${ }^{289}$ Falgás, Victor; Arquitectura Española. Villas y Chalets, s/d, 1924

${ }^{290}$ Wesser, Rudolf, Beiterage zur Bauwissenschaft, Verlag von Ernst Wasmuth, Berlin, 1903 

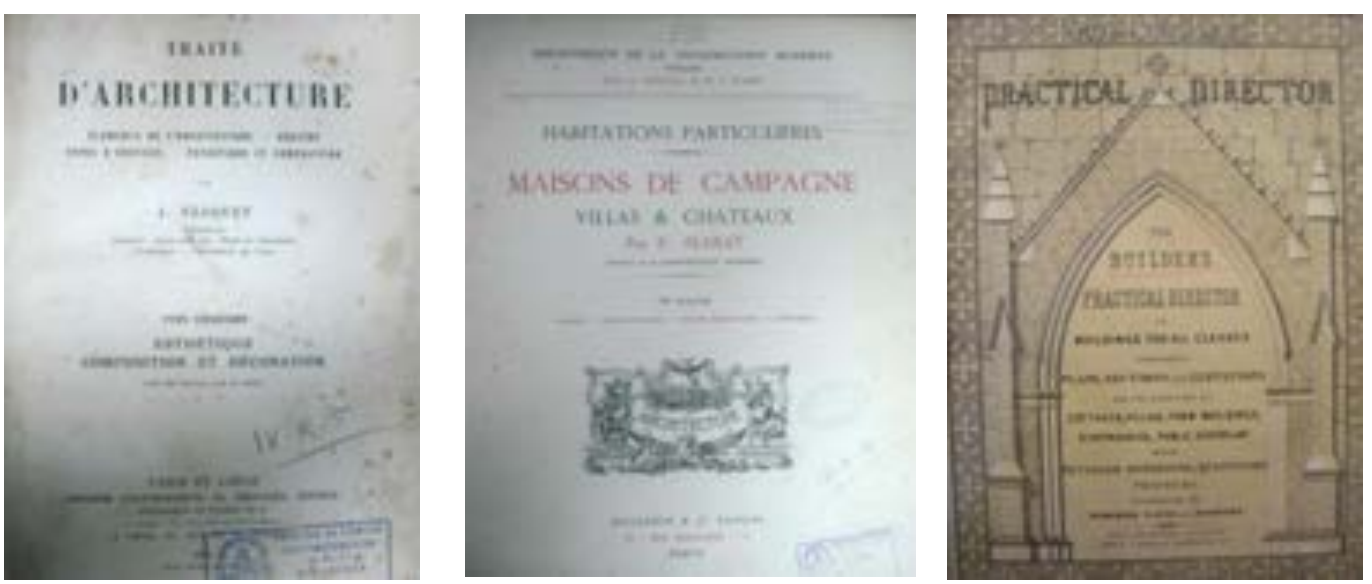

a. Cloquet, Louis; Traité d'architecture, Baudry et cue, s/d, 1898 ; Guadet, Julien, Elements et théorie de 1'architecture, Editeur L.C.M., Paris, 1909.

b. Planat, Pierre, Campagne, villas \& chateaux. Bibliotheque de la construction moderne, habitation particuliers, Dujardin Editeur, Paris, 1907.

c. Payne, A. H, The Builders Practical Director. Plans, sections and elevations with detailed estimates, quantities \& prices, Liepzig and Dresden, London, 1859.

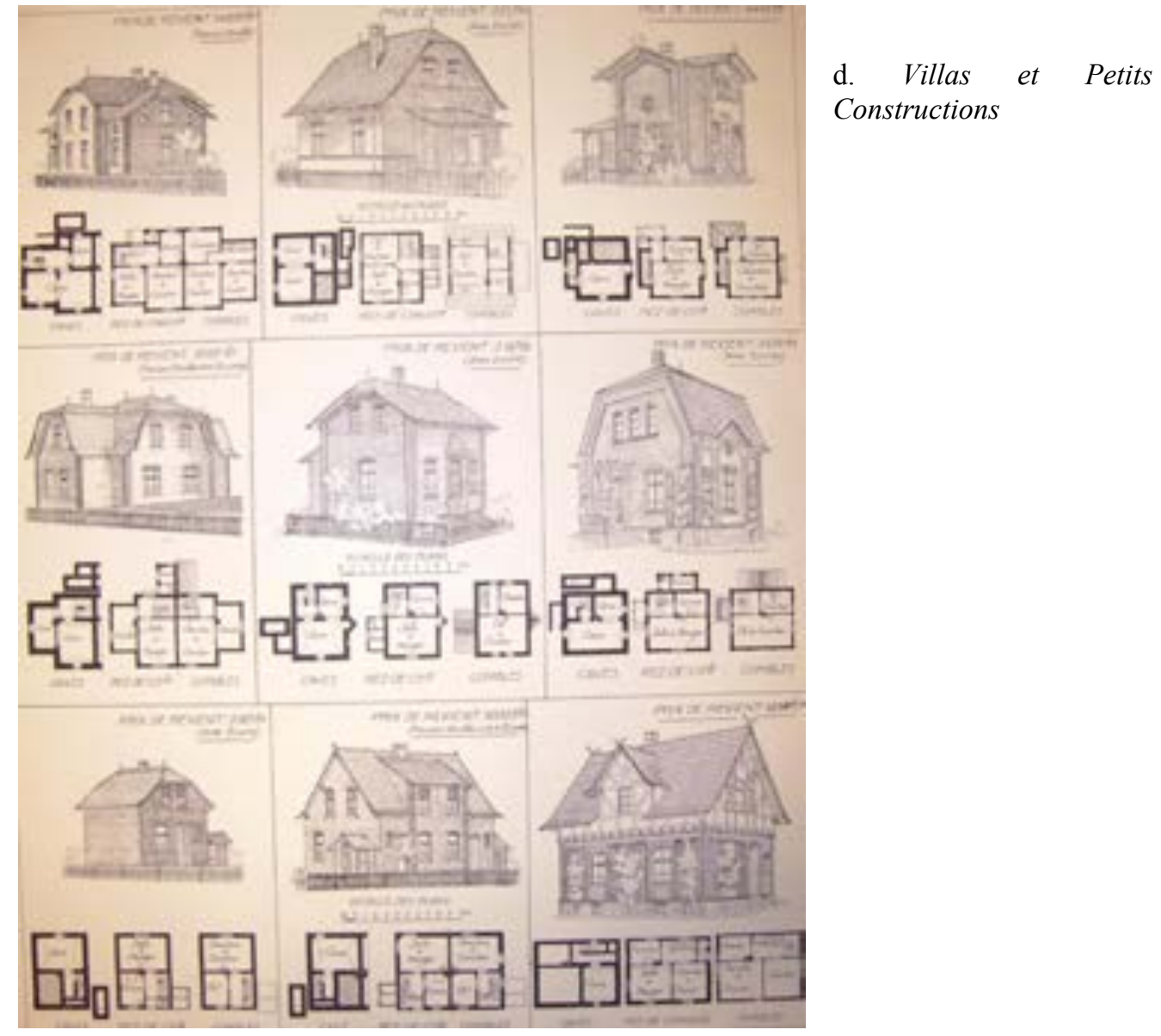


A partir de estas consideraciones generales, entre las opciones de configuración más conocidas, el Traité d'architecture de Luis Cloquet definía a su vez varios tipos. a- Villas: En general las villas - casa extraurbana o de reposo (maison de plaisance)eran construcciones utilizadas en verano, y en consecuencia su programa contenía principalmente habitaciones de estar y lugares de reposo en donde la etiqueta no tenía importancia. Dentro de esta categoría Cloquet reconoció dos tipos: las villas francesas conservaban la simetría y la búsqueda de la unidad, en contraposición a las villas flamencas que presentaban más movimiento y una disposición libre.

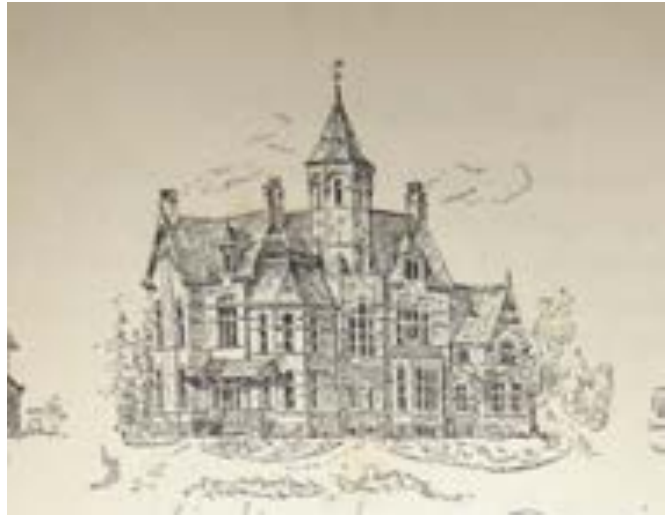

a. Maison de campagne à Flandre.

Fuente: Cloquet, L., Traité d'architecture. P. 67

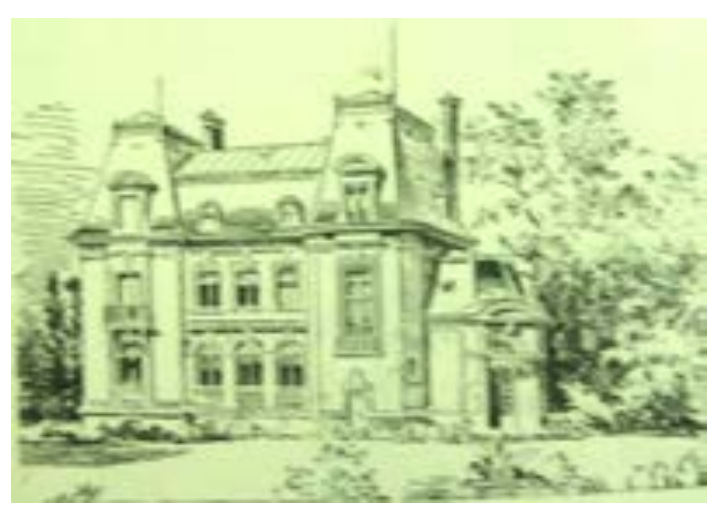

b. Villa française.

Fuente : Cloquet, L. Traité d'architecture P. 69

b- Casa de campo inglesa: su característica principal es la preocupación por el confort, a expensas de la regularidad. No existía en este tipo una búsqueda de monumentalidad ni de simetría. Los arquitectos ingleses se ocupaban de la vida privada, y su característica principal era la libertad. El aspecto general de las residencias no ofrecía un conjunto claro, era más bien una agregación de partes que se desarrollaban de forma extendida y se articulaban en torno al hall. Los espacios interiores eran casi siempre autónomos, y aun cuando se vincularan mediante vanos y arcadas, el carácter de cada uno se reafirmaba mediante vigas o escalones. Las grandes casas de campo poseían dos sectores bien definidos: de un lado las salas de recepción y del otro el sector de servicio. Los recursos formales más utilizados eran las techumbres múltiples de tejas con diversidad de formas y pendientes, los pan de bois aparentes (combinaciones de soportes verticales y horizontales, rellenas con planchas verticales de madera o mampostería), los balcones volados de madera, las chimeneas, los arcos enfatizando los portales y entradas y los contrafuertes de esquina. 


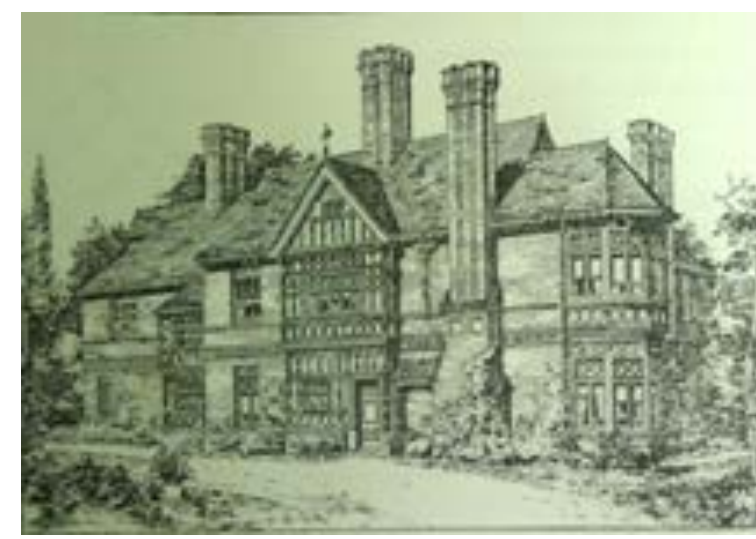

a. Manoir anglais.

Fuente: Cloquet, L.Traité d'architecture. P.74.

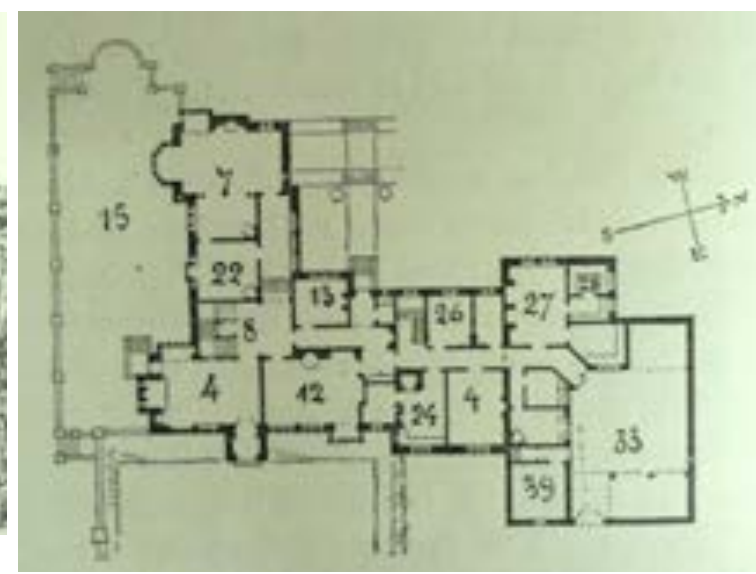

b. Barns dal Hill.

Fuente : Cloquet, L.Traité d'architecture P. 70

c- Cottage: Este tipo, como variante de la casa de campo inglesa, era fundamentalmente una construcción íntima y confortable. En conjunto se distinguía por su tono pintoresco y campestre

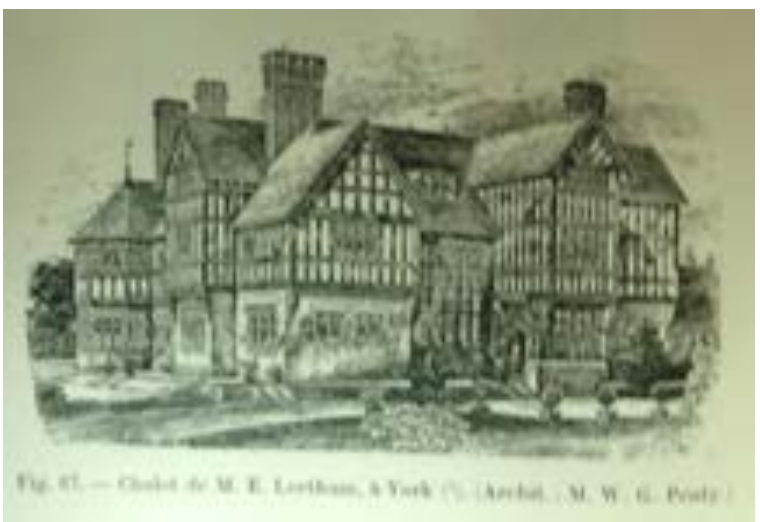

a. Chalet à York.

Fuente: Cloquet, L.Traité d'architecture. P. 72

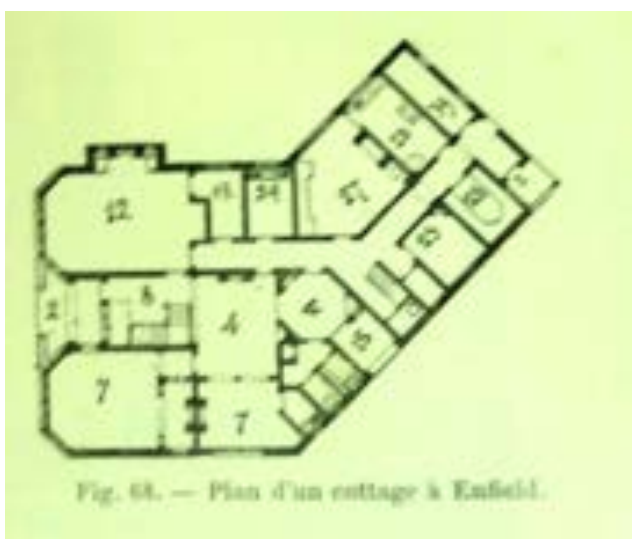

b. Cottage à Enfield.

Fuente: Cloquet, L.Traité d'architecture.P. 73

d- Cottage Americano: Se distinguían por su construcción maderera y por estar rodeados en tres o cuatro de sus lados por una galería. Por lo demás, la planta era simple, su programa respondía a las necesidades familiares y su forma en general era pintoresca. 


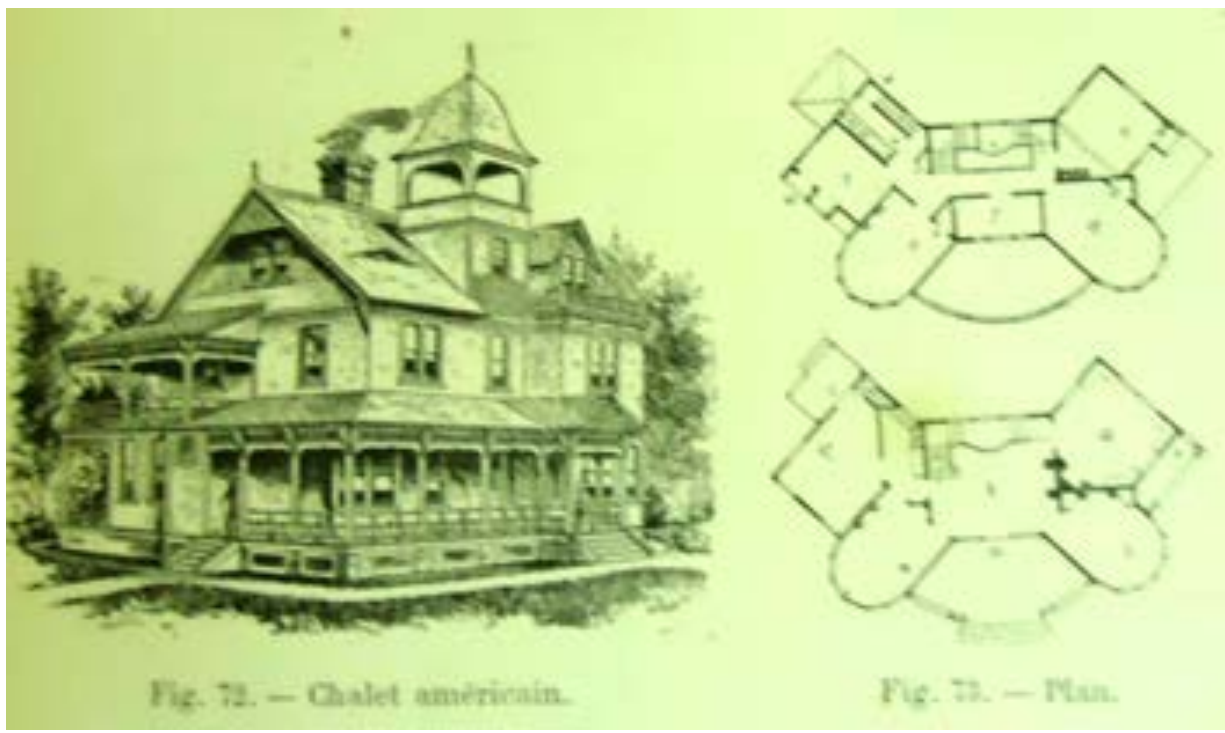

Chalet américain.

Fuente: Cloquet, L.Traité d'architecture. P. 74

e- Chalet: En este tipo predominaba el uso de madera, asociado particularmente a las construcciones de los Alpes. Se distinguían dos tipos, blockhaus (construcción de troncos superpuestos) y las construcciones en pan de bois. En cualquiera de las opciones el ordenamiento en planta era rectangular y muy sencillo.

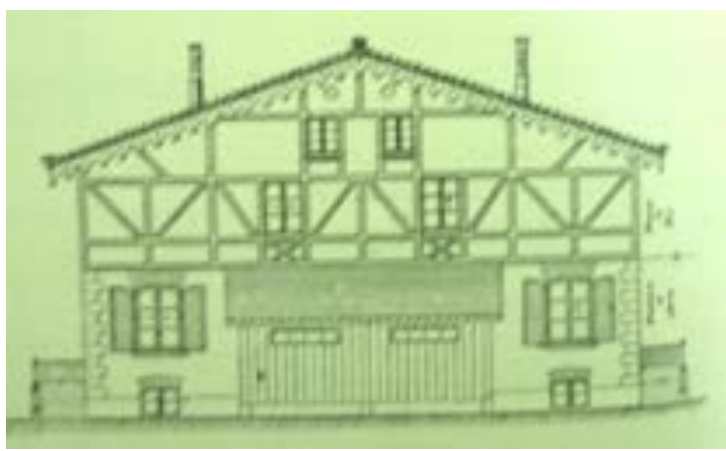

a. Chalet alsacien.

Fuente: Cloquet, L.Traité d'architecture. P. 86

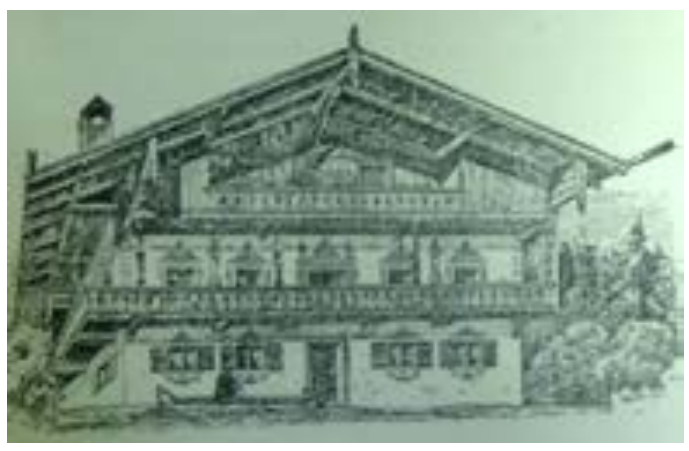

b. Chalet à Tegernese

Fuente: Cloquet, L.Traité d'architecture. P. 86

Hasta aquí se han presentado las opciones suburbanas como estaban definidas, fundamentalmente, en el contexto europeo. Los tipos organizados por los franceses: Cloquet, Planat, Colas, Lambert, Massin, Schmid o los ingleses: Elder-Duncan y Payne, entre otros, dan cuenta de este panorama hacia fines del siglo XIX. Veremos que la preeminencia de tipologías inglesas, francesas y del norte Europeo que hasta aquí señalamos, se asocia a una preeminencia de estos tipos en Argentina entre fines del siglo XIX y comienzos del XX. Mientras que, los tratados sobre arquitectura española y 
mediterránea marcan una etapa posterior, tanto en el panorama europeo, como en el local.

Entre tanto, en Estados Unidos los motivos suburbanos se organizaban a través de cottages y distribuciones pintorescas con fuertes asimetrías que permitían liberar la planta con volúmenes que se adelantaban y retrocedían siguiendo el tipo que Cloquet definió como la casa de campo inglesa. También, al igual que en esta última, los locales se concebían como partes separadas que se articulaban a través del hall como espacio de circulación. Pero, a diferencia de los tipos ingleses, en donde predominaban el uso del ladrillo y la piedra, entre mediados y fines del siglo XIX, en Norteamérica se desarrolló el estilo que se difundió como Styck Style, reconocible por su construcción en madera, a la vez que en planta se distinguía por la existencia de un porche y una galería que bordeaba todo el perímetro de la casa. Paulatinamente, a partir de 1880, el desarrollo de la vivienda suburbana daría lugar a un acercamiento del sector de servicio -que en las tipologías inglesas se mantenía como un núcleo alejado y bien definidoque comenzaba a vincularse más abiertamente con los salones de estar y a un nuevo tratamiento de los espacios interiores como un gran volumen que se articulaba más plásticamente.

Ya hacia fines del siglo XIX, en el Oeste americano, se desarrollaría un estilo característico del Sur de California, el Spanish Colonial Revival que tuvo lugar entre 1895 y $1930 .^{291}$

En tanto estas referencias cobraron importancia en un momento posterior al dominado por los modelos ingleses y franceses, se difundieron principalmente a través de revistas americanas que llegaban a la Argentina (Claudia Schmidt señala que fue hacia fines de

291 Desde la óptica de la historia cultural, algunos historiadores leyeron en la aceptación progresiva de los estilos californianos, particularmente el Mission Style, una creciente veneración hacia el pasado americano y la introducción de implicancias morales en la arquitectura que la relacionaban con la búsqueda de una vida simple y una existencia honesta. De los trabajos en relación a lo rústico surgen dos nombres pioneros, Albert Good, Park and Recreation Structures, US National Park Service, Princeton Architectural Press, New York, 1938 y Ellis Groben, Architectural trends, s/d, 1940. Más recientemente, pueden mencionarse a Harold Kirker, California's architectural frontier: style and tradition in the nineteenth century, Russell \& Russell, 1970; Karen Weitze, California's Mission Revival, Hennessey \& Ingalls, Los Angeles, 1984 y Jhon Mack Faragher; Bungalow and Ranch House, s/d, 2001. 
los años veinte que algunas bibliotecas institucionales comenzaron a recibir suscripciones regulares a revistas, además de obras técnicas modernas), o a través de la reproducción de obras escogidas que publicaban las revistas de edición local. ${ }^{292}$

En esta sintonía, podemos mencionar tres publicaciones clave: dos revistas marcaban la pauta del desarrollo de la arquitectura doméstica en el Oeste Norteamericano: California Arts \& Architecture y California Southland, y por último, vale la pena mencionar una obra de amplia difusión que reunió hacia fines de la década del veinte las tendencias predominantes del Spanish Colonial Revival, The Spanish house for America (1927) de Rexford Newcomb. En conjunto, estas referencias dieron lugar a lo que en nuestro país se conoció laxamente como "estilo californiano".

En cuanto al desarrollo arquitectónico que tuvo el Spanish Colonial Revival en su país de origen, se pueden reconocer dos etapas: la primera (1895-1910) llamada Mission Style, contenía referencias al pasado hispánico jesuítico y la segunda (19101930) se basaba principalmente en las referencias mediterráneas, incluyendo Italia, el Sur de España, pero también el norte de África y la cultura Azteca según habían sido combinados en México los elementos de la arquitectura española y la local. ${ }^{293}$ California Arts \& Architecture incluía en cada uno de sus números una nota dedicada a difundir la arquitectura de California y sus raíces, con títulos como "The inflluence of Adobe in California"; "The Unique charm of North Africa. Climate and Landscape Remind a Californian Home"; "American-Indian Architecture. California's Contribution to a New Style of Architecture", o "The Early California House. Blending Colonial and California Forms". ${ }^{294}$ Lo que en líneas generales se buscaba con estos

292 Claudia Schmidt, "Mirada y recepción de las principales teorías y libros de imágenes. Algunos aspectos acerca de la tratadística de arquitectura en Argentina. 1820-1920.” Op.cit.

293 Puede verse David Gebhard, “The Spanish Colonial Revival in Southern Califonia (1895-1930)”, en The Journal of the Society of Architectural Historians, vol 26, n 2 (mayo, 1967), pp. 131-147. o Rexford Newcomb, The Spanish House for America, J.B. Lippincott Company, s/d, 1927.

294 Jhon Byers, “The inflluence of Adobe in California”, en California Arts \& Architecture, Abril 1929. pp. 29-33; Mark Daniels, "The Unique charm of North Africa. Climate and Landscape Remind a Californian Home", California Arts \& Architecture, Julio 1929. pp. 19-21.; Hunter D. Scott, "AmericanIndian Architecture. California's Contribution to a New Style of Architecture", en California Arts \& Architecture, Agosto 1929. pp. 31-33; Roland E. Coate, “The Early California House. Blending Colonial and California Forms", en California Arts \& Architecture, Marzo 1929. pp. 21-23. 
textos era difundir e instalar este tipo de arquitectura a la que se entendía como eminentemente norteamericana, como lo expresaba una nota del año 1929,

“(..) in style it may be borrowed from other countries, but may have brought with it something which has made it adaptable to life in the new setting. For instance, the Normans brought to England their own style of dwelling and it grew in to so excellent an English house type as to seem indigenous to the English countryside." 295
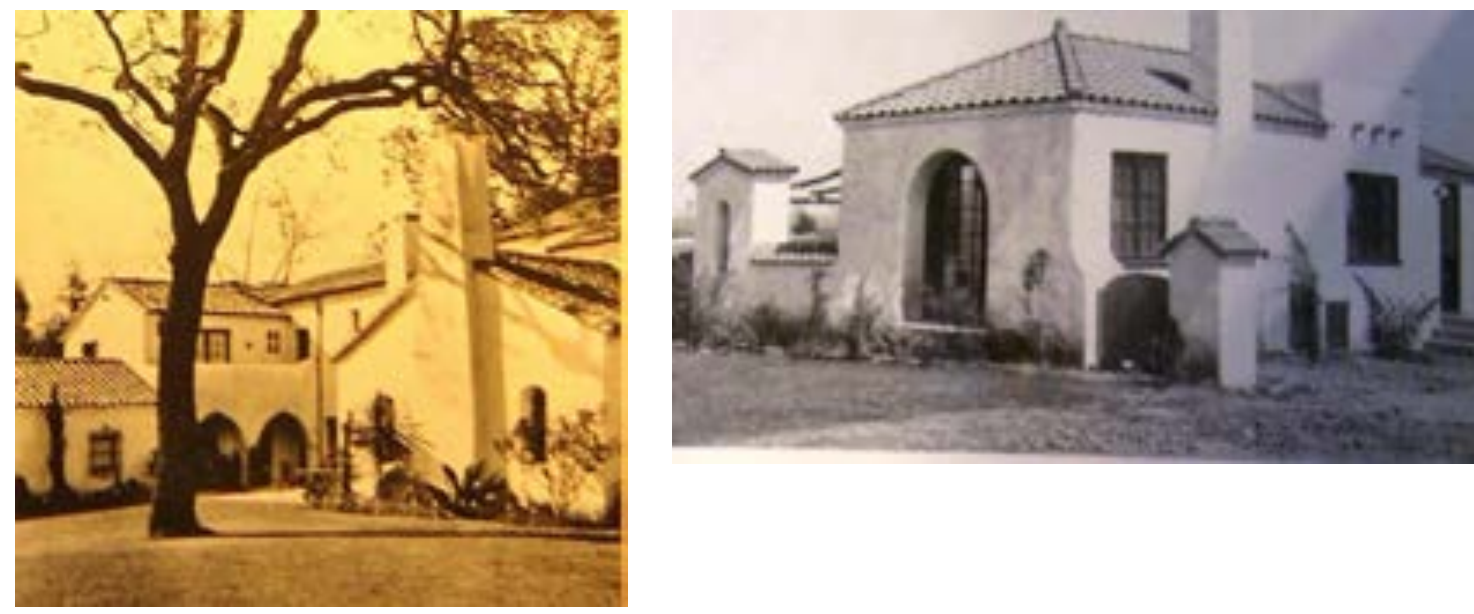

a. California Arts \&Architecture. Julio 1929. p. 29

b. Spanish House from America. P 40
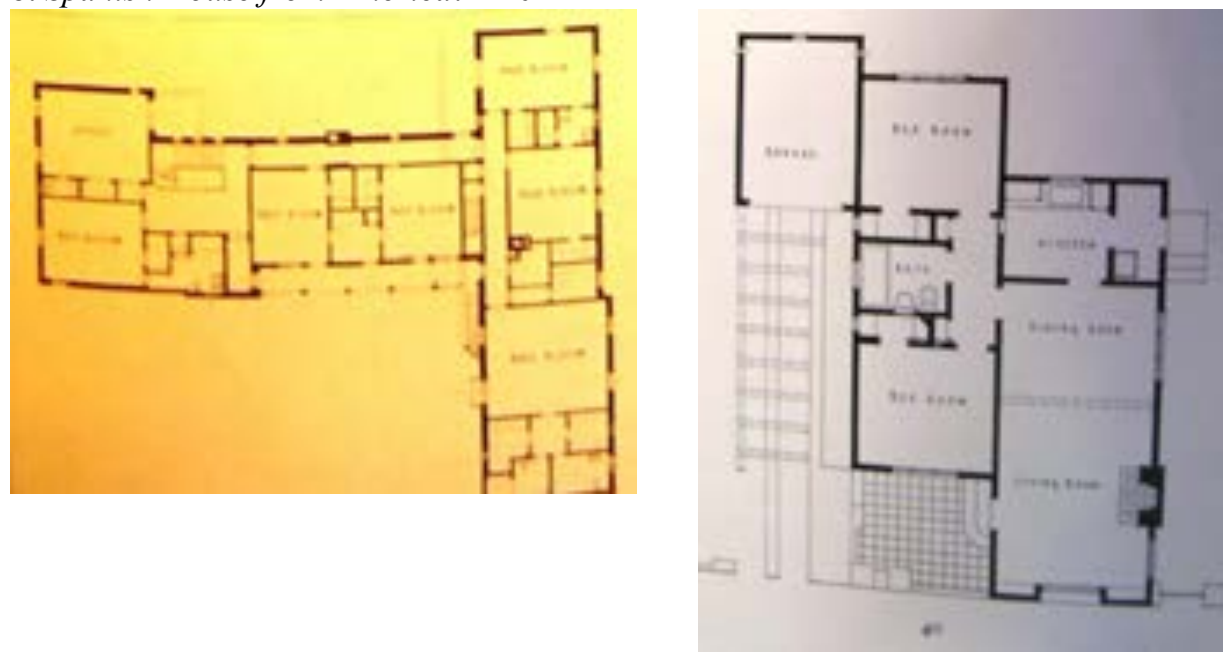

295 The early California House, op.cit. p.21 
En planta, estos tipos propiciaban una organización informal de los espacios concebidos como unidades en sí mismas y que funcionaban de forma independiente. David Gebhard ha mostrado los cruces que se establecieron entre los estilos de raíz hispánica, englobados dentro de los estilos pintorescos, y los movimientos de vanguardia que florecían paralelamente en la Costa Oeste. Concretamente, la apertura en el diseño de las plantas californianas, con su organización informal articulada a partir de una chimenea de ladrillo o de piedra puede compararse con las obras realizadas en el Oeste por arquitectos modernos de renombre como Frank Lloyd Wright, Rudolph Schindler o Richard Neutra. ${ }^{296}$ En volumetría, las residencias eran concebidas como un juego de volúmenes que de manera informal se esparcían sobre el terreno. Los detalles eran mínimos; de acuerdo a la intención de lograr una vivienda y una forma de vida simple, como lo proponía la misma revista que ya mencionamos. Para ello se utilizaban techos con suaves pendientes de teja española, importantes galerías provocaban juegos de luces y sombras y algún volumen en torre cortaba con la horizontalidad que, por lo demás, primaba en las composiciones. Los modelos eran "The simple cottages of England, the small houses of France, and the farm houses of Italy and Spain furnish us examples of modesty, simplicity and charm which have been a source of admiration to all lovers of beauty."297

Mientras que, en el Oeste Norteamericano el escenario puede resumirse a través de los modelos que presentamos, en la costa Este, el panorama era completamente diferente. A partir del análisis de la revista Neoyorkina, American Architect, se reconoce que los modelos para la habitación extraurbana perdían protagonismo frente a los desarrollos más novedosos que se desplegaban en la metrópolis, los rascacielos. En este contexto, las tipologías que se presentaban eran las que proliferaban en los estados del Norte de los Estados Unidos: cottages ingleses, neocolonial de New England y algunos motivos Georgian. En lo que nos concierne, no podemos decir que hayan comportado para el medio local una referencia significativa, en tanto estas imágenes difundían muchos de los estilos que ya se habían incorporado a través de la conexión europea.

\footnotetext{
${ }^{296}$ David Gebhard, “The Spanish Colonial Revival in Southern California (1895-1930)”, op.cit.

${ }^{297}$ Roy Kelley, "Simplicity. Simplicity is the Keynote of Beauty", en California Arts \& Architecture, octubre 1929. p. 36.
} 
Entrada la década del treinta, y durante la década del cuarenta el panorama que presentamos para la costa Oeste había variado, las imágenes más rústicas y los acabados más desprolijos dejaron lugar a superficies más lisas y limpias. Los fuertes contrastes volumétricos también daban paso a volumetrías más puras. En general, las referencias habían virado hacia el Este, ya no se encontraban en la España colonial del Sur, sino en la colonización Inglesa del Nor-Este (Massachussets, New England) que daban lugar al Georgian Americano.

Este estilo, originado en Inglaterra en el siglo XVIII se define fundamentalmente por extraer sus fuentes de la arquitectura clásica Greco-romana. A pesar de lo cual, en su pasaje a Estados Unidos, durante el período colonial, del repertorio amplio que el georgiano implicaba en Inglaterra, se escogieron los motivos más simples asociados a la arquitectura residencial: las villas suburbanas del palladianismo, o a las más modestas fachadas en ladrillo de las terrace-houses. ${ }^{298}$

Así, pasada la moda del Spanish Revival, hacia fines de los treinta y durante los años cuarenta, esta arquitectura, asociada al repertorio más tradicional de la Costa Este y de las raíces anglosajonas, se reformuló y se difundió a través de sus imágenes más comunes popularizadas por constructores y agentes inmobiliarios como sinónimo de buen gusto entre las clases medias. Formalmente, dentro del escenario norteamericano, sus características principales tuvieron que ver con el desarrollo de volúmenes puros. En contraposición a las corrientes pintoresquistas que habían dominado el período anterior, el Georgian buscaba recrear una imagen de orden, a través del uso de la simetría y la jerarquía, generalmente, a partir de la incorporación de pequeños frontis sobre los accesos y de la ubicación centralizada de estos últimos en la composición.

Ahora bien, una vez establecido este "mapa", veremos que no todas las tipologías ni los estilos desarrollados a escala internacional tuvieron lugar en los suburbios argentinos. Será el propósito de las próximas páginas caracterizar las líneas hegemónicas de la arquitectura residencial suburbana en el contexto local. Distinguir qué particularidades se desarrollaron y qué cuestiones se dejaron de lado.

Como se intenta demostrar a continuación, se dieron, por un lado, actitudes de hibridación sobre modelos pintoresquistas, inicialmente de origen europeo y

\footnotetext{
298 James Stevens Curl, Georgian Architecture, A David \& Charles Book, UK, 1996.
} 
posteriormente norteamericano. En este segundo momento, la definición tipológica de la vivienda unifamiliar se generó en el cruce entre las variantes pintorescas más modernas que provenían de Estados Unidos y la "casa cajón" como figura condensadora de las diferentes líneas que reaccionaban ante cualquier tipo de vivienda colectiva.

Para identificar e interpretar las propuestas en estudio y sus diferencias, apelamos a la idea de "postales suburbanas", planteada como una figura sugerente que alude a una imagen construida y convencionalizada, que busca dar cuenta de lo que Marcel Poête llamaba el "alma de la ciudad" y de la cual, sin embargo, no debemos olvidar que no es más que un fragmento seleccionado dentro de un universo más amplio. $^{299}$

\section{2.b Postales del suburbio}

Las primeras décadas del siglo XX

Algunos cottages ingleses, una villa italiana en Haedo y tres modelos de chalets económicos en Claypole, son algunas de las obras que recogen las principales tendencias en relación al panorama de la arquitectura suburbana, según surge de analizar los loteos promocionados en las primeras décadas del siglo XX.

El escenario de variedad arquitectónica que queda conformado por estas imágenes advierte sobre varias cuestiones, en primer lugar, sobre la existencia de un registro extenso de estilos y dimensiones -que se reconocería al menos hasta entrados los años treinta- con un denominador común, que es la correspondencia de estas imágenes dentro de un grupo amplio de la arquitectura pintoresquista. Y en segundo lugar, sobre la convivencia de diversas ideas de suburbio, lo que daba lugar a la ampliación de algunos núcleos suburbanos a sectores más vastos que los que tradicionalmente los habitaban en Argentina, y en consecuencia a este escenario de mezcla.

${ }^{299}$ Marcel Poête, Une vie de cité. Paris de sa naissance a nos jours. A. Picard, 1931. 
De acuerdo a lo que se publicaba en las revistas, se observa que, en general, entre las décadas del diez y del veinte las viviendas suburbanas desarrollaban programas extensos en dos o más niveles. Casi invariablemente se buscaba que fueran de perímetro libre, con techos inclinados, siguiendo la lógica pintoresca con volúmenes quebrados, bloques entrantes y salientes y techumbres con diferentes alturas.

A pesar de estos lineamientos genéricos, en los primeros años de la expansión, las revistas brindaban referencias heterogéneas. Aunque predominaban los motivos ingleses, coexistían con algunas villas y posteriormente con motivos mediterráneos $\mathrm{y}$, en otro registro, con tipologías compactas para la vivienda obrera. 
El suburbio en clave inglesa

Una descripción amplia de los modelos de origen británico en Argentina podría resumirse a través de la imagen de "serena dignidad", sintetizada en el modelo exento, de materiales nobles y volumetría quebrada que, como proponía Ruskin, generaba la fuerza y el carácter que el verdadero hogar debía tener. ${ }^{300}$

Los chalets de referencias británicas que mayoritariamente se desarrollaron en nuestro país pueden englobarse, fundamentalmente, bajo la definición del cottage propuesta por Cloquet: de construcción sencilla y una imagen en la que destaca la austeridad. Volumétricamente, en las obras de mayores dimensiones, prevalecieron los desarrollos horizontales y las imágenes simples del anglo-normando. Este estilo, retomaba en clave inglesa las referencias de las construcciones del Norte de Francia, particularmente de los centros vacacionales de la alta sociedad europea, como Biarritz o Trouville sur Mer, que desde fines del siglo XIX deslumbraban a las elites porteñas. Así, predominaban las construcciones de carácter fuertemente tectónico, con plantas bajas más pesadas, desarrolladas en ladrillo (o, eventualmente, en piedra cuando las obras se localizaban, por ejemplo, en Mar del Plata o Córdoba) y niveles superiores en falso pan de bois, como se puede ver en el ejemplo de un chalet en el Barrio Parque Aguirre, o en la vivienda del arquitecto inglés Medhurst Thomas, publicada por Revista de Arquitectura (órgano de la Sociedad Central de Arquitectos y Centros de estudiantes de Arquitectura), en su número especial dedicado a las construcciones veraniegas. En menor medida, tampoco faltaron ocasiones particulares en las que aparecieran motivos más cultos como el Tudor, o referencias rurales, con tejados de gran pendiente y revoque rústico.

\footnotetext{
300 John Ruskin, Las sietes lámparas de la Arquitectura, Safín, Buenos Aires, 1955. (1ra edición 1865). P. 91.
} 

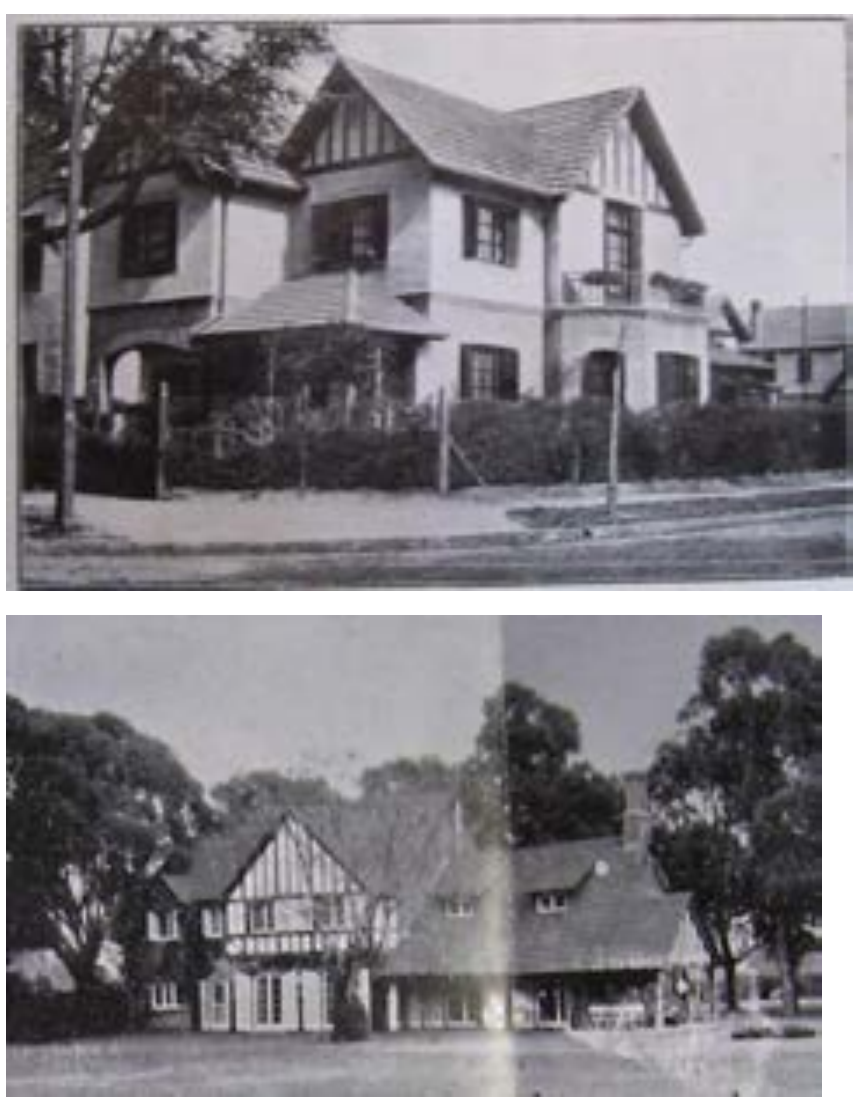

a. Chalet en el Barrio Parque Aguirre San Isidro, 1934

Fuente: prospecto de venta de lotes y una residencia en el Barrio Parque Aguirre. Carpeta Barrio Parque Aguirre, Archivo y Museo Histórico San Isidro.

b. Residencia "La Serena" del Ing. Pratti en el Barrio Parque Federico Alvear en San Isidro.

Fuente: Carpeta de Remates- Partido de San Isidro, Departamento de Investigación Histórica Cartográfica, Dirección de Geodesia, MOP, Pcia. de Buenos Aires.

En la planimetría se destacaban los locales más importantes a la calle y el área de servicio hacia la parte posterior de la vivienda, mientras que el hall que contiene la escalera funciona como articulación entre las dos áreas principales de la vivienda: los ambientes familiares y los de servicio.
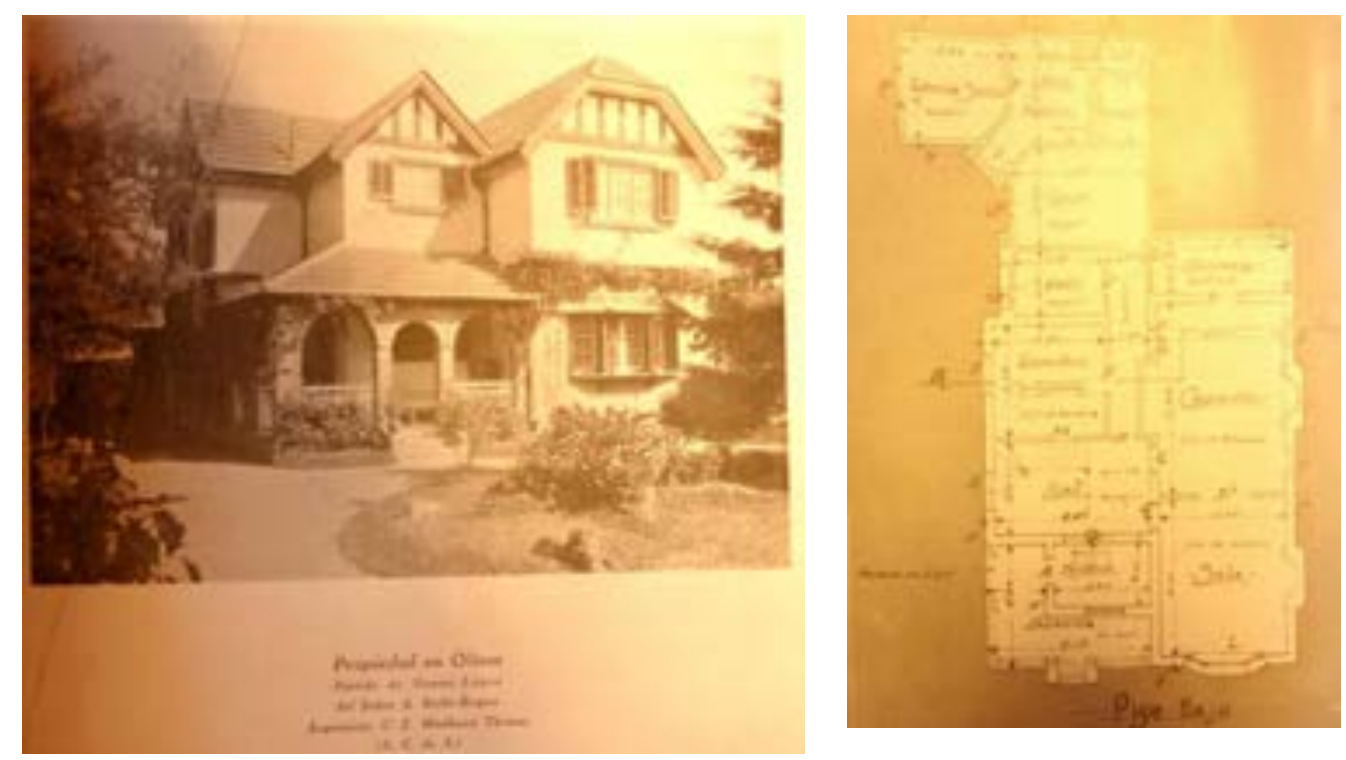

Casa particular en Olivos. Arquitecto Medhurst Thomas. Fuente: Revista de Arquitectura. 1929 
En otro registro, hay que destacar que los modelos británicos, además de dar forma a residencias medianas y grandes, en sus versiones más pequeñas se asociaron fuertemente a los modelos de vivienda obrera, producto de las representaciones sociales que tempranamente generaron los motivos introducidos por las compañías ferroviarias.

El suburbio para los trabajadores

Una postura diferente hacia el habitar suburbano, es la que, durante este primer período quedó expresada a través de la incorporación de tipologías compactas en las que se desarrollaba un programa reducido, con cocina, baño, sala y una, o dos habitaciones. En sus diferentes variantes, estos modelos eran presentados en libros y manuales como solución para la vivienda obrera y, promovidos en el medio local, bien dentro de esta misma lógica, por constructores y especuladores, o en el caso de las variantes compactas más amplias, se adoptaron, inicialmente, como modelos suburbanos para barrios de funcionarios o trabajadores jerárquicos de una empresa. Estos fueron los casos de las viviendas que la compañía Ferrocarriles del Sur construyó en Ranelagh (1913), las casas construidas para el personal jerárquico de la cervecería Quilmes (1920), o las viviendas del barrio Fisherton (1891-92) del Ferrocarril Central Argentino en Rosario; y se extendieron posteriormente a la construcción particular. Ejemplo de esto podría ser el chalet del Sr. Boesio construido en San Antonio de Padua.

Cuando se incorporaron tipologías más pequeñas, como las que, por ejemplo, Medhurst Thomas difundía desde revistas técnicas en los años veinte, o las que se propusieron para construir en el Barrio Parque Manuel Obligado en Claypole (1929), solo se aceptaban como solución a la vivienda popular o como motivo de inversión. ${ }^{301}$

\footnotetext{
${ }^{301} \mathrm{Al}$ respecto de esto, es ilustrativa una frase del arquitecto inglés, al referirse a la vivienda adosada "no recomiendo su adopción, excepto en casos en los que sea absolutamente necesario mantener los gastos lo más bajos posibles; en cuyo caso es la mejor solución, especialmente para el especulador.” Charles E. Medhurst Thomas, “Casas Baratas ?”, en Revista de Arquitectura, n 41, Junio 1924, pp. 135-138.
} 


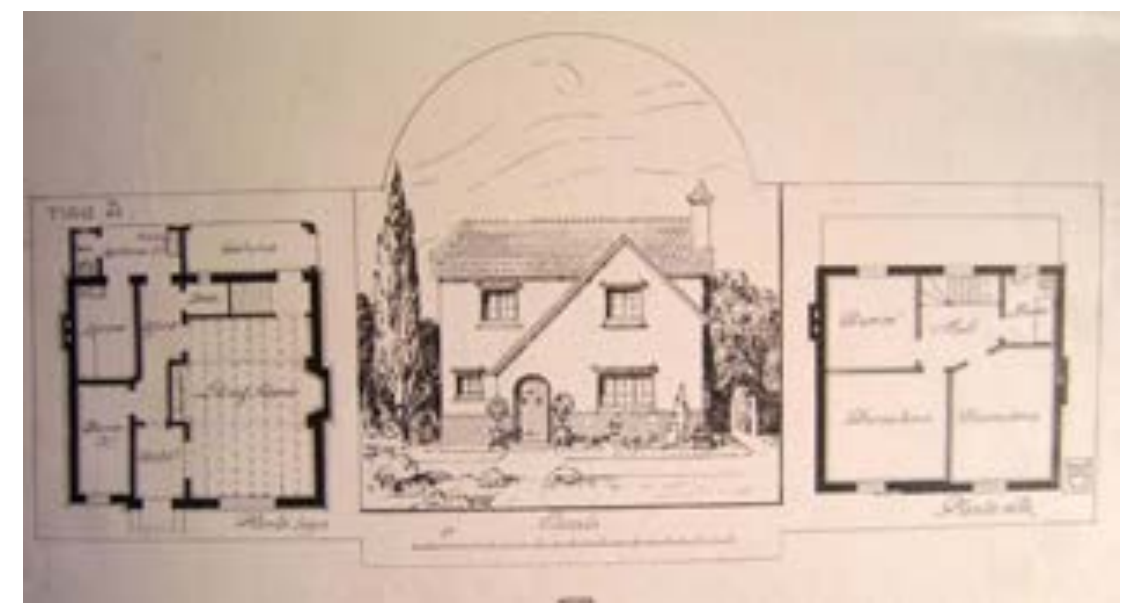

a y b. Prototipos de viviendas económicas. Arq. Medhurst Thomas

Fuente: "Casas Baratas ?" en Revista de Arquitectura, $\mathrm{n}^{\circ}$ 41, Junio 1924, pp. 135138.
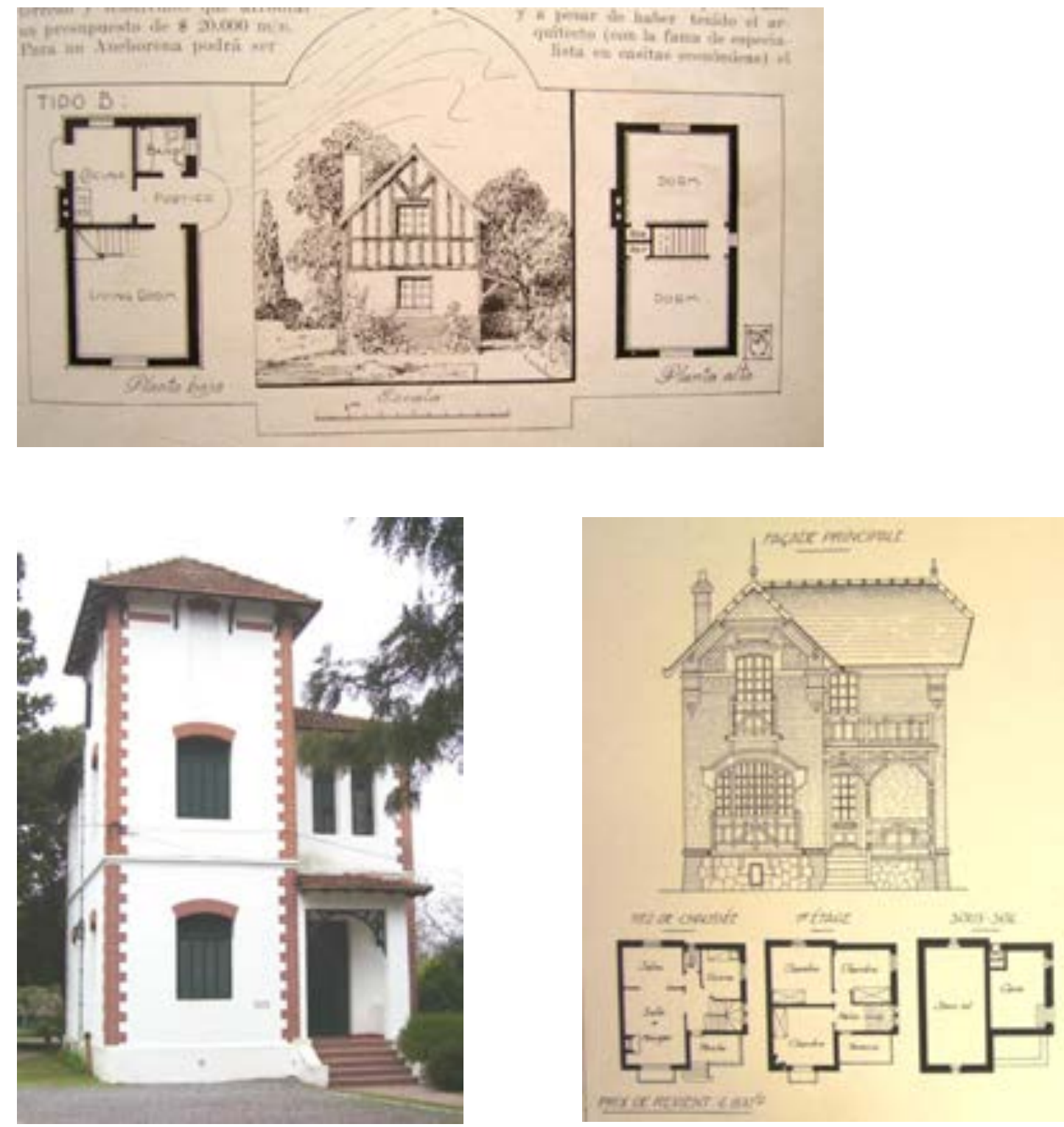

a. Vivienda construida por la Compañía Ferrocarril del Sur tal como permanece en la actualidad en el predio del Ranelagh Golf Club, Ranelagh. Arq. Raúl Pasman e Ing. Marcó del Pont. Fuente: Archivo de la autora b. Modelo de una vivienda económica.

Fuente: Lambert, Th, Villas et petites constructions, Ch. Schmidt editeur, Paris, 1900. 

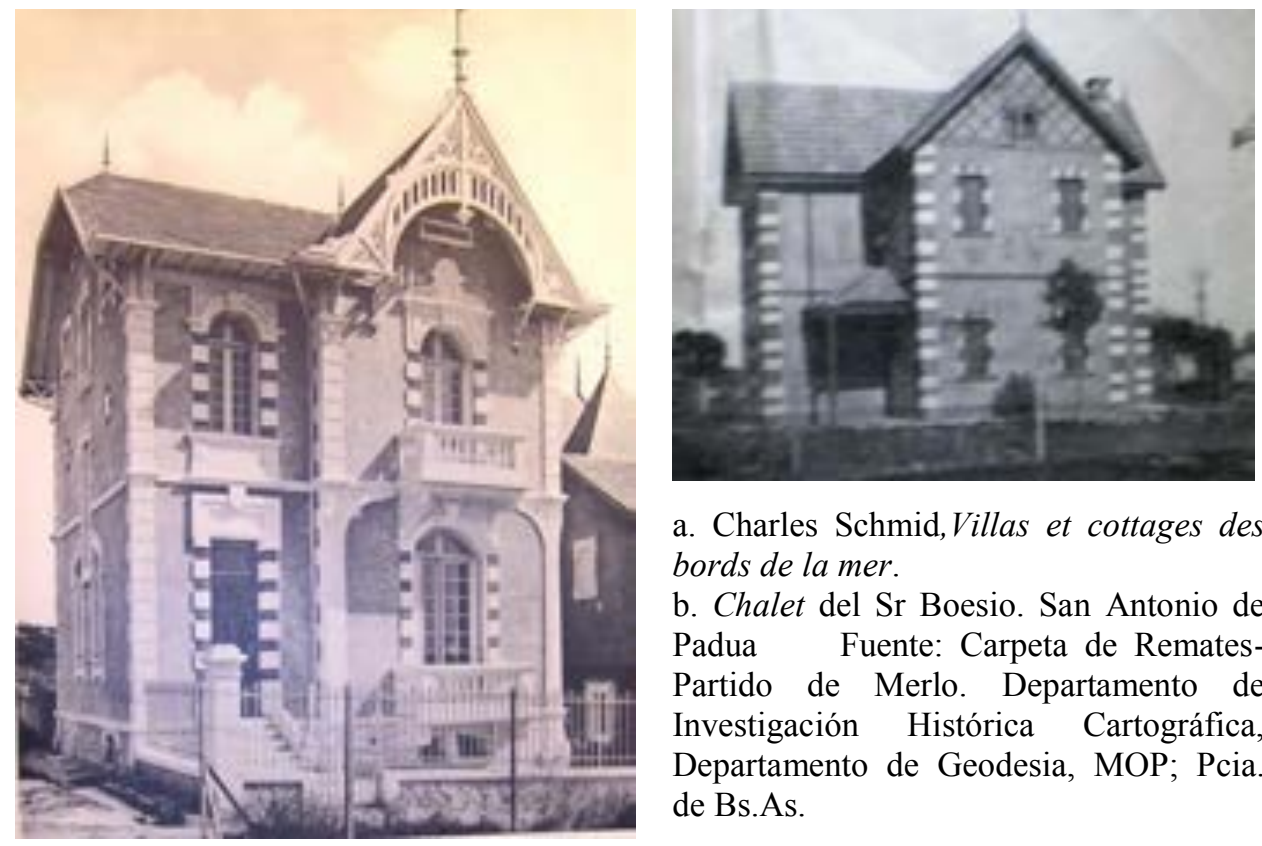

a. Charles Schmid, Villas et cottages des bords de la mer.

b. Chalet del Sr Boesio. San Antonio de Padua Fuente: Carpeta de RematesPartido de Merlo. Departamento de Investigación Histórica Cartográfica, Departamento de Geodesia, MOP; Pcia. de Bs.As.
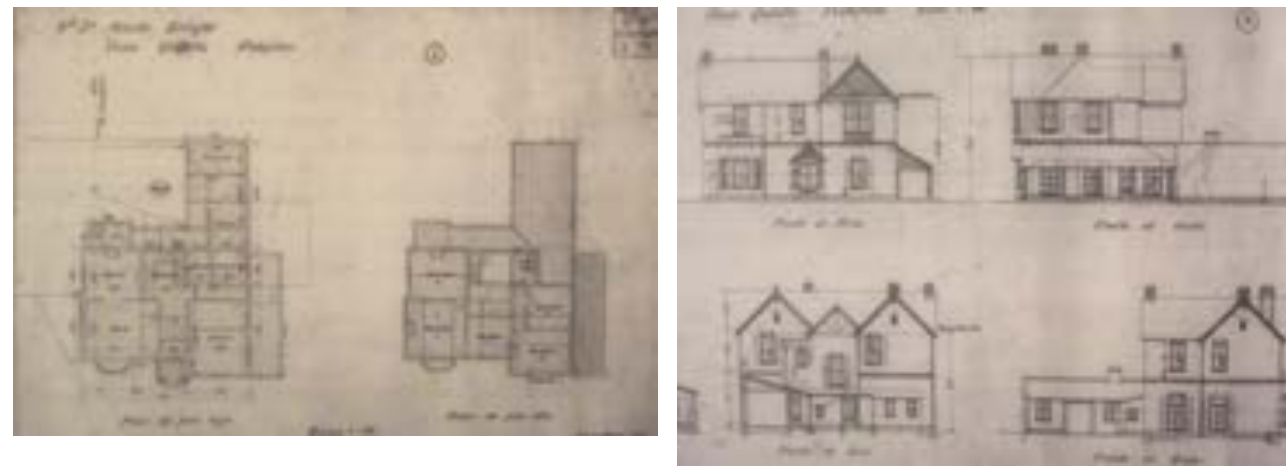

Viviendas en Fisherton

Archivo Follet, Fotos Fernando Williams

$\mathrm{Si}$ analizamos los tres modelos de chalets económicos que se promocionaban para construir en el Barrio Parque Manuel Obligado, cada unidad adoptaba una imagen particular. Las mismas, se encontraban en línea -como mencionamos- con las construcciones que, contemporáneamente, se levantaban en algunos emprendimientos residenciales asociados a las compañías ferroviarias. ${ }^{302}$ Pero, justamente, a diferencia

302 En Ranelagh, por ejemplo, los modelos construidos por la Compañía de Ferrocarril del Sur desarrollaban, siete años antes, modelos similares. Para profundizar sobre la urbanización de Ranelagh, 
de estos últimos, que tempranamente incorporaron adelantos modernos: compactación, distinción de los locales según su uso e introducción de servicios, en estos casos, si bien se deja de lado el ordenamiento más tradicional de la casa chorizo y se lee un esfuerzo por compactar el volumen de la vivienda, se mantiene cierta indiferenciación en las funciones de los locales, sobre todo los de estar. Posiblemente, con la intención de que todos los locales pudieran utilizarse como dormitorios, pensados como opciones para la vivienda popular o, como sala de estar o living en posibles versiones de fin de semana.

En los códigos lingüísticos de estos tres modelos se reconocían, laxamente, referencias a la tradición británica - pequeños porches, falsos pan de bois- o a la arquitectura neocolonial - rejas de hierro en voladizo, decoraciones sobre las aberturas y grandes superficies ciegas en revoque blanco-. Las primeras se inscriben en la línea de los modelos de viviendas económicas que Medhurst Thomas difundía como tipo ideal para introducir al espacio suburbano, mientras que las últimas -neocoloniales- marcan la pauta de la popularidad que adquirieron dichas imágenes en la década del veinte, principalmente porque su laxitud normativa y su rusticidad ofrecían una solución para ocultar la baja calidad de la mano de obra. ${ }^{303}$ En síntesis, se recurría a la utilización de algunos elementos que vagamente remitían a los modelos que se consolidaban en esos años y que mostraban las revistas y que, por sus características particulares, podían ser llevados a cabo en pequeñas construcciones, mediante el uso de técnicas sencillas y sin la participación de profesionales arquitectos.

ver, Ana Gómez Pintus, "Las dimensiones del pintoresquismo. Suburbios residenciales, arquitectura y prácticas profesionales. Buenos Aires, 1910-1940.” Op.cit

303 Ver, Jorge Liernur, "Neocolonial”, en Jorge Liernur y Fernando Aliata (dirs.), Diccionario de Arquitectura en la Argentina, Clarín, Buenos Aires, 2004. 


\section{Yodelos de chalets comomicos: adecuat- dos para edificar en este Barrio - Parous}

mosine a
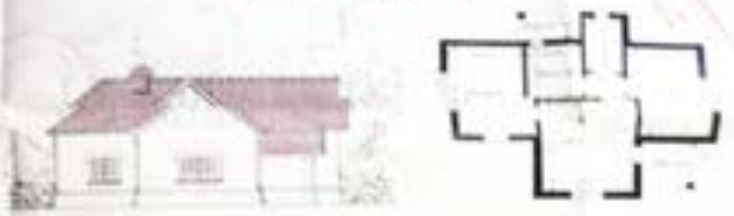

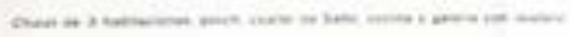

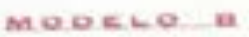

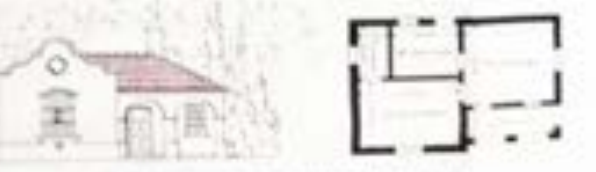

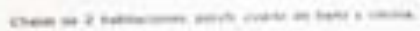

MoDKo a

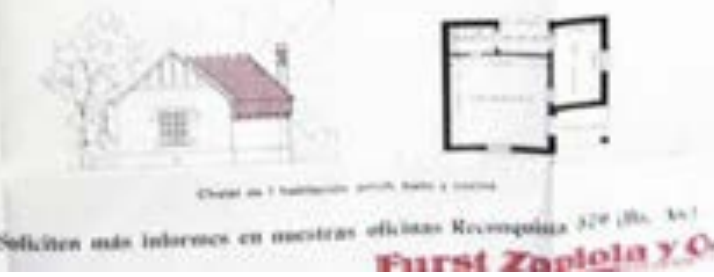

Modelos de chalets económicos para edificar en el Barrio Parque Manuel Obligado, Claypole.

Fuente: Carpeta de RematesPartido de Almirante Brown, Departamento de Investigación Histórica Cartográfica, Departamento de Geodesia, MOP; Pcia. de Bs.As.

En cuanto al grupo de imágenes variadas que se proponían para formar parte de una misma urbanización, podemos suponer que esta lógica estuvo guiada por la intención de eliminar todos aquellos rasgos que apuntaran al reconocimiento de las viviendas como tipos económicos, asociados tradicionalmente a las imágenes repetitivas y monótonas.

En efecto, durante los años veinte en Inglaterra los slogans más utilizados por las empresas constructoras dejaban en claro "todas las casas son distintas" o "no hay dos casas iguales". Evidentemente, allí también los promotores sabían que para venderse bien, la casa tenía que ser barata, pero debía además parecer de clase media. ${ }^{304}$

304 J, Burnett, A Social History of Housing 1815-1970. Newton Abbot: David and Charles. P. 264. Citado por Peter Hall, Ciudades del Mañana. Op.cit. p.85 
La renovación de los estilos pintorescos

Por último, nos encontramos con una villa italiana en Haedo. "Villa" era la denominación genérica que recibía en Italia la casa de campo, y desde esta óptica no definía ningún tipo específico. Sin embargo, este término se utilizó en Argentina -y de la misma forma se verifica en las revistas norteamericanas ya citadas- en relación a estéticas en las que predominaban los elementos del lenguaje italiano. Motivos con arcos de medio punto sobre columnas exentas, loggias, ventanas biforadas, torres y medallones aparecían tanto en los proyectos que el arquitecto Cremona realizaba para la revista El Arquitecto Constructor, como en los modelos que, más de una década antes, difundía el manual de arquitectura Il Villino, o que aparecían en las obras que bajo el nombre de villa publicaba la revista CACyA (Revista del Centro de Arquitectos Constructores y Afines) a comienzos de los años treinta. ${ }^{305}$ Véase por ejemplo la villa Genovesa en la ciudad de Mar del Plata, publicada en el n³5 de esta misma revista.

305 Ambas publicaciones, El Arquitecto Constructor (1907-1957) y CACyA (1927-1951) eran revistas prácticas de la construcción, que vinculaban arquitectos-constructores y constructores de obras con los demás gremios de la construcción. Llegaban a un público vasto formado por una nutrida clase media y proponían una oferta temática de mayor aceptación popular como era el art decó y los pintoresquismos. Ambas publicaciones fueron representativas de un conjunto amplio y heterogéneo de agentes compuesto por arquitectos con títulos extranjeros (sin validación en el país), los técnicos y los constructores de obras (maestros mayores) que cada vez eran más numerosos por la extensión del sistema de enseñanza técnica nacional. Ver, Silvia Cirvini, Nosotros los Arquitectos, op.cit. p 69. 

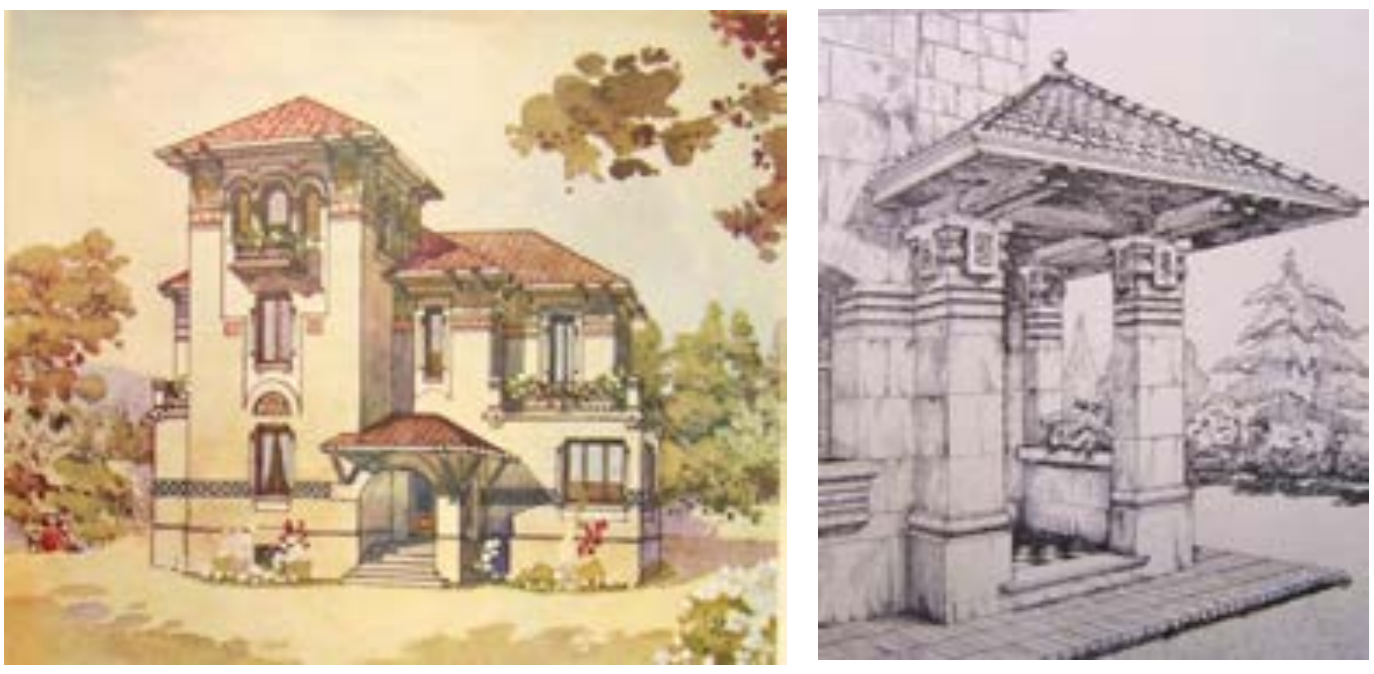

a. Modelo para una villa

Fuente: Covazzoni, A; Il Villino, Casa Editrice d'Arte Bestetti \& Tuminelli, Milano, 1909. Lámina 6

b. Modelo para entrada de un Chalet. Arq. Pedro Cremona.

Fuente: El arquitecto constructor. 1922
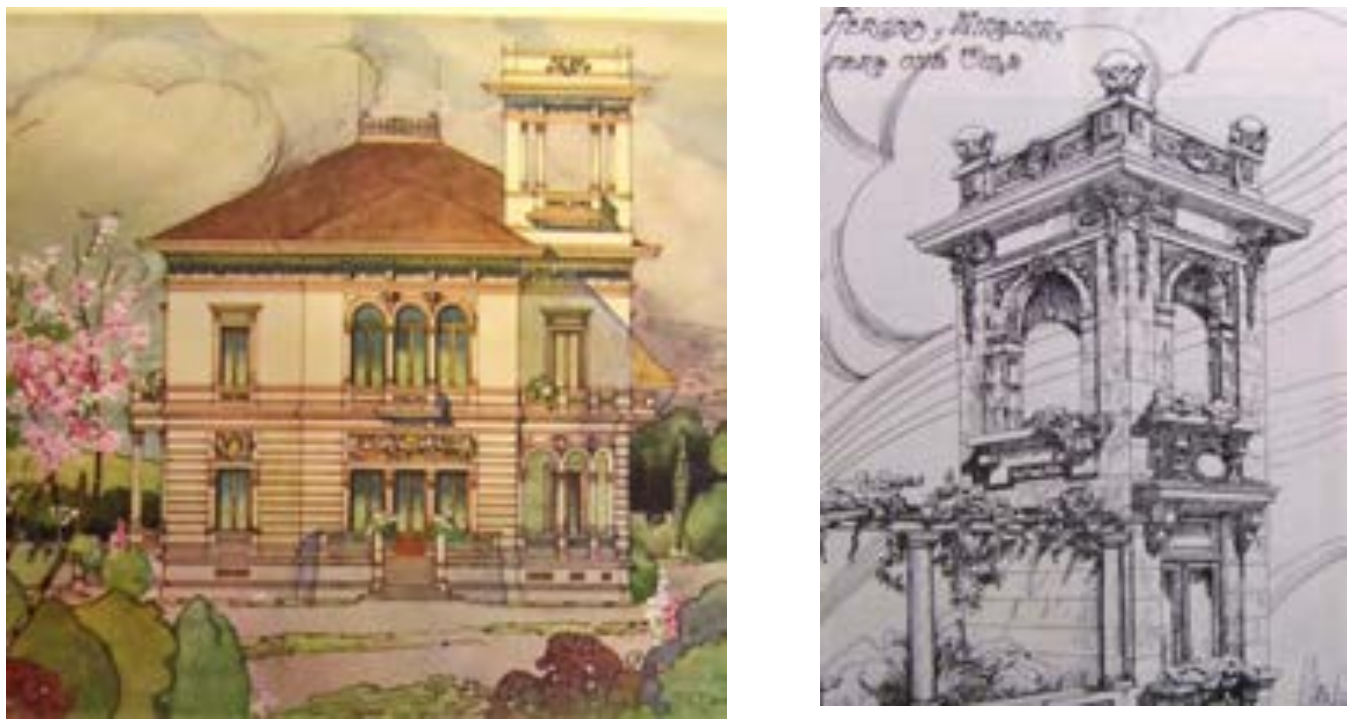

a. Modelo para una villa

Fuente: Covazzoni, A; Il Villino, Casa Editrice d'Arte Bestetti \& Tuminelli, Milano, 1909. Lámina 5

b. Modelo de Pérgola y Mirador para una Villa. Arq. Pedro Cremona

Fuente: El arquitecto constructor. 1922 

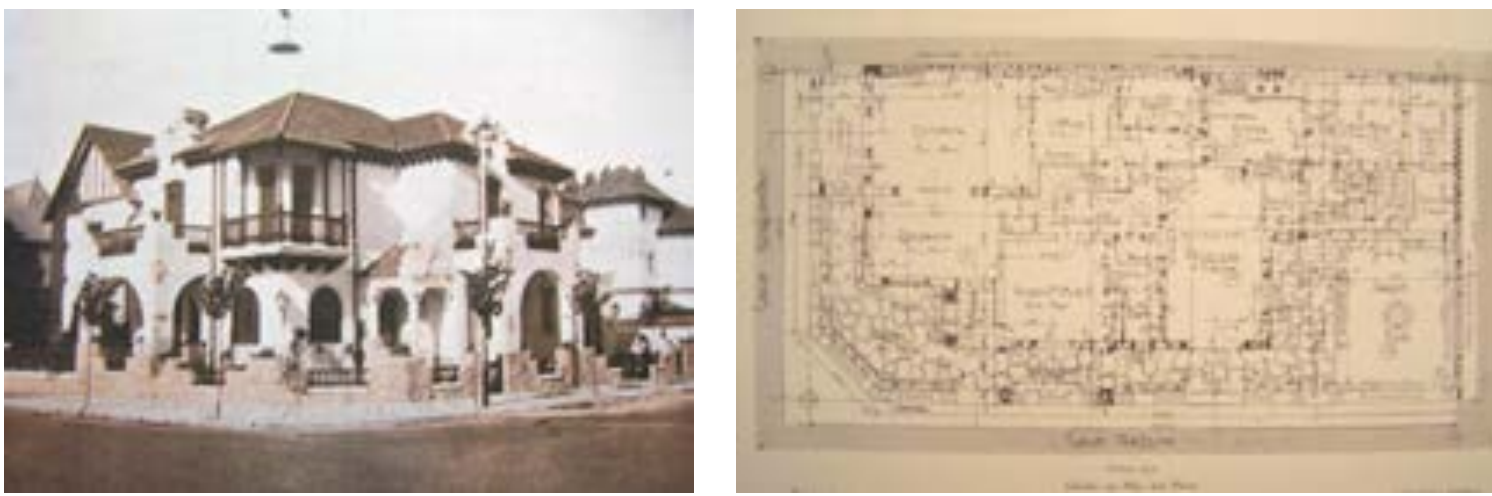

Villa Génova en Mar del Plata. Arqs. Bernardo y Roberto Fontán Fuente: $C A C y A, \mathrm{n}^{\mathrm{o}} 35$, abril de 1930. pp 327-329

En cuanto a la villa ubicada en Haedo, estaba organizada en dos niveles, con muros símil piedra, ventanas biforadas dentro de arcos de medio punto, loggias y torre con mirador, que recuerda las casas de campo de la zona del centro de Italia. ${ }^{306}$ Esta residencia de importantes dimensiones puede considerarse significativa del desplazamiento que venía produciéndose desde los años veinte de los estilos pintorescos del Norte de Europa hacia los estilos mediterráneos. ${ }^{307}$ Subrayemos que, en general el desplazamiento que señalamos hacia los estilos mediterráneos coincidió con una apertura los programas de la arquitectura suburbana en el plano social, ya que, a partir de la ampliación de las clases medias que se experimentó desde comienzos de los años veinte, una mayor proporción de la población pudo acceder a una vivienda en los suburbios residenciales o a pasar una temporada en alguno de los centros vacacionales existentes.

${ }^{306}$ Ver, Claudia Lazzaro, Rustic Country House to Refined Farmhouse: The Evolution and Migration of an Architectural Form, en The Journal of the Society of Architectural Historians, vol .44, $\mathrm{n}^{\circ} 4$ (Dic, 1985), pp.346-367. version on-line, Stable URL: http:/www.jstor.org/stable/990113 accessed $09 / 09 / 2008$

307 Este pasaje ha sido analizado por Anahí Ballent, ver Las huellas de la política. Vivienda, ciudad, peronismo en Buenos Aires, 1943-1955, op.cit. y “Country life: los nuevos paraísos, su historia y sus profetas", op.cit. 


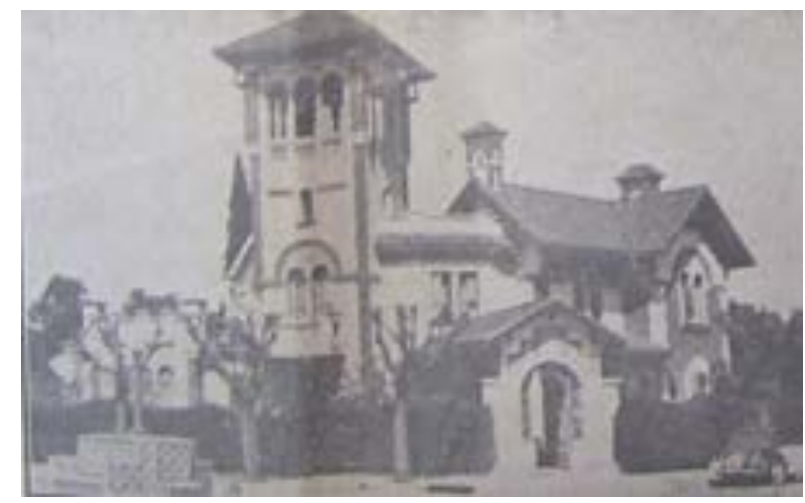

Villa en Haedo, frente a los lotes en venta del Barrio Parque Luis Güemes.

Fuente: Carpeta de Remates- Partido de Morón, Departamento de Investigación Histórica Cartográfica, Dirección de Geodesia, MOP, Pcia. de Bs. As.

Ante esta transformación de los suburbios, las viviendas de los sectores tradicionales, vinculados a las familias de elite, respondieron renovando las estéticas pintoresquistas, favoreciendo, particularmente, aquellas de origen mediterráneo que venían a renovar las variantes pintorescas tradicionales. No obstante, la incorporación de nuevas imágenes significó, para los pueblos suburbanos ya consolidados, y para las clases tradicionales, una actualización formal de los modelos arquitectónicos sobre la permanencia del método compositivo académico. Es decir que, para reproducir el sabor mediterráneo, profesionales y comitentes recurrían a fuentes históricas específicas, avalados por el conocimiento de los primeros que combinado con un núcleo de comitentes conocedor de los estilos vigentes, ya sea debido a viajes frecuentes o a la lectura de revistas de actualidad, dio como resultado estilos más puros, en cuanto a la correcta utilización de referencias historicistas, que las variantes californianas que surgían contemporáneamente y que abordaremos a continuación.

Las décadas del treinta y del cuarenta

Hacia los años treinta, los suburbios de la elite no sólo se desarrollarían en relación a las grandes residencias y a las imágenes aristocráticas. Desde fines de los años veinte, algunas familias de la "alta sociedad", particularmente las fracciones más jóvenes, fueron abandonando paulatinamente los modos más estrictos de refinamiento para abrazar prácticas y estilos de vida asociados a la modernidad. Dentro de este clima, el desplazamiento más importante se tradujo a través de la compactación de la vivienda, el alejamiento de los estilos considerados más severos -inglés o normando- y la 
adopción de otros considerados más "ligeros" como el californiano, las diversas variantes mediterráneas y hasta las imágenes más racionalistas. ${ }^{308}$

A partir de este momento, la arquitectura suburbana asumía mayor visibilidad. Dentro de los ámbitos profesionales, los programas suburbanos se habían incorporado a fines del siglo XIX como encargos singulares, pero la expansión territorial registrada en las primeras décadas del siglo $\mathrm{XX}$, junto al auge del turismo, fueron modificando paulatinamente su condición de singularidad. Por otra parte, los tratados y libros de láminas que se difundían en ámbitos disciplinares o entre constructores fueron perdiendo protagonismo frente al crecimiento de otras formas de difusión. Las revistas especializadas y aquellas otras dedicadas a un público más amplio -como sería Casas y Jardines, editada a partir de 1933- comenzaron a dedicar mayor espacio a los programas extraurbanos. En enero de 1929 la Revista de Arquitectura publicó un número extraordinario dedicado a las construcciones veraniegas. De manera semejante, la aparición en diciembre de 1930 de un número de Nuestra Arquitectura dedicado exclusivamente a la arquitectura suburbana es un interesante ejemplo que nos permite iluminar sobre las principales tendencias arquitectónicas que se consideraban adecuadas para incorporar a los ámbitos suburbanos. En el primer caso, la selección de obras mostraba chalets anglonormandos, residencias neo-coloniales, una villa italiana, un chalet vasco y una residencia mediterránea en Córdoba. En el segundo, los motivos también eran variados, aunque, a tono con el carácter más innovador de Nuestra Arquitectura, se incorporaban imágenes del "actual californiano". 309

En efecto, el panorama diverso que proponen las revistas daría cuenta de un estado de situación, que a grandes rasgos es el que presentamos en la sección anterior, tal como se reconocía hacia fines de la década del veinte. En oposición, el registro que conforman el conjunto de imágenes relevadas en los barrios parque y de fin de semana

308 “Casa en San Isidro", en Revista de Arquitectura, n ${ }^{\circ} 193$, enero 1937; "Pequeña casa de fin de semana", en Viviendas Argentinas, Tomo I, Editorial Contempora, Buenos Aires, 1940.

${ }^{309}$ La diferencia entre Revista de Arquitectura y Nuestra Arquitectura, es al la vez significativa de la oposición entre tradición y vanguardia que denotaban ambas publicaciones. Silvia Cirvini dice, que es posible advertir el recorrido zigzagueante que el tema de la modernidad describe entre las dos publicaciones más importantes del período. Revista de Arquitectura como portavoz del núcleo más ortodoxo de la profesión y Nuestra Arquitectura, como espacio alternativo de búsquedas renovadoras. Ver, Silvia Cirvini, Nosotros los Arquitectos, op.cit. p 139. 
en el segundo período que delimitamos, si bien reconoce matices particulares, pone en evidencia un paisaje de mayor homogeneidad formal en el que predomina, fuertemente, el californiano en sus diversas variantes.
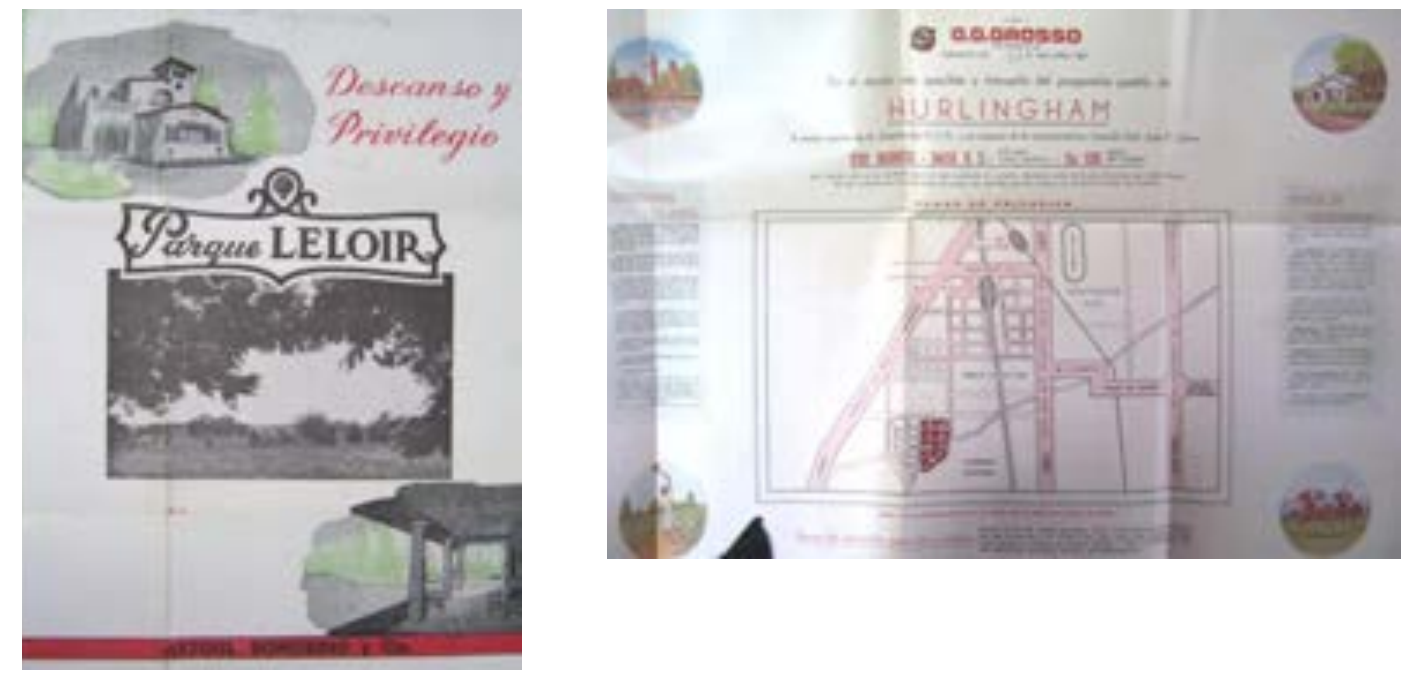

a. afiche de promoción del Parque Leloir, 1947. Fuente: Carpeta de Remates- Partido de Morón, Departamento de Investigación Histórica Cartográfica, Dirección de Geodesia, MOP, Pcia. de Bs. As.

b. afiche de promoción de un barrio parque en Hurlingham, 1947. Fuente: Carpeta de RematesPartido de Merlo, Departamento de Investigación Histórica Cartográfica, Dirección de Geodesia, MOP, Pcia. de Bs. As.

La modernización suburbana: Modernista o pintoresquista?

En un barrio parque de San Isidro proyectado por los arquitectos Moy, Castro y Madero en 1934 se incorporaban tipologías modernas, en relación con estéticas modernistas y pintoresquistas en el marco de un emprendimiento que adoptaba una actitud modernizadora, vinculando el habitar con "el goce pleno de los beneficios del aire, la luz y el sol". 310

El mismo grupo de profesionales proponía para la urbanización, una "casa moderna" y en el lote contiguo "una casa de estilo californiano". La primera, desarrollada en tres niveles, bien podría ser descripta en los términos que, de acuerdo a Francisco Liernur, permiten identificar a la Arquitectura Moderna en Argentina hasta 1939: sólida, de techos planos, de volúmenes puros claramente articulados, de mínimas

\footnotetext{
${ }^{310}$ Promoción del loteo del Barrio Parque Nelson en San Isidro, 1934, en Carpeta de Remates- Partido San Isidro, Departamento de Investigación Histórica Cartográfica, Dirección de Geodesia, MOP, Pcia. de Bs.As.
} 
indicaciones decorativas, discreta, prioritariamente muraria, opaca, con voluntad de permanencia y tendiente a descuidar la materialidad en favor de la abstracción. ${ }^{311}$ La segunda propuesta, se desarrollaba en un nivel y con un único volumen que sobresalía rompiendo la imagen predominantemente horizontal. En planta, las habitaciones se ordenaban de manera informal, produciendo una perspectiva quebrada, con tejado en pendiente, y en el cual se distinguían la galería y el porche con arcos de medio punto. ${ }^{312}$
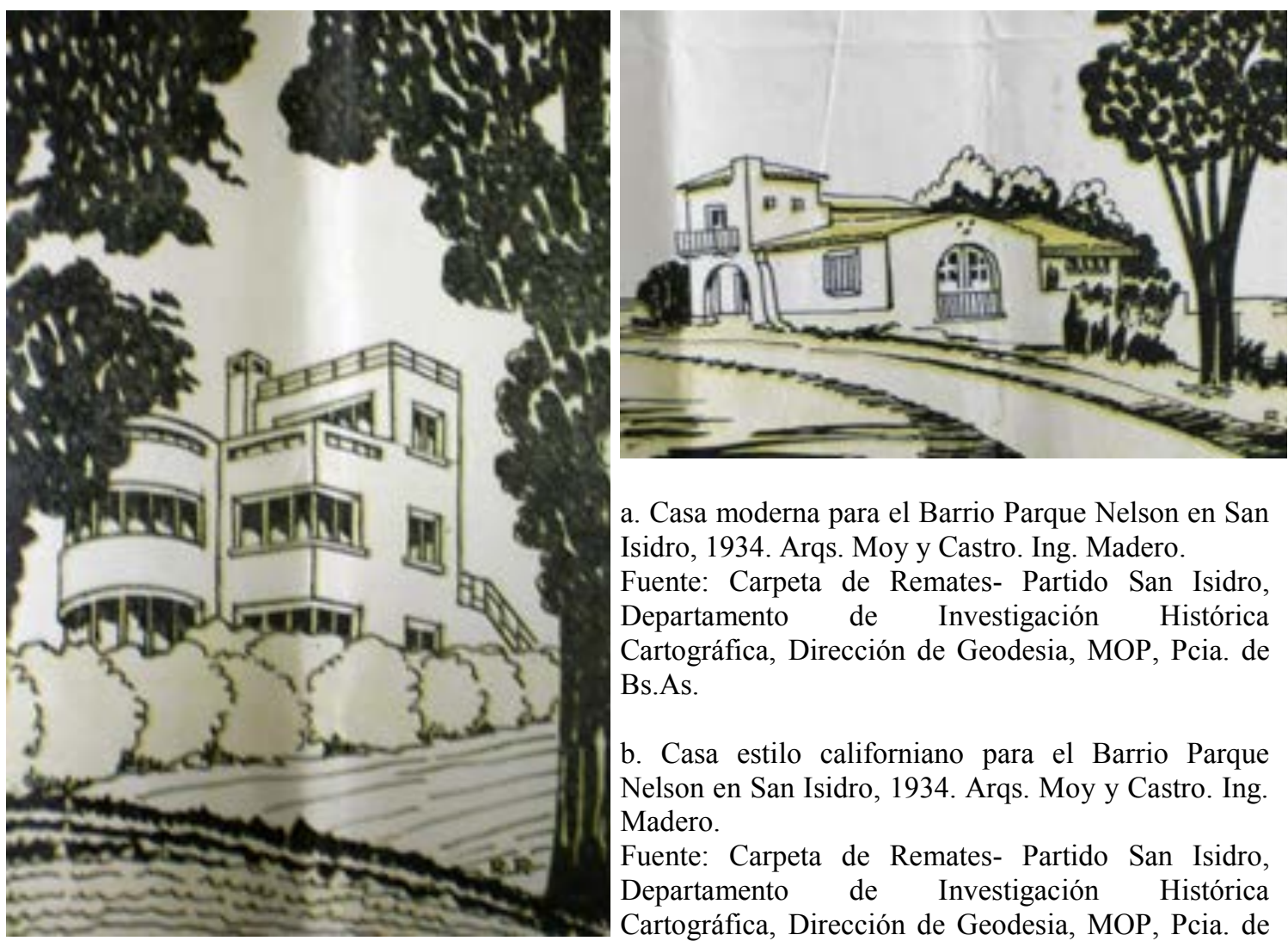

a. Casa moderna para el Barrio Parque Nelson en San Isidro, 1934. Arqs. Moy y Castro. Ing. Madero.

Fuente: Carpeta de Remates- Partido San Isidro, Departamento de Investigación Histórica Cartográfica, Dirección de Geodesia, MOP, Pcia. de Bs.As.

b. Casa estilo californiano para el Barrio Parque Nelson en San Isidro, 1934. Arqs. Moy y Castro. Ing. Madero.

Fuente: Carpeta de Remates- Partido San Isidro, Departamento de Investigación Histórica Cartográfica, Dirección de Geodesia, MOP, Pcia. de Bs.As.

De acuerdo al discurso que las acompañaba, estas imágenes propagaban los beneficios de la casa higiénica y moderna, no como consejo exclusivo de higienistas o reformadores sociales sino, como indicó Anahí Ballent, como parte de los cambios dentro de los gustos del habitar, renovadas maneras de experimentar y vivir los espacios domésticos. No sería la obligación la que impulsaría la transformación de la casa sino el gusto: el placer de "ser modernos" y de mostrarse como tales. En este

\footnotetext{
311 Francisco Liernur, Arquitectura en la Argentina del siglo XX. La construcción de la modernidad. Fondo Nacional de las Artes, Buenos Aires, 2008.

${ }^{312}$ Revista de Arquitectura, ${ }^{\circ}{ }^{\circ} 181$, enero 1936.
} 
sentido, la modernidad se imponía como un "estilo de vida" que implicaba llevar una vida dinámica y sobre todo más simple y auténtica. Este cambio en el paradigma de los modos de habitar y la modernización de la vivienda se difundió, inicialmente, asociado a la noción inglesa del home. De hecho, esta vinculación superaba ampliamente las fronteras de nuestro país, como lo demuestran el Traité $d$ Architecture de Cloquet, que ya había señalado este vínculo al referirse a la vivienda inglesa, o The English House de Hermann Muthesius, que también desarrolló esta idea cuando a comienzos del siglo XX buscaba difundir entre los profesionales alemanes la calidad que había alcanzado la arquitectura doméstica británica. ${ }^{313}$

Arquitectónicamente, este vínculo se traducía a través de una preocupación por los espacios interiores y el confort, en sintonía con lo que titulaba en uno de sus editoriales la revista Nuestra Arquitectura, en donde aseguraba que "el plan de la casa es lo que la hace moderna" ${ }^{\prime 314}$. De esta manera, se instalaba la posibilidad de introducir arquitecturas modernistas y algunas variantes rústicas sin incurrir en grandes contradicciones, ya que, desde esta óptica, ambas formaban parte del universo de la modernización. ${ }^{315}$

\footnotetext{
${ }^{313}$ Herman Muthesius, The English House, 1904.
}

En contraposición, en Estados Unidos, para la definición del Meditarranean Style durante la década del veinte, esta condición de introspección se asoció a las influencias árabes introducidas en Norteamérica por los colonizadores españoles. Ver, "The Unique Charm of North Africa." Op.cit. p.20

314 En relación a la idea de confort, puede verse La Casa. Historia de una idea, de Witold Rybczynski, en donde se traza la historia sobre los cambios y la evolución de la vivienda como espacio para el desarrollo de la familia y la vida privada, haciendo especial hincapié en la noción de confort. Rybczynski, Witold; La casa. Historia de una idea, Emecé, Buenos Aires, 1991 (1ra edición 1986); "El plan de la casa es lo que la hace moderna", en Nuestra Arquitectura, Abril 1931. pp. 844-848

315 La historiografía tradicional de la arquitectura moderna ha prestado escaso interés a las variantes de la arquitectura rústica y pintoresquista por considerarlas ajenas al proceso modernizador; sin embargo, ya en el año 1960 Peter Collins planteó la condición modernizadora de las arquitecturas pintorescas en cuanto ofrecieron una salida a las estrictas leyes del clasicismo, lo cual condujo a una modernización de la vivienda. A partir del estudio de la villa romántica suburbana mostró cómo los principios de irregularidad y asimetría del pintoresco no sólo se utilizaron para favorecer imágenes pictóricas en las vistas externas del edificio, sino que, además fueron la mejor herramienta para adoptar una amplia variedad de tamaños y formas en las habitaciones. Muchas de las características del diseño contemporáneo como la asimetría, la irregularidad de la planta y de la silueta, fueron, inicialmente, 
Así se experimenta en el Barrio Parque Nelson de San Isidro, y sin embargo, la convivencia de los modelos en este emprendimiento, no debe considerarse como representativo de lo que sucedía de manera más extendida en el ambiente suburbano. En un contexto general, serían las variantes californianas las que se repetirían de manera cada vez más frecuente.

La hegemonía del "californiano"

Como ya señalamos a inicios de este mismo Capítulo, la definición tipológica de la vivienda unifamiliar se generó en gran medida como reacción al inquilinato, al conventillo y a todo tipo de vivienda colectiva. Desde fines del siglo XIX y comienzos del XX las primeras propuestas de compactación de la vivienda se desarrollaron por una fuerte influencia de los tipos europeos que mencionamos en relación a viviendas mínimas del ferrocarril. En un primer momento, estas reflexiones que tomaban forma hacia el interior de la disciplina y entre los grupos que se consideraban afines al "problema de la vivienda"316, no se traducían en la construcción particular destinada a los sectores medios y populares. Como señala Francisco Liernur, los modelos compactos recién serían incorporados a la praxis particular en las intervenciones de la tercera década del siglo $\mathrm{XX} .^{317}$ Este momento sería decisivo en el viraje hacia las tipologías compactas. A partir de que se imponían en nuestro medio las llamadas

propias de las villas pintorescas. Ver, Peter Collins, Los ideales de la arquitectura moderna; su evolución (1750-1950), Gustavo Gilli, Barcelona, 1978. (1ra edición 1960)

${ }^{316}$ Los debates y reflexiones en torno al tema de la vivienda comenzaron a tomar forma a comienzos del siglo XX, y transitaron diferentes etapas, pasando desde un inicio hegemonizado por las ideas higienistas de la época, para incorporar posteriormente críticas de marcado tono moral y condenatorio. De este debate no sólo formaron parte los profesionales arquitectos, por el contrario, en un comienzo fueron médicos higienistas y abogados quienes propusieron las primeras soluciones, posteriormente se incorporarían los ingenieros, y sólo hacia mediados del veinte la intervención de los arquitectos se hizo más notoria, dando cuenta de que comenzaba a distinguirse como un tema significativo para la disciplina. Por último, cabe señalar que a lo largo de todo el período los grupos católicos se mantuvieron activos en relación a esta problemática.

${ }^{317}$ La Unión Popular Católica construyó en Barracas un barrio de viviendas de tipo compacto, la CNCB construyó el Barrio Caferata y Marcelo T. de Alvear. Ver, Jorge Liernur, “Casa Cajón”, en Jorge Liernur y Fernando Aliata (dirs.), Diccionario de Arquitectura en Argentina, Clarín, Buenos Aires, 2004. 
tradiciones del hogar anglosajón se hizo posible introducir en la habitación de los sectores medios-altos ámbitos de dimensiones pequeñas comprendidos dentro de la noción de modernización. ${ }^{318}$

Dentro de esta lógica, fue posible introducir en los suburbios de fin de semana más exclusivos las variantes del chalet californiano como la que presentamos en el Barrio Nelson de San Isidro, o como las que por ejemplo, el arquitecto Carlos Malbranche impuso, unos años antes, en el muy restrictivo e innovador Tortugas Country Club. ${ }^{319}$ Los modelos que proponía Malbranche se desarrollaron fundamentalmente en un nivel, con un programa que se reducía a las necesidades puramente familiares. La configuración en planta se ordenaba a partir de dos volúmenes desfasados que contenían, uno, las habitaciones de estar, y el otro, los dormitorios. Sólo se adicionaba una pérgola sobre uno de los laterales.

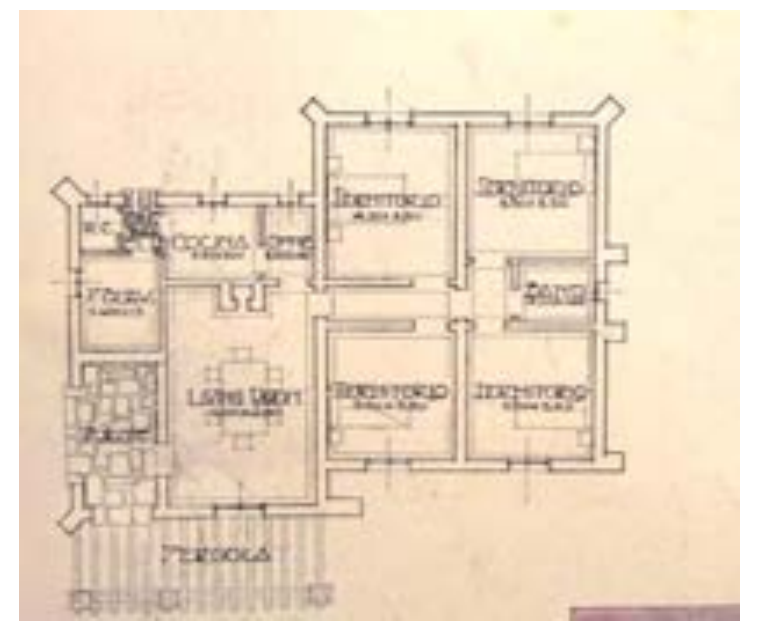

a $\mathrm{y}$ b. planta y fachadas de un proyecto de vivienda para el Tortugas Country Club. Arq. Carlos Malbranche.

Fuente: Revista Nuestra Arquitectura, diciembre 1930 y enero 1931, no 17 y 18. pp. 653-663 y $709-713$.

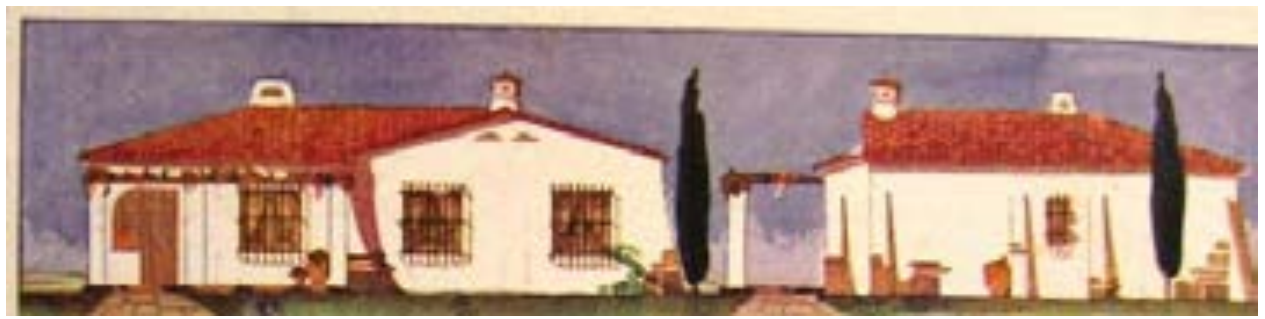

\footnotetext{
318 Jorge Liernur, “AAAdueño.2 amb.VA.Urq.”, op.cit.

${ }^{319}$ Sobre la obra de Calos Malbranche en el Tortugas Country Club ver, Nuestra Arquitectura, diciembre de 1930; Anahí Ballent, “Country life: los nuevos paraísos, su historia y sus profetas”, op.cit.
} 
Estos modelos fueron difundidos, inicialmente, en la obra de un importante número de profesionales, como parte de una actitud modernizante, acompañando una cierta flexibilización en los estilos arquitectónicos y una renovada idea de domesticidad dentro de la cual las referencias norteamericanas adquirían cada vez mayor protagonismo. $^{320}$

En este contexto, englobados dentro del denominado californiano se producían enorme cantidad de variantes. Las versiones más sofisticadas, se alejaban de las tipologías más compactas y se fundían muchas veces con las variantes mediterráneas, sobre todo con aquellas en las que prevalecía cierto sabor español. Tal como ilustra el ejemplo de una casa sevillana publicada en la revista Casas y Jardines, donde "este estilo muy común de la región sevillana, modificado, ha dado lugar al más conocido californiano."

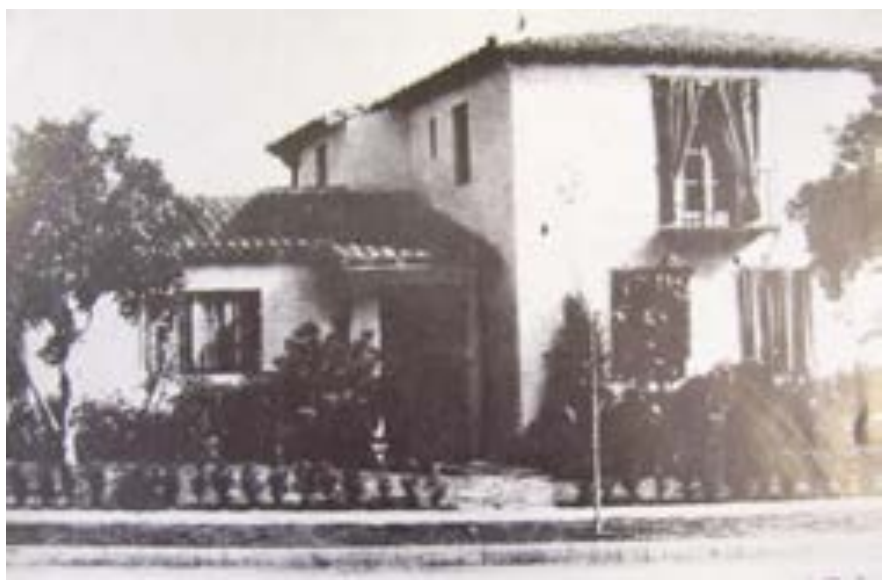

Casa sevillana de dos plantas.

Fuente: Revista Casas y jardines. Diciembre 1937

En este punto, cabe aclarar que el llamado "estilo californiano" y los "estilos mediterráneos" comparten el mismo origen en la arquitectura ibérica, lo cual, sumado a la laxitud formal y de referencias que podían incluir, hace compleja una definición acabada de las imágenes que cada uno de ellos podía generar. En líneas generales, podemos decir que ambos estilos se reconocen por la utilización de volúmenes

320 Es sintomático de un viraje en los modelos la cantidad de referencias al estilo californiano en Norteamérica que llenan las páginas de las revistas en la década de 1930; en donde por ejemplo se mostraba a "artista de la pantalla grande en su casa californiana en las colinas de Hollywood". 
quebrados, la apariencia fuertemente tectónica que le otorgan los pesados muros en revoque rústico blanco, en muchas oportunidades combinados con piedra en los basamentos, porches de entrada o galerías y por el uso de cubiertas de suaves pendientes en teja española. Si bien ambos estilos hacían uso de los mismos elementos, las referencias del estilo californiano llegaron hasta nosotros a través de Estados Unidos, según habían sido reformulados y simplificados en California, Arizona o Nuevo México los elementos de la arquitectura colonial de las misiones jesuíticas y los estilos españoles conocidos a través de las construcciones que permanecían en la región de México. Los estilos que aquí denominamos mediterráneos eran por lo general más complejos, en cuanto mantenían gran parte de la riqueza decorativa de los estilos andaluz, sevillano o de las villas italianas, incluyendo generalmente torres, loggias con arcos de medio punto, decoraciones con cerámicas y azulejos de inconfundible sabor morisco, que rara vez se asociaban a la simplicidad del californiano.

Paulatinamente, la heterogeneidad de tipologías que señalamos para las primeras décadas del siglo comenzaron a dar lugar a la preeminencia de tipos compactos $\mathrm{y}$, fundamentalmente, a aquel que en el medio local se conocería como "casa cajón". A pesar de que, como ya señalamos, no existía una vinculación entre la organización en planta y el lenguaje a través del cual se caracterizaban las fachadas, este pasaje tuvo lugar a medida que los motivos californianos iban ganando popularidad. Varias razones, no necesariamente relacionadas, se conjugaban para dar lugar a esta situación. Por un lado, la ya referida ampliación de los loteos suburbanos y la posibilidad de un sector cada vez más amplio de la población de acceder a la "casita" de recreo o de fin de semana. Y por otra parte, el desarrollo que se producía dentro del ámbito de la arquitectura y que buscaba dar respuesta a un tipo de vivienda mínima. En el cruce de estas dos cuestiones, esta tipología de costo reducido, desarrollada originalmente para acomodarse al lote urbano de 8,66 mts, se extendió al medio suburbano modificando su carácter introspectivo a través de la adición de un porche $\mathrm{y}$, ocasionalmente, una galería. En cuanto a su imagen, adoptó de acuerdo a la noción clásica de carácter $^{321}$, variantes pintorescas simples, del popular californiano.

321 Debe entenderse el concepto clásico de carácter como expresión exterior del edificio. Claudia Schmidt señala que desde la tradición de saberes clásica, un edificio debía representar aquello para lo que 

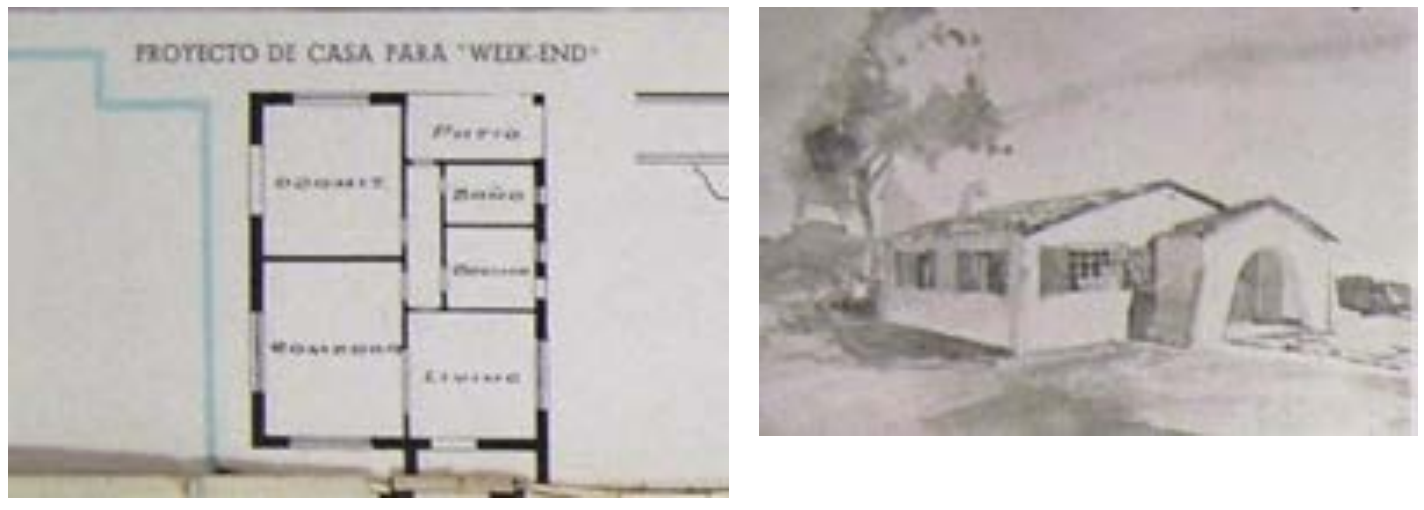

a y b. planta y volumetría de un proyecto para casa de week-end en un Barrio Parque en San Miguel, 1940.

Fuente: Carpeta de Remates- Partido de Morón, Departamento de Investigación Histórica Cartográfica, Dirección de Geodesia, MOP, Pcia. de Bs.As.

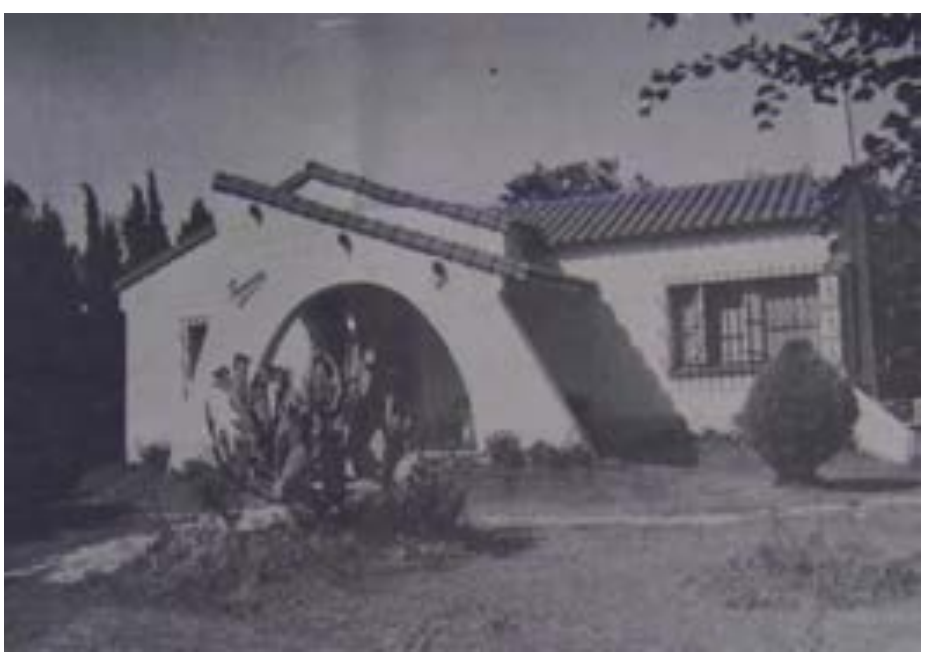

a. Chalet Fresinou, frente a los lotes en venta del Barrio Parque El Pericón, 1950.

Fuente: Carpeta de RematesPartido de Merlo, Departamento de Investigación Histórica Cartográfica, Dirección de Geodesia, MOP, Pcia. de Bs. As.

En esta versión simplificada se consolidó como unidad mínima durante la década del treinta. Por ejemplo, la Comisión Nacional de Casas Baratas (CNCB) presentaba una

estaba construido y su carácter, marcaría el rasgo que lo distingue. Esta teoría se desarrolló en el seno de la Ecole des Beaux Arts de París y a través de los textos de Quatremere de Quincy, quien señaló que el carácter arquitectónico debía expresar el destino del edificio a través del arte”.

Concretamente, en la práctica de la disciplina, entre mediados del siglo XIX y hasta que se instalan masivamente las estéticas modernas en arquitectura (alrededor de mediados del siglo XX), se entendía que los diferentes estilos englobados dentro del pintoresco eran los que mejor se adecuaban a las construcciones veraniegas o de recreo que se levantaban en ámbitos extraurbanos. Ver, "Carácter", en Antoine-Chrysostome Quatremera de Quincy, Dizzionario storico di architettura. Le voci teoriche. A cura di Valeria Farinati e Georges Teyssot, Venezia, Marsilio Editori, 1985. (Traducción Fernando Aliata y Claudia Schmidt, Diccionario de Arquitectura: voces teóricas, Buenos Aires, Nobuko, 2007) 
vivienda individual de planta compacta "tipo cajón" e imagen de chalet californiano en 1934; y en ese mismo año se inició la construcción del Barrio de Suboficiales Sargento Cabral en Campo de Mayo (1934-1937), cuyas unidades eran también, chalets californianos de planta compacta. ${ }^{322}$ Eventualmente, este modelo se consagró masivamente en la práctica de constructores y especuladores a lo largo de los años cuarenta encarnando el ideal de la vivienda suburbana. Ejemplos de esto son el modelo californiano que se ofrecía como alternativa para casa de week-end en un loteo de quintas en San Miguel (1940); el chalet californiano del Sr Fresinou que aparecía ilustrando el tipo de residencias que se levantaban frente a los lotes en venta en el nuevo Barrio Parque El Pericón (1950). Compartiendo la misma lógica se desplegaban imágenes de "chalecitos" cerca de los terrenos en venta en Paso del Rey (1947), en el Barrio Jardín sobre ruta ${ }^{\circ}$ 210, Est. Longchamps (1945); en el Barrio Parque La Teja en Merlo (1947), y en el Barrio Parque San José de Lomas de Zamora (1950). ${ }^{323}$ En este momento las imágenes se extendían entre un público amplio, como lo demuestra su aparición en revistas de amplia difusión que se vendían en quioscos de diarios y revistas, como Mi Ranchito ${ }^{324}$, y en localizaciones más distantes -no sólo física sino

322 Vivienda Individual proyectada por la CNCB, publicada en su órgano de difusión, La Habitación popular, 1934.

El Barrio de Suboficiales Sargento Cabral en Campo de Mayo, fue promovido por la Dirección General de Ingenieros del Ministerio de Guerra y proyectado por los arquitectos A. Prebisch, F. Bereterbide y C. Muzio y los ingenieros J.Rocca y J. Palazzo. Revista de Arquitectura, marzo de 1937.

323 Peter Ward describió un proceso similar por el cual el desarrollo de la casa individual, pequeña, económica, basada en la arquitectura de California de principios del siglo XX, llegó a constituirse en el ideal rústico suburbano de millones de canadienses: "it embodied a form of modern popular architecture, conferring the respectability, privacy and sense of territorial posesión sought by an aspiring middle class. For an increasing number of people it became their main symbol of home, the psychic fullfilment of the American Dream". Citado por Rosa Aboy, Viviendas para el pueblo. Espacio urbano y sociabilidad en el barrio Los Perales. 1946-1955. Fondo de Cultura Económica, Buenos Aires, 2005.

324 La revista Mi Ranchito era una publicación de difusión sobre temas relativos a la vivienda. A diferencia de Casas y Jardines, otra revista de difusión destinada a presentar ante el público general fundamentalmente femenino- las últimas tendencias en arquitectura y decoración del hogar; Mi Ranchito no sólo difundía tendencias en relación a la arquitectura y la decoración, sino que fundamentalmente proponía soluciones técnicas y constructivas, pensadas para ser resueltas por los propios usuarios. Lo 
también simbólicamente- de los centros hegemónicos que desde el punto de vista cultural originalmente habían sido sus cultores. Así, el estilo se difundía trasponiendo las condiciones que le habían dado origen -en el sentido de sus condiciones particulares de uso y producción.

En este punto, es pertinente problematizar dos cuestiones, por un lado, la idea de origen a partir de introducir, en perspectiva histórica, las relaciones múltiples y cambiantes que se producen en el contexto de la circulación de ideas e imágenes arquitectónicas entre "estilos arquitectónicos" y sus usos por parte de distintos sectores sociales. Y vinculado a esto, sobre la relación que se plantea entre la cultura de las clases populares y la de las clases dominantes.
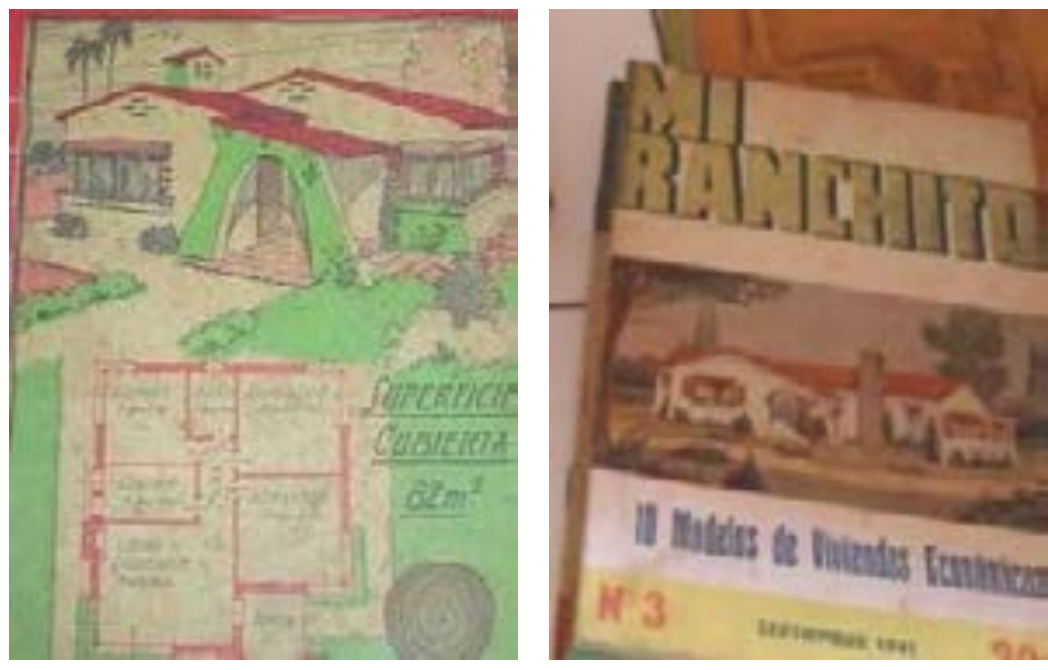

a y b. modelos de viviendas económicas tipo chalet californiano publicadas por la Revista Mi Ranchito, Número Aniversario 1950 y no 3 septiembre de 1941

En cuanto al primer problema, Pierre Bourdieu advierte sobre algunas características generales de los procesos de circulación de ideas. "Los intercambios internacionales están sometidos a un cierto numero de factores estructurales que son generadores de malentendidos. Primer factor: el hecho de que los textos circulan sin su contexto (...) que no importen con ellos el campo de producción (...) del cual son producto, y de que los receptores, estando ellos mismo insertos en un campo de producción diferente, los reinterpreten en función de la estructura del campo de recepción, es generador de formidables malentendidos..." En segundo lugar se trata de evitar algunas de las lecturas más esquemáticas que tienden a ver a la cultura de los sectores populares y 
medios como subalterna a la de las clases dominantes. Como copias o desviaciones de una supuesta cultura legítima. ${ }^{325}$

En relación a nuestra propia investigación podemos decir que las imágenes introducidas en nuestro país -vía Estados Unidos- dentro la amplia denominación de “estilo californiano", provenían -como se indicó más adelante- de la arquitectura popular de las misiones jesuíticas durante el período de la colonización californiana. Retomadas hacia fines del siglo XIX y comienzos del XX por un grupo de profesionales arquitectos fueron estilizadas y difundidas entre comitentes de los sectores medios-altos como parte de una creciente veneración hacia el pasado americano y la introducción de implicancias morales en la arquitectura que la relacionaban con la búsqueda de una vida simple y una existencia honesta.

Con este mismo sentido fueron retomados en Argentina por arquitectos de la elite como Carlos Malbranche que lo introducían en relación al habitar suburbano. En paralelo a su difusión en nuestro país, estas imágenes, fueron retomadas para dar respuesta a la vivienda de sectores más amplios, no ya por su referencia a las misiones jesuíticas, ni a la California Norteamericana, sino por su asociación a los modos de habitar de las clases acomodadas.

Desde otra perspectiva, este proceso de expansión es demostrativo de otras "virtudes" de los estilos rústicos y de su adecuación a las necesidades y posibilidades de los sectores medios. Al igual que, como mencionamos en relación al uso de las imágenes coloniales, aquí también se trataba de una cuestión de imagen o de carácter de las obras, independientemente de la organización de las plantas, podía utilizarse en construcciones económicas de una sola habitación o en grandes mansiones: era un conjunto de formas extraordinariamente maleable, que permitía producir obras de tamaños y costos tan diversos como diversos eran los estratos económicos y culturales de los amplios sectores medios.

${ }^{325}$ Pierre Bourdieu, Las condiciones sociales de la circulación de las ideas, en Intelectuales, política y poder (pp. 159-170) (A. Gutiérrez, Trad.). Buenos Aires: Eudeba/Universidad de Buenos Aires, 2000. (Trabajo original publicado en 1990) 
Como indicara Anahí Ballent, en paralelo a la popularización que registraban los modelos californianos, sus cultores iniciales en la Argentina -los sectores altos- los abandonaban en favor de opciones más refinadas. Dentro de este marco, se introducían en los suburbios estilos como el Georgian que aparece en el Golden Park (1949), los chalets "de líneas sencillas" que aparecen a modo ilustrativo en las publicidades del Barrio Parque Peluffo (1945), o algunas imágenes más exóticas, entre las que aparecía el bungalow. Estos nuevos motivos daban cuenta, ante todo, de la incorporación de nuevos referentes que remitían, a la creciente americanización y al cambio de referentes en esas latitudes y, por otro, a la reciente incorporación del Sur argentino como generador de nuevas referencias para los modelos extraurbanos que pretendían abandonar soluciones más extendidas o convencionales. ${ }^{326}$

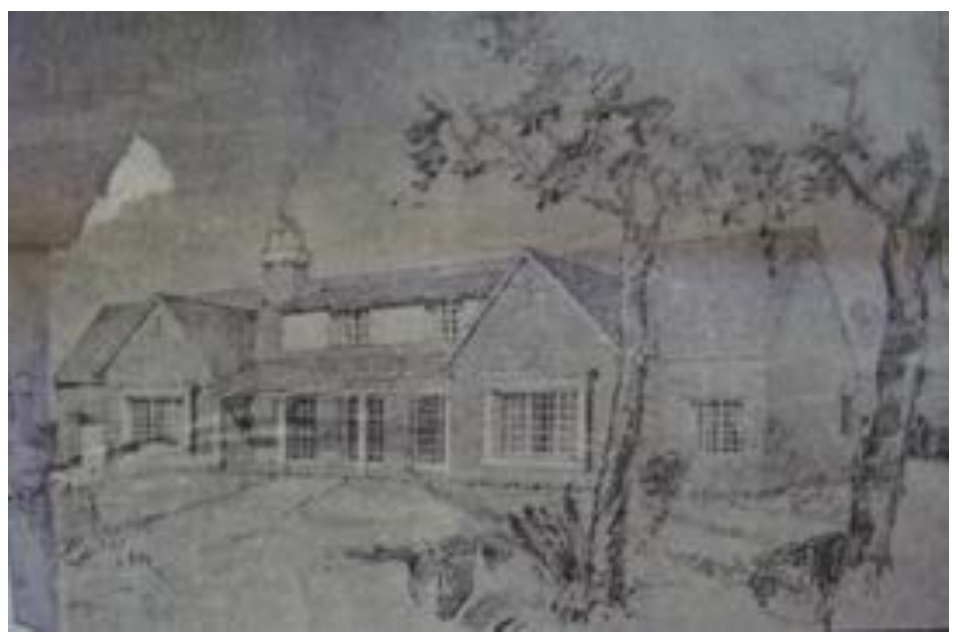

Chalet en construcción en el Barrio Parque Golden Park, 1949.

Fuente: Carpeta de RematesPartido de La Matanza, Departamento de Investigación Histórica Cartográfica, Dirección de Geodesia, MOP, Pcia. de Bs. As.

\footnotetext{
${ }^{326}$ Graciela Silvestri señala que para la década del treinta, cada región argentina ya poseía una figura definida por tres o cuatro perspectivas de tarjeta postal, y estas figuras convocaban precisos repertorios arquitectónicos. Las sierras de córdoba, con sus accidentes suaves, sus arroyos serpenteantes y su clima benigno, inspiraban una arquitectura de escala humana, fuertemente tectónica en el tratamiento de sus muros pesados en piedra de la zona, las plantas quebradas y los techos con pendientes suaves que se fundían en el paisaje, Mar del Plata, en cambio, estaba asociada a motivos pintorescos más civilizados....Los motivos del Sur argentino se incorporarían algunos años más tarde, en este sentido la construcción del hotel Llao Llao de Alejandro Bustillo (1936-1940) fue una obra suficientemente conocida y publicitada para concentrar las imágenes del paisaje sureño y convertirse en referencia obligada para renovados motivos pintorescos. Ver, Graciela Silvestri, "La medida de la naturaleza"; en Block, Naturaleza, no 2, mayo de 1998. UTDT, Bs. As.
} 
Este chalet, que hacia fines de la década del cuarenta está en construcción en un barrio parque del Oeste retoma, para usar los términos que proponía la revista California Arts $\&$ Architecture, un "Georgian modificado". En consonancia con el desplazamiento que se verifica en las revistas americanas, de los motivos más rústicos hacia otros más estilizados; en el medio local, la revista Nuestra Arquitectura bautizaba como Georgian al chalet que construyera el arquitecto Rodriguez Etcheto en Mar del Plata.

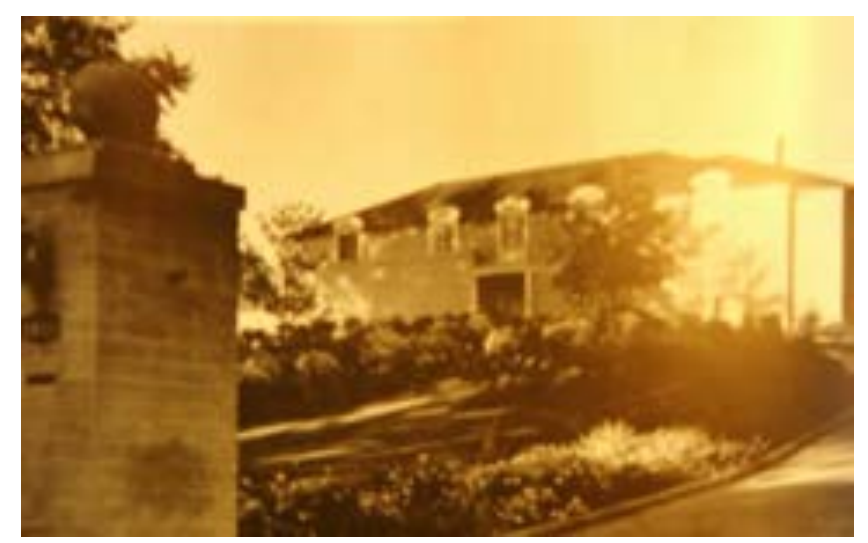

a. Modified Georgian. Arq. Herbert Riesenberg

Fuente: Califronia Arts \& Architecture, January 1940.
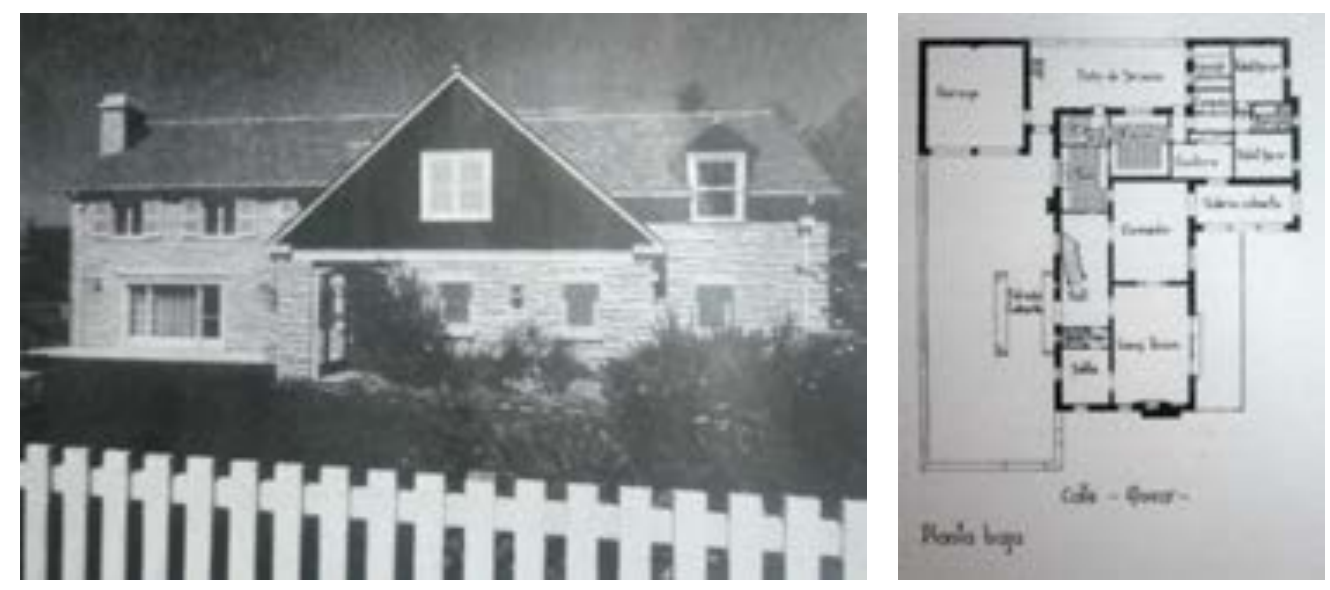

b. Casa en Mar del Plata, Alvear esq. Falucho. Arq. Rodriguez Etcheto. Fuente: Nuestra Arquitectura, junio 1945.pp. 250-251

En líneas generales, en ambos casos -el chalet en Mar del Plata y el chalet en construcción en el Barrio Parque Golden Park del Oeste- se verifica un pasaje de las imágenes más rústicas a otras en las que predominaba cierta elegancia asociada al ideal clásico. Frontones de mojinete, tejas tipo "Llao Llao", en obvia referencia a la obra del Hotel LLao Llao inaugurada en Bariloche por Alejandro Bustillo casi una década antes (1936-1940), porches y galerías que se ampliaban y se materializaban a partir de elementos más livianos. Las proporciones en general se hacían más esbeltas; y para las 
aberturas y las carpinterías se habían dejado de lado las maderas más oscuras y se adoptaron en su lugar carpinterías de vidrios repartidos (sash-windows) pintadas en colores claros. Las plantas eran complejas, en tanto los programas que debían albergar se complejizaban incorporando diferentes salones y áreas de servicio en respuesta a las necesidades de sus comitentes, los sectores medios-altos. En estas obras, salvando las distancias, se puede aplicar la observación que realizó Graciela Silvestri para el Hotel Llao Llao de Alejandro Bustillo, en tanto, si bien se hace uso del repertorio pintoresco, en su disposición, lejos de fragmentar las masas edificadas, la composición acentúa la monumentalidad a través de los recursos que ya mencionamos, simetrías, jerarquía, y que volvían a poner sobre el tapete las enseñanzas del academicismo. ${ }^{327}$

Contemporáneamente, con referencias mucho menos definidas también se incorporaban en las urbanizaciones de fin de semana chalets que compartían este sabor más refinado. A lo largo de la década del cuarenta, las revistas locales como Nuestra Arquitectura y Revista de Arquitectura los denominaban “casas de líneas sencillas". Si bien se mantenía el tejado con pendiente, como el vínculo más fuerte que une a lo largo de todo el período a la arquitectura suburbana con cierta imagen de lo pintoresco, algunas características de la Arquitectura Moderna comenzaban a colarse también en las viviendas de recreo y de fin de semana. Se agrandaban las proporciones de las aberturas, y se incorporaban soluciones técnicas y estructurales más complejas, paños vidriados en doble altura, o ventanales que doblaban la esquina. Esto, a su vez, conducía a interiores más iluminados y despejados, la fluidez entre los espacios interiores y exteriores, no sólo se reducía al porche o la galería, sino que las transformaciones ya mencionadas también contribuían a generar sensación de continuidad.

327 Graciela Silvestri, "La medida de la naturaleza”, op.cit. 

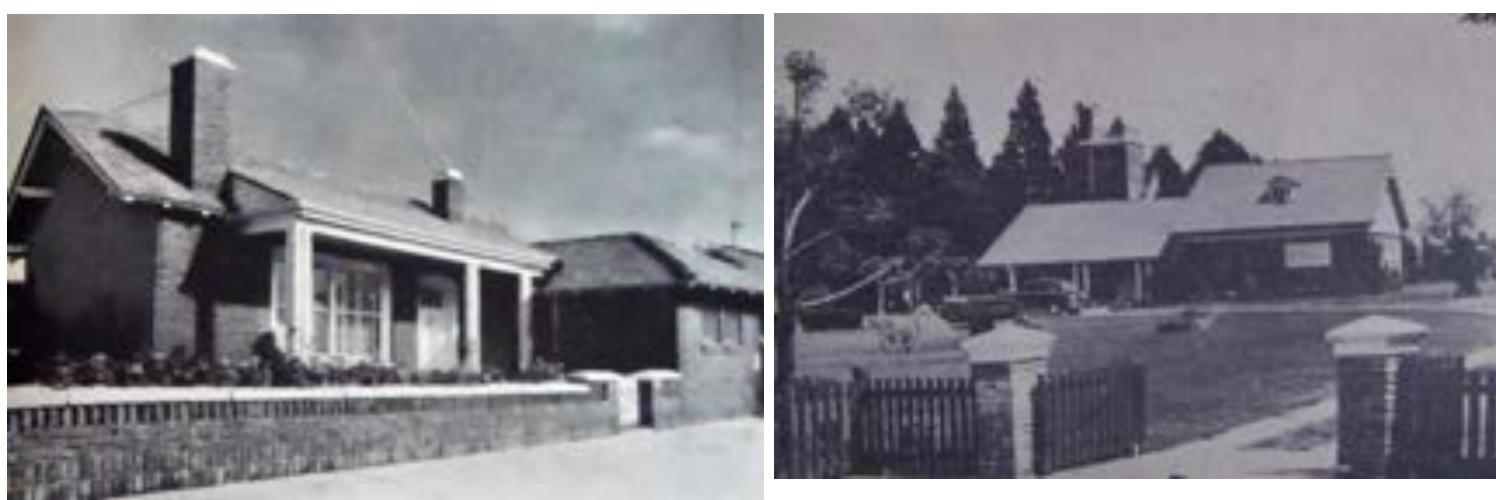

a. Vivienda de veraneo de línea "netamente americana", fue proyectada en Mar del Plata por los arqs. Repossini y Siperman. Fuente: Revista de Arquitectura, noviembre 1946.

b. Residencia en B. P. Peluffo. 1947

Recapitulando, podemos decir que el panorama analizado en relación a la arquitectura da cuenta de un escenario variable en el cual se observan múltiples corrimientos a lo largo de los dos períodos: de los sectores medios-altos y altos, a los sectores medios. Y de un predominio en las referencias de Europa del Norte, a los estilos más "alegres" de la Europa Mediterránea y California.

Vinculado a estas transformaciones, también hemos tratado de destacar el rol de los manuales de arquitectura, revistas, publicidades y medios de prensa en general a la hora de difundir y democratizar muchas de las imágenes y modos de habitar que se imponían en relación al habitar suburbano. Al respecto, en relación a los procesos de difusión y circulación de ideas es posible reconocer la complejidad de componentes y la versatilidad con la cual lenguajes y tipologías arquitectónicas se adaptan a diferentes contextos y situaciones, haciendo que su utilización cobre nuevos significados por fuera de la trama espacial y de actores a la cual originalmente se lo vincula. 


\title{
CAPÍTULO 6. Excursiones suburbanas: algunos estudios de casos
}

\author{
“(..) el territorio funciona como un canal de \\ comunicación insustituible entre presente y pasado; \\ y así también, como factor condicionante del \\ presente sobre el futuro." \\ (Leonardo Benévolo, La ciudad europea, \\ Ediciones Crítica, Barcelona, 1993)
}

Poner la lupa sobre algunos casos en particular nos permitirá desplegar en un análisis particularizado la trama de actores y procesos de ocupación del suelo que confluyen en la formación del área metropolitana, a la vez que poner a prueba hasta qué punto, o dentro de qué parámetros, son extrapolables algunas de las formulaciones más generales que hasta aquí hemos presentado.

Con este propósito, se han escogido algunos casos en base al total del corpus de barrios parque y urbanizaciones de fin de semana. Las razones por las cuales estos tres casos (Barrio Parque Aguirre, San Isidro, 1913; Barrio Parque Peluffo, La Matanza, 1947 y Barrio Parque Castelar, Morón, 1929) han sido seleccionados obedecen en principio a la necesidad de cubrir experiencias pertenecientes a distintos momentos, sectores geográficos -especialmente dentro de aquellas áreas en las que tuvieron mayor incidencia- y a contrastar propuestas destinadas a diferentes grupos sociales.

De esta manera hemos tratado de registrar diferentes modelos a través de los cuales se conforman aquellos núcleos que definimos globalmente como barrios parque. Consideramos que el estudio de casos en profundidad nos permitirá aproximarnos al grupo de variables que se vinculan para dar como resultado una conformación y desarrollo particulares. Por último, en relación a este tema proponemos un pequeño giro, se trata de verificar en algunos casos significativos el devenir de la expansión. Bajo la forma de la crónica -heredera de aquellas prácticas modernistas que a fines del siglo XIX y principios del XX se propusieron rastrear el sentido de la vida moderna en las ciudades-, buscamos la manera de testimoniar "lo real", la "vivencia cotidiana" de 
los barrios en tiempo presente, asumiendo que nos permitirá descubrir cómo en lo nuevo siempre anida algo de lo viejo. ${ }^{328}$

${ }^{328}$ Esta perspectiva es deudora de un núcleo de estudios urbano-territoriales, con gran influencia de la geografía. Ya citamos en el epígrafe de este mismo capítulo a Leonrado Benévolo, se deben también mencionar los estudios de André Corboz y Marcel Roncayolo. 


\subsection{El suburbio exclusivo: el Barrio Parque Aguirre}

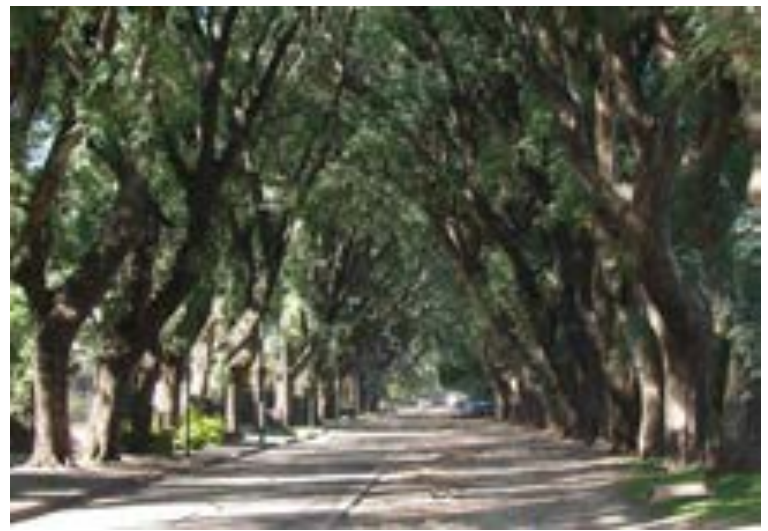

Barrio Parque Aguirre- 2012

Foto del autor

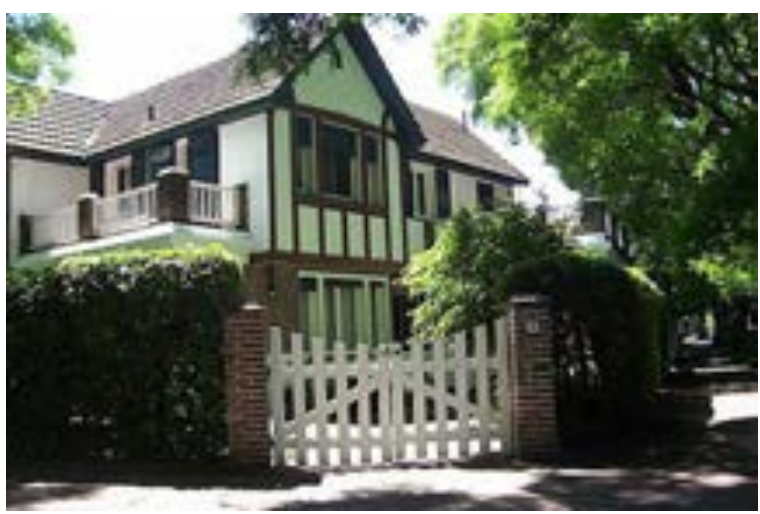

Barrio Parque Aguirre- 2012

Foto del autor

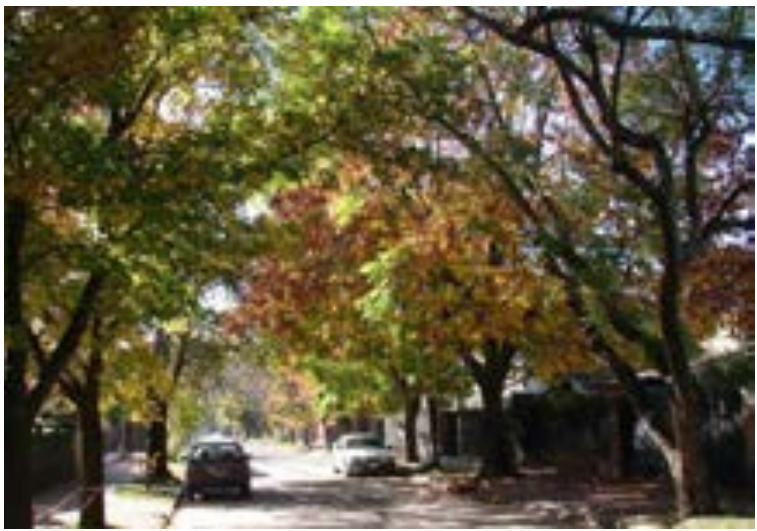

Barrio Parque Aguirre- 2012

Foto del autor

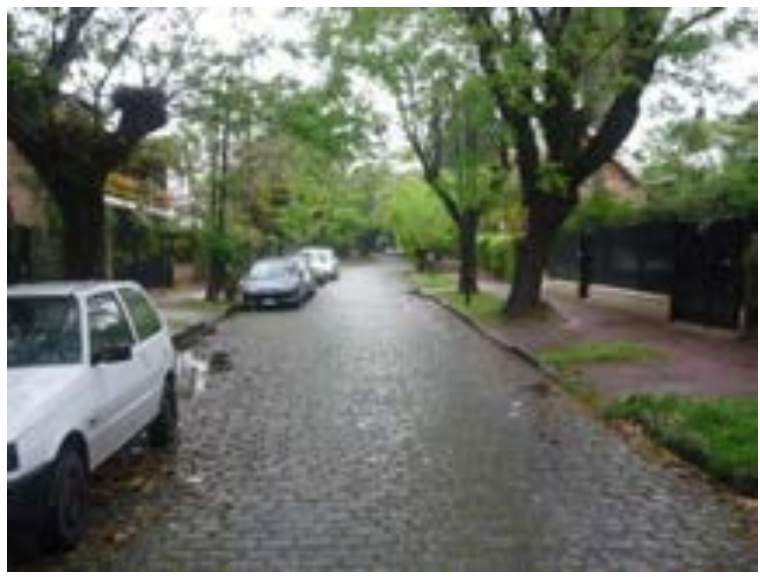

Barrio Parque Aguirre- 2012

Foto del autor 
A $20 \mathrm{~km}$ de Buenos Aires, el Barrio Parque Manuel Aguirre constituye un ejemplo característico del primer período de crecimiento (ver Capítulo 2). Formando parte de una línea incipiente de suburbanización que corría desde la Capital Federal hasta Tigre, jugó un rol fundamental dentro del proceso de expansión entendido como parte de un fenómeno más amplio de modernización y transformación de las pautas culturales.

Hace cien años (1913) el barrio se asentó en torno a una nueva parada del ferrocarril, en donde se localizaron fundamentalmente usos residenciales -de veraneo y fin de semana- destinados a las capas medias-altas de la sociedad junto a clubes deportivos y espacios de sociabilidad como el hipódromo y una sede social del Jockey $C l u b$. Las tierras sobre las que se produjo el loteo formaban parte de la sucesión de Don Manuel Aguirre, cuando sus herederos decidieron la realización de un loteo suburbano aprovechando la localización estratégica de las tierras, junto a la nueva estación Hipódromo -actualmente Acassuso- del FFCC y rodeadas por la expansión que registraba el núcleo original de San Isidro, por el Norte, y la población de Martínez, por el Sur. El emprendimiento, de unas 50 ha, estaba unido a la Capital Federal por la primera línea electrificada del ferrocarril. De manera que, como analizamos en los primeros capítulos, formaba parte de una de las primeras zonas en donde se registraron procesos de suburbanización y en donde fueron comunes las operaciones en torno a áreas donde se presentía mayor densificación y donde existían intereses inmobiliarios que buscaban favorecer la subdivisión del suelo y la creación de nuevos loteos.

Así, cuando se lotearon los primeros terrenos del barrio parque, las incipientes señales de suburbanización se formalizaban en forma de algunas casas, más o menos dispersas, en torno a las estaciones.

\section{Estación Acassuso}

Tomé el tren en la Estación Federico Lacroze, en Capital Federal, y luego de 25 minutos de viaje en la línea de trenes más moderna que sirve los alrededores de Buenos Aires ya estaba en la estación Acassuso. La llegada aún conserva algo del ambiente encantado que los habitantes de la metrópolis contemporánea asociamos a los suburbios del ferrocarril: en la avenida Eduardo Acosta, que corre paralela al ferrocarril, hay olor a tierra y a hojas húmedas y aplastadas que se amontonan en el suelo. En lo alto, se produce una especie de túnel que toma forma en las copas de los árboles plantados a 
ambos lados de la calle; y salvo dos o tres comercios pequeños que enfrentan la estación no se reconocen muchas "pistas" de la modernización.

Este panorama, que se despliega frente a la estación, se agudiza a medida que camino hacia el interior del barrio. Adentrarse por alguna de sus calles internas es como pasear por otro tiempo; a simple vista me animo a decir que la mayor parte de las viviendas por las que paso podrían ser testigo de la formación del núcleo en los años veinte y treinta.

Voy caminando por una vereda arbolada, en el interior de las parcelas también se despliegan añosas arboledas y la hiedra cubre los muros de las casas, dejando entrever sólo fragmentos de la arquitectura que está por detrás. Soy la única que transita a pie por estas calles adoquinadas, sólo veo autos último modelo que entran o salen de las casas. Adelante mío se abre un portón automático y sale una camioneta, van una mujer y unos niños con uniforme en el asiento trasero. Son muchas las casas con paredones altos y portones automáticos -evidencia de modernas reformas "en pos de la seguridad".

Sigo caminando, un poco desorientada llego a la pequeña plaza central -Plaza Pueyrredón-. Otra vez no hay nadie, dos hombres que podrían ser jubiliados charlan en un banco, pero de juegos infantiles o niños corriendo, no hay rastros. Cruzo la plaza y estoy perdida, no ubico en que dirección debo seguir para llegar al otro extremo del barrio, la Avenida del Libertador que continúa desde la Capital. La orientación no ayuda y la visión no alcanza más de unos cuantos metros, quizá una cuadra, hasta que la curva de las calles no me permite ver más allá. Tengo que preguntar, no es lejos. Ahora camino por Libertador, el paisaje sigue siendo enormemente arbolado y sólo se filtran algunos rayos de sol. Por lo demás, la fisonomía ha cambiado completamente, el paisaje es más diverso, con algunas residencias que permanecen entre los locales comerciales, mayoritariamente, bares y restaurantes de moda y algunos comercios de amoblamiento y decoración para la casa y el jardín. 



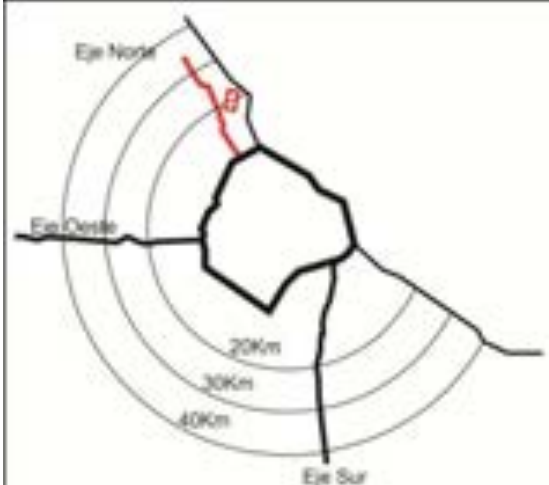

Barrio Parque Aguirre y desarrollo histórico del sector aledaño.
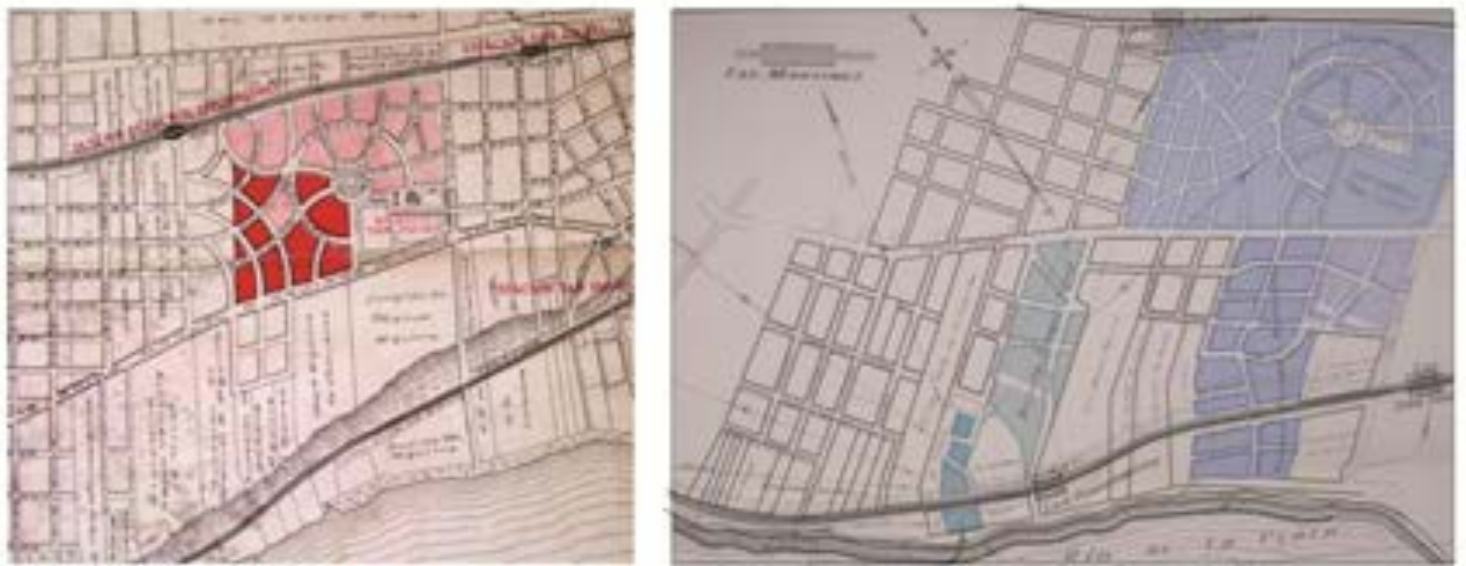

a. En ei centro, nudeo pionero del B.PAguirte y por debaja, berras sin lotear. 1931. Fiente. Promooon de remate de bertas, Cassai \& Cia. 1931. Carpeta B. PAgirre. Aechiro y Museo Histsrico de San hidro.

b. Cesamollo del mismo sector hacia fines de la dacada del cuarenta. En color se sehaian los diversos loteos de bavios parque. Fuente.

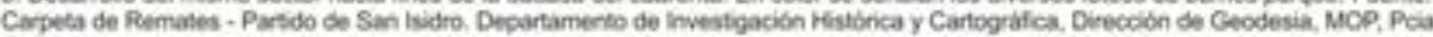
de Bs.As.
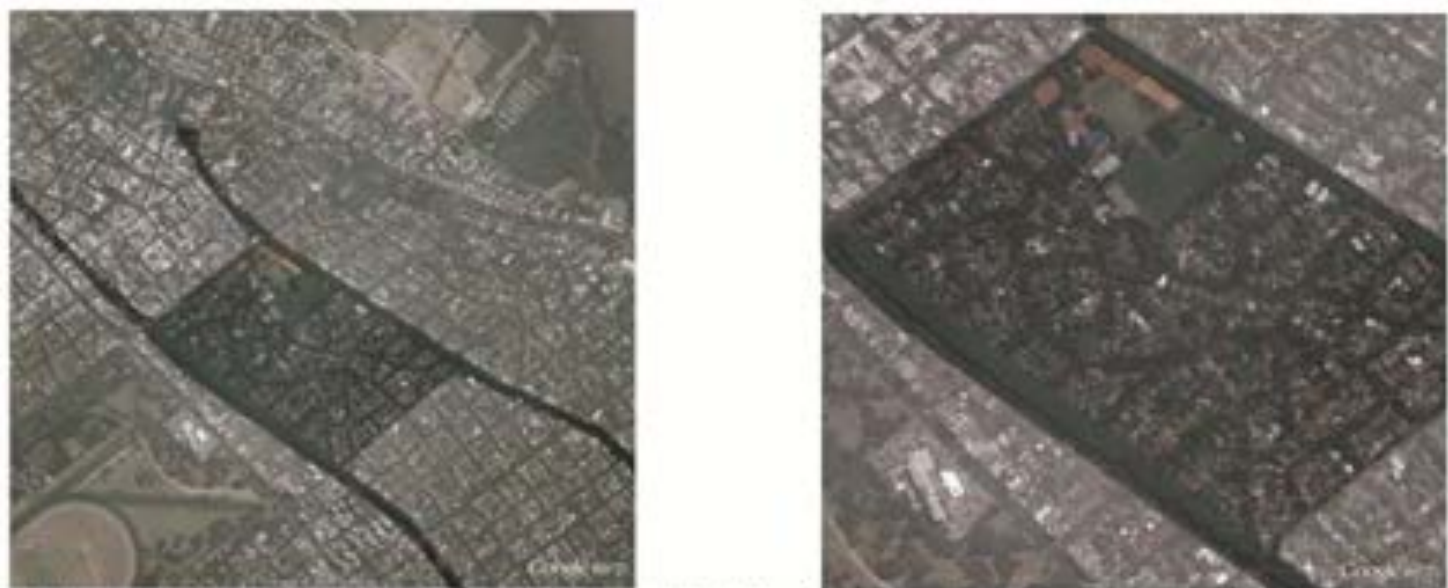

a. En la escuina inferior izquienda se reconoce ol Higbdromo de Sen isidro. Las des vias de bivisho que cruzan en diogonel ef escuema -limiando al barrio parque-corresponden: la inferior, a la traza del ferrocaml, y la superior, a la continusción de la Averida del Libertador desce la Capital.

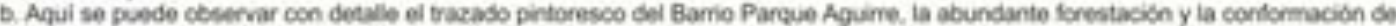
una trama abierta de baja densidad poblacional 


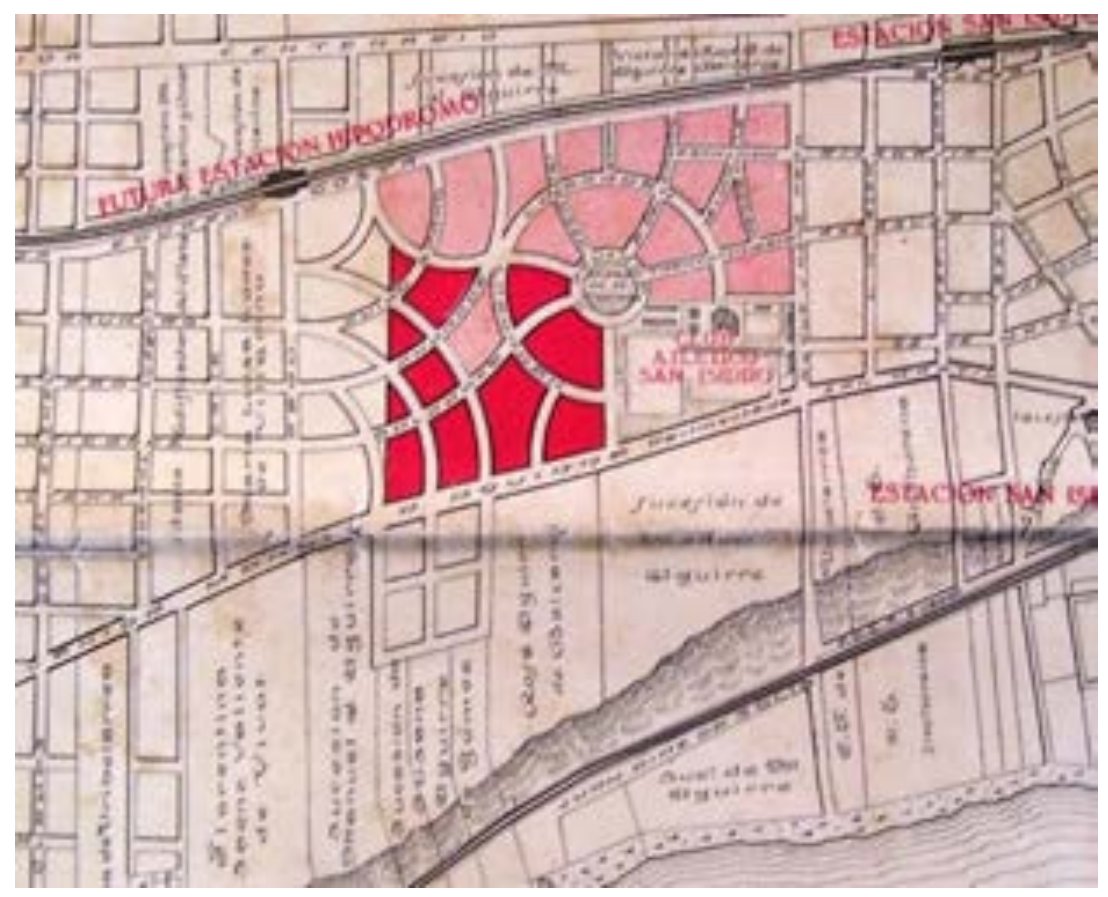

Plano del Barrio Parque Aguirre y alrededores en 1931. En rojo claro aparecen las manzanas ocupadas $\mathrm{y}$ en rojo pleno las manzanas en venta.

Obsérvese que en la zona inferior al Barrio Parque, entre la Avenida Manuel Aguirre (actual Libertador) y la barranca, se halla una zona no urbanizada. Muchos de los barrios que se instalaron allí fueron abordados en relación a las áreas de urbanización entre 1930-1950.

Fuente: Promoción de remate de tierras, Cassal \& Cía, 1931. Carpeta Barrio Parque Aguirre, Archivo y Museo Histórico de San Isidro.

El trazado sobre el cual en la década del diez se concretó el loteo -y al cual sin duda se deben hoy muchas de las cualidades suburbanas que conserva el sitio- fue sugerido al agrimensor por los mismos propietarios. Respondía a los modelos pintoresquistas que se implementaban en los desarrollos suburbanos anglosajones con calles curvas, perspectivas cortadas y lotes de amplias dimensiones. ${ }^{329}$ Hacia el interior del núcleo, esta morfología propiciaba la delimitación de manzanas con lados curvos y poco profundas que a su vez facilitaban la división en lotes más proporcionados -con largos de lote de 2 o 2.5 veces su ancho- que aquellos asociados a la cuadrícula tradicional con largos de 4 y hasta 5 veces su ancho.

En relación con la escala territorial, uno de los principales aciertos de este trazado fue generar- a partir de la morfología radial- una malla con límites bien determinados, que diferenció al emprendimiento del territorio más vasto al que se

\footnotetext{
329 Muchos de los tratados para constructores o libros de láminas extranjeros que reproducían imágenes de viviendas rurales o suburbanas, también incluían planos para pequeños desarrollos urbanos sobre la base de trazados informales. Ver, Tratados de arquitectura, en el apéndice Fuentes y Bibliografía.
} 
incorporaba. Si bien, algunas de las vías que nacían en la plaza central del conjunto se continuaban en la trama urbana, el ordenamiento general contribuyó a generar un espacio autocontenido, donde la telaraña de calles que se organizaron con una lógica propia y diferente de la cuadrícula más tradicional, materializó una frontera imaginaria y un espacio de deslinde entre la trama abierta de los alrededores y la del propio barrio.

Para mantener esta separación contribuyeron una serie de reglamentaciones que regulaban las condiciones de desarrollo del conjunto. Estas mismas, sancionadas junto con la ordenanza municipal del Departamento Ejecutivo de la Municipalidad de San Isidro que aprobó la formación del barrio, disponían la imposibilidad de subdividir los terrenos de manera tal que resultaran anchos de frente menores a los $15 \mathrm{mts}$ y superficies menores a los $400 \mathrm{~m} 2$. Además se establecieron retiros mínimos de línea municipal de $3 \mathrm{mts}$, estableciéndose desde el inicio algunas pautas que esbozaban el carácter residencial de baja densidad que se pretendía imprimir al desarrollo. ${ }^{330}$ Conceptualmente, la introducción de ciertas restricciones daba cuenta, por un lado, del conocimiento de ciertos métodos de gestión de la ciudad, pero, fundamentalmente, de la presencia subyacente de una idea suburbio, de una imagen predeterminada que para realizarse debía excluir ciertas prácticas arquitectónicas consideradas "menores", a la vez que resguardar la permanencia de otras características, como el tamaño amplio de los lotes o la separación entre viviendas, que se consideraban intrínsecas a la condición aristocrática de un núcleo.

En los hechos, se observa que los lotes vendidos en el decenio que va entre 1925 y 1935 -momento sobre el cual se cuenta con mayor información- superaban las dimensiones mínimas establecidas y se ubicaban en un promedio de $800 \mathrm{~m} 2$, dando lugar a la construcción de residencias aisladas en medio de jardines y zonas verdes. ${ }^{331}$

\footnotetext{
330 Ordenanza Municipal aprobando la formación del Barrio-Parque Manuel A. Aguirre. San Isidro, 25 de enero de 1913, en Carpeta Barrio Parque Aguirre, Archivo y Museo Histórico de San Isidro.

331 Informe de ventas de la inmobiliaria Cassal \& Cía.
} 


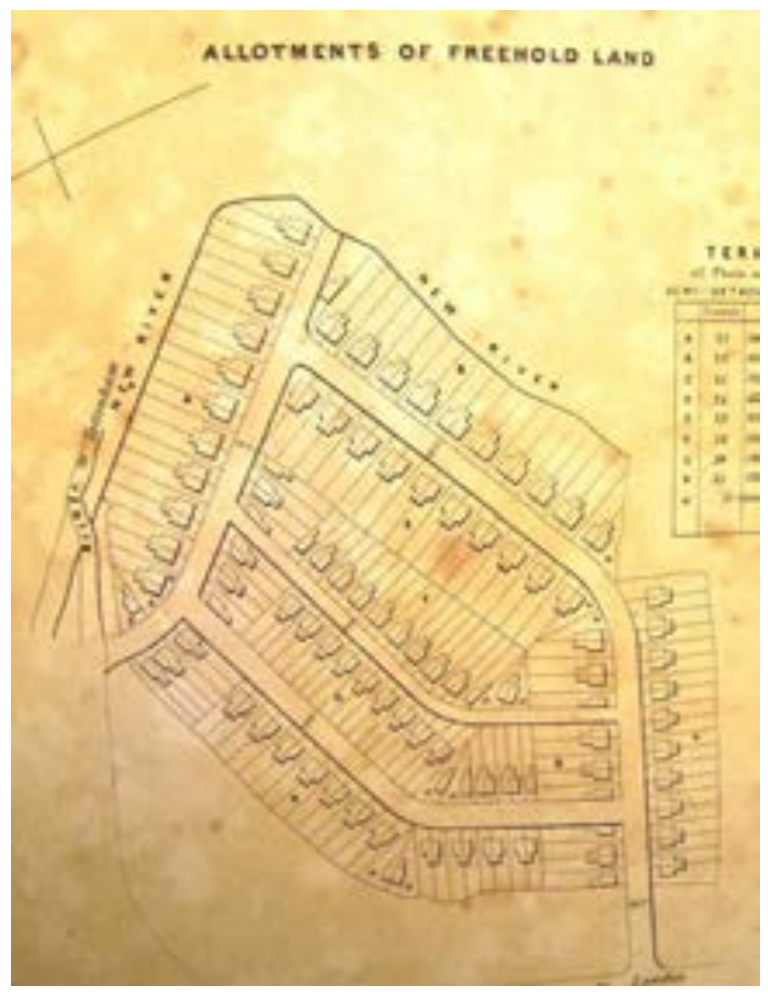

Modelo de loteo suburbano. Fuente: Payne, A. H, The Builders Practical Director. Plans, sections and elevations with detailed estimates, quantities \& prices, Liepzig and Dresden, London, 1859.

Foto área que muestra el trazado y la división de los lotes en el Barrio Parque Aguirre.

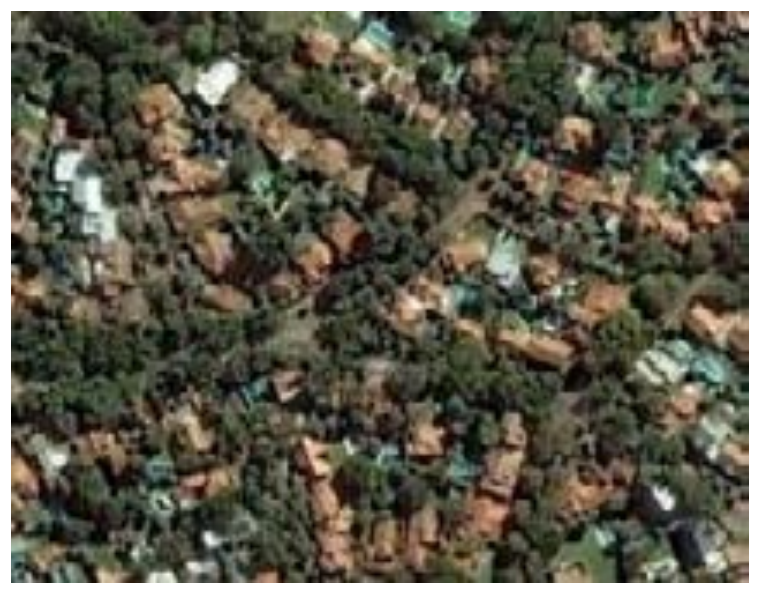

La chacra del presidente Roque Sáenz Peña

El Barrio Parque Aguirre se convirtió rápidamente en asiento de exclusivas familias de la elite porteña, más precisamente sus fracciones más jóvenes que dejaban las grandes mansiones del centro de la Capital para instalarse de modo permanente en este suburbio, aprovechando la cercanía al río y la oferta social de los clubes y el hipódromo. ${ }^{332}$

Entre los compradores de tierras figuran apellidos como los Gowland, cuya familia proveniente de Londres se había radicado en nuestro país en los primeros años del 1800. Daniel Gowland fue director del Banco Nacional, miembro de la Casa de la Moneda, fundador de la Bolsa de Comercio en 1854 y participó del primer directorio de la Compañía de Ferrocarril Oeste, creada ese mismo año. Los Saenz Valiente, familia de estancieros con campos en la zona de Lobería, al Sur de la provincia de Buenos

\footnotetext{
332 El valor promedio de un lote variaba para el período $1925-35$ entre $\$ 8.000$ y $\$ 12.000$; triplicando los valores estimados para un lote de 10x 25mts, a \$ 2.400 en 1929 en Castelar. Ver Cuadro 2, Capítulo 2.
} 
Aires y dueños de otras grandes propiedades en la zona Norte de la ciudad de Buenos Aires. Emparentados con la familia de Francisco F. Moreno, miembro fundador de la Compañía de Ferrocarril Oeste, padre de Francisco Pascasio Josué Moreno, científico autodidacta, fundador del Museo de Ciencias Naturales de la ciudad de La Plata. ${ }^{333}$ Otro de los nombres que surge es el de Mercedes Anchorena de Nazar; en esta ocasión prácticamente no es necesario dar cuenta de la importancia alcanzada por esta familia. Entre los miembros de los Anchorena se contaron personajes que ocuparon los primeros planos de la política y sobre todo de la economía desde que su fundador llegara a estas playas en los años cincuenta del siglo XVIII, a lo largo del siglo XIX y hasta entrado el siglo XX. El lugar que los Anchorena ocupaban en la sociedad rioplatense ya era evidente en las décadas centrales del XIX, cuando, para aludir a un grado inconmensurable de riqueza, se acuñara la expresión -en el Fausto de Estanislao del Campo, de 1866- "más rico que Anchorena". ${ }^{334}$ La sólida posición de esta familia se consolida en la Belle Epoque y se mantiene en la primera mitad del siglo XX, si tomamos como uno de los indicadores más ilustrativos la superficie de tierras de las que eran propietarios por entonces. Como grupo familiar los Anchorena poseyeron alrededor de 635.000 hectáreas hacia 1890-1900 y 511.776 hacia 1920-1930 (una menor cantidad aunque igual de impactante- seguramente compensada por el aumento del valor de la tierra a lo largo de este período, por efecto de la capitalización de la economía rural y porque se limitó poco a poco la cantidad de tierra disponible, una vez ocupados los territorios indígenas). ${ }^{335}$

Por su parte, la misma familia impulsora de la creación del barrio parque, que continuó poseyendo tierras y su residencia familiar en la zona, los Aguirre, también se contaban entre los estancieros más destacados del cambio de siglo, y además de una posición económica sólida mantenían una amplia red de relaciones con prestigiosas

\footnotetext{
333 Ver, Máximo Ferro, La formación del Museo de La Plata. Coleccionistas, comerciantes, estudiosos y naturalistas viajeros a fines del siglo XIX. Prohistoria ediciones, Rosario, 2009; y Jorge Schvarzer y Teresita Gómez, La primera gran empresa de los argentinos. El Ferrocarril del Oeste (1854-1862). Fondo de Cultura Económica, Buenos Aires, 2006.

334 Citado en Roy Hora, "Del comercio a la tierra y más allá: los negocios de Juan José y Nicolás Anchorena. (1810-1856), en DE vol 44, n 176, 2005, p 567.

335 Citado por Leandro Losada, La alta sociedad... op.cit.p 8.
} 
familias de la época. La hija de Manuel Aguirre - a quien debe su nombre el Barrio Parque-, María Eugenia Aguirre de Ibarguren solía asistir -durante el verano de 1913al té que organizaba semanalmente la primera dama, doña Rosa González -esposa del Presidente de la Nación Roque Saenz Peña- mientras pasaban los meses estivales en la chacra que le alquilaban a los Aguirre. Mientras que Carlos Ibarguren, yerno de Manuel Aguirre, compartía su actividad directiva en el Jockey Club con personalidades como Miguel Alfredo Martínez de Hoz. ${ }^{336}$

En medio de este panorama, la coincidencia de dos factores: la ampliación de los medios de prensa que comenzaron a funcionar como una pieza clave en el proceso de democratización, y la creciente demanda de imágenes y modelos que ilustraran a los nuevos sectores medios las transformaciones de la vida moderna -entendida como un "estilo de vida" que implicaba llevar una vida dinámica, volcada hacia el sport, el club y las actividades al aire libre- otorgó especial visibilidad a aquellos núcleos vacacionales, residenciales suburbanos $y$ de fin de semana, pioneros en su incorporación. La concentración de grupos de elite, de obras de profesionales destacados, los torneos deportivos y los eventos sociales que se desarrollaban convirtieron a algunos pueblos en protagonistas estelares de las secciones destinadas a retratar la vida moderna o las páginas de sociales en la revistas. Como se lee en la nota "San Fernando, San Isidro y Martínez en plena temporada" del diario La Nación: "la señora Lucrecia Travers de Campos de Williams Alzaga y su hijito Orlando, en la playa de su residencia en Martinez" o "Los grandes sombreros difundidos en las playas de Mar del Plata, ponen en la de San Isidro una nota graciosa y elegante.”337

De manera que se fue configurando un mecanismo de difusión fomentado por las publicidades y los medios gráficos que promovían los hábitos que asumieron algunos sectores.

336 Ver, Carlos Ibarguren (h); “Crónica de la Histórica Chacra de Aguirre en San Isidro”. Museo Brigadier Juan Martín Pueyrredón, mimeo. San Isidro, 1982.

337 “San Fernando, San Isidro y Martínez en plena temporada”, en diario La Nación, Domingo 2 de febrero del 1930. 
Arquitectura particular en el Barrio Parque Aguirre

La arquitectura fue la otra variable que otorgó al núcleo visibilidad. El carácter general de las obras estuvo dado, principalmente, por una serie de pautas introducidas en la ordenanza municipal que dio origen al barrio y que estimulaba la formación de tipos compactos en medio de un área verde y prohibía expresamente la utilización de materiales considerados precarios - como podía ser el caso de la madera- salvo para la realización de chalets de estilo. ${ }^{338}$

La ausencia de proyectos o emprendimientos globales para la construcción de viviendas dificulta la tarea de reconocer tipologías arquitectónicas predominantes y costos promedio para la construcción residencial. Intentaremos igualmente brindar algunos datos, aunque se debe ser cauteloso en cuanto a su representatividad, ya que surgen del análisis de un grupo reducido de operaciones particulares. Hecha esta salvedad, se reconoce como característica constante de la arquitectura residencial el predominio de residencias de dimensiones importantes, que superaban los $200 \mathrm{~m} 2 \mathrm{de}$ superficie, con valores de base de 30.000 pesos (en remate judicial-1925) y que resultaban en precios de compra de entre 50.000 y 60.000 pesos. ${ }^{339}$ Incluso se registró la venta de algunas residencias más espectaculares -con salón con chimenea, salón de fumar, escritorio, cinco dormitorios, pisos de roble de Eslavonia y parque- que podían llegar a los 150.000 pesos (1930), aunque no eran las más frecuentes. ${ }^{340}$ Este tipo de residencias, para sectores de altos ingresos, predominaron a lo largo de la década de 1920. Mientras que con el correr de la década de 1930, como resultado de un proceso ya asentado de llegada de sectores medios-altos a los suburbios y de un crecimiento en la construcción residencial, se presentaba un panorama más variado, dentro del cual

\footnotetext{
338 La manera en que las imágenes arquitectónicas ayudaron a materializar el paisaje pintoresco y el clima de barrio parque de estilo inglés que se concretó en el B.P.Aguirre fue estudiado en, Ana Gómez Pintus, "Las dimensiones del pintoresquismo. Suburbios residenciales, arquitectura y prácticas profesionales" op.cit.

339 Propaganda de remate empresa Bravo Barros \& Cía, 1925. Carpeta Barrio Parque Aguirre en Archivo y Museo Histórico de San Isidro.

Propaganda de remate empresa Rufino Elizalde, 1934. Carpeta Barrio Parque Aguirre en Archivo y Museo Histórico de San Isidro.

340 Propaganda de la inmobiliaria Mario Livingston. Diario La Nación, 1 de febrero de 1930.
} 
resultaba común encontrar residencias de un solo nivel y dimensiones más reducidas. ${ }^{341}$ En coincidencia con esta transformación, como ya señalamos en el Capítulo 5, se advertía un pasaje de los lenguajes más severos del Norte europeo, a los más simples y alegres cuyas referencias provenían del estilo californiano y los estilos mediterráneos.

La introducción de estas imágenes, estuvo guiada por lo que dictaba la moda y las prácticas que se desarrollaban en algunos centros veraniegos más consolidados. La producción de la arquitectura residencial fue resultado de la acción individual del binomio que formaron arquitectos y comitentes, pertenecientes a las llamadas "clases acomodadas" de la sociedad porteña que sin duda estaban familiarizados con las imágenes y los tipos arquitectónicos que se consideraban más adecuados para la construcción de las residencias de un núcleo de fin de semana, provenientes de los centros vacacionales europeos o de la misma Mar del Plata que ostentaba a principios del siglo XX muchos de los estilos y las prácticas culturales que se importaban de los centros europeos. ${ }^{342}$

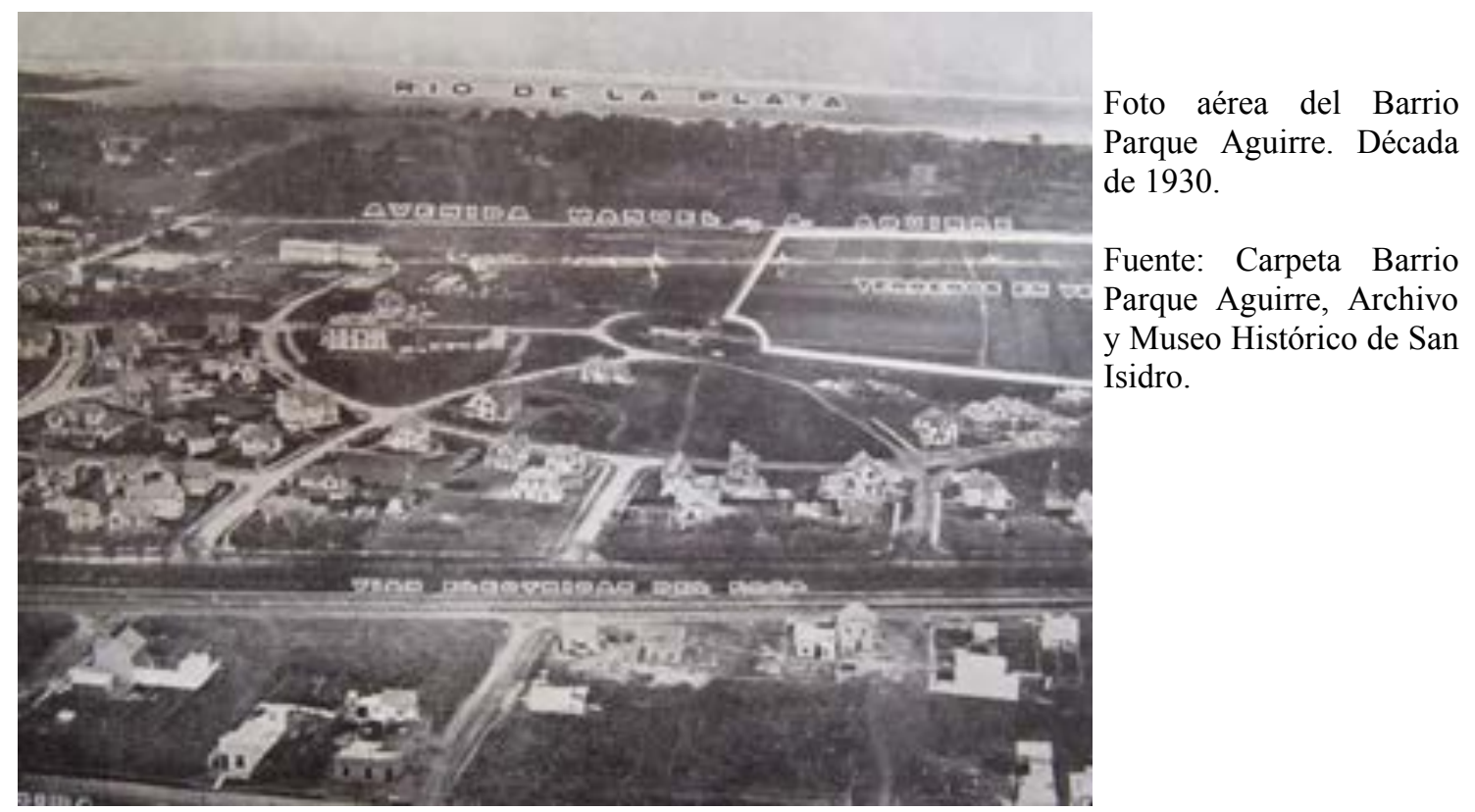

${ }^{341}$ En el Capítulo 5 se abordó más detalladamente la transformación acaecida entre las décadas de 1920 y 1930 en relación a la ampliación de los suburbios residenciales a sectores más amplios de la sociedad y la transformación que paralelamente registran las tipologías y las imágenes arquitectónicas.

342 Para un estudio más detallado sobre las corrientes de la arquitectura pintoresquista en Mar del Plata, ver Raúl Gómez Crespo y Roberto Cova, Arquitectura Marplatense: el Pintoresquismo, op.cit. 
Un aspecto que señala el carácter de núcleo de referencia asumido por el barrio parque, y por el núcleo de San Isidro en general, en la construcción y difusión de imágenes suburbanas fue la gran cantidad de personajes reconocidos del ámbito profesional que figuraban trabajando en la zona, entre ellos: José Aslan y Héctor Ezcurra, Charles Evans Medhurst Thomas, Ezequiel Real de Azua, Roberto Soto Acebal, Alberto Rodríguez Etcheto y Carlos Malbranche. Si bien no puede decirse que todos ellos pertenecieron a una primera línea, es innegable que alcanzaron cierta notoriedad publicando sus obras en medios como la Revista del Centro de Arquitectos, Constructores y Anexos (CACYA), El Arquitecto Constructor, Casas y Jardines o en la Revista de Arquitectura.

En este contexto, es posible argumentar que el Barrio Parque Aguirre se fue delineando como modelo de referencia para otros núcleos de la expansión suburbana que buscaban adoptar características similares, jugando un papel dominante en la definición y difusión, tanto de la arquitectura como de las prácticas suburbanas que se asociaron a los suburbios residenciales de carácter recreativo o de fin de semana. 


\subsection{El suburbio moderno: el Barrio Parque Peluffo}
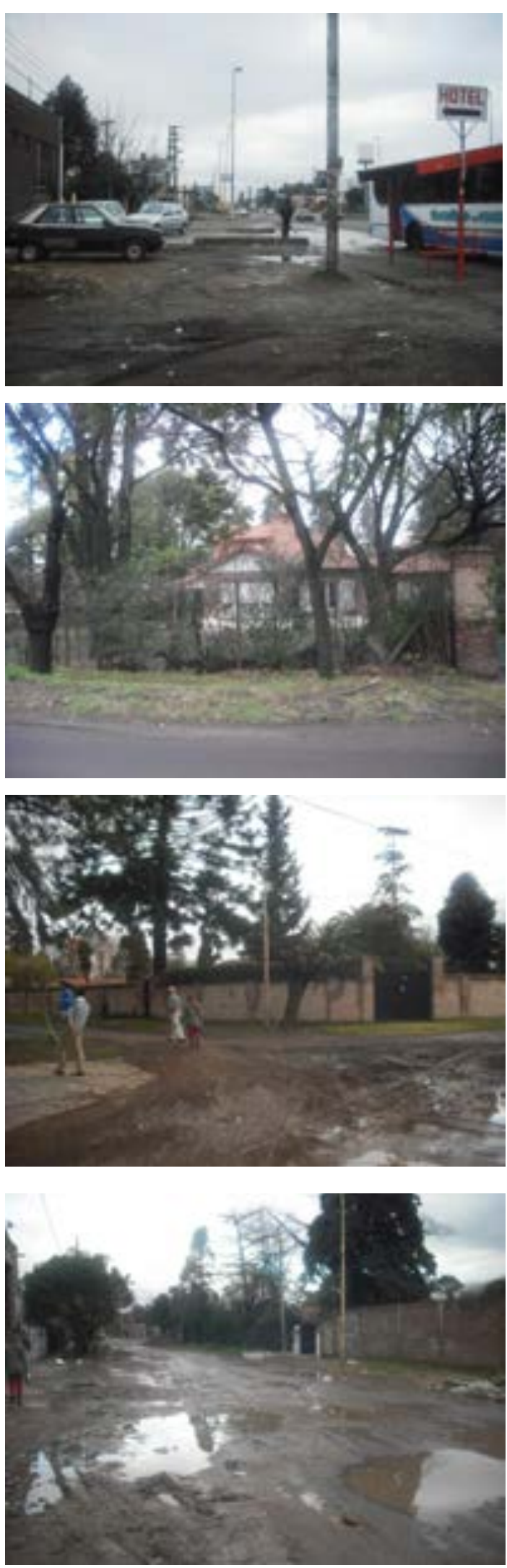

Camino de Cintura y Carabobo Barrio Parque Peluffo-2012

Foto del autor

Calle Carabobo

Barrio Parque Peluffo-2012

Foto del autor

Calle Carabobo y Centenera

Barrio Parque Peluffo-2012

Foto del autor

Calle Centenera

Barrio Parque Peluffo-2012

Foto del autor 
Como mostramos a lo largo de la tesis, los barrios parque cubrieron un abanico amplio de necesidades y deseos estructurados en torno al habitar. A lo largo del período podría trazarse un recorrido que va, de los llamados sectores acomodados hacia sectores más amplios de la sociedad. Y en cuanto a su localización, en consonancia con las transformaciones territoriales que tenían lugar en el GBA se ubicaron cada vez más alejados de las estaciones del FFCC y más en contacto con las vías de tránsito automotor.

Siguiendo estas lógicas, a lo largo de los años, se incorporaron en la zona Morón- Castelar- Ituzaingó- San Antonio de Padua, que entrada la década del cuarenta, y como se observa en el Mapa 10 (Capítulo 2), ya constituía un continuo urbano, más de veinte barrios parque. Algunos, de dimensiones menores, favorecieron a consolidar núcleos que existían con anterioridad, o se insertaron en áreas intersticiales entre dos núcleos de importancia, como podían ser Ituzaingo o Castelar. La mayoría, como ya demostramos en la primera parte de la tesis, se nucleó en torno a las vías de tránsito de reciente apertura. Un caso interesante de este tipo de operación nos lo proporciona el núcleo asociado a Morón que se generó en torno al Camino de Cintura.

La selección de este caso pretende poner de manifiesto el rol primordial que ejercieron los primeros loteos suburbanos - ubicados en áreas semirurales y alejados de otros núcleos de población- que operaron como polos de atracción para nuevos emprendimientos. El Barrio Parque Peluffo fue el primero de una serie de loteos que se realizaron durante la década del cuarenta cercanos a la Estación de Morón, en torno al recién pavimentado Camino de Cintura. La primer intervención comprendió originalmente unas 20 ha -dentro de un área de dimensiones mayores a nombre de Vicente Peluffo- ${ }^{343}$, que se insertaron en un área semi-rural del partido de La Matanza,

\footnotetext{
343 Los Peluffo tenían importantes extensiones de tierras en el partido de La Matanza. Debían su capital económico a un negocio de granja y vivero fundado por Vicente Peluffo a comienzos del siglo XX, que luego se extendió y se convirtió en la Casa Grimoldi-Peluffo, almacén de semillas, plantas y anexos con local de ventas en la calle Corrientes de la Capital. Además, el fundador de este negocio fue autor, junto a Fernando Mauduit de dos conocidos manuales de arboricultura de la época, El jardinero ilustrado, editado por primera vez en 1885, y Arboricultura Argentina editado en 1905.
}

Según puede rastrearse en el Fichero de Inscripción de Dominio de La Matanza, surge que la venta de sus primeras propiedades se retrotrae al año 1887, con sucesivas apariciones a nombre del mismo Vicente o de sus familiares los años 1897, 1901, 1910, 1916, 1923, 1924, 1927 y 1928. De la venta de los terrenos 
y que a lo largo de una década, luego de la adición de otros emprendimientos similares, terminaría de conformar un área residencial de baja densidad poblacional de aproximadamente 100 ha.

"No dejen nada a la vista"

Desde la Capital tomamos el Acceso Oeste, es sábado a la tarde y el tránsito es fluido. Salimos en la bajada Morón, para ir hacia el Sur tenemos que cruzar por debajo de la autopista, allí los puestos de frutas y verduras anuncian los "precios acordados con el gobierno"344. Tomamos la Av. Juan Manuel de Rosas, pasamos por la puerta del Plaza Oeste Shopping. Son las cuatro de la tarde -está nublado- y de los colectivos que se detienen frente al shopping bajan familias que se dirijen al paseo comercial.

Cruzamos el centro de Morón y preguntamos cómo llegar al barrio parque: primero en una casa de repuestos de autos, no conocen el Barrio Parque Peluffo, pero sí saben guiarnos a la dirección que mencionamos: Camino de Cintura y Carabobo. Todavía estamos más lejos de lo que pensábamos. Seguimos derecho, cinco cuadras, doblamos a la izquierda -hasta la avenida-, ahí otra vez a la izquierda, después de unas cuadras volvemos a preguntar. No parece que estemos en el lugar correcto. Ahora retomamos por la avenida, doblamos por Intendente Agüero, hacemos poco más de un kilómetro y ahí está Carabobo. Doblamos, para tomarla en dirección al Camino de Cintura. Todavía no se parece al barrio parque de quintas pintorescas que estamos buscando. En cambio, los lotes son angostos, las viviendas están construidas sobre línea municipal -si es que exista una-, porque en realidad no hay una sola construcción que

familiares surgió no sólo la subdivisión del Barrio Parque Peluffo en el partido de La Matanza (1945), sino también la formación del barrio que se conoció como La Marina (1951), comprendido dentro de lo que es actualmente Villa Luzuriaga. Finalmente, podemos rastrear algunas de sus tierras en la formación del pueblo de Pablo Nogués, en el actual partido de Malvinas Argentinas.

Ver, Martín Biaggini y Silvia Mielnicki, Villa Luzuriaga. Ayer, hoy y siempre. Editorial CLM, La Matanza, 2009.

344 Durante el año 2011 (y desde algún tiempo antes), ante una coyuntura inflacionaria, el Gobierno Nacional adoptó una política de acuerdos con hipermercados y ciertos sectores vinculados a la producción alimentaria, con el objetivo de mantener precios estables para los alimentos de la canasta básica. 
se alinee con la anterior. Aún así, se puede decir que están sobre línea municipal: sin retiros significativos, ni áreas ajardinadas al frente. Por lo demás, las casas son modestas, algunos negocios improvisados sobre garajes o un antiguo living con ventana a la calle alternan entre los usos residenciales.

Ahora vamos por Carabobo, y en pocas cuadras ya se intuyen restos del barrio parque. Las transformaciones territoriales que han tenido lugar en las últimas tres décadas: el desarrollo de las infraestructuras de comunicación y la aparición de nodos de importancia relacionados a usos comerciales y de servicios, han dado lugar a un funcionamiento del territorio del tipo reticular. El barrio que analizamos ha quedado, en cierta medida, preservado dentro de este esquema. En el corazón del barrio, la arboleda es frondosa y añeja. Es difícil divisar las casas, porque el deslinde entre el espacio público y privado (vereda como tal, embaldosada y con cordón, no hay) está materializado por setos vivos que dejan ver muy poco de lo que sucede detrás. Algún portón de rejas, o una ligustrina un poco rala permiten divisar un chalet, estimo que como a diez metros de la entrada. Seguimos. En otra quinta algunos hombres juegan al futbol en el parque delantero de otro chalet estilo californiano al que, evidentemente, le falta mantenimiento.

En la esquina, doblamos por una calle de tierra y dejamos el auto, aquí ya es imposible determinar donde termina la calle y empieza la vereda. Estacionamos casi pegados sobre el seto de una casa. Justo en frente hay una casita, un pequeño terreno adelante deja ver dos autos viejos (no me doy cuenta si están abandonados o en arreglo), un hombre se asoma hacia la calle, después de un saludo de cortesía le preguntamos si estará bien dejar el vehículo ahí (es un auto nuevo que claramente desentona con el clima del barrio), _ "no dejen nada a la vista”, nos sugiere. Eso hacemos, cerramos el auto y comenzamos a caminar. Hay barro, llovió casi toda la semana; a medida que nos alejamos, un vecino se asoma, otro está juntando hojas.

Alguno de estos vecinos bien podría formar parte de la Asociación Civil Peluffo Verde, que logró juntar más de 2.500 firmas para pedir por la preservación del barrio parque, como muestra la primera plana de la sección La Matanza del diario Clarín "San Justo: 40 manzanas entre Camino de Cintura, Venezuela, Triunvirato y Colonia. Juntan firmas para que el barrio Peluffo no pierda su estilo." y continúa la nota "es el mayor pulmón verde del distrito, los vecinos se movilizan para que no talen más árboles y 
prohíban construir duplex. Ya enviaron el proyecto al Consejo para que lo declaren reserva ecológica. Prometieron estudiarlo.” 345

Ahora, vamos caminando por lo que se supone es el corazón del barrio; aquí todavía se reconoce la división parcelaria de la década del cuarenta, donde cada unidad mantiene las características ideales del barrio parque -la vivienda individual pintoresca rodeada de un jardín privado-. Luego de haber caminado dos cuadras, el panorama más amplio, deja a la luz que las residencias de recreo se intercalan con galpones de almacenamiento, residencias abandonadas, invernaderos de cultivo.

Llegamos hasta el Camino de Cintura y el panorama cambia abruptamente. El camino es una avenida ancha, con dos carriles de cada mano, y además de vehículos particulares, el tránsito está cargado de colectivos y camiones. Sobre esta arteria casi ni hay rastros de las quintas, cuyos terrenos dejaron lugar a talleres mecánicos, corralones de materiales para la construcción, madereras-aserraderos y sectores que combinan establecimientos de grandes dimensiones, como el hipermercado (Carrefour) y un home-center $^{346}$ (Sodimac) sobre la intersección del Camino de Cintura y Av. Don Bosco.

Estos nuevos usos, darían cuenta de un proceso de descentralización -iniciado en la década del noventa- que ya no estaría exclusivamente basado en la residencia, sino que incorpora progresivamente sobre la tipología relativamente tradicional de la avenida de acceso -corredor comercial- comercios especializados de proximidad, y siguiendo las lógicas de alta accesibilidad desde el transporte individual da lugar a la configuración de "parques comerciales" integrados como el que mencionamos.

\footnotetext{
345 Diario Clarín, Sección La Matanza, 15 de Abril del 2008. p.1

346 Estas categorías fueron definidas como: Hipermercados: establecimientos en régimen de autoservicio con una oferta que incluye el sector cotidiano así como otros complementos (textil, bricolage, electrónica, etc) y con superficies de venta que varían entre los $2.500 \mathrm{~m} 2$ hasta $\operatorname{los} 10.000 \mathrm{~m} 2$. Homecenters: establecimientos con una oferta de productos especializados en la construcción, remodelación y equipamiento de la casa y el jardín, y una superficie de venta entre $3.500 \mathrm{~m} 2$ y $13.000 \mathrm{~m} 2$. Ver, Lorena Vecslir, Nuevas centralidades del ocio y del consumo. Ámbitos, modalidades e instrumentos de regulación de las grandes superficies comerciales en la Región Metropolitana de Buenos Aires, en Riurb no 8, Especulaciones Suburbanas, Buenos Aires- Barcelona, 2011.
} 
La imagen de conjunto que se despliega remite a la tesis de "ciudad contemporánea", definida por Bernardo Secchi como lugar privilegiado de la mixité. Entremezcla de casas y oficinas, de talleres-casas y comercios. La ciudad contemporánea es lugar de la co-presencia: de figuras sociales, de técnicas productivas, productos, materiales urbanos, formas espaciales pertenecientes a diversos períodos de la historia. ${ }^{347}$

Como hipótesis, es posible pensar que durante los años posteriores al crecimiento inicial, el conjunto no terminó de consolidarse, quedando una importante cantidad de lotes vacantes, sobre los cuales, décadas más tarde se imprimió un nuevo proceso de suburbanización que ya no era el de la residencia de fin de semana.

\section{La formación del núcleo}

Más allá del barrio original al que referimos, aprobado como Barrio Parque Peluffo y al cual se deben los orígenes de este núcleo suburbano, los planos que presentaremos confeccionados por las inmobiliarias que promocionaban los remates- dan cuenta de la multiplicación de proyectos similares en un área, lo cual terminaría por delinear un sector más amplio con características suburbanas particulares.

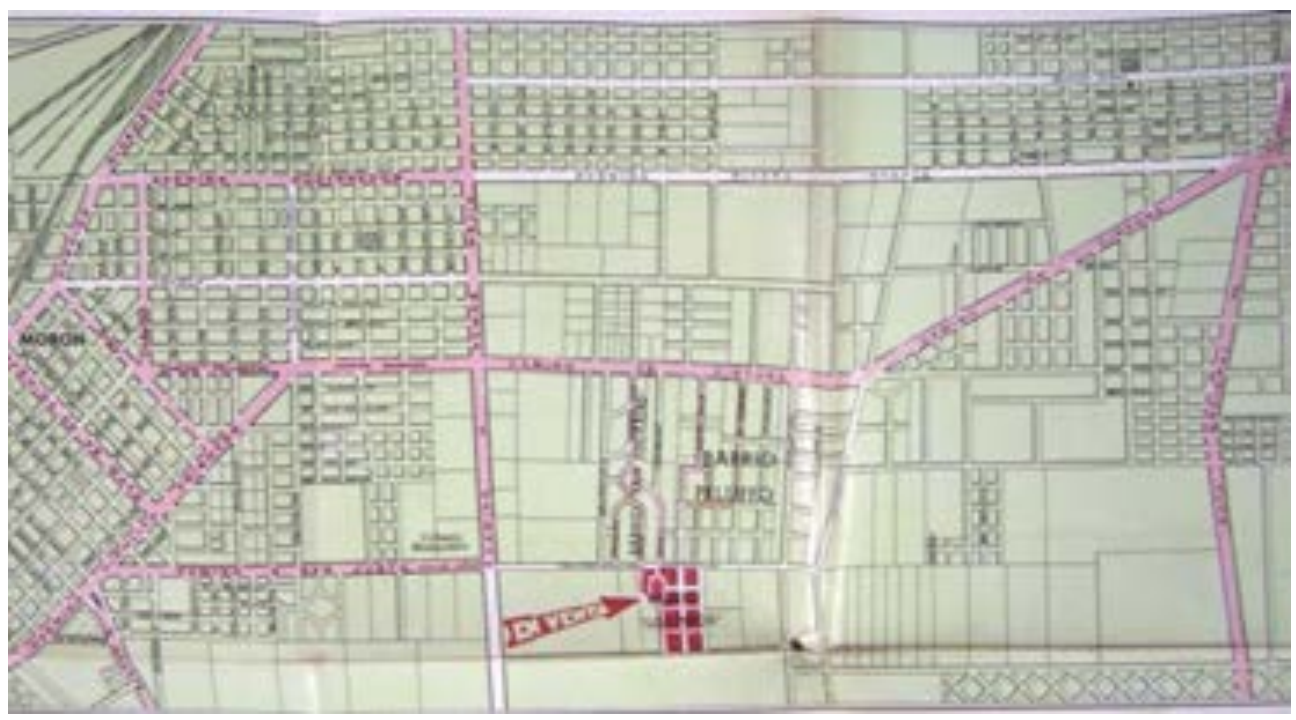

a- Plano de ubicación: a la izquierda, zona urbana Morón; en el centro, los nuevos loteos para quintas y residencias de fin de semana. Década de 1940. Fuente: Departamento de Investigación Histórica Cartográfica, Dirección de Geodesia, MOP, Provincia de Buenos Aires.

347 Bernardo Secchi, Ciudad moderna, ciudad contemporánea y sus futuros, en Lo Urbano en 20 autores...op.cit. 


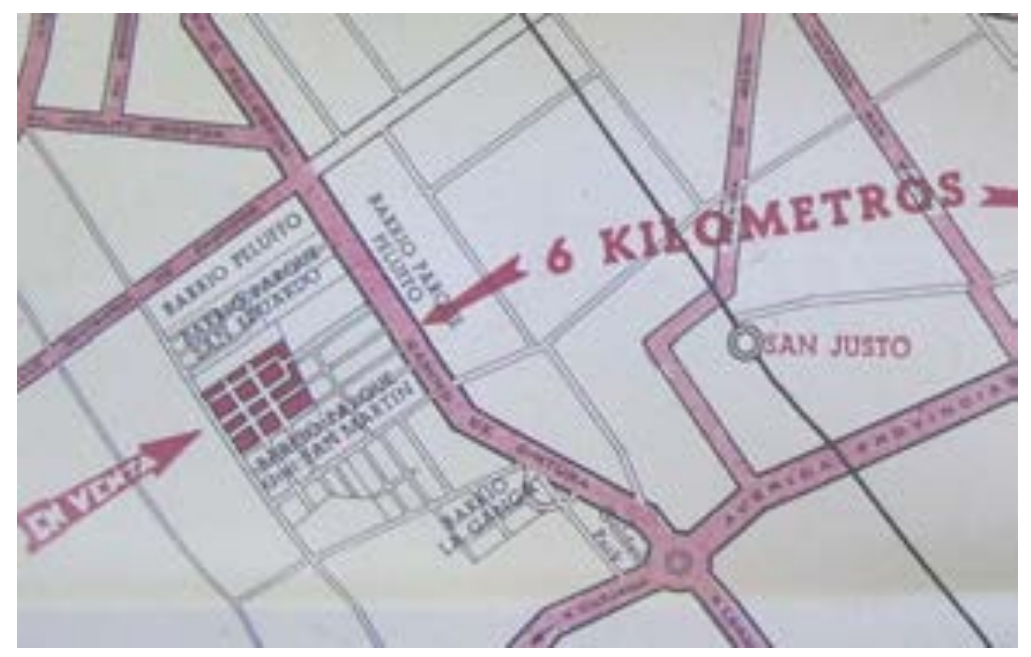

b- Plano de ubicación para la venta de 200 lotes en el Barrio Parque Peluffo. 1947 Fuente: Carpeta de remates Partido de La Matanza. Departamento de Investigación Histórica Cartográfica, Dirección de Geodesia, MOP.

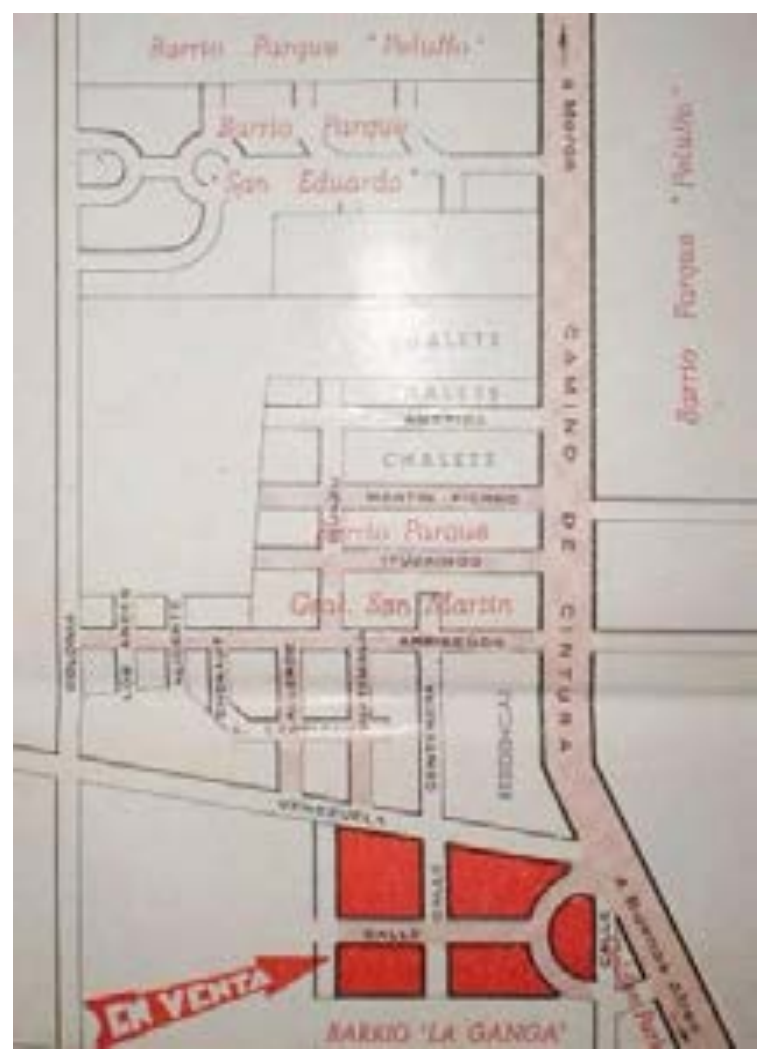

c- Plano de Ubicación Barrio La Ganga. 1947

Fuente: Carpeta de remates

Partido de Morón. Departamento de Investigación Histórica Cartográfica, Dirección e Geodesia, MOP.

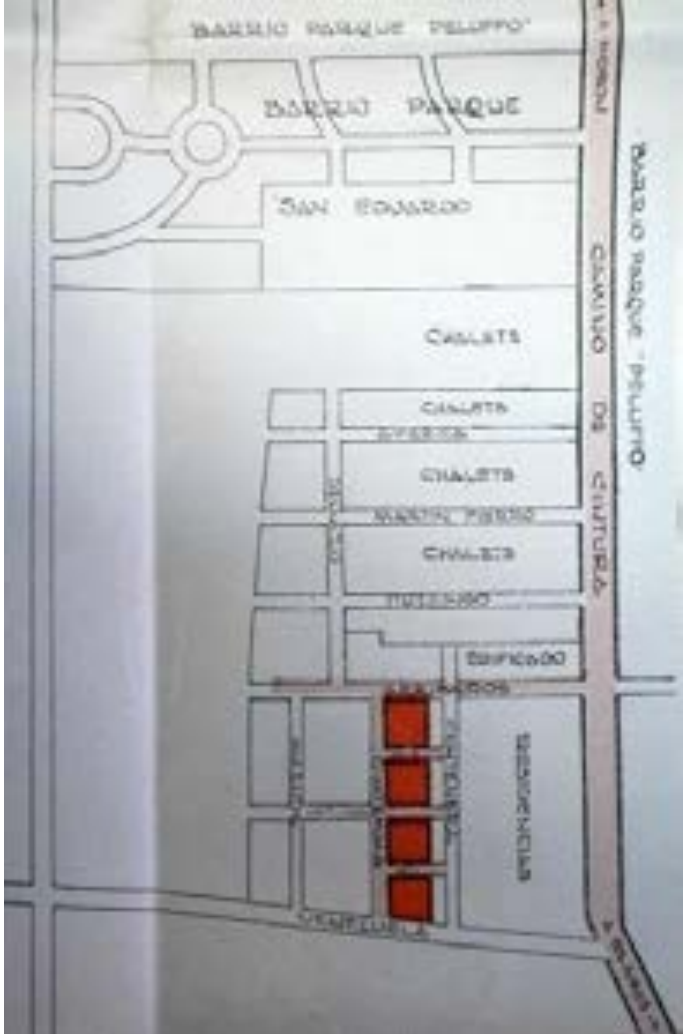

d- Lotes en venta en el área B.P.Peluffo. 1948 Fuente: Carpeta de remates

Partido de Morón. Departamento de Investigación Histórica Cartográfica, Dirección e Geodesia, MOP. 


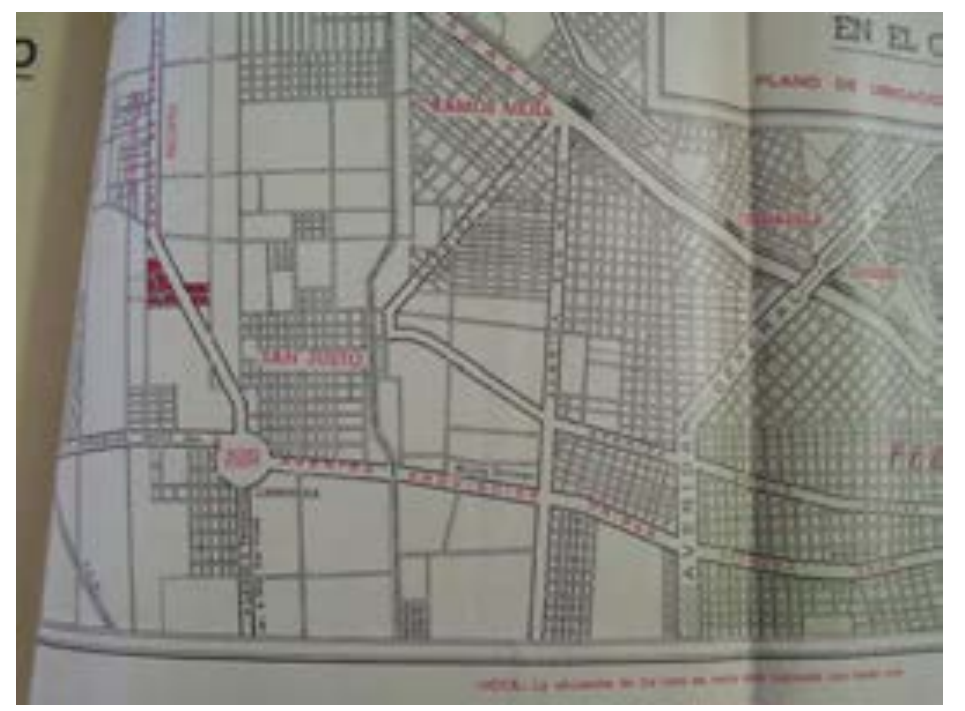

e- Plano de ubicación correspondiente al remate del barrio "Golden Park". 1949

Fuente: Carpeta de remates

Partido de La Matanza. Departamento de Investigación Histórica Cartográfica, Dirección e Geodesia, MOP.

La secuencia de planos que mostramos, nos enseña un proceso de crecimiento en donde, en el primer plano (plano A), se ubica el B.P. Peluffo en una localización central, entre el B.P. Los Pinos que se observa por debajo y la urbanización San Eduardo a la izquierda. En 1947, a esa primera urbanización Peluffo se agregan dos nuevos sectores con el mismo nombre, y un nuevo sector a la derecha; B.P. General San Martín. (plano B). Para el mismo año, encontramos otro plano (C) en el cual se incorpora el Barrio La Ganga. En este caso, nótese que aparecen referenciados los barrios parque de aparición previa, y además, se señalan las áreas edificadas con "chalets", confirmando, como demostramos en el capítulo anterior, la importancia simbólica que adquirían este tipo de construcciones en el ámbito metropolitano. Un año más tarde, el plano de un nuevo loteo (plano D) registra cómo pequeñas áreas intersticiales se van sumando dentro de la lógica generada por los barrios parque. Por último, en 1949, (plano E) se localiza un nuevo sector en venta (en rojo) y todas las fracciones mencionadas en los planos anteriores, ahora conforman el sector al que se denomina, genéricamente, Barrio Peluffo.

Este recorrido da cuenta de dos cuestiones. En primer lugar, de un proceso de expansión metropolitana que es característico de nuestro país: fragmentario, llevado a cabo a partir de la adición de porciones menores en manos de diferentes propietarios, y sin embargo, cuando nuevos proyectos se desarrollaron en localizaciones alejadas de las áreas ya urbanizadas; la incorporación de un emprendimiento más o menos exitoso solía contribuir a la multiplicación de proyectos similares en el área. Aquí, sucesivos emprendimientos destinados a usos residenciales de segunda residencia se fueron anexando a partir de operaciones de dimensiones intermedias, conformando lentamente 
un área con características urbanas particulares, capaces de ser definidas como suburbanas, especialmente en contraste con el territorio rural de los alrededores. Con todo, si queremos tener una visión más matizada de cómo fueron estos procesos, debemos imaginar que los límites que definían a este conjunto eran difusos, entre otras cosas, porque a lo largo del período que aquí abordamos se encontraban en constante trasformación. De esta manera, se generaba un grado de consolidación mayor en las urbanizaciones de más antigua data -que como se lee en los planos se convertían en referencias para las más recientes- y sobre los costados de la ruta principal. Sobre dichos sectores las residencias se levantaban a menor distancia una de otra, y se reconocían algunas calles pavimentadas cuyo trazado se iba perdiendo sobre los loteos más recientemente incorporados. Lo dicho, por otro lado, nos lleva a confirmar una cuestión que ya adelantamos: el rol primordial que ejercieron los primeros loteos suburbanos que se ubicaban en áreas semi-rurales y que operaron como polos de atracción para nuevos emprendimientos. Esto se hace visible en las constantes referencias que aparecen en los planos que señalamos y, en particular, en el más alejado de los loteos que quedan bajo la "zona de influencia" del Barrio Parque Peluffo, el Golden Park (en rojo en el plano E). Este conjunto ubicado "sobre el Gran Camino de Cintura, justamente donde empiezan las residencias del ya famoso Barrio Peluffo" contribuye a reforzar nuestra hipótesis, en cuanto confirma como las urbanizaciones más recientes, y especialmente aquellas de localización periférica al agrupamiento original, tomaban a este como núcleo de referencia. A través del discurso publicitario se constituye una suerte de jerarquía, el Golden Park se beneficia de su cercanía al Barrio Parque Peluffo, a la vez que tomándolo como modelo de referencia contribuye a consolidar su importancia simbólica.

Por otra parte, desde la mirada periférica -en el sentido literal- que aportan los nuevos emprendimientos, los límites dentro de los cuales, inicialmente, se definió cada uno de los loteos empiezan a fundirse, dando paso, justamente, a la formación del conjunto o el agrupamiento urbano al que aquí referimos. 


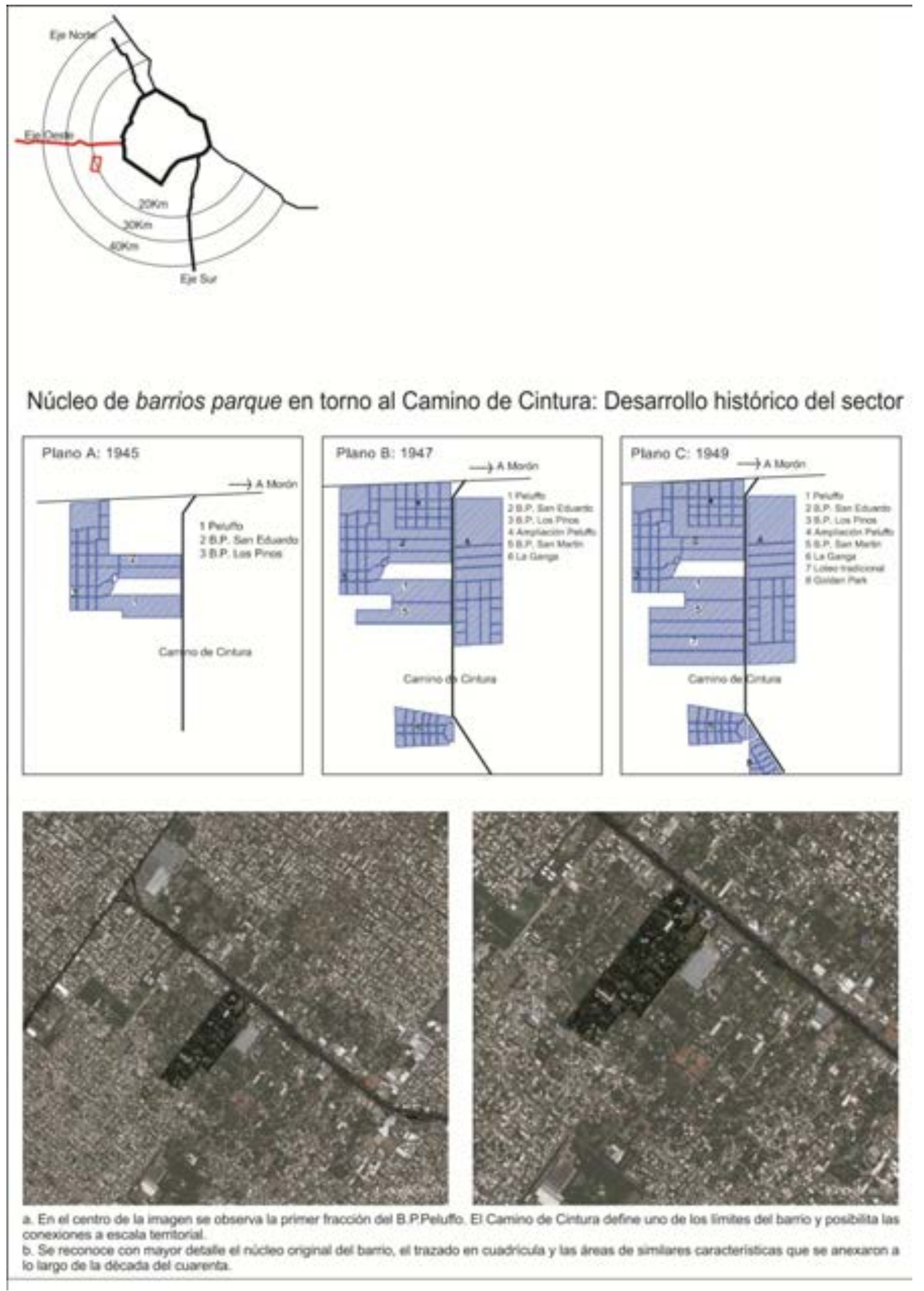


Contrastes: el tejido urbano

Una indagación morfológica-territorial, permite ver que la agrupación de emprendimientos de similares características en este sector contribuyó a definir una trama intermedia, desde el reticulado de manzanas más densas que se localizaban cercanas a la estación Morón y sobre los laterales de las vías de ferrocarril, hacia las zonas intersticiales interiores en que la trama se iba agrandando. El pasaje de una trama con características urbanas -manzanas más o menos regulares, con medidas uniformes y lotes angostos- a otra más irregular, que daba lugar a los grandes bloques en donde se levantaban los barrios de fin de semana, solía ser abrupto. Como se observa en el Plano A (p. 264), los cambios entre ambas lógicas iban generando quiebres en la estructura del territorio marcados por el paso de una avenida o vía pavimentada. Contrariamente a lo que se cree, muchos de estos quiebres provienen, en realidad, de más larga data, como lo muestra el Registro Gráfico de las Propiedades Rurales (circa 1860) y la propuesta de Pedro Benoit para ordenar la traza del pueblo de Morón (1859). Aquí se plantea como problemática que la expansión del poblado se estaba produciendo a expensas de las propiedades rurales circundantes, alterando el damero originario y provocando un proceso de asimetría. Se yuxtaponían dos tramas distintas, la de la cuadrícula original del poblado con calles tiradas de Este a Oeste. La otra, la de las calles que bordeaban las quintas en zonas más alejadas, trazadas con rumbo NoresteSudoeste, como el resto de las propiedades rurales. ${ }^{348}$ Como podemos ver, de vuelta en el siglo XX, se continúan registrando dos tramas que corresponden a lo que fue originalmente el pueblo y su zona de quintas.

\footnotetext{
348 Ver, Carlos María Birocco, "Morón. La construcción de un Municipio 1855-1900”, en Revista de Historia Bonaerense n²6. Historia Urbana.
} 


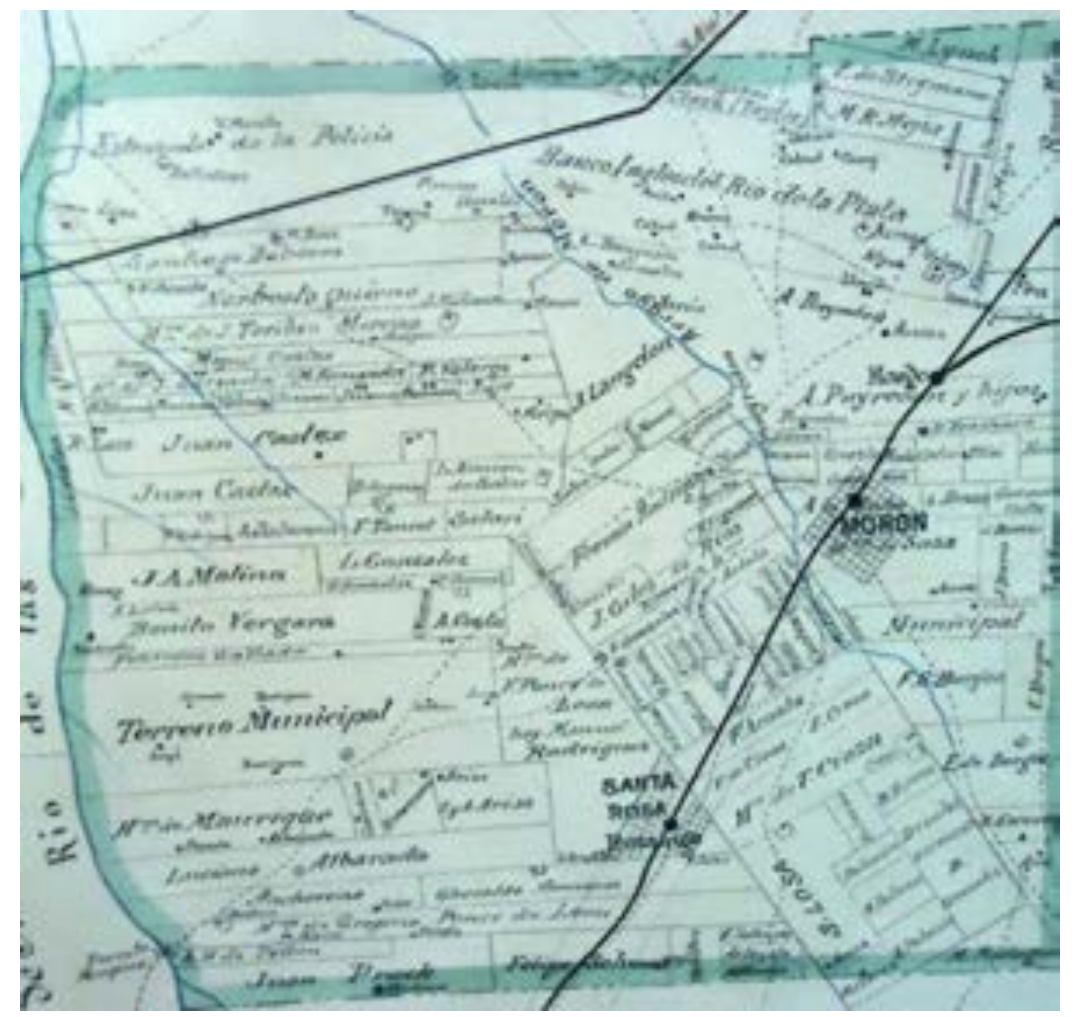

Plano del partido de Morón. Registro gráfico de las propiedades rurales. (Circa 1860) Fuente: Departamento de Investigación Histórica Cartográfica, Dirección de Geodesia, MOP, Provincia de Buenos Aires.

Se reconoce que las vías pavimentadas determinaron un primer nivel de ordenamiento en la estructura territorial, delimitando áreas que tomaban formas diversas, con dimensiones que tendían a agrandarse en tanto se alejaban de las áreas más densificadas sobre la traza del FFCC y que, mayoritariamente, se comportaron como bloques homogéneos hacia su interior. Es decir, que se registró una mayor cantidad de vías que delimitaban manzanas más pequeñas dentro del pueblo de Morón y en las tierras lindantes a la traza del ferrocarril, (las medidas variaban entre los 80 y los $110 \mathrm{mts}$ de lado). Dentro de estas áreas el parcelamiento de las manzanas también continuó el modelo más tradicional de lotes angostos y profundos (10 x 40mts). Por el contrario, manzanas de grandes dimensiones (se registraban medidas hasta los $220 \mathrm{mts}$ de lado) y pocas vías de acceso correspondían a las nuevas parcelaciones, en donde, al menos en el caso particular del Barrio Parque Peluffo, la subdivisión parcelaria era de grandes lotes, que llegaban a los $1000 \mathrm{~m} 2$ con relaciones de lados más proporcionadas $(25 \mathrm{x}$ $50 \mathrm{mts})$. 
La ausencia del barrio

Hacia el interior de los barrios parque, la nueva estructura territorial, de crecimiento lineal a lo largo del Camino de Cintura, llevó a que cada uno de los loteos se organizara en torno a un único acceso. A pesar de lo que muestra la estructura interna de cada emprendimiento, -que se desarrolla sobre una red vial que permite múltiples conexiones entre el conjunto, la vía de acceso principal y los nuevos loteos vecinos que se van adicionando, a la manera de una trama urbana abierta- en la realidad, estas vías rara vez superaban su condición de dibujo en el plano o a lo sumo de huella que marcaba el paso de los autos sobre la tierra. Sólo se consolidaban las calles que permitían llegar desde las parcelas ocupadas hasta una vía central que uniera al conjunto parcelario con la red urbana. En consecuencia, el Camino de Cintura se convertía en único elemento de relación entre el núcleo residencial del B.P.Peluffo y el territorio circundante.

Así, desde el punto de vista de sus habitantes, la principal característica de estos núcleos surgidos a partir de loteos "sueltos", fue su tendencia a conformarse de manera cada vez más autónoma. Durante el proceso de expansión previo, los loteos de barrios parque -como por ejemplo el Barrio Parque Castelar que abordaremos a continuaciónconformaron áreas más reducidas o se sumaron a pueblos de formación anterior tendientes a generar una fuerte identidad local. Allí, bajo la imagen de la pequeña comunidad se moldeó un tipo de sociabilidad entorno a la noción de felicidad familiar que coexistió con otra comunitaria, y cuyos focos eran la calle, la plaza, el café y las instituciones locales como la sociedad de fomento, el club o la biblioteca. Lentamente, estas iniciativas se irían perdiendo a medida que los primeros barrios se consolidaban y aumentaban sus dimensiones.

Para el Barrio Parque Peluffo y el conjunto de loteos que se introdujeron en los alrededores, la implementación de una sociabilidad común estaba vedada de antemano. Como vimos, los loteos como el Barrio Parque Peluffo situados sobre nuevas vías de acceso, salvo pocas excepciones carecieron de espacio público -veredas y mucho menos plazas- dado que el propio carácter de la parcelación suponía los espacios libres, recreativos, como función privada dentro de cada parcela. Además, reunidos a lo largo de un camino, como único aglutinante entre los loteos vecinos, se vio anulada -por sus características de vía rápida, sin equipamiento urbano, ni veredas- la posibilidad de generar un lugar de uso común, de reunión, o de juego. A la manera en que Lewis Mumford describió la formación del suburbio masivo, estas nuevas lógicas de 
crecimiento de la ciudad tendían a desvincularse del espacio público - privilegiando el uso del automóvil particular a través de una eficiente conexión con la red viaria- ${ }^{349}$ En la medida en que los núcleos suburbanos se alejaron del ferrocarril y de la estación como centro de referencia, el suburbio dejó de ser una unidad vecinal para convertirse en una extensión difusa, que por sus mismas características físicas debió renunciar a conformar una comunidad suburbana o una entidad similar al barrio, en el sentido que le otorga Gorelik, como un artefacto con identidad cultural y política. ${ }^{350}$

\footnotetext{
${ }^{349}$ Lewis Mumford, La ciudad en la historia, op.cit.

${ }^{350}$ Ver, Adrián Gorelik, La Grilla y el Parque, op.cit. p. 358.
} 


\subsection{El primer Barrio Parque del Oeste: Castelar}

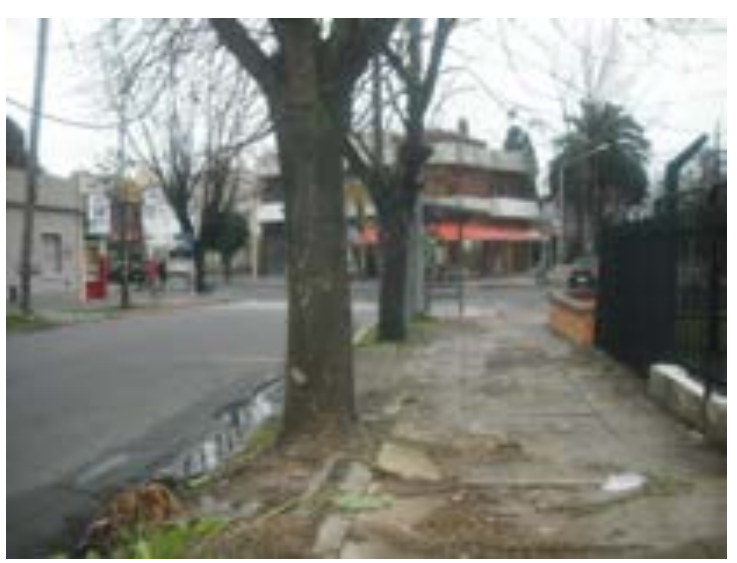

Barrio Parque Castelar Avenida Mitre

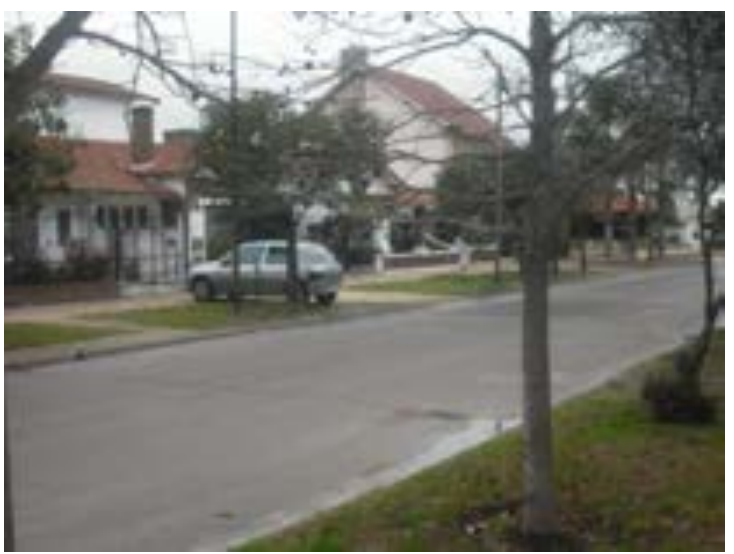

Barrio Parque Castelar

Calle Del Libertador 500-600

Foto del autor

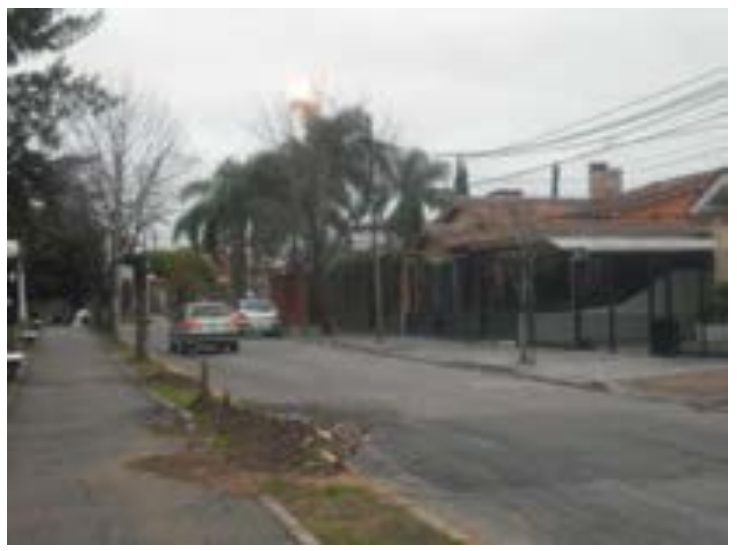

Barrio Parque Castelar

Calle Dardo Rocha 500-600

Foto del autor

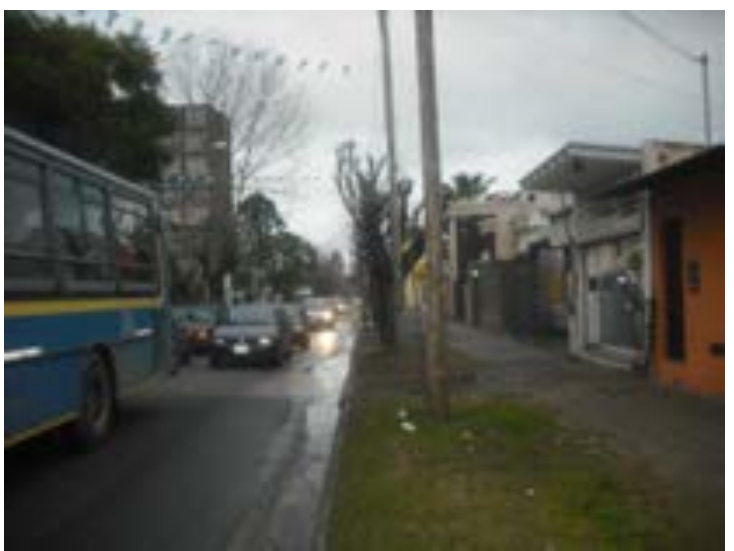

Barrio Parque Castelar Avenida Mitre 
Situado en el corazón de la Zona Oeste, el Barrio Parque Castelar es un excelente ejemplo que permite analizar las primeras transformaciones experimentadas sobre el eje Oeste en relación a la introducción de los primeros barrios parque. Y en este escenario, observar su inserción en torno a zonas de urbanización previa -concretamente en torno a núcleos ferroviarios que los antecedían-, así como también es sintomático del desplazamiento de este tipo de loteos hacia los sectores medios de la sociedad. Por último, este caso presenta la singular característica de tener entre sus creadores a los arquitectos Alberto Prebisch y Ernesto Vautier, lo cual nos permitirá analizar, entre otras cuestiones, el marco en el cual se desarrollaba la práctica profesional en el contexto de la expansión especulativa.

El barrio se asentó sobre un sector de la expansión que comenzaba a cosechar cierta fama de "Córdoba Chica", guiado fundamentalmente por la extensión del Ferrocarril Oeste. En 1859, apenas iniciado el nuevo servicio de ferrocarriles regular a Morón, una colorida nota periodística registra el florecer de una nueva moda: "los porteños se apasionan por ir a tomar un café a Morón; luego de cumplir con ese rito, felices, regresan al clásico casco urbano." ${ }^{351}$ Dos años más tarde, un viajero inglés, Thomas Woodbine Hinchcliff, relató el viaje en tren por la línea del Oeste, hacia la estancia de Harry Smith en Merlo. Hinchcliff apreciaba los efectos del nuevo medio de locomoción, el camino jalonado de barracas, molinos, hermosas villas y bares de recreo con lindos jardines que tentaban a muchos porteños inclinados a divertirse y pasar sus domingos y días de fiesta como los ingleses lo hacían en Richmond o en Gravesand. ${ }^{352}$

Sobre esta tradición comenzaron a instalarse a fines del siglo XIX las primeras quintas de veraneo, paulatinamente, su número iría en aumento, hasta que en 1913 el crecimiento del área justificó la inauguración de una nueva estación del Ferrocarril Oeste que recibió el nombre de "Estación Zeballos" (actualmente Estación Castelar). Entre esta inauguración y 1930, la población adquirió su nombre actual, se lotearon las

351 Diario El Nacional, 22 de febrero de 1859. Citado por Jorge Schvarzer y Teresita Gómez, en $L a$ primera gran empresa de los argentinos. El Ferrocarril del Oeste (1854-1862). Op.cit. p. 113.

352 Hinchcliff, Thomas W. Viaje al Plata en 1861.Citado por Garciela Silvestri en "La vida en clave verde. Cambios en las formas de habitar urbana y rural a mediados del siglo XIX”, en Registros. Revista anual de Investigación del Centro de Estudios Histórico Arquitectónico-Urbanos, año 5, $\mathrm{n}^{\mathrm{o}} 5$, Abril de 2008. pp.16-30. 
primeras manzanas cercanas a la estación, se electrificó la red del ferrocarril (1923), se formaron la Sociedad de Fomento Castelar, se instaló el alumbrado público y se pavimentaron las primeras calles del área central (1926) en donde se empezaban a concentrar los primeros comercios: farmacia, panadería, despensa y almacén. Para 1929, cuando los lotes del "primer Barrio Parque del Oeste"353 salieron a la venta, la población ya tenía algunas características bien definidas.

El plano presentado a la dirección de Geodesia de la Provincia de Buenos Aires en 1928, constituye una fuente primordial para analizar la formación del sector (p. 279 y 282). Allí se deja ver que muchas de las manzanas a lotearse pertenecieron a antiguas quintas que incorporaron áreas reducidas (entre 5-10 manzanas) que se fueron adjuntando hasta consolidar la trama urbana. ${ }^{354}$ Morfológicamente, la conformación del tejido urbano como resultado de sucesivas intervenciones inconexas dio lugar a una urbanización discontinua, en la cual la mayor parte de los loteos tendieron a homogeneizarse a través de la grilla, y otros, justamente, en su afán de diferenciarse, apelaron a trazados considerados "más modernos".

Este es por ejemplo el caso del Barrio Parque Castelar. Este emprendimiento comenzó su formación en 1928, localizado a 28 km de la Capital, se desarrolló en 20 ha ubicadas a cuatro cuadras de la estación de Ferrocarril y se incorporó a un área que, aunque dispersa, comenzaba a mostrar señales de urbanización.

353 Así lo refería la publicidad del loteo Barrio Parque Castelar. 1929. Fuente: Carpeta de Remates Partido de Morón, Departamento de Investigación Histórica Cartográfica, Dirección de Geodesia, MOP, Pcia Bs As.

354 Quinta de Canale; Quinta del Ing. Ayerza, Quinta de Zeballos, Plano realizado por la Sociedad de Fomento Castelar en 1928 con el proyecto de macadamizado. Carpeta 2, Planos de Castelar, en Departamento de Investigación Histórica Cartográfica, Dirección de Geodesia, MOP, Provincia de Buenos Aires. 

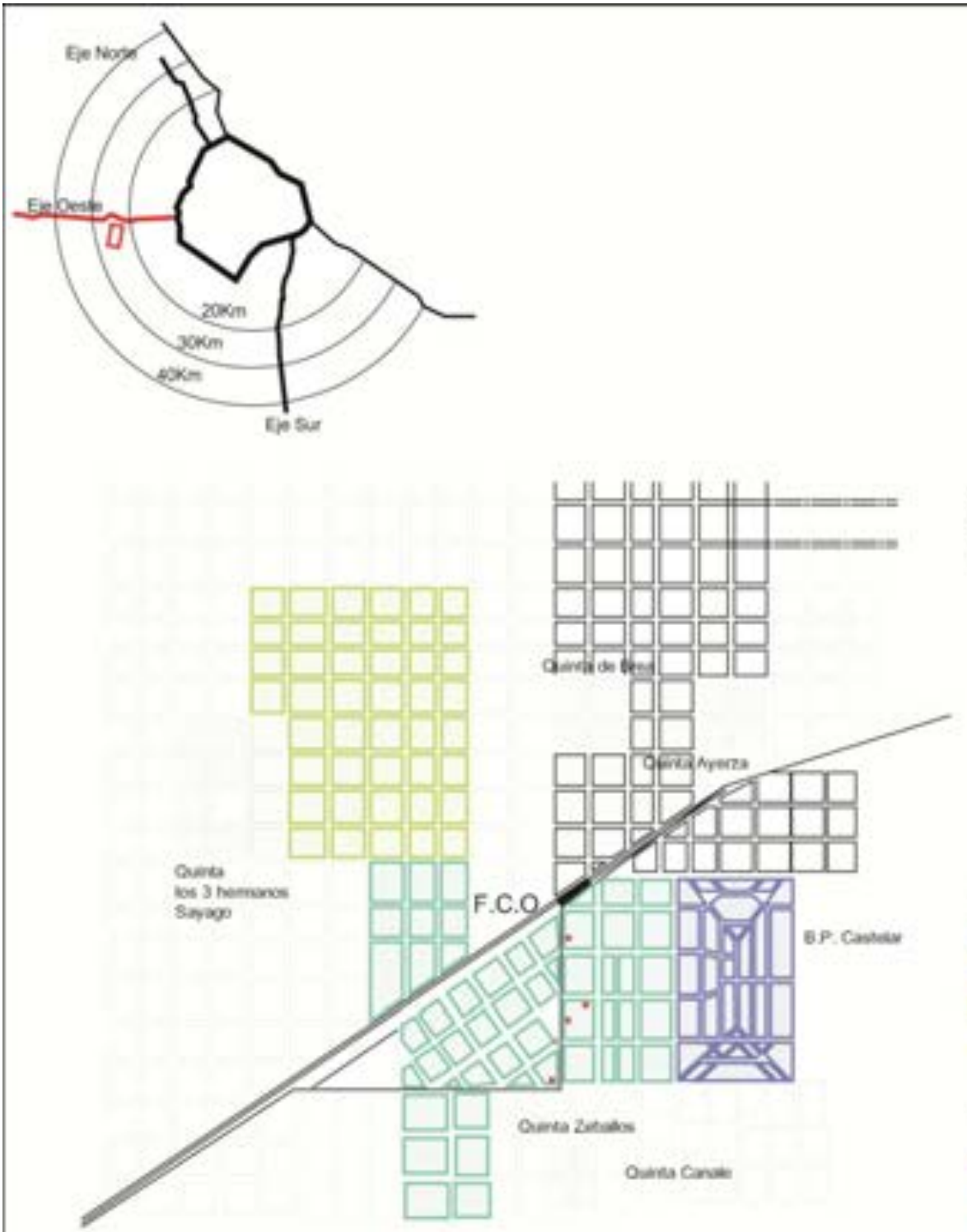

\section{CASTELAR}

1929

Antigua Quinta
E B. Castelar
E Loteos previos a 1929
Lotoos contemporineos a
B.P. Castelas
Calles proyectadas
- Calles existentes
- Ruta $n^{*} 7$
- Comercios existerses 1929

Cumpo Sent
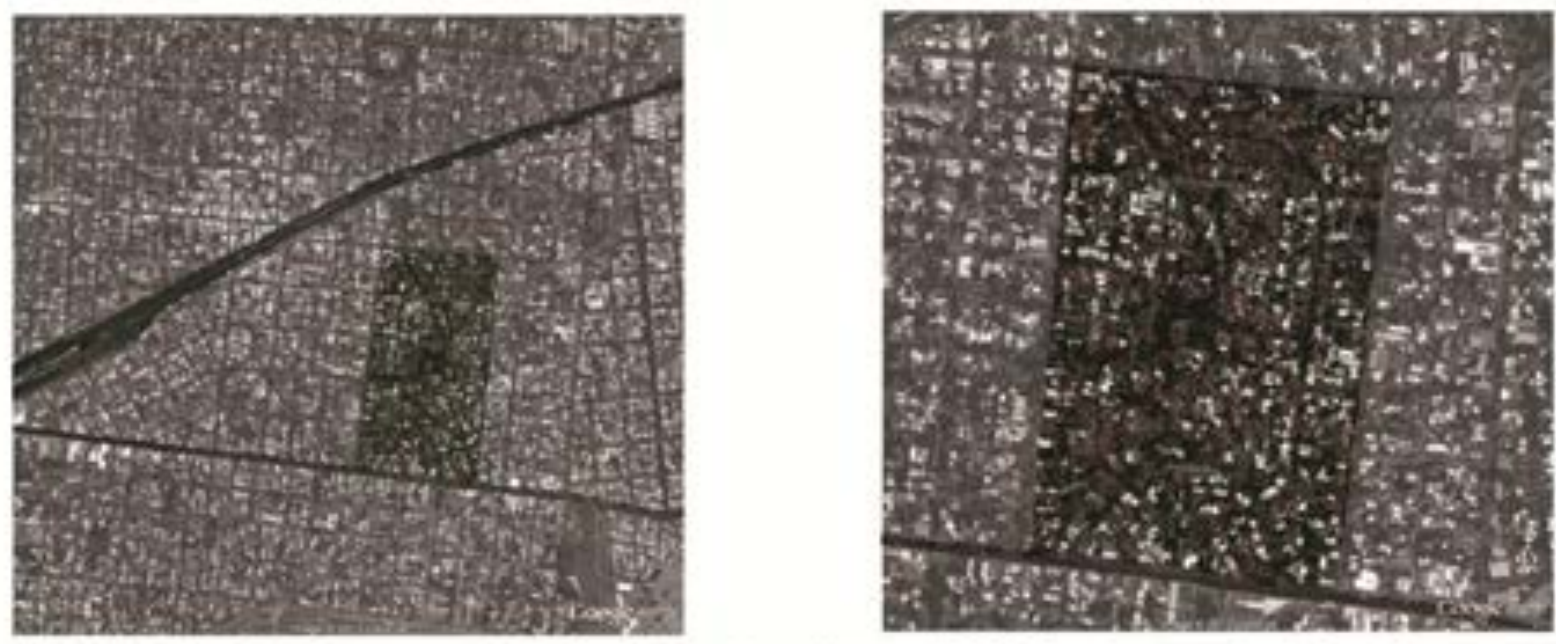

a. A la izquierda de la imagen se reconoce la Est Castelar y en diagonal la traza del F.C.O. En el centro -en color- el Bario Parque Castetar, y marcando el limite inferior del barrio, la Av, Estanistoo Zobalios. Procedenolax Google Earth

b. Trazado del B.P. Castelar e inmedaciones. Procedencia: Goople Earth 
La prolijidad de los frutales

Hoy, ante un recorrido por la zona, se despliega un área completamente urbanizada y a pesar del avance de la expansión, hacia el interior del barrio parque sobrevuela una sensación de calma.

Veníamos manejando por la Avenida Bartolomé Mitre, en una caravana lenta de autos y colectivos que transitan esta calle angosta y que cada vez que se detienen en las esquinas a levantar pasajeros ralentizan toda la circulación. La avenida está además jalonada de comercios de primera necesidad: almacenes, una farmacia, quioscos de paso, en donde un auto para y se mantiene en marcha mientras el acompañante baja corriendo a comprar cigarrillos.

Sobre esta misma arteria, que es una de las que vincula al conjunto con el resto de la expansión, se localizan algunos edificios de viviendas multifamiliares de poca altura (4-5 niveles) y hacia la zona de la estación ferroviaria Castelar, es posible reconocer una creciente mezcla de usos; el residencial pierde relevancia en favor de los usos comerciales y de servicios básicos, como consultorios, clínicas y estudios profesionales de pequeña escala.

Cual turistas ( $\sin$ GPS), tuvimos que parar en uno de estos negocios a preguntar por el Barrio Parque Castelar. De reojo, mirando desde la avenida hacia uno de los lados, lo que veía (un barrio tranquilo, sin tránsito, de casas individuales) se parecía bastante a lo que esperaba encontrar, pero quería corroborar. El quiosquero no conocía al Barrio Parque Castelar, dijo que era nuevo en la zona. Pero cuando le pregunté por una dirección particular -recordaba haber visto una antigua foto de la esquina de Davobe y Libertador- en seguida se ubicó: estábamos a dos cuadras.

Llegar con el auto no fue tan fácil, no se podía doblar a la izquierda en la avenida y tuvimos que dar un rodeo hasta encontrarnos en el barrio. Una vez allí, dentro de las manzanas que corresponden al trazado original observé que no hay comercios, y el tránsito automotor está naturalmente restringido. En parte, por las escasas actividades que se desarrollan en el barrio, pero también debido a que el trazado de la red vehicular no permite conexiones directas que lo atraviesen; lo cual ha llevado, entre otras cosas, a que los colectivos que llegan a la zona, bordeen el barrio sin atravesarlo.

Estacionamos el auto y nos bajamos, caminando por las calles internas impresionaba la pulcritud. Los árboles no abundan en las veredas -de manera que casi 
no hay hojas, y cuando sí los hay son frutales o arbustos de jardín minuciosamente podados. Las viviendas individuales conservan en su mayor parte un pequeño jardín al frente, con césped y flores, resguardados por prolijas rejas.

Claro que era sábado por la tarde, y el clima de agosto no invitaba a pasear, pero creo que en las siete cuadras que caminamos sólo cruzamos a un vecino lavando un Ford $\mathrm{Ka}$ en la vereda, a una señora con ropa deportiva paseando al perro y a dos adolescentes dando "la vuelta al perro" en una moto pequeña. Seguimos caminando y luego de tres cuadras me di cuenta que las manzanas se habían vuelto más largas, habíamos sobrepasado los límites del barrio sin darnos cuenta. En la dirección que caminábamos (sentido Este-Oeste), los bordes están materializados por calles internas, de manera que el pasaje de la trama del barrio parque a la trama cuadriculada tradicional es imperceptible. Sobre todo, por los usos predominantemente residenciales que son la razón de ser del barrio y que se extienden más allá del núcleo original, dando lugar a un paisaje homogéneo, de baja densidad poblacional, conformado por viviendas individuales.

Se hacía de noche, subimos al auto y tomamos la Avenida Estanislao Zeballos límite Sud-oeste del barrio, conectora a escala interzonal, de tránsito rápido-. Uno a uno fueron apareciendo los comercios de mayores dimensiones -depósitos, estaciones de servicio-, y sin embargo, ni esta, ni otras carreteras de acceso, como por ejemplo la Avenida Rivadavia, que concentran comercios especializados de proximidad han llegado a modificar el carácter netamente residencial del área.

Especulaciones en torno al proyecto

El proyecto del Barrio Parque Castelar habría sido realizado por los jóvenes arquitectos Alberto Prebisch (Tucumán 1899- Buenos Aires 1970) y Ernesto Vautier (Buenos Aires 1899-1989). Este hecho constituye un episodio particular en la formación de barrios parque y de fin de semana, si recordamos que en la mayor parte de los casos que comprenden nuestro corpus no tenemos información sobre sus proyectistas. 


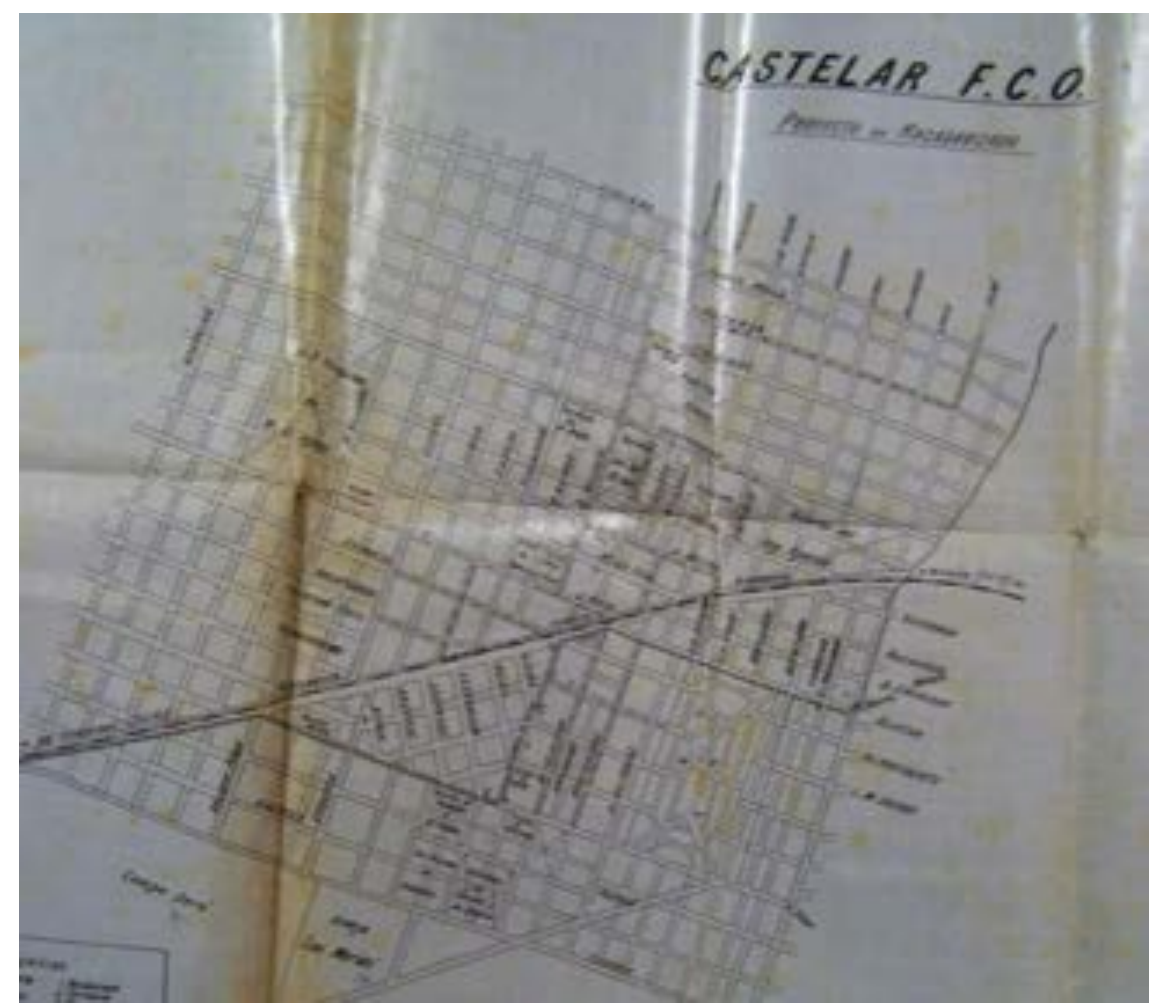

Núcleo de Castelar. En la parte inferior derecha del plano se aprecia el trazado del nuevo Barrio Parque Castelar y a su izquierda el núcleo de población original. Cortando el plano en diagonal la traza del FCO y la ruta 7 , continuación de calle Rivadavia.

Plano presentado al Departamento de Geodesia para aprobación del proyecto de macadamizado en 1928.

Carpeta de

Remates-Partido de Morón,

Departamento de Investigación

Histórica

Cartográfica,

Dirección de

Geodesia, MOP,

Pcia. Bs. As.

En este contexto, nos preguntamos si la actuación de los noveles arquitectos en el Barrio Parque Castelar, marca una diferencia cualitativa en relación a otros barrios parque. Analizando brevemente su trayectoria, nos encontramos frente a dos jóvenes profesionales que comenzaban a conquistar un lugar en el campo profesional, fundamentalmente, a partir de los desafiantes artículos que publicaban en la Revista Martín Fierro, y de su proyecto de Ciudad Azucarera para Tucumán, premiado en el Salón Nacional de Bellas Artes en 1924. ${ }^{355}$

De este modo, podríamos entender la participación de ambos arquitectos en el proyecto para Castelar, como una oportunidad para llevar a la práctica algunas cuestiones que sólo habían podido desarrollarse a nivel teórico. Al respecto, cabe

\footnotetext{
${ }^{355}$ Alicia Novick, “Alberto Prebisch. La Vanguardia Clásica", en Cuadernos de Historia IAA $n^{\circ}$ 9, Junio 1998. pp. 117-153.
} 
preguntarse qué estrategias compositivas, qué acomodamientos debieron llevarse a cabo en el proceso de convertir lo "ideal" en real. Concretamente, qué particularidades se dieron como producto de adaptar un ejercicio teórico-proyectual al contexto de la expansión capitalista de la ciudad teniendo en cuenta, además de la obra, las condiciones de encargo, las ideas fundantes, los debates teóricos en torno a la expansión, sin perder de vista los procesos y los medios productivos que constituyen, inevitablemente, su viabilidad.

Desde una perspectiva más amplia, encontramos en este caso concreto una oportunidad para analizar de qué manera los debates y las ideas que se inician en sede académica-profesional, se filtran en los proyectos comerciales. El tema es extenso, y reconoce diferentes aristas. En lo que concierne a la arquitectura -tema analizado en el capítulo previo-, la escasa presencia de arquitectos y profesionales de renombre, nos llevó a preguntarnos por el circuito a través del cual las obras y los modelos se difundían. Aquí, en cambio, estaríamos ante un caso singular, en el que se reconocería la participación de profesionales destacados. Ante este escenario, nos preguntamos de qué forma y en qué medida los debates y la experiencia recogida por ellos en otros ámbitos se tradujo en la formación de este suburbio.

A diferencia del diseño para la Ciudad Azucarera, con su área productiva, administrativa y sus barrios residenciales; en este caso el programa para el Barrio Parque Castelar respondía a necesidades puramente residenciales, incorporándose a un área con cierto grado de urbanización previa, cuyas actividades productivas ya estaban establecidas.

Como respuesta a este contexto, sobre la base de una planta urbana rectangular, el nuevo núcleo buscó articularse -a través de sus calles exteriores- con el trazado viario de la cuadrícula existente, dando cuenta de una preocupación significativa por establecer vínculos con el entorno. Argumento que se demuestra, además, a través de una de las promociones de venta que aclara que una de las vías laterales del barrio es continuación de la Avenida Zeballos (calle macadamizada que formaba parte del camino Morón-Ituzaingo). En cambio, la trama que se desarrolló hacia el interior del conjunto presentaba cierta búsqueda de autonomía, con cuatro diagonales que nacían de los vértices del rectángulo y culminaban en una calle principal, eje de la composición, que no se articulaba con la trama exterior del barrio (vemos aquí, que al igual que en el Barrio Parque Aguirre, la trama vehicular determina la separación con el trazado 
reticular que a la larga contribuye a "preservarlo" de una expansión sin calidad). Por otra parte, este tipo de organización viaria, dio lugar a diversas formas de amanzanamiento, entre las que predominaron las manzanas rectangulares de gran tamaño, con largos de 200 x 50mts, y parcelas pequeñas con frentes de $10 \mathrm{mts} \times 25 \mathrm{mts}$ de profundidad y manzanas más irregulares cortadas por las diagonales mencionadas que forman paralelogramos de 120 x 70 x 50x 100mts o triángulos de 100 mts de lado y dieron lugar a parcelas regulares de 10 x $25 \mathrm{mts}$ y a otras más irregulares en las esquinas y quiebres de dimensiones un poco mayores.

En principio, al cuestionar la cuadrícula los autores reiterarían el rechazo -que ya habían mencionado en su "Ensayo de Estética Contemporánea"356 - a las formas tradicionales de construir ciudad y supondrían una renovación profunda. Aunque debemos decir que por las condiciones propias del encargo, dentro de la lógica que imponía la subdivisión y venta de lotes bajo las reglas del mercado, el parcelamiento tradicional que se formuló no logró desprenderse de la lógica especulativa de la cuadrícula, poniéndolo en relación con el tipo de loteo masivo especulativo.

Por otra parte, a diferencia del Barrio Parque Aguirre, estructurado en torno a un club deportivo (Club Atlético San Isidro) y cuya ausencia de instituciones y edificios administrativos es significativa del carácter residencial no permanente que se pretendía otorgar a la comunidad, aquí la ciudad que imaginan Prebisch y Vautier seguiría organizándose de acuerdo a las instituciones y ámbitos de control tradicionales. Concretamente, como se reconoce en el plano, el tema principal del diseño, o para ponerlo en términos académicos -no olvidemos que dentro de esta tradición se formaron los jóvenes-, el point de la composición, estaba dado por la plaza central, de carácter administrativo-religioso, frente a la cual se proyectó la localización de la iglesia, el departamento policial y la delegación municipal.

En palabras de Alicia Novick, la versión de Vautier y Prebisch propone una Modernidad sin rupturas, donde las tradiciones, implícita y explícitamente, gobernaran el conjunto. Y esta situación, a pesar del doble desplazamiento que se produciría entre el proyecto de la Ciudad Azucarera y el Barrio Parque Castelar: de la escala urbana a la

\footnotetext{
356 Vautier Ernesto y Prebisch, Alberto, "Ensayo de Estética Contemporánea", en Revista de Arquitectura, Buenos Aires, 1924.
} 
barrial, y desde el ámbito teórico-proyectual al práctico, se reconoce de igual manera en ambos ejemplos.

En síntesis, este caso pone sobre el tapete la tensión entre "proyecto" y la realidad de la práctica profesional. En el caso del barrio parque los arquitectos habrían prescindido de los recursos compositivos más sofisticados -que sí utilizaban en otros proyectos-, como los callejones en $\mathrm{cul}$ de sac, y habrían repetido los instrumentos de diseño y referencias de uso más extendido - las manzanas rectangulares y las diagonales- que difícilmente podían considerarse una innovación para estos años. ${ }^{357}$

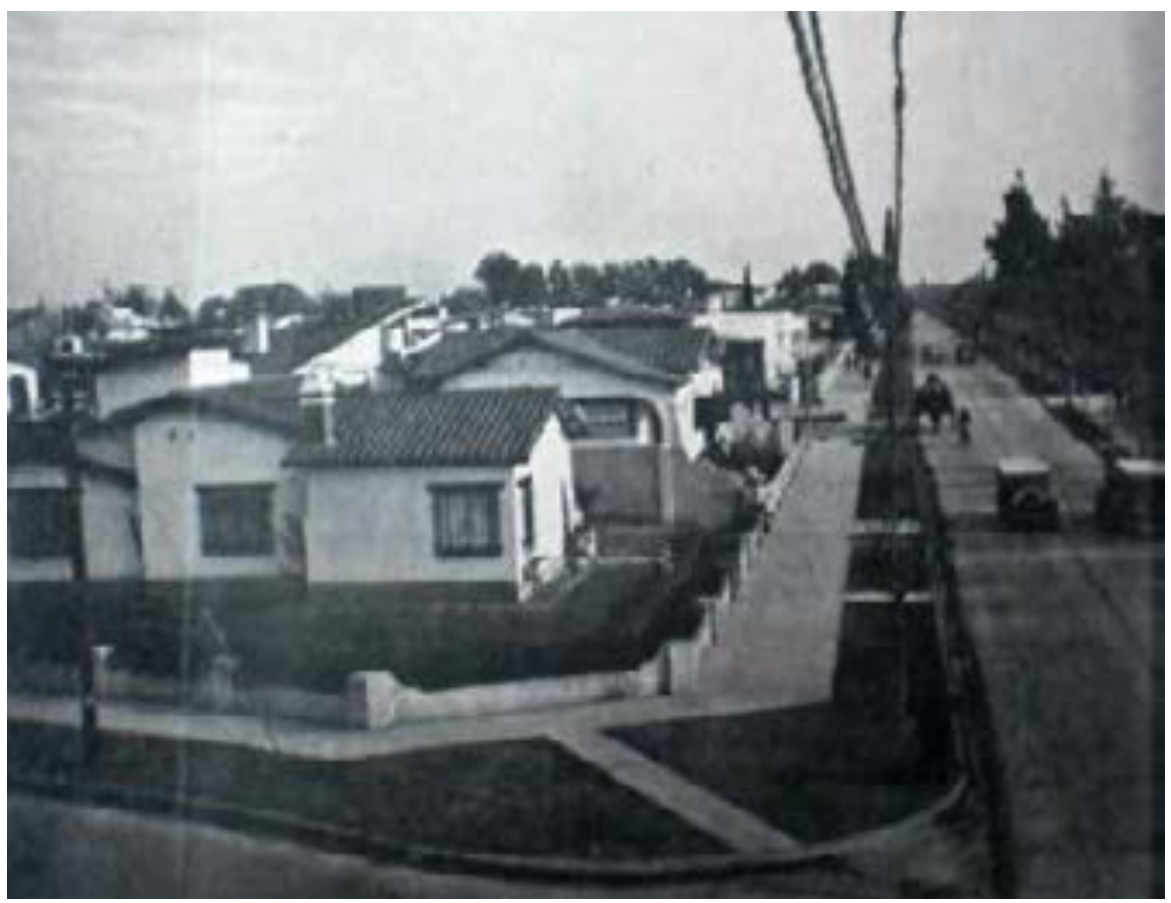

Fotografía del Barrio Parque Castelar. 1949

Fuente: Carpeta de Remates $\mathrm{n}^{\mathrm{o}}$ 10. Partido de Morón, Departamento de Investigación Histórica Cartográfica, Dirección de Geodesia, MOP, Pcia Bs As.

357 Alicia Novick plantea que para conocer más globalmente la obra de Prebisch es necesario incoporrar una nueva perspectiva: examinando las vinculaciones entre comitentes, empresas constructoras y mercado. En otras palabras, se trataría de examinar las alternativas de producción del espacio de la ciudad, donde los arquitectos no siempre han sido protagonistas. Ver, Alicia Novick, Alberto Prebisch. La vanguardia clásica. op.cit. 


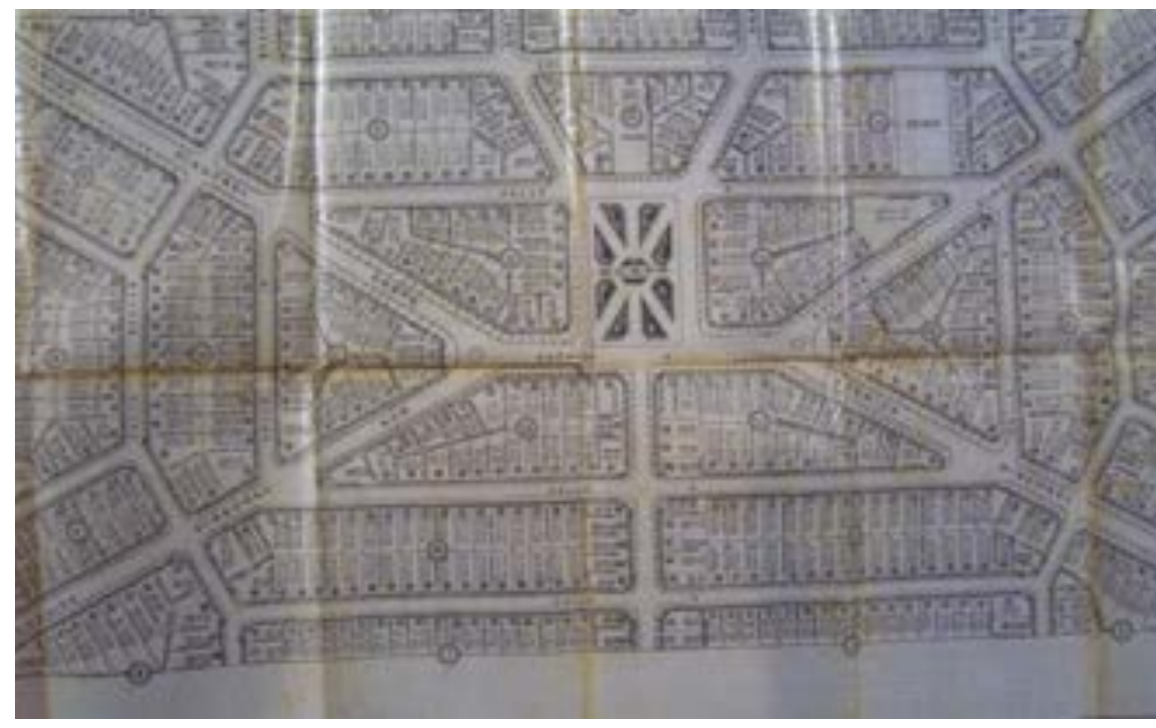

Plano del Barrio

Parque Castelar. Se puede apreciar el trazado de las manzanas y su parcelamiento.

Fuente: Carpeta de Castelar -Partido de Morón,

Departamento de Investigación Histórica Cartográfica, Dirección de Geodesia, MOP, Pcia Bs As.

Mercado de consumo y nuevos pobladores

Algunas de las cuestiones abordadas en las páginas precedentes fueron presentadas como hipótesis de trabajo. "El proyecto del Barrio Parque Castelar habría sido realizado por los jóvenes arquitectos A. Prebisch y E. Vautier..."'es la frase que abre el apartado anterior, en tanto hace referencia a la dificultad de comprobar fehacientemente la intervención de los jóvenes en el proyecto. De las fuentes contrastadas hasta el momento no se han encontrado planos, ni dibujos que liguen a los arquitectos al barrio parque, sólo su mención en la publicidad nos permite hablar de su actuación.

Ante este escenario, el interrogante que surge es por la importancia de su intervención en el proyecto. ¿Esta, se justificaba en sí misma o era tan, o más trascendente en términos publicitarios? En este punto, esta pregunta nos permitirá desplegar una serie de temáticas relacionadas al mercado inmobiliario, de consumo y a los compradores.

En primer lugar, dentro del ámbito inmobiliario, sería posible suponer que la mención a los profesionales forma parte de una estrategia de venta, destinada a posicionar al emprendimiento dentro de un grupo diferencial, teniendo en cuenta, como ya dijimos, que la incorporación de arquitectos y proyectistas no era una práctica habitual en el negocio de los loteos de barrios parque o de fin de semana.

Es sabido, que las inmobiliarias más importantes trabajaban con un grupo técnico propio. Era imprescindible la actuación de un agrimensor, en ocasiones él mismo se encargaba del diseño de subdivisión de los lotes, pero su tarea principal 
consistía en el replanteo de los terrenos y en la realización del plano de mensuras que debía ser presentado para su aprobación. Eran ellos los "peritos autorizados por la Provincia para subscribir y ejecutar este género de operaciones". ${ }^{358}$ En las "buenas épocas", cuando los remates eran masivos y las inmobiliarias buscaban mejorar y diferenciar el producto que ofrecían, se incorporaba la actuación de un equipo de diseño: un ingeniero o arquitecto y un paisajista, aunque, por lo demás, no contamos con ninguna información sobre ellos. Al respecto, puede entenderse que la existencia o ausencia de profesionales en la realización de un proyecto, sirve como reflejo de las condiciones generales del mercado. En efecto, como analiza Pierre Bourdieu, la oferta se presenta como un espacio diferenciado y estructurado de oferentes en competencia cuyas estrategias dependen de los otros competidores. ${ }^{359}$ Desde esta perspectiva, el hecho de que en general no contemos con información sobre los equipos de diseño, puede ser indicativo de dos cuestiones: de la exigua trayectoria o del escaso reconocimiento de los profesionales intervinientes a nivel público $\mathrm{y}$, fundamentalmente, de la escasa necesidad que reconocían los empresarios de incorporarlos. ${ }^{360}$ En otras palabras, si la oferta de una inmobiliaria, o de un barrio parque en particular, se regía en relación al universo total de inmobiliarias y barrios parque, en tanto el número de urbanizaciones que contratara los servicios de arquitectos de renombre se mantuviera bajo, seguiría siendo posible para el resto de los competidores mantenerse en el mercado ofreciendo configuraciones más simples, a valores más competitivos o apelando otros sectores de la demanda.

En síntesis, son pocas las ocasiones en que conocemos acerca de los proyectistas por detrás de un loteo. Cuando sí sucede, y en la publicidad de la venta o del remate se hace referencia al arquitecto o grupo de proyectistas a cargo de la obra, esto constituye una clara señal de distinción (que como ya se analizó en el Capítulo 5, se traduce en una suba de precios y contribuye a definir el perfil de los futuros

\footnotetext{
358 Así se menciona en la ley no 3487 (1913) de Fundación de pueblos y ampliación de ejidos.

${ }^{359}$ Ver, "El mercado de la casa" en, Pierre Bourdieu, Las estructuras sociales de la economía. Editorial Manantial, Buenos Aires, 2001. pp.31-92.

$360 \mathrm{Al}$ respecto, cabe recordar, como ya mencionamos en el Capítulo 4, que en este tipo de operaciones inmobiliarias se buscaba minimizar los gastos a fin de mejorar el rendimiento del negocio, y esto incluía también reducir los costos en el pago de honorarios profesionales.
} 
habitantes). Así se manifiesta en un barrio parque en San Isidro, a cargo de los arquitectos Moy y Castro en los años treinta y, específicamente, en el discurso publicitario del Barrio Parque Castelar.

"la subdivisión de este hermoso barrio ha sido trazado por los ingenieros Prebisch y Vautier, discípulos de Mrs. Jossely (sic.) de la Academia de París y se ha hecho consultando lo más moderno en esta clase de trazados, teniendo todos los lotes amplios frentes $\mathrm{y}$ fondos proporcionados, prohibiéndose las construcciones de madera. Allí se levantarán todas construcciones de mérito como las que la rodean. $" 361$

Como vemos, su intervención en este emprendimiento se convertía en una variable diferencial en relación a los demás barrios y cobraba especial trascendencia en términos propagandísticos.

A propósito de este tema, Fernando Rochi señala que desde comienzos del siglo XX se formó con mucha velocidad en la Argentina un verdadero "mercado de consumo" al que había que seducir con todas las prácticas comerciales que la modernidad exigía en las grandes ciudades del mundo. Esto significó que la publicidad comenzara a valerse de técnicas novedosas que asociaban el producto que se quería vender a un determinado "estilo de vida". Se pretendía inducir al consumidor a comprar para sentirse parte del grupo social al que aspiraba. Los servicios y bienes así ofrecidos se transformaban en algo más: podían ser usados como símbolos de status social. ${ }^{362}$ Siguiendo este argumento, comienza a perder centralidad el objeto en sí mismo, para ser suplantado por aquello que representa. Cabría pensar entonces, que la importancia de incorporar a un grupo reconocido de profesionales en un proyecto buscaba asegurar

\footnotetext{
${ }^{361}$ La caracterización errónea de ingenieros, en lugar de arquitectos, se corresponde de manera textual a los datos que aporta la publicidad.

362 Fernando Rochi desarrolla la formación de este mercado en "Consumir es un placer: la industria y la expansión de la demanda en Buenos Aires a la vuelta del siglo pasado”, en Desarrollo Económico, Revista de Ciencias Sociales, vol. 37, $\mathrm{n}^{\circ} 148$ (enero-marzo 1998) pp.533-557; mientras que Ezequiel Adamovsky analiza las formas de consumo de la clase media. Ver, Ezequiel Adamovsky, Historia de la clase media argentina. Apogeo y decadencia de una ilusión, 1919-2003, Editorial Planeta, Buenos Aires, 2009. p. 69.
} 
un producto de excelencia, pero además, lograr un efecto publicitario apelando a la componente simbólica, de manera que a través de la mención de un arquitecto o paisajista prestigioso se busca dotar del mismo status al barrio, y por transferencia, a quienes lo habitasen. Nuevamente, como explica Fernando Rocchi, con la aparición de nuevos consumidores en las primeras décadas del siglo XX, empresas y compañías ampliaron su oferta para ofrecer servicios que, manteniendo una apariencia lujosa, fuesen lo suficientemente económicos como para atraer a las clases medias. ${ }^{363}$ Es en este contexto que, en general, cobra sentido la gran profusión de barrios parque a la que se asiste hacia los años treinta, y en este caso en particular, la introducción de los nombres de Prebisch y Vautier, y a través de ellos el de su mentor -aunque no el más significativo- Mrs. Jaussely de la Academia de París, en tanto remite inmediatamente a uno de los principales polos de referencia de las elites.

En cualquiera de los casos, sea que los arquitectos hayan trabajado verdaderamente en el proyecto, o a través de la simple incorporación de su nombre en la publicidad, era posible instalar a la urbanización dentro de ese grupo reducido y, en consecuencia, selecto, de "barrios diseñados por arquitectos" y así orientar la demanda hacia un determinado sector, las nuevas clases medias que buscaban consolidar su posición a un precio que pudieran pagar. Cabe decir, que el carácter medio de la población, también queda manifestado, por la valuación de las tierras y de la edificación que en ellas se erigía, que para el caso de Castelar representaba una posición intermedia entre los sitios más exclusivos y los barrios de trabajadores. (véase Cuadro 1. Capítulo 2) ${ }^{364}$

Remitiendo a Bourdieu, este explica que la vivienda y su localización, en cuanto bienes materiales que se exponen a la percepción de todos y de manera duradera, expresa o delata, más decisivamente que otros, el ser social de su propietario, sus

\footnotetext{
363 Fernando Rocchi, “Consumir es un placer: la industria y la expansión de la demanda en Buenos Aires a la vuelta del siglo pasado", en Desarrollo Económico, Revista de Ciencias Sociales, vol. 37, n 148 (enero-marzo 1998) pp.533-557.

364 Ya señalamos que la mensualidad de un terreno en Castelar alcanzaba los \$20 mensuales para 1930. Este mismo año los datos aportados por el Departamento Nacional de Trabajo muestran una estimación del costo de vida de una familia en $\$ 110$ mensuales, el sueldo promedio de un obrero alcanzaba los 100 pesos mensuales y el del personal técnico y jerárquico se ubicaba entre 400 y 500 pesos mensuales. Ver, Capítulo 2.
} 
“medios" como suele decirse. ${ }^{365}$ Así, desde la perspectiva de los compradores, obtener un lote y levantar la vivienda en el barrio diseñado por los discípulos de Mrs. Jaussely, o por los arquitectos que estaban trabajando en obras reconocidas como la Avenida General Paz (Pascual Palazzo y Ernesto Vautier 1936-1941) o la erección del Obelisco de Buenos Aires (Alberto Prebisch, 1936), les permitía a quienes recientemente habían llegado a engrosar el grupo de los sectores medios imitar los estilos de vida de las llamadas clases acomodadas a las cuales aspiraban a parecerse. ${ }^{366}$

\section{Un empresario de Colonia Esperanza en Morón}

La otra cara de este mercado la conformaban un grupo de agentes (dueños de la tierrainmobiliarias-promotores) asociados al mercado inmobiliario.

Algunos trabajos sobre las clases dominantes en Argentina han debatido sobre el rol que jugó la propiedad de la tierra entre diferentes sectores de la elite económica local. Sintéticamente, es posible argumentar que, si bien entre un grupo de empresarios terratenientes se registraba como parte de una práctica habitual la colocación de activos en nuevas áreas de la economía (Jorge Sábato), la tierra nunca dejó de ser una inversión segura y rentable (Roy Hora). ${ }^{367}$ Incluso, como señaló Norma Lanciotti, la opción de

365 "El mercado de la casa” en, Pierre Bourdieu, Las estructuras sociales de la economía.op.cit. pp.3192.

366 Leandro Losada mostró que hacia la década del veinte empezaron a experimentarse en la sociedad argentina movimientos de ascenso social y económico desconocidos hasta el momento; y que dieron lugar a que algunas familias, si bien no pertenecían a la llamada "alta sociedad", pudieran "mezclarse" con estos sectores a través de ciertas actividades comunes como podían ser las prácticas deportivas o la frecuentación a ciertos clubes, etc. Ver, Leandro Losada, La alta sociedad en la Buenos Aires de la Belle Epoque, op.cit.

367 Trabajos como el ya clásico de Jorge Sábato, La clase dominante en la Argentina moderna, han puesto de manifiesto que la elite económica local no sólo basaba su poderío en la propiedad de la tierra y la actividad rural, sino que además colocaba sus activos en distintas esferas de inversión, lo cual constituiría su característica más distintiva. Estudios posteriores han contrastado esta hipótesis, señalando que si bien la inversión simultánea en distintos campos era una realidad, en un contexto comparativo, para la elite empresarial argentina la propiedad constituyó la base sobre la cual se fundaron las grandes fortunas. Roy Hora analizó 26 casos. Para estos empresarios tomados en consideración - entre los que se cuentan Saturnino y Mariano Unzué, Nicolás Anchorena, Leonardo Pereyra, José Prudencio Guerrico, 
invertir en propiedades se convirtió en una práctica común entre el empresariado urbano desde fines del siglo XIX, como parte de una estrategia comercial orientada a disminuir el riesgo económico a través de la diversificación no integrada. Comúnmente la inversión se realizaba a través de la compra venta de lotes o inmuebles, el alquiler de campos o la construcción de casas de renta; a lo cual cabría agregar la formación de barrios parque. ${ }^{368}$ Sirven como ejemplo las urbanizaciones de Villa Bosch, Parque Leloir, Parque Quirno (fundadas por las familias del mismo nombre) y el Barrio Parque Castelar. Para este último, Juan Francisco Mayoraz invirtió \$392.806 en la adquisición de las tierras sobre las que se ubicaría el barrio parque.

Juan Francsico era el mayor de diez hermanos, hijo de Juan Mayoraz y Julia Aufranc. Su abuelo había llegado a la Argentina proveniente del pueblo de Hermence, en el cantón Valais, Suiza, para instalarse en Esperanza, una de las primeras colonias agrícolas, fundada por Aaron Castellanos en Santa Fé en el año 1856. Antes de su arribo a nuestro país, en la Suiza natal, Juan Bautista Mayoraz (abuelo de Juan Francisco) se dedicaba a tareas agropecuarias, aparentemente a la molinería, y llegó a nuestro país con sus cuatro hijos luego de haber enviudado. Al poco tiempo de su llegada, la familia compró algunos campos aledaños a la colonia y estableció allí un molino harinero. Durante varias décadas, la agricultura ofreció grandes oportunidades de enriquecimiento que fueron aprovechadas por figuras subalternas: inmigrantes, pequeños productores, a los que les resultaba más sencillo ingresar en el negocio agrícola que en el ganadero que requería mayor inversión de capitales y se consideraba social y culturalmente más prestigioso. Este último permanecería en manos de los grandes terratenientes; en cambio, en las etapas iniciales de la expansión agraria, el bajo precio del suelo contribuyó a eliminar las barreras de entrada a la actividad rural, e hizo

Benjamín Martinez de Hoz, Felix de Alzaga, Emilio Bunge, Diego de Alvear, Pedro Luro, Urbano Duhau, Julio Pueyrredón, Tomás Duggan, Julio y Ataliva Roca- la inversión en propiedad y empresas rurales supera los tres cuartos del patrimonio, y representa un 76\%del total. La inversión en propiedades urbanas y suburbanas 16\% del total. La inversión en activos líquidos (créditos, depósitos bancarios, acciones, títulos públicos) y empresas comerciales y financieras es notablemente pequeña con apenas el $6 \%$.

Ver, Jorge F. Sábato, La clase dominante en la Argentina moderna. Formación y características. Op.cit. y Roy Hora, Los terratenientes de la pampa argentina ...op.cit. p.81.

368 Norma Lanciotti, De Rentistas a Empresarios. Op.cit. 
posible el éxito de muchos recién llegados. ${ }^{369}$ Como indica Roy Hora, el "Rey del Trigo" argentino no fue un gran terrateniente modernizador sino un inmigrante, Guiseppe Guazzone. ${ }^{370}$

Un recorrido similar al que narramos habrían transitado los Mayoraz, que a poco de llegar ya formaban parte de las familias más importantes de Esperanza y a comienzos del siglo XX podían - y aún pueden- considerarse como una familia reconocida asociada a los negocios y a la industria agrícola de Santa Fe. Poseyeron importantes extensiones de tierra en la provincia, parte de las cuales darían lugar al Barrio Jardín Mayoraz, en lo que fue en algún momento la periferia de la ciudad de Santa Fé, y que se encuentra hoy completamente anexado a la ciudad. ${ }^{371}$ Pero, a diferencia de esta ciudad jardín, las tierras sobre las cuales se subdividió el Barrio Parque Castelar no pertenecían originalmente a la familia; sino que fueron adquiridas en 1928 por Juan Francisco Mayoraz para ser subdivididas y puestas a remate un año más tarde.

Entre las opciones del mercado, a diferencia de los bienes urbanos que requerían de una inversión inicial importante y habían demostrado seguridad y rentabilidad al incrementar su valor en el tiempo; la compra de tierras en bloque para su posterior subdivisión y venta en lotes requería inversiones menores y podía arrojar ganancias mayores a cambio también de la enorme inseguridad que implicaba el negocio. La mayor rentabilidad estaba dada para aquellos que invirtieran en tierras antes de que llegaran las obras de infraestructura significativas -ferrocarriles o la apertura de callesy las vendieran después de que los valores se hubieran incrementado. ${ }^{372}$ Sin embargo,

369 Santa Fe presenta un caso excepcional de crecimiento agrícola. Esta provincia se convirtió en las cuatro décadas que siguieron a Caseros en una potencia agrícola de primera magnitud. En 1872 se cultivaban alrededor de 65.000 ha, en 1887 los tres productos principales, trigo, maíz y lino ya ocupaban casi 600.000 ha y llegaron a más de 1.600 .000 en 1895. Ver, Osvaldo Barsky y Jorge Gelman; Historia del Agro argentino. Desde la Conquista hasta fines del siglo XX. Grijalbo, Buenos Aires, 2001.

370 Roy Hora, Los terratenientes de la pampa argentina. Op.cit. p 111

371 Actualmente (período 2011-2013) Francisco Mayoraz se desempeña en el cargo de Director de la Confederación de Asociaciones Rurales de Santa Fe.

372 Este es el caso de Juan Castex, que compró los terrenos en cuestión en 1883 y su sucesor Eusebio Castex los vendió en 1928 (a J. F. Mayoraz), durante esos 45 años los valores de la tierra aumentaron con la apertura de la estación del ferrocarril y el crecimiento de la urbanización. 
este sí era un negocio inseguro y muy a largo plazo, en tanto las obras podían retrasarse más de lo previsto o ubicarse demasiado lejos de los terrenos. Más seguro era comparar tierra en bloque en zonas donde ya se vislumbraban los primeros signos de la urbanización, subdividirlas y venderlas como lotes urbanos, como ocurrió en la operación de Castelar.

En este sentido, la creación del barrio parque debe entenderse como una verdadera estrategia de inversión. A diferencia de los otros barrios parque ya citados, Leloir, Bosch y Parque Quirno, creados por familias cuyas fortunas provenían de los negocios agrícola-ganaderos y que aprovecharon la valorización que habían obtenido sus tierras por el aumento general de los precios del suelo, la actitud de Mayoraz que queda a la vista en esta operación se parece más a la de un promotor activo. ${ }^{373}$ Lo cual permite enmarcarlo dentro de un tipo de práctica inmobiliaria que era común, fundamentalmente, entre grupos empresariales y sociedades anónimas; entre los cuales, como ya se señaló en el Capítulo 4, era habitual la compra de tierras con fines expresos de desarrollo inmobiliario. Las ganancias previstas para estas operaciones podían llegar a triplicar los gastos de inversión. En efecto, Mayoraz compró en 1928 a \$392.806, 52, las tierras que un año más tarde vendería subdivididas en 450 lotes a razón de \$ 20 la mensualidad, en 120 mensualidades. Asumiendo que la totalidad de los lotes se vendieran en ese primer año y con esos valores, Mayoraz recibiría $\$ 9.000$ por mes, y al finalizar las cuotas, un total de $\$ 1.080 .000$. Claro que es improbable que esto sucediera así, de modo tan esquemático. Igualmente, esta estimación sirve para darnos una idea de la potencialidad del negocio, lo cual se corrobora, además, de manera casi exacta, con los cálculos que expusimos en el Capítulo 4, en donde las inmobiliarias reconocían triplicar la inversión como rentabilidad promedio para este tipo de emprendimientos.

En la realidad, lo que sabemos que sucedió en el Barrio Parque Castelar, de acuerdo a la Hoja $\mathrm{n}^{\mathrm{o}} 3$ del Catastro del Partido de Seis de Septiembre (actualmente Morón) que muestra el estado del Catastro para el barrio y los terrenos adyacentes al 1ro de enero del año 1935, es que para esta fecha más del $90 \%$ de los lotes aún permanecían sin venderse, a nombre de Juan Francisco Mayoraz. Este hecho, tampoco

\footnotetext{
373 Los precios del suelo en la Provincia de Buenos Aires entre 1894 y 1904 se multiplicaron por tres. En particular dentro de aquellas zonas alcanzadas por el proceso de expansión de la ciudad. Ver, Roberto Cortes Conde, El progreso argentino, 1880-1914. Buenos Aires, 1979. pp. 164-166.
} 
debe entenderse necesariamente como un fracaso, ya que como se analizó en el Capítulo 4, y se verifica también en otros países, la retención de la tierra en espera de una creciente valorización podía ser una estrategia de inversión en un contexto de expansión de la demanda y escasas cargas fiscales sobre los bienes inmobiliarios. ${ }^{374}$

Recapitulando, podría decirse que a través de los casos que abordamos se dibuja un arco que va desde el suburbio de las elites -Barrio Parque Aguirre-, a los barrios de clase media -Barrio Parque Peluffo-, y desde el suburbio compacto a la expansión difusa. ${ }^{375}$ En una posición intermedia -temporal y tipológicamente- el último caso que presentamos, Barrio Parque Castelar, nos permitió, entre otras cosas, analizar la manera en que las prácticas profesionales se desarrollaban en el contexto de la expansión, y en el marco de un mercado de consumo ampliado. Para vislumbrar, eventualmente, el desfase que se produce entre los debates que tienen lugar en el campo de la disciplina y la realidad de la práctica profesional.

374 Rafael Mas Hernández ha demostrado, por ejemplo, que el barrio de Salamanca en Madrid, comenzado en 1860 todavía tenía veinte años después la mayor parte de las manzanas sin edificar. Situación que persistió por la estrategia de los propietarios para mantener los solares esperando la elevación del precio del suelo. Sólo con el estatuto de 1924, que estableció impuestos sobre los solares sin edificar, se activó la construcción del área, levantándose solo en ese año 332 edificios. Ver, Mas Hernandez, Rafael, El barrio de Salamanca. Planeamiento y propiedad inmobiliaria en el Ensanche de Madrid. Instituto de Estudios de Administración Local, Madrid, 1982.

375 La expansión de la ciudad contemporánea ha recibido diferentes nombres de acuerdo a diferentes autores y a las características principales que estos reconocen. Francesco Indovina, La ciudad difusa, en Lo Urbano en 20 autores. op.cit 


\section{Reflexiones finales}

Esta tesis se propuso analizar el surgimiento de barrios parque y loteos de fin de semana y su rol en la conformación del Gran Buenos Aires entre 1910 y 1950. Como mostró la bibliografía, múltiples factores han contribuido a la construcción de este territorio, nuestro aporte ha sido demostrar la relevancia que entre ellos ha tenido la incorporación de barrios parque.

El relato toma por punto de partida el momento en el cual comenzaron a hacerse evidentes las señales de recuperación económica, (superada la crisis de 1890) y la incorporación de nuevas tierras, especialmente destinadas a usos recreativos y residenciales de fin de semana. La consolidación de una extensa red ferroviaria, sumada al crecimiento que registraba la ciudad Capital otorgaban nuevo dinamismo a la expansión. La costumbre de pasar las temporadas cálidas en sitios abiertos y elevados debe rastrarse hacia fines del siglo XIX, en la tradición fortalecida por las clases altas y algunos miembros de la comunidad británica. Sin embargo, en el marco de procesos de modernización social y cultural de nueva generación, estas prácticas fueron adoptando una nueva dimensión.

En efecto, Buenos Aires atravesaba un proceso de metropolización que se advertía no sólo en un cambio de escala, sino en la masividad y la velocidad con la cual se experimentaban los cambios, en las transformaciones espaciales y de los modos de vida propios de las grandes ciudades. En este contexto, los nuevos loteos reformularon algunos elementos del veraneo en las quintas, o la temporada en las estancias, pero se plantearon a la medida del "hombre moderno", como un escape de la rutina urbana, de la cual se podía entrar y salir en cualquier momento, y sobre todo, sin rescindir el confort y la comodidad que ya para estos años comenzaba a extenderse a sectores cada vez más amplios de la población.

De igual manera que las bases ideológicas sobre las cuales se asentaba la expansión retomaban elementos de más larga data, territorialmente, los nuevos loteos perpetuaban una estructura de crecimiento radial en base a tres ejes (Norte, Oeste y Sur) que ya se reconocían con anterioridad. Estos ejes nacían con una densidad habitacional más marcada en los bordes de la Capital, la cual iba disminuyendo a medida que se 
alejaban de ella. En el otro sentido, de crecimiento concéntrico, los nuevos loteos definían una porción territorial en forma de anillo alejada entre 20 y $40 \mathrm{~km}$ de la Capital, que quedaba más definido entre los ejes Norte y Oeste, y se desvanecía hacia el Sur.

Esta figura que describimos, se fue consolidando a lo largo de dos momentos, entre 1910 y 1935 y entre 1935 y 1950.

En una primera instancia, se mantuvo el esquema cristalizado en el siglo XIX de la ciudad matriz con su constelación de suburbios vinculados por el ferrocarril. A lo largo de estos primeros años se asistió a un proceso de suburbanización incipiente, en donde los nuevos loteos se introdujeron sobre los ejes Norte y Oeste, especialmente, en torno a nuevas paradas del ferrocarril o en las pequeñas porciones que permanecieron vacantes en el entorno inmediato de los pueblos fundados en el siglo XIX.

Más precisamente, el análisis de las localizaciones mostró que hacia el Norte los núcleos residenciales se concentraron fundamentalmente en las áreas vacantes a lo largo de los ejes ferroviarios, y en el Oeste, especialmente, cerca de los núcleos poblados que ya existían sobre esta misma línea. Estas intervenciones consagran, en orientación norte, las tendencias de urbanización residencial y recreativa, mientras que en orientación oeste, la convivencia de distintas actividades, junto a la permanencia de grandes áreas vacantes impidió la definición de una identidad. En contraste, en el Sur se perciben diferencias notables, pues las pocas propuestas de barrios parque se ubican lejos de la traza ferroviaria cuyos bordes ya presentaban un importante nivel de consolidación desde inicios del siglo.

En su configuración, los núcleos que dieron lugar a la expansión en las décadas del diez y del veinte se organizaron en forma compacta y autocontenida. Si bien los que se localizaron sobre la nuevas estaciones -en tanto generaron núcleos ex-novo ocuparon áreas de mayores dimensiones, estuvieron naturalmente limitados por la posibilidad de recorrer las distancias a pie.

Estas características se irían modificando a lo largo del ciclo 1935-1950, cuando se experimentó el boom de los loteos suburbanos en el marco de muy diversas tendencias de localización. En el nuevo escenario, se pueden identificar las huellas de una urbanización dispersa en relación a la accesibilidad que posibilitan las vías de acceso y 
el automóvil en contraposición a la organización en torno a ejes jerárquicos bien marcados del período anterior.

En efecto, la década del cuarenta fue testigo de una expansión del mercado de tierras sin precedentes cuando en este sector de la economía fue posible obtener tasas de ganancias más altas que en otros sectores. Al mismo tiempo, las estrategias estatales desplegadas para la construcción de caminos a partir de la década del treinta, ya dejaban ver nuevas rutas y calzadas adentrándose en el área metropolitana. Este fenómeno generó condiciones que hicieron posible la ocupación de áreas intersticiales $\mathrm{y}$, en el largo plazo, el pasaje hacia una urbanización dispersa. Aunque, simultáneamente, se consolidaban algunas diferencias que marcamos para el período previo. Sobre el eje Sur, la incidencia de este tipo de urbanizaciones siguió siendo exigua frente al tipo de loteo urbano tradicional del área. Contemporáneamente, los pequeños loteos del Norte contribuían a densificar las áreas de ocupación tradicionales, entre la Avenida del Libertador y el eje del ramal ferroviario Retiro-Tigre, mientras que una amplia gama de urbanizaciones de mayor tamaño fueron gestando nuevas áreas de crecimiento. En el Oeste, se experimentó el mayor incremento de barrios parque que, al igual que en el Norte, contribuyeron, a consolidar núcleos previos y áreas suburbanas en las que predominó el crecimiento de baja densidad. Pero, más importante fue el papel que desempeñaron los loteos de grandes dimensiones, ubicados sobre nuevas vías de acceso en áreas predominantemente rurales, funcionaron como punta de lanza para futuros procesos de suburbanización y dieron lugar a una notable variedad de situaciones registradas sobre este eje.

Algunos rasgos de este nuevo orden arrojaron como resultado la desaparición de los pequeños núcleos organizados en torno a las estaciones de ferrocarril. Estos últimos, atravesaron un proceso de transformación generado por la adición de nuevas tipologías de loteos periféricos de menor extensión, que en buena medida contribuyeron a desdibujar los límites del núcleo original y, en consecuencia aportaron a homogeneizar algunos sectores de la expansión.

Los loteos de grandes fracciones ubicados sobre las rutas y caminos recientemente abiertos, fueron sin embargo la figura destacada de este período. Enmarcados dentro de la línea del barrio jardín, marcaron un punto de inflexión en la tradición del suburbio como comunidad y espacio de sociabilidad, vinculándose así a futuros procesos de suburbanización de los años noventa. Situados sobre las vías de tránsito rápido sufrieron un proceso de introversión: de la calle y la plaza pública al 
espacio recreativo incorporado a la parcelación. A medida que los núcleos suburbanos se alejaron del ferrocarril y de los espacios de significación de la comunidad, el suburbio dejó de ser una unidad vecinal para convertirse en una extensión difusa, que por sus características físicas debió renunciar a conformar una comunidad suburbana o entidad similar al barrio como artefacto de identidad cultural y política.

Esos barrios parque, remiten a situaciones muy heterogéneas en cuanto a su escala, localización o sectores sociales a los cuales se destinaban. En ese escenario, los modelos urbanos y los instrumentos de diseño del barrio jardín -que encuentra sus lejanas raíces en la matriz anglosajona- se fueron transformando para dar respuesta a una demanda cada vez más amplia. De esta circunstancia darían cuenta la pluralidad de tramas y calidades que se incluyeron bajo esta denominación y que dieron lugar a dos grupos bien diferenciados, cuyos trazados urbanos se organizaron con base en tramas abiertas/informales, o en la utilización de la retícula.

El primero de estos modelos se remontaba a una tradición británica, iniciada a fines del siglo XVIII y retomada en Estados Unidos desde mediados del siglo XIX, en la cual los trazados urbanos informales -a la manera del jardín informal o pintoresco inglés-fueron utilizados para la formación de núcleos residenciales exclusivos que tendieron a plantearse como alternativas al crecimiento urbano y continuo.

En esta línea, cualquiera de los loteos informales que presentamos debe ser entendido como continuador de los valores del barrio jardín como espacio de distinción; aunque, su inserción en el GBA no necesariamente implicó la conformación de áreas exclusivas a las cuales el modelo se asociaba originalmente. En estas latitudes, si bien se apeló al modelo por una serie de asociaciones y modos de vida a los que remitía, su aparición en revistas de gran difusión y su aplicación por parte de un grupo cada vez más amplio de arquitectos, ingenieros, agrimensores y también de técnicos fue marcando una fisura entre las bases ideológicas que sirvieron de sustento a los modelos de origen y sus aplicaciones locales.

Por otra parte, el gran número de urbanizaciones en grilla que se llevaron a cabo buscaron mantener el vínculo con el perfil del suburbio jardín, procurando mantener al menos una variable constante, la baja densidad. Teniendo en cuenta estos antecedentes, la base de la amplia aplicación de la grilla al crecimiento suburbano en Argentina debe entenderse -como señala parte de la bibliografía- como la forma más llana al servicio de 
la especulación inmobiliaria. Pero también a partir de otras dos cuestiones cardinales: en primer lugar, a diferencia de lo que sucedió en Inglaterra, donde por detrás del ideal suburbano existió un fuerte rechazo a la ciudad tradicional - traducido en el abandono de los trazados en grilla que a ella se asociaban-. En Argentina, el largo camino recorrido desde la idea del suburbio aristocrático a la incorporación de loteos barrio parque en el GBA fue paulatinamente disolviendo la dicotomía ciudad-campo. Si bien los loteos de fin de semana seguirían viéndose como refugio ante la urbanización abrumadora, los valores morales que en los orígenes británicos se asociaban a la pequeña comunidad suburbana nunca llegaron a consolidarse en nuestro medio. Entre otras cosas, este quiebre permitió que en el GBA el concepto de barrio jardín también pudiera materializarse a través de la grilla.

Finalmente, no debe soslayarse una tradición de regularidad legal de larga data en nuestro país -señalada por Graciela Favelukes y Fernando Aliata- iniciada hacia mediados del siglo XVIII. En este sentido, la supuesta contradicción entre el barrio parque y su materialización a través de la grilla no es tal si pensamos que su implementación respondió, más que a un concepto de ciudad, al modo de construirla; y donde la vía, casi por defecto, era la trama cuadriculada.

Si bien se trata de propuestas e intervenciones que se gestan en el ámbito privado, el rol de las herramientas de control estatal se revela central al momento de analizar las transformaciones territoriales. En este punto, elementos que remiten a la acción del Estado -sus instituciones, organismos públicos, normativas-, y los demás agentes involucrados en la formación del territorio deben ser considerados con el fin de comprender muchas de las transformaciones acaecidas.

Asimismo, si hay una certeza que nos deja el análisis sobre el rol de los agentes, es que muchas de las decisiones y variables en pugna al momento de guiar la expansión se dirimen en las prácticas cotidianas; lejos de los planes de los expertos, o de los políticos que debaten las normativas, y mucho más cerca de los personajes ignotos que llevan adelante las acciones en el día a día. En ese marco, no se trata de un territorio configurado ni por la acción pública, ni por la sumatoria de acciones privadas sin ninguna restricción. Se trata del resultado de negociaciones entre agentes públicos y privados, entre idóneos y técnicos, entre acciones voluntarias y resultados inesperados de esas mismas acciones. 
En cuanto a los actores privados, el esquema estuvo, hacia fines del siglo XIX y comienzos del siglo $\mathrm{XX}$, dominado por las empresas urbanizadoras asociadas a los ferrocarriles y los propietarios rurales que actuaron a través de las ventas por sucesiones. Dicha situación se modificó, ya avanzado el siglo XX, cuando se verificó una mayor actuación de propietarios medianos, junto a compañías inmobiliarias y rematadores, quienes se destacaron de manera particular en el contexto de la expansión. Esta condición obedece a la forma de expansión predominante en Argentina, que se llevó a cabo a través de la subdivisión en lotes a los cuales, años más tarde, le llegaban los servicios y se construían las viviendas. Esta modalidad aunaba a los dueños de la tierra con las inmobiliarias, en donde los primeros aportaban la tierra y los segundos intervenían en el proceso de subdivisión, aprobación de los loteos, publicidad y comercialización. Mediante esta sociedad se buscaba minimizar los riesgos de las operaciones, en tanto ninguna de las partes intervenía con sumas importantes de capital. El tipo de intervención acotada que ejercían estas empresas inmobiliarias -más familiares- sobre la formación de las urbanizaciones puede calificarse de conservadora, en tanto eran mínimos los riesgos financieros que estaban dispuestos a correr.

Al igual que en el desarrollo de las ciudades, la participación de empresas que aportaran grandes capitales, absorbiendo las demandas del ciclo completo de subdivisión, urbanización y comercialización, fue escasa en el medio local, en donde se verifica que rara vez estas empresas tuvieron una existencia "autojustificada" y prolongada en el tiempo. Más bien se comprueba que, cuando existieron, se conformaban con un fin particular, como podía ser la urbanización de un sector determinado, y que sus accionistas no constituían sectores especializados sino que, en general, eran hombres de los sectores dirigentes cuyos contactos y acceso privilegiado a la información les permitía conducir con cierta seguridad las inversiones inmobiliarias.

En efecto, a diferencia de lo que muestran los desarrollos suburbanos residenciales en Brasil, Estados Unidos o Inglaterra, donde los promotores jugaron un rol fundamental, en Buenos Aires se reconoce que la acción de particulares -operando fundamentalmente a través de subdivisiones o de la compra-venta de lotes- fue más activa que en otras latitudes. 
Ahora bien, aparentemente, la interacción de los actores que hasta aquí analizamos habría dado como resultado, hacia mediados del siglo $\mathrm{XX}$, un "crecimiento caótico del GBA ${ }^{״ 76}$. En ese marco, pretendimos analizar, a través de los procesos de producción de los barrios parque, las tensiones que se generaron entre las acciones del Estado y la expansión territorial.

La visión que afirma sobre falta de legislación y de controles que llevara a cabo el Estado para regular el crecimiento frente a los intereses particulares, no parece agotar el tema. A pesar de lo que los propios actores y las lecturas más tradicionales señalaron, hemos visto que a partir del siglo XIX y de manera creciente, comenzaron a organizarse una serie de normativas y reglamentos tendientes a controlar y a ordenar el desarrollo territorial que reflejaron una ampliación en las funciones del Estado. De algún modo, también se asistió a una ampliación de sus capacidades para llevar a cabo esas reglamentaciones; no obstante, no parecen haber sido suficientes y/o pertinentes para enfrentar la dinámica de la expansión. Ciertamente, en lo que refiere a la intervención del Estado en relación a la configuración del territorio podría señalarse, por un lado, la falta de articulación entre las acciones propuestas y las posibilidades concretas de llevarlas a cabo y por otro lado serias deficiencias para saber "leer" las coordenadas de la expansión y actuar en consecuencia.

En efecto, los conflictos ocasionados para llevar adelante la gestión y los controles que aseguraran el correcto cumplimiento de las reglamentaciones se reflejaron en la imposibilidad de establecer jerarquías concretas entre los ámbitos provincial y municipal, como consecuencia de las "superposiciones" institucionales, herencia del siglo XIX, y por el propio carácter del Estado como organismo complejo, que expresa su acción a través de múltiples unidades que muchas veces tienden a representar intereses encontrados. ${ }^{377}$ Se verifica que más allá de los modos de gestión establecidos por la legislación, por medio de ordenanzas municipales y de la realización de trámites de excepción, fueron los gobiernos municipales los que en última instancia detentaban, de hecho, el control sobre los loteos. Más allá de lo que Oszlack propone, que el crecimiento y la conformación de un Estado centralizado fueron minando

\footnotetext{
${ }^{376}$ Informe de la Comisión Asesora del GBA, citado por José María Pastor y José Bonilla, Estudio sobre el uso de la tierra, op.cit.

${ }^{377}$ Oscar Oszlack, La formación del Estado argentino. Op.cit.
} 
paulatinamente las prácticas informales de los poderes locales, para mediados del siglo $\mathrm{XX}$ todavía era posible reconocer muchas de estas cuestiones.

En relación al desfase que se produce entre la matriz que está tomando el mapa de la expansión y las soluciones que se plantean desde la legislación, hay que destacar que más allá de juzgar la implementación o el cumplimiento de dicha normativa, lo que se revela al contrastar los contenidos que ella propone con las formas en que se está llevando a cabo la expansión, es que la legislación tendió a ofrecer una imagen simplificadora. Por un lado, daba cuenta de una deuda con la tradición reguladora de los topógrafos del siglo XIX y por otro, de la imposibilidad de pensar la complejidad y múltiples dimensiones de la expansión moderna. Por último, se verifica que una vez establecidas, las normativas y las instituciones estatales que se organizan para llevarlas a cabo, tienden a perdurar, y por ende su influencia va más allá del "clima de ideas" y las condiciones particulares que llevaron a su surgimiento. En ese sentido, al examinar el rol de las regulaciones y las relaciones público-privado los materiales ofrecen un mapa atravesado de ambigüedades.

Cambiando la escala de aproximación, y en relación a la arquitectura que acompañó el crecimiento de estos sectores, el estudio de los materiales también nos obliga a rechazar la idea de una imagen homogénea y predeterminada, para vislumbrar, sobre todo en las fases de formación inicial, una escena de lo más diversa, producto de la operación colectiva que les fue dando forma. Particularmente, en cuanto a la producción arquitectónica, creemos que la mayor parte de las imágenes que poblaron estos suburbios derivaron de la aplicación vaga de cierto pintoresquismo en manos de diversos actores ligados al ámbito de la construcción y de los mismos propietarios. En este contexto, hemos demostrado la importancia que adquirían los tratados y manuales de arquitectura -a inicios del siglo XX- entre los que predominaron los de origen inglés y francés, y posteriormente las revistas, nacionales e internacionales, como elementos de difusión en relación a las tipologías y las imágenes que se consideraban adecuadas para el entorno suburbano.

Más allá de la notoriedad alcanzada en términos simbólicos, las obras presentadas sólo representan, en términos reales, una porción de la producción suburbana, y aún dentro del recorte realizado observamos una inmensa diversidad -más notoria a inicios del período, que ha sido realzada por la imagen de "postales", lo cual 
también nos ha ayudado a organizar y asignar sentido a esa diversidad, mostrando el carácter plural de la construcción de los suburbios de fin de semana.

De este modo, hemos observado el predominio de distintos estilos arquitectónicos, que a lo largo del período se desplaza desde los estilos de impronta inglesa o francesa de fines del siglo XIX, pasando por los estilos mediterráneos, dentro de los cuales las referencias a Italia tenían un peso importante, a los rústicos, hegemonizados por el californiano, a partir de los años treinta. El registro que conforman las imágenes relevadas en este segundo período pone en evidencia una mayor homogeneidad formal, en donde predomina el californiano en sus diversas variantes. En paralelo a estos cambios, y como parte de un proceso de modernización a nivel internacional, las tipologías para la arquitectura doméstica asistieron a un proceso de compactación y reducción de la superficie de los locales.

En cuanto a las relaciones que se establecen entre sectores sociales y arquitectura, se ha observado a lo largo del período un desplazamiento en relación a los sectores a los que iba destinada esta arquitectura: de los sectores altos a los medios dentro del mercado inmobiliario, e incluso acercándose al mundo popular cuando las pequeñas residencias se presentaban como opción para la vivienda permanente. En las publicidades, esta ampliación se dejaba ver a través de una modificación en los discursos, en los cuales predominaba la mención a las "suntuosas residencias" en el primer período, para dar paso a la "casita de fin de semana" de los años posteriores.

En gran medida este pasaje tuvo su correlato en el cambio de actores que intervenían en la producción de las viviendas: de una mayoría de obras realizadas por profesionales, hacia una producción realizada por técnicos y maestros mayores de obra. Sin embargo, este proceso de difusión desde una "arquitectura de arquitectos" hacia una "arquitectura de técnicos" no debe entenderse como un hecho mecánico, en el cual sólo es posible asistir a una "deformación" de las tipologías o imágenes a través de su transmisión. En este sentido, la perspectiva histórica nos permitió reconocer la multiplicidad de tramas y contenidos cambiantes que se entretejen en el contexto de los procesos de difusión y circulación de ideas entre lenguajes y tipologías arquitectónicas y sus usos por parte de distintos sectores sociales, al igual que sobre la relación que se plantea entre la cultura de las clases populares y la de las clases dominantes. Particularmente, la arquitectura que denominamos ampliamente como pintoresca ha tomado inspiración de las más diversas fuentes. Como demostramos, hacia fines del siglo XIX las construcciones rurales inglesas, o los chalets vernáculos de la zona de los 
Alpes, entre otros, fueron codificados por profesionales europeos e incorporados a manuales y tratados, que serían posteriormente utilizados por otros profesionales alrededor del mundo.

Otro ejemplo lo constituyen las variantes pintorescas más modernas. Especialmente, el estilo que en Argentina se denominó Californiano retomó la arquitectura de las misiones jesuíticas en California, las construcciones populares del Norte de África, las construcciones de adobe de origen mexicano. Esta tradición, fusionada en el ambiente local con las construcciones rurales pampeanas o del pasado colonial fue reinterpretada por conocidos profesionales para dar lugar a residencias en los suburbios más exclusivos. Estas viviendas, publicadas y popularizadas en la prensa gráfica, volverían a formar parte del repertorio de los sectores medios poniendo en crisis las ideas más mecanicistas que entendieron los procesos de difusión de manera unidireccional: en general, de arriba hacia abajo.

En un último punto, hemos tratado de aproximarnos al espacio construido, tratando de responder acerca de cuál fue el impacto de esos trazados presentados. Metodológicamente, hemos optado por estudios de caso en profundidad, en tanto nos permitieron indagar detalladamente en los procesos de producción del territorio y en su devenir histórico. En ese sentido, buscamos apelar -como ya se mencionó en relación a la metodología- a una propuesta de Bernando Secchi en la que plantea comprender la dimensión histórica del territorio pensando que algunos de los hilos que nos mantienen ligados al pasado de vez en cuando se rompen, mientras otros permanecen bien visibles y fuertes.

Desde esta perspectiva, en cada uno de los casos estudiados, es posible identificar en el trazado viario original y en el parcelamiento, una suerte de sello fundacional que vincula a cada uno de los barrios con su propio pasado y que ha sido reescrito -en mayor o menor medida- en cada una de las sucesivas oleadas de la expansión.

En el Barrio Parque Aguirre (1913), se puede además identificar la marca de las construcciones originales -que sólo se verifica en reformas parciales: ampliaciones, reemplazo de carpinterías, incorporación de sistemas de control y vigilancia- y lo que es aún más excepcional, se mantienen en su mayoría afectadas por los mismos usos de antaño. De manera similar, en el Barrio Parque Castelar (1929), se reconoce un paisaje homogeneidad arquitectónica. Las características de la arquitectura original (mayores 
superficies revocadas y reducción de elementos rústicos, piedras, decoraciones en madera) son apenas afectadas por pequeñas operaciones de "maquillaje" producto de los dictados cambiantes de la moda. En contraste, en el Barrio Parque Peluffo (1947), profundamente transformado, sólo se despliegan unos pocos rasgos del proyecto original. En el corazón del barrio todavía se reconoce el loteo original y el contexto arbolado que aún permite -en una imagen aérea- reconocer la particularidad del sector; pero la cantidad de lotes vacantes, que se fueron completando con el tiempo, dan como resultado un paisaje más que heterogéneo. Cada unidad o parcela desagregada del tejido puede verse como la promesa de lo que alguna vez fue un barrio parque. Sobre esa base, se fueron yuxtaponiendo quintas sin mantenimiento, galpones vacíos y enormes territorios desocupados que se diluyen en la mancha más amplia de la urbanización.

¿Qué relación tienen estos barrios parque de la primera mitad del siglo XX con las urbanizaciones cerradas del fin de ese siglo?

En principio, independientemente de los sectores geográficos y de sus respectivas tradiciones en relación a diversas formas de asentamiento urbano, aparece como constante que la localización de unos y otros ha estado guiada por los cambios que arrojan en el territorio la incorporación de nuevas, transformadas, formas de movilidad. No es una novedad que la localización de las urbanizaciones cerradas responde a las transformaciones viales producidas por las nuevas autopistas de acceso a Buenos Aires en los años ochenta y noventa, al igual que en los años diez y veinte respondió a los ejes de crecimiento marcados por el FFCC, y a partir de la década del treinta a la apertura de nuevas vías de tránsito automotor.

De igual manera que sucedió cuando se operó el pasaje de la primacía de la movilidad ferroviaria hacia la preponderancia del automotor -que redundó en la formación de un tejido urbano más disperso y el alejamiento de los barrios parque de las áreas de urbanización previas-, en las urbanizaciones cerradas, las posibilidades de acceso directo por autopista acentuaron el quiebre con la estructura urbana tradicional, generando una ruptura con la trama y el tejido de los centros urbanos más próximos.

En cuanto a la configuración de los propios barrios, la introversión que en muchos de los barrios parque de la primera mitad del siglo surgió como respuesta a la falta de adecuación del espacio público, hoy se ha convertido en una elección. Desde los nuevos procesos de suburbanización de los sectores medios y medios-altos se niega 
cualquier posibilidad de construir espacio público común, y los límites -que en la periferia dispersa de los años cincuenta solían ser una calle sin asfalto o una zanja que no permitían la continuidad de la trama- se han convertido en cercos perimetrales electrificados y vigilancia privada. Mientras que en algunos de los barrios que mencionamos para la primera mitad del siglo XX se conformaron áreas autocontenidas gracias a un carácter urbano altamente definido y a una identidad comunitaria surgida a través del tiempo, en las nuevas urbanizaciones implantadas "desde arriba", la comunidad encapsulada ha sido una elección de los residentes y una imposición del diseño amurallado que asegura el mínimo contacto entre el adentro y el afuera. La nueva configuración "hacia adentro" ha marcado una ruptura definitiva con el modelo de "ciudad europea" -abierta y más equitativa en términos de apropiación social del espacio- que, como dijimos para la primera mitad del siglo XX, en la Capital estuvo asegurado por la extensión de una grilla homogénea y que en el Gran Buenos Aires, al menos en la teoría, se mantuvo siempre como una opción posible que la incorporación de loteos de barrios parque no necesariamente negaba. Salvo en escasas excepciones, la implantación de barrios parque contribuyó a irradiar en sus periferias áreas de similares características. Cuando dos emprendimientos se ubicaban a escasa distancia uno del otro - dejando una franja de tierras intermedia- esta última terminaría adoptando -casi por contagio- un carácter similar. En la nueva configuración territorial, esto resulta imposible.

El siguiente punto que debe considerarse tiene que ver con cambios en la modalidad de producción del espacio. A la multiplicidad de agentes y al proceso lento y fragmentado de producción de los núcleos registrados a lo largo de la primera mitad del siglo XX, se contrapone la acción centralizada y eficiente de los principales agentes que se encuentran actualmente involucrados en los emprendimientos de urbanizaciones cerradas. Estos son, mayoritariamente, promotores o developers que pueden asumir diferentes tareas: coordinador de las distintas instancias de un emprendimiento, o inversor. Mientras que, la compañía inmobiliaria tradicional -muchas veces de escala familiar- que analizamos para la primera mitad del siglo XX se ha visto transformada, $\mathrm{o}$ reemplazada por el broker inmobiliario, que además de vender se ocupa de las estrategias de comercialización, detecta "áreas de oportunidad", y en otras ocasiones aporta el capital inicial para la compra de terrenos de especulación. El producto que se ofrece es un barrio terminado: con calles asfaltadas, servicios, club house y 
parquización diseñados por profesionales y en funcionamiento al momento en que se muden los primeros habitantes.

En cuanto a la intervención del sector público, los Municipios cobran relevancia en virtud de las reformas y re-acomodamientos institucionales del último decenio del siglo XX. En este registro el cambio más importante que se ha operado tiene que ver con la desvinculación del Estado como constructor de obra pública y proveedor de infraestructuras. En las urbanizaciones cerradas, tanto la accesibilidad a través de autopistas privadas, como la provisión de los servicios dentro de cada emprendimiento quedan a cargo de los inversores. Como contraparte, sí se ha incrementado la acción que los Municipios ejercen de manera indirecta, a través de la puesta en práctica de un cuerpo de reglamentaciones más complejo y un sistema de aprobaciones relacionado directamente a las políticas locales que, por lo general, compiten por atraer nuevas inversiones.

Estos reacomodamientos, por un lado son producto de determinados cambios culturales, particularmente de las nuevas demandas en relación al diseño y carácter de las urbanizaciones, a la vez que se constituyen en impulsores de esos mismos cambios. $\mathrm{Al}$ iniciar la tesis enumeramos la tranquilidad del campo, el contacto con la naturaleza y la posibilidad de disfrutar de la familia y los deportes al aire libre, sumado a los crecientes problemas de inseguridad como condiciones fundantes de los procesos de suburbanización de los sectores medios, y medios altos. Salvo el último punto de la seguridad, las demás características ya estaban presentes desde comienzos del siglo $\mathrm{XX}$. No obstante, un cambio en las pautas de consumo del espacio residencial ha operado por detrás de las transformaciones en el diseño y producción de las urbanizaciones. Como señaló Maristela Svampa los protagonistas del fenómeno iniciado hacia fines de los años ochenta fueron los "ganadores" de un proceso de desestructuración y re-estructuración de las franjas socioeconómicas tal como se las conocía hasta ese momento en Argentina. ${ }^{378}$ En este marco, los nuevos sectores "medios-altos" y "medios en ascenso" buscaron asimilarse a los sectores altos y "tendieron a desarrollar lo que podría llamarse una cultura "internacionalizada",

378 Maristela Svampa, Los que ganaron. La vida en countries y barrios cerrados. Op. Cit. 
básicamente por la adopción de patrones de consumo análogos a los de esas clases en los países avanzados, en especial en los Estados Unidos". 379

En este escenario, los protagonistas del fenómeno actual que, a diferencia de lo sucedido en las primeras décadas del siglo XX han convertido al suburbio en lugar de residencia permanente, exigen cada vez más valores urbanos. Si los fenómenos de habitar suburbanos a los que referimos para la primera mitad del siglo fueron planteados como retiros o sitios de recreo que ofrecían un escape ante el trajín de la vida urbana, y que tenían sentido en tanto la ciudad se mantuviera como lugar de residencia permanente. En la nueva coyuntura, muchos de los nuevos emprendimientos buscaron trasladar al suburbio las características más valoradas del modo de vida urbano. En efecto, eficientes medidas de seguridad, comunicaciones rápidas, accesibilidad y colegios bilingües, aparecen como commodities prácticamente indispensables en estos emprendimientos. De la misma manera, se ha complejizado el programa de la casa que se aleja de la simplicidad del californiano de las décadas del treinta y cuarenta, en pos de espacios más grandes, más cualificados, con equipamientos sofisticados y sistemas de climatización.

Atrás quedó el tiempo en el que se subdividían unos lotes, se trazaban las calles y un nuevo barrio estaba listo para salir a la venta. Cambios en las exigencias para la aprobación de nuevos loteos $\mathrm{y}$, fundamentalmente, los crecientes requerimientos de los habitantes metropolitanos han derivado en la complejización y centralización de los procesos de producción relacionados al habitar. La aventura del week-end, que hizo posible para muchas familias de clase media comprar un terreno en cuotas $\mathrm{y}$, de a poco levantar allí su vivienda y ver crecer los primeros árboles junto a la llegaba del asfalto, ha desaparecido del horizonte de expectativas de los nuevos sectores medios que se posicionan frente a la vivienda como consumidores. En tanto- como mencionamos- las lógicas de producción espacial actuales ya no dependen de las políticas de planificación o de normativas urbanas producidas por el Estado, sino de las reglas de rentabilidad inmobiliarias producidas por el capital privado, se ha exaltado el "valor de cambio" de los nuevos espacios residenciales, reduciendo a su mínima expresión la memoria del

\footnotetext{
379 Pedro Pírez, "Buenos Aires o la expansión metropolitana sin gobierno", en Conferencia Internacional sobre el Control de la Expansión Urbana, México D.F., 8 y 9 de Noviembre, 1999.
} 
"valor de uso" de este tipo de "bienes durables". El valor que tradicionalmente se otorgaba a los momentos transcurridos en la casa de recreo, que muchas veces, a diferencia del departamento en la ciudad, brindaba la ocasión de compartir tiempo en familia o con los vecinos -en palabras de la revista Casas y Jardines- "haciendo rodar la carretilla" o "rastrillando hojas secas el domingo por la mañana" ha desaparecido. ${ }^{380}$ En la modalidad que proponen muchos barrios cerrados, el repertorio de tipologías arquitectónicas residenciales puede escogerse por catálogo, extendiendo las posibilidades de consumo residencial a las propuestas de venta "llave en mano" como un signo del alejamiento del habitante con los procesos de construcción de su propio ambiente.

Leonardo Benévolo consideraba que el territorio funciona como canal de comunicación entre presente y pasado. ${ }^{381}$ Por un lado, las formas del territorio se van superponiendo sin demasiadas precauciones y van rescribiendo sobre un sitio nuevas configuraciones que, sin embargo, llevan en su ADN las huellas de viejos proyectos. Al mismo tiempo, es cierto que cada configuración temporal es tributaria de la compleja estructura sociocultural y económica de la sociedad que alberga y eso dificulta el análisis.

En este sentido, las transformaciones que hemos vislumbrado en el territorio en relación a las formas de habitar por fuera de la ciudad revelan los profundos cambios producidos en la sociedad metropolitana a lo largo del siglo, a la vez que se inscriben en un conjunto de formas y prácticas urbanas que este mismo recorrido ha ido produciendo.

\footnotetext{
${ }^{380}$ Revista Casas y Jardines, no 2, marzo de 1933. p. 59.

381 Leonardo Benévolo, La ciudad europea, op.cit
} 


\section{Apéndice de loteos}

Relación del loteo con la red vial y ferroviaria

- Localidad: Almirante Brown

- Nombre de la Urbanización: Barrio Parque Manuel Obligado-Claypole

- Fecha del loteo: 1929

- Distancia a la Capital: $22 \mathrm{~km}$

- Datos de localización: 2 estaciones después de Temperley

- Descripción: 20000

- Servicios:

- Costos de lo lotes: base lotes \$ 5

la mensualidad en 100 mensualidades

- Inmobiliaria: Furst Zapiola

- Discursos de promoción:

- Normas de edificación:

Adjunta modelos y planos de chalets económicos y adecuados para edificar en este barrio:

Modelo A, 3 habitaciones.

Modelo B, 2 habitaciones

Modelo C, 1 habitación
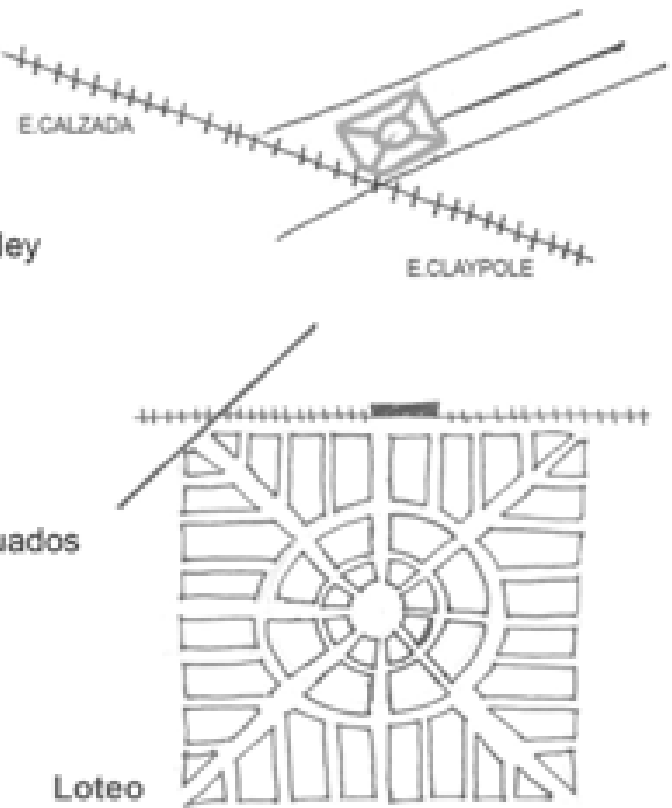

- Localidad: Almirante Brown

- Nombre de la Urbanización: Barrio Parque Burzaco

- Fecha del loteo:

- Distancia a la Capital: $25 \mathrm{~km}$

- Datos de localización: a cinco cuadras de la estación ferrocarril del sur

- Descripción: 100 lotes y 2 casas quinta

- Costos de lo lotes: base lotes entre \$ 3 y \$10 la mensualidad

en 120 mensualidades. Base de las casa quinta $\$ 12.000$ y

Relación del loteo con la red vial y ferroviaria
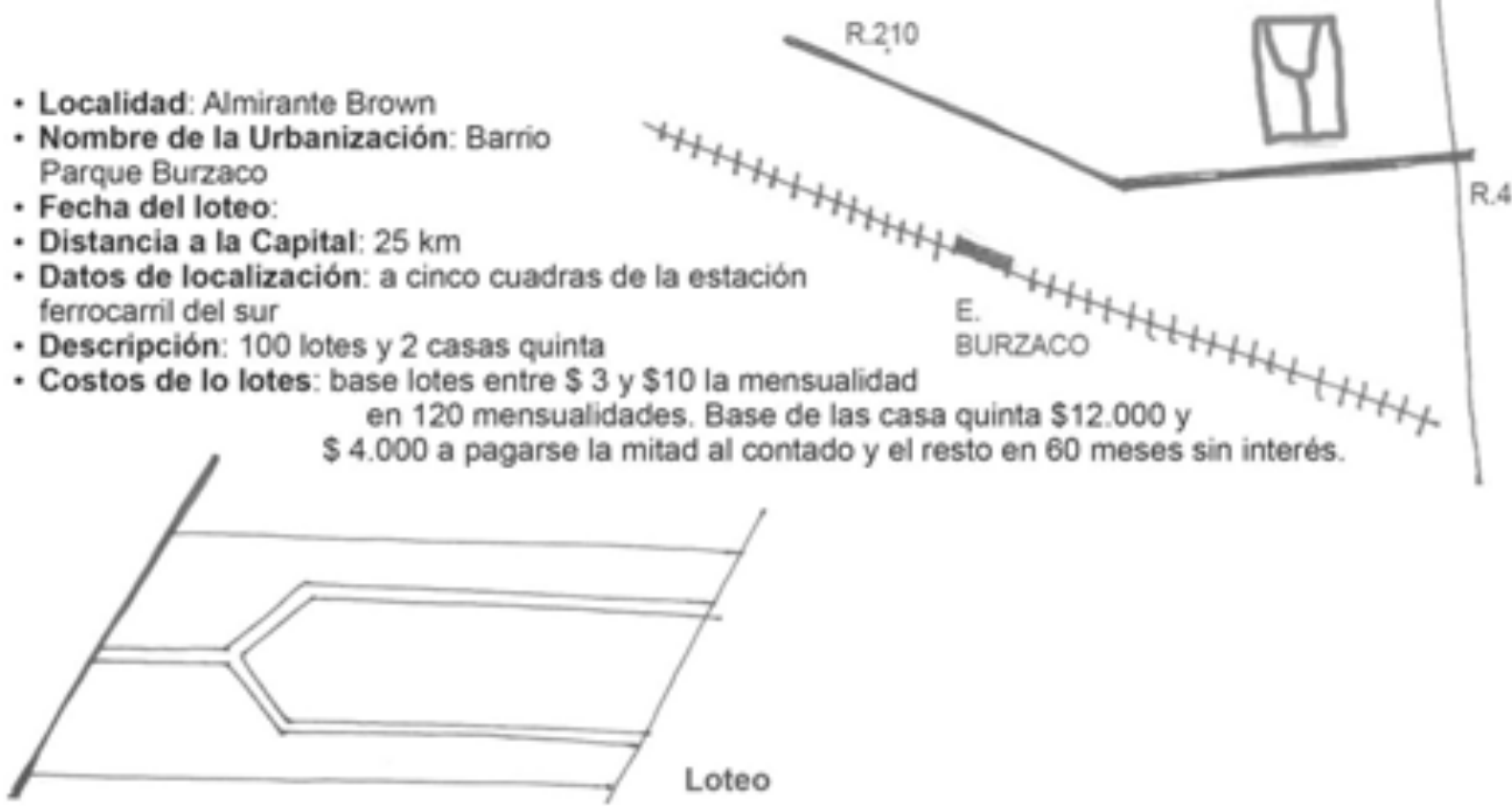
- Localidad: Almirante Brown

- Nombre de la Urbanización: Barrio Parque residencial cabaña "La Carmen" de Bonorino

- Fecha del loteo: 1947

- Distancia a la Capital: $26 \mathrm{~km}$ de Constitución

- Datos de localización: km 32 de la ruta nacional 210, a diez cuadras de estación Longchamps

- Descripción: 65 fracciones (trazado pseudo-pintoresco), dos chalets y un rancho criollo

- Costos de lo lotes: chalet moderno estilo americano, base $\$ 50.000 \mathrm{~m} / \mathrm{n}$

Chalet, base $\$ 10.000 \mathrm{~m} / \mathrm{n}$

Rancho criollo, base $\$ 6.000 \mathrm{~m} / \mathrm{n}$

- Normas de edificación:

no se podrán construir fincas que no sean de mampostería y techo de teja o pizarra

retiro obligatorio $5 \mathrm{mts}$ de frente y $3 \mathrm{mts}$ laterales

medianera de cercos vivos

se prohíbe cualquier edificación que no sea residencial

- Localidad: Gral. Sarmiento

- Nombre de la Urbanización: Parque Mattaldi- Bella Vista

- Fecha del loteo: (1er loteo)1926- (2do Iteo)1946

- Datos de localización: sobre el camino pavimentado a Pilar

y a una cuadra de la estación Bella Vista del FFCC.

- Descripción: 700 lotes con asfalto pago y amplia opción

- Costos de lo lotes: base \$ 5 por mes el lote en 120 meses

- Discursos de promoción:

"lindando con grandes construcciones y chalets de la compañia Michelin y las grandes obras de la nueva cerveceria Bella Vista, lo que traerá como consecuencia gran actividad y movimiento a este barrio hoy ya populoso. Son los terrenos más lindos y hermosos, con un trazado de calles y avenidas a estilo Europeo y Norteamericano, con amplios frentes y fondos proporcionados, siendo éstos terrenos los de más inmediata valorización y porvenir, pues alli se
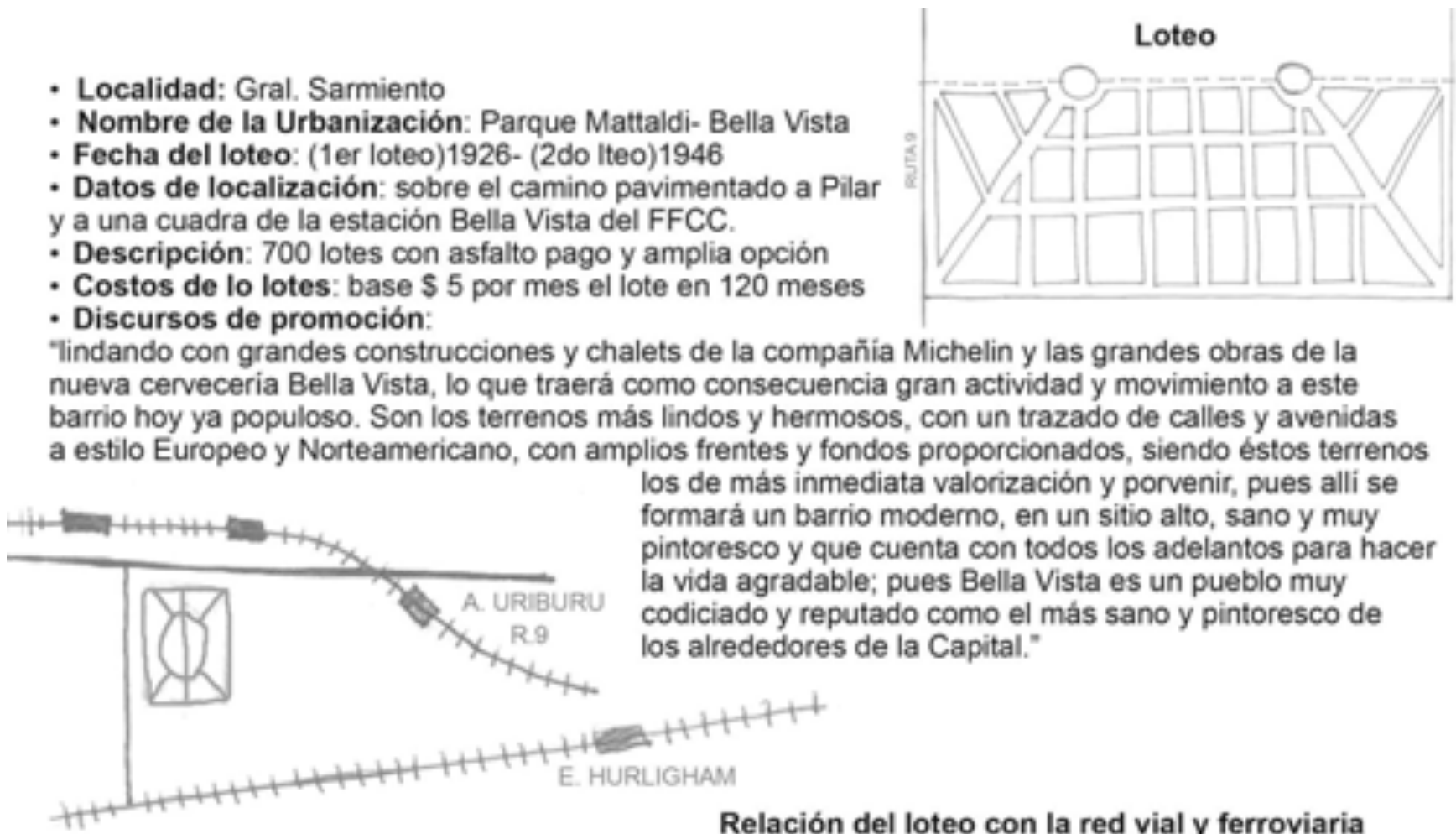

Relación del loteo con la red vial y ferroviaria 
- Localidad: Gral Sarmiento

- Nombre de la urbanización: quintas en San Miguel

- Datos de localización: frente al camino pavimentado a Pilar, Incluye planos para casa de week-end

- Fecha del loteo: 1940

distancia a la capitai $32 \mathrm{~km}$

- Servicios: calles arboladas- alumbrado eléctrico

- 133 quintas

Costos de lo lotes: base de $\$ 0.45$ la vara2.

en 120 meses daria $\$ 10 \times$ mes

- Inmobiliaria: Comi \& Pini

- Discursos de promoción: inmejorables para week-end o para fijar residencia.

"es el week-end de los ingleses o el wachen-end de los alemanes,

hábito que bienhechor se ha impuesto como una necesidad al habitante

de las grandes urbes modernas. El lugar ofrecido para week-end debe tener caracteristicas y ubicación especiales; el higienista S.Kesley las resume asi:

1. no deben estar cerca de las costas porque en inviemo generan humedad malsana y vientos molestos.

2- Deben estar situadas en tierras altas y con abundante vegetación.

3. No deben estar muy alejadas de centros de población

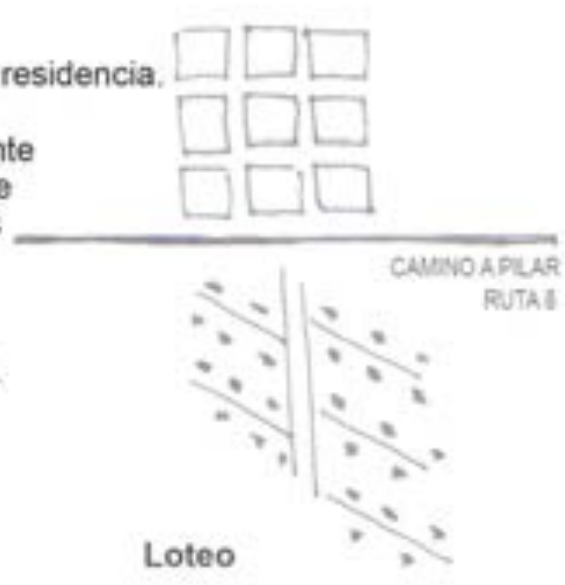

- Localidad: General Sarmiento

- Nombre de la Urbanización: Barrio Parque San Andrés

- Fecha del loteo: 1931/1942

- Distancia a la Capital: $15 \mathrm{~km}$

- Datos de localización: sobre la estación del tren eléctrico lindando con el Golf Club San Andrés. A veinte minutos de Retiro, a trece cuadras del centro de San Martín

- Descripción: 200 lotes

- Costos de lo lotes: base $\$ 7$ por mes el lote, en 100 mensualidades

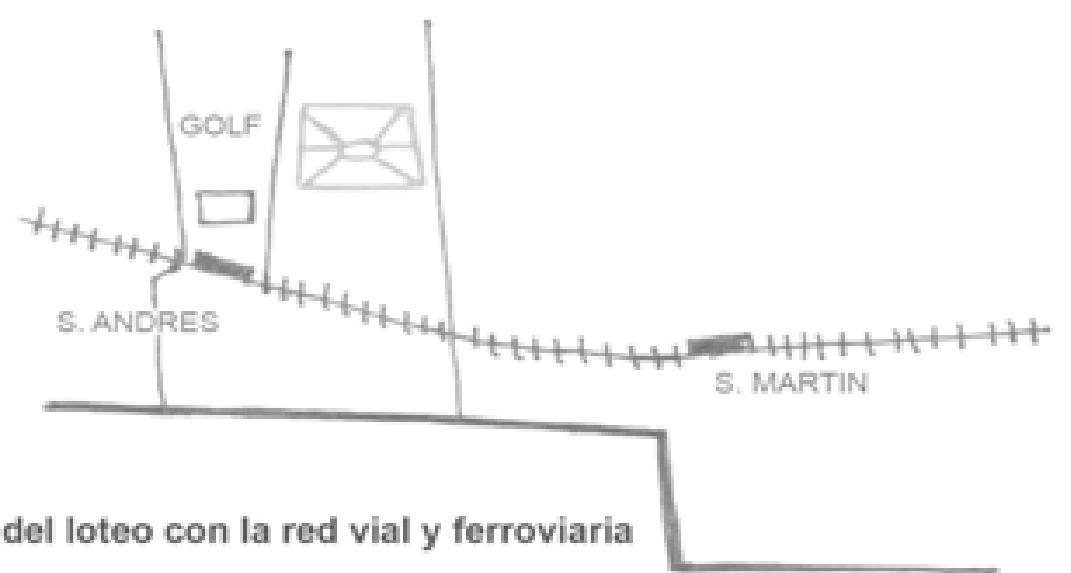

Relación del loteo con la red vial y ferroviaria 
- Localidad: General Sarmiento

- Nombre de la Urbanización: Barrio Parque La Primavera

- Fecha del loteo: 1946

- Distancia a la Capital: $34 \mathrm{~km}$ de retiro-

- Datos de localización: sobre ruta Panamericana- FFCC del Estado. frente al hermoso Barrio Parque Bellaflor

- Descripción: 200 amplias quintas. Trazado radial

- Inmobiliaria: Ungaro y Barbará

- Discursos de promoción:

"ideal para fin de semana, veraneo o vivienda permanente"

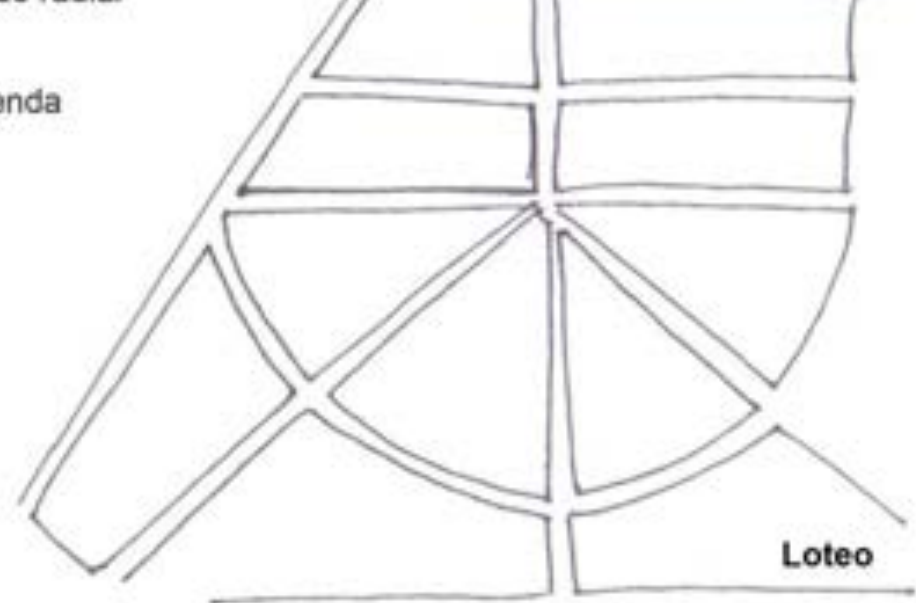

- Localidad: General Sarmiento

- Nombre de la Urbanización: Barrio Parque "Bellaflor"

- Fecha del loteo: 1944

- Distancia a la Capital: $30 \mathrm{~km}$

- Datos de localización:

- Descripción: una magnifica loma en Los Polvorines, para un gran barrio de veraneo o weekend

- Localidad: General Sarmiento

- Nombre de la Urbanización: Residencial- Barrio Parque La Huella

- Fecha del loteo: 1947

- Distancia a la Capital: $30 \mathrm{~km}$

- Datos de localización: próximo a la estación José C. Paz

- Descripción: 109 espléndidas quintas.

- Costos de lo lotes: base $\$ 0.75$ la vara2. suponiendo que el precio de venta duplicó la base y con terrenos de $800 \mathrm{~m} 2=\$ 1.600$ por lote, con mensualidades de $\$ 15$ 
- Localidad: La Matanza

- Nombre de la Urbanización: Barrio Jardin Puente Ezcurra

- Fecha del loteo: 1948

- Datos de localización: sobre la ruta nacional pavimentada a Cañuelas $n^{\circ} 3$; detrás del Aeropuerto de Ezeiza; con colectivos a Plaza Once.

- Descripción: 710 magnificos lotes

- Costos de lo lotes: bases $\$ 1 \mathrm{~m} 2$. Iotes de $400 \mathrm{~m} 2$, suponiendo que la venta duplique la base, cada lote $=\$ 800$ o 120 cuotas de $\$ 7$

- Discursos de promoción:

tha sido proyectada y realizada en un lugar ideal para la instalación de la casa de fin de semana con sólo una pequeña inversión. Se ha tratado de urbanizar conscientemente para poder ofrecer asi a los numerosisimos entusiastas de esta zona una casa bonita, cómoda, barata y de gran porvenir, que podrán adquirir con un pequeño desembolso."

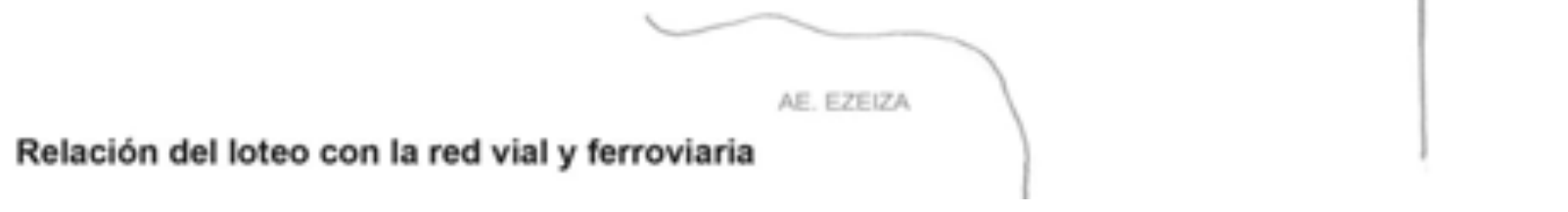

- Localidad: la matanza

- Nombre de la Urbanización: Barrio Parque Peluffo

- Fecha del loteo: 1-1945/2-1949

- Distancia a la Capital: $23 \mathrm{~km}$

- Datos de localización: a las puertas de la Capital, sobre el camino de cintura a $6 \mathrm{~km}$ de la avenida General Paz.

- Costos de lo lotes: (1945) $\$ 50 \times$ mes en 120 meses.

- Inmobiliaria: Vinelli Ithurralde

- Discursos de promoción:

(2do loteo) Un ofrecimiento de excepción en la zona residencial más próxima a la Capital y en uno de los sitios de mayor prestigio, por sus excelentes vistas, por su altura y la calidad de sus tierras y donde todos sin excepción son espléndidas residencias y magnificas casas quinta que han hecho de esta zona un lugar de preferencia para instalar la residencia de veraneo o de fin de semana.

Relación del loteo con la red vial y ferroviaria

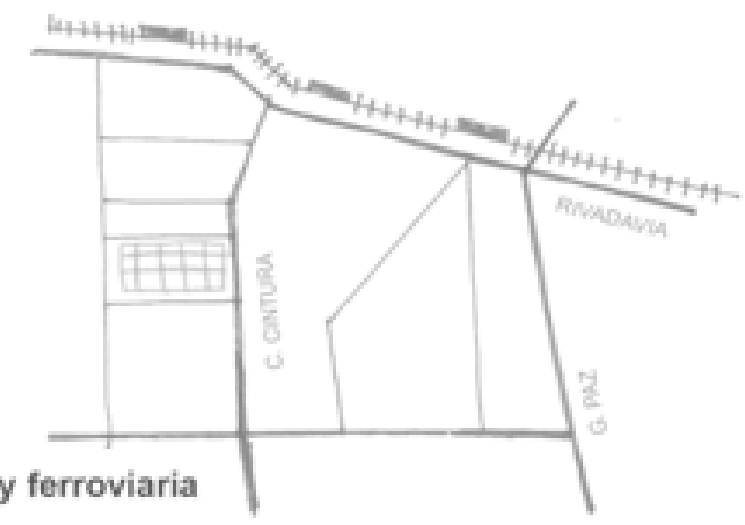


- Localidad: La Matanza

- Nombre de la Urbanización: Barrio Parque Santa Clara

- Fecha del loteo: 1945

- Distancia a la Capital: $18 \mathrm{~km}$

- Datos de localización: frente a la Avenida pavimentada Provincias Unidas. A 500mts de la estación Casanova y con servicio de colectivos.

- Descripción: 99 amplias quintas arboladas con pavimento pago. Todos los terrenos tienen medidas entre los 1.300 y $3.000 \mathrm{~m} 2$

- Costos de lo lotes: base 0.35 la vara2 $(0.75 \mathrm{~m} 2)$ lotes entre $\$ 1.000$ y $\$ 3.000$ en 120 meses cuotas de entre $\$ 9-25$

- Inmobiliaria: Rufino Elizalde

- Discursos de promoción:

- "Son terrenos altísimos, de amplias medidas y de inmediata valorización"

- Normas de edificación:

- $\quad$ Localidad: La Matanza

- $\quad$ Nombre de la Urbanización: El Pino

- Fecha del loteo: 1949-50

- Distancia a la Capital: $24 \mathrm{~km}$

- $\quad$ Costos de lo lotes: base desde $\$ 30$ por mes, por fracción.

- Discursos de promoción:

"Un bosque a las puertas de la Capital. De tal puede calificarse este extraordinario, ya que una tupida y magnifica arboleda de los más raros ejemplares cubre gran parte de estas tierras que se ofrecen a la venta. (...) Estos terrenos son parte de la estancia de Virrey del Pino, centro de importantes reuniones en su época. Fue refugio de J.M. de Rosas, habiéndose tejido diversas e interesantes leyendas alrededor de ella. Además de hallarse estas magníficas tierras a sólo $23 \mathrm{~km}$ de la Capital Federal y con extraordinarias condiciones de pago" 
- Localidad: La Matanza

- Nombre de la Urbanización: Barrio Parque lbáñez

- Fecha del loteo: 1947

- Distancia a la Capital:

- Datos de localización: frente a la estación Pontevedra

- Descripción:

- Servicios:

- Costos de lo lotes:

- Inmobiliaria: Vinelli Ithurralde

- Discursos de promoción:

"En cualquier zona que usted recorra los terrenos ubicados frente a la estación son los que tienen mayor valor. Además está la inmejorable calidad del suelo, el clima tan favorable con aire puro y seco, son condiciones de gran interés para quienes quieran formar una quinta de descanso. El paraje ofrece la ventaja de ser el paraje más alto del lugar y con ondulaciones que hacen más bello su paisaje. Además un pintoresco arroyo cruza el barrio.

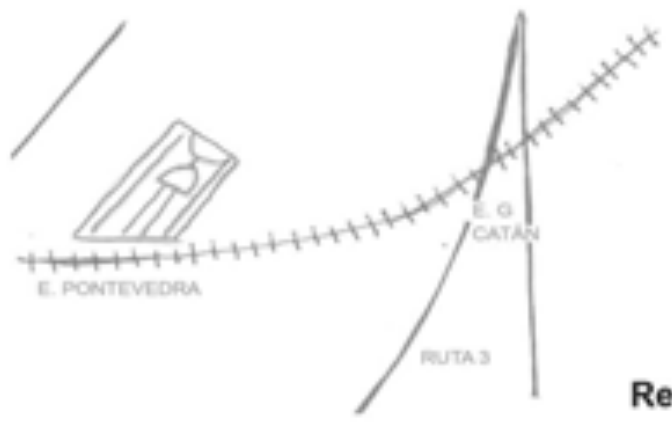

Trazado moderno del gran Barrio Parque Ibañez

Relación del loteo con la red vial y ferroviaria

- Localidad: La Matanza

- Nombre de la Urbanización: Barrio Parque Camping Club

- Descripción: 150 quintas y tres flamantes chalets

- Costos de lo lotes: bases $\$ 5$ por mes. Chalets entre $\$ 50$ y $\$ 150$ por mes.

- Discursos de promoción:

"Tal como hemos asegurado en los remates, está ocurriendo la prosecución de obras de rectificación del Riachuelo y Río Matanza, la construcción del gran Aeropuerto Nacional, el crecimiento de las subdivisiones, la edificación de hermosos chalets modernos, la formación de grandes barrios parque, el nuevo trazado de la autoestrada al centro de la metrópoli. En breve podremos ver llegar a los aviones, la llegada de la ruta hasta el centro, luego vendrá la prolongación del camino pavimentado a Puente La Noria y la General Paz. Así llegarán los servicios de ómnibus y colectivos con tránsito cada vez más intenso. ¿Qué pasará entonces con las tierras de esta zona privilegiada? Lo que en otras zonas exactamente. Adquieren valores insospechados, como el Olivos, en Ramos Mejía y otros lugares equidistantes de la Capital.

Camping Club es un barrio de trazado muy moderno obra de urbanistas insignes, ha sido proyectado con subdivisión tipo casas para week-end lo que asegura construcciones bellas, simpáticas que formarán un marco noble, arboledas, chalets modernos y jardines. Tiene porvenir grandioso y una valorización estupenda. 
- Localidad: La Matanza

- Nombre de la Urbanización: Golden Park

- Fecha del loteo: 1949

- Distancia a la Capital: $25 \mathrm{~km}$

- Datos de localización: a sólo 5 minutos de la Capital y a $20 \mathrm{~km}$ de la Plaza Congreso

- Descripción: foto de uno de los chalets. Construcción horizontal tipo americana

- Discursos de promoción:

"un magnifico Barrio Parque al Oeste, entre Ramos Mejía y San Justo, en el camino de cintura. La fracción del Golden Park, en la ubicación de privilegio, donde empiezan las hermosas residencias del ya famoso Barrio Parque Peluffo" 
- Localidad: La Matanza

- Nombre de la Urbanización: Barrio Parque Santa Clara

- Fecha del loteo: 1945

- Distancia a Capital: $18 \mathrm{~km}$

- Datos de localización: frente a la Avenida pavimentada Provincias Unidas. A 500mts de la estación Casanova y con servicio de colectivos.

- Descripción: 100 amplias quintas arboladas con pavimento pago. Todos los terrenos tienen medidas entre los 1.300 y $3.000 \mathrm{~m} 2$

- Costos de lo lotes: lotes entre $\$ 1.000$ y $\$ 3.000$ en 120 meses cuotas de entre $\$ 9-25$

- Inmobiliaria: Rufino Elizalde

- Discursos de promoción:
"Son terrenos altisimos, de amplias medidas y de inmediata valorización"

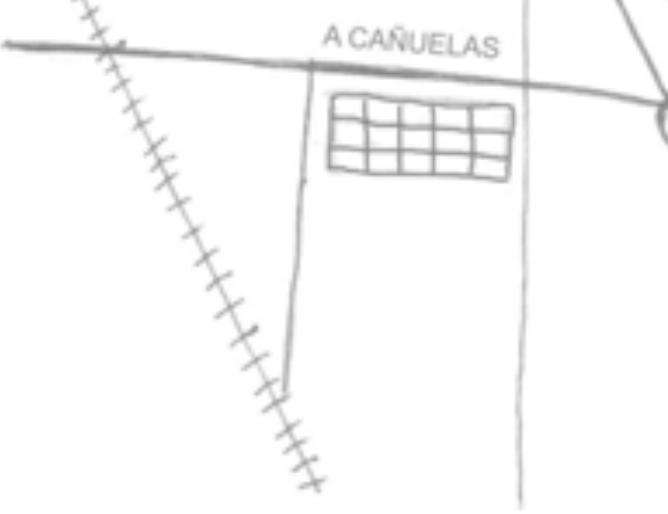

Relación del loteo con la red vial y ferroviaria

- Localidad: Lomas de Zamora

- Nombre de la Urbanización: sin nombre

- Fecha del loteo: 1947

- Distancia a la Capital:

- Datos de localización: frente a la estación Longchamps del FFCC del Sur y la ruta pavimentada 210 a Mar del Plata

- Descripción:

- Servicios: luz eléctrica, teléfono

- Discursos de promoción:

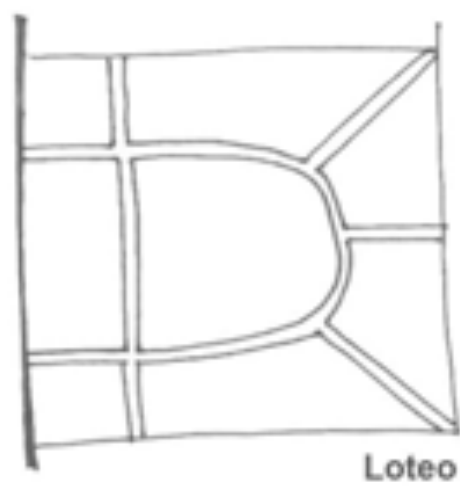

"en un barrio jardin rodeado de hermosas residencias, la última oportunidad para adquirir terrenos en un lugar de privilegio y mayor prestigio de la

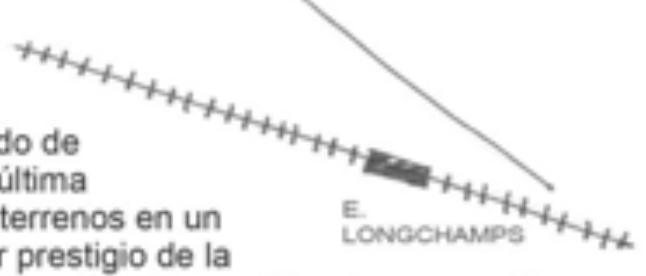
zona Sur, donde todas son esplendidas residencias y magnificas casas quinta, lo que ha hecho de este lugar uno de los predilectos para vivir por sus excelentes vistas y por la altura y calidad de sus tierras.

Estratégicamente ubicadas a las puertas mismas de la Capital Federal, cuyo trayecto se hace cómodamente en menos de 40 minutos. Cuenta además con variado comercio, clubs. Algunas de sus calles están pavimentadas, además de la ruta 210 , todo lo que contribuye a hacer cómoda y agradable la vida alli, ya sea como residencia de todo el año o veraniega."

- Localidad: Lomas de Zamora 
- Nombre de la Urbanización: Barrio Parque San Juan de Biocca

- Fecha del loteo: 1948

- Descripción: 438 lotes-quintas

- presenta una típica subdivisión en cuadricula y en el centro del trazado aparece un importante predio "donado al gobierno nacional para fábrica"

- Costos de lo lotes:. Base de \$ 3 por mes en 126 meses.

- Discursos de promoción:

- "concurra a este gran remate y realizará el sueño de la casa propia"

- $\quad$ Localidad: Lomas de Zamora

- Nombre de la Urbanización: Barrio "Las Torres"

- Fecha del loteo: 1949

- Distancia a la Capital: $30 \mathrm{~km}$ de Plaza Congreso

- Datos de localización: distan 3000mts de la autopista Ezeiza y del balneario San Sebastián sobre el río Matanzas

- Descripción: 269 quintas. Las quintas en venta tienen frentes de $18 \mathrm{mts}$ y amplias superficies de $900 \mathrm{~m} 2$.

- Servicios:

- $\quad$ Costos de lo lotes: base $\$ 25$ por mes en 126 mensualidades. Vendido a $\$ 70$ x mes

- Inmobiliaria: Pascual \& cía.

- Discursos de promoción:

- $\quad$ "en las cercanías de la Capital son cada vez más requeridas las tierras aptas para residencias de veraneo o fin de semana, como asimismo para cómodas viviendas familiares en un clima saludable, ya que quedan pocas zonas de un progreso tan seguro y rápido como las situadas frente al magnífico camino de cintura y sobre la gran autopista al aeropuerto Nacional de Ezeiza"

- $\quad$ Localidad: Lomas de Zamora

- $\quad$ Nombre de la Urbanización: Barrio Parque Lomas de Beheran

- Fecha del loteo: 1948

- Distancia a la Capital: $30 \mathrm{~km}$

- Datos de localización: sobre el camino de cintura a $6 \mathrm{~km}$ de la autopista a Ezeiza (en construcción) y por la cual se estará en la plaza Congreso en 25 minutos. A 11 km de General Paz.

- Costos de lo lotes: base $\$ 10$ la mensualidad en 120 meses, con lotes de $1.000 \mathrm{~m} 2$. Suponiendo que la venta duplique el precio de base, $\$ 20$ por mes, lotes de $\$ 2.400$ Inmobiliaria: Ungaro \& Barbará

- Discursos de promoción:

- $\quad$ "este no es uno de los tantos fraccionamientos trazados con fines de negocio, sin fundamento urbanístico que lo justifique. Su motor creador es el amor de sus propietarios a estas tierras, que las poseen desde años ha y que siendo prácticamente envueltas ya por el crecimiento del Gran Buenos Aires y conscientes de su deber de contribuir a este progreso han estudiado en ellas el lineamiento de una futura ciudad jardín, cuyo trazado consulte las necesidades de una vida agradable en donde el contacto con la naturaleza libere a los mayores del cansancio que la agitada vida moderna impone, a la vez que proporcione a los niños adecuado lugar para sus juegos. Ha sido de profunda satisfacción para sus propietarios la selecta concurrencia que acudió al remate, resultando compradora, lo que permite asegurar a este parque residencial un futuro muy promisorio. Se ofrece ahora a los interesados adquirir un terreno para construir su casa de veraneo, fin de semana o vivienda permanente, la más brillante oportunidad ya que se trata de altas y excelentes tierras. 
- $\quad$ Localidad: Lomas de Zamora

- $\quad$ Nombre de la Urbanización: Barrio Parque Lavallol

- $\quad$ Fecha del loteo: 1933- 2do 1947

- Distancia a la Capital: $22 \mathrm{~km}$ del Congreso

- Datos de localización: frente a la estación Lavallol. Dista sólo 31 minutos de Constitución y cuenta con excelente servicio de 63 trenes diarios.

- Descripción: 600 lotes

- Costos de lo lotes:

- Inmobiliaria: fusrt Zapiola

- Discursos de promoción:

- $\quad$ “Está formado este nuevo barrio por 59 soberbias manzanas de tierra altísima. Algunas de ellas con magnifica arboleda y dentro de un trazado moderno de estilo europeo, con grandes lotes de amplios frentes y fondos proporcionados y con calles asfaltadas y adoquinadas. En Lavallol se han instalado grandes establecimientos. Es propósito de los propietarios que se vaya formando un nuevo barrio moderno, por lo cual se ha resuelto no permitir una edificación que no sea de material. Para ello se entregarán a los compradores de dos o más lotes y absolutamente gratis, ladrillos y tejas para edificar"

- Localidad: Merlo

- Nombre de la Urbanización: Residencial El Pericón

- Fecha del loteo: 1950

- Distancia a la Capital: $33 \mathrm{~km}$.

- Datos de localización: a $600 \mathrm{mts}$ del conocido parque General San Martin

- Descripción: 300 espléndidos lotes

- Servicios: luz eléctrica por el frente y agua potable de primerisima calidad

- Costos de lo lotes: base de $\$ 15$ por mes cada lote, en 130 meses.

- Inmobiliaria: Comi \& Pini

- Discursos de promoción:

"Son lotes amplios, bien proporcionados con $80 \mathrm{~cm}$ de tierra negra, ideal para cualquier cultivo"

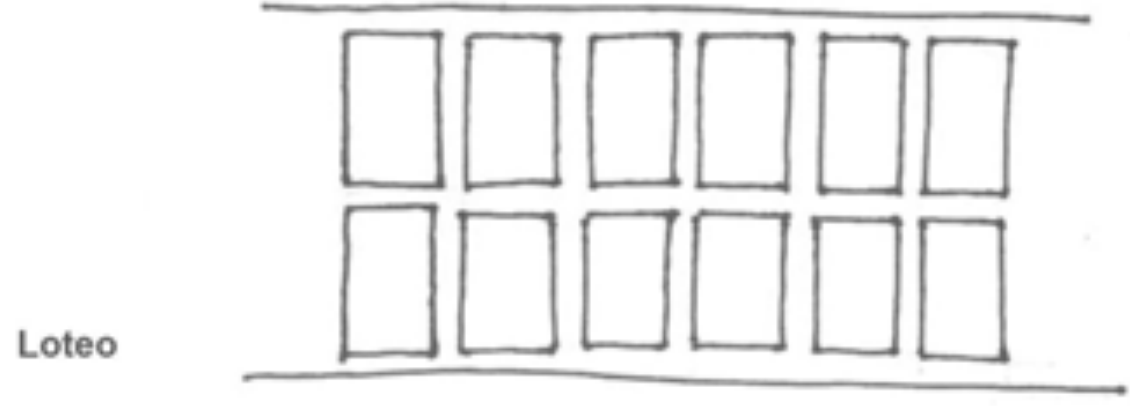

- Localidad: Merlo

- Nombre de la Urbanización: Barrio Parque "Los Indios" en Ituzaingo

- Fecha del loteo: 1946

- Distancia a la Capital: $30 \mathrm{~km}$

- Datos de localización: a una cuadra de importantes arterias 
- Costos de lo lotes:

- Discursos de promoción:

"una zona progresista en Castelar e Ituzaingo, son dos pueblos que gozan de singular preferencia.

En los últimos tiempos crecieron en forma gigantesca especialmente en la zona del norte. Diversas arterias, como ser Julio. A. Roca, Santa Rosa, Brandsen, o José C. Paz representan verdaderos tentáculos sobre los cuales giró una evolución trascendental. Abriéndose así nuevas sendas de urbanización, créanse nuevos barrios parque, e infinidad de casas quinta y chalets que surgieron en forma ponderable.

El barrio parque consta de un trazado moderno, de calles suavemente curvas y un desarrollo armónico que constituirá un centro de población atractivo, novedoso y simpático. Para quien quiere poseer la quinta de fin de semana en uno de los lugares más predilectos y además tener la certeza de su segura valorización"

- Localidad: Merlo

- Nombre de la Urbanización: Parque Agustin Ferrari

- Fecha del loteo: 1950

- Distancia a la Capital: a $37 \mathrm{~km}$ de Plaza Once

- Descripción: 2300 dobles lotes

- Costos de lo lotes: lotes de $800 \mathrm{~m} 2$.cuotas de $\$ 20$

- Discursos de promoción:

"en una pradera ondulante, verdeante, florida y llena de árboles con amables perspectivas a sus cuatro costados.

Un nuevo pueblo en los contornos del Gran Buenos Aires permitirá a millones de familias realizar el ansiado paraiso de su casa propia, creando las posibilidades de la realización por el propio esfuerzo, sin ayudas, sin cargas para nadie.

\section{Relación del loteo con la red vial y ferroviaria}

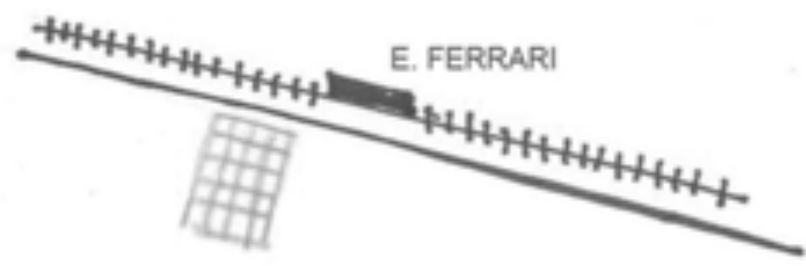

Loteo
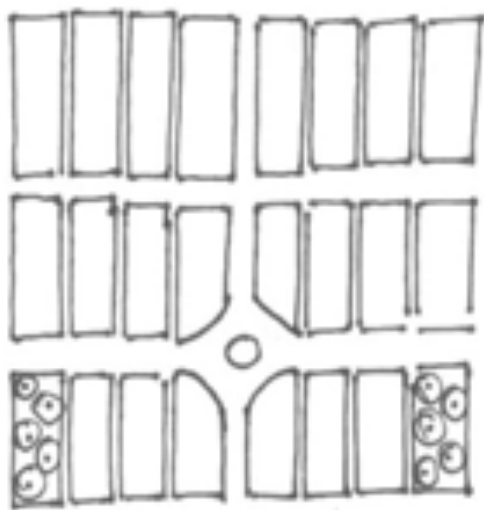
- Localidad: Merlo

- Nombre de la Urbanización: Barrio Parque "San Antonio"

- Fecha del loteo: 1945

- Distancia a la Capital: $32 \mathrm{Km}$.

- Datos de localización: lindando con el hermoso barrio parque Golf, frente a la estación San Antonio de Padua

- Descripción:140 lotes de $800 \mathrm{~m} 2$

- Costos de lo lotes: base $\$ 8$ por mes cada lote en 120 meses.

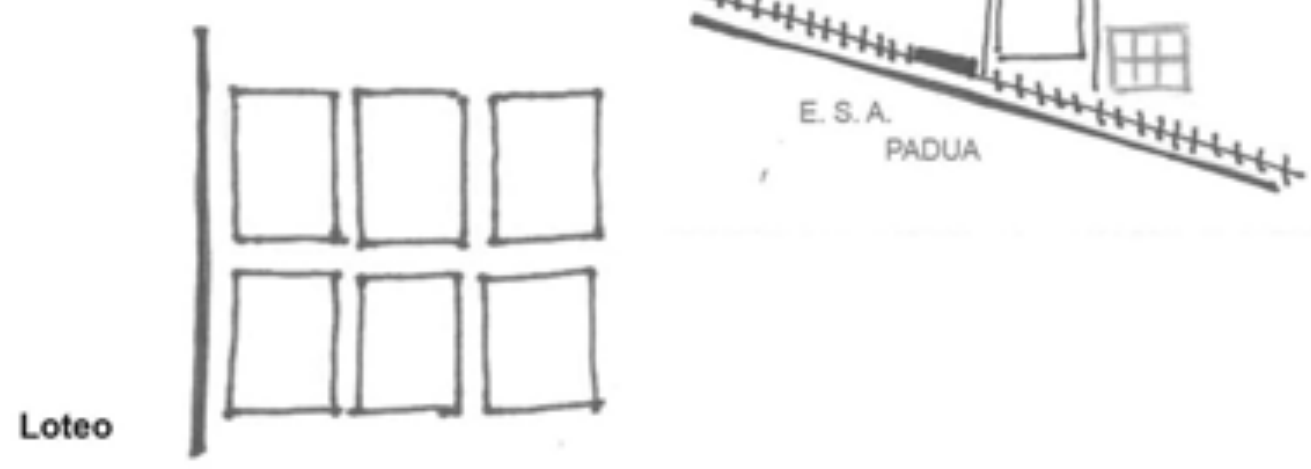

- Localidad: Merlo

- Nombre de la Urbanización: Pradera de Merlo

- Fecha del loteo: 1950

- Costos de lo lotes: vendido a \$50 por m2

- Inmobiliaria: Rodolfo Vinelli

- Discursos de promoción:

- Cerca del río, para su casita de fin de semana y veraneo.

- "La pradera es una llanura levemente ondulada, atravesada por un grato arroyo que zigzagueando en la planicie le brinda un sello de especial simpatía. En este barrio se halla la máxima mansedumbre y sosiego, pero al mismo tiempo se halla cercano a lugares de deportes, a pequeños bosques, a zonas populosas y dinámicas. Quienquiera hallar un lugar donde la naturaleza se brinde en su máxima plenitud y esplendor para levantar su casita de fin de semana o veraneo, este es el lugar ideal." 
- Localidad: Merlo

- Nombre de la Urbanización: Barrio Parque La Teja

- Fecha del loteo: 1947

- Distancia a la Capital: $35 \mathrm{~km}$ de Plaza Congreso

- Datos de localización: a $7 \mathrm{~km}$ de Merlo y a $8 \mathrm{Km}$ de Ituzaingo

- Descripción: 450 quintas de $1200 \mathrm{~m} 2$

- Servicios: luz eléctrica

- Costos de lo lotes: 120 cuotas \$15
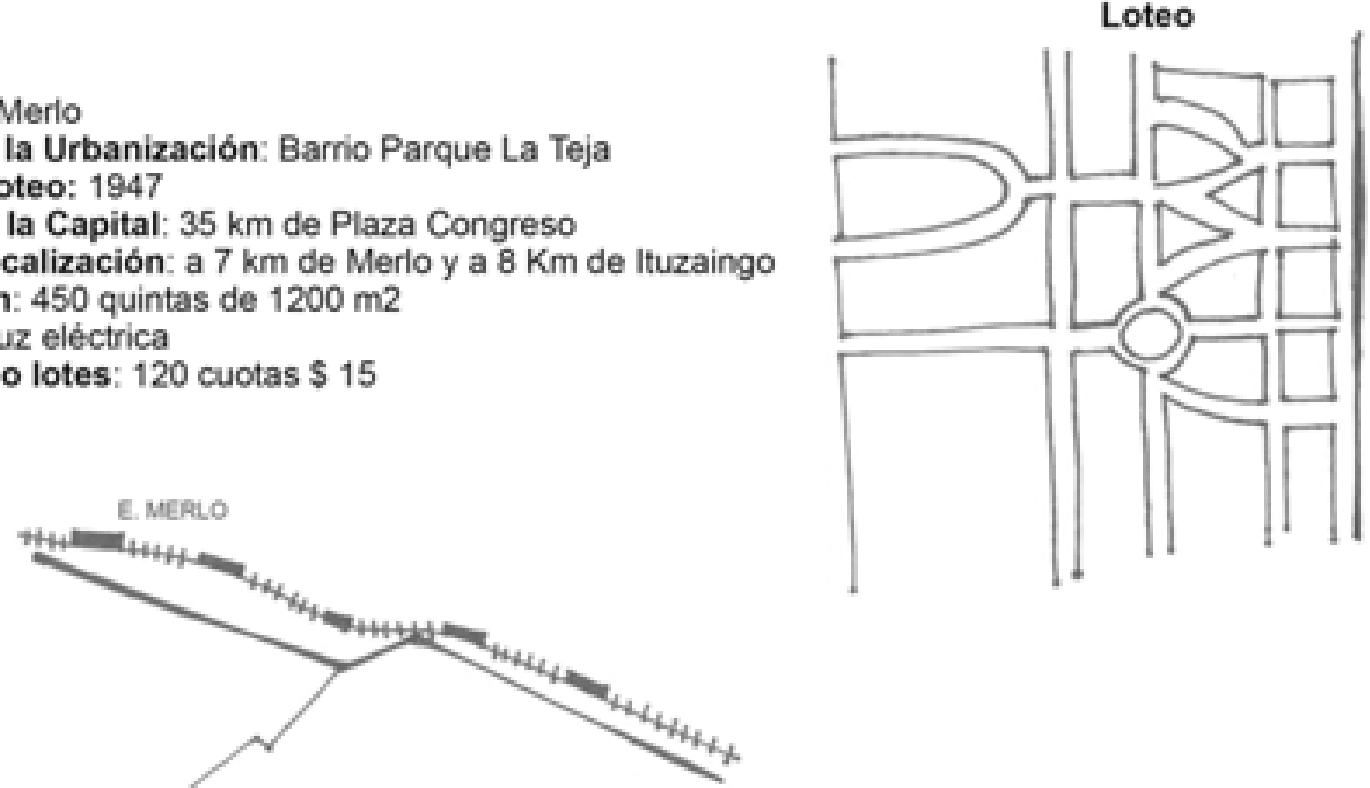

Relación del loteo con la red vial y ferroviaria

- Localidad: Merlo

- $\quad$ Nombre de la Urbanización: B. P. La Esmeralda- San Antonio de Padua

- Fecha del loteo: 1949

- Distancia a la Capital: $34 \mathrm{~km}$

- Datos de localización: vecindad al sistema fabuloso de transporte colectivo y el servicio de trenes conectado directamente con la línea de subtes a Plaza de Mayo.

- Descripción: 77 únicos lotes

- Costos de lo lotes: bases entre $\$ 30$ y $\$ 50$ por mes en 126 mensualidades

- Inmobiliaria: Romano- La Roca

- Discursos de promoción:

"La maravilla que es San Antonio de Padua alcanza su expresión máxima en el Barrio Parque La Esmeralda, verdadero modelo de elegante y sugestivo urbanismo. Su trazado bellísimo, sus calles asfaltadas. Su forestación de alto sentido plástico y sus chalets de líneas arquitectónicas de modernísimo estilo, crean un clima residencial de extraordinaria jerarquía."

Dada la categoría del Barrio Parque las construcciones deben practicarse retiradas del frente, dejando $3 \mathrm{mts}$ de franja para el jardín. No se permiten construcciones de madera si su ejecución no responde a un fin artístico, está prohibido el uso de chapa y otros materiales que afeen la arquitectura. 


\section{Relación del loteo con la red vial y ferroviaria}

- Localidad: Merlo.

- Nombre de la Urbanización: San Antonio de Padua

- Distancia a la Capital: a $16 \mathrm{~km}$ de la Capital y a $28 \mathrm{~km}$ de Plaza Once.

- Costos de lo lotes: Base \$12 por mes.

- Discursos de promoción:

"hermoso paraje donde la naturaleza fue pródiga y hombres inteligentes completaron su esplendor con hermosos chalets y modernas casas quinta.

(...) ¡Vivir en pleno campo y poder atender a las actividades de la ciudad es el ideal de unos! Solucionar el problema del alquiler y adquirir la casa propia el deseo de muchos! ¡Comprar terrenos cerca de la Capital, bien ubicados, con facilidades de pago y en un punto con perspectivas de valorización es el afán de todos!

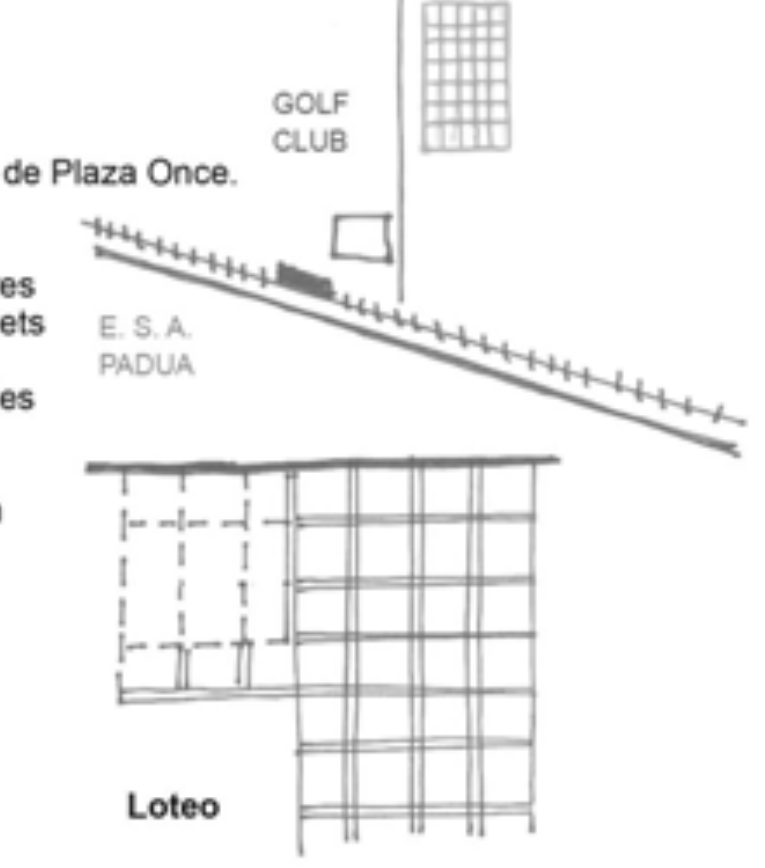

Relación del loteo con la red vial y ferroviaria

- Localidad: Merlo

- Nombre de la Urbanización: Barrio Golf Ituzaingo

- Fecha del loteo: 1936

- Distancia a la Capital: a $27 \mathrm{~km}$ de Plaza Once

- Datos de localización: sobre la estación San Antonio de Padua

- Descripción: 20lotes de hasta 1700 varas2. trazado pseudo-pintoresco

- Servicios:

- Costos de lo lotes: base \$ 5 por mes, por lote en 120 mensualidades. $\$ 1200$ por lote

- Inmobiliaria:

\section{- Discursos de promoción:}

"20 lotes en el barrio cuyo trazado consulta los adelantos más señalados en materia de urbanismo, grandes espacios abiertos, avenidas diagonales y circulares, rond-points, etc. Para levantar la vivienda permanente, para chalets, casas quinta, villas de recreo, para la casa del empleado o el obrero, libre del bullicio de la metrópolis.

Vivir en San Antonio de Padua es vivir en cualquier barrio metropolitano con la ventaja de la quietud del campo, con una vecindad distinguida y la posibilidad de practicar un sport saludable cerca del propio hogar. Vivir en San Antonio de Padua es más conveniente que vivir en Palermo,

Belgrano o Colegiales pues matemáticamente se salva la distancia a Plaza de Mayo en $\mathbf{4 0}$ minutos

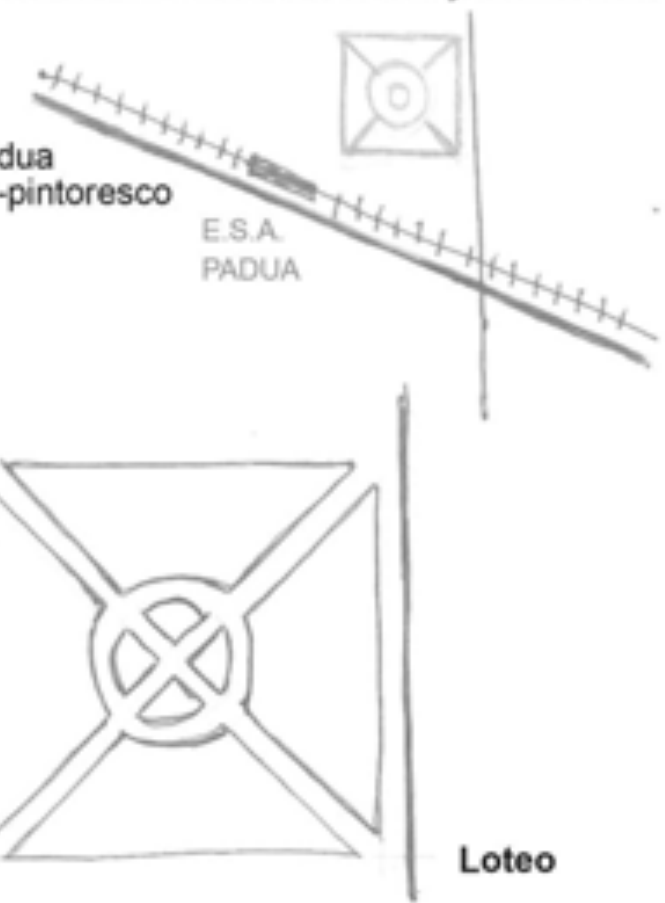




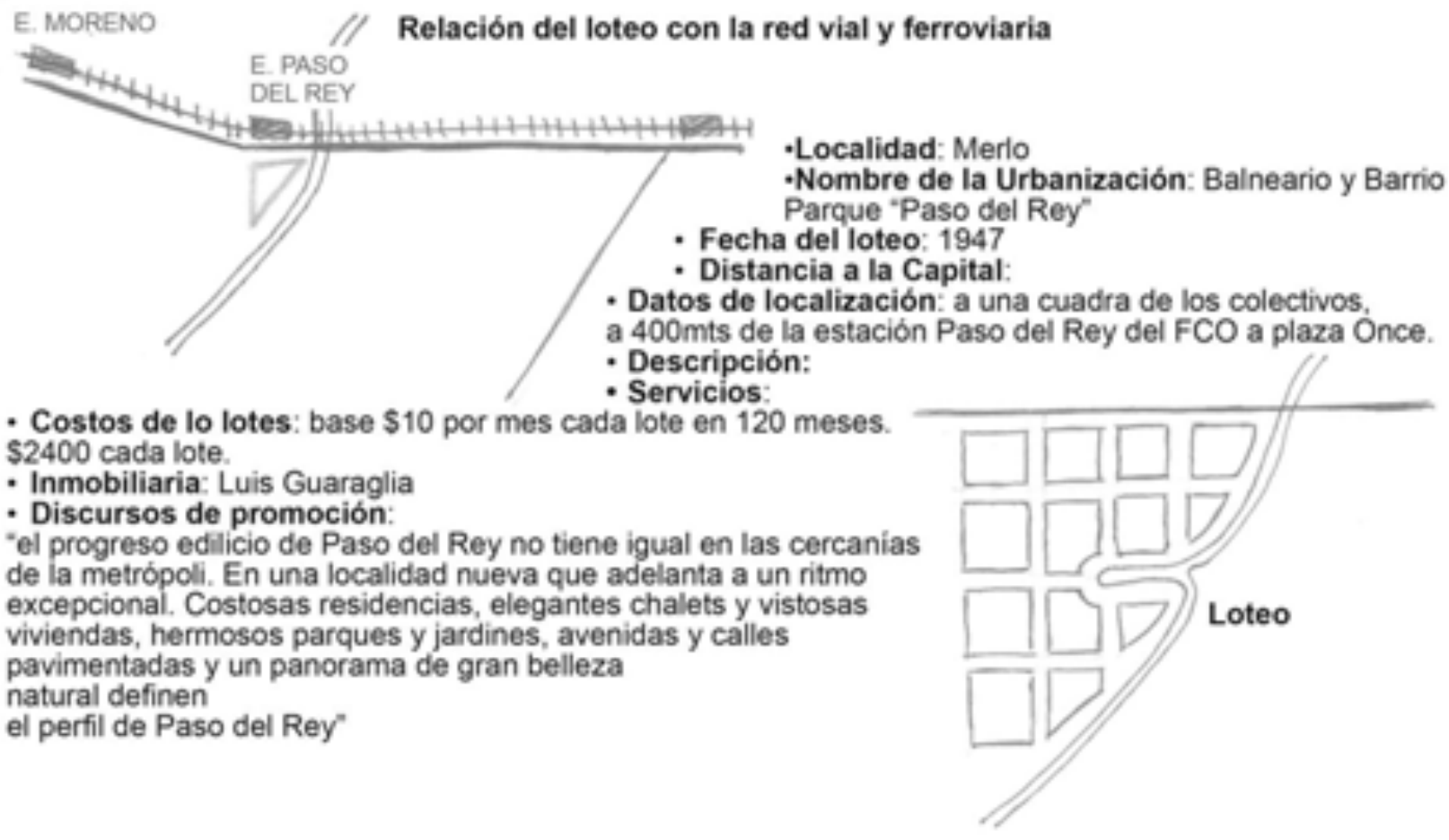

- Localidad: Merlo

- Nombre de la Urbanización:

Gran Barrio Parque San Martín

- Fecha del loteo: 1949

- Distancia a la Capital:

- Descripción: 5.000 lotes

- Costos de lo lotes: base \$8 por mes

- Discursos de promoción:

"dónde comprar un terreno para levantar una casita?

Esta pregunta se la formulan millones de habitantes de la urbe porteña. Es fácil hallar terreno para levantar la casita de fin de semana o veraneo pero se tropiezan

con grandes inconvenientes al querer resolver el problema de la vivienda permanente.

porque no existen buenos medios de comunicación, porque los terrenos son bajos o los precios exceden las posibilidades de los adquirientes. B.P San Martín está llamado a solucionar y dar liberación económica a muchos soñadores de la vivienda propia.

Nos sentiremos orgullosos de decir a todos aquellos que compren, que esta casa amiga ha hecho un gran esfuerzo más en su ya consagrada labor para crear bienestar, mejoramiento social, para afianzar la economía familiar, para determinar el progreso creciente de este pujante pais, para estimular a que el pueblo viva mejor, asegurándose el techo, elaborando asi su propia riqueza y bienestar" 


\section{Relación del loteo con la red vial y ferroviaria}

- Localidad: Moreno

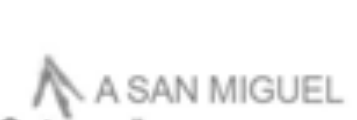

- Nombre de la Urbanización: Barrio Parque "Las Catonas"

- Fecha del loteo:

- Distancia a la Capital: $23 \mathrm{~km}$ de la Capital

- Datos de localización: tren FCP a San Miguel

- Costos de lo lotes: base entre $\$ 15$ y $\$ 30$ x mes en 1

20 meses. Entre $\$ 3600$ y $\$ 5.000$ cada lote

- Discursos de promoción:

"La gran zona residencial del Oeste, el cuadrilatero formado por las localidades Paso del Rey, Moreno, Bella Vista, San Miguel ya se perfila una importante zona residencial. A los barrios parque "Leloir",

"Rancho Grande", "Sambrizzi", "Gaona", "Haras de Trujui", "La guarida", "San Ignacio", "Bello Horizonte", "El cortijo", se suma el B.P Las Catonas en el corazón de ese privilegiado lugar, único por sus caracteristicas pues a su moderna urbanización

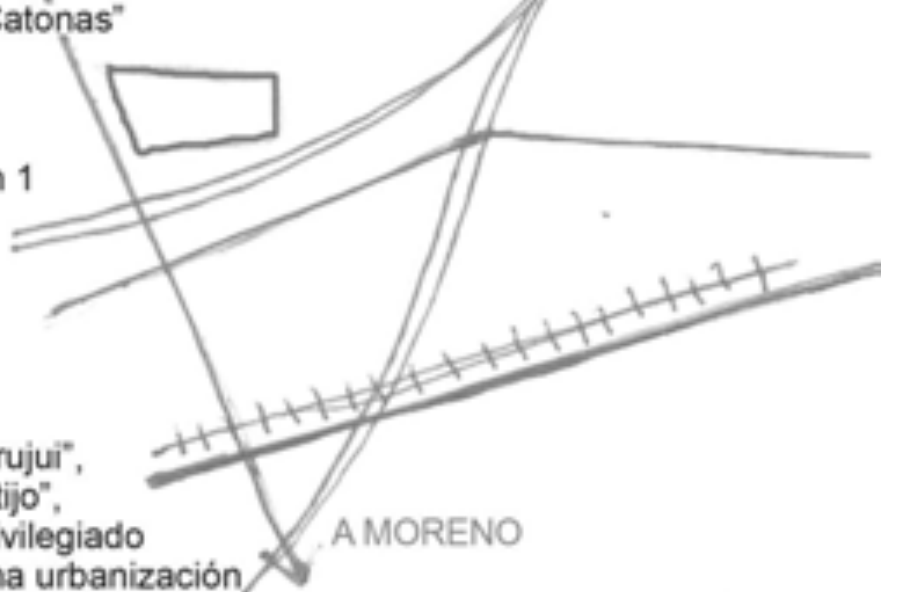
se une la particular topografia del terreno, de pronunciadas lomas, de pintorescas quebradas y el arroyo con arboladas riberas."

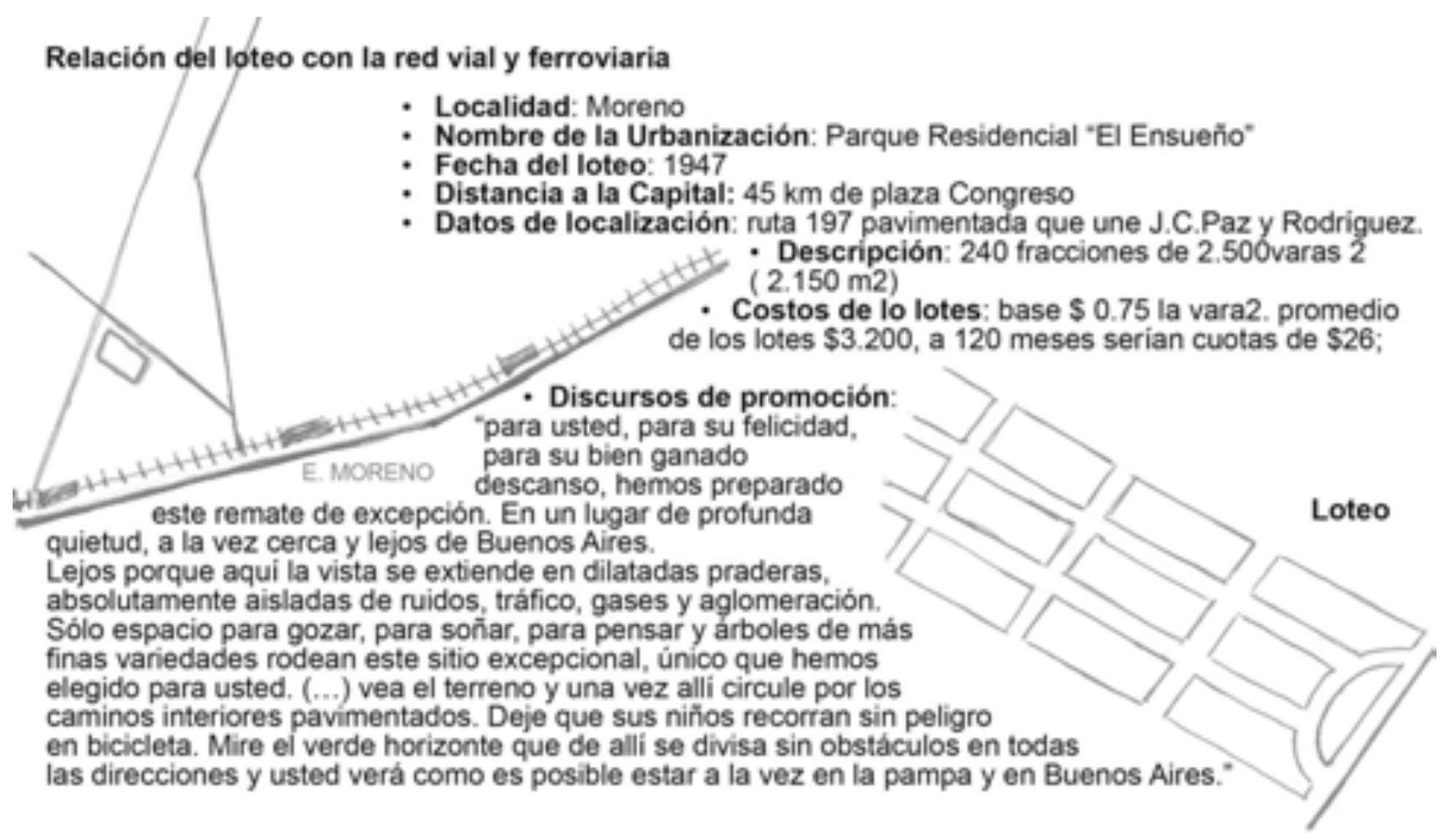


- Localidad: Moreno

- Nombre de la Urbanización: Barrio Parque Juan Pastorini, La Reja

- Fecha del loteo: 1950

- Datos de localización: a 300 mts de la estación La Reja. FCN Gral Sarmiento con 50 trenes diarios

- Distancia a Capital:35 Km.

- Costos de lo lotes: 23 quintas arboladas. $800 \mathrm{~m} 2$, lotes de $\$ 10.000$, cuotas de $\$ 90$ mensuales

- Discursos de promoción:

"sitio ideal para levantar en sus amplias quintas la coqueta casita de fin de semana y también para la vivienda de todo el año. El asfalto que conduce de cualquier punto a su casa quinta le permitirá aún en los dias de lluvia llegar a su cottage sin inconvenientes.

Todo el camino desde la Capital hacia La Reja ofrece notas de arte y de buen gusto, una vez que pasa Morón se respira a pulmón lleno aire puro y sano y asi como una película que va pasando ante su vista verá casas-quinta de los más refinados gustos, chalets con sus hermosos jardines decorados con plantas y flores, palacetes de lineas impecables. El verde esmeralda de su inigualable campiña haciendo contraste con el lienzo azul que la cubre y muchas cosas bellas y emotivas que nos brinda la naturaleza como sedante y medicina del espiritu. En un viaje de pocos minutos traspone usted los dinteles del paraiso terrenal."

\section{Relación del loteo con la red vial y ferroviaria}

- Localidad: Moreno

- Nombre de la Urbanización: Barrio Parque "Estancia Santa Teresa"

- Fecha del loteo: 1948

- Distancia a la Capital: $35 \mathrm{~km}$

- Datos de localización:

- Descripción: 296 lotes-quintas. Medidas: 26 x 76 mts, superficie de 1900m2.

- Costos de lo lotes: base $\$ 2 \mathrm{~m} 2$. vendido entre $\$ 4.5$ y $\$ 7.5 \mathrm{~m} 2$.

- $\quad$ Con lotes de $1900 \mathrm{~m} 2=$ lotes de entre $\$ 8.000$ y $\$ 12.000$ cuotas de $\$ 85$

- Inmobiliaria: Comi \& Pini 
- Localidad: Moreno

- Nombre de la Urbanización: Barrio Parque "Los Nogales"

- Fecha del loteo: 1949

- Distancia a la Capital: 34 km

- Datos de localización: a cuatro cuadras de la Est. Moreno con notable y continuado servicio de trenes. sobre la importante ruta nacional $n^{\circ} 7$ a Luján.

- Descripción: 120 excepcionales quintas.

- Servicios:

- Costos de lo lotes: cuotas de $\$ 30$ en 120 mensualidades
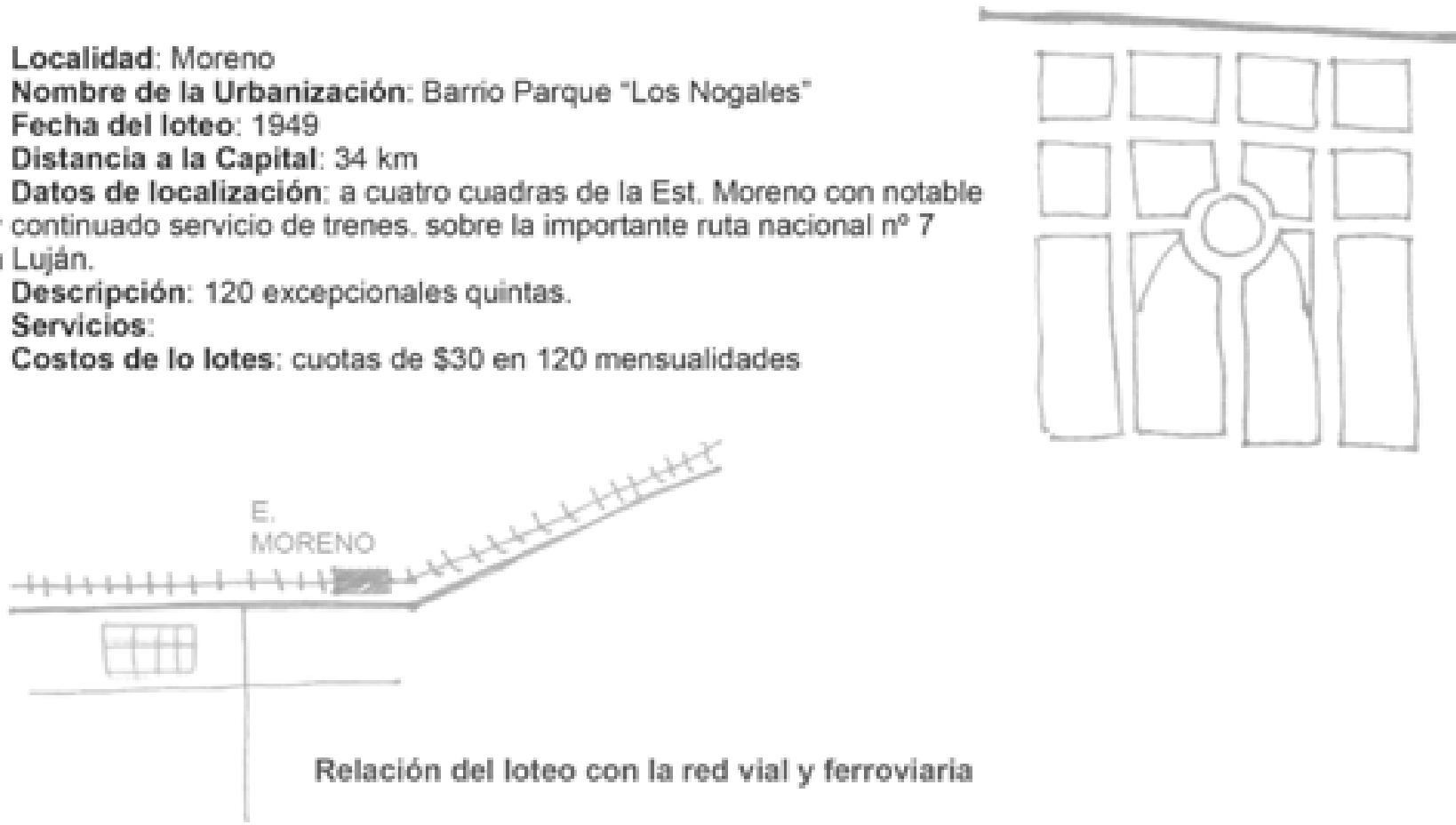

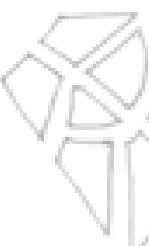

Loteo

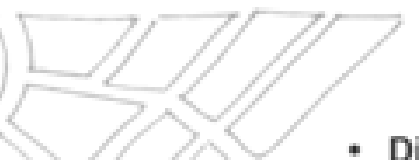

- Distancia a Capital: $34 \mathrm{~km}$

- Datos de localización: a pocas cuadras de la est. Moreno. Frente a la avenida Gaona, frente al monumental Barrio Parque Gaona.

- Descripción: 300 quintas arboladas

- Costos de lo lotes: base $\$ 2$ la vara2.\$25 en 120 mensualidades

- Inmobiliaria: Vinelli-Ithurralde

- Discursos de promoción:

"Barrio Parque de ensueño. Cientifica y artisticamente creado para brindar alegria y felicidad a sus futuros propietarios. Rancho grande ha ensamblado lujosamente ambos términos, "barrio" y "parque" en su expresión más feliz. Un trazado digno del gran ingeniero y urbanista de renombrada fama, un parque que hace honor al insigne técnico creador.

El barrio expresa lo noble de la zona del Oeste, en lo que respecta a sus tantas virtudes que le dieron renombre: altura, panorama, belleza y el afán de sus propietarios de crear algo nuevo, de brindar un lugar de jerarquia, atrayente, exitosamente romántico para la gente de buen gusto, para quienes aspiran a levantar su confortable chalet no en una zona heterogénea, sino en lugar lleno de encantos, engarzado entre los follajes de los parques vecinos y las techumbres de otros chalets lujosos que rivalizan en belleza y completan el cuadro que la naturaleza y la inteligente mano del hombre ha creado" 
Parque Trujui

- Localidad: moreno

- Descripción: 26 lotes de 2000 m2

- Fecha de loteo: 1949

- Distancia a capital $34 \mathrm{~km}$

- Costos de los lotes: $\$ 100$ en 120 meses.
Relación del loteo con la red vial y ferroviaria

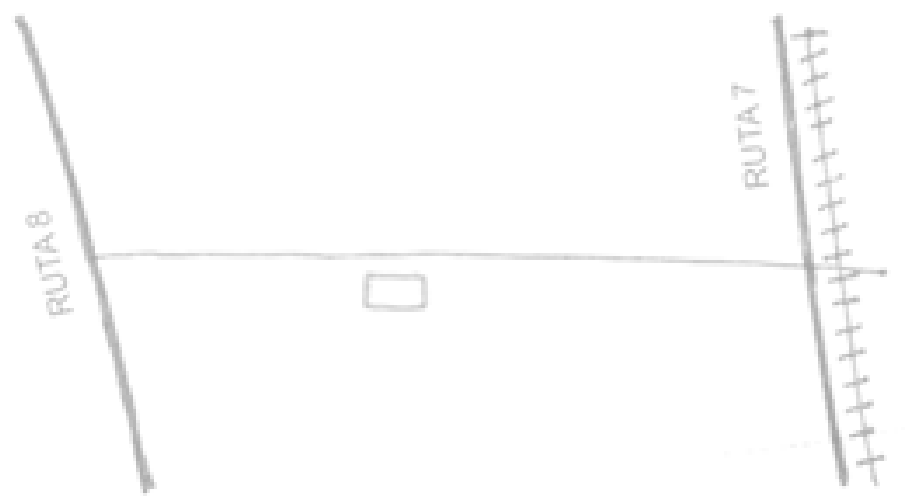

Loteo

- Localidad: Morón

- Nombre de la Urbanización: Nuevo Barrio Parque "General Alvear"

- Fecha del loteo:

- Distancia a la Capital: $25 \mathrm{Km}$

- Datos de localización: una venta de categoria en Ituzaingo

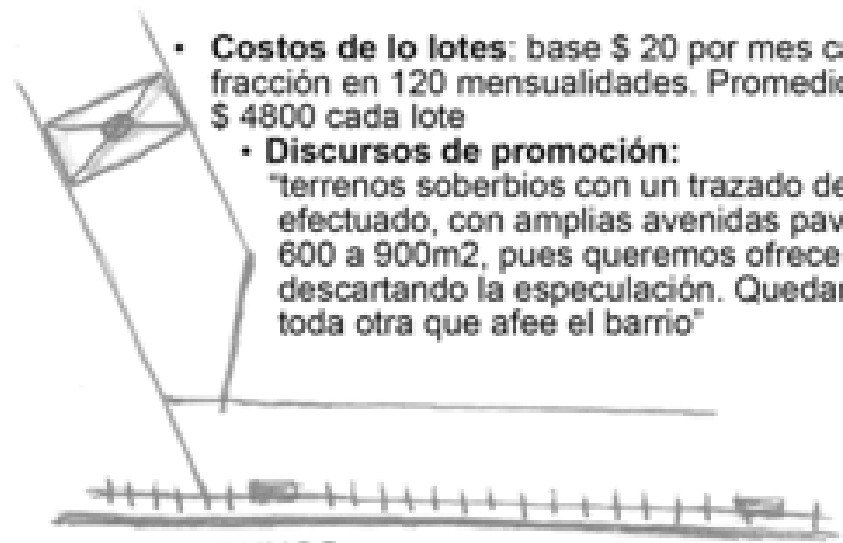

E. ITUZAINGO 
- Localidad: Morón

- Nombre de la Urbanización: Barrio Parque Lomas de Castelar

- Fecha del loteo: 1943

- Distancia a la Capital:25 Km.

- Descripción: trazado pintoresco, 150 lotes de $1.000 \mathrm{~m} 2(28 \times 42 \mathrm{mts})$

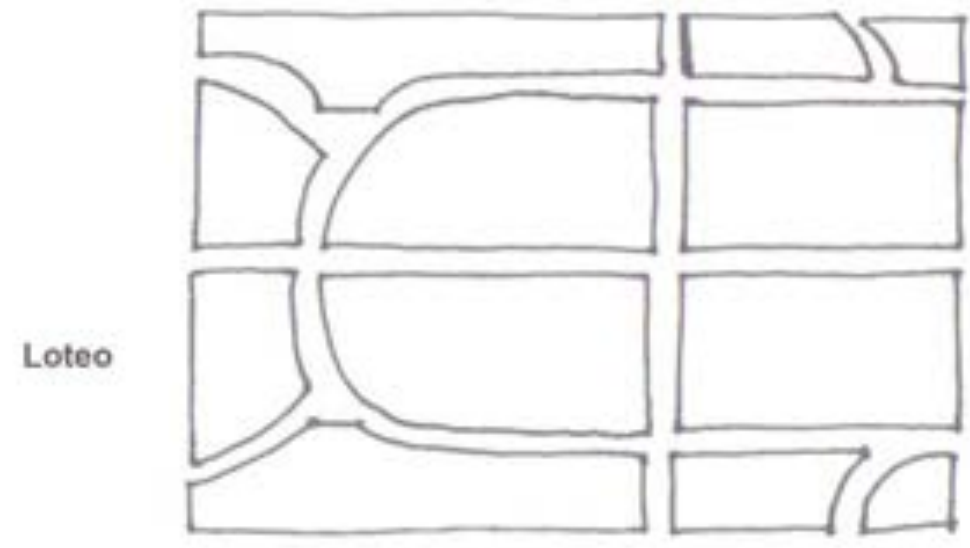

- Localidad: Morón

- Nombre de la Urbanización: Morón week-end

- Fecha del loteo: 1945

- Datos de localización: en la loma más interesante de Haedo

- Descripción: 196 lotes espléndidos para week-end

- Costos de lo lotes: base \$ 5 por mes cada lote.

- Inmobiliaria: Comi \& Pini

- Discursos de promoción:

"Haedo es un núcleo central del magnifico conjunto de

importantes localidades suburbanas de la linea Oeste que se extiende desde Ramos Mejia a Morón en un alarde constante de progreso. Ubicarse en Haedo ya sea con la residencia permanente o con la casa de fin de semana, significa gozar de todas las ventajas de las localidades suburbanas y con las que ofrece la Capital misma."
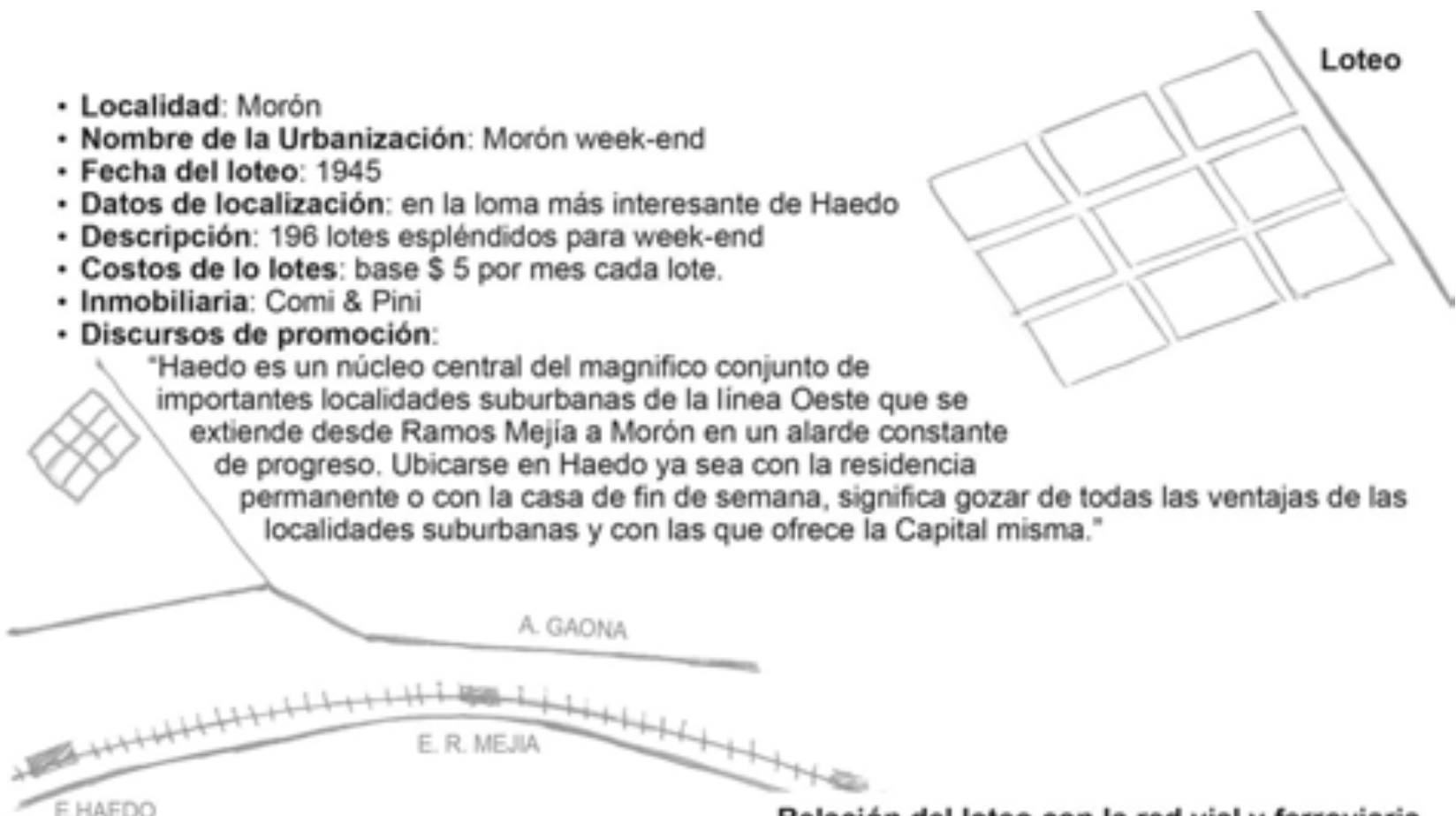

Loteo

Relación del loteo con la red vial y ferroviaria 
- Localidad: Morón

- Nombre de la Urbanización: Parque Güiraldes

- Fecha del loteo: 1946

- Distancia a la Capital: $30 \mathrm{~km}$

- Datos de localización: a quince cuadras de la Estación Morón

- Descripción: 132 fracciones de 1.000 a $1.800 \mathrm{~m} 2$

- Costos de lo lotes: base $\$ 1.250 .75 \mathrm{~m} 2$.

Lotes entre $\$ 2.000$ y $\$ 4.000$ (dependiendo el precio real de venta y la sup. Del lote) cuotas de $\$ 35-40$

- Inmobiliaria: Astoul-Bonorino

- Discursos de promoción:

"El esplendido casco que fue el antiguo Haras "Las Hortigas"

- Localidad: Morón

- Nombre de la Urbanización: Parque Leloir

- Fecha del loteo: 1947

- Distancia a la Capital:

- Datos de localización: entre Morón e Ituzaingo

- Descripción: 65 fracciones entre 3.000 y 7.000 varas2

- Costos de lo lotes: base \$2 por mes la vara2. $10 \%$ al escriturar y

8 cuotas semestrales.

Si se duplica la base, las fracciones menores se pueden comprar con $\$ 12.000$ en mano. 120 cuotas de $\$ 100$

- Inmobiliaria: Astoul Bonorino

- Discursos de promoción:

"Descanso y privilegio, estas fracciones salpicadas entre hermosos chalets y cottages de categoria dentro de un marco encantador y en sitio realmente privilegiado, codiciado y distinguido. A fin de mantener la fisonomia y caracteristicas de este barrio se mantendrán las mismas restricciones en la edificación que rigieron las ventas anteriores, lo que asegura a los compradores la calidad y hermosura del barrio"
Relación del loteo con la red vial y ferroviaria

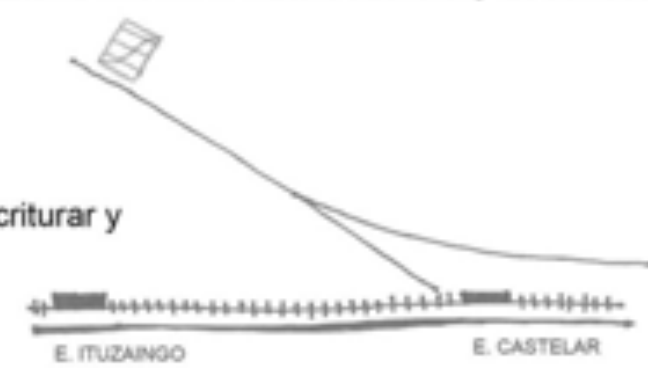

\author{
iores,

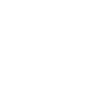

Loteo

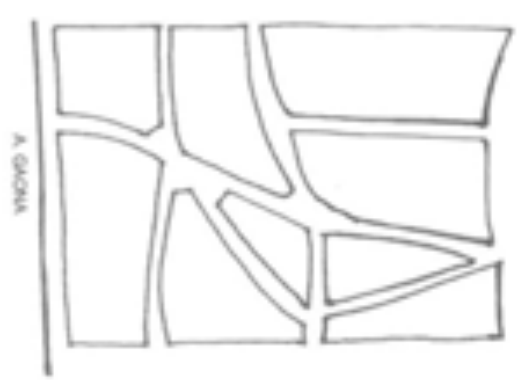




\section{Relación del loteo con la red vial y ferroviaria}

- Localidad: Morón

- Nombre de la Urbanización: Parque Quirno

- Fecha del loteo: 1947

- Datos de localización: En el rincón más apacible y tranquilo del progresista pueblo de Hurlingham

- Descripción: 230 quintas. Terrenos de 1000 m2, (20 x 50 mts)

- Costos de lo lotes: base \$ 5 por mes cada quinta en 120 meses
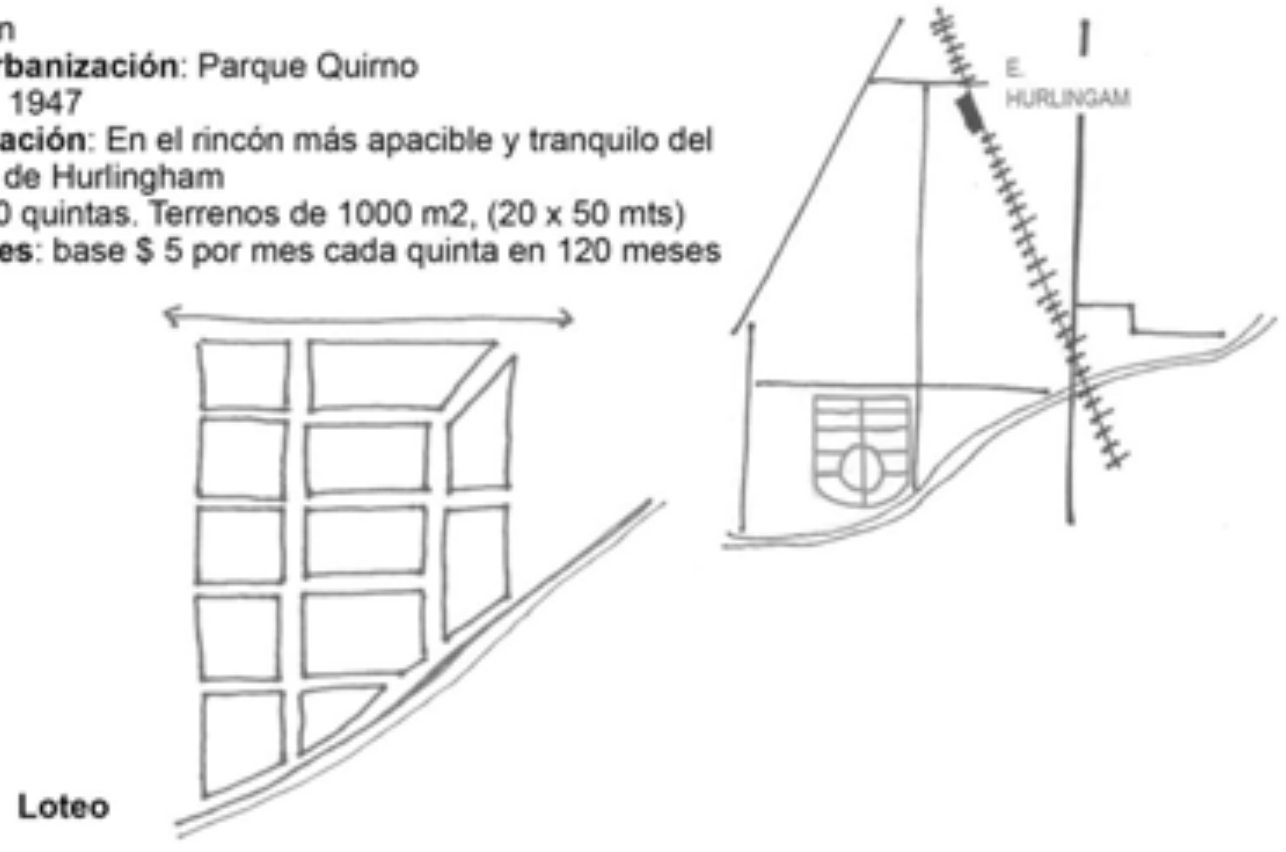

Relación del loteo con la red vial y ferroviaria

- Localidad: Morón

- Nombre de la Urbanización: Barrio Parque

"San Francisco"-Castelar

- Fecha del loteo: 1947

- Distancia a la Capital: $29 \mathrm{Km}$

- Datos de localización:

- Descripción: 260 amplios lotes-quintas

- Costos de lo lotes: base \$ 3 por mes los $0.75 \mathrm{~m} 2$. lotes $800 \mathrm{~m} 2$. 120 cuotas de $\$ 30$.
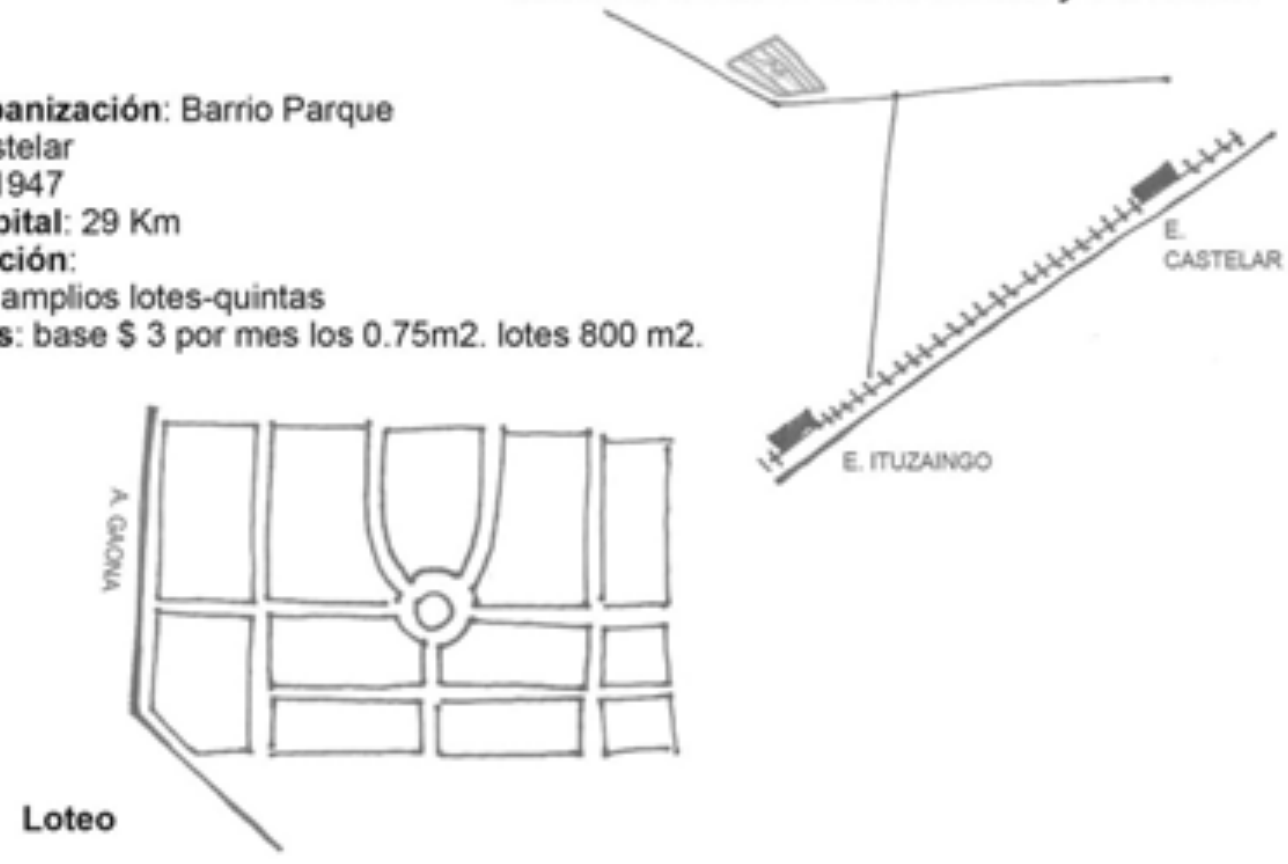
Relación del loteo con la red vial y ferroviaria

- Localidad: Morón

- Nombre de la Urbanización: Barrio Parque Castelar

- Fecha del loteo: 1929

- Distancia a la Capital: $25 \mathrm{Km}$.

- Datos de localización: a dos cuadras de la linea eléctrica del FCO, en combinación con el subte en $\mathbf{2 2}$ minutos a Plaza de Mayo.

- Descripción: 620 lotes. Se han donado tierras para una gran plaza, escuela, destacamento de policia y correo

- Costos de lo lotes: base de $\$ 20$ por mes en 100 meses

- Inmobiliaria: Astoul Bonorino

- Discursos de promoción:

"la subdivisión de este hermoso barrio ha sido trazado por los ingenieros Prebisch y Vautier, discipulos de Mrs. Jossely de la Academia de Paris y se ha hecho consultando lo más moderno en esta clase de trazados, teniendo todos los lotes amplios frentes y fondos proporcionados, prohibiéndose las construcciones de madera. Alli se levantarán todas construcciones de mérito como las que la rodean."

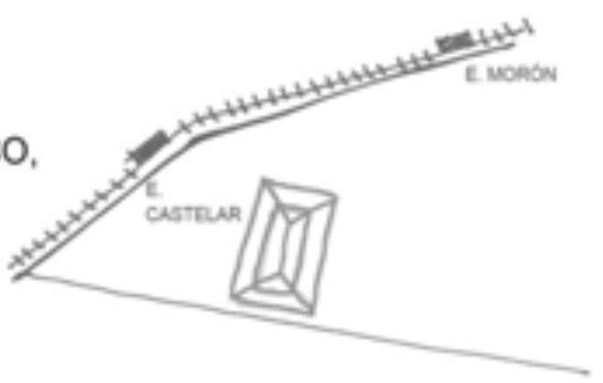
Loteo

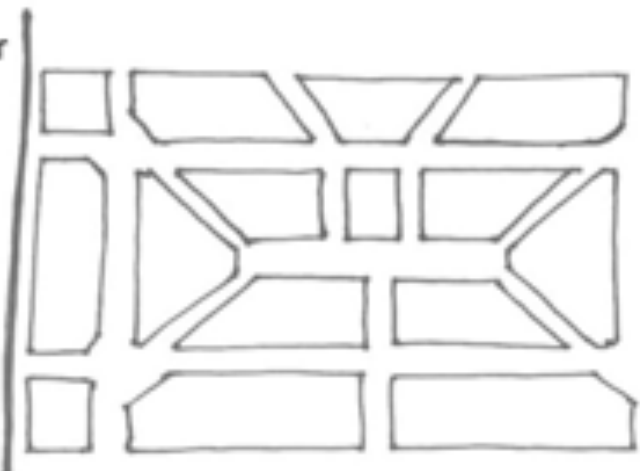

- Localidad: Morón

- Nombre de la Urbanización: El Parque Morón

- Fecha del loteo: 1932

- Distancia a la Capital: $27 \mathrm{Km}$.

- Datos de localización: entre Morón e Ituzaingo

- Descripción: 1000 lotes, con adoquinados pagos. Todos los lotes tienen amplios frentes con fondos proporcionados de manera que todos puedan tener entrada para autos.

- Costos de lo lotes: base \$ 6 por mes, por lote en 120 mensualidades.

- Inmobiliaria: Astoul Bonorino
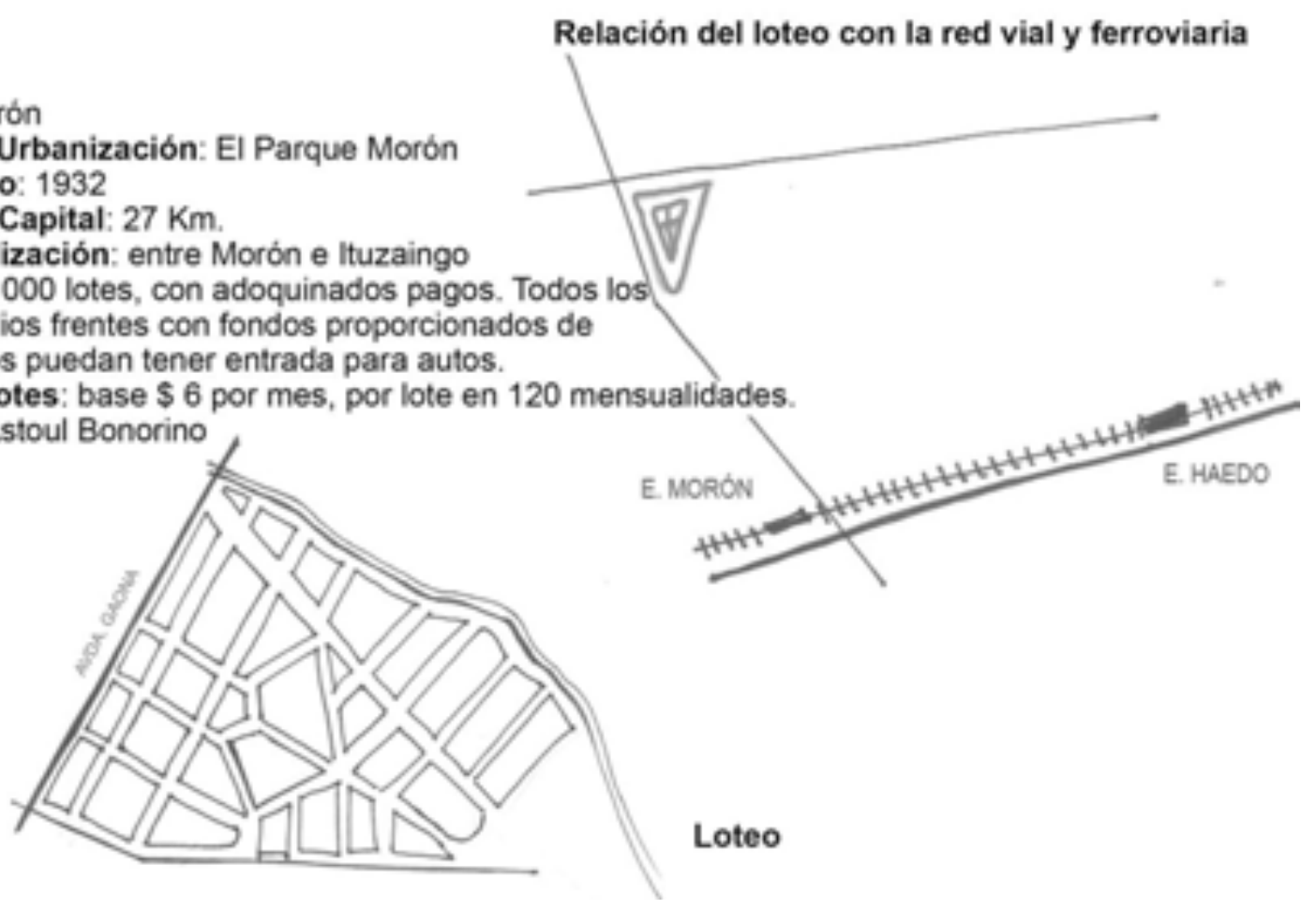

Loteo 
- Localidad: Morón

- Nombre de la Urbanización: Barrio Parque Lomas de Castelar

- Fecha del loteo: 1943

- Distancia a la Capital: $25 \mathrm{~km}$

- Datos de localización:

- Descripción: trazado pintoresco con lotes de 1.000m2 (28 x 42mts)

- Localidad: Morón

- Nombre de la Urbanización: Barrio Parque "Francisco Verde"

- Fecha del loteo: 1945

- Distancia a la Capital: $30 \mathrm{~km}$

- Datos de localización

- Descripción: 283 grandes lotes en Castelar

- Costos de lo lotes: base $\$ 10$ por mes en 120 meses. Suponiendo un precio de venta que duplique la base $\$ 20$ por mes, lotes de $\$ 2400$

- Inmobiliaria: Taquini

- Discursos de promoción:

"queda prohibida toda construcción de madera y zinc"

- Localidad: Morón

- Nombre de la Urbanización: Barrio Parque "Maupas" en Castelar

- Fecha del loteo: 1948

- Distancia a la Capital: $31 \mathrm{~km}$.

- Descripción: 200 magnificos lotes de parque, y una casa de habitación y un chalecito con pileta de natación.

- Servicios:

- Costos de lo lotes: bases entre \$12 .Lotes promedio 800m2,

- Inmobiliaria: Rufino Elizalde

- Discursos de promoción:

"El barrio parque de trazado moderno con calles interiores pavimentadas y con una fina y selecta arboleda"

Relación del loteo con la red vial y ferroviaria 
- Localidad: Morón

- Nombre de la Urbanización: Barrio Parque "Los ángeles"

- Fecha del loteo: 1945

- Distancia a la Capital: $24 \mathrm{~km}$

- Datos de localización:

- Descripción: 364 magníficos lotes

- Costos de lo lotes: base $\$ 2$ x mes en 126 meses

- Inmobiliaria: Romano Larroca

- Localidad: Morón

- Nombre de la Urbanización: Barrio Parque "Alto verde"

- Fecha del loteo: 1945

- Distancia a la Capital: $31 \mathrm{~km}$

- Datos de localización: lindando con el Club de polo Lon Indios

- Descripción: 128 lotes, mejorado asfáltico pago

- Costos de lo lotes: base $\$ 3$ por mes

- Discursos de promoción:

"Esta fracción ha sido subdividida bajo la reglamentación de los barrios parque, entre edificios rodeados de hermosa arboleda"

- Localidad: Morón

- Nombre de la Urbanización: Ituzaingo Residencial.

- Fecha del loteo: 1947

- Distancia a la Capital: $30 \mathrm{~km}$.

- Descripción: 9 notables lotes en el conocido parque del Dr. Leguizamon

- Costos de lo lotes: base $\$ 12$ la vara2. 120 cuotas de $\$ 40$ por mes

- Inmobiliaria: Astoul Bonorino

- Discursos de promoción: "ponemos en venta la única reserva de la fracción para satisfacer los exigentes y numerosos pedidos de los que quieren radicarse de inmediato en este lugar inigualable. A todos los interesados mediante este remate les ofrecemos la oportunidad de adquirir la tierra más excelente y privilegiada dentro del corazón de la progresista Villa del Oeste y en su centro aristocrático y residencial"

Relación del loteo con la red vial y ferroviaria

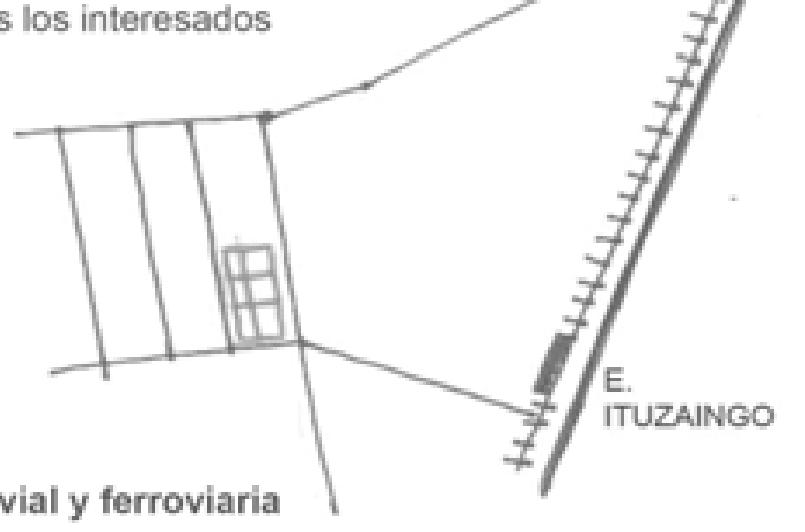


- Localidad: Morón

- Nombre de la Urbanización: Barrio Los Pinos

- Fecha del loteo: 1950

- Distancia a la Capital:

- Datos de localización: en Barrio Peluffo

- Descripción:

- Servicios:

- Costos de lo lotes: base $\$ 500$ en 12 meses

- Inmobiliaria: Juan Borachia

- Discursos de promoción: entre hermosos chalets, casas quinta y arboledas

- Normas de edificación:

- Localidad: Morón

- Nombre de la Urbanización: Barrio Parque "San Francisco"-Castelar

- Fecha del loteo: 1947

- Distancia a la Capital: $29 \mathrm{~km}$

- Descripción: 258 amplios lotes-quintas

- Servicios:

- Costos de lo lotes: base $\$ 3$ por mes los $0.75 \mathrm{~m} 2$. lotes promedio $\$ 5.000$, cuotas de $\$ 40$ a 120 meses

- Localidad: Quilmes

- Nombre de la Urbanización: Barrio Parque Jacarandá.

- Fecha del loteo: 1949

- Distancia a la Capital: $19 \mathrm{~km}$

- Datos de localización: a pocas cuadras de la estación de Berazategui.

- Descripción: 1400 espléndidos lotes

- Costos de lo lotes vendido en mensualidades a \$20 por mes.

En 120 cuotas sin interés.

- Discursos de promoción:

"para el mundo trabajador: un maravilloso parque, ideal para el descanso integral. Empleados, obreros, trabajadores. He aqui lo que todos ustedes buscan, un verdadero sedante para reponer las energias perdidas durante el dia de intensa labor y lo que es más. al alcance del más modesto bolsillo"

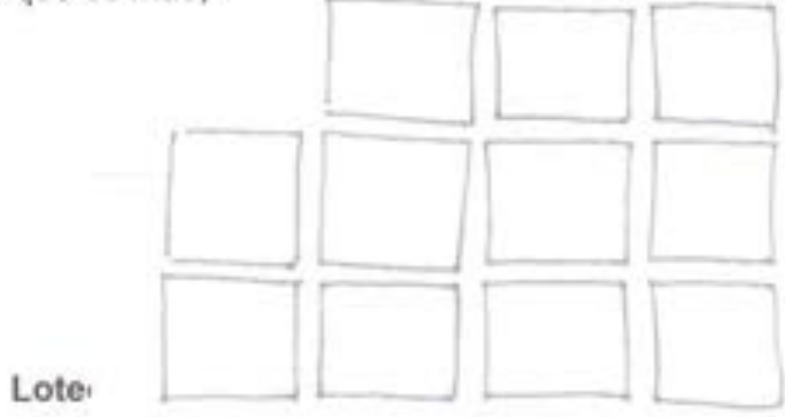


- Localidad: Quilmes

- Nombre de la Urbanización: Barrio Parque "San Juan de Pereyra"

- Fecha del loteo: 1946

- Distancia a la Capital: $20 \mathrm{~km}$

- Descripción: 30 amplios lotes y un chalet amueblado. Lotes de $3.000 \mathrm{~m} 2$ ( $80 \times 45 \mathrm{mts}$ )

- Costos de lo lotes: base de los lotes entre \$2 y \$3 la vara. 36 mensualidades de \$150

Base del chalet $\$ 65.000$,

- Inmobiliaria: Furst Zapiola

- Discursos de promoción:

" 30 lotes forman parte de este hermoso barrio parque donde se están levantado suntuosas residencias que rivalizan entre si, por su costo, buen gusto y diferentes estilos arquitectónicos"

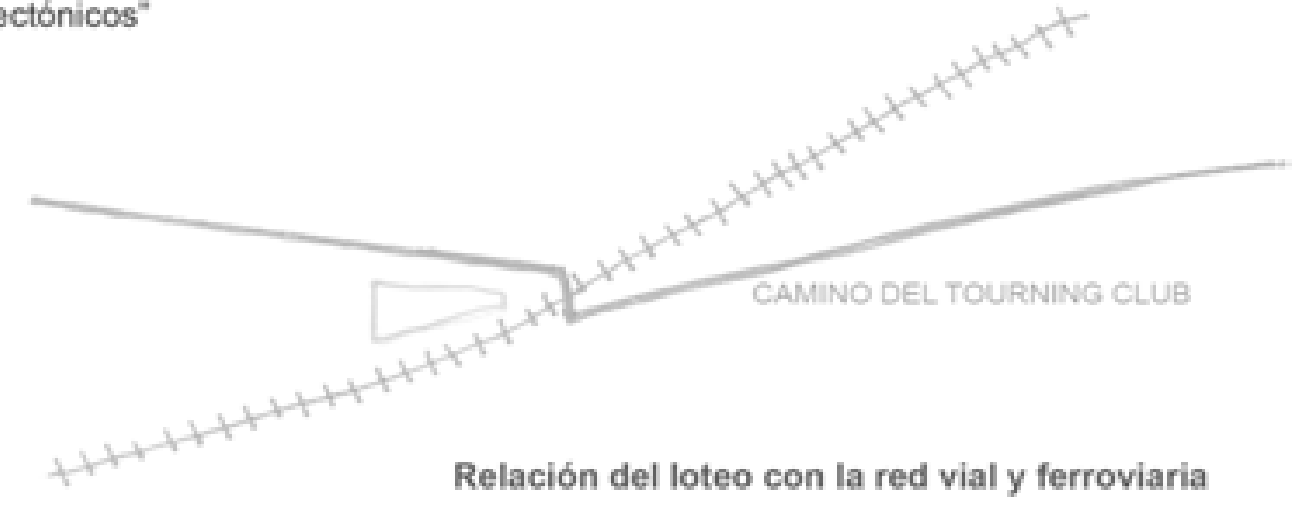

- Localidad: Quilmes

- Nombre de la Urbanización: Barrio Parque "balneario Quilmes"

- Fecha del loteo: 1947

- Distancia a la Capital: 18 km

- Datos de localización: a cinco cuadras de la estación ferrocarril del sur

- Descripción: 200 lotes. Sobre un trazado radial

- Servicios:

- Costos de lo lotes: base lotes de $\$ 30$ por mes. Vendido a $\$ 80$ la mensualidad.

- Inmobiliaria: Fiorito, Chiesa y Grillo

- Discursos de promoción:

"Se reúnen aqui dos codiciados elementos: la frondosidad de la arboleda del nuevo barrio parque y la

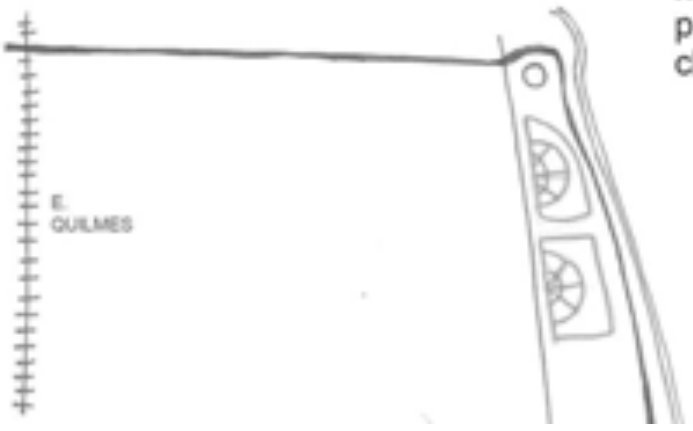
majestuosidad del Plata. Pueden concretarse alli todos los propósitos: la vivienda permanente, saludable y alegre, chalet de fin de semana o de temporada."

Relación del loteo con la red vial y ferroviaria 
- Localidad: San Martín

- Nombre de la Urbanización: Ciudad Jardín Lomas del Palomar

- Fecha del loteo: 1946

- Distancia a la Capital: $24 \mathrm{~km}$

- Datos de localización:

- Descripción: Trazado radial. Lotes de entre 400-600 m2

- Localidad: San Martin

- Nombre de la Urbanización: Barrio parque y residencial Villa Zagala

- Fecha del loteo: 1er loteo1936/ 2do loteo 1945.

- Distancia a la Capital: $12 \mathrm{Km}$

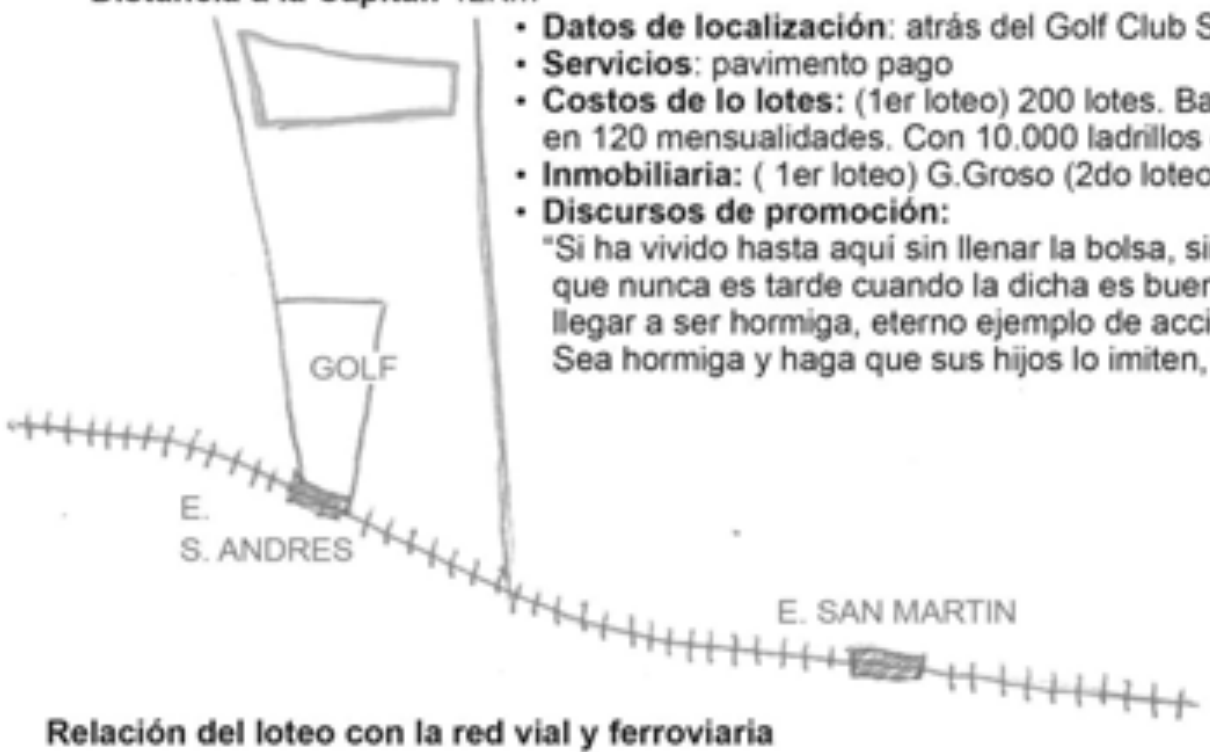


- Localidad: San Martín

- Nombre de la Urbanización: Villa Bosch

- Fecha del loteo: 1934(cuarto loteo)

- Distancia a la Capital: $17 \mathrm{~km}$.

- Datos de localización: a treinta minutos del centro por subte Lacroze; frente a la Estación Villa Bosch del FCCBA

- Descripción: 500 grandes lotes
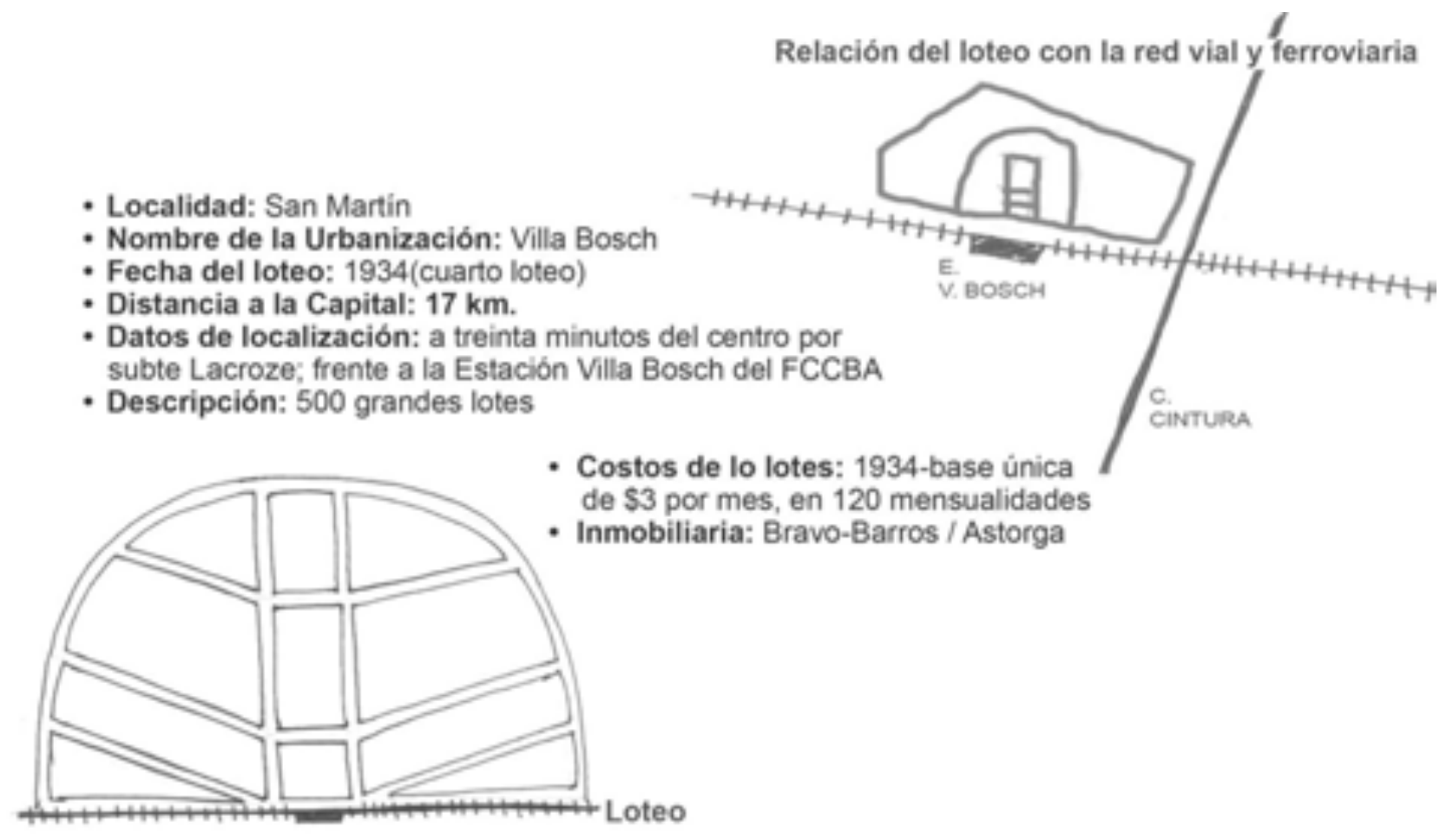
oteo

- Localidad: San Martín

- Nombre de la Urbanización: Barrio Parque Villegas

- Fecha del loteo: 1942

- Distancia a la Capital: $21 \mathrm{Km}$.

- Datos de localización: Avenida Constituyentes y General Paz. A cuatro cuadras del FCCA San Martín, ómnibus de la línea 2, línea 6; colectivos linea 19.

- Descripción: 523 espléndidos lotes.

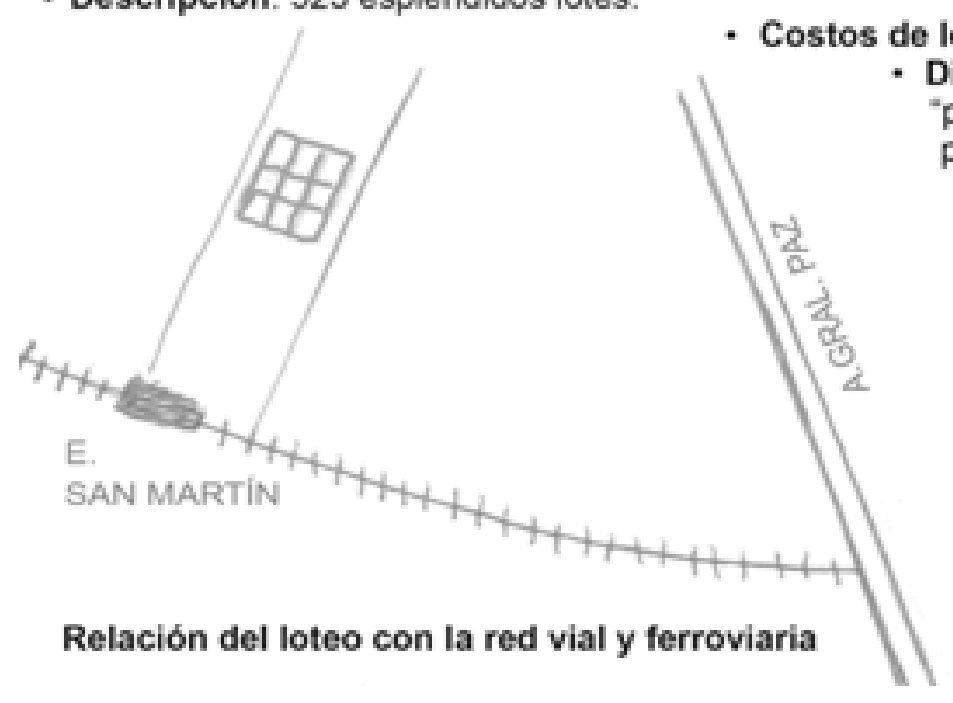
Discursos de promoción: "para pequeñas casas quinta o para la residencia permanente" 
- Localidad: San Fernando

- Nombre de la Urbanización: "La Floresta"

- Fecha del loteo: 1950

- Distancia a la Capital: $26 \mathrm{~km}$

- Datos de localización: entre las estaciones de San Fernando Residencial y Punta Chica

- Descripción: 87 lotes ideales para fin de semana.

- $\quad$ Costos de lo lotes: base $\$ 15$ por mes en 130 meses - $\quad$ Lotes de $\$ 2.000$

- Inmobiliaria: Castiglioni-Iglesias

- Discursos de promoción:

"En el balneario La Floresta, zona de gran valor actual y radiante futuro, linda con el balneario gozando así de la saludable temperatura de la costa y del agradable y festivo ambiente de los deportes acuáticos. En sus alrededores se encuentran hermosos parques residenciales, edificación moderna y suntuosas mansiones, entre ellas las de Alvear, Unsué y otras. Ideal para la natación y el yachting"

\section{Relación del loteo con la red vial y ferroviaria}

- Localidad: San isidro

Nombre de la Urbanización: Barrio Parque Santa Rosa

- Fecha del loteo: 1945

- Distancia a la Capital: $24 \mathrm{~km}$

- Datos de localización: Frente al San Isidro Golf Club y a 10 cuadras del Golf del Jockey Club. A una cuadra de la Avenida Bernabé Marquez, camino pavimentado que une San Isidro y Boulogne.

- Descripción: 63 lotes arbolados. Trazado radial con lotes entre 700 y $1000 \mathrm{~m} 2$ con proporciones de lados de 1 a 2 aproximadamente.

- Costós de lo lotes: de $\$ 3$ los 0,75 la vara2. 48 cuotas de $\$ 100$

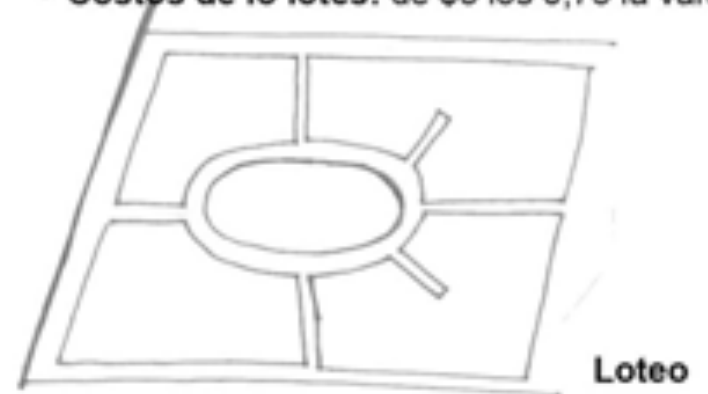




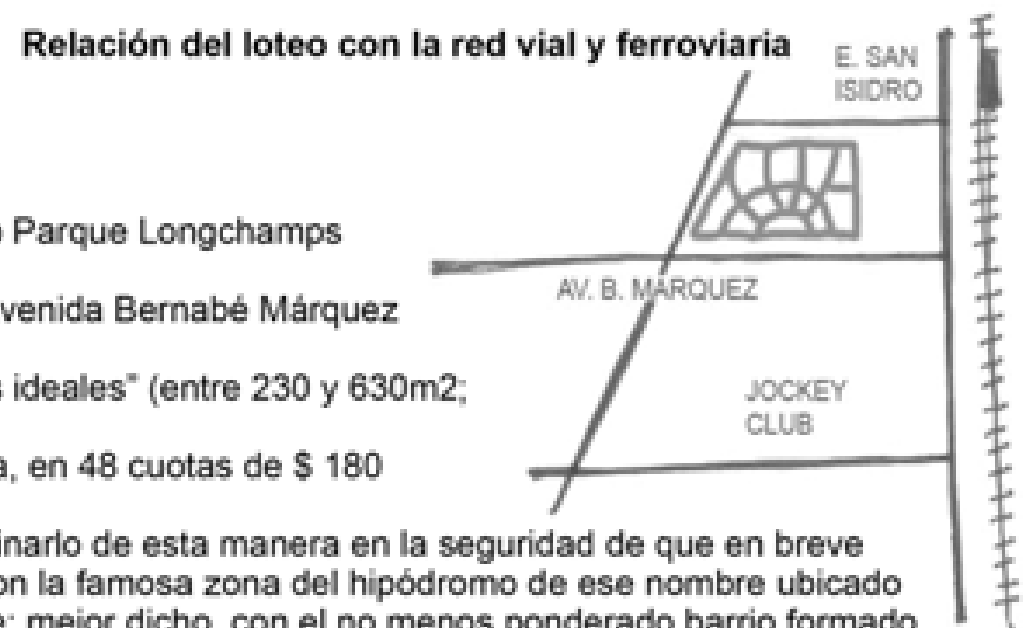

- Localidad: San Isidro

- Nombre de la Urbanización: Barrio Parque Longchamps

- Fecha del loteo: 1945

- Datos de localización: frente a la avenida Bernabé Márquez y frente al parque del Hipódromo.

- Descripción: 158 lotes "de medidas ideales" (entre 230 y $630 \mathrm{~m} 2$; $12 \times 30 \circ 12 \times 40 \mathrm{mts}$ )

- Costos de lo lotes: base $\$ 7$ la vara, en 48 cuotas de $\$ 180$

- Discursos de promoción:

"sus propietarios han decidido denominarlo de esta manera en la seguridad de que en breve tiempo adquirirá una cierta similitud con la famosa zona del hipódromo de ese nombre ubicado en Paris, próxima al Bois de Boulogne; mejor dicho, con el no menos ponderado barrio formado alrededor del hipódromo Auteuil, que se encuentra a corta distancia del primero y donde se ha formado

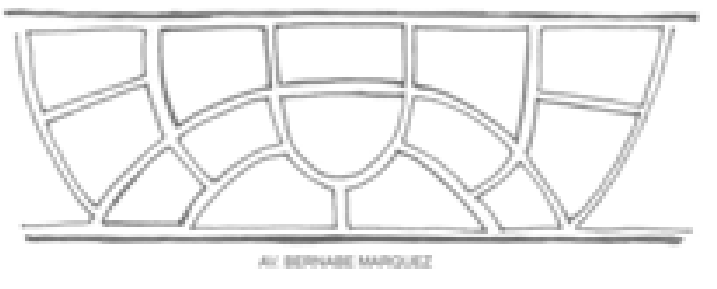
uno de los barrios modernos y más aristocráticos de aquella maravillosa ciudad"

\section{Loteo}

- Localidad: San Isidro

- Nombre de la Urbanización: Parque Nelson

- Fecha del loteo: 1934

- Distancia a la Capital: $21 \mathrm{~km}$

- Datos de localización:

- Descripción: 51 lotes. proyecto de los ingenieros y el arquitecto Moy \& Castro y Madero. Se proponen para el proyecto casas modernas (de lineas racionalistas) y chalets californianos. Foto del proyecto y plano de ubicación.

Relación del loteo con la red vial y ferroviaria

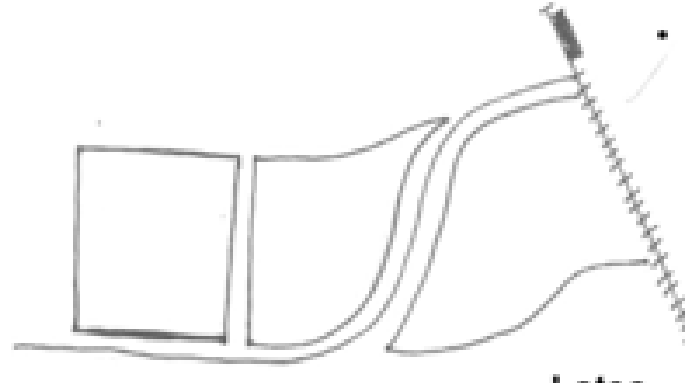

- Discursos de promoción:

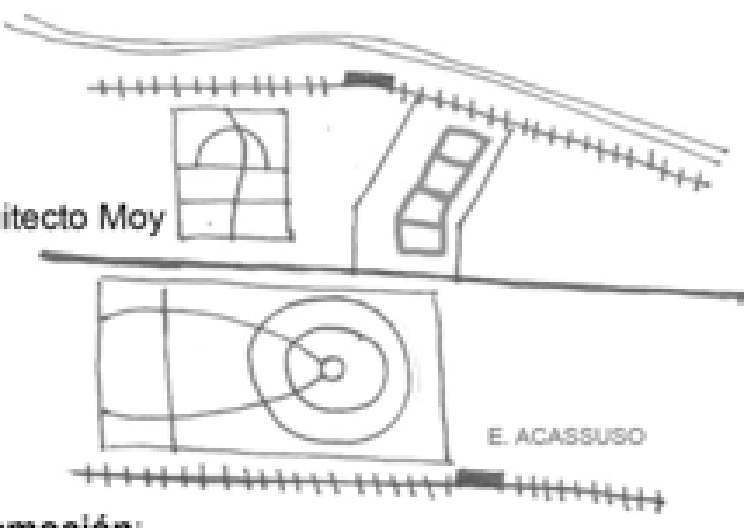
"como una exteriorización de esta, nuestra era del deporte, el goce pleno de los beneficios del aire, la luz y el sol, destacan en todo su magnifico esplendor la gloria de la forma eterna y triunfal

Loteo 
- Localidad: San Isidro

- Nombre de la Urbanización: Barrio Parque Balcarce

- Fecha del loteo: 1935

- Distancia a la Capital: $21 \mathrm{~km}$.

- Datos de localización: frente al rio de La Plata. Entre el Barrio Parque Aguirre y el bajo

- Descripción: 107 lotes con arboleda y calles pavimentadas. Trazado tipo barrio parque con manzanas cuadradas y calles curvas.

- Servicios: calles interiores pavimentadas

- Costos de lo lotes: venta judicial por la división de la sucesión Balcarce. Base \$4.5 la vara2.60 cuotas de $\$ 170$

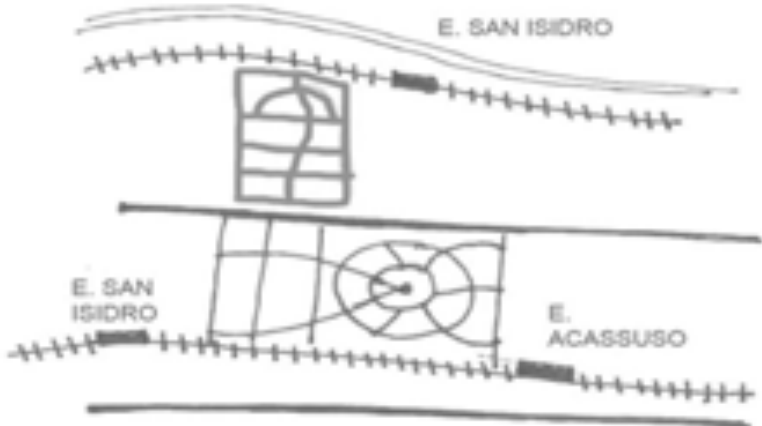

Relación del loteo con la red vial y ferroviaria

Relación del loteo con la red vial y ferroviaria

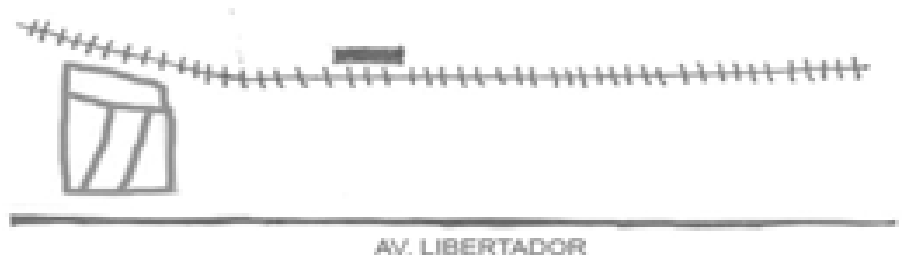

- Localidad: San Isidro

- Nombre de la Urbanización: Barrio Parque "Elortondo"

- Fecha del loteo: 1931

- Distancia a la Capital: $21 \mathrm{~km}$

- Datos de localización: a cuatro cuadras de la Iglesia

- Descripción: últimos 51 lotes en las barrancas de San Isidro

- Servicios: calles interiores pavimentadas

- Costos de lo lotes: base $\$ 6$ la vara2. $\$ 160$ en 48 cuotas.

- Discursos de promoción:

"a cuatro cuadras de la iglesia y la plaza, su cercania a la estación de ferrocarril y a la Capital coloca a estos terrenos en inmejorables condiciones para la construcción de la residencia de todo el año. Además de ser un barrio en donde se levantan magnificas casas quinta y chalets. 
- Localidad: Boulogne

- Nombre de la Urbanización: Barrio Parque

"General Urquiza"

- Fecha del loteo: 1946

Distancia a la capital: $28 \mathrm{~km}$.

- Descripción: 416 lotes. Manzana tradicional con lotes en el centro de la cuadra que alcanzan los $50 \mathrm{mts}$ de largo y anchos uniformes de $10 \mathrm{mts}$.

- Costos de lo lotes: base de $\$ 8$ por mes en 120 meses

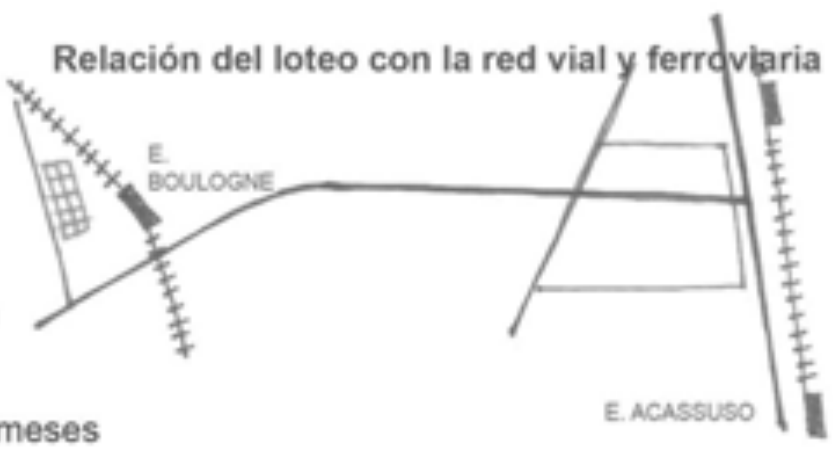

- Discursos de promoción:

"Es un hermoso centro residencial, donde las construcciones rivalizan en riqueza y en donde las plantaciones superan todo elogio y contribuyen a dar tono y color a un maravilloso paisaje natural realzado por la mano del hombre en concepciones artisticas de jardines de gran belleza.

Queremos que la residencia permanente, temporaria o de fin de semana cuente con la amplitud, y a tal efecto, los lotes son de medidas apropiadas. Queremos, y cuente usted desde ahora, con el pedazo de tierra amplio, saludable y económico que lo libere para siempre de la tirania de la ciudad con su secuela de caseros, vecinos molestos y ambientes malsanos"

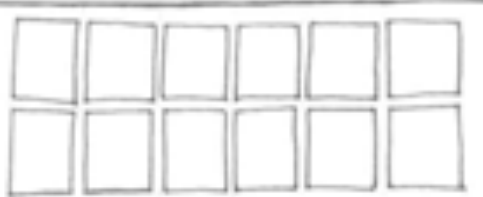

Loteo

- Localidad: San Isidro

- Nombre de la Urbanización: Barrio Parque Alvear

- Fecha del loteo: 1940

- Distancia a la Capital: 24 km

- Datos de localización: entre La Lucila y Martinez, zona completamente urbanizada

- Descripción: zona urbanizada a cinco cuadras de la avenida continuación Cabildo

- Costos de lo lotes: base $\$ 120 \mathrm{~m} 2$. vendidos en $\$ 300 \mathrm{~m} 2$ Chalet base $\$ 100.000$

Lotes de $400 \mathrm{~m} 2: \$ 120.000$
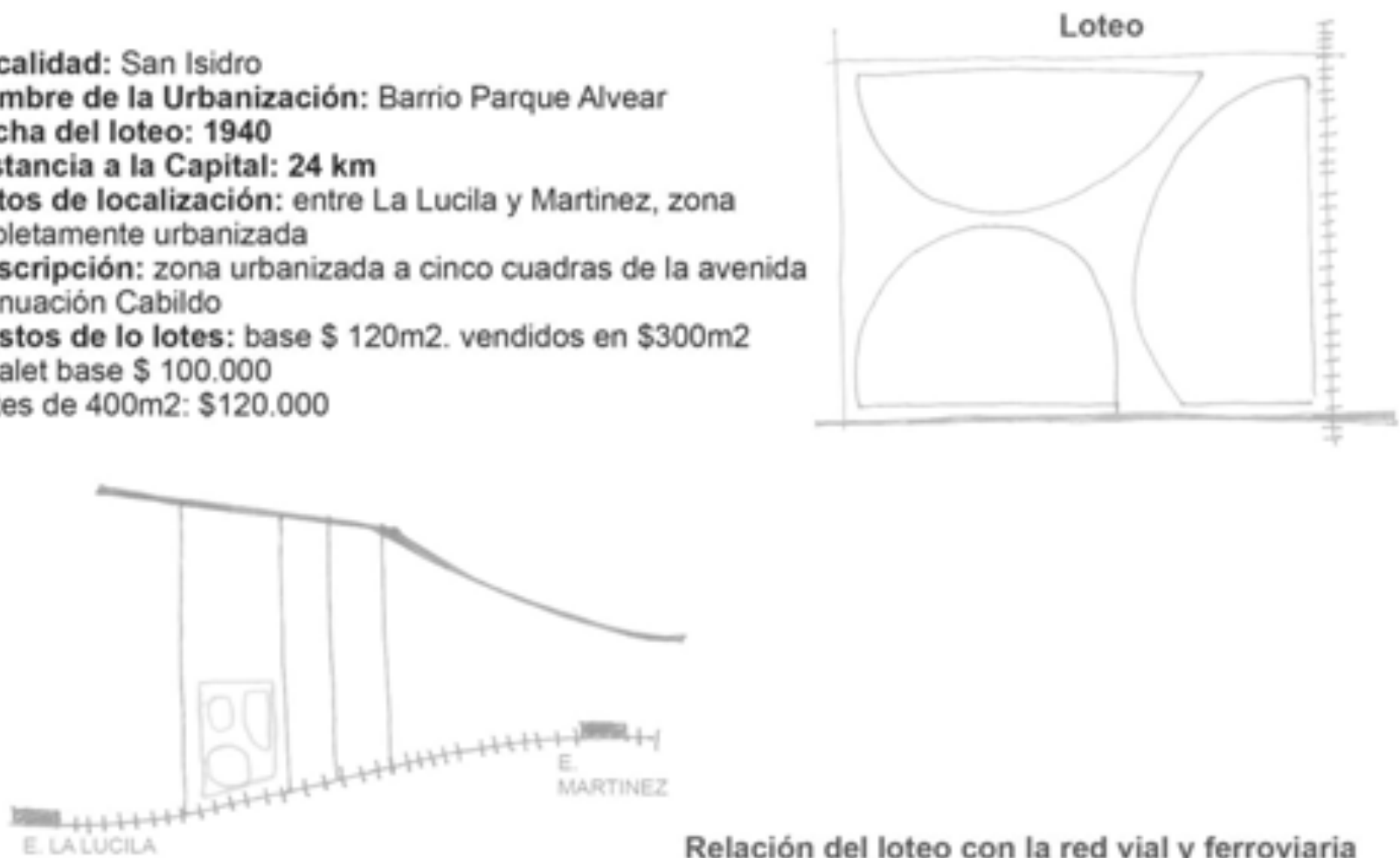

Relación del loteo con la red vial y ferroviaria 
- Localidad: San Isidro

- Nombre de la Urbanización: Barrio Parque Vivot

- Fecha del loteo: 1935

- Distancia a la Capital: $21 \mathrm{~km}$

- Datos de localización: pegado al Barrio Parque Aguirre

- Descripción: 224 fracciones

- Costos de lo lotes: base de $\$ 3.75$ los $0.75 \mathrm{~m} 2$. pagadero $20 \%$ al contado y el resto en dos años.

- Lotes promedio $\$ 4.000$, se ingresa con $\$ 1.000$. Y veinticuatro cuotas de $\$ 125$

- Inmobiliaria: Furst Zapiola

- Localidad: San Isidro

- Nombre de la Urbanización: Barrio Parque Federico Alvear

- Fecha del loteo:

- Distancia a la Capital: $27 \mathrm{~km}$

- Descripción: 156 magnificas fracciones de entre 1.000 y $2.000 \mathrm{~m} 2(20$ x $50 \mathrm{mts})$ y $(40$ x 50mts)

- Costos de lo lotes: base de $\$ 20 \mathrm{~m} 2$. pagadero el $20 \%$ al contado y el resto en ocho cuotas semestrales a $6 \%$ de interés. Aquellos compradores que dentro de 6 meses edifiquen una casa tipo chalet de más de $100 \mathrm{~m} 2$, serán liberados del pago de intereses.

- Vendidos 27 lotes, entre $\$ 37$ y $\$ 56$ el m2

- Lotes de $800 \mathrm{~m} 2$ : $\$ 29.000$ a 120 meses (cuotas de $\$ 250$ )

\section{Loteo}

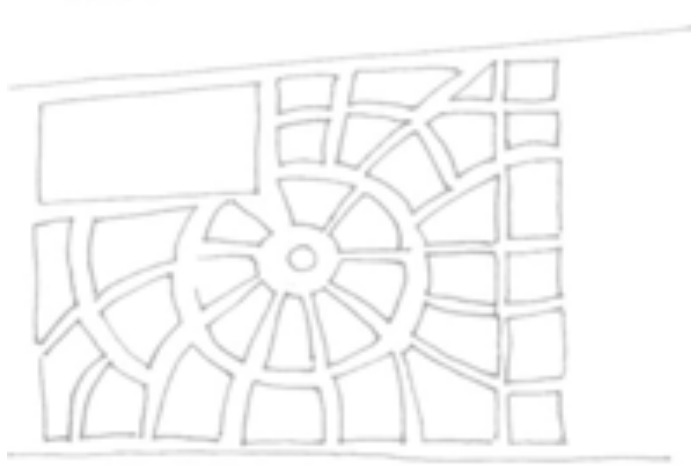

- Localidad: San Isidro

- Nombre de la Urbanización: Barrio Parque Manuel Aguirre

- Fecha del loteo: 1920

- Distancia a la Capital: 22 km

- Datos de localización:

- Descripción: 300 lotes

- Costos de lo lotes: base de $\$ 8$ los $0.75 \mathrm{~m} 2.24$ cuotas

de $\$ 250$

- Inmobiliaria: Adolfo Bulrich

Relación del loteo con la red vial y ferroviaria 
- Localidad: San Isidro

- Nombre de la Urbanización: Barrio Parque Atalaya en las Lomas de San Isidro

- Fecha del loteo: 1949

- Datos de localización: a cuatro cuadras de Bernabé Marquez y a pocas cuadras de la Estación Boulogne de los ferrocarriles del Estado. Frente a ruta Panamericana.

- Descripción: lotes de entre 600 y $1.000 \mathrm{~m} 2$

- Costos de lo lotes: base de \$14 m2 \$250 en 24 cuotas

- Inmobiliaria: Rufino Elizalde/ S.Astorga

- Discursos de promoción:

"en uno de los sitios más pintorescos y de más categoria del pueblo de San Isidro, se halla el "barrio residencial Atalaya" donde se levantan suntuosas residencias, circundadas de espléndidos jardines que evidencian la calidad de sus moradores, quienes en un esfuerzo común transformaron aquel rincón privilegiado en un verdadero parque. La ruta panamericana que se halla en construcción atraviesa estas tierras y acortará la distancia con la Capital a 20KM. El Atalaya Polo Club se encuentra dentro de este barrio parque y el hipodromo de San Isidro y los campos de golf del S.I Jockey Club están a sólo $1800 \mathrm{mts}$."

Relación del loteo con la red vial y ferroviaria

- Localidad: Tigre

- Nombre de la Urbanización: Barrio Parque Guadalupe

- Fecha del loteo: 1948

- Distancia a la Capital: $29 \mathrm{~km}$

- Datos de localización: sobre ruta pavimentada 202, lindando con el Barrio Parque Sancalal y próximo al Hindú Club.

- Costos de lo lotes: base de $\$ 20$ mensuales a pagar en 120 meses.

- Inmobiliaria: Juan Borachia

- Discursos de promoción: La dificultad de hallar cerca de la metrópoli en un ambiente propicio al descanso integral, un solar apto para erigir el chalet de residencia permanente o de fin de semana ha sido allanado felizmente con la presentación del Barrio Parque Guadalupe (...) Surge este parque como una solución providencial para quienes las amplias perspectivas campestres, plenas del encanto de su verdor perenne, aire y calma pastoral, constituyen una necesidad imperiosa que podrán satisfacer ya, sin riesgo de perder con su afincamiento definitivo o periódico, el rápido contacto con los centros urbanos. El Parque Guadalupe está situado a un paso de la Capital Federal en una zona privilegiada y cuya vecindad da la tónica de su excepcional jerarquía. 
- Localidad: Tigre

- Nombre de la Urbanización: Parque Sancalal

- Fecha del loteo: 1948

- Distancia a la Capital: $28 \mathrm{~km}$

- Datos de localización: frente al camino pavimentado que une San Fernando y J.C.Paz, sobre el Hindú Club, y el Automóvil Club Argentino

- Descripción: 200 quintas. Fotos de la maqueta, ilustrando una de las residencias a construir.

- Costos de lo lotes: base $\$ 2$ la vara $(0.75 \mathrm{~m} 2)$ y $\$ 30.000$ el chalet

Ampliación base $\$ 3 \mathrm{~m} 2=$ lotes promedio de $800 \mathrm{~m} 2$ y suponiendo que el precio de venta duplique la base, lotes de $\$ 4.800$, mensualidades de $\$ 40$

- Inmobiliaria: Astoul Bonorino

- Discursos de promoción:

"un ofrecimiento de jerarquía, un trazado de calles de lo más moderno y del mejor gusto.

En una ubicación estratégica a $400 \mathrm{mts}$ del Hindú Club con sus espléndidas canchas de deporte, grandes edificios y parques." Don Torcuato es una bonita localidad. Toda de modernas construcciones que está tomando un ritmo de progreso y valorización asombrosa" 


\section{Bibliografía}

\section{Bibliotecas y Archivos}

Archivo y Museo Histórico San Isidro

Departamento de Investigación Histórica Cartográfica, Dirección de Geodesia, Ministerio de Obras Públicas, Provincia de Buenos Aires

Instituto y Archivo Histórico Municipal de Morón.

Archivo Inmobiliaria Vinelli

Archivo personal familia Buchelle

Biblioteca del Honorable Consejo Deliberante de la Ciudad de Buenos Aires

\section{Diarios y Revistas}

Nacionales

Casas y Jardines

CACyA

El Arquitecto Constructor

Nuestra Arquitectura

Revista de Arquitectura

\section{Internacionales}

California Arts \& Architecture

California Southland

American Architect

Tratados y manuales de Arquitectura y Construcción Pintoresca, Suburbana o Veraniega

- Cloquet, Louis, Traité d'architecture, Baudry et cue, s/d, 1898.

- Colas, Luis, L'Habitation Basque, Moreau, s/d, 1927

- Covazzoni, A, Il Villino, Casa Editrice d'Arte Bestetti \& Tumminelli, Milano, 1909

- Elder-Duncan, J. H, Country Cottages and Week-end Homes, Cassell and Company Limited, London, 1912;

- Falgás, Victor, Arquitectura Española. Villas y Chalets, s/d, 1924 
- Guadet, Julien, Elements et théorie de l'architecture, Editeur L.C.M., Paris, 1909.

- ------------------L'Architecture $d u$ litoral. Côte d'Azur. Librarie de la Construction Moderne, Paris

- Lambert, Th, Villas et petites constructions, Ch. Schmidt editeur, Paris, 1900.

- Le Village moderne, d'apres les projets des architectes français et étrangers. Habitations economiques. Constructions rurales, fermes, plans, etc. Ch. Massin editeur, París, 1915

- Massin, Charles, Villas normandes et anglaises, Ch.Massin editeur, Paris, 1913

- Mella, Edoardo, Elementi di Architettura Lombarda. Torino. Bocca. 1885.

- Payne, A. H, The Builders Practical Director. Plans, sections and elevations with detailed estimates, quantities \& prices, Liepzig and Dresden, London, 1859.

- Planat, Pierre, Campagne, villas \& chateaux. Bibliotheque de la construction moderne, habitation particuliers, Dujardin Editeur, Paris, 1907.

- Schmid, Charles, Villas et Cottages des bords de la mer: façades. intérieurs, plans, s/d, 1910.

- Varin, Pierre Amédée, L'Architecture Pittoresque en Suisse ou coix de constrctions rustiques prises dans toutes les parties de la Suisse. Par A. Et E. Varin, A. Morel, París, 1873.

- Wesser, Rudolf, Beiterage zur Bauwissenschaft, Verlag von Ernst Wasmuth, Berlin, 1903

\section{Fuentes Editas}

- Esteban, Francisco, El Departamento Topográfico de la Provincia de Buenos Aires (actual Dirección de Geodesía). Su creación y desarrollo. Antecedentes y documentos demostrativos de la importancia de sus funciones. Breve reseña para su historia. Buenos Aires, 1962.

- Guaraglia, Luis, Manual del rematador, Ediciones Machi, Buenos Aires, 1971.

- Vinelli 1906-2006. 100 Años de Experiencia y Dedicación en el Mercado Inmobiliario. 
- Comisión de Estética Edilicia, Proyecto Orgánico para la urbanización del municipio. El plano regulador y de reforma de la Capital Federal. Talleres Peuser, Bs.As., 1925.

- Ley que divide los Ejidos de los Pueblos de Campaña, Buenos Aires, Octubre, 1870.

- Ley $\mathrm{n}^{\mathrm{o}} 3487$, De creación de nuevos centros de población y ampliación de ejidos. Buenos Aires, 19 de junio, 1913.

- Guerrico, en AHCD, 29 de septiembre de 1908, pp 361-366.

- Guerrico, en AHCD, Ordenanza Formación de Barrios Parque, 1911, p. 556

\section{Publicaciones en Revistas Especializadas}

\section{California Arts \& Architecture}

- Byers, John, "The inflluence of Adobe in California", en California Arts \& Architecture, Abril 1929. pp. 29-33;

- Daniels, Mark, "The Unique charm of North Africa. Climate and Landscape Remind a Californian Home", California Arts \& Architecture, Julio 1929. pp. 19-21.;

- Scott, Hunter D, “American-Indian Architecture. California's Contribution to a New Style of Architecture", en California Arts \& Architecture, Agosto 1929. pp. 31-33;

- Coate, Roland E, "The Early California House. Blending Colonial and California Forms", en California Arts \& Architecture, Marzo 1929. pp. 21-23.

- Kelley, Roy, "Simplicity. Simplicity is the Keynote of Beauty", en California Arts \& Architecture, octubre 1929. p. 36.

\section{Revista de Arquitectura}

Medhurst Thomas, Charles E., “Casas Baratas ?”, en Revista de Arquitectura, n 41, Junio 1924, pp. 135-138.

\section{Nuestra Arquitectura}

"El plan de la casa es lo que la hace moderna", en Nuestra Arquitectura, Abril 1931. pp. $844-848$ 


\section{Casas y Jardines}

“El servicio ferroviario Suburbano"en Revista Casas y Jardines, Enero, 1937

\section{Arquitectura}

Chanourdie, Enrique, "Habitaciones económicas e higiénicas", Junio/Julio 1905. 


\section{Fuentes Secundarias}

\section{Bibliografía Específica}

- Aboy, Rosa, Viviendas para el pueblo. Espacio urbano y sociabilidad en el barrio Los Perales. 1946-1955, Fondo de Cultura Económica, Buenos Aires, 2005.

- Aliata, Fernando, "Virginio Colombo", en Liernur, Jorge y Aliata, Fernando (dirs.), Diccionario de Arquitectura en la Argentina, Clarín, Buenos Aires, 2004.

- --------------------, “Departamento Topográfico”, en Liernur, Jorge y Aliata, Fernando (dirs.) Diccionario de Arquitectura en la Argentina, Clarín, Buenos Aires, 2004.

- -------------------, La ciudad regular. Arquitectura, programas e instituciones en el Buenos Aires posrevolucionario, 1821-1835. Universidad Nacional de Quilmes y Prometeo, Buenos Aires, 2006.

- Aymonino, Carlo, Orígenes y desarrollo de la ciudad moderna, Barcelona, G.Gili, 1972.

- Ballent, Anahí, Las huellas de la política. Vivienda, ciudad, peronismo en Buenos Aires, 1943-1955. Prometeo y Universidad Nacional de Quilmes, Buenos Aires, 2005.

- - -------------, “Country life: los nuevos paraísos, su historia y sus profetas”, en Block, n², Universidad Torcuato Di Tella, Buenos Aires, 1998.

- ---------------, “vivienda de interés social”, en Liernur, Jorge y Aliata, Fernando (dirs.), Diccionario de Arquitectura en la Argentina, Clarín, Buenos Aires, 2004.

- Berman, Marshall, Todo lo sólido se desvanece en el aire. La experiencia de la modernidad. Siglo XXI, Madrid, 1988. (1ra edición 1982)

- Bohoslavsky, Ernesto y Soprano, Germán, “Una evaluación y propuestas para el estudio del Estado en Argentina", en Bohoslavsky, Ernesto y Soprano, Germán (editores). Un Estado con rostro humano. Funcionarios e instituciones estatales en Argentina (desde 1880 a la actualidad). UNGS y Prometeo, Buenos Aires, 2010. 
- Borello, José (coord.), Aproximaciones al mundo productivo de la Región Metropolitana de Buenos Aires. Universidad Nacional de General Sarmiento, Los Polvorines, 2007.

- Bourdieu, Pierre, Las estructuras sociales de la economía. Manantial, Buenos Aires, 2001.

- - ------------, Cosas dichas. Gedisa, Barcelona, 1993.

vol 31, 1980.

- Bourdieu, Pierre y Wacquant, Louis, Respuestas: por una antropología reflexiva, Grijalbo, México, 1995.

- Bozzano, Horacio, "Buenos Aires desde sus orígenes. Transformaciones territoriales y mutaciones productivas", en Borello, José (coord.), Aproximaciones al mundo productivo de la Región Metropolitana de Buenos Aires, Universidad Nacional de General Sarmiento, Los Polvorines, 2007.

- Calabi, Donatella (comp.), Architettura domestica in Gran Bretagna. 18901939. Electa Editrice, Milan, 1982.

- Caride, Horacio, "La casa propia: el caso del chalet. Notas en las revistas populares de Buenos Aires durante la década infame.", en DANA. 1992, Num. 31/32. pp. 57-64.

- -------------, “Un poco antes del horizonte. Estructura administrativa de la campaña de Buenos Aires en el siglo XVIII", en Seminarios de Crítica del Instituto de Arte Americano, $\mathrm{n}^{\circ}$ 52, 1994.

- ---------------, La construcción de una idea: El conurbano bonaerense, $1925-$ 1947, Instituto de Arte Americano e Investigaciones Estéticas "Mario J. Buschiazzo" FADU, UBA, Colección Crítica n 76, Buenos Aires, 1977.

- Clichevsky, Nora, El mercado de tierras en el área de la expansión de Buenos Aires y su incidencia sobre los sectores populares, período 1943-1973. (mimeo) Centro de Estudios Urbanos y Regionales, Instituto Torcuato Di Tella, Buenos Aires, 1975.

- ---------------, Tierra Vacante en Ciudades Latinoamericanas. Nora Clichevsky Editora, Toronto, 2002. 
- -------------------, “Algunas reflexiones sobre informalidad y regularización del suelo urbano", en Bitácora Urbano Territorial, volumen 14, enero-junio 2009, Universidad Nacional de Colombia, Bogotá, 2009. pp. 63-89.

- ---------------, “Acceso a la tierra urbana y políticas del suelo en el Buenos Aires Metropolitano", en Riurb 08, Buenos Aires: Procesos metropolitanos, Barcelona-Buenos Aires, 2012.

- Clichevsky, Nora y Herzer, Hilda, Construcción y administración de la ciudad latinoamericana. Buenos Aires, I.I.D.A.L. 1990.

- Clichevsky, Nora y Manzanal, Mabel, El Estado de la investigación urbana en la Argentina: sus perspectivas. Centro de Estudios Urbanos y Regionales. Buenos Aires, 1987.

- Collins, Peter, Los ideales de la arquitectura moderna; su evolución (17501950). Gustavo Gili, Barcelona, 1978. (1ra edición 1960)

- Dal Co, Francesco, De los parques a la región. Ideología progresista y reforma de la ciudad americana, en A.A.V.V, La Ciudad Americana. De la guerra civil al New Deal. Gustavo Gili, Barcelona, 1975.

- Edwards, A. M, The Design of Suburbia: A Critical Study in Environmental History, Prembridge Press, Londres, 1981.

- Esperdy, Gabrielle, "Defying the Grid: A Retroactive Manifesto for the Culture of Decongestion”, en Perspecta 30. 1999. Pp.10-33.

- Favelukes, Graciela, "Medios técnicos y construcción de la ciudad", en Registros $n^{\circ} 5$, Facultad de Arquitectura, Urbanismo y Diseño, Universidad Nacional de Mar del Plata, 2008. pp.87-104.

- - ----------------------, "Figuras y paradigmas. Las formas de Buenos Aires (17401870)", en Anales del Instituto de Arte Americano e Investigaciones Estéticas "Mario J. Buschiazzo", Buenos Aires en Proyectos, Universidad de Buenos Aires, Facultad de Arquitectura y Urbanismo, año 2011. pp 11-26

- Fishman, Robert, Burgeois utopias: the rise and fall of suburbia, Basic Books, New York, 1987.

- Gebhard, David, "The Spanish Colonial Revival in Southern California (18951930)", en The Journal of the Society of Architectural Historians, vol 26, no 2 (mayo, 1967), pp. 131-147. 
- Gómez Pintus, Ana, "Las dimensiones del pintoresquismo. Suburbios residenciales, arquitectura y prácticas profesionales. Buenos Aires, 1910-1940.” Tesis de Maestría. Universidad Torcuato di Tella, Buenos Aires, 2010.

- Gorelik, Adrián, La grilla y el parque. Espacio público y cultura en Buenos Aires. 1887-1936, Universidad Nacional de Quilmes, Buenos Aires, 1998.

- ----------------, "Roles de la periferia. Buenos Aires: de ciudad exoansiva a ciudad archipiélago", en Peripheries: Decentering Urban Theory, International Conference, U.C. Berkeley, 5-7 February 2009.

- Gravagnuolo, Benedetto, Historia del Urbanismo en Europa. 1750-1960. Ediciones Akal, Madrid, 1998.

- Hall, Peter, Ciudades del mañana. Historia del urbanismo en el siglo XX. Ediciones del Serbal, Barcelona, 1996.

- Herzer, Hilda, La investigación urbana en la Universidad de Buenos Aires, Documento de trabajo, Programa Especial de Investigaciones Ciudad. Universidad de Buenos Aires, 1996

- Hora, Roy, Los terratenientes de la pampa Argentina. Una historia social y politica, 1860-1945. Editores Siglo XXI, Buenos Aires, 2002.

- ------------, “Del comercio a la tierra y más allá: los negocios de Juan José y Nicolás Anchorena. (1810-1856), en DE vol 44, n 176, 2005, p 567.

- Howard, Ebenezer, Garden Cities of To-Morrow, Faber\&Faber, London, 1902. (1ra edición Tomorrow: A Peaceful Path to Real Reform, 1898)

- Kostof, Spiro, The City Shaped. Urban Patterns and Meanings Through History. Thames \& Hudson, London. 1991

- Lanciotti, Norma, "Mercado inmobiliario en Rosario: inversores, empresas y empresarios en la expansión urbana entresiglos, 1880-1914.", en Séptimas Jornadas "Investigaciones en la Facultad" de Ciencias Económicas y Estadística, Universidad Nacional de Rosario, octubre 2002

- -----------------, De rentistas a empresarios. Inversión inmobiliaria y urbanización en la pampa argentina. Rosario, 1880-1910. Edición de la Universidad Nacional del Litoral, Rosario, 2009.

- Liernur, Jorge F., “Casas y Jardines. La construcción del dispositivo doméstico moderno (1870-1930)", en Devoto, Fernando (dir.), Historia de la Vida Privada en la Argentina. Taurus, Buenos Aires, 1999. pp. 103-104. 
- ---------------, “AAdueño. 2 amb. Va.Urq. chiche. 4522.4789. Consideraciones sobre la construcción de la casa como mercancía en la Argentina. 1870-1950”, en Revista SCA, julio, n 217: Modos de habitar, Buenos Aires, 2005, pp. 54-61.

- ---------------, Arquitectura en la Argentina del siglo XX. La construcción de la modernidad. Fondo Nacional de las Artes, Buenos Aires, 2001.

- Marcuse, Peter, "The grid as City Plan: New York City and laissez faire planning in the nineteenth century”. Planning Perspectives $\mathrm{n}^{\circ} 2$. Nueva York. 1987

- Mumford, Lewis, La Ciudad en la Historia. Ediciones Infinito, Buenos Aires, 1979

- ---------------, La Cultura de las Ciudades. Emecé Editores, Buenos Aires, 1945

- Nelson, Garret, "Grid and Anti-Grid. A landscape dialectic of socioenvironmental ideals", 2009 http://people.matinic.us/garrett/papers/grid-antigrid.pdf (consulta: 2 de octubre 2011)

- Novick, Alicia, "City Planning in the history of the city", en Bruce Stiftel, Vanessa Watson and Henri Acselrad (dirs), Dialogues in Urban and Regional Plannig Vol. 2, Routledge, 2007. pp. 268-295.

- Oszlak, Oscar, La formación del Estado argentino: orden, progreso y organización nacional. Editorial Planeta, Buenos Aires, 1982.

- Pastor, José María y Bonilla, José, Estudio sobre el uso de la tierra. Editado por el Instituto de Planeamiento Regional y Urbano, Buenos Aires. 1958.

- Pírez, Pedro, “Actores sociales y gestión de la ciudad”, en Ciudades n o 28, octubre-diciembre, RNIU, México, 1995.

- ------------, “Buenos Aires o la expansión metropolitana sin gobierno”, en Conferencia Internacional sobre el Control de la Expansión Urbana, México D.F., 8 y 9 de Noviembre, 1999.

- Rocchi, Fernando, "Consumir es un placer: la industria y la expansión de la demanda en Buenos Aires a la vuelta del siglo pasado", en Desarrollo Económico, Revista de Ciencias Sociales, vol. 37, nº 148 (enero-marzo 1998) pp.533-557.

- -------------------, La americanización del consumo: las batallas por el mercado argentino, 1920-1945”, en María I. Barbero y Andrés Regalsky (editores), Americanización. Estados Unidos y América Latina en el Siglo XX. 
Transferencias económicas, tecnológicas y culturales. Eduntref, Buenos Aires, 2003.

- Roncayolo, Marcel, Lectures de villes.Formes et Temps. Éditions Parenthèses, Marseille, 2002.

- Sargent, Charles, The Spatial Evolution of Greater Buenos Aires, 1870-1930, Center for Latin American Studies, Arizona State University, 1974.

- Schorske, Carl, E, La Viena de Fin de Siglo. Política y Cultura. Siglo Veintiuno Editores, Buenos Aires, 2011. (1ra edición 1961)

- Schmidt, Claudia, "Miradas y recepción de las principales teorías y libros de imágenes. Algunos aspectos acerca de la tratadística de arquitectura en Argentina. 1820-1920" en, Cuadernos de Crítica IAA n ${ }^{\circ}$ 58, Facultad de Arquitectura y Urbanismo, UBA. 1995

- Scobie, James, Buenos Aires: del centro a los barrios, 1870-1910. Ediciones Solar, Buenos Aires, 1977.

- Sennet, Richard, Vida urbana e identidad personal. Los usos del desorden. Ed, Península, Barcelona, 1975.

- - ----------------, "Las ciudades norteamericanas: planta ortogonal y ética protestante." Revista Internacional de Ciencias Sociales, Barcelona. $\mathrm{n}^{\circ} 125$, septiembre 1990. pp.281-299.

- Sikkink, Katryn, "Las capacidades y la autonomía del Estado en Brasil y la Argentina: un enfoque neo-institucionalista.”, en Desarrollo Económico, Buenos Aires. 1993. Pp. 32-128.

- Skocpol, Theda, "Bringing the State Back In: Strategies of Analysis in Current Research", en P.Evans, D. Rueschemeyer y Th. Skocpol (editors) Bringing the State Back In, Cambridge University Press, Cambridge, U.K. 1985.pp.3-44.

- Topalov, Christian, Le Logement en France. Histoire d'une marchandise impossible. Presses de la Fondation Nationale des ciences Politiques, París, 1987.

- Torre, Juan Carlos y Pastoriza, Elisa, "La democratización del bienestar", en Nueva Historia Argentina, t VIII., J.C. Torre (dir.), Los años peronistas (19431955). Sudamericana, Buenos Aires, 2002. 
- Torres, Horacio, "Evolución de los procesos de estructuración espacial urbana. El caso de Buenos Aires", en Desarrollo Económico, Vol.15, № 58, 1975. pp. 281-306

Buenos Aires y los modelos urbanos" en Desarrollo Económico, Vol.18, No 70 , 1978. pp163-204

- Vapñarsky, César, La aglomeración Gran Buenos Aires. Expansión espacial y crecimiento demográfico entre 1869 y 1991. Eudeba, Buenos Aires, 2000.

- Vecslir, Lorena, "La Región Metropolitana de Buenos Aires como área de investigación”, Informe, Universidad Nacional de General Sarmiento, 2009.

- Weitze, Karen, California's Mission Revival. Hennessey \& Ingalls, Los Angeles, 1984.

- Whitehand, Jeoffrey y Carr, Caroline, Twentieth-Century Suburbs: A Morphological Aproach. Routledge, Londres, 2001.

- Williams, Raymond, El campo y la ciudad, Editorial Paidós, Buenos Aires. 2001

- Zucconi, Guido, "De la fase heroica a la estandarización", en Calabi, Donatella (comp.), Architettura domestica in Gran Bretagna. 1890-1939. Electa Editrice, Milan, 1982. 


\section{Bibliografía secundaria}

- Adamovsky, Ezequiel, Historia de la clase media argentina. Apogeo y decadencia de una ilusión, 1919-2003, Editorial Planeta, Buenos Aires, 2009.

- Adorno, Theodor W., Teoría Estética, Orbis-Hyspamérica, Madrid, 1984.

- Almandoz, Arturo, Entre libros de historia urbana. Para una historiografía de la ciudad y el urbanismo en América Latina. Editorial Equinoccio, Universidad Simón Bolivar, Caracas, Venezuela, 2008.

- ---------------------, "Notas sobre Historia Cultural Urbana. Una perspectiva latinoamericana", en revista electrónica Perspectivas Urbanas. 2002. http://upcommons.upc.edu/revistes/html/2099/20/art01-3.htm

- Alonso, William, Location and Land Use, Harvard University Press, Cambridge, Massachussets, 1964.

- Andrews, Malcom, The search for the Picturesque. Landscape Aesthetics and Tourism in Britain. 1760-1800, Stanford University Press, Stanford, 1990.

- Baer, Luis, "Sobre el funcionamiento del mercado inmobiliario porteño y las mayores restricciones para acceder a la vivienda luego de la crisis de 2001/02.", en Serie Urbana, año 9, $\mathrm{n}^{\circ}$ 18, Instituto de Investigaciones en Humanidades, UBA, Colegio Nacional Buenos Aires, 2009. pp. 17-30.

- --------------, “Mercados del suelo y producción de vivienda en Buenos Aires y su área metropolitana”, en Riurb 08, Buenos Aires: Procesos metropolitanos, Barcelona-Buenos Aires, 2012.

- Ballent, Anahí, "La condición profesional en la década del '50", en Materiales, Buenos Aires, 1983.

- -----------------, “Ingeniería y Estado: la red nacional de caminos y las obras públicas en la Argentina, 1930-1943.”, en Hist. ciênc.saùde-Manguinhos; 15 (3): 827-847. jul-set. 2008.

- Barba, Fernando Enrique, "En torno a la fijación de las fechas de fundación de pueblos y partidos de la Provincia de Buenos Aires", en Revista de Historia Bonaerense $\mathrm{n}^{\circ}$ 9. Origen y Fundación de Pueblos.

- Barcos, Fernanda, "Los ejidos de los pueblos de campaña: ocupación y acceso a la propiedad legal en Monte, 1829-1865.", en Mundo Agrario, vol 7, no 14, 
primer Semestre de 2007. Centro de Estudios Histórico Rurales, Facultad de Humanidades y Ciencias de la Educación, Universidad Nacional de La Plata.

- Barrel, Jhon, The dark side of Landscape. The rural poor in English painting. 1730-1840. Cambridge University Press, Cambridge, 1980.

- Barsky, Osvaldo y Gelman, Jorge, Historia del Agro argentino. Desde la conquista hasta fines del siglo XX. Grijalbo, Buenos Aires, 2001.

- Béjar, María Dolores, El Régimen Fraudulento. La política en la Provincia de Buenos Aires, 1930-1943, Siglo XXI editores, Buenos Aires, 2005.

- Benévolo, Leonardo, Historia de la Arquitectura Moderna. Gustavo Gili, Barcelona, 1978. (1ra edición 1960)

- Biaggini, Martín y Mielnicki, Silvia, Villa Luzuriaga. Ayer, hoy y siempre, editorial CLM, La Matanza, 2009.

- Birocco, Carlos María, “Morón. La construcción de un Municipio 1855-1900”, en Revista de Historia Bonaerense n⿳⺈ 26.

- Bock, Gordon, “The Stick Style”, en Old House Journal, May, 2003.

- Bradford, Sarah, "Richard Morris Hunt, the Continental Picturesque, and the Stick Style" en The Journal of the Society of Architectural Historians, Vol. 42, $\mathrm{n}^{\circ} 3$ (Oct., 1983), pp. 272-289. Versión on-line: http://www.jstor.org/stable/989950en JStore

- Bruno, Perla, "Reflexiones para una historia conjunta: derivaciones americanas de la ciudad jardín en la extensión y planificación moderna de ciudades de Argentina y Brasil, 1930-1945", en Registros, n 1, Facultad de Arquitectura, Urbanismo y Diseño, UNMdP, Mar del Plata, 2003.

- Buján, Jorge, La colectividad británica en Quilmes. Tesis de Maestría, U.B.A, Buenos Aires, 2006.

- Burke, Peter, Visto y no visto. El uso de la imagen como documento histórico. Editorial Crítica, Barcelona, 2005.

- Cacopardo, Fernando y Pastoriza, Elisa, "Mar del Plata", en Liernur, Jorge y Aliata, Fernando (dirs.) Diccionario de Arquitectura en la Argentina. Clarín, Buenos Aires, 2004.

- Ciccolella, Pablo, "Grandes inversiones y dinámicas metropolitanas: Buenos Aires, ¿Ciudad Global o ciudad dual del siglo XXI?”, en Mundo Urbano. 
Buenos Aires: Secretaría de Comunicación y Tecnologías de la Información de la Universidad Nacional de Quilmes, 2000.

- --------------, “Distribución global y territorio. Modernización y concentración comercial en Argentina en los años '90”, en Economía, Sociedad $y$ Territorio, vol II, $\mathrm{n}^{\circ}$ 7, Toluca. El Colegio Mexiquense, 2000. pp. 459-496.

- Cicolella, Pablo y Vecslir, Lorena, "Dinámicas, Morfologías y singularidades en la restructuración metropolitana de Buenos Aires", en Riurb 08, Buenos Aires: Procesos metropolitanos, Barcelona-Buenos Aires, 2012.

- Cirvini, Silvia, Nosotros, los arquitectos. Campo disciplinar y profesión en la Argentina Moderna. Zeta Editores, Mendoza, 2004.

- Clawson, Marion, Urban Sprawl and speculation in Suburban Land, JSTOR. 1962

- Corboz André, El territorio como palimpsesto (1983), en Lo Urbano en 20 Autores Contemporáneos. Ediciones UPC, Barcelona, 2004.

- Cortés Conde, Roberto, El progreso argentino, 1880-1914. Buenos Aires, 1979.

- De Franco, Guillermo, City Bell. Crónica de la tierra de uno. Edición del autor. Buenos Aires, 2005.

- Dixon Hunt, John, The Genius of the Place : the English Landscape Garden. 1620-1820, MIT Press, Cambridge, Massachusetts, 1988.

- Facciolo, Ana, "Crecimiento industrial, expansión metropolitana y calidad de vida", en Desarrollo Económico, vol. 20, nº 80, 1981. pp. 549-568.

- Faragher, Jhon Mack, "Bungalow and Ranch House: The Architectural Backwash of California”, en Western Historical Quarterly, n 32, 2001. Versión on-line:

$<\mathrm{http}$ ://www.historycooperative.org/cgibin/justtop.cgi?act=justtop\&url=http://w ww.historycooperative.org/journals/whq/32.2/faragher.html>.

- Fernandez, Noelia, “Temas y problemas: obras públicas y política en el gobierno de Fresco, 1936-1940”, en 1ras Jornadas de Investigadores en Formación, IDES, Noviembre 2011.

- Fernandez Poblet y Ortúzar Alejandro, "Proyecto de barrio obrero", en Arquitectura, Apartado de la Revsita Técnica, Junio-Julio 1909. 
- Ferro, Máximo, La formación del Museo de La Plata. Coleccionistas, comerciantes, estudiosos y naturalistas viajeros a fines del siglo XIX. Prohistoria ediciones, Rosario, 2009

- Franquesa Sánchez, Jordi, "Las Comunidades Jardín. Algunas intuiciones para nuevas ciudades" en, Revista Iberoamericana de Urbanismo n5, 2011.

- Frediani, Julieta C., Lógicas y tendencias de la expansión residencial en áreas periurbanas. El Partido de La Plata, Buenos Aires, Argentina, entre 1990 y 2010. Tesis doctoral en Geografía, Universidad Nacional de La Plata, Facultad de Humanidades y Ciencias de la Educación, 2010. on-line: http://www.fuentesmemoria.fahce.unlp.edu.ar/tesis/

- Freestone, R, “The Garden City idea in Australia”, en Australian Geographical Studies - interscience.wiley.com, 1982.

- Gentile, Eduardo, “Karman, René”, en Liernur, Jorge y Aliata, Fernando (dirs.), Diccionario de Arquitectura en la Argentina, Clarín, Buenos Aires, 2004.

- Germani, Gino, "La clase media en la ciudad de Buenos Aires: Estudio preliminar", en Boletín del Instituto de Sociología, n ${ }^{\circ}$, Facultad de Filosofía y Letras, UNBA, 1942. Versión on-line: http://www.jstor.org/stable/3466371.

- Gideon, Sigfried, Espacio, tiempo y arquitectura. (El futuro de una nueva tradición). Hoepli, Barcelona, 1958. (1 ra edición 1941)

- Girouard, Mark, The Victorian Coountry House, Clarendon Press, 1971.

- Gómez Crespo, Raúl y Cova, Roberto, Arquitectura Marplatense: el Pintoresquismo. Instituto Argentino de Investigaciones de Historia de la Arquitectura y el Urbanismo, Resistencia, 1982.

- González Bollo, Hernan, La estadística publica y la expansión del estado argentino: una historia social y política de una burocracia especializada, 18691947. Tesis del Programa de Posgrado en Historia, Universidad Torcuato Di Tella, 2007.

- González Leandri, Ricardo, "La nueva identidad de los sectores populares", en (dir.) Alejandro Cattaruzza, Crisis Económica, avance del Estado e incertidumbre política (1930-1943). Col. Nueva Historia Argentina, T VII. Editorial Sudamericana, Buenos Aires, 2001.

- --------------------------------, Breve historia del Departamento Nacional de Higiene. Estado, gobernabilidad y autonomía médica en la segunda mitad del 
siglo XIX, en Bohoslavsky, Ernesto y Soprano, Germán (comp.), Un Estado con rostro humano. Funcionarios e instituciones estatales en Argentina (desde 1880 a la actualidad). UNGS y Prometeo, 2010.

- Good, Albert, Park and Recreation Structures, US National Park Service, Princeton Architectural Press, New York, 1938.

- Greenberg, Allan, Lutyen's Architecture restudied. MIT Press, Cambridge, Massachusetts, 1969.

- Groven, Ellis, Architectural trends, s/d, 1940

- Gruschetsky, Valeria, Saberes sin fronteras. La vialidad norteamericana como modelo de la Dirección Nacional de Vialidad, 1920-1940., en Mariano Plotkin y Eduardo Zimmerman (comps.) Los Saberes del Estado en la Argentina, siglos XIX y XX. Editorial Edhasa, Buenos Aires, 2012.

- Guinzburg, Carlo, El queso y los gusanos. Ediciones Muchnik, Barcelona, 1981.

- Gutiérrez, Andrea, “Gestión Metropolitana del transporte colectivo en Buenos Aires”, en Riurb 08, Buenos Aires: Procesos Metropolitanos, Barcelona-Buenos Aires, 2012

- Gutiérrez, Leandro y Romero, Luis Alberto; Sectores populares, cultura y política. Buenos Aires en la entreguerra, Editorial Sudamericana, Buenos Aires, 1995.

- Gutierrez, Ramón, Arquitectura y Urbanismo en Iberoamérica, Editorial Cátedra, Madrid, 1983.

- Harris, R y Larkham, Peter, Changing Suburbs: Foundation, Form and Function. E \& F Spon, London, 2000.

- Hess, Alan y Weintraub, Alan, Rancho Deluxe, s/d, 2000.

- Hussey, Christopher, The Picturesque. G.P. Putnam's Sons, Londres, 1927.

-

- - -------------------, English Country Houses, Country Life, 1955.

- Ibarguren, Carlos (h), "Crónica de la Histórica Chacra de Aguirre en San Isidro". Museo Brigadier Juan Martín Pueyrredón, mimeo, San Isidro, 1982.

- Izaskun, Landa, "Modelos urbanos y transferencias en Caracas: el caso del primer suburbio jardín de Manuel Mujica", en Proceedings, 11th Conference of the Internacional Planning History Society (IPHS), Barcelona, 2004 
- Kirker, Harold, California's architectural frontier: style and tradition in the nineteenth century. Russell \& Russell, 1970.

- Koolhaas, Rem, Deliruis New York. A Retroactive Manifesto for Mahattan. The Monacelli Press, New York, 1994.

- --------------, La Ciudad Genérica (1994), en Lo Urbano en Autores Contemporáneos. Ediciones UPC, Barcelona, 2004.

- Lacoste, Alberto César, Las mejores "plumas" del gallo de Morón. Autores Asociados, Morón, 1991.

- Lazzaro, Claudia, Rustic Country House to Refined Farmhouse: The Evolution and Migration of an Architectural Form, en The Journal of the Society of Architectural Historians, vol .44, $\mathrm{n}^{\mathrm{o}} 4$ (Dic, 1985), pp.346-367. version on-line, Stable URL: http://www.jstor.org/stable/990113 accessed 09/09/2008

- Levene, Ricardo (dir); Historia de la Provincia de Buenos Aires y formación de sus pueblos. Archivo Histórico de la Provincia de Buenos Aires. Taller de Impresiones Oficiales, La Plata, 1941.

- Lewis, Michael y Frank, Furnes, Architecture and the violent mind. Norton, New York, 2001.

- Liernur, Jorge F., "Buenos Aires: la estrategia de la casa autoconstruida", AA. VV. Sectores populares y vida urbana, CLACSO, Buenos Aires, 1984.

- ------------, “Neocolonial”, en Liernur, Jorge y Aliata, Fernando (dirs.), Diccionario de Arquitectura en la Argentina, Clarín, Buenos Aires, 2004.

- -------------, “Comisión Nacional de Casas Baratas”, en Liernur, Jorge y Aliata, Fernando (dirs.), Diccionario de Arquitectura en la Argentina, Clarín, Buenos Aires, 2004.

- Losada, Leandro, La alta sociedad en la Buenos Aires de la Belle Epoque, Siglo XXI, Buenos Aires, 2008.

- Lupano, María Marta, "vivienda ferroviaria", en Liernur, Jorge y Aliata, Fernando (dirs.), Diccionario de Arquitectura en la Argentina. Clarín, Buenos Aires, 2004.

- Manwaring, Elizabeth, Italian Landscape in Eighteenth Century England: a study chiefly of the influence of Claude Lorrain and Salvator Rosa on English taste, 1700-1800. Rusell \& Rusell, Londres, 1965. (1ra edición 1925) 
- Martin, Leslie, "The grid as generator". Urban Spaces and Structures. Martin, Leslie y March, Lionel (ed.) Cambridge University Press, Londres. 1972

- Mas Hernandez, Rafael, El barrio de Salamanca. Planeamiento y propiedad inmobiliaria en el Ensanche de Madrid. Instituto de Estudios de Administración Local, Madrid, 1982.

- Mazza, Carlos (editor), La Ciudad de Papel. Análisis histórico de Normativas y Planes Urbanos para la ciudad de Mar del Plata, 1885-1975, Facultad de Arquitectura, Urbanismo y Diseño. Universidad de Mar del Plata, 1997.

- Mazza, Carlos, "Del Barrio Parque a la Unidad Vecinal. Trayectorias urbanísticas y normativas de conceptos provenientes de la idea de Ciudad Jardín en Mar del Plata", en V seminario de Historia da cidade e do urbanismo, PUC, FAU, Campinas, Brasil, 1998.

- Miller, Mervin, “Garden Cities and Suburbs: at home and abroad”, en Journal of Planning History, 2002. Versión on-line en http://jph.sagepub.com/cgi/content/abstract/1/1/6

- Montaner, José María, Arquitectura y Crítica, Gustavo Gilli, Barcelona, 1999.

- Muthesius, Herman, The English House, 1904.

- Novick, Alicia, Planes realizados y proyectos inconclusos en la construcción de la ciudad moderna. Buenos Aires, 1900-1940. Tesis doctoral, Universidad de San Andrés, Buenos Aires, 2006.

- ----------------, “Alberto Prebisch. La Vanguardia Clásica”, en Cuadernos de Historia IAA n $\mathrm{n}^{\circ}$ 9, Junio 1998. pp. 117-153.

- Novick, Alicia y Piccioni, Raúl Enrique, "Morales, Carlos María”, en Liernur, Jorge y Aliata, Fernando (dirs.) Diccionario de Arquitectura en Argentina. Clarín, Buenos Aires, 2004.

• - -----------------------------------------------, “Lagos, José Marcelino”, en Liernur, Jorge y Aliata, Fernando (dirs.) Diccionario de Arquitectura en Argentina. Clarín, Buenos Aires, 2004

- Pastoriza, Elisa (editora), Las puertas del mar: consumo, ocio y política en Mar del Plata, Montevideo y Viña del Mar. Ed. Biblos, Buenos Aires, 2002.

- Pérez, Roxana, "Rodríguez Etcheto, Alberto", en Liernur, Jorge y Aliata, Fernando (dirs.), Diccionario de Arquitectura en la Argentina, Clarín, Buenos Aires, 2004. 
- Perrot, Michelle, "Modos de habitar. La evolución de lo cotidiano en la vivienda moderna", en A\&V monografías, $n^{\circ}$ 14, El espacio privado, Madrid, 1988.

- Pevsner, Nikolaus, Pioneros del diseño moderno. De William Morris a Walter Gropius, Ediciones Infinito, Buenos Aires, 1958. (1ra edición 1936)

- --------------, The Englishness of English Art, Willmer Brothers, London, 1956.

- Piglia, Melina, Automóviles, Turismo y Carreteras como problemas públicos: los clubes de automovilistas y la configuración de las políticas turísticas y viales en la Argentina (1918-1943). Tesis de Doctorado inédita, UBA, 2009.

- Pírez, Pedro; Rosenfeld, Elías; Karol, Jorge; San Juan, Gustavo, El sistema urbano-regional de redes de servicios e infraestructura. $1^{\mathrm{o}}$ ed. Editorial Universitaria de La Plata (EDULP), La Plata, 2003.

- Poete, Marcel, Une vie de cité. Paris de sa naissance á nos jours. A. Picard, París, 1931.

- Rexford, Newcomb, The Spanish House for America. J.B. Lippincott Company, s/d, 1927.

- Rigotti, Ana María, Alberdi. De pueblo a suburbio. Centro Universitario Rosario de Investigaciones Urbanas y Regionales. Facultad de Arquitectura, Planeamiento y Diseño. U.N.R. 1985.

- Romero, José Luis, La ciudad occidental. Culturas urbanas en Europa y América, Siglo XXI editores, Buenos Aires, 2009.

- - -----------------, Latinoamérica. Las ciudades y las ideas. Siglo XXI Editores, Buenos Aires, 2001.

- Rosanvallon, Pierre, La crisis del Estado Providencia. Civitas, Madrid, 1995.

- Rosenthal, Michael, British Landscape painting. Phaidon Books, Cornell, 1982.

- Ruskin, Jhon, Las siete lámparas de la arquitectura. Safín, Buenos Aires, 1955. (1ra edición 1865)

- Rybczynski, Witold, La casa. Historia de una idea. Emecé, Buenos Aires, 1991 (1ra edición 1986).

- Sabatini, Francisco, "Reforma de los mercados del suelo en Santiago, Chile: efectos sobre los precios de la tierra y la segmentación residencial", en EURE (Santiago) vol.26 n 77 . Mayo 2000. 
- Sábato, Jorge, La clase dominante en la Argentina moderna. Formación y características. Imago Mundi, Buenos Aires, 1991.

- Saez, Graciela, "El castillo de los Ayerza", en Revista de Historia Bonaerense n 33. Instituto y Archivo Histórico Municipal de Morón. Agosto 2008.

- Salas, Marcelo N., Del Pago de la Costa al San Isidro Actual: la obra de dos vascos. Fundación Vasco Argentina Juan de Garay, Buenos Aires, 2005.

- Santos Wolf, Silvia, Jardín América: el primer barrio jardín y su arquitectura, Editora da Universidade de São Paulo, San Pablo, 2001.

- Sarlo, Beatriz, Una modernidad periférica. Buenos Aires 1920-1930. Nueva Visión, Buenos Aires, 1998. (1ra edición, 1988)

- Sarmiento, D.F; “Arquitectura doméstica” (15-10-1879), en Obras Completas. Citado por Gorelik, Adrián. 1998. La grilla y el parque. Espacio público y cultura en Buenos Aires. 1887-1936. Buenos Aires, Universidad Nacional de Quilmes.

- Schvarzer, Jorge y Gómez Teresita, La primera gran empresa de los argentinos. El ferrocarril Oeste (1854-1962). Fondo de Cultura Económica, Buenos Aires, 2006.

- Schmidt, Claudia y Silvestri, Graciela, "Enseñanza de Arquitectura”, en Liernur, Jorge y Aliata, Fernando (dirs.), Diccionario de Arquitectura en la Argentina, Clarín, Buenos Aires, 2004.

- Schuyler, David, The New Urban Landscape. The redefinition of City Form in Nineteenth Century America. Johns Hopkins University Press, Baltimore, 1986.

- Scully, Vincent, The Shingle Style and the Stick Style. Yale University Pres, New Heaven, 1971.

- Scully, Vincent y Downing, A, The Architectural Heritage of Newport, Rhode Island 1640-1915. Harvard Univesity Press, Cambridge, Massachusetts, 1952.

- Selva, Domingo, "Edificación Obrera”, en Arquitectura, Apartado de la Revista Técnica, Marzo-Abril 1910.

- Silvestri, Graciela, "La medida de la naturaleza", en Block, Naturaleza, no 2 , UTDT, Bs. As, 1998.pp.62-75.

- - -------------------, “La vida en clave verde. Cambios en las formas de habitar urbana y rural a mediados del siglo XIX", en Registros, $\mathrm{n}^{\circ}$ 5, Facultad de Arquitectura, Universidad Nacional de Mar del Plata, Abril 2008, pp. 16-29. 
Prometeo y Universidad Nacional de Quilmes, Buenos Aires, 2003.

- Simmel, Georg, El individuo y la libertad. Ensayos de crítica de la cultura. Península, Barcelona, 1986. (1ra edición 1903)

- Smolka, Martín, "Precio de la tierra y valorización inmobiliaria urbana: esbozo para una conceptualización del problema", en Revista Interamericana de Planificación. Vol,15. №60, diciembre, 1981; O capital incorporador e seus movimentos de valorizacão, en Cadernos IPPUR/UFRJ, $\mathrm{n}^{\circ} 1$, jan-abril. Rio de Janeiro, 1987.

- Solkin, David, Richard Wilson: The Landscape of Reaction. Tate Gallery, Londres, 1982.

- Souza de Andrade, Liza, "El concepto de Ciudad Jardín: una adaptación para ciudades sustentables", en Arquitextos 042.02, Noviembre, Brasil, 2003.

- Stevens Curl, James, Georgian Architecture. A. David \& Charles Book, UK, 1996.

- Stieber, Nancy, "Microhistory of the Modern City: Urban Space. It's use and Representation", en Journal of the Society of Architectural Historians, septiembre 1999. pp. 382-891.

- Stone, Lawrence, J, The family, Sex and Marriage in England, 1500-1800, New York, Harper \& Row, 1977.

- Svampa, Maristella, Los que ganaron. La vida en los countries y barrios privados. Editorial Biblos, Buenos Aires, 2001.

- --------------------, La brecha urbana. Countries y Barrios privados en Argentina. Editorial Biblos, Buenos Aires, 2004.

- Szajnberg, Daniela, "La producción del espacio residencial en la Región Metropolitana de Buenos Aires. El caso de los barrios privados en Pilar y Berazategui “, en Actas del Seminario de Investigación Urbana. El nuevo milenio y lo urbano, Instituto de Investigaciones Gino Germani, FCS, UBA; Instituto de Geografía, FFyL-UBA; CEUR/CEA-UBA; UNQ; Instituto del Conurbano, UNGS, 2001.

- - ---------------, “Tendencias en la organización del espacio residencial en la RMBA en los noventa. Torres amuralladas y urbanizaciones cerradas: la recentralización del centro de la metrópolis y la suburbanización de las elites", 
en La Metrópolis Postsocial. Buenos Aires entre la economía global y la sociedad polarizada. Pablo Ciccolella e Iliana Mignaqui (comps.). Eudeba, Buenos Aires, 2000

- Tatarkiewicz, Wladislaw, Historia de seis ideas. Arte, belleza, forma, creatividad, mímesis, experiencia, estética. Tecnos, Marid, 1992.

- Ternavasio, Marcela, Municipio y representación local. Santa Fe: 1900-1920; en Julio Pirro y Elisa Pastoriza (editores) Los caminos de la democracia. Alternativas y prácticas políticas, 1900-1943. Universidad Nacional de Mar del Plata y Editorial Biblos, Buenos Aires, 1996.

- Teyssot, Georges, "Lo social contra lo doméstico. La cultura de la casa en los últimos dos siglos", en $A \& V$ monografías, $n^{\circ} 14$, El espacio privado, Madrid, 1988.

- Torchiaro, Saverio y Barnett, Jaime (comp.), Ranelagh., Ciudad Jardín, Editado por la Asociación de Amigos de la Estación de Ranelagh, 1977.

- Tournikiotis, Panayotis, The Historiography of Modern Architecture, MIT Press, Cambridge, Massachusetts, 1999.

- Unwin, Raymond y Parker, Barry, Town Planning in Practice: an introduction to the art of designing cities and suburbs. T. Fisher, London, 1909.

- Vallejo, Gustavo, "Pasman, Raúll, en Liernur, Jorge y Aliata, Fernando (dirs.), Diccionario de Arquitectura en la Argentina, Clarín, Buenos Aires, 2004.

- Vecslir, Lorena y Ciccolella, Pablo, "Nuevos territorios del ocio y el comercio en la región metropolitana de Buenos Aires (1990-2008)”. Proyección. Vol. 2, no. 7. Mendoza: CIFOT. 2009

- Vecslir, Lorena, Nuevas centralidades del ocio y del consumo. Ámbitos, modalidades e instrumentos de regulación de las grandes superficies comerciales en la Región Metropolitana de Buenos Aires, en Riurb $n^{\circ}$ 8, Especulaciones Suburbanas, Buenos Aires-Barcelona, 2011.

- Watkin, David y Murray, John, The English Vision. The Piscturesque in architecture, landscape and Garden Design, London, 1982.

- Williams, Fernando, "La formación de los técnicos y profesionales: agrimensores, geógrafos e ingenieros", en Jornadas Interdisciplinarias: formas y representaciones del territorio y la ciudad. Rosario, Agosto del 2000. 
- - -------------------, "Estudio Follet. Documentos de una Colección", en Summa + Historia, Buenos Aires, 2004. pp. 90-95.

- Wingo, Lowdon, Transportation and urban land. Washington, DC. Resouces for the future, 1961.

- Yujnovsky, Oscar, Claves políticas del problema habitacional argentino. Grupo Editor Latinoamericano, Buenos Aires, Argentina. 1984

- -------------------, La estructura interna de la ciudad. El caso latinoamericano. SIAP, Buenos Aires, 1971. 


\section{Agradecimientos}

La presente tesis es el resultado de una experiencia formativa iniciada hace siete años en la Maestría de Historia y Cultura de la Arquitectura y la Ciudad, perteneciente a la Escuela de Arquitectura y Estudios Urbanos de la Universidad Torcuato Di Tella y que continuó posteriormente en el Doctorado en Arquitectura de la Facultad de Arquitectura y Urbanismo de la Universidad Nacional de La Plata. La investigación contó con el apoyo de una beca de posgrado CONICET, y una beca de Formación Superior, otorgada por la UNLP. Ambas, con sede en el Instituto de Investigaciones en Historia, Teoría y Praxis de la Arquitectura y la Ciudad (HiTePAC) perteneciente a la Facultad de Arquitectura de la Universidad Nacional de La Plata.

A lo largo de estos años, muchos docentes y colegas han aportado ideas para la definición de este trabajo y por ello quiero agradecerles, en primer lugar a mi director y codirectora, Fernando Aliata y Alicia Novick, cuyos comentarios agudos han sido de una ayuda inestimable, y en segundo lugar, a Fernando Gandolfi, quien desde mi período de estudiante supo generar en mí un entusiasmo singular por la historia, y a quien aún recurro en los momentos de duda y desilusión que, ineludiblemente, acompañan la escritura de una tesis. Tampoco pueden estar ausentes en esta lista aquellos otros profesores con quienes, de manera más o menos intermitente, he cruzado comentarios e información. Claudia Schmidt, Adrián Gorelik, Ana María Rigotti, Anahí Ballent y Graciela Favelukes.

Quisiera mencionar algunas oportunidades que tuve de presentar públicamente mi trabajo. Considero que ellas fueron vertebrando la presente tesis. Por orden cronológico quiero mencionar; el Seminario, "Mirar, dibujar y proyectar el territorio y sus lecturas gráficas", llevado a cabo en la Universidad Nacional de General Sarmiento en octubre del 2010. De aquella ocasión agradezco especialmente los comentarios atentos de Alicia Novick, Graciela Favelukes y Lorena Vecslir. En segundo lugar, rescato las sugerencias bibliográficas de dos colegas y amigas, Valeria Gruchetsky y Noelia Fernandez, en el marco de las " $1{ }^{\circ}$ Jornadas de Investigadores en Formación. Reflexiones en torno al proceso de investigación”, organizadas por el IDES en noviembre 2011. Contemporáneamente también se llevaron a cabo los encuentros del taller de discusión de la FAU, de los cuales reconozco los comentarios y críticas de mi director y de Juan Etulain. Y más recientemente, el programa de encuentros de la 
Revista Serie Urbana, dirigida por Guillermo Jajamovich. La discusión de uno de mis artículos junto al mismo Guillermo y a Ana Sanchez Troillet ha servido para reorganizar gran parte del capítulo dedicado a la arquitectura suburbana.

Asimismo, merecen una mención especial aquellos colegas y amigos con quienes comparto cotidianamente mi trabajo en el HITEPAC y en las dos cátedras de las cuales participo: Omar Loyola, Virginia Galcerán, Rossana Obregón, Susana Cricelli, Fabiana Carbonari, Fernando Williams, Ana Ottavianelli, Graciela Silvestri, Eduardo Gentile, Tereza Zweifel, Virginia Bonicato, Melina Yuln, Mariana Santángello y José Bjerring.

Finalmente, esta tesis no se podría haber realizado sin el apoyo del personal del Departamento de Investigación Histórica y Cartográfica, Dirección de Geodesia, MOP, Pcia. de Buenos Aires; Museo y Archivo Histórico San Isidro; Instituto Histórico del Partido de Morón, Biblioteca Nacional, Biblioteca de la Sociedad Central de Arquitectos. Y de algunas amigas que contribuyeron a redibujar y corregir diversos fragmentos de la tesis, mi hermana Guadalupe, Carolina, Patricia Feysulaj y Paula Fulía.

Por último, quiero dedicar este trabajo a mi padre, quien desde hace pocos meses ya no me acompaña, y a aquellos que sí han estado conmigo en cada momento, a mi abuela, mi madre y mi hermana. A Gerónimo, y a Fausto por las risas y berrinches cotidianos. 